INSTITUTO DE PESQUISAS ENÉRGETICA E NUCLEARES

Autarquia associada à Universidade de São Paulo

\title{
AVALIAÇÃO DE METAIS E ELEMENTOS-TRAÇO EM ÁGUAS E SEDIMENTOS DAS BACIAS HIDROGRÁFICAS DOS RIOS MOGI- GUAÇU E PARDO, SÃO PAULO
}

Marcos José de Lima Lemes

Dissertação apresentada como parte dos requisitos para a obtenção do grau de Mestre em Ciências na área de Tecnologia Nuclear

Orientadora:

Dra. Maria Ap. Faustino Pires 


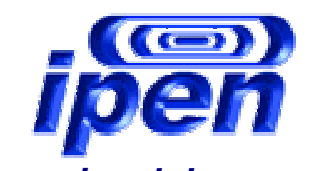

comissão nacional de energia nuclear instituto de pesquisas energéticas e nucleares 
"Se já construístes castelos no ar, não te envergonhes deles; estão onde deviam estar. Agora constrói os alicerces."

[Thoreau] 


\section{AgradeCimentos}

A Dra. Maria Aparecida Faustino Pires pela orientação, confiança e amizade, que desde o inicio acreditou em minha pessoa.

Ao Instituto de Pesquisas Energéticas e Nucleares e ao Centro de Química e Meio Ambiente (CQMA) pela oportunidade de desenvolver este trabalho.

Ao Dr. Antônio Theodorovicz e a Dra. Angela M. G. Theodorovicz, do CPRM pelas discussões e valiosa contribuição que realizaram na parte geológica da região de estudo deste trabalho.

A Dra. Elisabeth Oliveira do Instituto de Química da USP pela iniciação na técnica ICP-OES e auxilio na fase inicial deste trabalho.

Ao Dr. Paulo Miranda pela ajuda e discussões na análise de difração de raios-X.

Ao Sr. Elias Santana da Silveira pela valiosa colaboração que foi prestada a esta dissertação.

A Sra. Marta Yoshiko Maekawa pela colaboração na parte artística desta dissertação.

A Dra. Lidia Katsuóka, Msc. Sérgio L. G. Petroni, Dr. Hélio Akira Furusawa, Dra. Elizabeth Sonoda Keiko Dantas, Msc. Maria Nogueira Marques, Ricardo dos Santos Coelho e Msc. Marycel Cotrim pelas discussões técnicas, valiosas sugestões e amizade.

A Emy Komatsu pelo carinho e companheirismo nesta etapa da minha vida.

Ao pessoal do CQMA pela colaboração na realização deste trabalho. 
A diretoria do Gerenciamento de Recursos Hídricos do Interior do Estado de São Paulo da SABESP pelo apoio logístico.

A todos os meus colegas, amigos que direta e indiretamente muito colaboraram para esta para a realização deste trabalho.

A minha família que sempre me deram suporte e incentivo na vida acadêmica e profissional.

A FINEP/PADCT III e RHAE/CNPq, pelo apoio financeiro. 


\title{
Avaliação de Metais e Elementos-traço em Águas e Sedimentos das Bacias Hidrográficas dos rios Mogi-Guaçu e Pardo, Estado de São Paulo
}

\section{MARCOS José DE LIMA LEMES}

\author{
RESUMO
}

As Bacias Hidrográficas dos rios Mogi-Guaçu e Pardo, integram uma importante área de recarga do Aqüífero Guarani, e localizam-se na região nordeste do Estado de São Paulo. Essas bacias drenam áreas com forte influência agropecuária, que influenciam de forma significativa as características limnologicas e físico-químicas. Destaca-se como a única região do estado cujas captações de água são todas superficiais. Assim, no presente estudo procurou-se avaliar a qualidade de amostras de água e sedimentos em áreas de captação superficial para abastecimento público pertencentes nas 13 micro bacias dessa região. Foram realizadas análises de metais e elementos-traço da água bruta e tratada e da água sobrenadante e intersticial do sedimento, de acordo com as normas contidas no Standard Methods for Examination of Water and Wastewater, $17^{\circ}$ edition. Foram realizadas também análises dos metais biodisponíveis nos sedimentos. Foram coletadas amostras de água superficial, que convencionamos chamar de água bruta, e de sedimento próximos aos pontos de captação e de água tratada, nas estações de tratamento de água da SABESP, com uma periodicidade bimestral, no período de Abril de 1998 a Abril 1999, totalizando sete campanhas de campo, representando 49 amostras por comunidade, num total de 637 amostras coletadas. Os elementos analisados foram selecionados atendendo-se as exigências de duas legislações federais: a resolução CONAMA no 20 e a Portaria 36/MS 90. Foram analisadas as espécies iônicas: $\left(\mathrm{F}^{-}, \mathrm{Cl}^{-}, \mathrm{SO}_{4}{ }^{2-}, \mathrm{Na}^{+}, \mathrm{K}^{+}\right.$e $\left.\mathrm{NH}_{4}{ }^{+}\right)$, nutrientes $\left(\mathrm{NO}_{3}{ }^{-}\right.$ e $\mathrm{PO}_{4}{ }^{3-}$ ) utilizando a técnica de Cromatografia Iônica, metais ( $\mathrm{Ag}, \mathrm{Al}, \mathrm{Ba}, \mathrm{Ca}, \mathrm{Cd}, \mathrm{Co}, \mathrm{Cr}$, $\mathrm{Cu}, \mathrm{Fe}, \mathrm{Mg}, \mathrm{Mn}, \mathrm{Ni}, \mathrm{P}, \mathrm{Pb}$ e $\mathrm{Zn}$ ) utilizando a técnica de Espectrometria de Emissão Atômica com Plasma de Argônio; os sedimentos foram caracterizados utilizando as técnicas de Espectrometria de Fluorescência de Raios X e Difração de Raios X. A análise descritiva mostrou que as concentrações de Fe, Mn e Al diminuíram com o tratamento, os elementos $\mathrm{Mg}, \mathrm{Co}, \mathrm{P}, \mathrm{Cu}, \mathrm{Na}^{+}$e $\mathrm{K}^{+}$permaneceram na mesma concentração após o tratamento e, os elementos $\mathrm{Ca}, \mathrm{F}^{-}, \mathrm{Cl}^{-}$e $\mathrm{SO}_{4}{ }^{2-}$ apresentaram concentrações superiores após 
tratamento. A água intersticial apresentou concentrações de metais, em média 2 a 30 vezes maiores do que concentração na coluna de água. As análises químicas revelaram que nenhum metal tóxico foi observado em concentrações acima daquelas estabelecidas por lei para as águas de rio classe 2. Somente o ferro e o manganês apresentaram concentrações superior em algumas comunidades. Os ribeirões, córregos e rios pertencentes às diferentes micro bacias analisadas mostraram concentrações de metais distintas. A análise de componentes principais para a água bruta apresentou seis fatores: o primeiro, o segundo e o quarto fator ( $\mathrm{Ba}, \mathrm{Ca}, \mathrm{Fe}, \mathrm{Mn}, \mathrm{Mg}, \mathrm{Na}, \mathrm{Co}, \mathrm{Cu}$ e $\mathrm{P}$ ) parecem estar associados a fatores mineralógicos (formação geológica da região); o terceiro fator $\left(\mathrm{Cl}^{-}, \mathrm{SO}_{4}{ }^{2-}\right.$ e pluviometria) à possibilidade de uma influência antrópica. Para a água tratada o programa apresentou 4 fatores: o primeiro e o segundo $\left(\mathrm{Mg}, \mathrm{Ca}, \mathrm{Ba}, \mathrm{K}^{+}\right.$e $\left.\mathrm{P}\right)$, sugerem a possibilidade de associação a formação geológica; e o terceiro e o quarto $\left(\mathrm{F}^{-}, \mathrm{Cl}^{-}\right.$e $\left.\mathrm{NO}_{3}{ }^{-}\right)$poderiam ser de compostos usados pela Estação de Tratamento de Água. A análise de componentes principais apresentou 3 fatores para cada uma das fases sobrenadante e intersticial, para ambos: o primeiro fator ( $\mathrm{Mg}, \mathrm{Ca}, \mathrm{Mn}$ e $\mathrm{Fe}$ ) poderia estar ligado ao Complexo Granitognaisse, o segundo, e o terceiro fator $(\mathrm{Cu}, \mathrm{Ba}, \mathrm{P}$ e $\mathrm{Ni})$ rochas alcalinas do grupo de Poços de Caldas e a rochas metabasicas. As amostras de sedimentos também foram analisadas por componentes principais e foram obtidos 5 fatores: o primeiro e o segundo fator $(\mathrm{Mn}$, $\mathrm{Fe}, \mathrm{Co}, \mathrm{Cu}, \mathrm{Cd} \mathrm{Al}, \mathrm{Ca}$ e Ba) sugerem ligação com formação geológica, o quarto fator (P) poderia estar associado do Complexo de Poços de Caldas. Este estudo não mostrou a correlação entre metais biodisponíveis e matéria orgânica. 


\title{
METALS AND TRACE ELEMENTS CONCENTRATION IN WATER AND SEDIMENTS OF THE HYDROGRAPHIC BASINS FROM MOGI-GUAÇU AND PARdo RIVERS IN THE STATE OF São Paulo, Brazil
}

\section{Marcos José de LiMA LeMES}

\begin{abstract}
The present work aimed to evaluate the environmental water and sediment quality in Mogi-Guaçu and Pardo Rivers Basins (São Paulo State), in the localities of water supply intake for the 13 cities in the basins. Metals and ions analysis of the water and sediment were performed according to methods to procedures described in Standard Methods for Examinations of Water and Wastewater, $17^{\text {th }}$ edition. The hydrographic basins from MogiGuaçu and Pardo Rivers have a large agriculture influence on limnologic, physical and chemical characteristics and this area is unique in the State of São Paulo that the water catchment for supply is only surface and is used for water supply agriculture, public and industrial as well as far other uses, and it is also the recharge of Guarani's aquifer and it is one of huge aquifers in the world. In this study sampling was carried out at in a hydrological period, they were sampled bimonthly for 12 months (April 98/April 99) and analyzed: ions $\left(\mathrm{F}^{-}, \mathrm{Cl}^{-}, \mathrm{SO}_{4}{ }^{2-}, \mathrm{Na}^{+}, \mathrm{K}^{+}\right.$and $\left.\mathrm{NH}_{4}{ }^{+}\right)$, nutrients $\left(\mathrm{NO}_{3}{ }^{-}\right.$and $\left.\mathrm{PO}_{4}{ }^{3-}\right)$ using the Ion Chromatographic technique, metals (Ag, Al, Ba, Ca, Cd, Co, Cr, Cu, Fe, Mg, Mn, Ni, P, $\mathrm{Pb}$ and $\mathrm{Zn}$ ) using the Inductively Coupled Plasma Optical Emission Spectrometric technique, organic carbon, using the Volumetric technique, for characterization of the sediments was used X Ray Fluorescence Spectrometric and X Ray Diffraction Spectrometric techniques in the 13 communities. During the catchment's period was gotten a large number of results. For it was used a computer software programs for descriptive, correlation and principal components analysis. The descriptive analyze was written $\mathrm{Fe}, \mathrm{Mn}$ and $\mathrm{Al}$ getting down concentration after treatment water, the $\mathrm{Mg}, \mathrm{Co}, \mathrm{P}, \mathrm{Cu}, \mathrm{Na}$ and $\mathrm{K}$ elements still at same concentration after treatment concentration and, the $\mathrm{Ca}, \mathrm{F}^{-}, \mathrm{Cl}^{-}$and $\mathrm{SO}_{4}{ }^{2-}$ elements getting upper concentration after treatment water. The interstitial phase showed 2 to 30 fold values than natural water. For supernatant and interstitial water, the most elements still at same concentration both phases, except for $\mathrm{Al}$, $\mathrm{Co}$ and $\mathrm{Cu}$ that showed larger concentration on interstitial phase. The principal components analyze was written six factors: the first and second factors ( $\mathrm{Ba}, \mathrm{Ca}, \mathrm{Fe}, \mathrm{Mn}, \mathrm{Mg}, \mathrm{Na}, \mathrm{Co}, \mathrm{Cu}$ and $\mathrm{P}$ )
\end{abstract}


suggest geological formation; the third factor $\left(\mathrm{Cl}^{-}, \mathrm{SO}_{4}{ }^{2-}\right.$ e pluviometry) the possibility of an anthropogenic influence for natural water. For treatment water the software written 4 factors: the first and second factors $\left(\mathrm{Mg}, \mathrm{Ca}, \mathrm{Ba}, \mathrm{K}^{+}\right.$and $\mathrm{P}$ ) have the possibility to be associated to geological formation, and the third and fourth factor $\left(\mathrm{F}^{-}, \mathrm{Cl}^{-}\right.$and $\left.\mathrm{NO}_{3}{ }^{-}\right)$could be from used compounds at Water Treatment Station. The component principals analyze for supernatant and interstitial phases wrote three factors for both: the first factor $(\mathrm{Mg}, \mathrm{Ca}$, $\mathrm{Mn}$ and $\mathrm{Fe}$ ) would be linkage to Granite-gneiss Complex, the second and third factor $(\mathrm{Cu}$, $\mathrm{Ba}, \mathrm{P}$ and $\mathrm{Ni}$ ) suggest a linkage to metabasic and Poços de Caldas alkaline rocks. The sediment samples also were analyzed by principal components and were got five factors: the first, second and third ( $\mathrm{Mn}, \mathrm{Fe}, \mathrm{Co}, \mathrm{Cu}, \mathrm{Cd} \mathrm{Al}, \mathrm{Ca}$ e $\mathrm{Ba}, \mathrm{Fe}, \mathrm{Co}, \mathrm{Cu}, \mathrm{Cd} \mathrm{Al}, \mathrm{Ca}$ and $\mathrm{Ba}$ ) factors suggests geological formation; the fourth factor (P) could be from Poços de Caldas Complex. This study didn't show the correlation among bioavailable metals with organic matter. 


\section{SUMÁRIO}

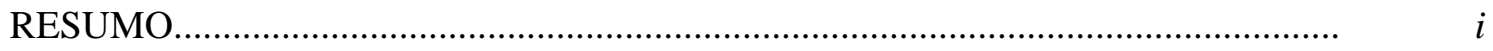

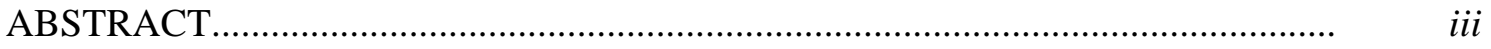

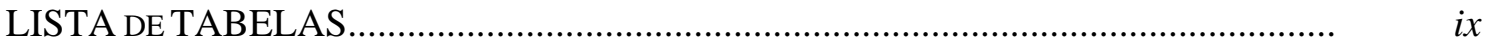

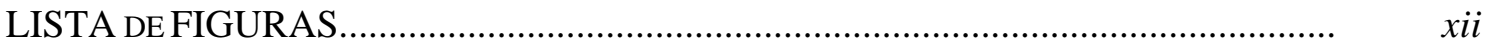

LISTA DE ABREVIATURAS E/OU DEFINIÇÕES................................................. $\quad x v i$

1. INTRODUÇÃ

2. OBJETIVOS E ASPECTOS RELEVANTES DO TRABALHO...................... 7

2.2. OBJETIVOS ESPECÍ́FICOS.......................................................................... 7

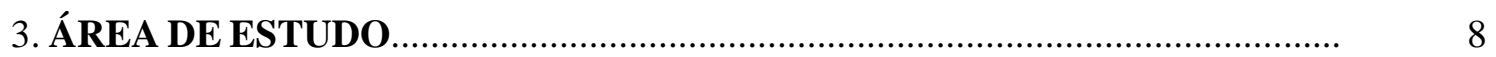

3.1. LEVANTAMENTO DA SitUAÇÃo GEOGRÁFICA E GEOLÓGICA..................... 9

3.2. CARACTERIZAÇÃo da Área SEgUndo AS UNidAdES DE

GERENCIAMENTO DERECURSOS HÍDRICOS........................................... 13

4. ASPECTOS GERAIS SOBRE ÁGUA E SEDIMENTO.................................. 23

4.1. AvaliaÇão E Monitoramento da QuALIDAdE da ÁGUA.................... 23

4.1.1. PARÂMETROS E INDICADORES DE QUALIDAdE............................ 25

4.1.2. PAdRÕES DE QUALIDADE, NORMAS E LEGISLAÇÃO....................... 26

4.2. MobiLiZAÇÃo de Metais PeSAdos EM Sedimento.................................. 29

4.3. IMPACTOS AMBIENTAIS E EFEITO SOBRE A SAÚDE.................................. 36

4.4. Métodos Analíticos para a DeterminaÇÃo de Metais e EsPÉcies

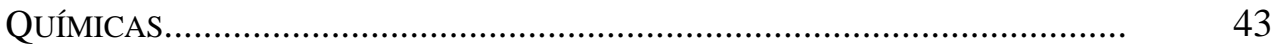

4.4.1. CROMATOGRAFIA DE ÍONS...................................................... 44

4.4.1.1. SISTEMA SUPRESSOR.................................................... 
4.4.2. ESPECTROMETRIA DE EMISSÃo ÓTICA COM PLASMA DE ARGÔNIO (ICP-OES) .......................................................... 49

4.4.2.1. PLASMA (ICP) ......................................................... 49

4.2.2.2. INTRODUÇÃO DA AMOSTRA LÍQUIDA............................ 51

4.2.2.3. MEINHARD............................................................... 51

4.2.2.4. EXCITAÇÃO DA AMOSTRA........................................... 52

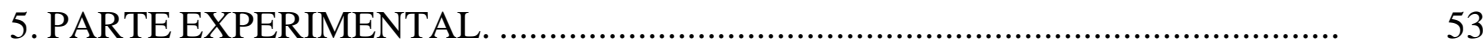

5.1. MATERIAIS E MÉTODOS.................................................................... 54

5.1.1. EQUIPAMENTO E MATERIAIS................................................. 54

5.1.2. REAGENTES E SOLUÇÕES...................................................... 54

5.1.3. PADRÕES EELUENTES............................................................ 55

5.2. CertificaÇão da Metodologia AnalíticA........................................ 57

5.2.1. DETERMINAÇÃO DE ESPÉCIES IÔNICAS POR CROMATOGRAFIA DE ÍONS - IC ................................................................ 57

5.2.2. DeterminaÇÃo de Metais e Elementos-Traço POR ESPECTROMETRIA DE EMISSÃo ÓTICA COM PLASMA DE ARGÔNIO (ICP-OES) ........................................................... 64

5.2.3. AVAliaÇÃo do MÉTOdo de LiXIVIAÇÃo (BIOdiSPONÍVEL)......... 69

5.3. Estabelecimento do Programa de Monitoramento......................... 70

5.4. COLETA E PRESERVACÃO DAS AMOSTRAS............................................... 72

5.5. CARACTERIZAÇÃO DAS VARIÁVEIS FíSICAS E QUÍMICAS.......................... 74

5.5.1. Locais de Amostragem e Periodicidade de Coleta.............. 74

5.5.2. DETERMINAÇÃO DE METAIS....................................................... 74

5.5.3. DETERMINAÇÃO DE ÂNIONS ECÁTIONS..................................... 78

5.5.4. DETERMINAÇÃO do TEOR DE MATÉRIA ORGÂNICA....................... 78

5.5.5. ANÁLISE MINERALÓGICA............................................................ 80

5.5.5.1. MÉtodo de DeCANTAÇÃo PELA LEI DE STOKES............ 82

5.5.5.2. INTERPRETAÇÃO DOS DIFRATOGRAMAS........................ 83

5.6. TRATAMENTO MATEMÁtico E EstATístico dos DADOS......................... 84 


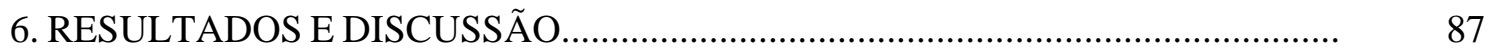

6.1. ANÁLISE FísICA E QUímICA DA ÁGUA..................................................... 87

6.1.1. VariaÇão da Concentração de Metais E Elementos-

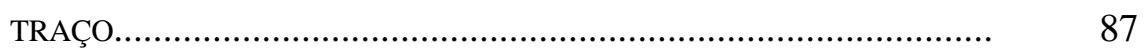

6.1.2. ANÁLISE EstATÍSTICA MultivARIADA.......................................... 110

6.1.2.1. ANÁLISE DE COMPONENTES PRINCIPAIS NA ÁGUA

BRUTA..................................................................... 110

6.1.2.2. ANÁlise DE CORRELAÇÃO DOS ELEMENTOS COM

PLUVIOMETRIA E PH DA ÁGUA BRUTA......................... 112

6.1.2.3. ANÁLISE DE COMPONENTES PRINCIPAIS NA ÁGUA

TRATADA............................................................ 112

6.1.2.4. ANÁlise de CORRELAÇÃo dA ÁGUA TRATADA.............. 115

6.1.2.5. COMPARAÇÃO ENTRE RESULTADOS ENCONTRADOS

PARA METAIS EM ÁGUA BRUTA................................... 116

6.2. ANÁLISE FísICA E QUÍMICA DO SEDIMENTO.......................................... 120

6.2.1. CONCENTRAÇÃo de MatÉRIa ORGÂNICA NOS SEDIMENTOS........ 120

6.2.2. CARACTERIZAÇÃO DA COMPOSIÇÃO DO SEDIMENTO POR

ESPECTROMETRIA DE FLUORESCÊNCIA DE RAIOS X.................. 122

6.2.3. ANÁLISE MinERALÓGICA dos SEDIMENTOS................................ 122

6.2.4. VARIAÇÃO DA CONCENTRAÇÃO DE FÓSFORO BIODISPONÍVEL NO

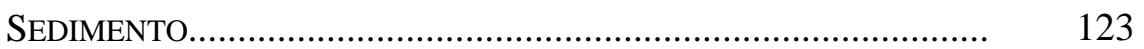

6.2.5. VARIAÇÃO DA CONCENTRAÇÃO DE METAIS NO SEDIMENTO NAS

FASES SOBRENADANTE, INTERSTICIAL E BIODISPONÍVEL........... 124

6.2.6. ANÁlISE DE COMPONENTES PRINCIPAIS DAS VARIÁVEIS DO

SEDIMENTO................................................................... 126

6.2.6.1. ANÁlise DE COMPONENTES PRINCIPAIS DA FASE

SOBRENADANTE....................................................... 126

6.2.6.2. ANÁlise de CORRELAÇÃO dOS ElEMENTOS

METÁlicos da FASE SobRENADANTE.......................... 129

6.2.6.3. ANÁLISE DE COMPONENTES PRINCIPAIS DA FASE

INTERSTICIAL .......................................................... 130

6.2.6.4. ANÁlise DE CORRELAÇÃO dOS ELEMENTOS

METÁLICOS DA FASE INTERSTICIAL............................. 132 
6.2.6.5. ANÁliSE DE COMPONENTES PRINCIPAIS DA DigESTÃO.. 132

6.2.6.6. ANÁLISE DE CORRELAÇÃo dOS ELEMENTOS METÁliCOS DA FASE DigESTÃO................................... 134

6.2.6.7. CoMPARAÇÃO ENTRE OS RESUltados da FASE SOBRENADANTE E INTERSTICIAL.................................. 135

6.2.6.8. ANÁliSE EstATÍSTICA dOS METAIS COM MATÉRIA

ORGÂNICA.......................................................... 136

6.2.6.9. ANÁlise DE CORRELAÇÃO dOS ELEMENTOS DA

DiGESTÃO COM A MATÉRIA ORGÂNICA......................... 138

6.3. COMPARAÇÃO ENTRE RESUltados EnCONTRAdOS PARA METIAS POTENCIALMENTE BIODISPONÍVEIS.

7. CONCLUSÃO

8. APÊNDICE 1

9. APÊNDICE 2

10. APÊNDICE 3 .

11. APÊNDICE 4

12. APÊNDICE 5

13. APÊNDICE 6 . 


\section{LISTAS DE TABELAS}

Tabela 3.1 - Resumo das principais características das Unidades de Gerenciamento de recursos Hídricos - UGRHI's Pardo e MogiGuaçu, SP.

Tabela 4.1 - Comparação dos valores máximos permissíveis estabelecidos por

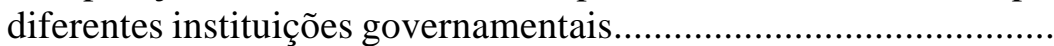

Tabela 4.2 - Esquema de extração seqüencial em sedimentos......

Tabela 4.3 - Extração de metais associado à diferentes fases químicas nos sedimentos.

Tabela 4.4 - Classificação dos elementos de acordo com a toxicidade e ocorrência.

Tabela 4.5 - Características dos principais parâmetros analisados........................

Tabela 5.1 - Reprodutibilidade, precisão e desvio padrão relativo.

Tabela 5.2 - Coeficiente de correlação, limite de detecção (L.D.) e de quantificação dos analitos iônicos e catiônicos.

Tabela 5.3 - Coeficiente de correlação, limite de detecção e de quantificação dos analitos metálicos.

Tabela 5.4 - Reprodutibilidade, precisão e desvio padrão relativo.

Tabela 5.5 - Resultados obtidos da lixiviação com $\mathrm{HCl} 0,1 \mathrm{~mol} \mathrm{~L}^{-1}$ do SRM 2704

Tabela 5.6 - Caracterização e localização dos pontos de captação de água............

Tabela 6.1 - Razão entre o número de valores que não estão de acordo com a legislação e o número de coletas para os metais e elementos iônicos na fração bruta nas comunidades.

Tabela 6.2 - Razão entre o número de valores que não estão de acordo com a legislação e o número de coletas para os metais e elementos iônicos na fração tratada nas comunidades.

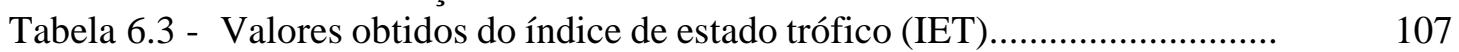

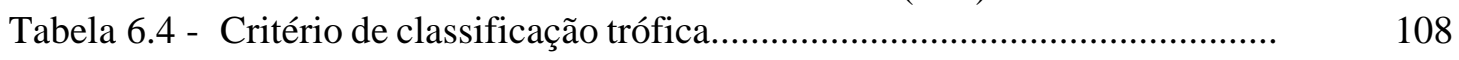

Tabela 6.5 - Análise de componentes principais nos elementos da água bruta.....

Tabela 6.6 - Resultados da análise de componentes principais para a água bruta.

Tabela 6.7 - Esquematização das informações da ACP para os elementos da água bruta.

Tabela 6.8 - Matriz de correlação entre a pluviometria, pH e os elementos metálicos e iônicos na água bruta.

Tabela 6.9 - Análise de componentes principais nos elementos da água tratada...

Tabela 6.10- Resultados da análise de componentes principais para a água tratada.

Tabela 6.11- Esquematização das informações da ACP para os elementos da água tratada.

Tabela 6.12- Matriz de correlação entre os elementos metálicos e iônicos na água tratada. 
Tabela 6.13- Concentração de metais pesados em água bruta, em coletânea de vários trabalhos para intercomparação com os resultados obtidos neste trabalho

Tabela 6.14- Resultado do carbono orgânico e matéria orgânica.

Tabela 6.15- Capacidade de troca catiônica e aniônica dos grupos mineralógicos e da matéria orgânica, em miliequivalentes por $100 \mathrm{~g}$ $(\mathrm{pH}=7,0)$.

Tabela 6.16- Presença dos grupos argilominerais nas comunidades identificados a partir da analise de difração de raios $\mathrm{X}$

Tabela 6.17- Razão entre o número de valores que não estão de acordo com o folhelho médio e o número de coletas para os metais na fração digestão nas comunidades

Tabela 6.18- Análise de componentes principais nos elementos da fase sobrenadante.

Tabela 6.19- Resultados da análise de componentes principais para a fase sobrenadante.

Tabela 6.20- Esquematização das informações da ACP para os elementos da fase sobrenadante.

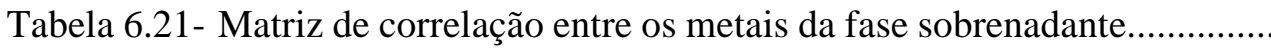

Tabela 6.22- Análise de componentes principais nos elementos da fase intersticial.

Tabela 6.23- Resultados da análise de componentes principais para a fase intersticial

Tabela 6.24- Esquematização das informações da ACP para os elementos da fase intersticial

Tabela 6.25- Matriz de correlação entre dos metais da fase intersticial................. 132

Tabela 6.26- Análise de componentes principais nos elementos da digestão..........

Tabela 6.27- Resultados da análise de componentes principais para a fase digestão.

Tabela 6.28- Esquematização das informações da ACP para os elementos da fase digestão

Tabela 6.29- Matriz de correlação entre os metais da digestão.

Tabela 6.30- Análise de componentes principais nos elementos da digestão com matéria orgânica

Tabela 6.31- Resultados da análise de componentes principais para a digestão e matéria orgânica

Tabela 6.32- Esquematização das informações da ACP para os elementos da digestão e matéria orgânica

Tabela 6.33- Matriz de correlação entre dos metais da digestão com matéria orgânica

Tabela 6.34- Concentrações de metais em fase biodisponível em $\mu \mathrm{g} \mathrm{g}^{-1}$ de sedimento seco, em coletânea de vários trabalhos na literatura para intercomparação com os resultados nas comunidades encontrados neste trabalho

Tabela A.1 - Estatísticas descritivas para as concentrações $\left(\mu \mathrm{g} \mathrm{mL} \mathrm{L}^{-1}\right)$ dos metais na água bruta

Tabela A.2 - Estatísticas descritivas para as concentrações $\left(\mu \mathrm{g} \mathrm{mL}^{-1}\right)$ dos elementos iônicos na água. 
Tabela A.3 - Estatísticas descritivas para as concentrações $\left(\mu \mathrm{g} \mathrm{mL}^{-1}\right)$ dos metais na água tratada

Tabela A.4 - Estatísticas descritivas para as concentrações $\left(\mu \mathrm{g} \mathrm{mL} \mathrm{m}^{-1}\right)$ dos elementos iônicos na água tratada.

Tabela A.5 - Estatísticas descritivas para as concentrações $\left(\mu \mathrm{g} \mathrm{mL}^{-1}\right)$ dos metais

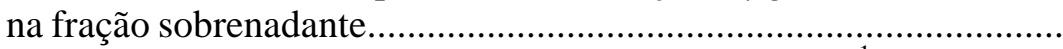

Tabela A.6 - Estatísticas descritivas para as concentrações $\left(\mu \mathrm{g} \mathrm{mL}{ }^{-1}\right)$ dos metais

Tabela A.7 - Estatísticas descritivas para as concentraçõo. fração digestão (biodisponível).

Tabela A.8 - Estatísticas descritivas dos índices pluviométricos mensais e do

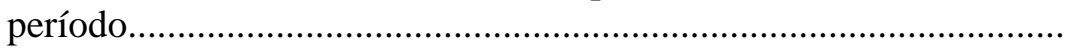

Tabela A.9 - Estatísticas descritivas para o pH nas águas bruta e tratada...............

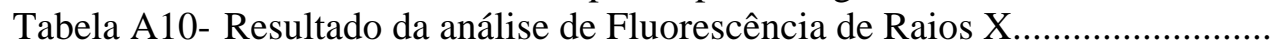

TabelaA.11- Valores médios do folhelho. 


\section{LISTA DE FigURAS}

Figura 3.1 - Localização da região em estudo.

Figura 3.2 - Mapa do Estado de São Paulo contendo os 11 grupos das Unidades de Gerenciamento de Recursos Hídricos.

Figura 3.3 - Mapa esquemático da vulnerabilidade das águas subterrâneas da região estudada......

Figura 3.4 - Mapa esquemático da UGRHI-9, contendo os seus principais corpos de água, municípios, atividades agrícolas e industriais.

Figura 3.5 - Mapa esquemático da UGRHI-4, contendo os seus principais corpos de água, municípios, atividades agrícolas e industriais.

Figura 3.6 - Localização geográfica dos pontos de coleta...

Figura 3.7 - Mapa da carga poluidora potencial das águas subterrâneas do Estado de São Paulo, fontes pontuais.

Figura 4.1 - Resposta biológica à dependência na concentração de um nutriente essencial (curva sólida) e de uma substância perigosa (curva tracejada).

Figura 4.2 - Fluxograma da técnica de cromatografia de íons............................... 45

Figura 4.3 - Esquema de supressão química em I.C............................................. 46

Figura 4.4 - Representação esquemática do sistema auto-regenerante aniônico......

Figura 4.5 - Representação esquemática do sistema supressor auto-regenerante catiônico.

Figura 4.6 - Diagrama esquemático de uma fonte de plasma de argônio................. 50

Figura 4.7 - Esquema do nebulizador Meinhard................................................... 52

Figura 4.8 - Representação da emissão atômica................................................. 52

Figura 5.1 - Cromatograma das espécies aniônicas............................................. 58

Figura 5.2 - Cromatograma das espécies catiônicas........................................... 59

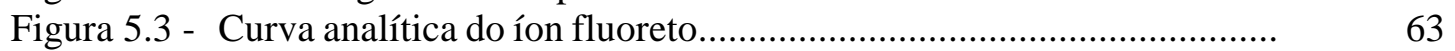

Figura 5.4 - Curva analítica do íon cloreto............................................................ 63

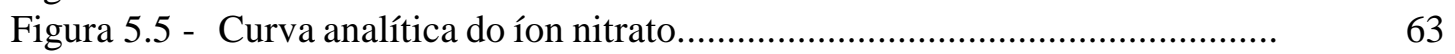

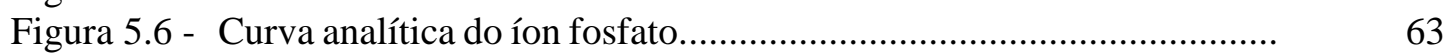

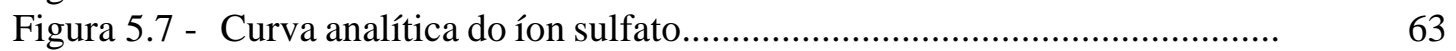

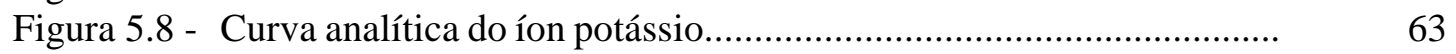

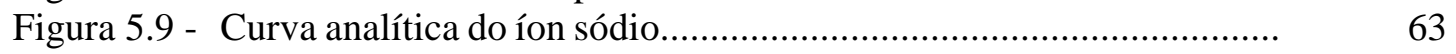

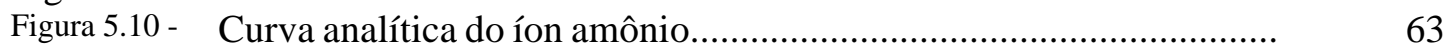

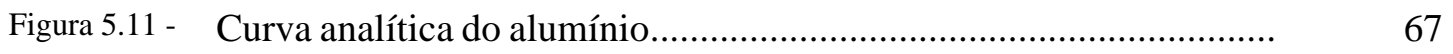

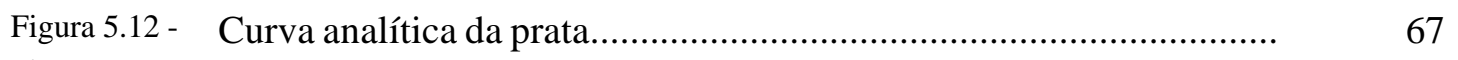

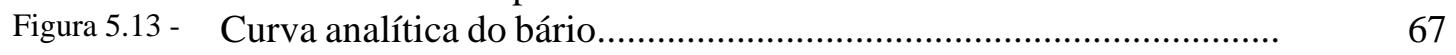

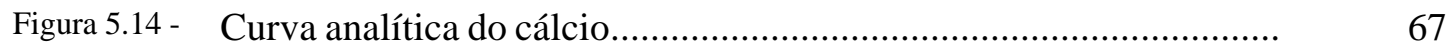

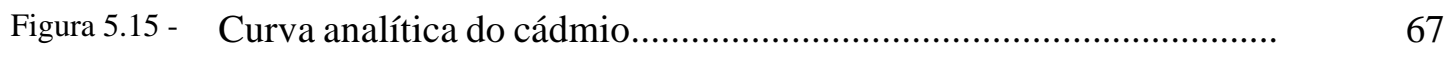

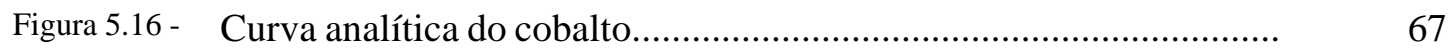

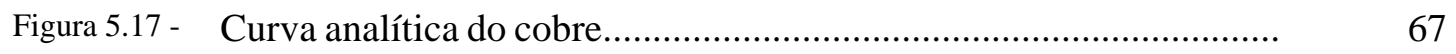

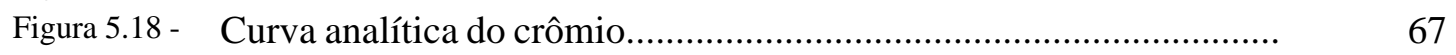

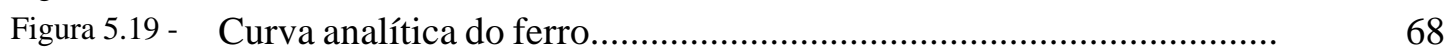

Figura 5.20 - Curva analítica do magnésio.......................................................... 68 
Figura 5.21 -

Figura 5.22 -

Figura 5.23 -

Figura 5.24 -

Figura 5.25 -

Figura 5.26 -

Figura 6.1 -

Figura 6.2 -

Figura 6.3 -

Figura 6.4 -

Figura 6.5 -

Figura 6.6 -

Figura 6.7 -

Figura 6.8 -

Figura 6.9 -

Figura 6.10 -

Figura 6.11 -

Figura 6.12 -

Figura 6.13 -

Figura 6.14 -

Figura 6.15 -

Figura 6.16 -

Figura 6.17 -

Figura 6.18 -

Figura 6.19 -

Figura 6.20 -

Figura 6.21 -

Figura 6.22 -

Figura 6.23 -

Figura 6.24 -

Figura 6.25 -

Figura 6.26 -

Figura 6.27 -

Figura 6.28 -

Figura 6.29 -

Figura 6.30 -

Figura 6.31 -

Figura 6.32 -

Figura 6.33 -

Figura 6.34 - Variação temporal e espacial do fósforo no período de seca.

Figura 6.35 - Variação temporal e espacial do fósforo no período de chuva

Figura B.1 - Concentração dos metais (em $\mu \mathrm{g} \mathrm{mL}^{-1}$ ) nas águas bruta e tratada para cada comunidade.
68

68

68

68

68

77

88

88

88

89

89

89

90

90

90

91

91

91

92

92

92

93

94

94

94

95

95

95

96

96

96

97

97

97

98

98

98

104

104

124

124

157 
Figura B.2 - Concentração dos elementos iônicos $\left(\mathrm{em} \mu \mathrm{g} \mathrm{mL} \mathrm{m}^{-1}\right)$ nas águas bruta e tratada para cada comunidade.

Figura B.3 - Concentração dos metais (em $\mu \mathrm{g} \mathrm{mL}^{-1}$ ) nas frações sobrenadante e intersticial para cada comunidade

Figura B.4 - Concentração dos metais $\left(e m \mu g \mathrm{~mL}^{-1}\right.$ ) na fração digestão para cada comunidade.

Figura B.5 - Índice de pH nas águas bruta e tratada por comunidade........................ 165

Figura B.6 - Índices pluviométricos mensais e do período

Figura C.1 - Alisamentos das concentrações dos metais na água bruta em função do tempo de coleta.

Figura C.2 - Alisamentos das concentrações dos elementos iônicos na água bruta em função do tempo de coleta.

Figura C.3 - Alisamentos das concentrações dos metais na água tratada em função do tempo de coleta.

Figura C.4 - Alisamentos das concentrações dos elementos iônicos na água tratada em função do tempo de coleta.

Figura C.5 - Alisamentos das concentrações dos metais na fração sobrenadante em função do tempo de coleta.

Figura C.6 - Alisamentos das concentrações dos metais na fração intersticial em função do tempo de coleta.

Figura C.7 - Alisamentos das concentrações dos metais na fração digestão em função do tempo de coleta.

Figura C.8 - Alisamentos dos índices pluviométricos mensais (mm) em função das concentrações dos metais analisados na água

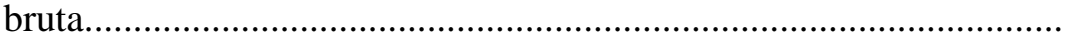

Figura C.9 - Alisamentos dos índices pluviométricos mensais (mm) em função das concentrações dos elementos iônicos analisados na água bruta.

Figura C.10- Alisamentos dos índices pluviométricos do período (mm) em função das concentrações dos metais analisados na água bruta.

Figura C.11- Alisamentos dos índices pluviométricos do período $(\mathrm{mm}) \mathrm{em}$ função das concentrações dos metais analisados na água tratada

Figura D.1 - Dendrogramas das concentrações dos metais na água bruta em relação à época de coleta.

Figura D.2 - Dendrogramas das concentrações dos metais na água tratada em relação à época de coleta.

Figura D.3 - Dendrogramas das concentrações dos metais na fração digestão em relação à época de coleta.

Figura D.4 - Dendrogramas das concentrações dos elementos iônicos na água bruta em relação à época de coleta.

Figura D.5 - Dendrogramas das concentrações dos elementos iônicos na água tratada em relação à época de coleta.

Figura E.1 - Difratograma da fração argila de sedimento pertencente a comunidade IG 60 (Natural) 
Figura E.2 - Difratograma da fração argila de sedimento pertencente a comunidade IG 60 (Glicolada)........................................................

Figura E.3 - Difratograma da fração argila de sedimento pertencente a comunidade IG 60 (Aquecida).........................................................

Figura E.4 - Difratograma da fração argila de sedimento pertencente a comunidade IG 63 (Natural)........................................................

Figura E.5 - Difratograma da fração argila de sedimento pertencente a comunidade IG 64 (Natural)......

Figura F.1 - Áreas de captação de água para abastecimento da SABESP, pertencente a UGRHI 9 - Mogi-Guaçu....

Figura F.2 - Áreas de captação de água para abastecimento da SABESP, pertencente a UGRHI 4 - Pardo 


\title{
LiSTA DE ABREVIATURAS E/OU DEFINIÇÕES
}

\begin{abstract}
A
AAS: Atomic Absorption Spectrometric - Espectrometria de absorção atômica

ACP: Análise de componentes principais.
\end{abstract}

Afloramento: Exposição diretamente observável de uma rocha.

Aglomerado: Rocha piroclástica constituída de fragmentos grosseiros.

Alcalina (rocha): Rocha magmática caracterizada pela alta porcentagem de álcalis em relação à sílica e a alumina.

Aluvião: Termo genérico designativo de todos os detritos e materiais depositados ou em transito nos curso de água, inclusive cascalho, areia, silte, argila, assim como todas as suas variações e misturas.

Amorfo: Não cristalino

Areia: Partícula de solo com dimensões entre 0,05 e $2 \mathrm{~mm}$ de diâmetro.

Argila: Fração granulométrica do solo $<0,002$ mm de diâmetro equivalente.

Argilomineral: Ocorrência natural de material inorgânico (em geral cristalino) encontrada em solos e em outros depósitos terrosos; as partículas apresentam-se com tamanho da argila, isto é < 0,002 $\mathrm{mm}$ de diâmetro.

\section{B}

Bacia Sedimentar: Área de sedimento mais ou menos extensa em que as camadas mergulham em geral da periferia para o centro.

Basal: Conglomerado representando o inicio de uma transgressão numa seqüência sedimentar. Em condição similar, mas com litologia diversa pode-se referir arenito basal, arcósio basal, etc.

C

Caulinita: Mineral silicato de alumínio com reticulado cristalográfico do grupo 1:1, isto é, que consiste numa lâmina tetraédrica de silício, alternada com uma lâmina octaédrica. Constituinte das rochas 
sedimentares detríticas e da argila dos solos. Origina-se da alteração de aluminossilicatos (feldspato e mica).

CETESB: Companhia de Tecnologia de Saneamento Ambiental.

Classe de textura de solo: Agrupamento de unidades texturais do sol, baseado nas proporções relativas das diversas frações granulométricas do solo (areia, silte e argila).

Clástico: Composto de fragmentos partidos de rochas e de minerais.

Clorita: Encontrada em quase todos os tipos de rocha, é constituinte importante de rochas metamórficas.

Colóide do solo: Matéria orgânica e inorgânica, com tamanho de partícula muito pequeno e que possui, em concomitância, grande área de exposição por unidade massa.

Conglomerado: Rocha clástica formada de fragmentos arredondados e de tamanho superior ao de um grão de areia.

CONAMA: Conselho Nacional do Meio Ambiente.

Cristalino: Estado da matéria sólida, caracterizado por uma estrutura interna regular e periódica.

Cuesta: Elevação assimétrica, escarpada de um lado, e caindo suavemente do outro.

\section{D}

DAEE: Departamento de Água e Energia Elétrica.

Diagênese: Transformação de sedimentos incoerentes em rochas. P.e.: a consolidação de argila em argilito ou em folhelho. É caracterizada por condições de pressão e de temperatura semelhantes as reinantes na superfície terrestre.

Dique: Massa rochosa de forma tabular discordante preenchendo um fenda aberta em outra rocha.

DOU: Diário Oficial da União. 


\section{$\mathbf{E}$}

Eutrófico: Corpos de água com alta produtividade de nutrientes em relação às condições naturais, de baixa transparência, em geral afetados por atividades antrópicas, em que ocorrem alterações indesejáveis na qualidade da água e interferências no seus múltiplos usos.

EPA: Environmental Protection Agency - Agência de Proteção Ambiental.

Esmectita: Grupo de argilas silicatadas que possuem estrutura de reticulados do tipo 2:1, tanto nas duas lâminas tetraédricas quanto na octaédrica, o que possibilita elevada carga negativa no permeio das lâminas e também ampla capacidade de permuta de cátions; tal fato induz a grandes expansões dos permeios, com conseqüentes intumescimentos e contrações alternados.

ETA: Estação de Tratamento de Água.

EUA: Estados Unidos da América.

\section{$\mathbf{F}$}

FAAS : Florescence Absorption Atomic Espectrometric- Espectrometria de absorção de fluorescência atômica.

Filossilicatos: Apresentam estruturas em lâminas onde 3 oxigênios de cada tetraedro são compartilhados com os tetraedros adjacentes. A maioria dos argilominerais pertencem a este grupo.

\section{G}

Granada: Mineral característico de rochas metamórficas (xistos e gnaisses), sendo também encontradas em rochas ígneas ultrabasicas e graníticas. Sua alteração produz clorita e hidróxido de ferro (limonita).

Gênese do solo: Sistemática da origem do solo, com referência especial aos processos responsáveis pelo desenvolvimento do solum, que é o verdadeiro solo, a partir do mineral originário, não consolidado.

GF-AAS : Grafite Furnace - Atomic Absorption Spectrometric Espectrometria de absorção atômica com atomização eletrotérmica ou formo de grafita.

GPS: Global Positioning System - Sistema de posição global. 


\section{$\mathbf{H}$}

HPLC: High Performance Liquid Chromatography - Cromatografia Líquida de Alta Eficiência.

IBGE: Instituto Brasileiro de Geografia e Estatística.

IC: Ion Chromatographic - Cromatografia de íons.

ICP-OES: Inductively Coupled Plasma Optical Emission Spectrometric Espectrometria de emissão óptica com plasma de argônio.

ICP-MS: Inductively Coupled Plasma - Mass Spectrometric - Espectrometria de massas com plasma de argônio.

IG: Designação da SABESP para o núcleo do interior dos rios Pardo e Grande. A SABESP para melhor gerenciar os recursos hídricos e distribuir água potável, agrupou três grandes núcleos: Região Metropolitana - "M" (Centro, Norte, Leste, Sul e Oeste), Litoral - "L" (Baixada Santista, Vale do Ribeira e Litoral Norte) e Interior - "I" (Vale do Paraíba, Médio Tietê, Baixo Tietê e Grande, Alto Paranapanema, Baixo Paranapanema; Pardo e Grande).

Ilita: Mica hidratada.

Intemperismo: Todas as modificações físicas e químicas produzidas em rochas, à superfície do solo ou nas suas proximidades, por agentes atmosféricos.

Intrusiva: Introdução de material magmático no interior da crosta. As formas de intrusão são: batólitos, diques, sills e necks.

\section{$\mathbf{M}$}

Maciço: Bloco da crosta terrestre limitado por falhas sem modificação interna.

Magmática: Rocha proveniente da consolidação do magma.

MAS: Methanesulfonic acid - Ácido Metanosulfônico.

Matéria orgânica no solo: Fração orgânica do solo que inclui resíduos vegetais e animais em diversos estágios de decomposição, células e 
tecidos dos organismos do solo e substâncias sintetizadas pela população do solo.

Material originário: Matéria orgânica ou material não consolidado e submetido a intemperismo químico, de onde se desenvolve o solum dos solos, por processos pedogênicos.

Mesotrófico: Corpos de água com produtividade intermediária de nutrientes, com possíveis implicações sobre a qualidade da água, mas em níveis aceitáveis, na maioria dos casos.

Mica Hidratada: Argila silicatada que possui estrutura reticulada do tipo 2:1, em que parte do silício da lâmina tetraédrica foi substituída por alumínio; dispões de muito potássio no permeio das camadas, o que retém unidas e impede a expansão desses permeios mediante dilatação. Outrossim, limita sua capacidade de permuta de cátions.

Montmorilonita: Mineral argiloso aluminossilicatado do grupo esmectita, com reticulado cristalográfico expansionista do tipo 2:1, com duas lâminas tetraédricas de silício que entremeiam uma lâmina octaédrica de alumínio.

Muscovita: Mica mais comum e importante das rochas metamórficas (gnaisse, xisto e quartzitos). Por intemperismo pode se tranformar em cxaulinnta ou gibbsita.

NAA: Neutron Activation Analysis - Análise por ativação neutrônica.

NIST: National Institute of Standards \& Technology - Instituto Nacional de Padrões \& Tecnologia (E.U.A).

\section{$\mathbf{O}$}

Oligotrófico: Corpos de água limpos, de baixa produtividade de nutrientes, em que não ocorrem interferências indesejáveis sobre os usos da água.

\section{$\mathbf{P}$}

Pedogênese: É a parte da ciência do solo que tenta explicar os fatores e processos que intervêm na gênese e evolução dos solos. 
Petrográfico: Rocha plástica em estado úmido, integrada Por elementos clásticos finos, com diâmetros compreendidos entre 4 e $2 \mu$.

PIXE: Particle Induced X ray Emission - Emissão de raios X emitido por partículas

PTFE: Politetrafluoretileno.

Rocha Ígnea: Rocha formada mediante esfriamento e solidificação do magma e que não passou por modificações apreciáveis após sua formação.

Rocha metamórfica: São derivadas de outras pré-existentes que, no decorrer dos processos geológicos, sofreram mudanças mineralógicas, químicas e estruturais.

Rocha sedimentar: Rocha formada com materiais em suspensão ou precipitados de solução e que se encontram mais ou menos consolidados. As rochas sedimentares mais importantes são arenitos, folhelhos, calcários e conglomerados.

RPM: Rotação por minuto.

$\mathbf{S}$

SABESP: Companhia de Saneamento Básico do Estado de São Paulo.

Sills: Massa rochosa de forma tabular concordante preenchendo uma fenda aberta em outra rocha.

SPSS: Statistical Packet of Social Science - Pacote estatístico de ciências sociais

SRM: Standard Reference Material - Material de Referência Padrão.

\section{$\mathbf{T}$}

Textura: Aspecto menor inerente à rocha, que depende do tamanho, forma arranjo e distribuição dos seus componentes.

W

WHO: World Health Organization - Organização Mundial da Saúde. 


\section{INTRODUÇÃo}

As reservas hídricas do planeta Terra são estimadas em 1.400 milhões de $\mathrm{km}^{3}$. Embora expressivas, apenas $2 \%$ são de água doce, constituindo os rios, lagos, e águas subterrâneas, praticamente $1 \%$ de neve e geleiras permanentes e apenas $0,0005 \%$ de vapor d'água na atmosfera. Excluindo-se a água contida nas calotas polares e nos aquíferos, a humanidade conta com pouco mais de $2.000 \mathrm{~km}^{3}$ das águas dos rios para suprir quase a totalidade de suas demandas. Destes recursos, quase metade $\left(946 \mathrm{~km}^{3}\right)$ encontra-se na América do Sul [REBOUÇAS et al., 1999].

Visto que a água é um recurso renovável, o seu reuso pode ser comprometido pela qualidade, que se deteriora em função do grande aporte de resíduos e rejeitos oriundos das atividades antrópicas.

É muito difundido no nosso país a crença de que os efluentes industriais são os grandes responsáveis pela degradação dos recursos hídricos. Salvo alguns bolsões de alta concentração industrial, o esgoto doméstico ainda é o principal responsável pela situação atual em que se encontram os nossos mananciais. No entanto, o crescimento industrial e agrícola projetado para os países em desenvolvimento pode alterar esta tendência.

Existem cerca de vinte elementos considerados tóxicos para a saúde dos humanos incluindo $\mathrm{Hg}, \mathrm{Cd}, \mathrm{Pb}, \mathrm{As}, \mathrm{Mn}, \mathrm{Tl}, \mathrm{Cr}, \mathrm{Ni}, \mathrm{Se}, \mathrm{Te}, \mathrm{Sb}, \mathrm{Be}, \mathrm{Co}, \mathrm{Mo}, \mathrm{Sn}, \mathrm{W}$ e V. Destes, os dez primeiros são os de maior utilização industrial e, por isso mesmo, são os mais estudados do ponto de vista toxicológico. Tais elementos reagem com ligantes difusores, com macromoléculas e com ligantes presentes em membranas o que, muitas vezes, lhes conferem as propriedades de bioacumulação, biomagnificação na cadeia alimentar, persistência no ambiente e distúrbios nos processos metabólicos dos seres vivos. As bioacumulações e biomagnificações se encarregam de transformar concentrações consideradas normais em concentrações tóxicas para as diferentes espécies da biota e para o homem. A persistência garante os efeitos ao longo do tempo ou de longo prazo, mesmo depois de interrompidas as emissões [TAVARES \& CARVALHO, 1992]. 
Muitos desses elementos são essenciais a vida na Terra. Geralmente, as concentrações naturais estão na faixa de parte por milhão ou parte por bilhão e a natureza se encarrega de oferecer as quantidades necessárias para a manutenção saudável do ciclo vital. Outros metais não exercem nenhuma função conhecida no ciclo biológico, sendo suas concentrações naturais na faixa de parte por milhão ou parte por bilhão. Em ambos os casos, a presença de concentrações crescente de metais acima das naturais passa do meramente tolerável ao tóxico.

A toxicidade dos metais é uma questão de dose ou tempo de exposição, da forma física e química do elemento e da via de administração/adsorção.

As principais fontes antrópicas de metais no ambiente são fertilizantes, pesticidas, água de irrigação contaminada e queima de biomassa na zona rural, combustão a carvão e óleo, emissões veiculares, incineração de resíduos urbanos e industriais e, principalmente mineração, fundição e refinamento, tanto nas regiões urbanas como na zona rural. Existe uma demanda crescente de muitos metais nos países desenvolvidos e em desenvolvimento. Dessa forma, parte dos metais imobilizados nos depósitos naturais estão sendo transformados em metais mobilizados no ambiente.

A agricultura constitui uma das mais importantes fontes não pontuais de poluição por metais [ALLOWAY et al., 1997]. As principais fontes são:

- Impurezas em fertilizantes: Cd, Cr, Mo, Pb, U, V, Zn (por exemplo: Cd e U em fertilizantes fosfatados);

- Pesticidas: $\mathrm{Cu}, \mathrm{As}, \mathrm{Hg}, \mathrm{Pb}, \mathrm{Mn}, \mathrm{Zn}$ (ex. Cu, Zn e Mn em fungicidas);

- Preservativos de madeira: As, $\mathrm{Cu}, \mathrm{Cr}$;

- Dejetos de produção intensiva de porcos e aves: $\mathrm{Cu}, \mathrm{As}, \mathrm{Zn}$.

A água proporciona um habitat para um grande número de vegetais, animais e espécies microscópicas sendo estes organismos diretamente afetados pela composição da água. Um ser humano adulto consome aproximadamente $2 \mathrm{~L}$ de água potável por dia, mas normalmente utiliza muito mais para cozinhar, lavar e para higiene. Somente a água usada para cozinhar e beber necessita ser de alta pureza, mas na maioria dos casos o mesmo 
suprimento doméstico é usado para todas os propósitos [ALLOWAY et al., 1997 e REBOUÇAS, 1999].

Do ponto de vista ambiental e legal, os rios são classificados de acordo com o nível de qualidade que deve ser mantido em função dos usos previstos para suas águas, sendo as maiores exigências para as águas de reservas ecológicas e às que se destinam ao abastecimento público. A qualidade das águas na Bacia depende da natureza geológica do terreno, da cobertura vegetal e do uso e ocupação do solo. Uma avaliação da correlação de várias espécies em águas superficiais reflete fielmente o uso que é feito dos solos da bacia correspondente.

O material inorgânico e orgânico nos sedimentos de rios e lagos pode ser um importante meio de avaliação da poluição uma vez que estes estão predispostos a rápidas trocas na composição com a coluna de água. A troca dos íons do sedimento para a coluna de água enriquece o sedimento na fração argila $(2-4 \mu \mathrm{m})$. Nesta fração os poluentes se agregam com maior facilidade por existir uma maior área superficial e nesta fração existem diferentes grupos argilominerais com capacidade de troca iônica distinta. Portanto, amostras de sedimento podem ser um guia útil para a avaliação da história da poluição de um corpo da água. Amostragem e análise de sedimento de rios e riachos têm provado ser uma ferramenta muito útil nos estudos de poluição [BRADY, 1989]

Recentemente, sedimentos de rios, lagos e oceanos contaminados têm-se tornado assunto de interesse. O sedimento está associado a contaminantes que podem ser transportados por ressuspensão de partículas do próprio sedimento, podem acumular uma cadeia alimentar ou afetar a biota ou ainda a qualidade da água no ambiente aquático. Para se avaliar a contaminação do sedimento no meio ambiente aquático é necessário coletar amostras para definir as características químicas e físicas do sedimento adequadamente, verificar o transporte de sedimento-contaminante associado por ressuspensão da partícula de sedimento ou imigração sedimento-água (fase intersticial), e testar os efeitos dos sedimentos contaminados na biota. Até o presente, não há um método definitivo de padronização na amostragem de sedimentos, de partículas de sedimento e da fase intersticial, e para o manuseio das amostras para análises físico-químicas [MUDROCH \& MACKNIGHT, 1994]. 
Historicamente, o entendimento dos mecanismos de transporte dos metais pesados no meio ambiente e seus efeitos em sistemas biológicos estiveram intimamente associados ao desenvolvimento da química analítica. Métodos sensíveis são essenciais para a determinação desses elementos. Especificidade em relação à espécie química do metal é altamente desejável para a elucidação de mecanismos e avaliação precisa dos efeitos. Especificidade em relação às fases ou parcelas de uma fase (geralmente obtida na etapa amostral) é necessária para descrição do transporte dos metais. A multi-elementariedade da análise é desejável para permitir analogias e avaliações ambientais mais abrangentes [GATTI, 1997 e MOZETO \& ALBUQUERQUE, 1997].

$\mathrm{Na}$ grande maioria dos casos são necessárias análises em escala micro (ng $\mathrm{mL}^{-1} \mathrm{a}$ $\mu \mathrm{g} \mathrm{mL} L^{-1}$ ) e geralmente a quantidade de amostra disponível é pequena. A análise pontual em amostras sólidas e em partículas individuais permite obter informação da distribuição de um metal sobre a superfície e, a análise a diferentes profundidades da amostra de sedimento oferece informação histórica sobre partículas individuais.

A Legislação Brasileira sobre os limites de contaminantes na água existe desde a década de 70. A legislação ambiental vigente - Resolução CONAMA n ${ }^{\circ}$ 20/86 - classifica as águas do território brasileiro, de acordo com a sua salinidade e de diferentes usos a que se destinam.

A Legislação Nacional sobre Potabilidade da Água, elaborada pelo Ministério da Saúde, é a Portaria 36/GM-MS/90 (D.O.U. 19/01/90), que foi usada como referência neste trabalho, que foi substituída pela Portaria $\mathrm{n}^{\mathrm{o}}$ 1469/GM-MS/00, publicada no DOU de 29/12/2000 que: "Dispõe sobre procedimentos e responsabilidades inerentes ao controle e à vigilância da qualidade da água para consumo humano, estabelece as normas e o padrão de potabilidade da água para consumo humano, e dá outras providências", discriminando os valores máximos permitidos das substâncias que afetam a saúde, indicando também, a freqüência mínima de amostragens para a análise dos parâmetros estabelecidos (esta Portaria atualizou o Decreto Federal n ${ }^{0} 79.637 / 77$ e Portaria 56/77).

A água dita "potável” (por definição: água para consumo humano cujos parâmetros microbiológicos, físicos, químicos e radiológicos atendam ao padrão de potabilidade e não ofereçam riscos a saúde) deve não apenas ser inócua à saúde, como também portadora de 
substância "protetoras" desta última, como é o caso da aplicação de compostos de flúor como preventiva da cárie dentária.

A água é indispensável à vida e é necessária tê-la a disposição para um abastecimento satisfatório, fazendo todo o possível para se obter a melhor qualidade que as circunstâncias permitem. A primeira linha de defesa é protegê-la da contaminação e para isso, o melhor método é proteger a fonte, o que é preferível ao tratamento da água contaminada.

Além do esgoto doméstico, um fator que pode comprometer a qualidade da água de um manancial é a presença de certas atividades industriais, mesmo que artesanais ou extrativas, que levam às águas princípios tóxicos, e de atividades agrícolas, mesmo que pontuais, principalmente quando a captação de água para a distribuição à população é superficial.

O serviço público de abastecimento de água vem, cada vez mais, se deparando com situações críticas em relação à qualidade de seus pontos de captação, devido a aceleração da degradação ambiental.

O Estado de São Paulo, que detém uma alta predominância agrícola e pastoril, tem nos defensivos uma fonte significativa de poluição ambiental. Agregado ao uso inadequado dos agrotóxicos, temos despejos de resíduos de usinas de açúcar e álcool e os efluentes industriais.

Devido a necessidade de avaliar de forma integrada o comportamento de sistemas hídricos destinados a captação de água para fim de potabilidade, procurou-se neste trabalho, contribuir para o desenvolvimento de estudos de diagnóstico ambiental, com ênfase em programas de monitoramento em ambiente aquáticos naturais e de sistema de tratamento e distribuição da água, significando uma contribuição para o desenvolvimento sustentável da região em estudo.

O estudo está voltado para a avaliação da contribuição de metais tóxicos e elementos, essências a saúde, bem como ânions e cátions em água bruta, tratada, 
sedimentos e água intersticial e, de espécies biodisponiveis em área destinadas a captação de água superficial.

Para o desenvolvimento deste estudo escolheu-se com área piloto 13 comunidades pertencentes as Bacias hidrográficas dos rios Mogi-Guaçu e Pardo. Estudos realizados pela Companhia de Tecnologia de Saneamento Ambiental do Estado de São Paulo [CESTESB, 1989] demonstraram que estas bacias foram consideradas as Bacias do Estado com maior número de casos de mortandade de peixes; somando-se $51,1 \%$ do total.

Este projeto completa as ferramentas de avaliação de risco do projeto "Modelagem Diagnóstica e Prognóstica da Qualidade da Água em Áreas de Captação”, em parceria com a Sabesp e o Instituto de Biociências da USP, financiado pelo FINEP/PADCT III e CNPq/RHAE, nº 03-PCRS-01/98 e nº 610039/89-9, respectivamente.

No contexto de política estadual de controle da qualidade da água, este projeto também contribui para a melhoria contínua da qualidade da água para consumo humano, fornecendo subsídios ao projeto 00/02024-4, Programa de Pesquisa em Políticas Públicas, financiado pela FAPESP, sob o título "Análise crítica do padrão de potabilidade da água destinada ao abastecimento público: Avaliação da qualidade das águas destinadas ao abastecimento público em áreas de captação do Estado de São Paulo" também sob coordenação da Dra. Maria Aparecida F. Pires. 


\section{OBJetivos e ASPECtOS RELEVANTES do TrABALHO}

\subsection{OBJETIVO GERAL}

Avaliar a qualidade ambiental de estações de captação superficial pertencentes as Bacias Hidrográficas dos Rios Mogi-Guaçu e Pardo realizando um diagnósticos dos sistemas de captação quanto a contribuição de metais e elementos-traço na coluna de água e após tratamento convencional e, de metais imobilizados concentrados no sedimento que tem tendência a se tornarem biodisponíveis.

\subsection{OBJETIVOS ESPECÍfICOS}

- Obter informações sobre a distribuição espacial e temporal da ocorrência e abundância de metais e elementos - traço em áreas de captação de água superficial, destinadas ao abastecimento público em 13 tributários, pertencentes as Bacias Hidrográficas dos Rios Mogi-Guaçu e Pardo, Estado de São Paulo.

- Desenvolver um estudo geoquímico das águas e sedimentos nas estações de captação de água.

- Avaliar e monitorar os efeitos das atividades antrópicas em áreas de captação visando um programa de proteção a saúde pública e conservação e recuperação do meio ambiente.

- Realizar um gerenciamento de ecossistemas aquáticos, destinados a captação de água potável, compreendendo as etapas de monitoramento, integração de monitoramento, controle, uso e tratamento dos resultados, banco de dados, análise estatística e de implantação de sistema suporte à decisão com base nesses dados. 


\section{3. ÁREA DE ESTUdO}

A área objeto de estudo engloba os municípios da gerência Divisional de São João da Boa Vista, a saber: São João da Boa Vista, Águas da Prata, Espírito Santo do Pinhal, Santo Antônio do Jardim, Cascata, Vila Nossa Senhora Aparecida, São Roque da Fartura, Campestrinho, Divinolândia, Itobi, São Sebastião da Grama e o município de Mococa.

A escolha da área levou em conta vários aspectos sócio-econômicos, bióticos e abióticos e políticos:

a) É a única área do Estado de São Paulo cujas captações são todas superficiais, mais susceptíveis à contaminação antrópica;

b) Faz parte da Bacia do Mogi-Guaçu que é área de recarga do aqüífero Guarani, que ocupa $60 \%$ do estado e se constitui na principal reserva de água subterrânea do estado;

c) A falta de informação sobre o impacto de metais na região;

d) O grande interesse da Companhia de Saneamento Básico do Estado de São Paulo (SABESP) e das prefeituras locais em avaliar a região;

e) A existência do CIPREJIM - Consórcio Intermunicipal de Preservação da Bacia do Jaguarí - Mirim, firmado em 1981, dos quais fazem parte 06 comunidades das 11 integrantes da área de estudo.

A região escolhida apresenta uma precipitação média de $1.408 \mathrm{~mm} \mathrm{ano}^{-1}$, dos quais $40 \%$ são convertidos em escoamento superficial. Os $60 \%$ restantes alimentam os recursos subterrâneos que são de extrema importância, pois representam ricas reservas de água. A rede de drenagem da região apresenta algumas nascentes minerais e pontos de contaminação pontual e não pontual. Essa região possui uma agricultura diversificada, grandes industriais de papel e celulose e alimentícia (refinados de milho e lacticínios), destacando-se também a exploração mineral das bacias [OLIVEIRA et al., 1995]. 
O Vale do Jaguari-Mirim pertence a bacia do Mogi-Guaçu, localiza-se na região nordeste do Estado de São Paulo. Os municípios dessa região são: São João da Boa Vista, Vargem Grande do Sul, Aguaí e Santo Antônio do Jardim. Estudos sobre a mata ripária no médio Rio Jaguari - Mirim, realizados por Azevedo [AZEVEDO, 1994], contribuíram para o estudo do impacto das atividades humanas sobre o ambiente. Azevedo observou que as atividades extrativistas, de madeira para construção e lenha no passado e de argila e areia, atualmente, têm sido as responsáveis pela devastação e não regeneração da mata ripária do médio Jaguari-Mirim.

Recentemente Gatti, [GATTI, 1997], estudou através da avaliação dos sedimentos em ambientes lacustres o registro histórico da atividade antrópica na Bacia do Rio Mogi-Guaçu.

\subsection{LeVantamento da Situação Geográfica e Geológica}

A área em estudo está localizada na região nordeste do Estado de São Paulo, cerca de $180 \mathrm{~km}$ da capital paulista, engloba 9 municípios e 4 distritos (Figura 3.1). Geologicamente, a região em estudo é representada, predominantemente, por rochas do Complexo Varginha de idade arqueana (anterior a 2,5 bilhões de anos), estendendo-se nas regiões de Pinhal, São João da Boa Vista, São José do Rio Pardo e Caconde.

A topografia da região em estudo é acidentada, apresentando as maiores altitudes nos contrafortes do edifício vulcânico de Poços de Caldas com cotas ao redor de 1500 metros. As altitudes decrescem em direção a oeste chegando a 700 metros no limite da área. A geomorfologia corresponde à transição entre as uniformidades morfoesculturais do Planalto Atlântico (Planalto do Alto Rio Grande) e Depressão Periférica Paulista (Depressão Mogi-Guaçu) [OLIVEIRA et al., 1995].

A área do Estado de São Paulo faz parte da Plataforma Sul-Americana, e o seu registro geológico, embora não retrate de modo contínuo o tempo, é bastante extenso. Até o inicio do Paleozóico na metade oriental do Brasil constituíram-se rochas diversas, por processos distintos, compondo o que tradicionalmente se chama complexo cristalino (por ser formado essencialmente de rochas magmáticas e metamórficas), ou basal (por 
se posicionar estratigraficamente sob mantos sedimentares) e que representa o embasamento da plataforma [IPT, 1981].

De acordo com IPT [1981] na área de estudo destacam-se constituições geológicas das eras Proterozóica, Paleozóica, Mesozóico e Cenozóica. No Pré-cambriano tem-se o Complexo de Varginha que aprece nas regiões de Pinhal, São João da Boa Vista, São José do Rio Pardo e Caconde, sendo delimitado pela falha de Jacutinga que opõe em confronto com o Complexo Amparo. A litologia predominante na unidade são migmatitos diversos de paleossomas granulíticos, calcosilicáticos, anfibolítico, xistosos, dioríticos e quartzíticos incluindo ainda termos gnássicos a biotita e granada já bastante migmatizados (AvHM). Esta associação litológica distribui-se pelas áreas de São João da Boa Vista, Caconde, Mococa, penetrando pelo vizinho Estado de Minas Gerais. Também são encontrados diversos núcleos, bolsões e faixas de rochas granulíticas $(\mathrm{AvH})$ relativamente preservada do processo de migmatização. São constituídos de charnockitos, granulitos básicos e ácidos e piroxênio granulitos, destacando-se os núcleos de Mococa e Divinolândia. A mediada que se caminha para o sul existe progressivo feldspatização, migmatização, a uma associação litológica de migmatitos, corpos anatexíticos e granitóides diversos (AvM). A medida que se caminha para o sul existe progressivo feldspatização, migmatização, a uma associação litológica de migmatitos, corpos anatexíticos e granitóides diversos (AvM). [IPT, 1981].

Da era Paleozóica existe o afloramento da Formação Aquidauana (Cpa) na região de Águas da Prata que estreita-se para o norte. Nela se apresenta as rochas em maior parte desfeitas em solos arenosos. Pequenas ocorrências isoladas da Formação Aquidauana no embasamento cristalino ocorrem a oeste de Aguaí e na borda ocidental do maciço de Poços de Caldas, na região de Águas de Prata. No Cretáceo existe a suíte alcalina presente no maciço de Poços de Caldas (Ka3d). Situa-se quase inteiramente no Estado de Minas Gerais, porém sua borda ocidental penetra em São Paulo, na região vizinha a Águas da Prata. Embora quase inteiramente constituída de rochas intrusivas, possui algumas lavas e rochas piroclásticas, justamente na região onde penetra em São Paulo. É uma suíte de rochas de natureza agpaítica, com várias peculiaridades que a distinguem dentro da província alcalina. O Jurássico está representado pela Formação Intrusiva Básica com Corpos Intrusivos Tabulares (JKß), na parte superior das cuestas basálticas e de morros testemunhos delas isolados pela erosão. Nos planaltos de rebordo dessas cuestas podem 


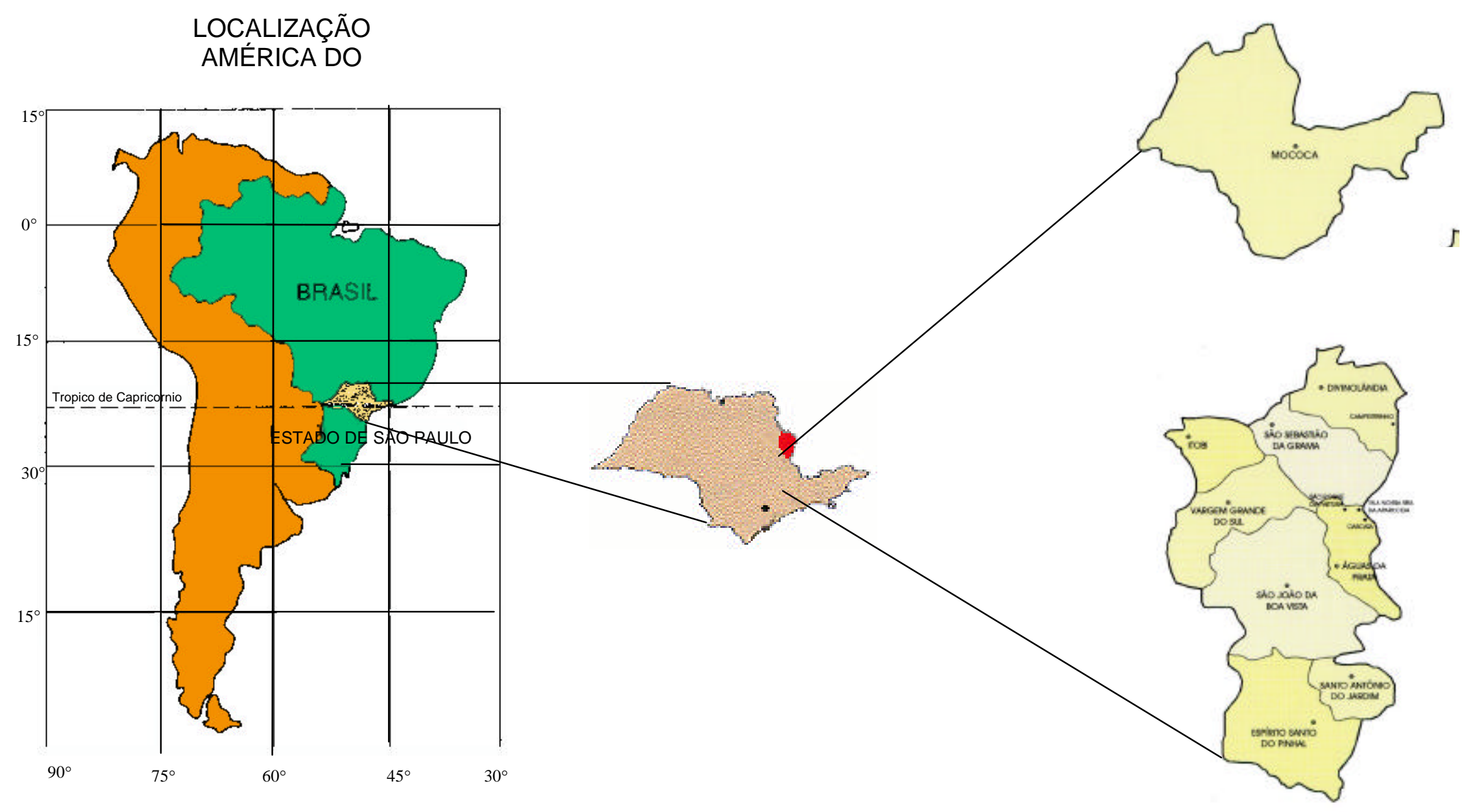

Figura 3.1 - Localização da região em estudo 
cobrir grandes extensões, como o nordeste do Estado. Penetram pelos vales que drenam o Planalto Ocidental, expondo-se principalmente nos dos rios Paranapanema, Tietê, MogiGuaçu e Grande. No Cenozóico de Formação de Rico Claro (TQir) que é constituída por sedimentos predominantemente areníticos, por vezes conglomeráticos, com lâminas e leitos de argilas subordinados. Os depósitos aluviais (Qa) da Depressão Periférica, de várzeas e terraços, têm uma notável expressão em área a norte do rio Tietê, diversamente do que ocorre a sul desse curso de água. Essa divisão coincide com a maior abundância de "sills" básicos também do norte do Tietê, situação muito favorável à criação de soleiras litológica a montante das quais ter-se-iam acumulados os aluviões. Esta mesma situação deve ter prevalecido quando da deposição da Formação do Rio Claro e correlatas [IPT, 1981].

Do ponto de vista da geologia, a área se caracteriza por uma complexa associação de rochas de várias composições químicas e de várias características texturais [OLIVEIRA \& BRITO, 1998]. Conseqüentemente isso se reflete na composição química da água. Em termos litológicos ocorrem na área [THEODOROVICZ \& THEODOROVICZ, comunicação pessoal]:

- Granito-gnaisse: rochas ricas em feldspato potássio [ $\mathrm{KAlSi}_{3} \mathrm{O}_{8}$, plagioclásio $\quad\left[(\mathrm{Na}, \mathrm{Ca})\left(\mathrm{Al}, \mathrm{Si}_{)} \mathrm{AlSi}_{2} \mathrm{O}_{8}\right], \quad\right.$ biotita $\left[\mathrm{K}_{2}(\mathrm{Mg}, \mathrm{Fe}, \mathrm{Al})_{6}(\mathrm{Si}, \mathrm{Al})_{8} \mathrm{O}_{20}(\mathrm{OH})_{4}\right], \quad$ quartzo $\quad\left[\mathrm{SiO}_{2}\right] \quad$ e hornblenda $\left[(\mathrm{Na}, \mathrm{Ca})_{2}(\mathrm{Mg}, \mathrm{Fe})_{5} \mathrm{Si}_{7} \mathrm{AlO}_{22}(\mathrm{OH})_{2}\right]$;

- Xisto: composto por muscovita $\left[\mathrm{K}_{2} \mathrm{Al}_{4} \mathrm{Si}_{6} \mathrm{Al}_{2} \mathrm{O}_{20}(\mathrm{OH})_{4}\right]$ e biotita;

- Dioríticos: composto por plagioclásio sódico-cálcico, biotita, hornblenda e/ou piroxênio (composto de augita $\left[(\mathrm{Ca}, \mathrm{Na})(\mathrm{Mg}, \mathrm{Fe}, \mathrm{Al})\left(\mathrm{Si}_{2}, \mathrm{Al}_{2}\right)_{2} \mathrm{O}_{6}\right]$ e clorita $\left.\left[(\mathrm{Mg}, \mathrm{Fe}, \mathrm{Al})_{6}(\mathrm{Al}, \mathrm{Si})_{4} \mathrm{O}_{10}(\mathrm{OH})_{8}\right]\right)$

- Charnockitos: rico em hiperstênio $\left[(\mathrm{Mg}, \mathrm{Fe})_{2} \mathrm{Si}_{2} \mathrm{O} 6\right]$;

- Granada: $\mathrm{Fe}_{3} \mathrm{Al}_{2} \mathrm{Si}_{3} \mathrm{O}_{12}$;

- Rochas calcossilicáticas: à essas rochas estão associadas ocorrências magnesíferas;

- Rochas metabasicas, meta-ultrabasicas e anfibolíticas (hornblenda e plagioclásio): com presença de $\mathrm{Ni}, \mathrm{Ba}, \mathrm{Cd}$ e $\mathrm{Cu}$; 
- Rochas alcalinas de Poços de Caldas: rochas ricas em álcalis ( $\mathrm{K}$ e $\mathrm{Na}$ ), ferromagnesianos (biotita e hornblenda), piroxênio e apatita $\mathrm{Ca}_{10}\left(\mathrm{PO}_{4} \mathrm{CO}_{3}\right)_{6}(\mathrm{~F}, \mathrm{Cl}, \mathrm{OH})_{2}$.

Este conjunto topografia-geologia determinou uma situação peculiar no Estado para o estudo do comportamento das águas. A leste estão os divisores de água determinando as cabeceiras hidrográficas da região. A oeste estão as rochas sedimentares da Bacia do Paraná, que se estendem até Goiás e Mato Grosso, a noroeste, à Argentina a leste e o Uruguai a sudoeste. Assim sendo, estas condições permitem ter-se um domínio dos fatores de influência na constituição das águas e, conseqüentemente das influências antrópicas.

Tomando-se como base o estudo realizado no Estado de São Paulo sobre "Mapeamento da Vulnerabilidade e Risco de Poluição das Águas Subterrâneas no Estado de São Paulo" [IG, CETESB, DAEE, 1997], as informações de caráter estrutural sobre o Censo Agropecuário de 1995-1996, realizado pelo IBGE (Instituto Brasileiro de Geografia

e Estatística) [IBGE, 1997] e o Relatório de Qualidade das Águas Interiores do Estado de São Paulo [CETESB, 1999] foram relacionadas as várias atividades antrópicas responsáveis pela degradação do ambiente (fontes potenciais de poluição), em especial, do possível comprometimento dos recursos hídricos superficiais. Este levantamento permitiu uma identificação inicial da área em estudo.

\subsection{Caracterização da Área Segundo as Unidades de GERENCIAMENTO DE RECURSOS HÍDRICOS - UGRHI'S}

As treze comunidades em estudo constituem os grupos 4 e 9 das Unidades de Gerenciamento de Recursos Hídricos - UGRHI's, divisão adotada pela Lei Estadual n 7663 de Dezembro de 1991, que instituiu a Política Estadual de Recursos Hídricos e o Sistema Integrado de Gerenciamento de Recursos Hídricos [CETESB, 1999](Figura 3.2).

Os municípios de São João da Boa Vista, Águas da Prata, Espírito Santo do Pinhal, Santo Antônio do Jardim, Cascata, Vila Nossa Senhora Aparecida e São Roque da Fartura pertencem a UGRHI-9, denominada Mogi-Guaçu (Figura 3.4). Os municípios de Campestrinho, Divinolândia, Itobi, Mococa, São Sebastião da Grama e Mococa pertencem 
a UGRHI-4, denominada Pardo (Figura 3.5). A Tabela 3.1 apresenta um resumo das principais características das Unidades de Gerenciamento de Recursos Hídricos UGRHI's Pardo e Mogi-Guaçu, SP. A Figura 3.6 apresenta a localização dos pontos de coleta e respectivas unidades geológicas.

De acordo com CETESB [1995], dos municípios estudados, os municípios de Mococa e São João da Boa Vista, quanto da carga potencial de poluição por fontes pontuais decorrentes de atividades industriais, mineração e disposição de resíduos domiciliares, constituem municípios com menos de 3 atividades, no entanto estas são consideradas elevadas (Figura 3.7). Os demais municípios não possuem tais atividades. Estas fontes pontuais poderão gerar cargas significativas com relação ao potencial de degradação dos aquíf́eros. No município de São João da Boa Vista destaca-se a presença de um lixão para disposição de resíduos domiciliares

A título ilustrativo, nas Figuras F.1 e F.2 (Apêndice 6) são mostrados fotografias dos pontos de coletas das UGRHI's 9 e 4, respectivamente. 
Tabela 3.1 - Resumo das principais características das Unidades de Gerenciamento de recursos Hídricos - UGRHI's Pardo e Mogi-Guaçu, SP [CETESB, 1999].

\begin{tabular}{|c|c|c|c|c|c|c|}
\hline UGRHI & $\begin{array}{c}\begin{array}{c}\text { Área / } \\
n^{0} \text { de } \\
\text { municípios }\end{array} \\
\end{array}$ & $\begin{array}{c}\text { Área de } \\
\text { drenagem } \\
\left(\mathbf{k m}^{2}\right)\end{array}$ & $\begin{array}{c}\text { Constituintes } \\
\text { principais }\end{array}$ & $\begin{array}{l}\text { Uso do } \\
\text { solo }\end{array}$ & Uso da água & $\begin{array}{l}\text { Principais } \\
\text { atividades } \\
\text { industriais } \\
\end{array}$ \\
\hline $\begin{array}{c}04 \\
\text { Pardo }\end{array}$ & $\begin{array}{l}8.816 \mathrm{~km}^{2} \\
23 \\
\text { municípios }\end{array}$ & 8.818 & $\begin{array}{l}\text { Rio Pardo } \\
(240 \mathrm{~km})\end{array}$ & $\begin{array}{l}\text { Atividades } \\
\text { Agrícolas, } \\
\text { pastoril, } \\
\text { avícola, } \\
\text { industrial } \\
\text { e urbana. }\end{array}$ & $\begin{array}{l}\text { Abastecimento } \\
\text { público e } \\
\text { industrial, } \\
\text { recepção de } \\
\text { efluentes } \\
\text { domésticos e } \\
\text { industriais, } \\
\text { irrigação de } \\
\text { plantações. }\end{array}$ & $\begin{array}{l}\text { Industriais } \\
\text { alimentícias, } \\
\text { usinas, } \\
\text { engenhos, } \\
\text { curtumes, } \\
\text { papel e } \\
\text { celulose, } \\
\text { metalúrgicas. }\end{array}$ \\
\hline $\begin{array}{c}09 \\
\text { Mogi- } \\
\text { Guaçu }\end{array}$ & $\begin{array}{c}36 \\
\text { municípios }\end{array}$ & 14.653 & $\begin{array}{l}\text { Rio Mogi- } \\
\text { Guaçu } \\
(320 \mathrm{~km})\end{array}$ & $\begin{array}{l}\text { Atividades } \\
\text { agrícolas } \\
\text { (cana-de- } \\
\text { açúcar, } \\
\text { café, } \\
\text { citrus, } \\
\text { milho e } \\
\text { algodão), } \\
\text { pastoril, } \\
\text { granjeira e } \\
\text { urbana. }\end{array}$ & $\begin{array}{l}\text { Abastecimento } \\
\text { público e } \\
\text { industrial, } \\
\text { recepção de } \\
\text { efluentes } \\
\text { domésticos e } \\
\text { industriais, } \\
\text { irrigação de } \\
\text { plantação }\end{array}$ & $\begin{array}{l}\text { Industriais } \\
\text { alimentícias } \\
\text { (feculárias, } \\
\text { laticínios, } \\
\text { frigoríficos e } \\
\text { matadouros), } \\
\text { usinas } \\
\text { engenhos e } \\
\text { destilarias, } \\
\text { curtumes, } \\
\text { papel e } \\
\text { celulose, } \\
\text { metalúrgicas. }\end{array}$ \\
\hline
\end{tabular}

A Figura 3.3 apresenta o mapa da vulnerabilidade das águas subterrâneas segundo estudo do IG, CETESB e DAEE [1997].

Pode-se observar que a área em estudo não representa vulnerabilidade definida, destaca-se Mococa com alta vulnerabilidade das águas subterrâneas. 


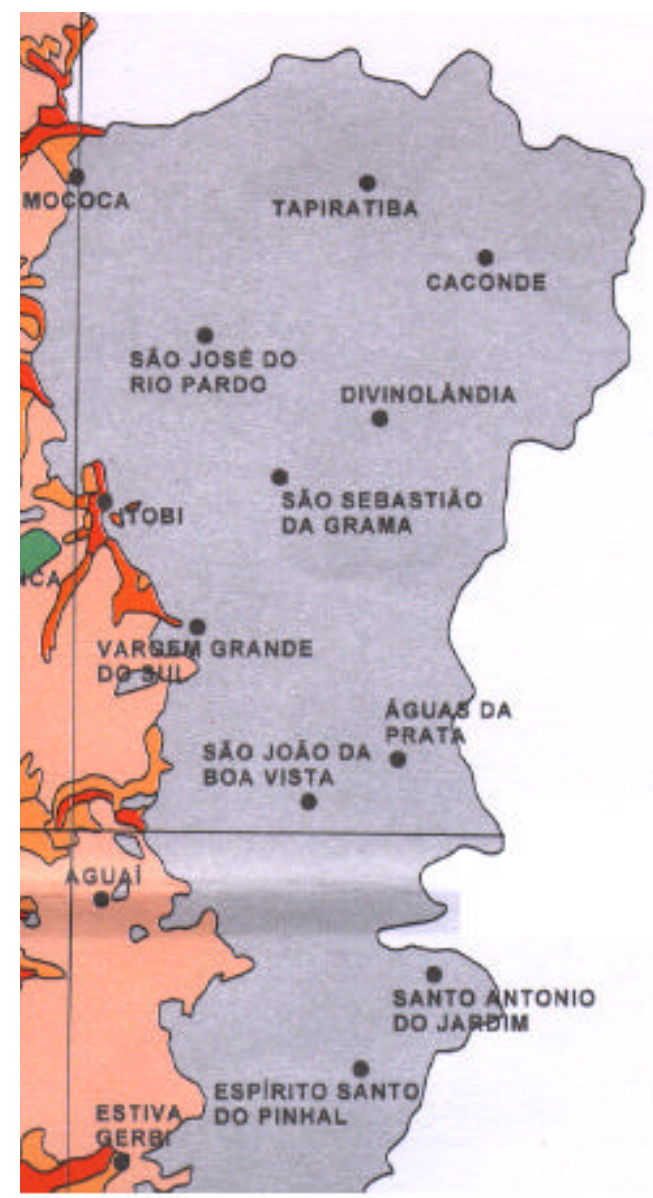

Escala 1: 1000000

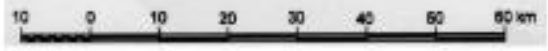

\begin{tabular}{|c|c|c|c|c|c|c|}
\hline \multirow{2}{*}{ Non } & \multicolumn{2}{|c|}{3000} & \multicolumn{2}{|c|}{1000} & \multicolumn{2}{|c|}{$N=0$} \\
\hline & yas & 479 & 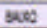 & 500 & 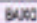 & KTo \\
\hline
\end{tabular}

Figura 3.3 - Mapa esquemático da vulnerabilidade das águas subterrâneas da região estudada [CETESB, 1999] 


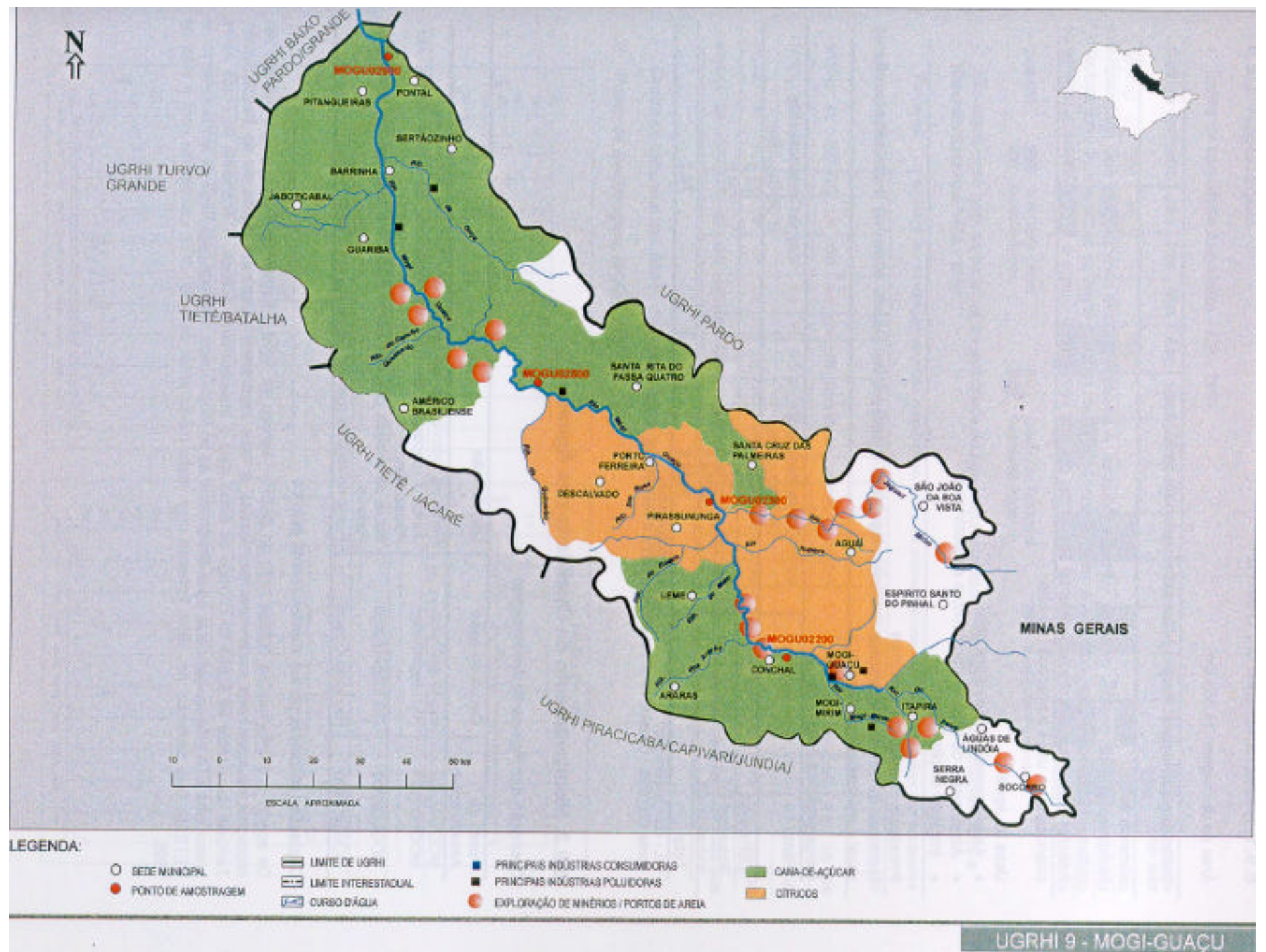

Figura 3.4 - Mapa esquemático da UGRHI-9, contendo os seus principais corpos de água, municípios, atividades agrícolas e industriais [CETESB, 1999]. 


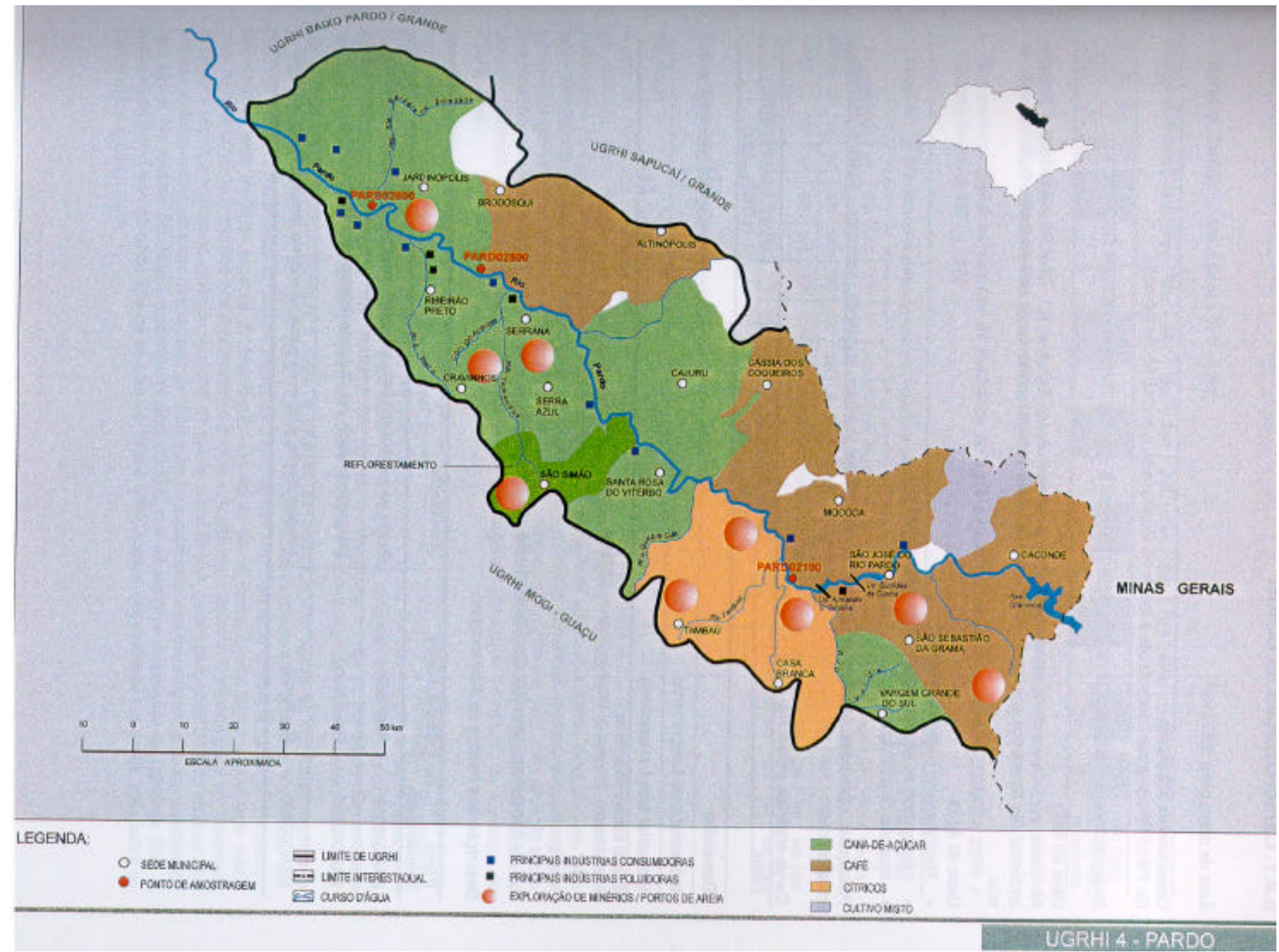

Figura 3.5 - Mapa esquemático da UGRHI-4, contendo os seus principais corpos de água, municípios, atividades agrícolas e industriais [CETESB, 1999]. 


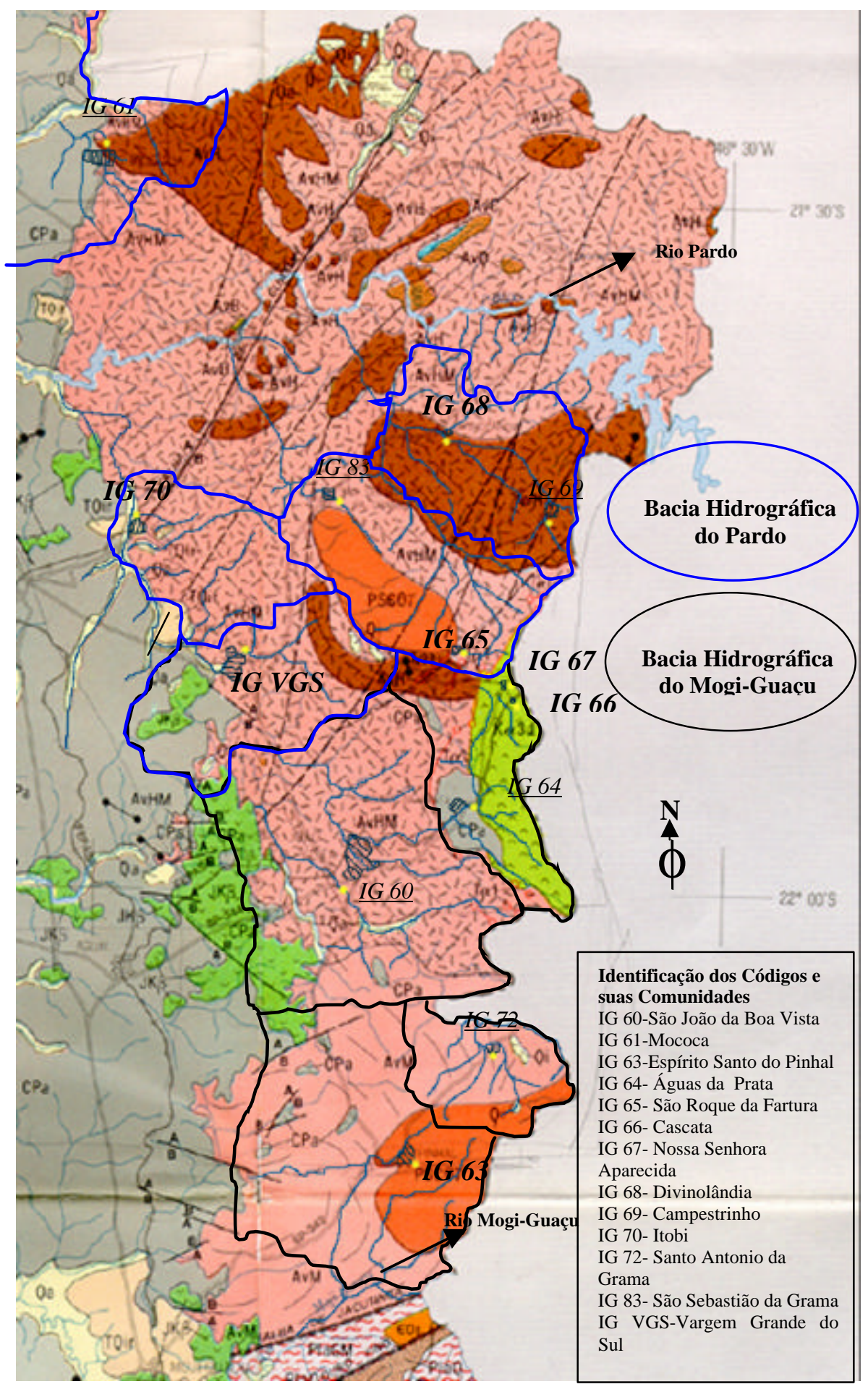

Figura 3.6 - Localização geográfica dos pontos de coleta FONTE: IPT [1981] - adaptado 
Legenda da Figura 3.6 - Quadro das unidades geológicas

\begin{tabular}{|c|c|}
\hline Era & Descrição \\
\hline Cenozóica & $\begin{array}{l}\text { TQir (bege) - Arenitos finos a médios e argilosos } \\
\text { Qa (amarelo) - Aluviões em geral, incluindo areias inconsolidas de } \\
\text { granulação Variável, argilas e cascalheiras fluviais. }\end{array}$ \\
\hline Mesozóica & $\begin{array}{l}\text { Ka3d (verde limão) - Suíte alcalina com rochas intrusivas, possui } \\
\text { algumas lavas, rochas piroclástica e rochas agpaítica } \\
\text { JKß (verde escuro) - Soleiras diabásicas, diques básicos, dioritos e } \\
\text { andesitos }\end{array}$ \\
\hline Paleozóica & $\begin{array}{l}\text { Cpa (cinza) - Depósitos continentais, predominando arenitos } \\
\text { vermelho-arroxeado, médios a grossos, feldspáticos, siltitos, e } \\
\text { diamictitos. }\end{array}$ \\
\hline Pré-cambriano & $\begin{array}{l}\text { PSeO? (alaranjado) - Granitos e granitóides polidiapíticos com } \\
\text { predominância de termos profiríticos com granulações variadas. } \\
\text { AvM (salmão) - Migmatitos diversos, incluindo } \\
\text { núcelos anatexíticos e granitóides profiríticos e } \\
\text { feldspatização. } \\
\text { AvHM (salmão tracejado) - Migmatitos diversos de } \\
\text { paleossomas granulíticos, calcosilicáticos, } \\
\text { anfibolítico, xistosos, dioríticos e quartzíticos } \\
\text { AvH (marrom escuro) - Rochas granulíticas } \\
\text { relativamente preservada do processo de } \\
\text { migmatização. São constituídos de charnockitos, } \\
\text { granulitos básicos e ácidos e piroxênio granulitos. }\end{array}$ \\
\hline
\end{tabular}




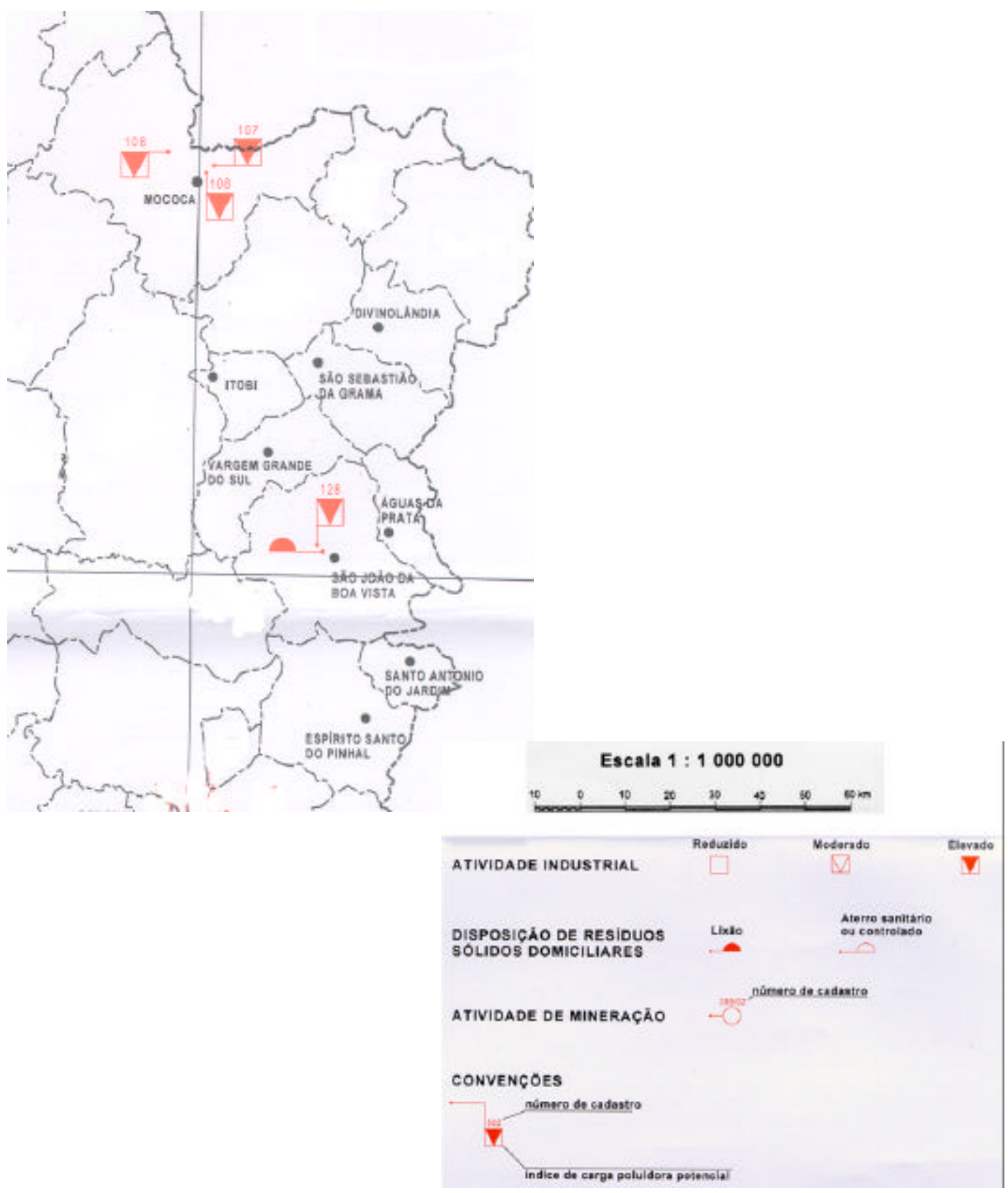

Figura 3.7 - Mapa da carga poluidora potencial das águas subterrâneas do Estado de São Paulo, fontes pontuais [IG, CETESB e DAEE, 1997]. 


\section{Aspectos Gerais sobre Água e Sedimento}

\subsection{Avaliação e Monitoramento da Qualidade da Água}

A poluição das águas tem como origem diversas fontes, dentre as quais se destacam os efluentes domésticos; os efluentes industriais e a carga difusa urbana e agrícola. Essas fontes estão associadas ao tipo de uso e ocupação do solo. Cada uma dessas fontes possui características próprias quanto aos poluentes que carregam. Por exemplo, os esgotos domésticos apresentam contaminantes orgânicos biodegradáveis, nutrientes e bactérias.

A qualidade das águas superficiais depende do clima e da litologia da região, da vegetação circundante, do ecossistema aquático e da influência do homem [CETESB, 1999].

A química da água superficial de um rio a qualquer ponto reflete muitas influências, incluindo a litologia do local da amostragem, influência atmosférica, influência das condições climáticas e antrópicas. Identificando e quantificando estas influências seria uma forma importante do gerenciamento dos recursos da terra e águas, em particular do rio amostrado [MARKICH \& BROWN, 1998].

Em geral, o deflúvio superficial urbano contém todos os poluentes que se depositam na superfície do solo. Quando da ocorrência de chuvas, os materiais acumulados em valas, bueiros, etc., são arrastados pela enxurrada para os cursos de água superficiais, constituindo uma fonte de poluição tanto maior quanto mais deficiente for a limpeza pública.

O deflúvio superficial agrícola tem características diferentes. Seus efeitos dependem muito das práticas agrícolas utilizadas em cada região e da época do ano em que se realiza a preparação do terreno para o plantio, a aplicação de fertilizantes e defensivos agrícolas e a colheita. A contribuição representada pelo material proveniente da erosão de solos intensifica-se quando da ocorrência de chuvas em áreas rurais. 
Quando a água da chuva atinge o solo, inicia-se um processo de dissolução e arraste que transportará material retirado do solo até os rios e oceanos. Espécies químicas ou elementos comumente encontrados nas águas superficiais incluem íons como cálcio, magnésio, sódio, potássio, bicarbonatos, cloretos, sulfatos, nitratos e outros. Aparecem ainda, traços de chumbo, cobre, arsênio, manganês, e uma grande quantidade de compostos orgânicos [CETESB, 1995].

A influência do clima se dá por meio da distribuição da chuva, temperaturas e ventos que ocorrem na região. Esses fatores influenciam o processo de decomposição da rocha e erosão do solo e, dependendo do tipo de rocha, aparecerão em maior quantidade aqueles elementos que fazem parte da sua composição. Em rochas cristalinas, por exemplo, baixos teores de cálcio produzirão águas com menor dureza e quase ausência de moluscos.

O clima também influencia o tipo de vegetação existente na região e, conseqüentemente, na qualidade da água. Climas úmidos exibem vegetação abundante, em geral baixas em concentrações de sólidos na água e altos teores de compostos orgânicos. A influência do clima não se dá somente na quantidade de material presente na água, mas também na flutuação das concentrações ao longo do ano.

Os seres vivos presentes na água também alteram sua composição. Algas fazem fotossíntese consumindo $\mathrm{CO}_{2}$ da água e liberando $\mathrm{O}_{2}$. Um ciclo diário bem definido indica a flutuação do $\mathrm{pH}$ da água, o mesmo acontecendo com as concentrações de carbonato e bicarbonato de cálcio, por exemplo, devido ao processo de produção e consumo de $\mathrm{CO}_{2}$. Plantas aquáticas utilizam nutrientes dissolvidos na água. Toda a cadeia é sustentada com base no teor de nutrientes presentes e, conseqüentemente, tais concentrações regulam a produtividade do ecossistema [PORTO et al., 1991].

A ação antrópica sobre o meio aquático é a responsável pela maioria das alterações nos recursos hídricos. Os rios vêm sendo depositários de rejeitos por muitos anos, alterando profundamente o estado natural do meio aquático. As alterações da qualidade da água representam uma das maiores evidências do impacto das atividades humanas sobre a biosfera [PORTO et al., 1991].

A toxicidade dos metais é uma questão de dose ou tempo de exposição, da forma 
física e química do elemento e da via de administração/adsorção. Os níveis máximos permitidos pelos órgãos de controle ambiental, CONAMA (Comissão Nacional do Meio Ambiente), EPA (Environmental Protection Agency, EUA) e WHO (World Health Organization, ONU), quanto à qualidade da água variam entre si, sendo as diferenças reflexos do potencial toxicológico do metal e da qualidade ambiental de cada país [PIRES et al., 2000].

Quando comparada à legislação de outros países, como por exemplo, Canadá, EUA e organizações internacionais como a World Health Organization, o Brasil, de certo modo, tem os seus limites alinhados e, em alguns casos, é mais restritivo.

Um programa sistemático e amplo de monitoramento da água no Brasil não foi realizado ainda, talvez por falta de uma proposta mais objetiva e econômica para que seja viabilizado pelo governo [PIRES et al., 2000]. No Brasil existem pesquisas de monitoramento isoladas como a da CETESB, com os relatórios anuais sobre a qualidade das águas do interior do Estado de São Paulo [CETESB, 1999], que desde 1974 tem avaliado a rede dos principais cursos de água do Estado de São Paulo, os trabalhos individuais de pesquisadores, como por exemplo, de GOBBI et al. [1999] e PAMPLIN [1999]. Os EUA e países europeus, desde a década de 70, vêm desenvolvendo uma série de trabalhos visando o monitoramento de corpos de água para a determinação de contaminantes, sendo que alguns agrotóxicos e fertilizantes têm sido encontrados, e mesmo no tratamento da água estes compostos não são eliminados. Existem casos de suspensão da coleta de água de algumas fontes de abastecimento devido aos limites de contaminação estar acima dos permitidos, em função do risco para a saúde pública.

\subsubsection{PARÂMETROS E INDICADORES DE QUALIDADE}

Os padrões da qualidade da água são utilizados para que se possam regulamentar os níveis de qualidade a serem mantidos num corpo de água, dependendo do uso que ela está destinada. A utilização de padrões de qualidade atende, a dois propósitos: 1) manter a qualidade do curso da água ou definir a meta a ser atingida e, 2) ser a base para definir os níveis de tratamento a serem adotados na bacia, de modo que os efluentes lançados não alterem as características do curso da água estabelecidas pelo padrão [PORTO et al., 1991]. 
A Tabela 4.1 relaciona os padrões de qualidade da água, estabelecidos por diferentes instituições governamentais.

\subsubsection{Padrões de Qualidade, Normas e Legislação Ambiental}

$\mathrm{Na}$ esfera Federal, foi a Portaria MINTER n ${ }^{\circ}$ GM 0013 de 15/01/76, que inicialmente regulamentou a classificação dos corpos de água superficiais, com os respectivos padrões de qualidade e os padrões de emissão para efluentes.

No Estado de São Paulo estes padrões foram fixados pelo Decreto ${ }^{\circ}{ }^{\circ} 8468$, de 08/09/76, que regulamentou a Lei ${ }^{\circ}$ 997, de 31/05/76, a qual dispões sobre a preservação e o controle da poluição do meio ambiente. Esse decreto define a classificação das águas interiores situadas no território do Estado de São Paulo, segundo os usos preponderantes, variando da Classe 1, a mais nobre, até a Classe 4, a menos nobre. Também são fixados, entre outros, padrões de qualidade das águas para as quatro classes e padrões de emissão para efluentes líquidos de qualquer natureza [CETESB, 1995; CETESB, 1999].

Em 1986, a Portaria GM 0013 foi substituída pela Resolução n 20 do Conselho Nacional do Meio Ambiente (CONAMA), qual estabelece nova classificação para as águas doces, bem como para as águas salobras e salinas do Território Nacional. São definidas nove classes, segundo os usos preponderantes a que as água se destinam [CETESB, 1995].

As águas doces, em particular, são classificadas em cinco classes:

I. Classe Especial - águas destinadas:

a) ao abastecimento doméstico sem prévia ou com simples desinfecção;

b) à preservação do equilíbrio natural das comunidades aquáticas.

II. Classe 1 - águas destinadas:

a) ao abastecimento doméstico após tratamento simplificado;

b) à proteção das comunidades aquáticas;

c) à recreação do contato primário (natação, esqui aquático e mergulho); 
d) à irrigação de hortaliças que são consumidas cruas e de frutas que se desenvolvam rentes ao solo e que sejam ingeridas cruas sem remoção de película;

e) à criação natural e/ou intensiva (aqüicultura) de espécies destinadas à alimentação humana.

III. Classe 2 - águas destinadas:
a) ao abastecimento doméstico após tratamento convencional;
b) à proteção das comunidades aquáticas;
c) à recreação do contato primário (natação, esqui aquático e mergulho);
d) à irrigação de hortaliças e plantas frutíferas,
d) à criação natural e/ou intensiva (aqüicultura) de espécies destinadas à alimentação humana.

IV. Classe 3 - águas destinadas:
a) ao abastecimento doméstico após tratamento convencional;
b) à irrigação de culturas arbóreas, cerealíferas e forrageiras:
c) a dessedentação de animais.
d) aos usos menos exigentes.

V. Classe 4-águas destinadas:
a) à navegação comercial;
b) à harmonia paisagística:
c) à recreação do contato secundário.

O fato de um trecho de rio estar enquadrado em determinada classe não significa, necessariamente, que esse seja o nível de qualidade que apresenta, mas sim aquele a ser alcançado e/ou mantido ao longo do tempo.

Para cada classe acima descrita, a Resolução $\mathrm{n}^{\circ} 20$ estabelece limites e/ou condições de qualidade a serem respeitados, sendo mais restritivos quanto mais nobre for o uso pretendido. 
Um resumo das normas ambientais vigentes no Brasil foi descrito por MARQUES [1999].

Tabela 4.1 - Comparação dos valores máximos permissíveis estabelecidos por diferentes instituições governamentais.

\begin{tabular}{|c|c|c|c|c|c|c|c|}
\hline \multicolumn{8}{|c|}{ ELEMENTOS INORGÂNICOS QUE AFETAM A SAÚDE } \\
\hline \multicolumn{8}{|c|}{ Concentração Máxima Permissível $\left(\mu \mathrm{g} \mathrm{mL}^{-1}\right)$} \\
\hline \multicolumn{6}{|c|}{ Padrão de Potabilidade } & \multicolumn{2}{|c|}{$\begin{array}{c}\text { Padrão de Qualidade } \\
\text { Ambiental }\end{array}$} \\
\hline Elemento & $\begin{array}{c}\text { Portaria } \\
\text { n }^{\circ} 36 / 90- \\
\text { MS }\end{array}$ & $\begin{array}{c}\text { Portaria } \\
n^{0} \\
1469 / 2000 \\
\text {-MS }\end{array}$ & $\begin{array}{c}\text { D. } \\
\text { Estadual/ } \\
\text { S.P. } \\
\mathbf{n}^{\circ} \\
\mathbf{1 2 . 4 8 6 / 7 8}\end{array}$ & WHO & EPA & $\begin{array}{c}\text { CONAMA } \\
\text { no20/86 }^{\circ} \\
\text { Classe I / II }\end{array}$ & $\begin{array}{c}\text { CONAMA } \\
\text { n }^{\circ} 20 / 86 \\
\text { Classe III }\end{array}$ \\
\hline $\mathrm{Ag}$ & 0,05 & - & - & - & 0,05 & 0,01 & 0,05 \\
\hline Al & $0,2(*)$ & 0,2 & - & 0,2 & - & 0,1 & 0,1 \\
\hline $\mathrm{Ba}$ & 1,0 & 0,7 & 1,0 & - & 1,0 & 1,0 & 1,0 \\
\hline $\mathrm{Ca}$ & - & - & - & - & - & - & - \\
\hline $\mathrm{Cd}$ & 0,005 & 0,005 & 0,010 & 0,005 & 0,010 & 0,0010 & 0,01 \\
\hline $\mathrm{Co}$ & - & - & - & - & - & 0,2 & 0,2 \\
\hline $\mathrm{Cr}$ (total) & 0,05 & 0,05 & - & 0,05 & 0,05 & - & - \\
\hline $\mathrm{Cu}$ & 1,0 & 2,0 & 1,0 & 1,0 & 1,0 & 0,02 & 0,5 \\
\hline $\mathrm{Fe}$ & 0,3 & 0,3 & 0,3 & 0,3 & 0,3 & - & - \\
\hline $\mathrm{Mg}$ & - & - & - & - & & - & - \\
\hline $\mathrm{Mn}$ & 0,10 & 0,10 & 0,05 & 0,10 & 0,05 & 0,10 & 0,50 \\
\hline $\mathrm{Ni}$ & - & - & - & - & - & 0,025 & 0,025 \\
\hline $\mathrm{P}$ & - & - & - & - & - & 0,025 & 0,025 \\
\hline $\mathrm{Pb}$ & 0,05 & 0,01 & 0,05 & 0,05 & 0,05 & 0,03 & 0,05 \\
\hline $\mathrm{Zn}$ & 5,0 & 5,0 & 5,0 & 5,0 & - & 0,18 & 5,0 \\
\hline $\mathrm{F}^{-}$ & $0,6-1,7$ & 1,5 & 1,0 & 1,5 & 4,0 & 1,4 & 1,4 \\
\hline $\mathrm{Cl}$ & 250 & 250 & 250 & 250 & 250 & 250 & 250 \\
\hline $\mathrm{K}^{+}$ & - & - & - & - & & - & - \\
\hline $\mathrm{Na}^{+}$ & - & 200 & - & 200 & - & - & - \\
\hline $\mathrm{SO}_{4}^{2-}$ & 400 & 250 & 250 & 400 & - & 250 & 250 \\
\hline $\mathrm{NO}_{3}{ }^{-}(\mathrm{N})$ & 10 & 10 & 10 & 10 & 10 & 10 & 10 \\
\hline $\mathrm{NH}_{4}{ }^{+}$ & - & - & - & - & & - & - \\
\hline $\mathrm{pH}$ & $6,5-8,5$ & $6,0-9,5$ & $5,0-9,0$ & $6,5-8,5$ & $6,5-8,5$ & $6,0-9,0$ & $6,0-9,0$ \\
\hline
\end{tabular}

** EPA - Environmental Protection Agency (EUA) - Critério de Qualidade de Água WHO - World Health Organization (ONU) - Guia para Água Potável / (*) Valor experimental

Portaria $\mathbf{n}^{\circ}$ 36/90 (Diário Oficial da União/Ministério da Saúde / Decreto Estadual 12.342/78, Código Sanitário).

Portaria n¹469/2000 (Diário Oficial da União/Ministério da Saúde em 29 de Dezembro de 2000) - nova Portaria vigente 


\subsection{Mobilização de Metal PeSado em Sedimento}

A deterioração do meio ambiente e a rápida depleção de fontes naturais não renováveis, decorrentes do grande crescimento econômico e tecnológico da indústria após a 2- Guerra Mundial, levaram a sociedade a se preocupar com a qualidade do meio ambiente. De fato, quase toda atividade humana termina por gerar impacto nos ecossistemas aquáticos [BOHRER, 1995]. A poluição originada por esgotos domésticos, pela agricultura e pelas práticas industriais trazem inúmeras conseqüências. As atividades agrícolas causam, através da introdução de pesticidas, danos à biota, além de afetar comunidades de peixes utilizados na alimentação, como também a qualidade d'água para consumo humano. As atividades industriais contribuem com uma quantidade considerável de produtos químicos tóxicos e persistentes, tais como metais pesados, entre eles mercúrio e chumbo, até orgânicos perigosos como dioxinas e bifenilas policloradas (PCBs).

Para se avaliar a qualidade do ambiente, alguma forma de monitoramento se faz necessária. Segundo CHAPMAN [1989], o monitoramento do ambiente além de fornecer informações importantes sobre a extensão da poluição, avalia a eficiência de ações mitigadoras, adotadas com o propósito de diminuir ou mesmo eliminar sua origem.

O material inorgânico e orgânico nos sedimentos de rios e lagos pode ser um importante meio de avaliação da poluição já que estão predispostos a rápidas trocas da composição com a coluna de água. Portanto, estes tipos de amostras são guias úteis para a história da poluição do corpo de água. Todavia, a simples determinação da concentração total de um determinado elemento, em uma amostra de sedimento, não oferece informação adicional além da taxa de estocagem. Hoje em dia, a biogeoquímica de um determinado poluente que adentra em um compartimento ambiental é determinada mais por sua forma de ligação específica e reatividade, do que por sua taxa de acumulação. De acordo com BEVILACQUA [1996], está reconhecido que somente uma fração do conteúdo total de metais em materiais contaminados (solos, sedimentos e dejetos) está biologicamente disponível.

Para se ter uma correta interpretação da quantidade de metais que estão presentes nos sedimentos, deve-se distinguir entre os processos de origem natural (geológicos, 
mineralógicos, hidrológicos e biológicos), daqueles que tem como origem a ação do homem. Com relação a isto, entende-se que um sedimento é geralmente formado por fases sólidas de elementos majoritários: metais ( $\mathrm{Fe}, \mathrm{Al}, \mathrm{Ca}, \mathrm{Mn})$, não metais $(\mathrm{C}, \mathrm{S}, \mathrm{Si}$ e P) e elementos-traço $(\mathrm{Cd}, \mathrm{Cr}, \mathrm{Cu}, \mathrm{Pb}, \mathrm{Zn}, \mathrm{Ni}$, etc); precipitados e compostos hidrolisados como: $\mathrm{Cu}_{2}(\mathrm{OH})_{2} \mathrm{CO}_{3} ; \mathrm{Pb}_{5}\left(\mathrm{PO}_{4}\right)_{3} \mathrm{Cl} ; \mathrm{Pb}_{3}\left(\mathrm{PO}_{4}\right)_{2} ; \mathrm{Zn}_{5}(\mathrm{OH})_{6}\left(\mathrm{CO}_{3}\right)_{2} ; \mathrm{Zn}_{3}\left(\mathrm{PO}_{4}\right)_{2} \cdot \mathrm{H}_{2} \mathrm{O}$ e $\mathrm{ZnSiO}_{4}$. Estes elementos podem estar presentes em altas concentrações, devido a processos diagenéticos ou por contaminação, já que possuem maior tendência a co-precipitar e adsorver no material particulado do que sofrer sedimentação.

Em águas naturais, os sedimentos consistem predominantemente de detritos orgânicos, colóides, células vivas (bactérias e algas) e sólidos inorgânicos, tais como: óxidos e hidróxidos de metais, carbonatos e argilas [AUALIITIA \& PICKERING, 1988].

O Fe, juntamente com o Mn, são elementos considerados carreadores de elementostraço por meio de mecanismos tais como precipitação (hidróxidos, sulfito e carbonatos) e adsorção, principalmente nas formas de óxidos e hidróxidos [FÖRSTNER \& WITTMANN, 1981; WETZEL, 1983; ESTEVES, 1988; SOARES et al. 1999].

Existem muitos fatores que influenciam a adsorção e a retenção de contaminantes na superfície das partículas, o mais importante parece ser o tamanho da partícula. A tendência observada é que quando o grão diminui, as concentrações de nutrientes e contaminantes aumentam. Esta tendência primaria é devido ao fato das pequenas partículas terem grandes áreas de superfície para a adsorção por contaminantes. A variação do grau de cristalização do mineral também pode influenciar. A necessidade de se conhecer a fração quimicamente ativa para o transporte tem feito vários pesquisadores preferirem frações de grãos finos $(<63 \mu \mathrm{m})$ para amostragem e análises [LACERDA et al., 1990; DAVIDSON et al., 1994; DROPPO \& JASKOT, 1995; TRUCKENBRODT \& EINAX, 1995; GATTI, 1997; LIU et al., 1999; SOARES, 1999]. Esta fração corresponde ao material de granulometria mais fina, mostrando uma grande interação na superfície do mesmo [FÖRSTNER \& WITTMANN, 1981; WETZEL, 1983; GATTI, 1997]. Na fração acima de $63 \mu \mathrm{m}$, que é considerada essencialmente areia, nota-se que o conteúdo de metais decresce linearmente [FÖRSTNER \& WITTMANN, 1981; WETZEL, 1983]. 
Os vários níveis de poluentes no sistema de água natural, assim como a ameaça do compartimento aquático (coluna de água e sedimento), necessitam de caracterização para avaliar as concentrações de metais adquiridos diagenéticamente ou por contaminação, isto porque, o sedimento apresenta um importante indicador da contaminação tendo como principal característica, acumular a maioria dos poluentes do sistema. Metais apresentam variação espacial e temporal menor no sedimento do que na coluna de água. Normalmente, apresentam concentrações maiores do que na forma dissolvida na água [FÖRSTNER \& WITTMANN, 1981; WETZEL, 1983; VICENT-BECKETT, 1991].

Os sedimentos do leito de um rio desempenham o papel mais importante na avaliação de sua poluição. Eles refletem a qualidade corrente do sistema aquático e, podem ser usados para detectar a presença de contaminantes que não permanecem solúveis após o seu lançamento em águas superficiais. Além disso, os sedimentos agem como carreadores de possíveis fontes de poluição, como os metais pesados, que não são permanentemente fixados por eles e podem ser redispostos para a água através de mudanças nas condições ambientais tais como: $\mathrm{pH}$, potencial redox ou a presença de quelantes orgânicos.

As propriedades acumulativas e de redisposição das espécies nos sedimentos os qualificam como de extrema importância em estudos de impacto ambiental, registrando em caráter mais permanente os efeitos da contaminação [FÖRSTNER \& WITTMANN, 1981; BEVILACQUA, 1996].

A mobilização dos metais pesados presentes no material suspenso e no sedimento é potencialmente perigosa, não somente para o ecossistema, mas também para o suprimento de água potável. Essa mobilização pode ser principalmente causada por quatro tipos de mudanças químicas na água:

1) Elevada concentração de sal pelo qual os cátions dos metais alcalinos, metais alcalino-terrosos, podem competir com os íons metálicos adsorvidos nas partículas sólidas;

2) Mudança na condição redox, usualmente junto com a diminuição do potencial de oxigênio devido à avançada eutrofização. Hidróxidos de ferro e manganês são parcialmente ou completamente dissolvidos e, parte dos metais pesados incorporados ou absorvidos são liberados; 
3) Queda do $\mathrm{pH}$, a qual dissolve carbonatos e hidróxidos, bem como, aumenta a desorção dos cátions metálicos devido a competição com íons $\mathrm{H}^{+}$;

4) $\mathrm{O}$ aumento do uso de agentes naturais e sintéticos, o qual pode formar complexos de metais solúveis de alta estabilidade com metais pesados que são, por outro lado, absorvidos a partículas sólidas.

Além desses quatros processos, existem outros processos de transformação, pelos quais os metais pesados são transferidos do sedimento para o corpo d'água , para o animal ou para as plantas [FÖRSTNER \& WITTMANN, 1981].

O tipo de solo também pode influenciar na mobilização dos metais. Solos que contêm argilominerais e matéria orgânica possuem diferentes capacidades de troca. A capacidade de troca aumenta consideravelmente na ordem caulinita < clorita < ilita < montmorilonita < vermiculita. Este aumento está relacionado a redução do tamanho da partícula e conseqüentemente ao aumento da área da superfície.

Até o presente, não há um método normalizado para a amostragem de sedimento, suas partículas e fase intersticial, bem como no manuseio das amostras para análises físicas, químicas e biológicas [MUDROCH \& MACKNIGHT, 1994]. O método que apresenta mais controvérsias é o da biodisponibilidade. Os autores divergem na aplicação de extração simples (um tipo de ácido) [NOVOZAMSKY et al., 1993; BEVILACQUA, 1996; GATTI, 1997]; com diferentes ácidos ou extração seqüencial (diferentes tipos e concentrações variadas) [DAVIDSON et al., 1994; DAUS et al., 1995; GONZALEZ et al., 1994; KRAUSE et al., 1995; URASA \& MACHA, 1996]. Os procedimentos desenvolvidos por Tessier et al. e modificado por Förstner são os mais utilizados na literatura e estão esquematizados na Tabela 4.2. 
Tabela 4.2 - Esquema de extração seqüencial em sedimentos

\begin{tabular}{|c|c|c|c|c|c|}
\hline Método & 1 & 2 & 3 & 4 & 5 \\
\hline Tessier et al. & $\begin{array}{l}\mathrm{MgCl}_{2} \\
1 \mathrm{~mol} \mathrm{~L}^{-1} \\
(\mathrm{pH} \mathrm{7})\end{array}$ & $\begin{array}{l}\text { Acetato de } \\
\text { Sódio } \\
1 \text { mol L }{ }^{-1} \\
(\mathrm{pH} \mathrm{5)}\end{array}$ & $\begin{array}{l}\mathrm{NH}_{2} \mathrm{OH} . \mathrm{HCl} \\
0,04 \mathrm{~mol} \mathrm{~L}^{-1} \\
25 \% \text { ácido } \\
\text { acético }\end{array}$ & $\begin{array}{l}\mathrm{H}_{2} \mathrm{O}_{2} 8,8 \mathrm{~mol} \mathrm{~L}^{-1} \\
\mathrm{HNO}_{3} / \text { Acetato } \\
\text { de Amônio }\end{array}$ & $\mathrm{HF} / \mathrm{HClO}_{4}$ \\
\hline Fase & trocável & carbonato & $\begin{array}{l}\text { óxidos } \\
\text { (Fe/Mn) }\end{array}$ & $\begin{array}{l}\text { Matéria orgânica } \\
\text { e sulfito }\end{array}$ & $\begin{array}{l}\text { Fase residual - } \\
\text { sílica }\end{array}$ \\
\hline Förstner & $\begin{array}{l}\text { Acetato de Sódio } \\
1 \mathrm{~mol} \mathrm{~L}^{-1} \\
(\mathrm{pH} \mathrm{5)}\end{array}$ & $\begin{array}{l}\mathrm{NH}_{2} \mathrm{OH} . \mathrm{HCl} \\
0,1 \mathrm{~mol} \mathrm{~L}^{-1}\end{array}$ & $\begin{array}{l}\text { Acetato de } \\
\text { Amônio/ } \mathrm{H}_{2} \mathrm{O}_{2} \\
0,1 \mathrm{~mol} \mathrm{~L} \mathrm{~L}^{-1} \\
\text { (pH 3) }\end{array}$ & $\begin{array}{l}\mathrm{H}_{2} \mathrm{O}_{2} \\
8,8 \mathrm{~mol} \mathrm{~L}-1 \\
(\mathrm{pH} 7) \\
\text { Acetato de Amônio }\end{array}$ & $\mathrm{HNO}_{3}$ \\
\hline Fase & $\begin{array}{l}\text { Trocável } \\
\text { +carbonato }\end{array}$ & $\begin{array}{l}\text { Facilmente } \\
\text { reduzível }\end{array}$ & $\begin{array}{l}\text { No escuro } \\
\text { moderamente } \\
\text { reduzível }\end{array}$ & $\begin{array}{l}\text { matéria } \\
\text { orgânica + } \\
\text { sulfito }\end{array}$ & $\begin{array}{l}\text { Fase residual - } \\
\text { sílica }\end{array}$ \\
\hline
\end{tabular}

Fonte: RAURET [1998]

RAURET [1998] avaliou os métodos comumente utilizados nas extrações simples e seqüenciais, encontrando problemas relacionados ao selecionamento, nas baixas concentrações dos analitos e principalmente quando um extractante fraco é usado.

A biodisponibilidade dos contaminantes no sedimento está associada a seu comportamento de partição com a matéria orgânica presente, além dos processos adsortivos que ocorrem entre os metais e as partículas de granulação fina, como por exemplo, as argilas e siltes. Os metais de associação fraca que comumentes se encontram ligados ao sedimento, podem ser facilmente rompidas pela biota, é que recebem a denominação de biodisponíveis [FÖRSTNER \& WITTMANN, 1981; WETZEL, 1983; GATTI, 1997].

MACKNIGHT [1994] propôs que: a menos que exista um interesse específico na investigação do sedimento (área de erosão ou de transporte), o local ou estações de amostragem devem ser localizadas em áreas de acumulação de grãos finos, pois eles geralmente estão relacionados com contaminações metálicas e orgânicas.

É extremamente importante determinar os metais fracamente ligados, isto é, os metais que estão associados às fases consideradas instáveis e reativas no sedimento, pois 
estes dão uma noção do potencial poluente dos metais contidos no sedimento, bem como os índices de contaminação mais recentes.

De acordo com Chester e Hugles [1967] apud FÖRSTNER \& WITTMANN [1981], em 1967 foram feitos os primeiros ensaios para estabelecer uma metodologia para extração de metais em sedimentos e verificar as principais formas de ligação desses metais. Empregaram técnicas químicas para estudar metais-traço incorporados no sedimento pelágico por ferro-manganês, carbonatos, e adsorção nos minerais envolvendo o uso de ácido acético diluído e agentes redutores, como por exemplo, hidroxilamina hidroclorídrica $1 \mathrm{~mol} \mathrm{\textrm {L } ^ { - 1 }}$. O passo seguinte envolveu o uso de agentes oxidantes, como um meio de determinar a quantidade de matéria orgânica e sulfitos.

Um resumo dos diferentes métodos de extração de metais associado com as diferentes fases químicas dos sedimentos é apresentado na Tabela 4.3.

FIZMAN et al [1984] comprovaram o desempenho de diferentes reagentes na extração de metais em sedimentos. A extração com $\mathrm{HCl} \mathrm{0,1}$ mol L ${ }^{-1}$ permitiu disponibilizar as fases orgânicas e inorgânicas do sedimento com um mínimo ataque a matriz, não apresentando diferença significativa com os procedimentos utilizando hidroxilamina clorídrica $0,1 \mathrm{~mol} \mathrm{~L}^{-1} / \mathrm{HNO}_{3} 0,1 \mathrm{~mol} \mathrm{~L}{ }^{-1} ; \mathrm{H}_{2} \mathrm{O}_{2} 30 \%$ e soluções aquosa de citrato de sódico 20g/ diotionato de sódio $2 \mathrm{~g} / 120 \mathrm{~mL}$.

Dada a importância do sedimento na avaliação de um corpo de água, este trabalho teve como objetivo específico investigar o impacto de metais, de origem natural e antrópica, em sedimentos. Apesar da literatura fazer uso de um amplo leque de reagentes extratores, o processo de extração com $\mathrm{HCl} 0,1 \mathrm{~mol} \mathrm{~L}^{-1}$, adotado para o desenvolvimento desse trabalho visou disponibilizar os metais presentes nos fins orgânicos e inorgânicos,

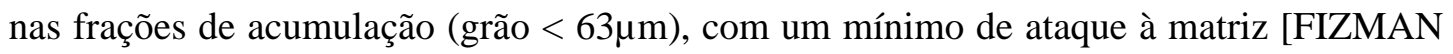
et al., 1984; LIMA, 1990 apud GATTI, 1997; BEVILAQUA, 1996; GATTI, 1997].

Esse procedimento possibilitou também comparar os resultados com os vários trabalhos encontrados na nossa literatura, que utilizou o mesmo procedimento [FIZMAN et al., 1984; LIMA, 1990 apud GATTI, 1997; BEVILAQUA, 1996; GATTI, 1997]. 
Tabela 4.3 - Extração de metais associado à diferentes fases químicas nos sedimentos

\begin{tabular}{|c|c|c|}
\hline Fase Química & Método de Extração & Autores \\
\hline Adsorção e troca catiônica & $\begin{array}{l}\text { (a) } \mathrm{BaCl}_{\text {, (b) } \mathrm{MgCl}_{2}} \text { (c) } \mathrm{NH}_{4} \mathrm{OAc}\end{array}$ & $\begin{array}{l}\text { JACKSON [1958]; GIBBS } \\
\text { [1973] }\end{array}$ \\
\hline Fase detrital & EDTA & $\begin{array}{l}\text { GODBERG \& } \\
\text { ARRHENIUS [1958]; GAD } \\
\text { \& LE RICHE [1966] }\end{array}$ \\
\hline Fases hidrogenia /litogenia & $\begin{array}{l}\text { (a) } 0,1 \mathrm{~mol} \mathrm{~L}^{-1} \mathrm{HCl} \text {, } \\
\text { (b) } 0,3 \mathrm{~mol} \mathrm{~L}^{-1} \mathrm{HCl} \text {, } \\
\text { (c) } 0,1 \mathrm{~mol} \mathrm{~L}^{-1} \mathrm{HNO}_{3}\end{array}$ & $\begin{array}{l}\text { PIPER [1971] } \\
\text { JONES [1973]; MALO } \\
\text { [1977] }\end{array}$ \\
\hline Fase reduzível & $\begin{array}{l}1 \mathrm{~mol} \mathrm{~L}^{-1} \mathrm{NH}_{2} \mathrm{OH} . \mathrm{HCl} \text {, Ac. } \\
\text { Acético }(25 \% \mathrm{v} / \mathrm{v})\end{array}$ & $\begin{array}{l}\text { CHESTER \& HUGLES } \\
{[1967]}\end{array}$ \\
\hline $\begin{array}{l}\text { Fases reduzíveis moderadas } \\
\text { (hidroxi Fe-óxidos) }\end{array}$ & $\begin{array}{l}\text { Oxalato } \\
\text { Ditionato/citrato }\end{array}$ & $\begin{array}{l}\text { SCHWERTMANN [1964] } \\
\text { HOLMGREN [1967] }\end{array}$ \\
\hline $\begin{array}{l}\text { Fase facilmente reduzível } \\
\text { (Mn-óxido e amorfo, Fe- } \\
\text { óxido carbonatos) }\end{array}$ & $\begin{array}{l}0,1 \mathrm{~mol} \mathrm{~L}^{-1} \mathrm{NH}_{2} \mathrm{OH} . \mathrm{HCl}, \\
0,01 \mathrm{~mol} \mathrm{~L}^{-1} \mathrm{HNO}_{3}\end{array}$ & CHAO [1972] \\
\hline Carbonatos & $\begin{array}{l}\text { (a) } \mathrm{CO}_{2} \\
\text { (b) coluna de troca }\end{array}$ & $\begin{array}{l}\text { PATCHINEELAM [1975] } \\
\text { DEURER et al. [1978] }\end{array}$ \\
\hline Orgânicos, sulfitos & $\begin{array}{l}30 \% \mathrm{H}_{2} \mathrm{O}_{2} \text { à } 95{ }^{0} \mathrm{C} \text {, extraído } \\
\text { com (a) } 1 \mathrm{~N} \mathrm{NH}_{4} \mathrm{OAc} \text { ou } \\
\text { (b) } 0,01 \mathrm{~mol} \mathrm{~L}^{-1} \mathrm{HNO}_{3} \text {, } \\
\text { solventes (ex.: Clorofórmio, } \\
\text { éter, gasolina, benzeno, } \\
\text { disulfito de carbono) }\end{array}$ & $\begin{array}{l}\text { JACKSON [1958]; } \\
\text { ENGLER et al. [1974]; } \\
\text { GUPTA \& CHEN [1975] } \\
\text { BERGMANN [1963] } \\
\text { WELTE [1963] } \\
\text { COOPER \& HARRIS [1974] }\end{array}$ \\
\hline Ácidos fúlvico e húmico & $\begin{array}{l}0,5 \mathrm{~N} \mathrm{NaOH} ; \\
0,1 \mathrm{~N} \mathrm{NaOH} / \mathrm{H}_{2} \mathrm{SO}_{4}\end{array}$ & $\begin{array}{l}\text { RASHID [1971]; VOLKOV } \\
\& \text { FOMINA [1974] }\end{array}$ \\
\hline Material orgânico Sólido & $\begin{array}{l}\text { Hipoclorito de sódio, } \\
\text { ditionato/citrato }\end{array}$ & GIBBS [1973] \\
\hline Silicatos detritais & $\begin{array}{l}\text { Digestão com } \mathrm{HF} / \mathrm{HClO}_{4} \text {, } \\
\text { Metaborato de lítio } \\
\left(1000{ }^{0} \mathrm{C}\right)\end{array}$ & $\begin{array}{l}\text { FÖRSTNER [1981]; capítulo } \\
\text { D.2.3 }\end{array}$ \\
\hline
\end{tabular}

Fontes: FÖRSTNER [1977]; FÖRSTNER \& WITTMANN [1981] 


\subsection{Impactos Ambientais e Efeitos Sobre a SAÚde}

Toxicidade é a propriedade dos agentes tóxicos de promoverem efeitos nocivos às estruturas biológicas, através de interações físico-químicas. A toxicidade de qualquer substância depende da quantidade ingerida por um determinado organismo. A pele, os pulmões e o canal alimentar são as principais barreiras de separação entre os organismos superiores e o ambiente. As substâncias tóxicas precisam atravessar essas barreiras para serem absorvidas e exercer efeitos nocivos sobre o corpo. A utilização dos metais, para as diversas finalidades, exerce influência nos efeitos potencias à saúde, através do transporte ambiental ou da contribuição antrópica (ar, solo, água e alimento), e por alterações das espécies do elemento [MERTZ, 1969; MICROMEDEX, 1998 apud MARQUES 1999].

As atividades industriais da civilização moderna estão utilizando cada vez mais um grande número de novos compostos, bem como, aumentando a concentração de certos metais e substâncias inorgânicas no meio ambiente. Uma das consequiências dessa situação é que certas substâncias acumulam em níveis tóxicos, ampliando os efeitos toxicológicos nos ecossistemas (plantas, animais e seres humanos).

Os íons metálicos presentes nos sistemas aquáticos são abundantes na natureza na forma solúvel. A abundância genérica se restringe aos números atômicos $\leq 40$, alguns dos quais são praticamente impossíveis de ocorrer devido à baixa solubilidade de seus hidróxidos. Do ponto de vista da poluição ambiental, os metais podem ser classificados de acordo com três critérios: (1) não crítico, (2) tóxico, muito insolúvel ou muito raro e, (3) muito tóxico e relativamente acessível como apresentado na Tabela 4.4 [FÖRSTNER \& WITTMANN, 1981]. 
Tabela 4.4 - Classificação dos elementos de acordo com a toxicidade e ocorrência

\begin{tabular}{|c|c|c|c|c|c|c|c|}
\hline \multicolumn{3}{|c|}{ Não Tóxico } & \multicolumn{2}{|c|}{$\begin{array}{c}\text { Tóxico, } \\
\text { muito insolúvel ou } \\
\text { muito raro }\end{array}$} & \multicolumn{3}{|c|}{$\begin{array}{l}\text { Muito tóxico e } \\
\text { relativamente acessível }\end{array}$} \\
\hline $\mathrm{Na}$ & $\mathrm{C}$ & $\mathrm{F}$ & $\mathrm{Ti}$ & $\mathrm{Ga}$ & $\mathrm{Be}$ & As & $\mathrm{Au}$ \\
\hline $\mathrm{K}$ & $\mathrm{P}$ & $\mathrm{Li}$ & Hf & $\mathrm{La}$ & Co & $\mathrm{Se}$ & $\mathrm{Hg}$ \\
\hline $\mathrm{Mg}$ & $\mathrm{Fe}$ & $\mathrm{Rb}$ & $\mathrm{Zr}$ & Os & $\mathrm{Ni}$ & $\mathrm{Te}$ & $\mathrm{Tl}$ \\
\hline $\mathrm{Ca}$ & S & $\mathrm{Sr}$ & $\mathrm{W}$ & $\mathrm{Rh}$ & $\mathrm{Cu}$ & $\mathrm{Pd}$ & $\mathrm{Pb}$ \\
\hline $\mathrm{H}$ & $\mathrm{Cl}$ & $\mathrm{Al}$ & $\mathrm{Nb}$ & $\mathrm{Ir}$ & $\mathrm{Zn}$ & $\mathrm{Ag}$ & $\mathrm{Sb}$ \\
\hline $\mathrm{O}$ & $\mathrm{Br}$ & $\mathrm{Si}$ & $\mathrm{Ta}$ & $\mathrm{Ru}$ & Sn & $\mathrm{Cd}$ & $\mathrm{Bi}$ \\
\hline $\mathrm{N}$ & & & $\operatorname{Re}$ & $\mathrm{Ba}$ & & $\mathrm{Pt}$ & \\
\hline
\end{tabular}

Fonte: WOOD [1974] apud FÖRSTNER \& WITTMANN [1981]

Na Figura 4.1 tem-se a representação da resposta biológica de um tecido ao aumento da concentração de um nutriente essencial. Esta enfatiza o ponto que um nutriente essencial pode se tornar tóxico em uma certa concentração. Quase todas as substâncias em excesso se tornam perigosas mesmo se a ação de nutrientes essenciais for indireta.

Existem vários caminhos possíveis para se expor um organismo ao metal tóxico. O principal meio de exposição está associado ao meio ambiente em geral. Compostos inorgânicos estão presentes no alimento e na água, como resultado de sua ocorrência natural na crosta terrestre. Para estes compostos, existem um potencial tóxico mínimo. Durante o curso da evolução dos animais, estes têm desenvolvido mecanismos de resistência. Por exemplo, alumínio é mais comum dos metais e o terceiro elemento mais comum na crosta terrestre, e apresenta toxicidade extremamente incomum, exceto para pacientes com tratamento de hemodiálises. Outros metais menos abundante como $\mathrm{Pb}, \mathrm{Hg}$ e As exibem sérios problemas toxicológicos quando liberados no meio ambiente como uma conseqüência do desenvolvimento industrial [FÖRSTNER \& WITTMANN, 1981]. 


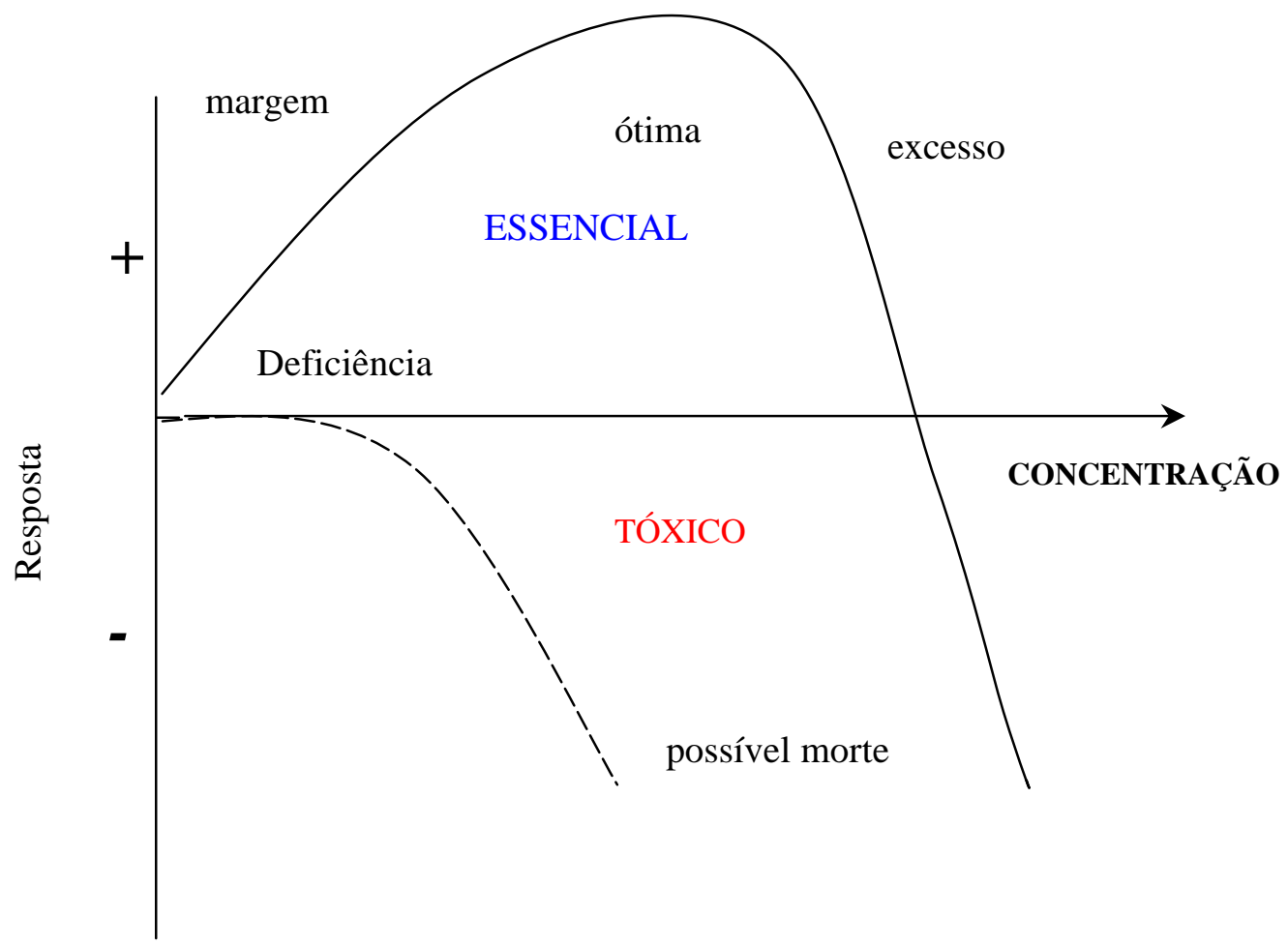

Figura 4.1 - Resposta biológica à dependência na concentração de um nutriente essencial (curva sólida) e de uma substância perigosa (curva tracejada).

Fonte: SEILER \& SIGEL [1998]

$\mathrm{Na}$ Tabela 4.5 são apresentadas as principais fontes de origem e a toxicidade relativa de alguns elementos metálicos e não-metálicos. Esses elementos foram escolhidos por sua importância na qualidade da água segundo a Portaria n³6/90, Portaria n¹469/00 e a Resolução CONAMA n²0/86.

O estudo da associação química das espécies metálicas presentes no sedimento pode dar indicações da liberação destas substâncias na água por processos metabólicos com efeitos tóxicos sob determinadas condições ambientais. Além disso, o conhecimento dos tipos de ligação de diferentes metais no sedimento pode ser a chave para a detecção de fontes especificas de poluição no sistema aquático [FÖRSTNER, 1977]. 
Tabela 4.5 - Características dos principais parâmetros analisados

\begin{tabular}{|c|c|c|c|}
\hline Elemento & $\begin{array}{c}\text { Características } \\
\text { Gerais }\end{array}$ & $\begin{array}{l}\text { Origem nas Águas e } \\
\text { Fatores de Alteração }\end{array}$ & $\begin{array}{l}\text { Inconvenientes e } \\
\text { toxicidade }\end{array}$ \\
\hline $\mathrm{Al}$ & $\begin{array}{l}\text { Condições físico-químicas } \\
\text { particulares favorecem ou } \\
\text { não a solubilidade do íon. }\end{array}$ & $\begin{array}{l}\text { Alumínio é abundante nas } \\
\text { rochas e minerais. O } \\
\text { aumento do seu teor nas } \\
\text { águas é decorrente do } \\
\text { lançamento de efluentes } \\
\text { industriais, esgotos } \\
\text { domésticos, resíduos } \\
\text { industriais, de mineração e } \\
\text { de produtos utilizados na } \\
\text { agricultura, bem como } \\
\text { através de fontes minerais. }\end{array}$ & $\begin{array}{l}\text { Não é considerado tóxico } \\
\text { ou prejudicial à saúde, mas } \\
\text { há interesse em se controlar } \\
\text { a concentração nas águas de } \\
\text { abastecimento público e } \\
\text { industrial, para prevenir } \\
\text { precipitações } \\
\text { sedimentações. }\end{array}$ \\
\hline
\end{tabular}

$\mathrm{Ba}$ A presença de metais em $\mathrm{O}$ bário em geral ocorre nas $\mathrm{A}$ ingestão do bário pode águas de abastecimento, águas naturais em causar desde o aumento águas residuárias concentrações muito baixas, transitório da pressão domésticas e industriais, e de 0,7 a $900 \quad \mu \mathrm{g} \quad \mathrm{L}^{-1}$. sangüínea, por em coleções de água Quantidades elevadas são vasoconstrição, até sérios recptoras, é uma decorrentes de efluentes feitos tóxicos sobre coração, preocupação constante, industriais e de resíduos de vasos e nervos. Até hoje dadas as propriedades minerações. não se comprovou efeito tóxicas deste elemento. Eles acumulativo.

afetam os consumidores de

águas residuárias e o

sistema biológico de águas

brutas.

Cd $\ddot{E}$ um elemento de elevado Em condições naturais é Em pequenas doses afeta os potencial tóxico encontrado nas águas em órgãos reprodutores de apresentando efeito níveis de traços. alguns animais.

cumulativo nos organismos A ocorrência de No homem, provoca aquáticos, e não aquáticos concentrações mais irritação gastrointestinal com meia-vida da ordem de elevadas nas águas está com ocorrência de vômitos, 10 anos, podendo, portanto, relacionadas ao contato com ataca a medula óssea integrar-se às cadeias recipientes e canalizações conseqüentemente redução alimentares. que contenham este dos glóbulos vermelhos elemento, inclusive gerando anemia, causa plásticas, ao uso de hipertensão, doenças fertilizantes e ao cardiovasculares,

lançamento de despejos diminuição da massa óssea, industriais de retardo do crescimento em galvanoplastia, de crianças, prejudica a mineração e metalurgia do capacidade excretora dos zinco bem como de rins.

processos de combustão. 
Cont.

\begin{tabular}{|c|c|c|c|}
\hline Elemento & $\begin{array}{c}\text { Características } \\
\text { Gerais }\end{array}$ & $\begin{array}{l}\text { Origem nas Águas e } \\
\text { Fatores de Alteração }\end{array}$ & $\begin{array}{c}\text { Inconvenientes e } \\
\text { toxicidade }\end{array}$ \\
\hline $\mathrm{Cl}$ & $\begin{array}{l}\text { O cloreto na forma iônica } \\
\mathrm{Cl}^{-} \text {é um dos principais } \\
\text { annions inorgânicos } \\
\text { presentes na água e em } \\
\text { efluentes. } \\
\text { As concentrações de } \\
\text { cloretos são geralmente } \\
\text { mais altas em águas } \\
\text { residuárias do que em } \\
\text { esgotos domésticos. }\end{array}$ & $\begin{array}{l}\text { Ocorrem em águas naturais } \\
\text { em teores variados devido } \\
\text { ao contato com depósitos } \\
\text { minerais ou com a água do } \\
\text { mar. } \\
\text { Maiores concentrações } \\
\text { decorrem da contaminação } \\
\text { por esgotos domésticos, } \\
\text { efluentes industriais } \\
\text { diversos (químicos, de } \\
\text { tintas, explosivos, fósforos, } \\
\text { papel, de galvanoplastia, } \\
\text { bebidas carbonatadas, } \\
\text { processamento de } \\
\text { alimentos) e do retorno de } \\
\text { água de irrigação. }\end{array}$ & $\begin{array}{l}\text { Embora em quantidades } \\
\text { razoáveis não sejam } \\
\text { prejudiciais à saúde } \\
\text { humana, transmitem à água } \\
\text { sabor salgado repulsivo. } \\
\text { Quando inspirado pode } \\
\text { causar irritação nas } \\
\text { membranas mucosas dos } \\
\text { olhos, nariz, garganta e } \\
\text { traquéia. }\end{array}$ \\
\hline $\mathrm{Cr}$ & $\begin{array}{l}\text { Baixos teores o cromo III } \\
\text { são necessários ao } \\
\text { metabolismo humano e } \\
\text { animal, porém a espécie } \\
\text { hexavalente não tem função } \\
\text { nenhuma ao organismo } \\
\text { humano além de ser } \\
\text { extremamente tóxica. }\end{array}$ & $\begin{array}{l}\text { Ë um elemento raramente } \\
\text { encontrado em águas } \\
\text { naturais não poluídas. } \\
\mathrm{O} \text { cromo trivalente presente } \\
\text { nas águas decorre } \\
\text { principalmente do } \\
\text { lançamento de despejos de } \\
\text { curtumes. A presença do } \\
\text { cromo hexavalente advém } \\
\text { de despejos de indústrias } \\
\text { que utilizam processos de } \\
\text { cromagem de metais, } \\
\text { galvanoplastias, indústria de } \\
\text { corantes, explosivos, } \\
\text { cerâmica, vidro, papel, etc. }\end{array}$ & $\begin{array}{l}\mathrm{Na} \text { forma trivalente } \\
\text { apresenta menos toxidez } \\
\text { que na hexavalente. } \\
\text { Apesar de não ser } \\
\text { cumulativo, por bloquear } \\
\text { enzimas responsáveis por } \\
\text { determinados processos } \\
\text { metabólicos, pode ser } \\
\text { prejudicial à saúde humana } \\
\text { em concentrações maiores } \\
\text { que } 11 \mathrm{mg} \mathrm{L}^{-1} \text {. } \\
\text { Quando inspirado pode ser } \\
\text { carcinogênico. }\end{array}$ \\
\hline $\mathrm{Cu}$ & $\begin{array}{l}\text { Em pequenas concentrações } \\
\text { participa dos processos } \\
\text { metabólicos e sua ausência } \\
\text { pode causar anemia. }\end{array}$ & $\begin{array}{l}\text { Ocorre em águas naturais } \\
\text { em pequenas concentrações. } \\
\text { Maiores teores são } \\
\text { decorrentes de sua } \\
\text { utilização como algicida, do } \\
\text { lançamento de despejos } \\
\text { industriais e do desgaste de } \\
\text { canalização de cobre. }\end{array}$ & $\begin{array}{l}\text { Causa sabor às águas de } \\
\text { abastecimento. } \\
\text { Concentrações elevadas são } \\
\text { danosas para os organismos } \\
\text { aquáticos, podendo } \\
\text { ocasionar problemas de } \\
\text { fígado no homem (doença } \\
\text { do Willson). }\end{array}$ \\
\hline
\end{tabular}


Cont.

\begin{tabular}{|c|c|c|c|}
\hline Elemento & $\begin{array}{c}\text { Características } \\
\text { Gerais }\end{array}$ & $\begin{array}{l}\text { Origem nas Águas e } \\
\text { Fatores de Alteração }\end{array}$ & $\begin{array}{l}\text { Inconvenientes e } \\
\text { toxicidade }\end{array}$ \\
\hline $\mathrm{F}^{-}$ & $\begin{array}{l}\text { São essenciais em águas } \\
\text { para consumo humano em } \\
\text { concentrações baixas }(0,8 \text { a } \\
\left.1,2 \mu \mathrm{g} \quad \mathrm{L}^{-1}\right) \text { para a } \\
\text { prevençãa de cáries infantis. } \\
\text { Maiores concentrações são } \\
\text { prejudiciais à saúde } \\
\text { humana. }\end{array}$ & $\begin{array}{l}\text { Sua presença em águas } \\
\text { naturais não poluídas deve- } \\
\text { se ao contato com rochas } \\
\text { que contenham flúor. } \\
\text { Maiores concentrações } \\
\text { ocorrem devido ao } \\
\text { lançamento de despejos de } \\
\text { industriais químicas, de } \\
\text { vidro, de beneficiamento de } \\
\text { minérios, dentre outras. }\end{array}$ & $\begin{array}{l}\text { Concentrações altas, entre } \\
8,0 \text { e } 20,0 \mu \mathrm{g} \mathrm{L}^{-1} \text { são } \\
\text { prejudiciais à saúde por } \\
\text { causarem fluorose dental } \\
\text { em crianças e fluorose } \\
\text { endêmica cumulativa, com } \\
\text { conseqüentes lesões } \\
\text { esqueléticas em crianças e } \\
\text { adultos. }\end{array}$ \\
\hline
\end{tabular}

Fe Existe em grande Em águas não poluídas, seu Confere sabor e coloração quantidade na natureza, teor varia muito em função avermelha às águas. sendo encontrado em solos da litologia da região e do Sua presença causa e minerais principalmente período chuvoso, quando depósitos em tubulações. na forma de óxido férrico pode ocorrer o carreamento Pode causar manchas em insolúvel e sulfeto de ferro, de solos com teores de ferro aparelhos sanitários e em solúvel em água na mais elevados. roupas durante a lavagem. presença de dióxido de Pode ocorrer em maiores Pode causar problemas no carbono. Pode também concentrações devido à sistema de distribuição e ocorrer como carbonato de drenagem de áreas de promover o crescimento de ferro, fracamente solúvel. mineração, ou ao ferrobactérias, causando Nas águas superficiais pode lançamento de efluentes vômito e prejudicar ao ser encontrado sob as industrias de metalurgia ou fígado e aos rins.

formas de (ferro ferroso) e de processamento de trivalente (ferro férrico), metais.

como solução, colóide, suspensão ou em complexos orgânicos e minerais.

$\mathrm{Hg}$ Embora seja um elemento Encontra-se distribuído no Sua toxicidade é maior sob a com alto índice de meio ambiente, podendo forma metil-mercúrio podendo toxicidade, tem sido ocorrer em águas naturais, causar danos irreversíveis no utilizado em larga escala principalmente incorporado cérebro devido à destruição para fins industriais, aos sedimentos de fundo. dos tecidos neurais, lesões minerários e agrícolas. Maiores concentrações renais, tremores musculares, Apresenta efeito cumulativo originam-se de efluentes de irritabilidade, distúrbios da nos organismos, integrando- industrias que utilizam paralisação dos órgãos dos se às cadeias alimentares, processos eletrolíticos, sentidos, náuseas, perturbação principalmente sob a forma madeireiras, resíduos de do sono, diminuição da de compostos organo- bactericidas e fungicidas capacidade de concentração, mercúricos, cuja meia vida utilizados na agricultura e vômitos, dores abdominais, no organismo humano é de do seu uso em atividades de diarréias, danos nos ossos e a 70 a 100 dias. garimpo. morte. 
Cont.

\begin{tabular}{|c|c|c|c|}
\hline Elemento & $\begin{array}{c}\text { Características } \\
\text { Gerais }\end{array}$ & $\begin{array}{l}\text { Origem nas Águas e } \\
\text { Fatores de Alteração }\end{array}$ & $\begin{array}{c}\text { Inconvenientes e } \\
\text { toxicidade }\end{array}$ \\
\hline $\mathrm{Mg}$ & & $\begin{array}{l}\text { Ocorrem em águas naturais } \\
\text { devido a dissolução de } \\
\text { rochas carbonáticas, } \\
\text { silicatos, minérios e } \\
\text { ferromagnesianos. }\end{array}$ & $\begin{array}{l}\text { Pode ser prejudicial aos rins } \\
\text { e causar severa obstrução } \\
\text { intestinal. }\end{array}$ \\
\hline $\mathrm{Mn}$ & $\begin{array}{l}\text { Está presente em quase } \\
\text { todos os solos, } \\
\text { principalmente na forma de } \\
\text { dióxido de manganês, } \\
\text { insolúvel em águas que } \\
\text { contenham dióxido de } \\
\text { carbono. Sob condições } \\
\text { anaeróbicas, o dióxido de } \\
\text { manganês é reduzido para } \\
\text { as formas solúveis. }\end{array}$ & $\begin{array}{l}\text { Em águas naturais podem } \\
\text { ocorrer em pequenas } \\
\text { concentrações devido à } \\
\text { lixiviação de minerais e } \\
\text { solos. } \\
\text { Maiores concentrações } \\
\text { decorrem dos lançamentos } \\
\text { de efluente industriais. }\end{array}$ & $\begin{array}{l}\text { Confere sabor, coloração } \\
\text { marrom e turbidez às águas, } \\
\text { além de formar depósitos } \\
\text { em tubulações. }\end{array}$ \\
\hline $\mathrm{Ni}$ & $\begin{array}{l}\text { Ë um elemento utilizado na } \\
\text { produção de várias ligas, na } \\
\text { fabricação de moedas, } \\
\text { magnetos, baterias de } \\
\text { acumulação, etc. }\end{array}$ & $\begin{array}{l}\text { Maiores } \\
\text { provêm de efluentes de } \\
\text { fábricas de tintas e de } \\
\text { processos de galvanoplastia. }\end{array}$ & $\begin{array}{l}\text { A ingestão de sais solúveis } \\
\text { pode provocar alergia, } \\
\text { náuseas, vômitos, diarréia e } \\
\text { desordem respiratória. }\end{array}$ \\
\hline $\mathrm{Pb}$ & $\begin{array}{l}\text { É um metal tóxico ao } \\
\text { homem e animais. O } \\
\text { chumbo ingerido é } \\
\text { absorvido parcialmente pelo } \\
\text { organismo; entretanto, o } \\
\text { contido no ar inspirado é } \\
\text { absorvido rápida e } \\
\text { completamente pelos } \\
\text { pulmões, entretanto na } \\
\text { corrente sanguínea } \\
\text { distribui-se por todo o } \\
\text { organismo. }\end{array}$ & 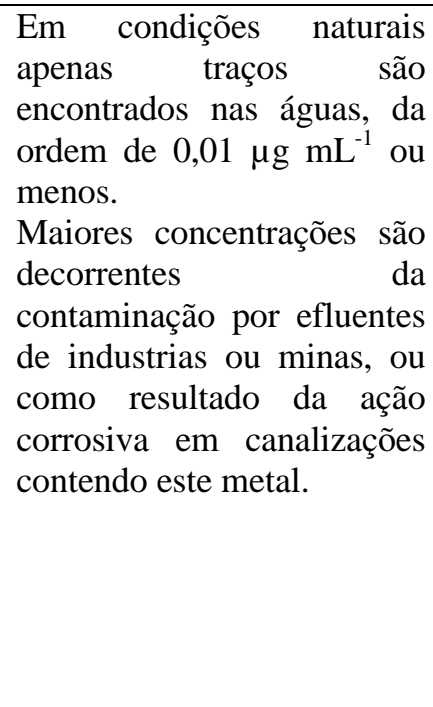 & $\begin{array}{l}\text { Apresenta poder cumulativo } \\
\text { no organismo. } \\
\text { Quando assimilado pode } \\
\text { desencadear uma série de } \\
\text { perturbações: } \\
\text {-danos ao sistema nervoso } \\
\text { central, podendo ocasionar } \\
\text { epilepsia, convulsões e } \\
\text { paralisia; } \\
\text {-redução da capacidade } \\
\text { intelectual em crianças; } \\
\text { diminuição da resistência } \\
\text { frente a infecções; } \\
\text {-anemia; } \\
\text {-intoxicação crônica ou } \\
\text { saturnismo, que pode levar } \\
\text { à morte. }\end{array}$ \\
\hline
\end{tabular}

FONTE: SEILER \& SIGEL [1988]; CPRM [1999]. 


\subsection{Métodos Analíticos para a Determinação de Metais e Espécies QUÍMICAS}

Nos últimos anos têm surgido várias técnicas analíticas para a determinação de elementos em nível de traços $\left(0,01-100 \mu \mathrm{g} \mathrm{L}^{-1}\right)$ e ultratraços $\left(<0,01 \mu \mathrm{g} \mathrm{L} \mathrm{L}^{-1}\right)$. Apesar de todos os benefícios alcançados nenhuma técnica analítica por si só resolve todos os problemas levando-se em conta os diferentes tipos de matrizes.

As técnicas instrumentais analíticas comumente utilizadas para a determinação de elementos em nível de traços são a espectrometria de absorção atômica com chama (AAS), espectrometria de absorção atômica com atomização eletrotérmica (ou forno de grafita) (GFA-AAS), a espectrometria de absorção de fluorescência atômica (FAAS), a espectrometria de emissão óptica com plasma de argônio (ICP-OES), a espectrometria de massas com plasma de argônio (ICP-MS), a análise por ativação neutrônica (NAA), espectrometria de emissão de raios X emitido por partículas (PIXE), espectrometria por fluorescência de Raios X (XRF), a cromatografia líquida de alta eficiência (HPLC), cromatografia iônica (IC) e métodos polarográficos, voltamétricos e potenciométricos [CLEMENT et al, 1995].

A Espectrometria de Absorção Atômica com chama é aplicável a concentrações moderadas $\left(1-100 \mu \mathrm{g} \mathrm{L}^{-1}\right)$. O forno de grafita geralmente é mais sensível $\left(0,01-3 \mu \mathrm{g} \mathrm{L}^{-1}\right)$. A técnica de ICP-OES no que diz respeito a limite de detecção, é menos sensível quando comparada ao método de AAS pela técnica de forno de grafita, porém é uma técnica multielementar. A cromatografia iônica além da vantagem de ser também multielementar pode analisar espécies iônicas e também íons com funções organolépticas [PIRES, 1989; CLEMENT et al., 1995].

Existe um amplo leque de métodos e técnicas aplicados para a determinação de metais e elementos-traço em água e matriz ambiental. Neste trabalho fez-se uso de duas técnicas multielementares muito sensíveis para que os objetivos fossem atingidos: a espectrometria de emissão óptica com plasma de argônio e a cromatografia de íons. A seguir está descrito um breve resumo sobre as técnicas utilizadas. 


\subsubsection{Cromatografia DE ÍONS (IC)}

O termo "cromatografia" é usado para indicar um número de técnicas de separação físico-químicas baseada na distribuição dos solutos entre uma fase móvel e uma estacionária. A classificação de vários tipos de cromatografia é baseada na natureza dessas duas fases envolvidas.

A cromatografia de íons fundamenta-se no fenômeno de troca iônica, associada a detecção condutométrica e supressão química (Figura 4.2). A amostra é bombeada através de uma coluna de troca iônica, passando por um sistema supressor auto-regenerante, até atingir o detector de condutividade. A coluna separadora é empacotada com um trocador aniônico de baixa capacidade (para sistema aniônico) ou um trocador catiônico de baixa capacidade (para sistema catiônico). A separação dos íons baseia-se na afinidade destes com os pontos de troca da resina e com o eluente. A função do sistema supressor é reduzir o sinal de fundo do eluente e converter os ânions (ou cátions) da amostra na forma de seus ácidos (ou hidróxidos) correspondentes, tornando-os espécies mais condutivas, para posterior medida em uma célula de condutividade. Os íons são identificados por comparação dos seus tempos de retenção com os de padrões conhecidos. A quantificação é feita por medida da área do pico comparada com a área de um padrão de concentração conhecida. 


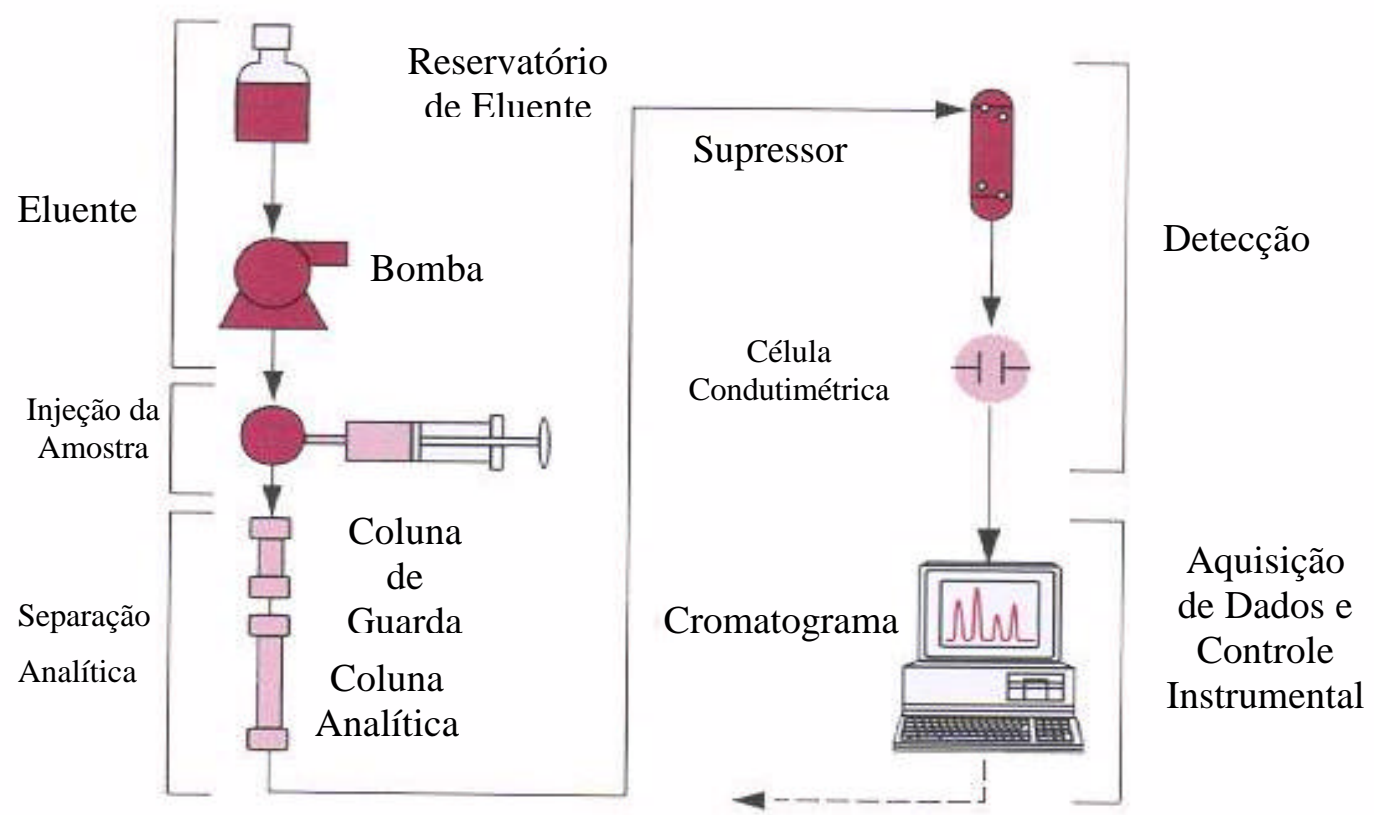

Figura 4.2 - Fluxograma da técnica de cromatografia de íons

\subsubsection{SISTEMA SUPRESSOR}

A função do sistema supressor é suprimir ou neutralizar o eluente da coluna separadora e transformar as espécies de interesse numa forma mais condutiva, como mostrado na Figura 4.3. Os sistemas de separação tiveram um grande avanço desde a implementação da técnica de IC em 1975 [PIRES, 1989].

Os primeiros sistemas de supressão foram as colunas de troca iônica. Esses sistemas, apesar de eficiente possuíam o inconveniente da regeneração, limitando o número de amostras em função da capacidade de troca da resina.

Com o avanço das micros-membranas elas foram introduzidos no sistema de supressão dos Cromatógrafos Iônicos. Esses supressores permitiram a utilização de sistemas de gradiente e são sistemas auto-regenerantes. 
O sistema supressor auto-regeneração aniônico (Figura 4.4) necessita de uma alimentação constante de água na câmara regenerante para que se tenha supressão. A água ao entrar no sistema supressor auto-regenerante sofre eletrólise formando gás hidrogênio e íons hidróxidos na câmara catódica, simultaneamente, o gás oxigênio e o íon hidrônio são

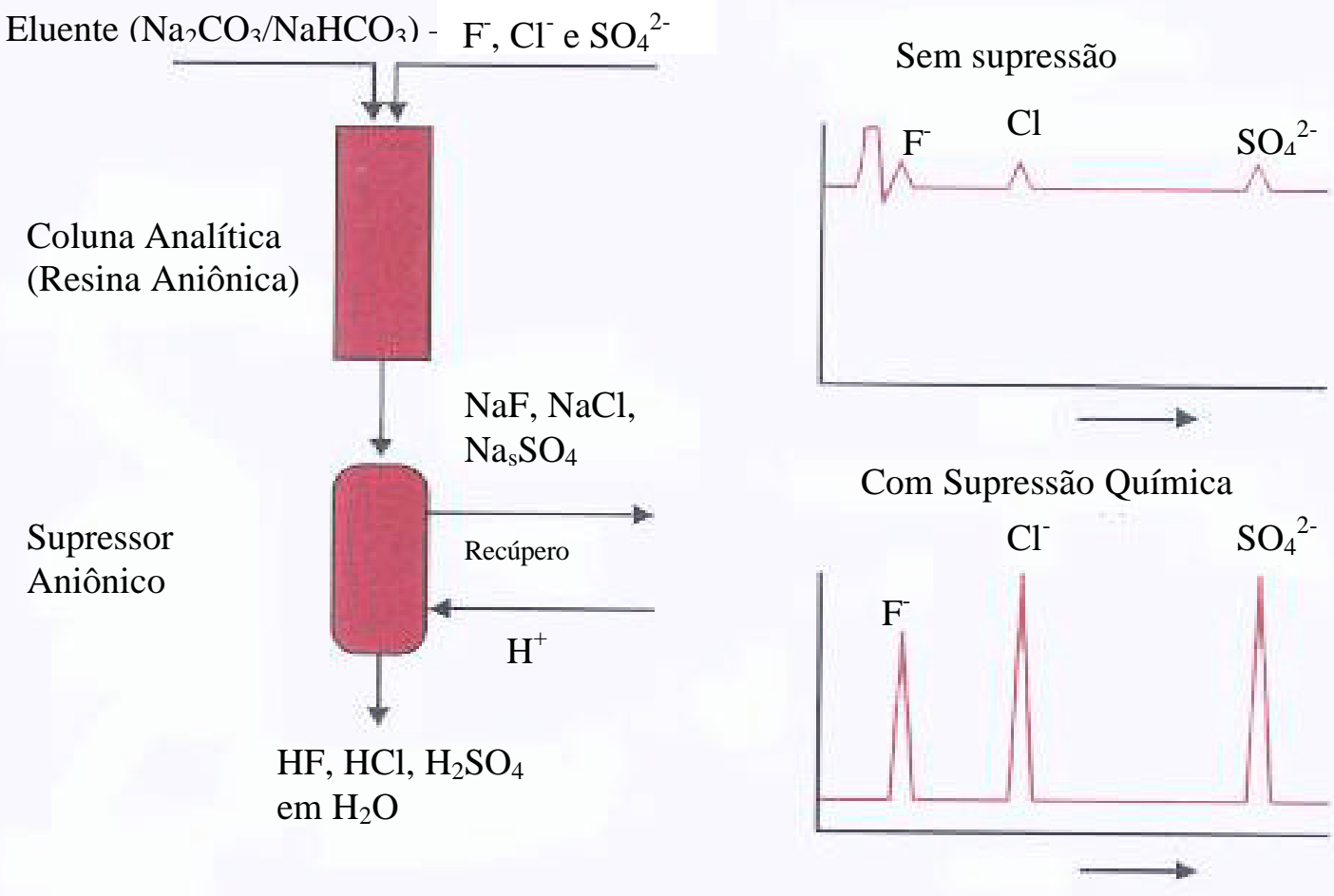

Figura 4.3 - Esquema da supressão química em I.C.

formados na câmara anódica. Cátions em geral permeiam na membrana em direção do cátodo permitindo aos íons hidrônio se movam da câmara anódica até câmara do eluente para neutralizar o hidróxido. Íons de sódio do eluente são atraídos pela potencial elétrico para o cátodo, mantendo a neutralidade eletrônica no eletrodo com íons hidróxido [DIONEX, 1993a]. 


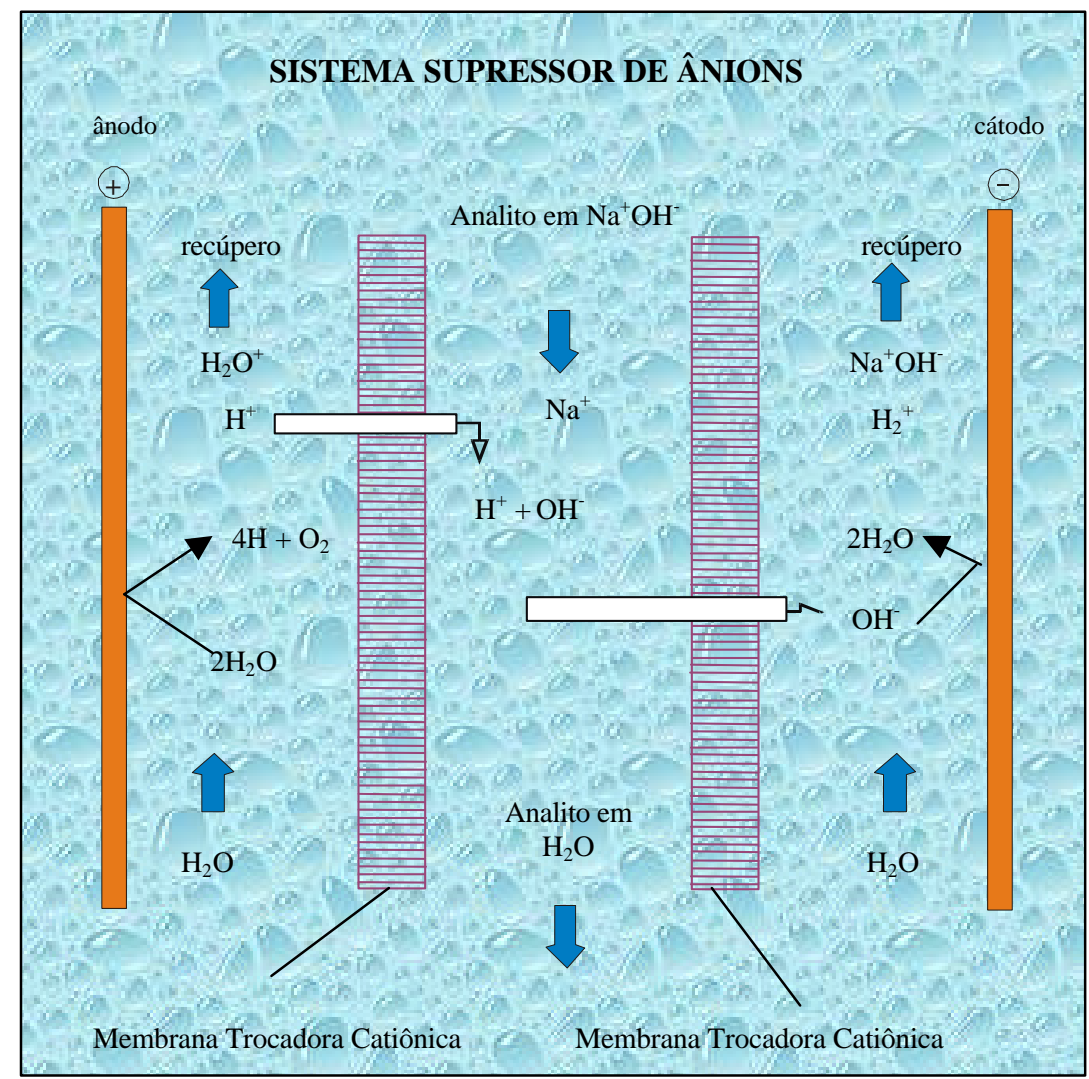

Figura 4.4 - Representação esquemática do sistema auto-regenerante aniônico

O sistema supressor auto-regenerante catiônico (Figura 4.5) opera basicamente como o sistema anterior. A água sofre hidrólise formando gás hidrogênio e íons hidróxido na câmara catódica, simultaneamente, o gás oxigênio e os íons hidrônio são formados na câmara anódica. Ânions em geral permeiam na membrana permitindo que os íons hidróxidos se movam da câmara catódica até a câmara do eluente para neutralizar os íons hidrônio. Ânions no eluente são atraídos pelo potencial elétrico para o anodo mantendo a neutralidade eletrônica no eletrodo com os íons hidrônio [DIONEX, 1993b]. 


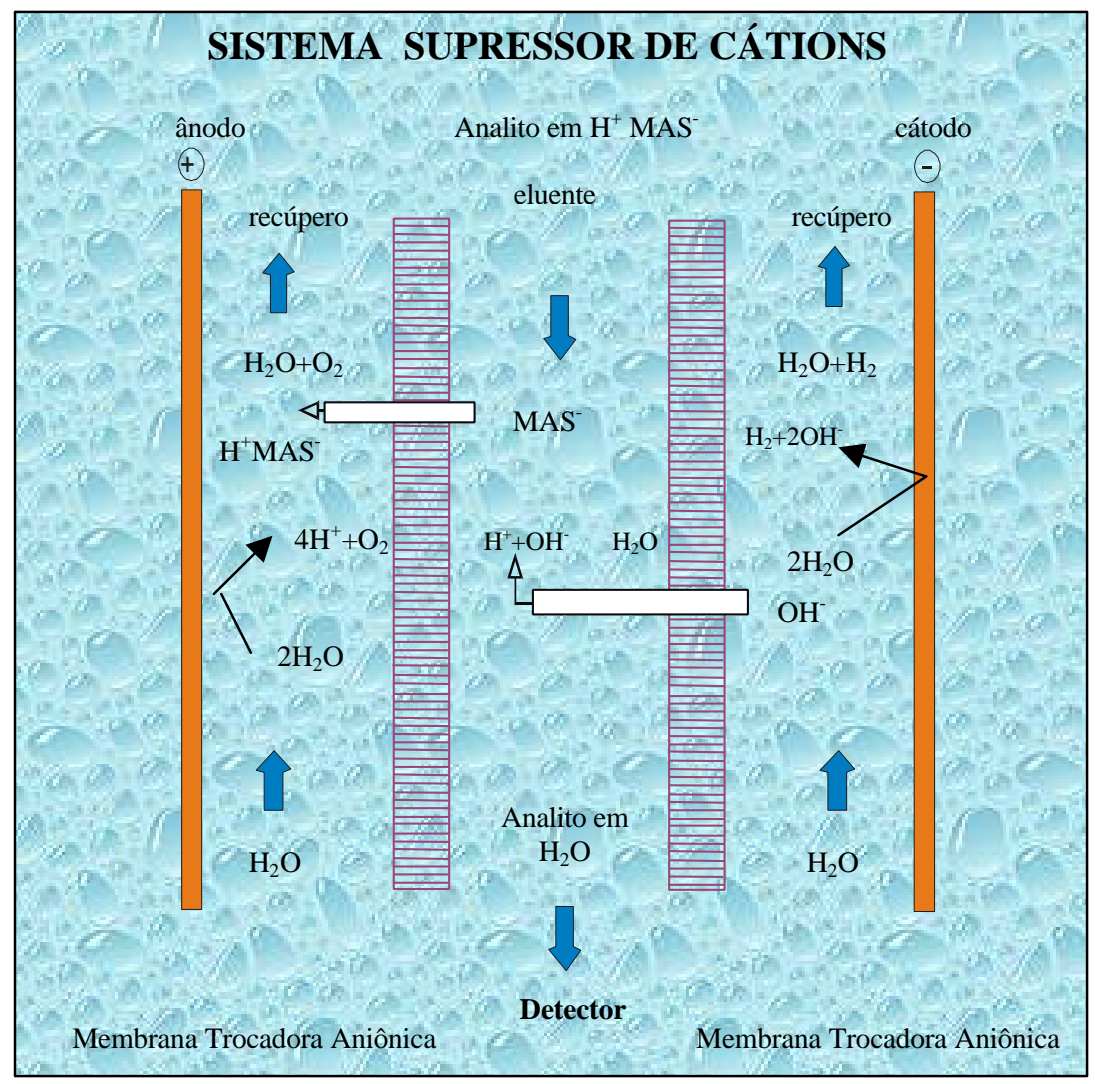

Figura 4.5 - Representação esquemática do sistema supressor auto-regenerante catiônico. $\mathrm{H}^{+} \mathrm{MAS}^{-}$: Methano Acid Sulfonic (Ácido metanosulfônico)

A aplicabilidade da técnica de Cromatografia de Íons é diversificada, pois, é uma técnica que exige pouco ou nenhum preparo, na maioria das vezes basta filtrar e/ou diluir a amostra em água e injetá-la diretamente no cromatógrafo. Esta técnica é empregada em diversas áreas, tais como: ambiental (águas, solos, efluentes, etc), biológicas, alimentícia, médica, geologia e nuclear [HANSEM et al., 1979; BUTLER \& GERSHEY, 1984; MOSKO, 1984; HOOVER \& YAGER, 1984; LEE \& HAAK, 1988; PIRES, 1989; FRANKENBERGER et al., 1990; CERK et al., 1993; NGUYEN, 1996; CLEMENT \& YANG, 1995; NOVIC et al., 1997].

MOU [1991] demonstrou em seu trabalho a aplicação da cromatografia de íons na área atmosférica, e em água potável, efluente industrial e solo, comprovando com seu estudo a versatilidade da técnica e sua precisão nas análises. 


\subsubsection{EsPectrometria de EMissão Óptica CoM Plasma de Argônio (ICP-OES)}

A Espectrometria de Emissão Óptica com Plasma de Argônio (ICP-OES) é amplamente utilizada para análises ambientais [YABE, 1995; CHARLES \& FREDEEN, 1997; GATTI, 1997; DANTAS, 1999; SANTOS, 1999] por suas características gerais:

- É uma técnica multielementar rápida que permite a determinação simultânea de seus constituintes maiores, menores e traço.

- Embora a sensibilidade da técnica para muitos dos elementos comumente determinados não seja muito baixa (por exemplo, $\mathrm{Cu}, \mathrm{Cd}$, $\mathrm{Ni}, \mathrm{Pb}, \mathrm{Zn}$ ) não existe grande diferença quando comparada a técnica Espectrométrica de Absorção Atômica (AAS), porém ela é muito sensível para elementos metálicos refratários (por exemplo, V, Be) bem como para alguns não-metálicos como B e P.

- A baixa vulnerabilidade do ICP-OES para os interferentes interelementares, faz com que a calibração para uma variedade de materiais ambientais seja muito mais fácil do que para a técnica de Espectrometria de Absorção Atômica.

\subsubsection{Plasma (ICP)}

O plasma é um gás parcialmente ionizado, formado eletromagnéticamente por indução de radiofreqüência acoplado ao gás argônio e usado como fonte de excitação para análise quantitativa de amostras líquidas e sólidas (Langmuir, [1929] apud OLIVEIRA [1998]).

Na Figura 4.6 tem-se representado o esquema da tocha (quartzo) que é a configuração que sustenta o plasma, circundada por um bobina de indução (resfriada a água ou ar) através da qual a energia de até $2-3 \mathrm{~kW}$ é fornecida, sendo o gerador de freqüência de 27 ou $40 \mathrm{MHz}$. 


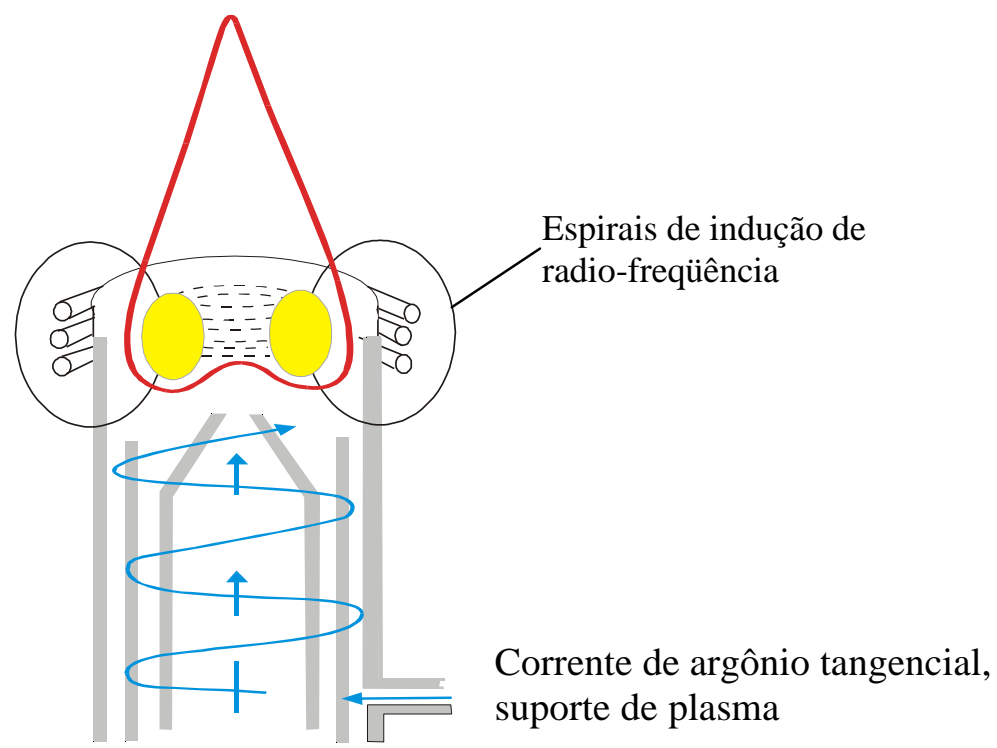

Figura 4.6 - Diagrama esquemático de uma fonte de plasma de argônio [CHARLES \& FREDEEN, 1997]

A tocha consiste de três tubos concêntricos, o fluxo de argônio que flui tangencialmente entre o tubo exterior e intermediário $\left(12-18 \mathrm{~L} \mathrm{~min}^{-1}\right)$ é chamado gás refrigerante ou gás do plasma e atua para formar o plasma e refrigerar a tocha. $\mathrm{O}$ tubo intermediário carrega o gás argônio auxiliar a cerca de 1,0 $\mathrm{L} \mathrm{min}^{-1}$. Este fluxo de argônio é ionizado por meio de uma bobina Tesla, trabalhando-se com argônio a 0,5 $\mathrm{L} \mathrm{min}^{-1}$. O tubo central é o que conduz a amostra em forma de aerosol para o plasma $\left(0,7-1,5 \mathrm{~L} \mathrm{~min}^{-1}\right)$ que é chamado de gás de arraste.

O plasma pode ser gerado por baixas freqüências $(5 \mathrm{MHz})$, onde a amostra segue a trajetória ao redor da superfície externa. Com freqüência da ordem de $30 \mathrm{MHz}$, é assegurada uma boa configuração do plasma com aerosol da amostra entrando pelo tubo central. A fonte de $40 \mathrm{MHz}$ tem um canal central mais largo e pronunciado, isto permite que a amostra penetre na descarga anular a uma velocidade linear menor e conseqüentemente, aumentando o maior tempo de residência no plasma, resultando uma alta tolerância a sólidos dissolvidos e a solventes orgânicos. Outro beneficio é que a potência de saída é mais eficientemente acoplada à descarga do plasma, permitindo que o plasma opere a uma potência menor (cerca de 300 a $500 \mathrm{~W}$ ), ou seja, menor que o plasma de $27 \mathrm{MHz}$ e, portanto a menor consumo de gás argônio. 
O princípio físico da formação de um campo magnético a partir de corrente elétrica que circula por uma selenóide é o utilizado para a formação do plasma. A fonte de radiofreqüência fornece corrente elétrica que circula pelas espirais da bobina, induzindo um campo magnético oscilante com linhas de forças orientadas axialmente dentro do tubo, formando elipses fechadas.

O campo magnético induzido acelera os elétrons, os quais fluem em trajetórias anulares dentro da tocha produzindo ionização por colisão. Após a ionização, um plasma em forma de chama de vela forma-se perto do topo da tocha [OLIVEIRA, 1998]

\subsubsection{INTRODUÇão dA AMOSTRA LíQUiDA}

A amostra é introduzida seguindo na forma de aerosol nos nebulizadores comuns ou por nebulizadores ultra-sônicos. O nebulizador de Fluxo Cruzado tem uma boa resistência ao ácido fluorídrico (HF) e não entope facilmente, ele suporta solução contendo $5 \%$ de sal. Para soluções com alta concentração de sal o nebulizador tipo spray (Babington) é o mais adequado. O nebulizador tipo "Meinhard" dá uma boa sensibilidade para soluções com concentração salina abaixo de $1 \%$. O nebulizador tipo ultra-sônico requer uma concentração salina muito menor do que os nebulizadores pneumáticos (Fluxo Cruzado, Meinhard e Babington), e resulta um aumento de sensibilidade da ordem de 10 a 50 vezes [ALLOWAY \& AYRES, 1997].

\subsubsection{NEBULIZADOR TIPO MEINHARD}

Existem dois tipos de configuração de nebulizadores "Meinhard" (Figura 4.7), com a taxa de operação e o tipo do bocal. A pressão interna varia de 70 a $350 \mathrm{kPa}$, no momento da entrada do líquido varia de $0,5 \mathrm{a} 4 \mathrm{~mL} \mathrm{~min}^{-1}$. A taxa de fluxo de argônio, varia de $0,5 \mathrm{a}$ $0,8 \mathrm{~L} \mathrm{~min}^{-1}$, na entrada da solução pode ser obtida uma taxa menor que 0,5 a $1 \mathrm{~mL} \mathrm{~min}^{-1}$ [MONTASER \& GOLIGHTLY, 1992]. A solução é introduzida por um tubo capilar para uma região de baixa pressão criada pelo fluxo rápido do gás no fim do capilar. A baixa pressão e a alta velocidade do gás é adequada para transformar a solução em aerosol [CHARLES \& FREDEEN, 1997]. 


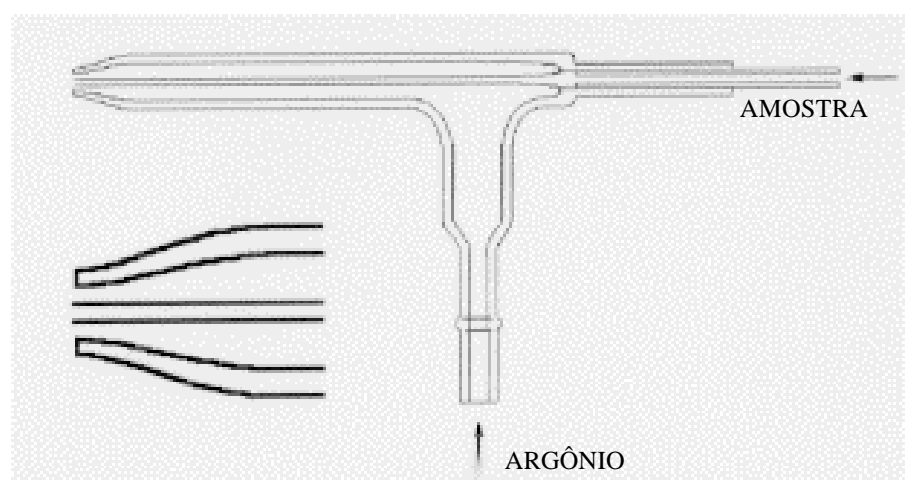

Figura 4.7 - Esquema do nebulizador Meinhard (CHARLES \& FREDEEN, 1997)

\subsubsection{EXCITAÇÃO DA AMOSTRA}

A amostra em solução, por meio da nebulização, transforma-se em aerosol o qual após desolvatação passa a partícula seca que, por volatização-dissociação, vai para a forma de vapores atômicos-vapores iônicos, os quais são excitados na forma de átomos-íons. $\mathrm{O}$ mecanismo de excitação é colisional. A tendência dos elétrons excitados é de voltarem ao estado fundamental e ao fazerem-no, devolvem a energia de emissão, onde os comprimentos de onda são característicos de cada elemento (Figura 4.8), e a intensidade da linha do espectro de emissão é proporcional à concentração do elemento em determinação [OLIVEIRA, 1998].

\section{Processo de Emissão Atômica}

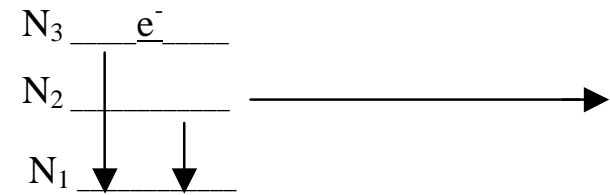

Estado Excitado

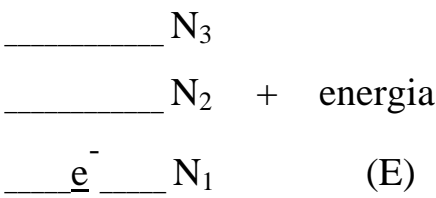

Estado Fundamental

Figura 4.8 - Representação da emissão atômica 


\section{PArte Experimental}

O principal interesse deste trabalho esta voltado para a avaliação de metais e elementos-traço em áreas de captação de água, e estações de tratamento com predominância à biodisponibilidade nos sedimentos das estações de captação superficial das bacias Hidrográficas dos Rios Mogi-Guaçu e Pardo.

Para atingir os objetivos dividiu-se o estudo experimental em etapas distintas:

Levantamento dos dados disponíveis pelos órgãos públicos para reconhecimento da paisagem hídrica e possíveis fontes de poluição;

$\checkmark$ Validação de metodologia analítica para a determinação de espécies aniônicas e catiônicas utilizando a técnica de cromatografia de íons e determinação de metais e elementos-traço utilizando espectrometria de emissão óptica com plasma de argônio;

$\checkmark$ Estabelecimento do programa de monitoramento, levantamento dos pontos de coleta e definição da metodologia para preservação das amostras;

$\checkmark$ Caracterização da área piloto por um ciclo hidrológico avaliando-se: a) as concentrações dos metais nas águas bruta e tratada e, b) no sedimento, as frações sobrenadante e intersticial; e na fase sólida a fração de metal biodisponível e a análise mineralógica.

$\checkmark$ Análise dos dados:

$\checkmark$ Comparar as comunidades quanto às concentrações dos elementos quanto a sazonalidade;

$\checkmark$ Verificar a existência de correlação entre índice pluviométrico e concentração dos elementos analisados na água bruta;

$\checkmark$ Verificar o comportamento dos metais e elementos-traço após tratamento convencional das ETA e a possibilidade de risco a comunidade. 


\subsection{Materiais e Métodos}

\subsubsection{EQUiPAMENTOS E MATERIAIS}

- Cromatógrafo de íons Dionex, DX 120, equipado com sistema supressor autoregenerante, detetor de condutividade e injetor com loop de $100 \mu \mathrm{L}$; sistema integrador Waters 100;

$>$ Espectrômetro de emissão atômica com plasma de argônio, Espectro Flame M 120, Spectro;

$>$ Centrífuga, Fanen - modelo 240;

> Agitador mecânico horizontal, Ética - modelo 340;

$>$ pHmetro de Campo, Digimed - modelo 330;

$>$ Sistema de purificação de água Milli-Q, Millipore;

$>$ Coluna separadora aniônica (250mm x $4 \mathrm{~mm}$ de diâmetro interno), HPIC - AS14, Dionex e respectiva pré-coluna;

> Coluna separadora catiônica (250mm x 4 mm de diâmetro interno) HPIC - CS14, Dionex e respectiva pré-coluna;

Balança analítica; estufa, geladeira, freezer;

$>$ Frascos de polietileno (100 e $25 \mathrm{~mL}$ de capacidade) e vidraria em geral.

\subsubsection{REAGENTES E SOLUÇÕES}

Todos os reagentes usados são de grau analítico: ácido clorídrico concentrado; ácido nítrico concentrado; pirofosfato de sódio, carbonato de sódio; bicarbonato de sódio; cloreto de sódio; fluoreto de sódio; nitrato de sódio; sulfato de sódio; fosfato de sódio; cloreto de amônio, cloreto de potássio, ácido metanosulfônico, dicromato de potássio, sulfato ferrroso amoniacal e difenilamina.

Solução padrão da Merck, concentração $1 \mathrm{~g} \mathrm{~L}^{-1}$, dos metais: alumínio, bário, cádmio, cálcio, cobalto, cobre, cromo, chumbo, ferro, fósforo, magnésio, manganês, níquel prata e zinco.

Material de referência padrão de sedimento: NIST SRM 2704 (Buffalo River Sediment).

Material de referência padrão de água, para metais NIST SRM 1643C (Trace Element in Water). 


\subsubsection{PAdRões e Eluentes}

Todas as soluções-padrão, soluções-estoque e eluentes foram preparadas com água deionizada, ultra-pura, com condutância específica $<0,1 \mu \mathrm{S} \mathrm{cm} \mathrm{cm}^{-1}$. As soluções padrãoestoque foram preparadas a partir de soluções ou sais padrão, pesados e/ou diluídos com água nas concentrações desejadas. As soluções padrão menos concentradas foram preparadas diariamente por diluições sucessivas com água ultra-pura e guardadas em frascos de polietileno.

Todo o material (vidraria, material de polietileno) foi lavado com ácido nítrico, várias vezes com água destilada e por último com água deionizada ultra-pura.

\section{Preparo das Soluções-Estoque e Padrões}

- Solução estoque de fluoreto, $1 \mathrm{~g} \mathrm{~L}^{-1}$ : Dissolver $0,2210 \mathrm{~g}$ de NaF, previamente seco a $110^{\circ} \mathrm{C}$, em água deionizada, transferir para balão volumétrico de $100 \mathrm{ml} \mathrm{e}$ completar o volume com água.

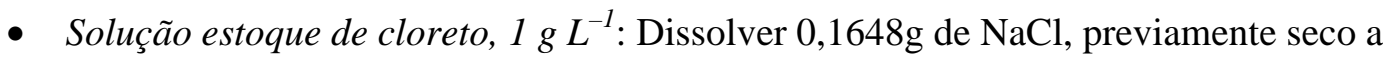
$110^{\circ} \mathrm{C}$, em água deionizada, transferir para balão volumétrico de $100 \mathrm{ml} \mathrm{e}$ completar o volume com água.

- Solução estoque de nitrato, $1 \mathrm{~g} \mathrm{~L}^{-1}$ : Dissolver $0,1371 \mathrm{~g}$ de $\mathrm{NaNO}_{3}$, previamente seco a $110^{\circ} \mathrm{C}$, em água deionizada, transferir para balão volumétrico de $100 \mathrm{ml} \mathrm{e}$ completar o volume com água.

- Solução estoque de sulfato, $1 \mathrm{~g} \mathrm{~L}^{-1}$ : Dissolver $0,1478 \mathrm{~g}$ de $\mathrm{Na}_{2} \mathrm{SO}_{4}$, previamente seco a $110^{\circ} \mathrm{C}$, em água deionizada, transferir para balão volumétrico de $100 \mathrm{ml} \mathrm{e}$ completar o volume com água.

- Solução estoque de fosfato, $1 \mathrm{~g} L^{-1}$ : Dissolver $0,3772 \mathrm{~g}$ de $\mathrm{Na}_{2} \mathrm{HPO}_{4}$ em água deionizada, transferir para balão volumétrico de $100 \mathrm{ml}$ e completar o volume com água.

- Soluções padrão de ânions: A partir das soluções-estoque prepararam-se soluções padrão contendo diferentes concentrações dos ânions e mistura destes, por exemplo: $2 \mu \mathrm{g} \mathrm{mL}^{-1}$ de $\mathrm{F}^{-}, 3 \mu \mathrm{g} \mathrm{mL}^{-1} \mathrm{de} \mathrm{Cl}^{-}, 10 \mu \mathrm{g} \mathrm{mL}^{-1}$ de $\mathrm{NO}_{3}{ }^{-}, 5 \mu \mathrm{g} \mathrm{mL}^{-1}$ de $\mathrm{SO}_{4}{ }^{2-}, 5 \mu \mathrm{g} \mathrm{mL}{ }^{-1}$ de $\mathrm{PO}_{4}{ }^{3-}$. 
- Solução estoque de sódio, $1 \mathrm{~g} \mathrm{~L}^{-1}$ : Dissolver $0,1522 \mathrm{~g}$ de $\mathrm{NaCl}$, previamente seco a $110{ }^{0} \mathrm{C}$, em água deionizada, transferir para balão volumétrico de $100 \mathrm{ml} \mathrm{e}$ completar o volume com água.

- Solução estoque de amônio, $1 \mathrm{~g} \mathrm{~L}^{-1}$ : Dissolver 0,2965g de $\mathrm{NH}_{4} \mathrm{Cl}$, previamente seco a $110{ }^{0} \mathrm{C}$, em água deionizada, transferir para balão volumétrico de $100 \mathrm{ml} \mathrm{e}$ completar o volume com água.

- Solução estoque de potássio, $1 \mathrm{~g} \mathrm{~L}^{-1}$ : Dissolver $0,1907 \mathrm{~g}$ de $\mathrm{KCl}$, previamente seco a $110{ }^{0} \mathrm{C}$, em água deionizada, transferir para balão volumétrico de $100 \mathrm{ml} \mathrm{e}$ completar o volume com água.

- Soluções padrão de cátions: A partir das soluções-estoque preparou-se soluçãopadrão contendo diferentes concentrações dos cátions e mistura destes, por exemplo: 5,0 $\mu \mathrm{g} \mathrm{mL}^{-1}$ de $\mathrm{Na}^{+} ; 5,0 \mu \mathrm{g} \mathrm{mL}^{-1} \mathrm{de} \mathrm{NH}_{4}{ }^{+} ; 10 \mu \mathrm{g} \mathrm{mL}^{-1} \mathrm{de} \mathrm{K}^{+}$

- Solução padrão de $\mathrm{K}_{2} \mathrm{Cr}_{2} \mathrm{O}_{7} 1 \mathrm{~N}$ : Dissolver 49,04g do sal (padrão primário) previamente seco a $105^{\circ} \mathrm{C}$ em água completando o volume a 1 litro em balão volumétrico.

- Solução ácida de $\mathrm{Fe}\left(\mathrm{NH}_{4}\right)_{2}\left(\mathrm{SO}_{4}\right)_{2}$. $6 \mathrm{H}_{2} \mathrm{O}$ - 0,5 N: Dissolver 196,07g do sal em 800 $\mathrm{mL}$ de água deionizada. Adicionar $20 \mathrm{~mL}$ de $\mathrm{H}_{2} \mathrm{SO}_{4}$ concentrado e completar o volume a 1 litro em balão volumétrico.

- Solução indicadora de difenilamina 1\%: Dissolver 1g do sal (padrão primário) previamente seco a $105^{\circ} \mathrm{C}$ em água completando o volume a 1 litro em balão volumétrico

\section{Preparo dos eluentes:}

Todos os eluentes foram preparados com água deionizada ultra-pura e foram filtrados em papel de filtro $<0,45 \mu \mathrm{m}$.

Para a determinação dos ânions foi utilizado como eluente uma solução alcalina de 3,5 mmol L ${ }^{-1} / 1,0 \mathrm{mmol} \mathrm{L}^{-1}$ carbonato/bicarbonato de sódio. Para a separação e determinação das espécies catiônicas foi utilizada uma solução de 10 mmol L ${ }^{-1}$ do ácido metanosulfônico.

- 1,0 mmol L $\mathrm{maHCO}_{3} / \quad 3,5 \mathrm{mmol} \mathrm{L}^{-1} \mathrm{Na}_{2} \mathrm{CO}_{3}$ : Dissolver 0,0840g de $\mathrm{NaHCO}_{3}$ e $0,3710 \mathrm{~g} \mathrm{Na}_{2} \mathrm{CO}_{3}$, previamente secos em estufa a $110{ }^{\circ} \mathrm{C}$ por duas horas, em 
água ultra pura. Em seguida, transferir esta solução para um balão volumétrico de $1000 \mathrm{~mL}$ e completar o volume com água deionizada.

- $10 \mathrm{mmol} \mathrm{L}{ }^{-1}$ ácido metanosulfônico: Pipetar 0,65 mL de ácido metanosulfônico P.A. (Fluka) em um balão volumétrico de $1000 \mathrm{~mL}$ e completar o volume com água deionizada.

\subsection{CertificaÇÃo da Metodologia Analítica}

\subsubsection{DETERMINAÇÃo DE ESPÉCIES IÔNICAS POR CROMATOGRAFIA DE ÍONS-IC}

Para se conhecer a faixa em que a resposta do detector de condutividade é linear com a concentração do íon em estudo e, se as condições aplicadas são as mais adequadas para a quantificação é necessário construir curvas analíticas.

Como medida de quantificação foi utilizada a área do pico (integrador Waters). Obtiveram-se as curvas analíticas traçando-se a área do pico em função da concentração do analito. As condições experimentais estão descritas nas Figuras 5.1 e 5.2, as quais apresentam cromatogramas de identificação das espécies aniônica e catiônica estudadas.

O volume fixo de injeção (loop) de amostra foi de $100 \mu \mathrm{L}$. A amostra foi introduzida no sistema de injeção, após filtração com filtros millipore < 0,45 $\mu \mathrm{m}$, com uma seringa hipodérmica descartável de $1 \mathrm{~mL}$.

As curvas analíticas dos analitos aniônicos $\left(\mathrm{F}^{-}, \mathrm{Cl}^{-}, \mathrm{NO}_{3}{ }^{-}, \mathrm{PO}_{4}{ }^{3-}\right.$ e $\left.\mathrm{SO}_{4}{ }^{2-}\right)$ e catiônicos $\left(\mathrm{Na}^{+}, \mathrm{K}^{+}, \mathrm{NH}_{4}{ }^{+}\right)$foram realizadas de acordo com os métodos 300.6 e 300.7 da Environmental Protection Agency (USEPA) [EPA, 1986 (a) e (b)], respectivamente. As Figuras 5.3, 5.4, 5.5, 5.6, 5.7, 5.8, 5.9 e 5.10, representam as curvas analíticas dos analitos.

Calculou-se, para cada reta, o fator de correlação linear (r) para confirmar a linearidade dos pontos. Os valores encontrados para praticamente todos os fatores de correlação, para diferentes concentrações, foi de 0,99 indicando que estão intimamente relacionados. 


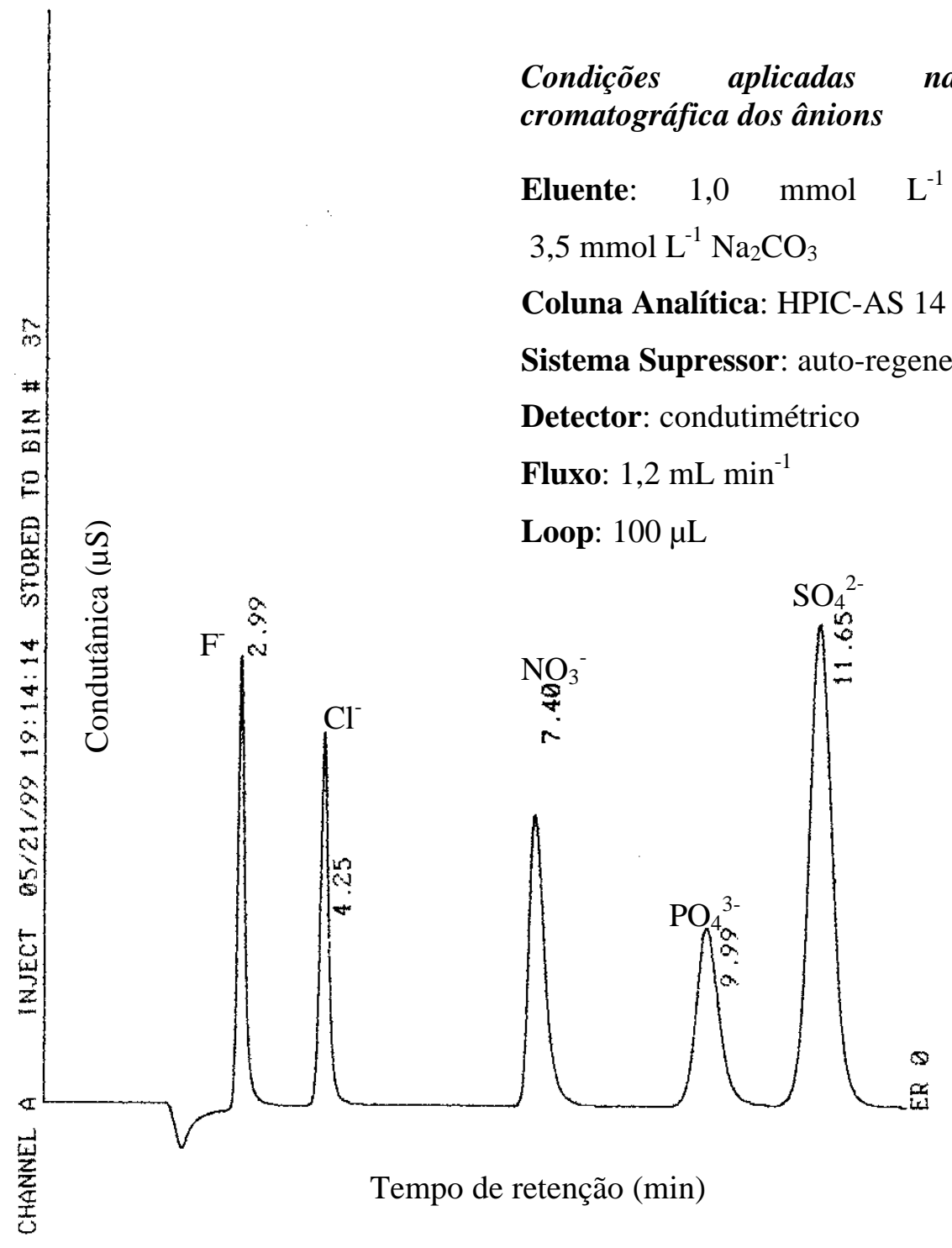

Figura 5.1 - Cromatograma das espécies aniônicas.

Concentração: $\mathrm{F}^{-} 1 \mu \mathrm{g} \mathrm{mL}^{-1}$; $\mathrm{Cl}^{-} 3 \mu \mathrm{g} \mathrm{mL}^{-1} ; \mathrm{NO}_{3}^{-} 2 \mu \mathrm{g} \mathrm{mL}^{-1}$; $\mathrm{PO}_{4}{ }^{3-} 5 \mu \mathrm{g} \mathrm{mL}^{-1}$; $\mathrm{SO}_{4}{ }^{2-} 5 \mu \mathrm{g} \mathrm{mL}{ }^{-1}$ 


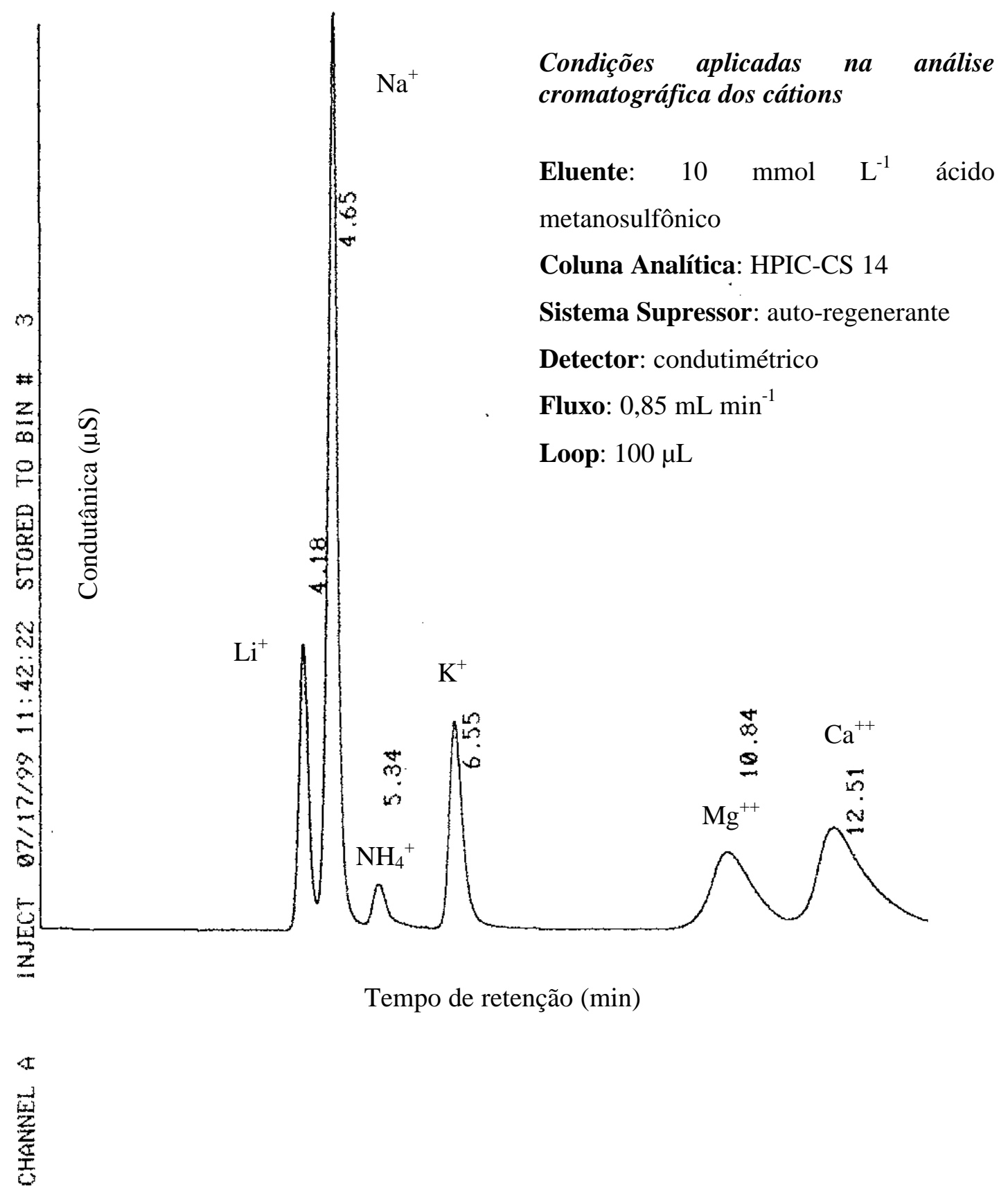

Figura 5.2 - Cromatograma das espécies catiônicas.

Concentração: $\mathrm{Li}^{+} 1 \mu \mathrm{g} \mathrm{mL}{ }^{-1} ; \mathrm{Na}^{+} 10 \mu \mathrm{g} \mathrm{mL}^{-1} ; \mathrm{NH}_{4}^{+} 1 \mu \mathrm{g} \mathrm{mL}^{-1} ; \mathrm{K}^{+} 5 \mu \mathrm{g} \mathrm{mL}^{-1}$; $\mathrm{Mg}^{2+} 2 \mu \mathrm{g} \mathrm{mL}{ }^{-1} ; \mathrm{Ca}^{2+} 5 \mu \mathrm{g} \mathrm{mL}^{-1}$ 
As medidas quantitativas não estão limitadas aos intervalos de concentrações mencionados. A sensibilidade do detector pode ser ajustada para diferentes intervalos de concentração. Não se deve esquecer também que o principal fator que afeta o limite de detecção na cromatografia de íons é a variação de temperatura.

A precisão e a exatidão que afetam os principais parâmetros e eficiência dos métodos analíticos em termos de variação percentual foram verificadas pela determinação da concentração das espécies de interesse utilizando soluções padrão de referência (Tabela 5.1)

Para verificar a precisão do método, o "test-t" foi aplicado para os parâmetros "a" e “b” [MANILOV, 1963; WERNIMONT, 1967 apud MARQUES, 1999], mostrando que para um nível de significância de 0,05 , os valores $a=0$ e $b=1$ podem ser assumidos para a espécie estudada. O valor de r obtido foi maior que 0,99 indicando que $99 \%$ da variação de $x$ (fator independente) com a variação de $y$ (fator dependente) demonstrando que os valores para cada ponto estão correlacionados..

O limite de detecção foi calculado por meio da equação da reta e da equação de MALIMOV [1963] (equação 5.1), onde se substituiu o fator 5 por 2, ou seja, admitindo como positiva qualquer resposta superior a duas vezes o desvio padrão. Contudo, para maior segurança das determinações foram utilizados valores de limite de determinação práticos. Os resultados obtidos são apresentados na Tabela 5.2.

A sensibilidade refere-se à relação entre o sinal obtido e a massa do componente analisado. A sensibilidade do detector pode ser ajustada para diferentes concentrações de trabalho. $\mathrm{O}$ limite prático que se refere à concentração do analito é equivalente a 2 vezes a área do pico do ruído da linha de base no cromatograma registrado [WEISS, 1986]. 


$$
x^{\prime}=\frac{\left(y^{\prime}-a\right)}{b}=5 \frac{S_{0}}{b}\left[\frac{1}{n}+\frac{1}{m}+\frac{\left(y^{\prime}-\bar{y}^{2}\right)}{b^{2}\left(\sum x^{2}-n \bar{x}\right)}\right]^{1 / 2} \quad \text { (equação 5.1.) }
$$

onde:

$y^{\prime}$ : é a altura e/ou área do pico no limite de detecção;

$\bar{x}$ : valor médio das massas;

$\bar{y}$ : valor médio das alturas e/ou áreas dos picos nas respectivas concentrações;

$S_{0}$ : Desvio Padrão da regressão;

$n$ : número de pontos experimentais;

$m$ : número de medidas para cada ponto;

$a$ : coeficiente linear da reta;

$b:$ coeficiente angular da reta. 
Tabela 5.1 - Reprodutibilidade, precisão e desvio padrão relativo

\begin{tabular}{ccccc} 
& \multicolumn{2}{c}{ Concentração } & & \\
\cline { 2 - 3 } Analito & $\begin{array}{c}\text { Padrão } \\
\left(\mathrm{ng} \mathrm{mL}{ }^{-1}\right)\end{array}$ & $\begin{array}{c}\text { Encontrado* } \\
\text { Média } \pm \mathrm{DP} \\
\left(\mathrm{ng} \mathrm{mL}^{-1}\right)\end{array}$ & $\begin{array}{c}\text { D.P.R. } \\
(\%)\end{array}$ & $\begin{array}{c}\text { Recuperação } \\
(\%)\end{array}$ \\
\hline $\mathrm{F}^{-}$ & 25 & $24,8 \pm 0,1$ & 0,4 & 99,3 \\
$\mathrm{Cl}^{-}$ & 25 & $24,7 \pm 0,6$ & 2,4 & 98,8 \\
$\mathrm{NO}_{3}{ }^{-}$ & 50 & $49,3 \pm 0,5$ & 1 & 98,7 \\
$\mathrm{PO}_{4}{ }^{3-}$ & 25 & $25,4 \pm 0,2$ & 0,8 & 100,8 \\
$\mathrm{SO}_{4}{ }^{2-}$ & 200 & $205,1 \pm 0,2$ & 0,1 & 102,6 \\
$\mathrm{~K}^{+}$ & 10 & $10,0 \pm 0,3$ & 3 & 99,4 \\
$\mathrm{Na}^{+}$ & 10 & $10,1 \pm 0,2$ & 2 & 100,3 \\
$\mathrm{NH}_{4}{ }^{+}$ & 25 & $25,0 \pm 0,5$ & 2 & 100,1 \\
\hline
\end{tabular}

$* \mathrm{n}=05$

Tabela 5.2 - Coeficiente de correlação, limite de detecção (L.D.) e de quantificação dos analitos iônicos e catiônicos.

\begin{tabular}{ccccc}
\hline Analito & $\begin{array}{c}\text { Faixa de } \\
\text { Concentração } \\
\left.(\text { ng mL })^{-1}\right)\end{array}$ & $\begin{array}{c}\text { Coeficiente de } \\
\text { Correlação }\end{array}$ & $\begin{array}{c}\text { Limite de } \\
\text { Detecção } \\
\left(\text { ng mL }^{-1}\right)\end{array}$ & $\begin{array}{c}\text { Limite de } \\
\text { Quantificação } \\
\left(\text { ng mL }^{-1}\right)\end{array}$ \\
\hline $\mathrm{F}^{-}$ & $25-150$ & 0,9988 & 3 & 25 \\
$\mathrm{Cl}^{-}$ & $25-150$ & 0,9996 & 5 & 25 \\
$\mathrm{NO}_{3}{ }^{-}$ & $50-200$ & 0,9958 & 7 & 50 \\
$\mathrm{PO}_{4}{ }^{3-}$ & $25-200$ & 0,9993 & 4 & 25 \\
$\mathrm{SO}_{4}{ }^{2-}$ & $200-1400$ & 0,9995 & 70 & 200 \\
$\mathrm{~K}^{+}$ & $10-400$ & 0,9999 & 3 & 10 \\
$\mathrm{Na}^{+}$ & $10-400$ & 0,9989 & 3 & 10 \\
$\mathrm{NH}_{4}{ }^{+}$ & $25-150$ & 0,9996 & 4 & 25 \\
\hline
\end{tabular}




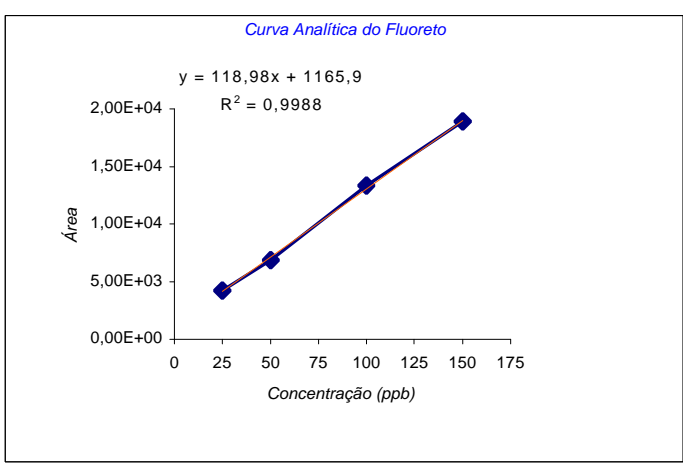

Figura 5.3 - Curva analítica do íon fluoreto

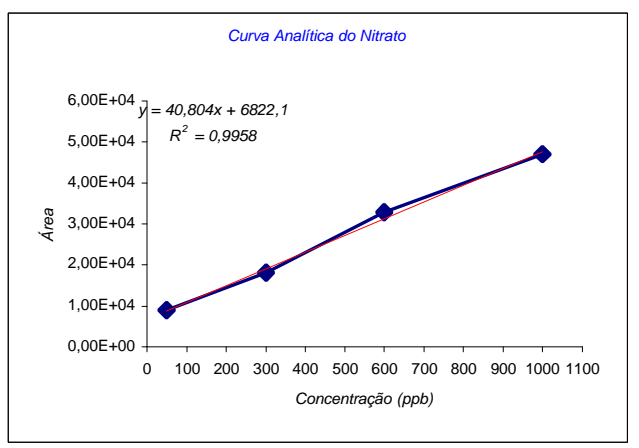

Figura 5.5 - Curva analítica do íon nitrato

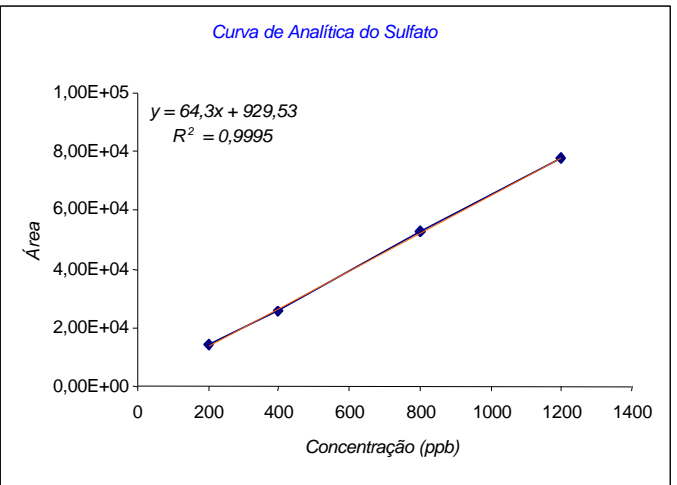

Figura 5.7 - Curva analítica do íon sulfato

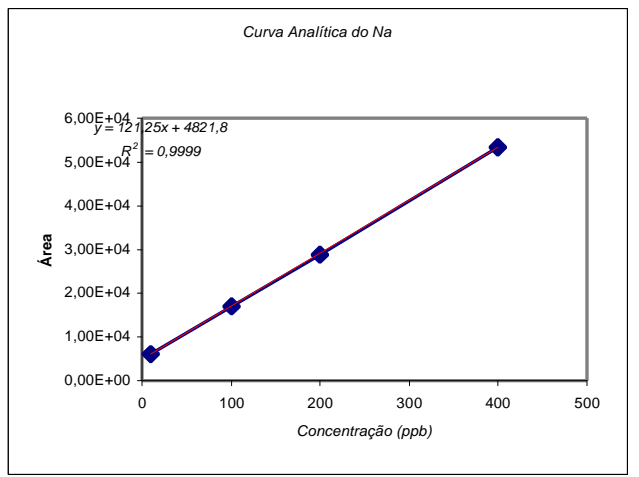

Figura 5.9 - Curva analítica do íon Sódio

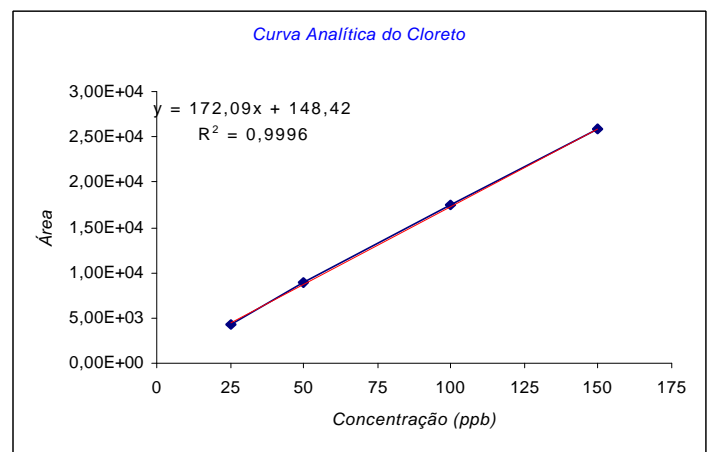

Figura 5.4 - Curva analítica do íon cloreto

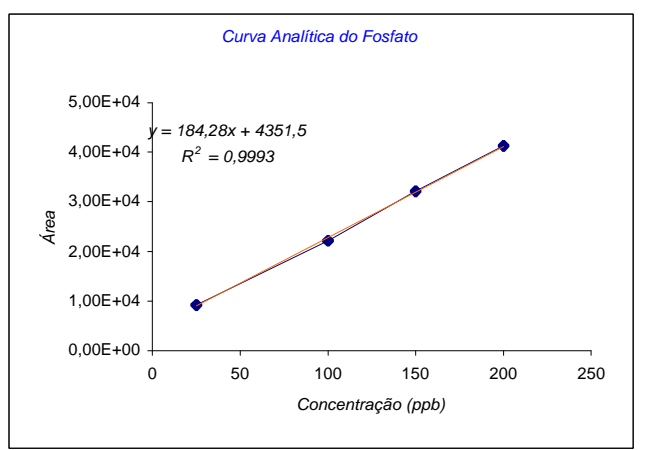

Figura 5.6 - Curva analítica do íon fosfato

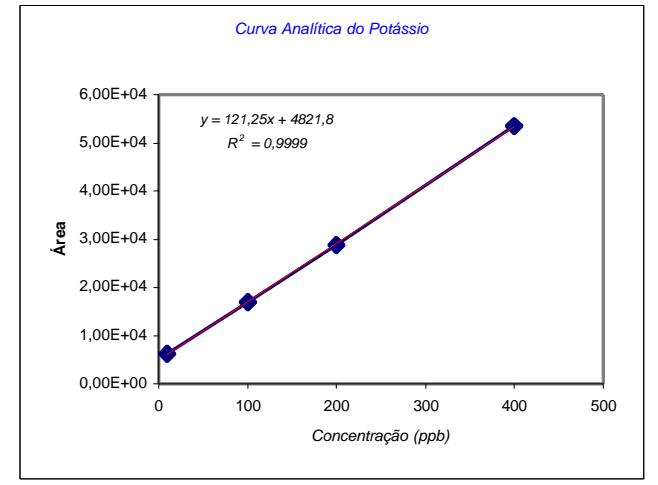

Figura 5.8 - Curva analítica do íon Potássio

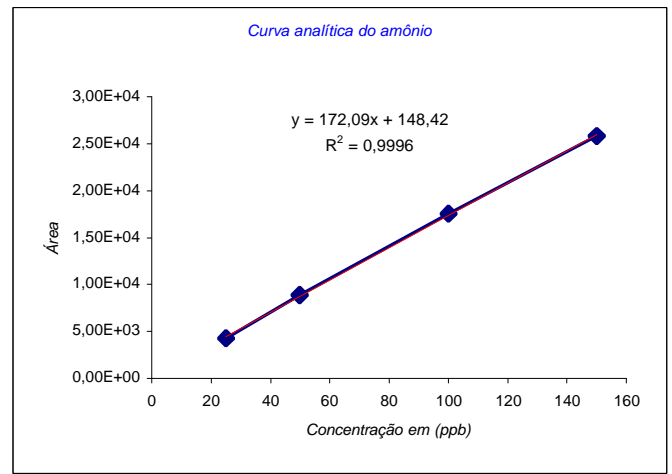

Figura 5. 10 - Curva analítica do íon Amônio 


\subsubsection{DETERMINAÇÃO DE METAIS E ELEMENTOS-TRAÇO POR ESPECTROMETRIA DE EMISSÃO ÓPTICA COM PLASMA DE ARGÔNIO - ICP/OES}

Inicialmente, foram elaborados programas analíticos para a determinação de todos os elementos de interesse. O equipamento utilizado (Espectro Flame M 120- Spectro) dispõe de recursos em seu programa que permitem fazer uma escolha criteriosa das linhas de emissão a serem utilizadas para cada elemento. Utilizou-se o método da curva analítica na determinação dos elementos, através do uso de soluções-padrão multielementares. Os coeficientes de correlação, limite de detecção utilizados para a análise dos metais estão descritos na Tabela 5.3.

As curvas analíticas obtidas (Figuras 5.11 a 5.25) são representadas pela equação da reta ou regressão linear, sendo a concentração de cada analito dada pela equação [SANTOS, 1999]:

$$
\text { Concentração do analito }\left(\mathrm{mg} \mathrm{L}^{-1}\right)=\mathrm{A}_{\mathrm{o}}+\mathrm{A}_{1} \cdot \mathrm{Ir}
$$

Onde: $\mathrm{A}_{\mathrm{o}}=$ coeficiente linear;

$\mathrm{A}_{1}=$ coeficiente angular da regressão;

Ir = intensidade relativa da emissão do analito.

De acordo com THOMPSON [1987], o limite de detecção instrumental é definido com a concentração do analito que fornece uma resposta igual a três vezes o valor do desvio padrão do branco, o qual, no presente trabalho, foi calculado pelo software do equipamento. A determinação do limite de detecção instrumental calculado pelo software geralmente é muito "otimista" quando comparado com o limite de detecção prático. Para maior segurança foram usados valores de práticos ou limites de quantificação (fator de 5), que, de acordo com THOMPSON [1987] e SPECTRO [1999] o valor difere de 2 a 5 vezes do limite de detecção instrumental.

A precisão e a exatidão que afetam os principais parâmetros e eficiência dos métodos analíticos em termos de variação percentual foram verificadas pela determinação 
da concentração das espécies de interesse utilizando material de referência padrão (Tabela $5.4)$

Tabela 5.3 - Coeficiente de correlação, limite de detecção e de quantificação dos analitos metálicos

\begin{tabular}{|c|c|c|c|c|c|}
\hline Analito & $\begin{array}{c}\lambda \\
(\mathrm{nm})\end{array}$ & $\begin{array}{c}\text { Faixa de } \\
\text { Concentração } \\
\left(\mathrm{ng} \mathrm{mL}^{-1}\right)\end{array}$ & $\begin{array}{l}\text { Coeficiente } \\
\text { de Correlação }\end{array}$ & $\begin{array}{l}\text { Limite de } \\
\text { Detecção } \\
\left(\mathrm{ng} \mathrm{mL}^{-1}\right) \\
\end{array}$ & $\begin{array}{c}\text { Limite de } \\
\text { Quantificação } \\
\left(\mathrm{ng} \mathrm{mL}^{-1}\right)\end{array}$ \\
\hline $\mathrm{Al}$ & 167,083 & $1-1200$ & 0,9999 & 0,2 & 1 \\
\hline $\mathrm{Ag}$ & 328,068 & $1-1200$ & 1,0000 & 0,2 & 1 \\
\hline $\mathrm{Ba}$ & 455,403 & $4-6000$ & 0,9986 & 0,8 & 4 \\
\hline $\mathrm{Ca}$ & 318,128 & $360-60000$ & 1,0000 & 72 & 360 \\
\hline $\mathrm{Cd}$ & 226,502 & $4-1200$ & 1,0000 & 0,8 & 4 \\
\hline $\mathrm{Co}$ & 231,498 & $17-1200$ & 0,9998 & 3,4 & 17 \\
\hline $\mathrm{Cu}$ & 324,754 & $3-1200$ & 1,0000 & 0,7 & 3 \\
\hline $\mathrm{Cr}$ & 284,325 & $44-1200$ & 1,0000 & 8,8 & 44 \\
\hline $\mathrm{Fe}$ & 261,187 & $10-1200$ & 0,9999 & 2,1 & 10 \\
\hline $\mathrm{Mg}$ & 383,826 & $8-1200$ & 1,0000 & 1,7 & 8 \\
\hline Mn & 257,610 & $1-1200$ & 1,0000 & 0,2 & 1 \\
\hline $\mathrm{Ni}$ & 352,454 & $26-1200$ & 1,0000 & 5,2 & 26 \\
\hline $\mathrm{P}$ & 178,290 & $10-1200$ & 1,0000 & 2 & 10 \\
\hline $\mathrm{Pb}$ & 168,220 & $16-1200$ & 0,9998 & 3,2 & 16 \\
\hline $\mathrm{Zn}$ & 213,856 & $3-1200$ & 0,9999 & 0,6 & 3 \\
\hline \multicolumn{6}{|c|}{ Condições de operação do sistema } \\
\hline \multicolumn{2}{|c|}{$>$ gás refrigerante $(\mathrm{Ar})$} & \multicolumn{2}{|c|}{$14 \mathrm{~L} \mathrm{~min}^{-1}$} & & \\
\hline \multicolumn{2}{|c|}{$>$ gás auxiliar (Ar) } & \multicolumn{2}{|c|}{$0,5 \mathrm{~L} \mathrm{~min}^{-1}$} & & \\
\hline \multicolumn{2}{|c|}{$>$ pressão do nebulizador } & \multicolumn{2}{|c|}{3,2 bar } & & \\
\hline \multicolumn{2}{|c|}{$>$ potência do plasma } & \multicolumn{2}{|c|}{$1200 \mathrm{~W}$} & & \\
\hline \multicolumn{2}{|c|}{$>$ fluxo de amostra } & \multicolumn{2}{|c|}{$1 \mathrm{~mL} \min ^{-1}$} & & \\
\hline
\end{tabular}


Tabela 5.4 - Reprodutibilidade, precisão e desvio padrão relativo

\begin{tabular}{|c|c|c|c|c|}
\hline \multirow[b]{2}{*}{ Analito } & \multicolumn{2}{|c|}{ Concentração } & \multirow[b]{2}{*}{$\begin{array}{c}\text { D.P.R. } \\
(\%)\end{array}$} & \multirow[b]{2}{*}{$\begin{array}{c}\text { Recuperação } \\
(\%)\end{array}$} \\
\hline & $\begin{array}{c}\text { Padrão } \\
\left.\text { (ng mL } L^{-1}\right)\end{array}$ & $\begin{array}{c}\text { Encontrado* } \\
\text { Média } \pm \text { DP } \\
\left(n g \mathrm{~mL}^{-1}\right)\end{array}$ & & \\
\hline $\mathrm{Al}$ & 114,6 & $114 \pm 1$ & 0,9 & 99,9 \\
\hline $\mathrm{Ba}$ & 49,6 & $37,9 \pm 0,2$ & 0,5 & 76,4 \\
\hline $\mathrm{Ca}$ & 36800 & $(3,75 \pm 0,02) \times 10^{4}$ & 0,5 & 102 \\
\hline $\mathrm{Cd}$ & 12,2 & $13,3 \pm 0,2$ & 1,5 & 109 \\
\hline $\mathrm{Co}$ & 23,5 & $23 \pm 1$ & 4,3 & 97,8 \\
\hline $\mathrm{Cu}$ & 22,3 & $20 \pm 1$ & 5 & 88,8 \\
\hline $\mathrm{Cr}$ & 19,0 & $17 \pm 2$ & 12 & 89,3 \\
\hline $\mathrm{Fe}$ & 106,9 & $100 \pm 2$ & 2 & 93,8 \\
\hline $\mathrm{Mg}$ & 9400 & $(8,77 \pm 0,04) \times 10^{3}$ & 0,5 & 92,7 \\
\hline Mn & 35,1 & $36 \pm 1$ & 2,8 & 103 \\
\hline $\mathrm{Ni}$ & 60,6 & $53 \pm 2$ & 4 & 88,2 \\
\hline $\mathrm{Zn}$ & 73,9 & $72 \pm 1$ & 1,4 & 97,9 \\
\hline
\end{tabular}

* $n=09$ - Material de referência padrão NIST SRM 1643C. 


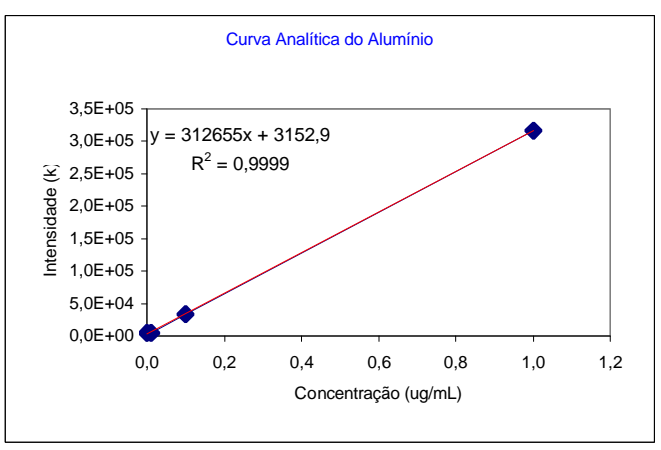

Figura 5.11 - Curva analítica do alumínio

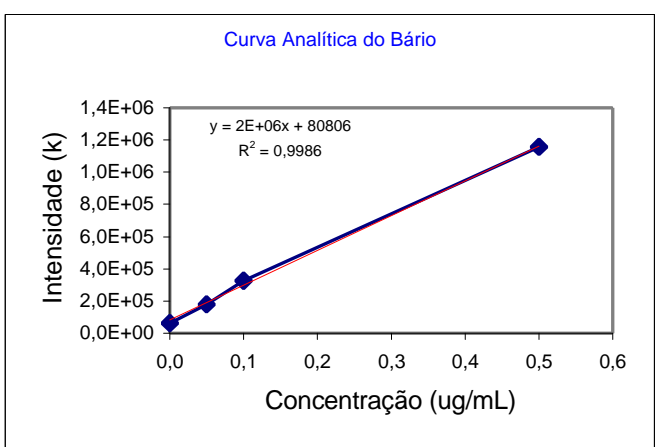

Figura 5.13 - Curva analítica do bário

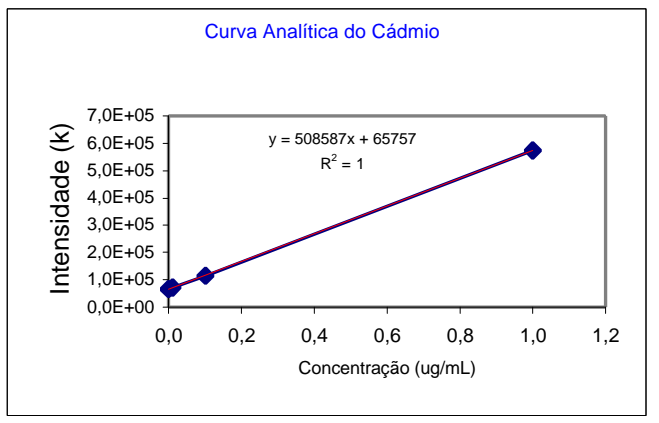

Figura 5.15 - Curva analítica do cádmio

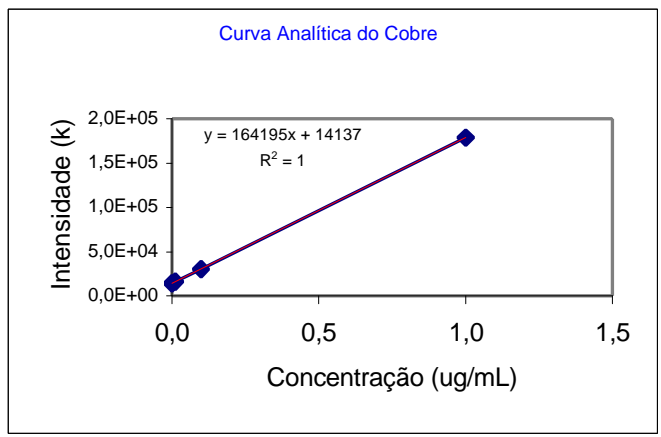

Figura 5.17 - Curva analítica do cobre

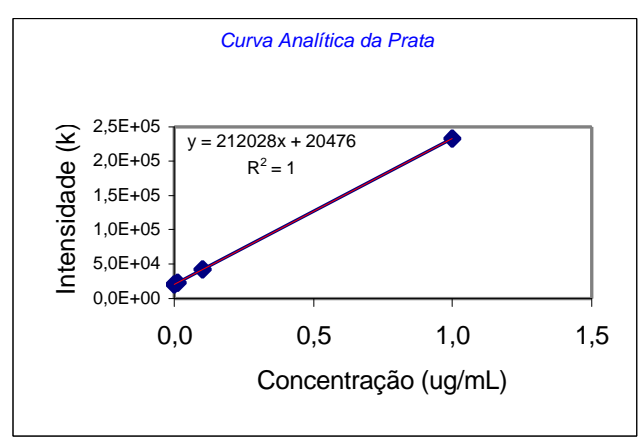

Figura 5.12 - Curva analítica da prata

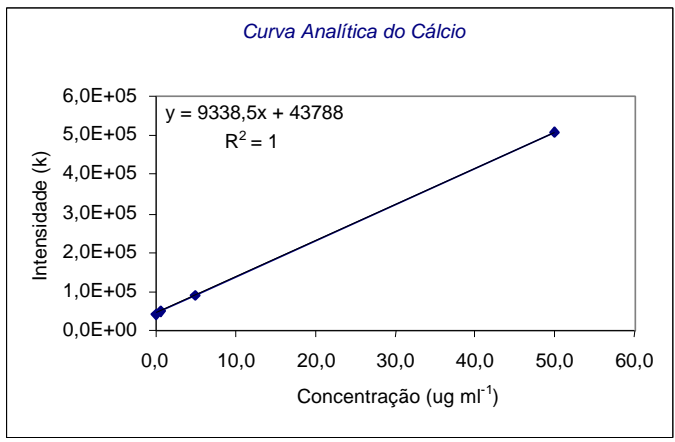

Figura 5.14 - Curva analítica do cálcio

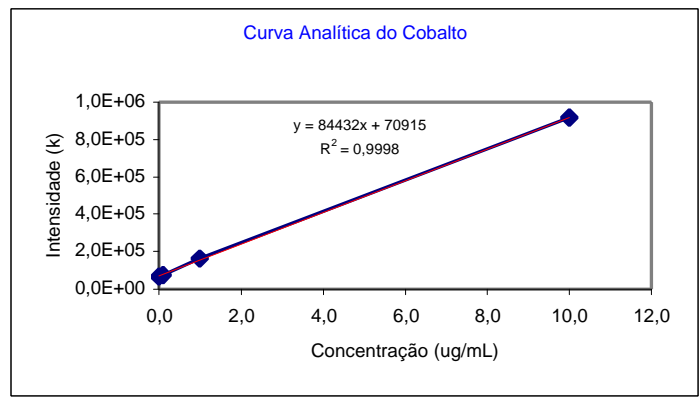

Figura 5.16 - Curva analítica do cobalto

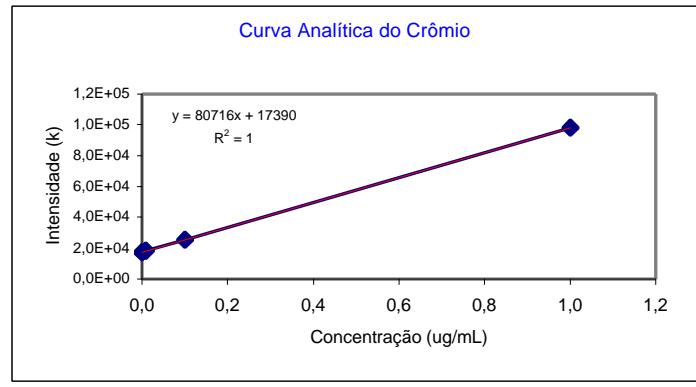

Figura 5.18 - Curva analítica do crômio 


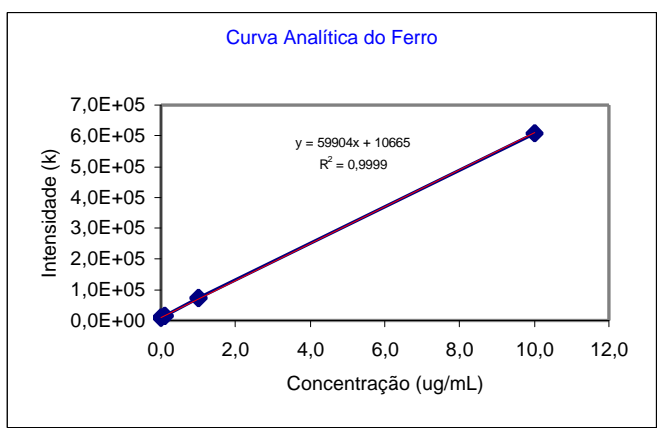

Figura 5.19 - Curva analítica do ferro

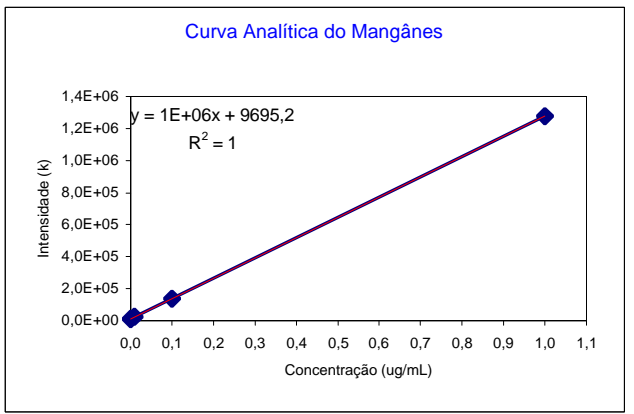

Figura 5.21 - Curva analítica do manganês

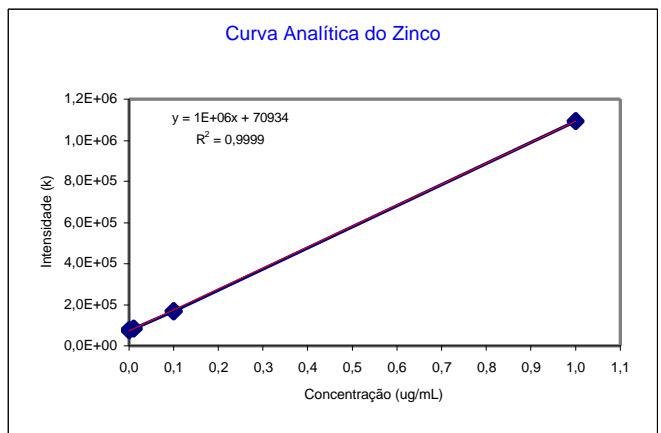

Figura 5.23 - Curva analítica do zinco

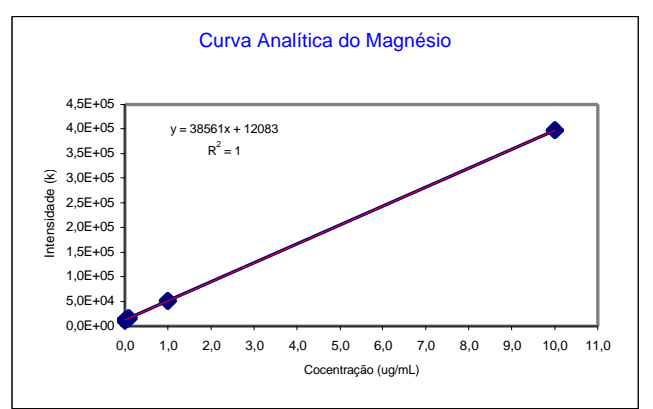

Figura 5.20 - Curva analítica do magnésio

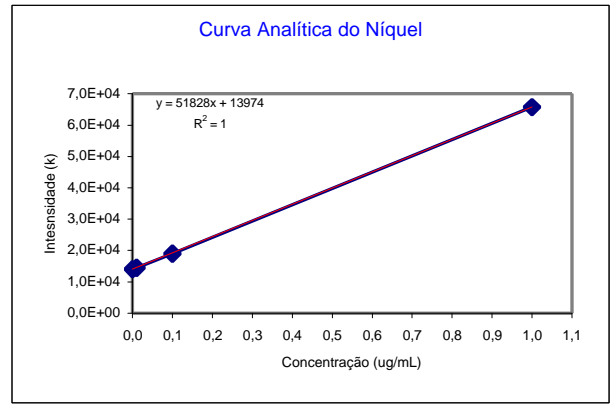

Figura 5.22 - Curva analítica do níquel

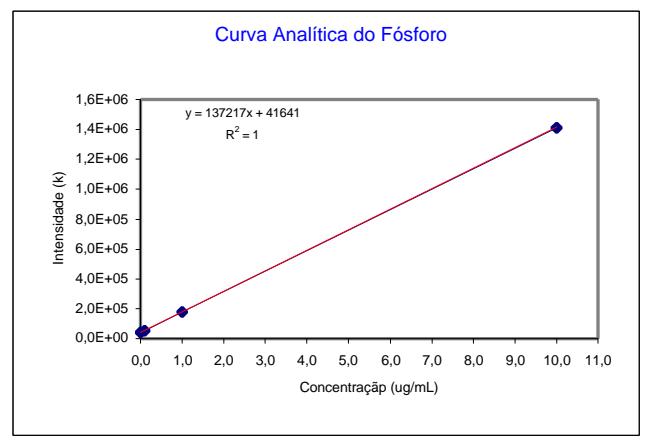

Figura 5.24 - Curva analítica do fósforo

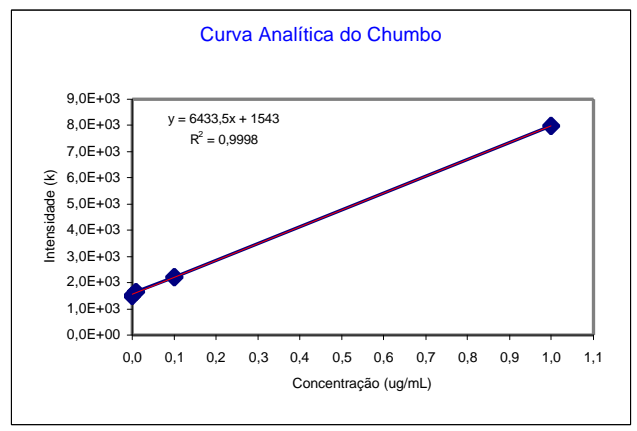

Figura 5.25 - Curva analítica do chumbo 


\subsection{3- Avaliação do Método de LiXiviação (BIOdisponível)}

$\mathrm{Na}$ avaliação da eficiência do procedimento de lixiviação empregado, foi utilizada uma amostra de sedimento de referência do NIST (National Institute of Standard \& Technology) SRM 2704 (Buffalo River Sediment). Os resultados obtidos são apresentados na Tabela 5.5.

A determinação dos elementos analisados na amostra de referência demonstra que a metodologia aplicada é reprodutiva. Os valores de Desvio Padrão Relativo estão abaixo $\operatorname{dos} 10 \%$.

Tabela 5.5 - Resultados obtidos na lixiviação com $\mathrm{HCl}$ 0,1 mol L ${ }^{-1}$ do SRM 2704

\begin{tabular}{ccccc} 
Elemento & $\begin{array}{c}\text { Valores } \\
\text { Certificados } \\
\left(\mu \mathrm{g} \mathrm{g}^{-1}\right)\end{array}$ & $\begin{array}{c}\text { Média } \\
\text { Obtida }+\mathrm{DP} \\
\left(\mu \mathrm{g} \mathrm{g}^{-1}\right)\end{array}$ & $\begin{array}{c}\text { Desvio } \\
\text { Padrão } \\
\text { Relativo }(\%)\end{array}$ & $\begin{array}{c}\text { Porcentagem } \\
\text { Lixiviada } \\
(\%)\end{array}$ \\
\hline $\mathrm{Al}$ & 61100 & $(9,88 \pm 0,21) \times 10^{2}$ & 2,0 & 1,5 \\
$\mathrm{Ca}$ & 26000 & $(2,91 \pm 0,08) \times 10^{5}$ & 2,8 & 112 \\
$\mathrm{Co}$ & 14 & $9,9 \pm 0,5$ & 5,1 & 71,4 \\
$\mathrm{Cr}$ & 135 & $20,7 \pm 1,0$ & 4,8 & 15,3 \\
$\mathrm{Cu}$ & 98,6 & $56,2 \pm 0,8$ & 1,5 & 56,8 \\
$\mathrm{Fe}$ & 41100 & $5057 \pm 52$ & 1,0 & 12,3 \\
$\mathrm{~K}$ & 20000 & $140 \pm 3$ & 2,1 & 0,7 \\
$\mathrm{Mg}$ & 12000 & $(51,2 \pm 0,8) \times 10^{2}$ & 1,5 & 42,5 \\
$\mathrm{Mn}$ & 555 & $348 \pm 5$ & 1,5 & 62,7 \\
$\mathrm{Na}$ & 5470 & $112 \pm 5$ & 4,5 & 2,0 \\
$\mathrm{Ni}$ & 44,1 & $5,5 \pm 0,3$ & 5,5 & 12,5 \\
$\mathrm{~Pb}$ & 161 & $177 \pm 7$ & 3,9 & 110 \\
$\mathrm{Zn}$ & 438 & $246 \pm 2$ & 0,8 & 56,2 \\
\hline $\mathrm{n}=5$ & \multicolumn{5}{c}{}
\end{tabular}




\subsection{ESTABELECIMENTO DO PROGRAMA DE MONITORAMENTO}

O monitoramento é a realização de processos de observações sistemáticas, para fins bem definidos de um ou mais fatores, indicadores de um problema específico para obter informações sobre as características desse problema no tempo e no espaço, utilizando-se para isso métodos comparáveis de amostragem, análise e de sensoriamento ambiental. Todo programa de monitoramento deve poder identificar as condições existentes, e sua variação num dado período de tempo. Um monitoramento físico-químico de águas permite avaliar o grau de qualidade [SIMPSON apud GOBBI,1999].

São várias as considerações envolvendo a seleção das posições do ponto de coleta ao longo do rio, por exemplo, a localização de pontos no qual a qualidade da água é de interesse para a potabilidade; pontos que recebem água de um efluente; pontos que recebem contribuição de um afluente; pontos que recebem grande quantidade de efluentes industriais ou domésticos; pontos que tenham representatividade da bacia ou da maioria dos bairros residenciais em que passa, etc. A Tabela 5.5 apresenta um resumo identificando as unidades de Gerenciamento de Recursos Hídricos com os respectivos pontos de coleta e sua localização. A Figura 3.6 (capítulo 3) apresenta a localização dos pontos de coleta e respectivas unidades geológicas.

É essencial planejar o tempo de amostragem de modo a observar as variabilidades temporais como: períodos de estiagem, períodos chuvosos, atividades industriais ou agrícolas aceleradas em determinadas épocas do ano. 
Tabela 5.6 - Caracterização e localização dos pontos de captação de água

\begin{tabular}{|c|c|c|c|c|}
\hline $\begin{array}{l}\text { IDENTIFICAÇÃO } \\
\text { UGRHI'S }\end{array}$ & $\begin{array}{l}\text { CÓDIGO } \\
\text { SABESP }\end{array}$ & MUNICÍPIOS/DISTRITOS & CAPTAÇÃO & $\begin{array}{l}\text { LOCALIZAÇÃO } \\
\text { POR GPS }\end{array}$ \\
\hline \multirow[t]{7}{*}{$\begin{array}{c}\text { Pardo } \\
\text { UGRHI-4 }\end{array}$} & IG 61 & Mococa & Rio Canoas & $\begin{array}{l}\text { S } 21^{0} 25^{\prime} 45,1^{\prime}, \\
\text { O } 047^{0} 00^{\prime} 50,6^{\prime},\end{array}$ \\
\hline & IG 65 & $\begin{array}{c}\text { São Roque da Fartura } \\
\text { (Distrito de Águas da } \\
\text { Prata) }\end{array}$ & $\begin{array}{l}\text { Córrego da } \\
\text { Fartura }\end{array}$ & $\begin{array}{l}\text { S } 21^{0} 50^{\prime} 35,5^{\prime}, \\
\text { O } 046^{0} 44^{\prime} 07,6,\end{array}$ \\
\hline & IG 68 & Divinolândia & $\begin{array}{l}\text { Córrego } \\
\text { Santo } \\
\text { Ambrósio }\end{array}$ & $\begin{array}{l}\text { S } 21^{0} 41^{\prime}, 06,4^{\prime}, \\
\text { O } 046^{0} 42^{\prime} 03,1^{\prime},\end{array}$ \\
\hline & IG 69 & $\begin{array}{c}\text { Campestrinho (Distrito } \\
\text { de Divinolândia) }\end{array}$ & Rio do Peixe & $\begin{array}{l}\text { S } 21^{0} 43^{\prime} 03,0,0^{\prime}, \\
\text { O } 046^{\circ} 38^{\prime} 36,5^{\prime},\end{array}$ \\
\hline & IG 70 & Itobi & $\begin{array}{l}\text { Ribeirão } \\
\text { Doce }\end{array}$ & $\begin{array}{l}\text { S } 21^{0} 44^{\prime} 39,2^{\prime}, \\
\text { O } 046^{0} 58^{\prime} 08,9^{\prime},\end{array}$ \\
\hline & IG 83 & São Sebastião da Grama & $\begin{array}{l}\text { Córrego da } \\
\text { Anhuma }\end{array}$ & $\begin{array}{l}\text { S } 21^{0} 42^{\prime} 50,3^{\prime}, \\
\text { O } 046^{0} 48^{\prime} 23,1,\end{array}$ \\
\hline & IG VGS & Vargem Grande do Sul & Rio Verde & $\begin{array}{l}\text { S } 21^{0} 49^{\prime} 24,4^{\prime \prime}, \\
\text { O } 046^{0} 53^{\prime} 02,8^{\prime},\end{array}$ \\
\hline \multirow[t]{6}{*}{$\begin{array}{l}\text { Mogi-Guaçu } \\
\text { UGRHI-9 }\end{array}$} & IG 60 & São João da Boa Vista & $\begin{array}{c}\text { Rio } \\
\text { Jaguari-Mirim }\end{array}$ & $\begin{array}{l}\text { S } 22^{0} 00^{\prime} 11,1^{\prime \prime}, \\
\text { O } 046^{0} 47^{\prime} 33,1^{\prime},\end{array}$ \\
\hline & IG 63 & Espírito Santo do Pinhal & $\begin{array}{l}\text { Ribeirão da } \\
\text { Capelinha }\end{array}$ & $\begin{array}{l}\text { S } 22^{0} 12^{\prime} 56,6^{\prime \prime} \\
\text { O } 046^{0} 43^{\prime} 13,2^{\prime},\end{array}$ \\
\hline & IG 64 & Águas da Prata & $\begin{array}{l}\text { Ribeirão da } \\
\text { Prata }\end{array}$ & $\begin{array}{c}\text { S } 21^{0} 56^{\prime} 53,2^{\prime}, \\
\text { O } 046^{0} 42^{\prime} 22,0^{\prime},\end{array}$ \\
\hline & IG 66 & $\begin{array}{c}\text { Ponto da Cascata } \\
\text { (Distrito de Águas da Prata) }\end{array}$ & $\begin{array}{c}\text { Córrego dos } \\
\text { Cascais }\end{array}$ & $\begin{array}{l}\mathbf{S} 21^{0} 51^{\prime} 38,1^{\prime}, \\
\mathbf{O} 046^{0} 40^{\prime} 38,8,\end{array}$ \\
\hline & IG 67 & $\begin{array}{l}\text { Vila Nossa Senhora } \\
\text { Aparecida (Distrito de } \\
\text { Águas da Prata) }\end{array}$ & $\begin{array}{l}\text { Mina da } \\
\text { Encosta }\end{array}$ & $\begin{array}{l}\text { S } 21^{0} 500^{\prime} 47,00^{\prime}, \\
\text { O } 046^{0} 41^{\prime} 23,8^{\prime},\end{array}$ \\
\hline & IG 72 & $\begin{array}{c}\text { Santo Antônio do } \\
\text { Jardim }\end{array}$ & $\begin{array}{l}\text { Córrego do } \\
\text { Jardim }\end{array}$ & $\begin{array}{l}\text { S } 22^{0} 07^{\prime} 24,8^{\prime}, \\
\text { O } 046^{0} 40^{\prime} 59,2^{\prime},\end{array}$ \\
\hline
\end{tabular}

\footnotetext{
GPS - Global Positioning System (Latitute S - Sul e Longitude O-Oeste).
} 


\subsection{ColetA E PRESERVAÇÃo dAS AMOSTRAS}

Para que uma análise tenha um resultado confiável, determinados cuidados devem ser observados quanto a preservação da integridade da amostra. Os cuidados devem abordar desde o tipo de frasco a ser utilizado para a amostragem, passando pelo procedimento de conservação e de transporte, até o momento da análise em si. Procedimentos geralmente utilizados como a refrigeração das amostras de água a $4^{0} \mathrm{C}$ retardam as atividades físicas e químicas, sendo empregada como inibidor bacteriano. Os ciclos do nitrogênio e do fósforo são exemplos da influência biológica na composição da amostra. A preservação química é utilizada para alcançar a estabilidade da amostra após a coleta.

STURGEON \& BERMAN [1987] apresentaram um review onde destacam a composição dos materiais geralmente empregados para a amostragem de águas, os tipos de amostradores, procedimentos de preservação para os analitos mais comuns e estocagem dos mesmos.

BETTI \& PAPOFF [1988]; BENOLIEL [1994]; KRAMER [1994] e NOLTING \& DE JONG [1994] também descrevem procedimentos para caracterização de elementostraço em sistemas aquáticos, abordando métodos de coleta, preservação e limpeza dos materiais .

As coletas realizadas neste trabalho foram realizadas conforme recomendação do guia de coletas da CETESB [1991], e do Standard Methods [1985], considerando o tipo de frasco para cada parâmetro, volume necessário para análise, preservação de amostra e prazo para a realização da análise de cada parâmetro.

Neste trabalho o procedimento utilizado para a limpeza e descontaminação dos frascos para análise de metais [NOLTING \& DE JONG, 1994] foi:

Lavar o frasco com água desmineralizada para remover sujeiras e plásticos remanescentes;

Adicionar ácido nítrico (de grau analítico) 2:3 em água destilada por um período aproximado de uma semana; 
$>$ Encher o frasco com ácido nítrico 1:12 (de grau analítico) por um período aproximado de uma semana;

$>$ Estocar com água acidulada $\left(\mathrm{Milli}-\mathrm{Q} / \mathrm{HNO}_{3}\right) \mathrm{com} \mathrm{pH}$ 1,6 até ser usado.

O procedimento utilizado para a preservação de amostras de água para a análise de ânions e cátion foi a refrigeração a $4{ }^{\mathrm{O}} \mathrm{C}$. Para a determinação de metais as amostras foram preservadas com a adição de solução de $\mathrm{HNO}_{3}$ 1:1, supra-puro, até $\mathrm{pH}<2$. As amostras de água bruta foram coletadas a aproximadamente $10 \mathrm{~cm}$ da superfície em frascos de polietileno previamente descontaminados, acidificadas e transportadas em recipientes termicamente isolados.

As amostras de sedimento foram coletadas utilizando-se uma draga do tipo EkmanBirge, com área igual a $22,5 \mathrm{~cm}^{2}$, em alguns casos, devido a dificuldade de coleta, a coleta foi realizada com o auxílio de uma enxada. 


\subsection{CARACTERIZAÇÃo dAS VARIÁVEIS FÍSICAS E QUÍMICAS}

\subsubsection{LOCAIS DE AMOSTRAGEM E PERIODICIDADE DE COLETA}

Foram coletadas amostras de água superficial, que convencionamos chamar de água bruta, e de sedimento nos pontos de captação de água nas microbacias e de água tratada nas respectivas estações de tratamento de água da SABESP.

A caracterização das variáveis físicas $(\mathrm{pH})$ e químicas (metais e elementos-traço) da água bruta, tratada e do sedimento, e suas respectivas frações, foram realizadas nas treze comunidades com uma periodicidade de amostragem bimestral, no período de abril de 98 a abril de 99, totalizando 7 campanhas de campo, representando 49 amostras por comunidade e um total de 637 amostras coletadas.

Os metais determinados neste estudo foram selecionados atendendo-se as exigências de duas legislações que avaliam a qualidade da água, estabelecendo limites máximos permissíveis para a concentração de metais: a Legislação Federal (CONAMA 20) e a Portaria 36/90 MS, referente a potabilidade. Assim, foram realizadas medidas de 23 elementos, divididos em dois grandes grupos, espécies iônicas e espécies metálicas. Também foram determinados o teor de matéria orgânica e realizada a análise mineralógica do sedimento.

\subsubsection{DETERMINAÇÃO DE METAIS}

As amostras de água bruta e tratada foram previamente acidificadas e os metais ou elementos de interesse (Al, Ba, Ca, Cd, Cr, Co, Cu, Fe, Mg, Mn, Na, Ni, P, Pb, Zn) foram determinados por espectrometria de emissão óptica com plasma de argônio (ICP-OES).

As amostras de sedimento foram subdivididas em três frações ou fases: fase sobrenadante, fase intersticial e fase de digestão parcial ou de lixiviação dos metais potencialmente biodisponíveis. 


\section{Fase sobrenadante}

Como fase sobrenadante denominou-se a água sobre a superfície do sedimento, após coleta. A fase sobrenadante do sedimento foi sifonada, previamente filtrada, transferida para um frasco de polietileno, acidificada e conservada sob refrigeração até o momento da análise.

\section{Fase intersticial}

A fase intersticial da água no sedimento foi obtida após centrifugação de aproximadamente $100 \mathrm{~g}$ de sedimento por 15 minutos $(2500 \mathrm{rpm})$. Os metais na fase intersticial foram determinados após filtração e acidificação da água. [SCHULTZ et al, 1992; ANKLEY \& SCHUBAUERBERING, 1994; BUFFLATER \& ALLEN, 1995].

\section{Metais Potencialmente Biodisponíveis (Digestão Parcial)}

Para avaliar a influência de elementos traços nos sedimentos, e em particular a questão da mobilização de metais pesados, o primeiro fator a considerar é a fração móvel destes elementos, destacando-se as etapas de adsorção, precipitação ou coprecipitação (carbonatos e óxidos de Fe/Mn).

Ataques com ácidos diluídos, agentes quelantes e sais neutros têm sido comumente usados para a extração de metais em solos e sedimentos, fornecendo dados para a avaliação da toxicidade e o potencial de acumulação [LIANG \& SHOENAU, 1995]. Ácidos diluídos extraem parcialmente elementos-traço associados a diferentes frações como os trocáveis, carbonatos, óxidos de ferro e manganês e matéria orgânica [RAUTET, 1998].

FÖRSTNER \& SALOMONS [1980] apud SOARES et al [1999] sugerem o uso de frações de grãos < $63 \mu \mathrm{m}$, pois estes apresentam várias vantagens: 1) os metais pesados estão principalmente ligados ao silte e a argila; e 2) esta fração tem sido utilizada por outros autores em estudos de contaminação de metais pesados, podendo ser obtido por peneiramento a seco ou úmido. O peneiramento a seco é utilizado por vários autores [LACERDA et al., 1990; RUBIO \& URE, 1993; DAVIDSON et al., 1994; URASA \& MACHA, 1996; AVILA-PÉREZ et al., 1999]. SOARES et al [1999] em seus estudos 
comparativos concluiu que o peneiramento a seco é o procedimento mais adequado a ser empregado em diferentes amostras de sedimento, levando-se em conta os compostos orgânicos voláteis.

Segundo MALO apud ROSADO [1998] os metais presentes nas camadas superficiais das partículas do sedimento possuem uma disponibilidade potencial muito superior à daqueles que constituem a matriz cristalina, podendo inclusive passar à forma dissolvida dependendo das características da água.

Para realizar este estudo as amostras de sedimento foram distribuídas em bandejas de vidro pirex para a remoção de materiais indesejáveis, como fragmentos de vegetais, pedregulhos, entre outros, e previamente secas a $60^{\circ} \mathrm{C}$, por 24 horas em estufa com circulação de ar. A essa temperatura, os metais não são arrastados pelo vapor de água e podemos também realizar outros ensaios como, por exemplo, a determinação de carbono orgânico. [LACERDA et al, 1990; DAVIDSON et al, 1994; GONZALEZ, 1994; AVILAPEREZ et al., 1999; GATTI, 1997].

Após secagem, as amostras foram pulverizadas em almofariz de ágata e passadas em peneira de 0,250 $\mathrm{mm}$ de malha. Em seguida, cerca de 2,5 $\mathrm{g}$ da amostra de sedimento foram submetidas a uma lixiviação em $50 \mathrm{~mL}$ de $\mathrm{HCl} 0,1 \mathrm{~mol} \mathrm{~L}^{-1}$, sob agitação constante por duas horas a $150 \mathrm{rpm}$ [GATTI, 1997]. Após essa lixiviação ácida, as amostras foram filtradas em papel de filtro de filtração lenta e condicionadas em frascos de polietileno até a determinação dos metais.

A Figura 5.26 apresenta um esquema das etapas descritas no processo de lixiviação. 


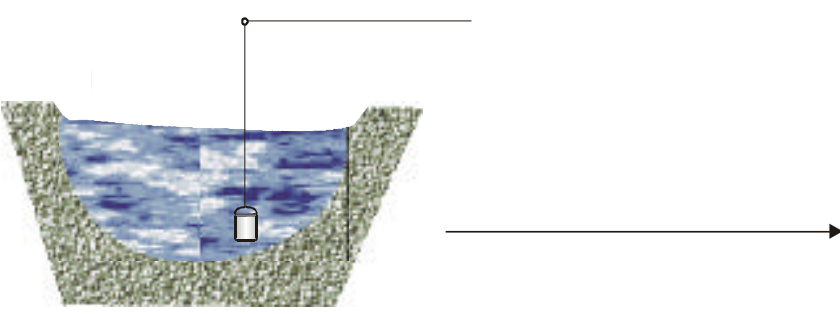

Coleta (rio)
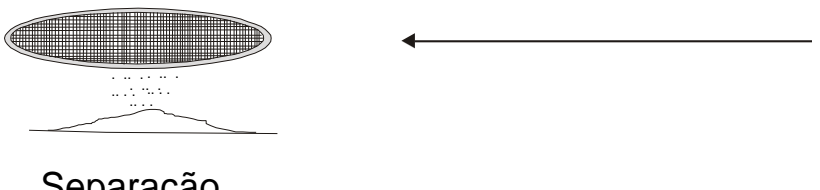

Separação
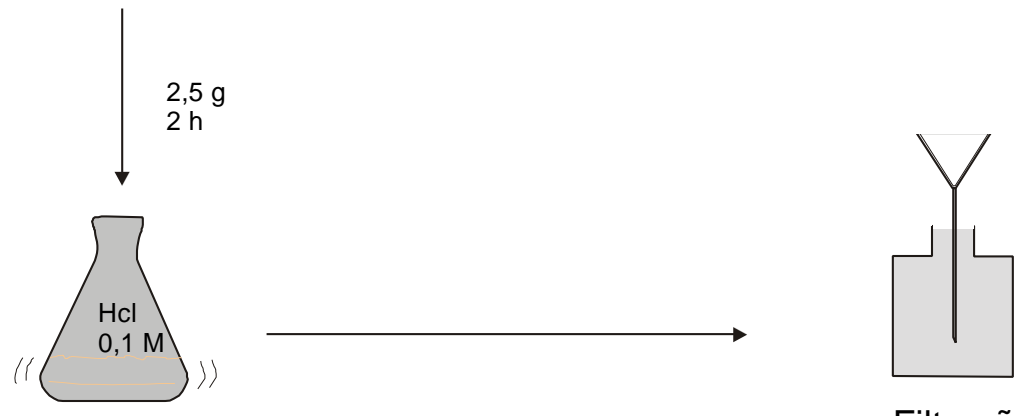

Filtração

Extração

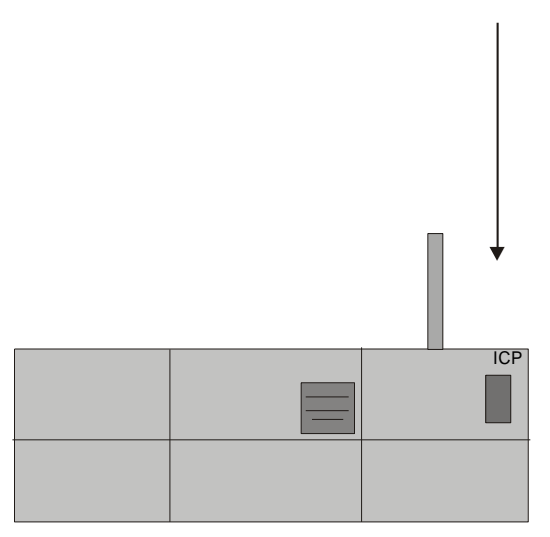

Análise

Figura 5.26 - Representação esquemática do tratamento da amostra 


\subsubsection{DETERMINAÇÃO DE ÂNIONS E CÁTIONS}

As espécies aniônicas e catiônicas (fluoreto, cloreto, nitrato, fosfato, sulfato, e amônio) foram analisadas por cromatografia de íons, utilizando o cromatógrafo de íons DIONEX, modelo DX 120, conforme descrito anteriormente. Um volume de $100 \mu \mathrm{L}$ de amostra foi injetado no cromatógrafo, a programação isocrática de $100 \%$ de eluente, com

um fluxo de $1,2 \mathrm{~mL} \mathrm{~L}^{-1}$ de eluente aniônico e $0,86 \mathrm{~mL} \mathrm{~L}^{-1}$ de eluente catiônico, que se manteve constante durante toda a análise. As determinações foram realizadas em triplicata. Apenas uma filtração com filtros millipore $<45 \mu \mathrm{m}$ foi realizada antes da injeção da amostra no cromatógrafo.

\subsubsection{DeterminaÇão do TeOr de Matéria Orgânica}

O carbono ocorre em sedimento tanto na forma inorgânica como orgânica. Sendo a grande maioria encontrada na matéria orgânica e em minerais carbonatados [CAMARGO et al., 1986 apud PETRONI 1999].

Segundo Singer [1977] apud FÖRSTNER e WITTMANN [1981] as substâncias orgânicas dissolvidas são capazes de:

(1) complexar metais e aumentar a solubilidade destes;

(2) alterar a distribuição entre as formas oxidada e reduzida dos metais;

(3) reduzir a toxicidade do metal e alterar a disponibilidade para a vida aquática;

(4) influenciar a extensão para o qual os metais são adsorvidos na matéria suspensa;

(5) afetar a estabilidade do metal contaminante coloidal.

Segundo BRADY [1989] e VICENT-BECKETT \& PASCUAL [1991] a matéria orgânica está intimamente ligada aos elementos $\mathrm{Cu}, \mathrm{Zn}$ e Fe nos sedimentos de lagos e ao $\mathrm{Cu}$ nos sedimentos de rios. A matéria orgânica tem uma boa capacidade de adsorção para metais pesados, esta afinidade pode tanto concentrar metais no ambiente, impactando-o, quanto pode ser empregada na remoção de metais em ambientes impactados. Uma importante propriedade física da matéria orgânica está associada à textura fina dos sedimentos, contendo geralmente uma porcentagem natural de material húmico derivado 
de transformações biológicas de plantas e detritos de animais. O material húmico pode estar presente como uma discreta partícula ou como uma camada em partículas de argila, pois o material húmico aumenta a afinidade do sedimento com metais [FÖRSTNER \& WITTMANN, 1981; WETZEL, 1983; EPA, 1991].

FÖRSTNER \& WITTMANN [1981], SOARES [1999] e outros pesquisadores relatam a existência de uma relação entre teor de matéria orgânica e a concentração de elementos-traço em sedimentos aquáticos.

A matéria orgânica é determinada por métodos indiretos usando combustão por via úmida ou via seca, medindo-se a subseqüente evolução do gás carbônico, ou pela extensão da redução de um agente oxidante forte [PETRONI, 1999].

A determinação de carbono (orgânico, inorgânico e total) em amostras de sedimento permite estimar os processos de mineralização e de imobilização da matéria orgânica e com isso avaliar o grau que estes processos possam estar ocorrendo. Conhecendo-se os níveis de carbono em sedimentos, pode-se estabelecer importantes correlações, como por exemplo, matéria orgânica e sua interação com metais pesados [BEVILACQUA, 1996].

O material orgânico pode absorver entre $1 \%$ e $10 \%$ peso seco de $\mathrm{Co}, \mathrm{Cu}, \mathrm{Fe}, \mathrm{Pb}$, $\mathrm{Mn}, \mathrm{Mo}, \mathrm{Ni}, \mathrm{Ag}, \mathrm{V}$ e Zn. Isto demonstra que o enriquecimento de metais nas rochas carbonáceas pode ser largamente atribuído aos ácidos húmicos tendo atuado como agentes complexantes, SWANSON et al. [1970] apud FÖRSTNER \& WITTMANN [1981].

Um método simples para a determinação do carbono orgânico consiste na oxidação dos compostos orgânicos do sedimento por uma solução de dicromato de potássio em presença de ácido sulfúrico. A reação é catalisada pelo calor desprendido pela adição do ácido [PETRONI, 1999].

A determinação do teor de carbono orgânico (\% C) é realizada pela titulação do excesso de dicromato com uma solução de sulfato ferroso amoniacal. A porcentagem de matéria orgânica (\% M.O.) pode ser obtida multiplicando-se a porcentagem de carbono orgânico pelo fator 1,725 (Van Bemmelen). Este fator é utilizado em virtude de se admitir 
que na composição média de húmus, o carbono participa com 58\% [WALKLEY \& BLACK, 1933; FORSTNER \& WITTMANN, 1981; EMBRAPA, 1997; PETRONI, 1999].

A metodologia descrita abaixo foi aplicada nas amostras de sedimento para a determinação do teor de matéria orgânica.

Transferiu-se $0,5 \mathrm{~g}$ sedimento (seco a $60{ }^{0} \mathrm{C}$ e fração $<63 \mu \mathrm{m}$ ) para um erlemmeyer de $500 \mathrm{~mL}$. Adicionou-se $20 \mathrm{~mL}$ de ácido sulfúrico concentrado e $10 \mathrm{~mL}$ de dicromato de potássio $1 \mathrm{~N}$, agitando-se levemente o franco por um minuto. Deixou-se em repouso por 30 minutos. Após esse tempo adicionou-se $200 \mathrm{~mL}$ de água deionizada e 10 $\mathrm{mL}$ de ácido fosfórico concentrado. Como solução titulante foi utilizado uma solução de $0,5 \mathrm{~N}$ de $\mathrm{Fe}\left(\mathrm{NH}_{4}\right)_{2}\left(\mathrm{SO}_{4}\right)_{2}$ e como indicador difenilamina 1\% [EMBRAPA, 1997].

\subsubsection{AnÁlise Mineralógica}

A contribuição geoquímica dos metais para a coluna de água através das rochas é obscura em muitas áreas por uma variedade de fontes [BUBB \& LESTER, 1991]. O alto grau de variação de metais nas rochas é uma possibilidade que os solos e sedimentos no local estudado tem sido "poluídos" por elas. O enriquecimento natural de metais nos solos e sedimentos pode causar um efeito perigoso na vida dos organismos vivos [ALLOWAY et al., 1997].

Segundo Gomes apud SILVA \& LIMA [1999], a interação entre materiais geológicos e os poluentes está intimamente ligada à química de superfície desses materiais.

Os argilominerais e minerais associados que constituem as argilas podem apresentar diferentes propriedades, tais como diferentes produtos de desidratação e de decomposição e também a existência ou não da troca de cátions, quando em suspensão [SILVA \& LIMA, 1999]. Essas características diferentes são resultantes das diferentes composições químicas e estruturas cristalinas e tais diferenças levaram a classificação dos grupos:

- grupo das ilitas;

- grupo das esmectitas; 
- grupo das montmorilonitas;

- grupo da vermiculita;

- grupo caulinita.

O objetivo da análise mineralógica é determinar a possível origem dos componentes dos sedimentos. Para isso utilizamos a análise de Difração de Raios X aplicando a Lei de Stokes [PADILHA \& FILHO, 1985; SANTOS, 1989 (a) e (b)].

O procedimento da análise normalmente começa com o peneiramento da amostra para obtermos uma granulometria (do sedimento) abaixo de $63 \mu \mathrm{m}$. Este método, entretanto, pode causar contaminação do sedimento devido à corrosão do metal que é constituído a peneira. Por esta razão utilizamos o método de decantação que utiliza a densidade das partículas minerais em uma coluna de água para separá-las em uma granulometria adequada para a realização da análise. A granulometria obtida por este método é classificada como fração "argila", pois é nesta fração que encontramos a maioria dos metais agregados por conter maior superfície de adsorção.

\section{BATES \& JACKSON [1987] apud CHRISTOFOLETTI [1999] definem} argilominerais como substância cristalina pertencente ao grupo dos filossilicatos, sendo silicatos hidratados, essencialmente de alumínio e, as vezes, de $\mathrm{Mg}$ e Fe e quantidades menores de outros elementos $(\mathrm{Ca}, \mathrm{Na}, \mathrm{K}, \mathrm{Cr}, \mathrm{Li})$; caracteriza-se também por ser de pequena dimensão e apresentar habilidade de absorver água e íons na superfície da partícula.

Costuma-se classificar os argilominerais em dioctaédricos e trioctaédricos dependendo do grau de ocupação das camadas octaédricas. Em ambas camadas podem ocorrer substituições como de $\mathrm{Si}^{2+}$, por $\mathrm{Al}^{3+}$ nas camadas tetraédricas, e de $\mathrm{Al} \mathrm{e} \mathrm{Fe}^{3+}$ e $\mathrm{Fe}^{2+}, \mathrm{Mg}$, e ocasionalmente $\mathrm{Cr}^{3+}, \mathrm{Mn}^{2+}, \mathrm{Zn}^{2+}, \mathrm{Li}^{+}$, nas camadas octaédricas, mas geralmente com um certo grau de substituição isomórfica.

Após o emprego do método de decantação pela Lei de Stokes as amostras foram analisadas pela técnica de Difração de Raios X. Para se ter certeza de qual grupo argila 
pertence foram realizados mais dois ensaios em cada uma delas: 1) glicolação: ocorre um espaçamento basal e 2) aquecimento: ocorre uma redução desse espaçamento basal.

Esta análise foi realizada no Laboratório de Difração de Raios X, na Divisão da Caracterização Física, e as interpretações dos difratogramas foram realizadas com o auxílio do Dr. Paulo Miranda F. Filho da Divisão de Engenharia Química e Ambiental (IPEN) e do Dr. Flávio M.S. Carvalho do Laboratório de Difração de Raios X do Instituto de Geociências da USP. Para ajudar na interpretação dos resultados foi realizada também a análise de Fluorescência de Raios X no Centro de Tecnologia de Cerâmica (CTC) pela Sra. Degmar Carvalho, mostrado na Tabela A.10 (Apêndice 1). Para a análise de Fluorescência de Raios X também foram utilizadas amostras com granulometria $<63 \mu \mathrm{m}$.

\subsubsection{MÉTODO DE DECANTAÇÃO PELA LEI DE STOKES}

As amostras de sedimento foram secas em estufa a $60{ }^{\circ} \mathrm{C}$, posteriormente foram maceradas com cuidado para não destruir a composição original e, realizado em seguida o mesmo procedimento em todas as amostras [SANTOS, 1989 (a) e (b)]:

- Pesar 30 gramas da amostra;

- adicionar pirofosfato de sódio $0,35 \%$;

- agitar por 5 minutos;

- transferir para um almofariz, macerar levemente; transferir o sobrenadante para uma proveta de $1 \mathrm{~L}$;

- adicionar $100 \mathrm{~mL}$ de água deionizada e macerar novamente até completar $~ 900 \mathrm{~mL}$ da proveta;

- completar o volume a $1 \mathrm{~L}$ e agitar;

- deixar em repouso por 2 horas;

- pipetar $20 \mathrm{~mL}$ da solução a uma distância de $10 \mathrm{~cm}$ do topo;

- transferir a solução pipetada para um béquer de 100 mL, já contendo uma lâmina;

- deixar a solução evaporar em temperatura ambiente e analisar.

Esta metodologia é usada para se obter a fração argila. De acordo com FÖRSTNER \& WITTMANN [1981]; ROSADO [1998] e SOARES [1999] esta fração corresponde à região onde os poluentes potencialmente biodisponível se agregam. 


\subsubsection{INTERPRETAÇÃO DOS DIFRATOGRAMAS}

A melhor técnica de identificação dos grupos dos argilominerais de sedimento é pela técnica de expansão basal (glicolação) e/ou retração basal (aquecimento).

A glicolação (tratamento onde a amostra é submetida a vapores de etilenoglicol em sistema fechado por 12 horas) visa determinar os argilominerais expansivos, enquanto o tratamento térmico realizado em uma mufla durante 2 horas a uma temperatura de $500^{\circ} \mathrm{C}$, tem a finalidade de detectar a presença de argilominerais sensíveis ao aquecimento. A avaliação da amostra na condição natural é importante como efeito de comparação com amostra. Na interpretação é importante conhecer as características de cada um dos grupos argilominerais. A seguir são descritos alguns grupos argilominerais e suas características:

\section{Minerais de argila do grupo da Caulinita}

A estrutura destes minerais é composta por tetraedros de silício e octaedros de alumínio combinados na unidade estrutural. Apresenta espaçamento basal de 7,2 $\mathrm{A}$, não é expansiva, não tem portanto capacidade de absorver água.

A haloysita é um mineral pertencente ao grupo da caulinita, apresenta estrutura semelhante à da Caulinita e sua estrutura basal é de 7,2-7,6 .

\section{Minerais de argila do grupo de Montmorilonita}

Os minerais do grupo da montmorilonita são constituídos por duas camadas de tetraedro de silício e uma de octaedro de alumínio. O espaçamento basal deste mineral é de $14 \AA$, ao natural, sendo que com tratamento de aquecimento reduz para $10 \AA$ e glicolação

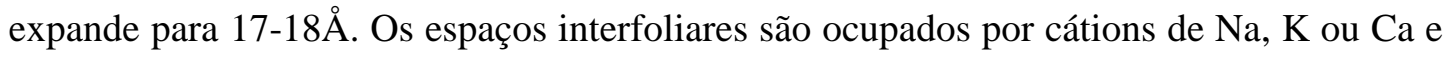
por duas camadas de água. 
Os minerais do grupo da vermiculita são constituídos por camadas de octaedro. O espaçamento basal deste mineral é de $14 \AA$, ao natural, sendo que com tratamento de aquecimento reduz para $10 \AA$ e glicolação retorna para $14 \AA$.

\section{Minerais de argila do grupo de Clorita}

Os minerais do grupo da clorita são constituídos por camadas de octaedro. O espaçamento basal deste mineral é de $14 \AA$, ao natural, sendo que com tratamento de aquecimento permanece a $14 \AA$ e glicolação continua a $14 \AA$.

\subsection{TRATAMENTO MATEMÁtico E ESTATÍSTICO DOS DADOS}

O perfil espacial do corpo de água permite identificar os trechos mais críticos, isto é, onde a qualidade se encontra significativamente comprometida, possibilitando estimar quais são as principais fontes de emissão de poluentes presentes na UGRHI em avaliação. Tais fontes podem estar associadas a esgotos domésticos, efluentes industriais ou carga difusas.

Para representar o perfil espacial de cada parâmetro selecionado, ao longo do corpo de água, foram utilizadas representações gráficas do tipo Box-plot. Esta metodologia possibilita a visualização da assimetria da distribuição, a faixa de variação dos dados, além de permitir a detecção de possíveis pontos extremos, que podem ou não ser excluídos da análise.

As representações de Box-plot possibilitam ainda a visualização das seguintes grandezas estatísticas: a média, a mediana (divide o conjunto de dados ao meio, deixando metade dos dados abaixo e metade acima dela), o máximo, o mínimo, o $1^{\text {o }}$ quartil (é o valor que deixa $1 / 4$ das observações abaixo dele), o $3^{-0}$ quartil (é o valor que deixa $3 / 4$ das observações abaixo dele) e os valores extremos da distribuição dos dados. Os pontos extremos podem indicar erros de amostragem, de medida e, mesmo, de transcrição dos dados, ou ainda, simplesmente, um comportamento fora do habitual. 
Para melhor avaliar e interpretar a grande base de dados gerada no desenvolvimento de trabalhos de monitoramento e avaliação ambiental, onde tanto o número de casos quanto o número de variáveis são grandes, a análise estatística multivariada (análise descritiva univariada e análise de conglomerados) tem se destacado. Quando duas ou mais variáveis de uma base de dados não são completamente independentes, elas podem ser agrupadas através da criação de uma única nova variável a partir das antigas [GERAB, 1996].

A quimiometria é a química que utiliza métodos matemáticos e estatísticos para definir ou selecionar as condições ótimas de medição de experiência e também converter dados químicos em informações para que possam ser utilizadas na redução de problemas.

A análise estatística multivariada é uma ferramenta essencial que ajuda a avaliar os resultados, organizar, interpretar e analisar um grande número de dados, como informações sobre as principais tendências da variabilidade das observações: concentração dos diversos metais, localidade da amostragem e sazonalidade. Esse método reduz a complexidade do problema em questão, sem acarretar numa perda relevante de informação, ao mesmo tempo em que evidencia as relações entre as variáveis constituintes da base de dados. Um dos métodos estatísticos muito utilizado é a análise multivariada por componentes principais (ACP), que tem como finalidade identificar novas variáveis, denominadas componentes variáveis, que são combinações lineares das variáveis originais. As novas variáveis são utilizadas para analisar os dados através de algum tipo de geometria ou representação.

Para interpretar a grande base de dados gerada neste trabalho (Apendicê 1) e melhor avaliar os resultados obtidos os dados foram divididos em dois grupos de variáveis: a) variáveis independentes (fatores): comunidades, época de coleta, tipo de amostra analisada; e,

b) variáveis dependentes: variáveis pluviométricas e $\mathrm{pH}$ da água; concentração dos metais: metais (Fe, Mg, Mn, Ca, Al, Co, Ag, Ba, Cr, Ni, Cu, Zn, Cd e Pb) e o elemento $\mathrm{P}$ e concentração de elementos iônicos: $\mathrm{F}^{-}, \mathrm{Cl}^{-}, \mathrm{NO}_{3}{ }^{-}, \mathrm{SO}_{4}{ }^{2-}, \mathrm{Na}^{+}, \mathrm{K}^{+}$, $\mathrm{NH}_{4}^{+}$.

OBS: Esta etapa do trabalho contou com a colaboração da Prof. Dra. Carmen D. S. André e do Sr. Willian W. Rodrigues do Instituto de Matemática e Estatística da USP. 
Visando resumir os resultados do experimento, foram construídos três tipos de gráficos - para comparar as concentrações dos elementos analisados nas diversas comunidades nas águas brutas e tratadas, foram construídos box-plot [BUSSAB \& MORETTIN, 1987].

Para avaliar o comportamento das concentrações dos metais ao longo do tempo e comparar esses comportamentos nas diferentes comunidades, foram construídos gráficos onde são representados alisamentos do diagramas de dispersão em função da data de coleta. Esta técnica permite visualizar possíveis tendências das concentrações dos elementos no estudo.

Com o objetivo de agrupar as comunidades com o mesmo comportamento das concentrações de cada metal nas coletas, foi utilizada a técnica de análise de agrupamento [BUSSAB et al., 1990]. Considerou-se que os dados correspondentes a cada metal, em uma dada comunidade, correspondem à uma realização da variável multidimensional.

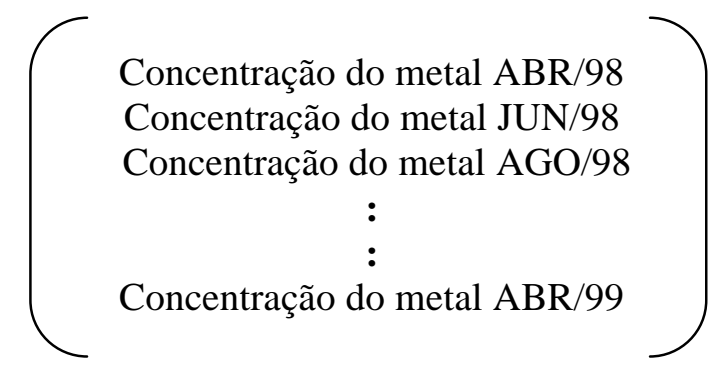

A análise foi feita separadamente para as amostras de água bruta, tratada e digestão, utilizando o método da Centróide (que calcula a distância entre dois clusters com a distância entre sua médias para todos os itens, a distância a qual o cluster está combinado pode diminuir de um estágio para outro) e a distância Euclidiana (a diferença entre dois itens é o quadrado da raiz da soma do quadrado das diferenças no valor para cada variável). As frações sobrenadante e intersticial possuem um número menor de valores coletados, portanto, não foi possível realizar a análise de agrupamentos. Os resultados obtidos por essa técnica foram analisados através de sua representação gráfica denominada dendrograma. 


\section{Resultados e DiscuSSÃo}

Utilizando como ferramenta a análise estatística multivariada, os dados foram trabalhados e avaliados visando:

- Comparar as concentrações dos metais e elementos-traço na água bruta e tratada avaliando a eficiência dos processos de tratamento, de modo a fornecer subsídios a um programa de proteção a saúde pública e conservação e recuperação do meio ambiente.

- Obter informações sobre a distribuição espacial e temporal da ocorrência e abundância de metais e elementos-traço em áreas de captação de água superficial, destinadas ao abastecimento público nas áreas de captação nas bacias Hidrográficas dos Rios Mogi-Guaçu e Pardo, Estado de São Paulo.

- Desenvolver um estudo geoquímico das águas e sedimentos nas estações de captação de água.

- Realizar um gerenciamento de ecossistemas aquáticos, destinados a captação de água potável, compreendendo as etapas de monitoramento, controle, uso e tratamento dos resultados, banco de dados, análise estatística e de implementação de sistema suporte à decisão com base nesses dados.

\subsection{ANÁllSE FíSICA E QUÍMICA DA ÁGUA}

\subsubsection{VARIAÇÃO DA CONCENTRAÇÃO DE METAIS E ELEMENTOS- TRAÇO}

As Figuras de 6.1 a 6.16 e de 6.17 a 6.31 apresentam os resultados dos perfis dos metais e elementos-traço nas águas bruta e tratada, respectivamente, em todas as 13 comunidades, em um ciclo hidrológico completo, podendo destacar os períodos seco e chuvoso. Como comparativo temos em destaque no gráfico as concentrações limite estabelecidas pela legislação CONANA 20, no caso da água bruta, e a Portaria 36/90, no caso da água tratada. 


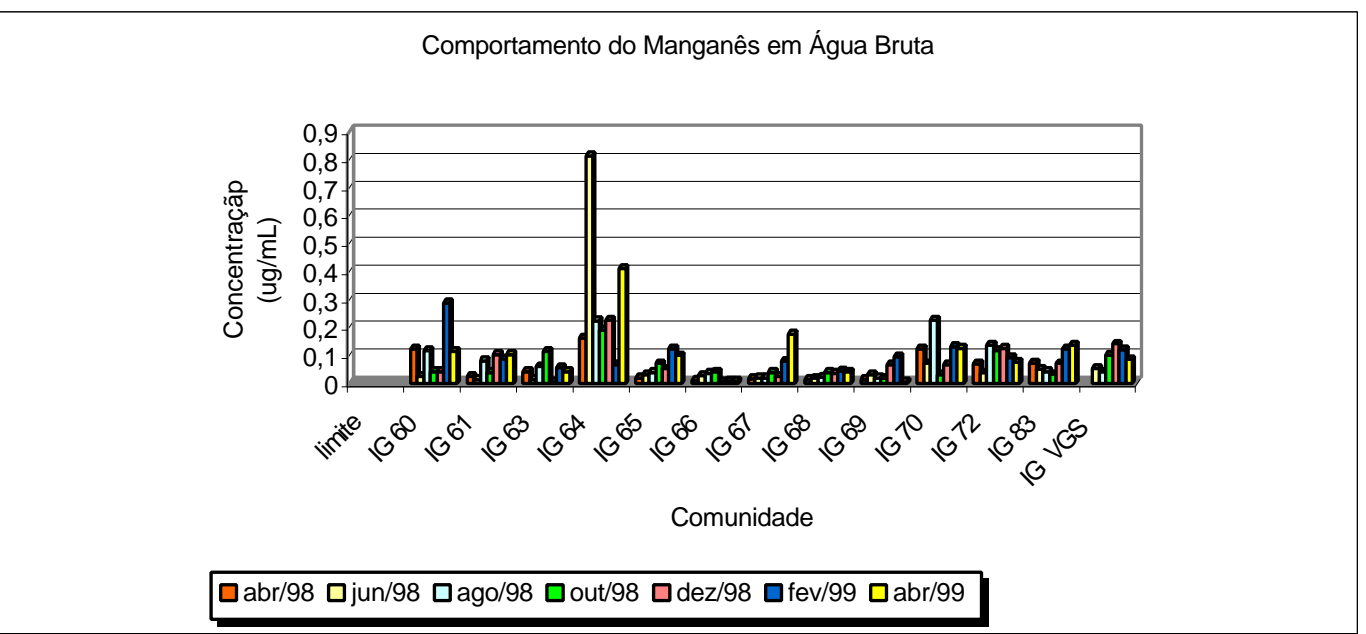

Figura 6.1 - Perfil do manganês na água bruta

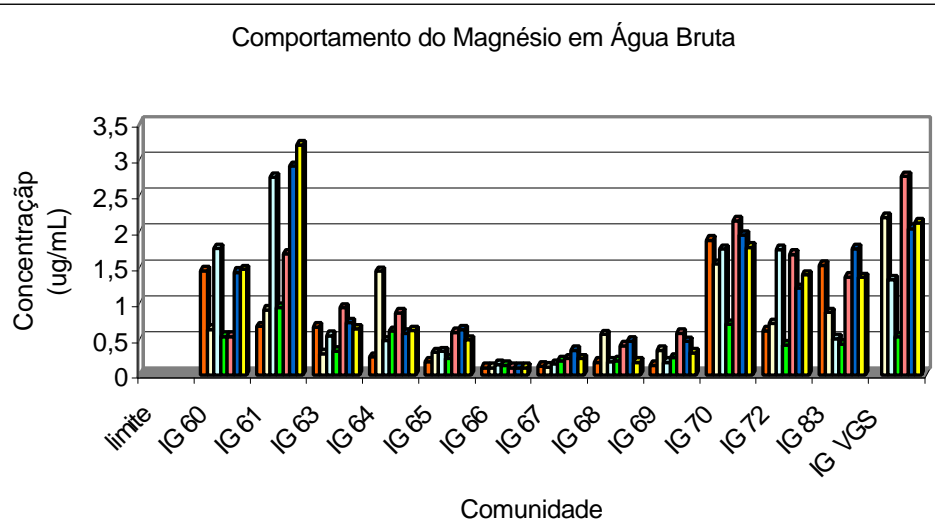

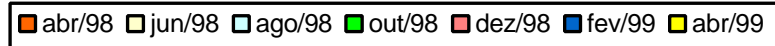

Figura 6.2 - Perfil do magnésio na água bruta

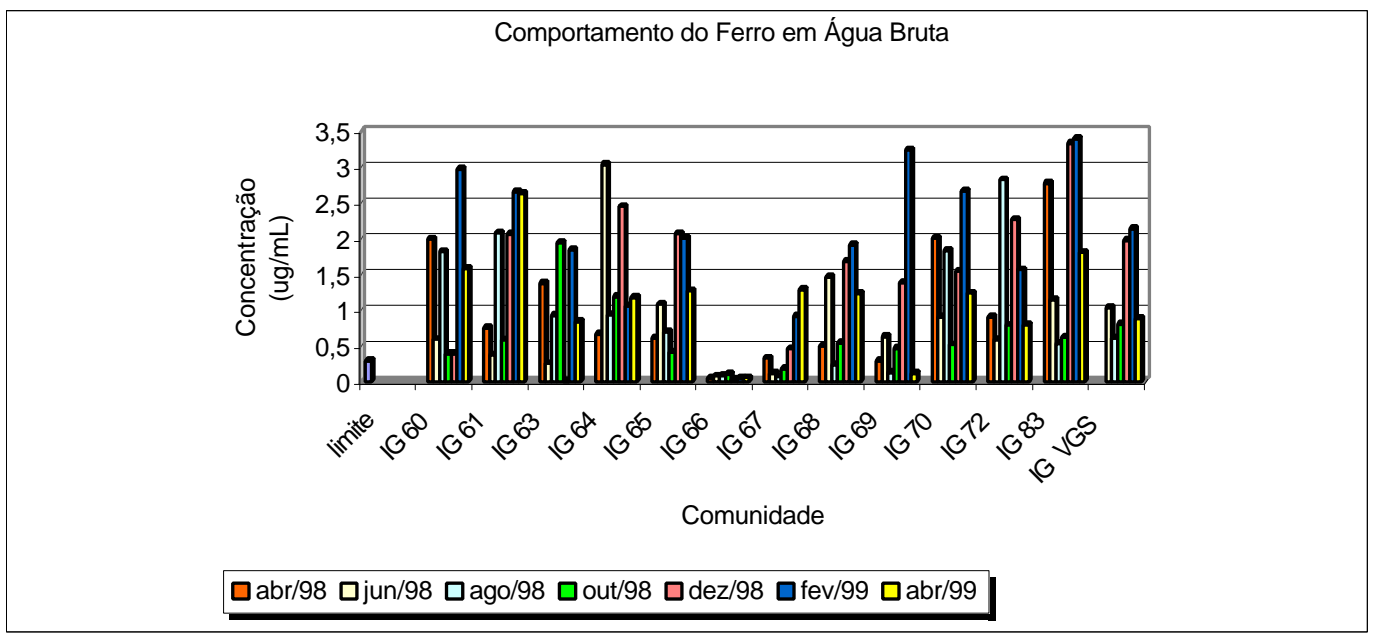

Figura 6.3 - Perfil do ferro na água bruta 


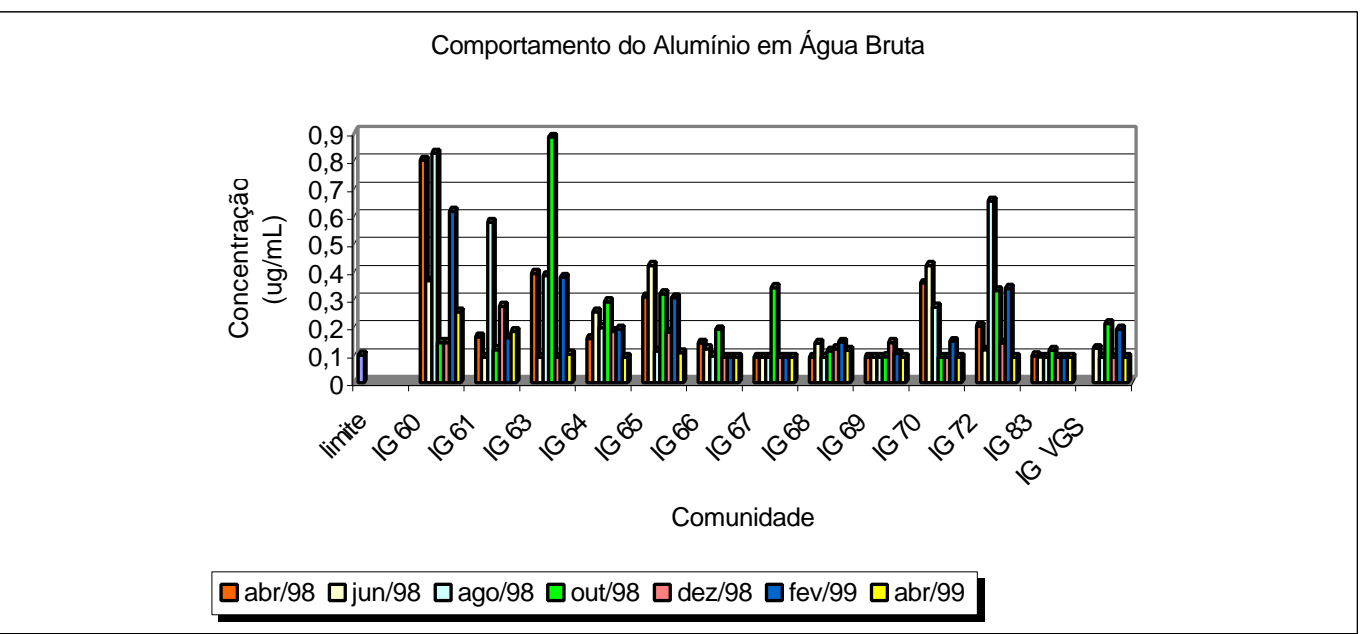

Figura 6.4 - Perfil do alumínio na água bruta

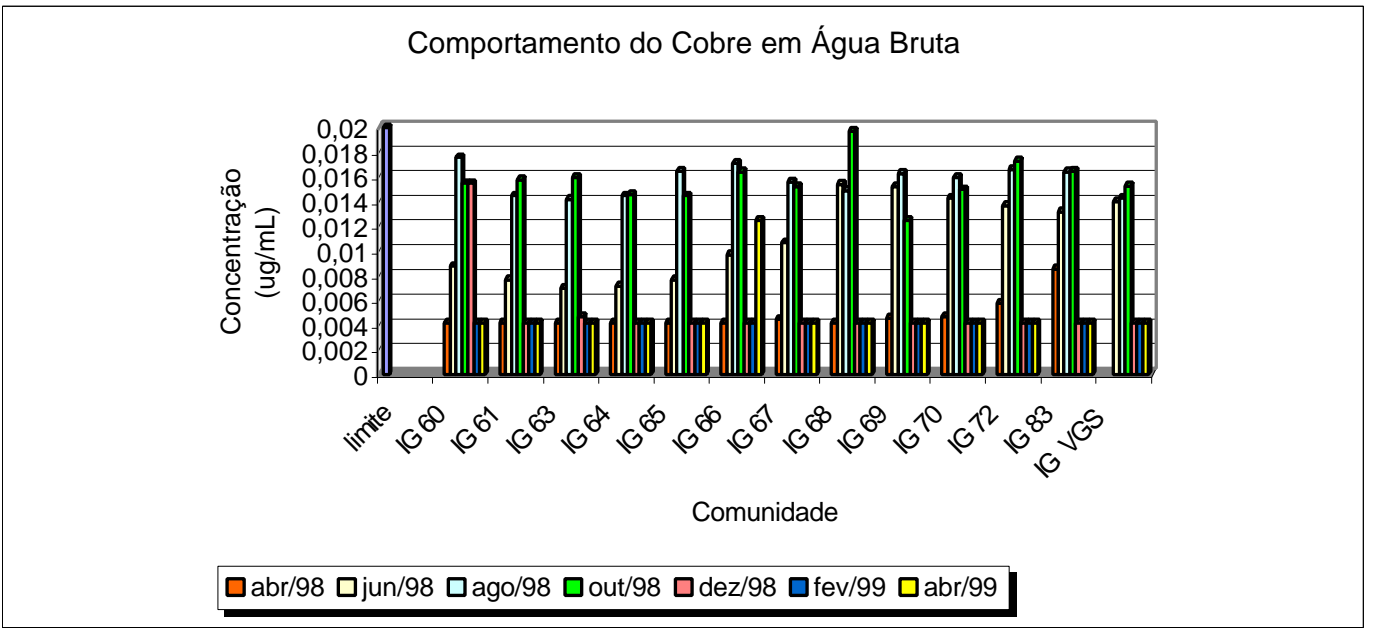

Figura 6.5 - Perfil do cobre na água bruta

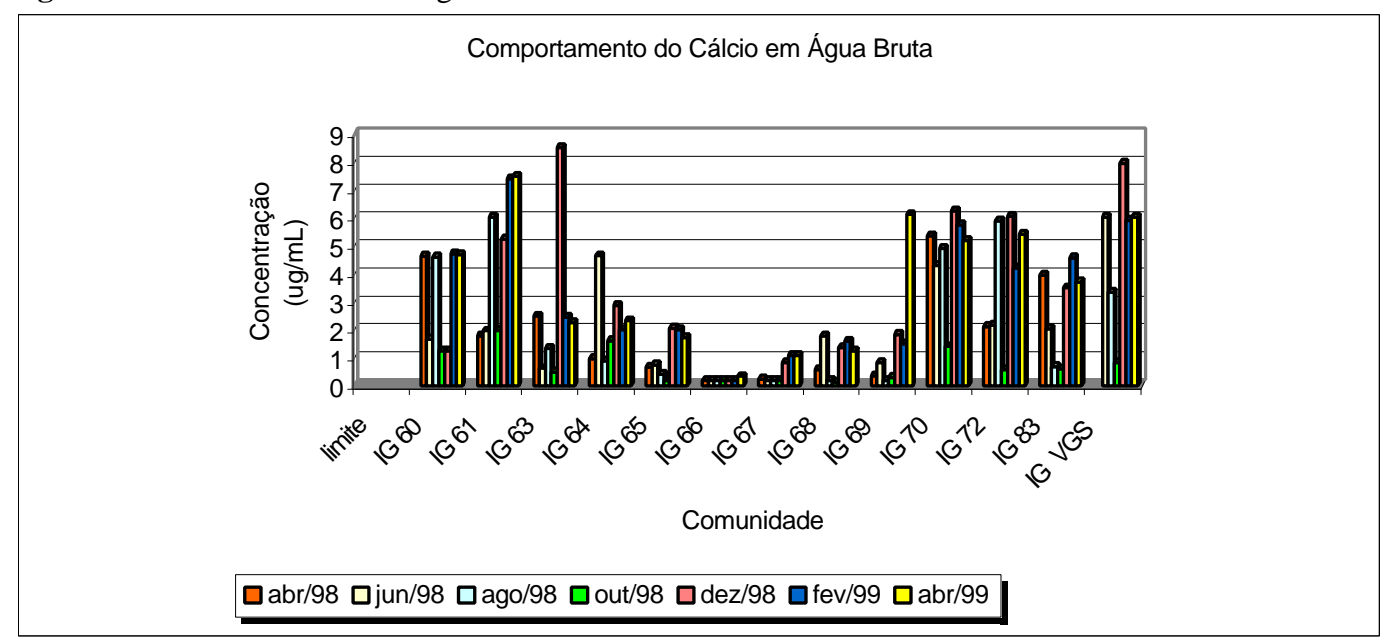

Figura 6.6 - Perfil do cálcio na água bruta 


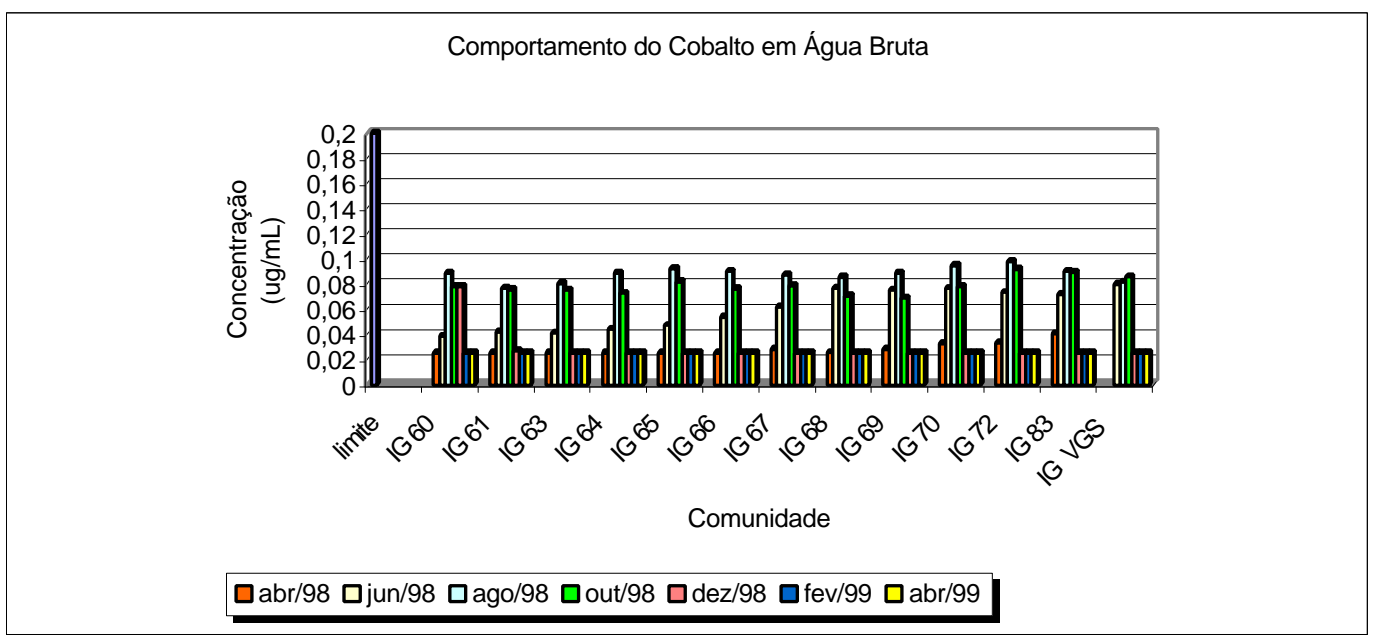

Figura 6.7 - Perfil do cobalto na água bruta

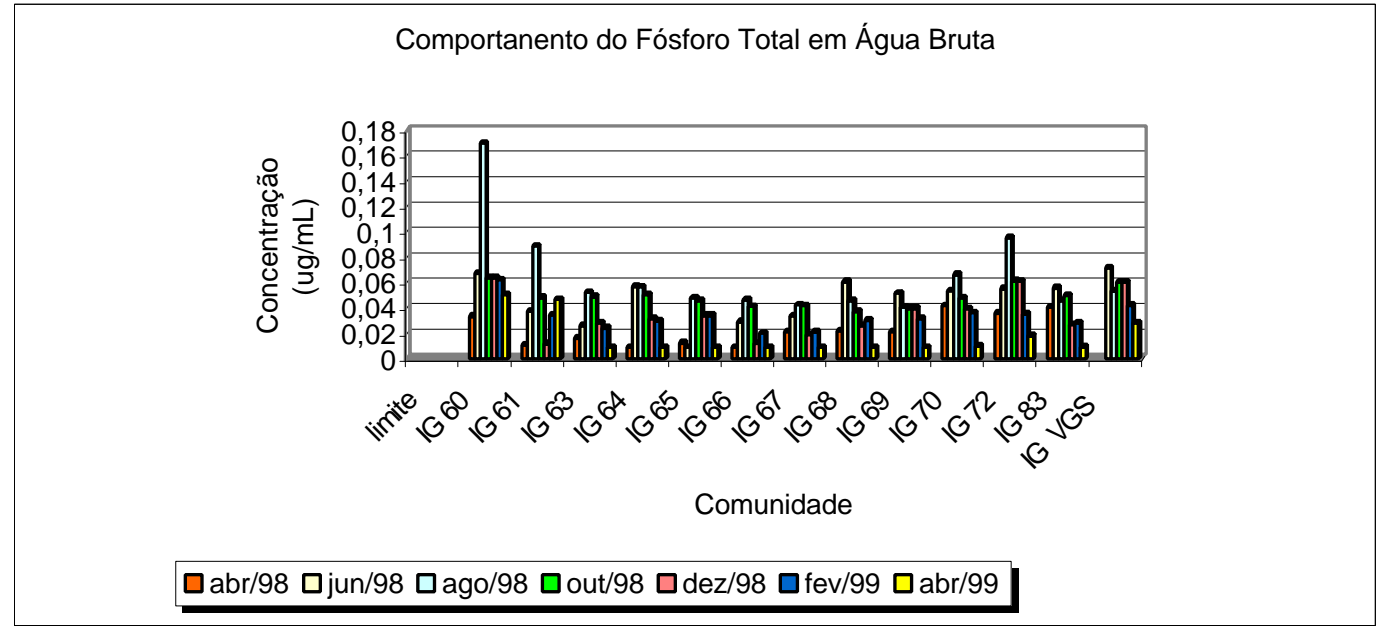

Figura 6.8 - Perfil do fósforo total na água bruta

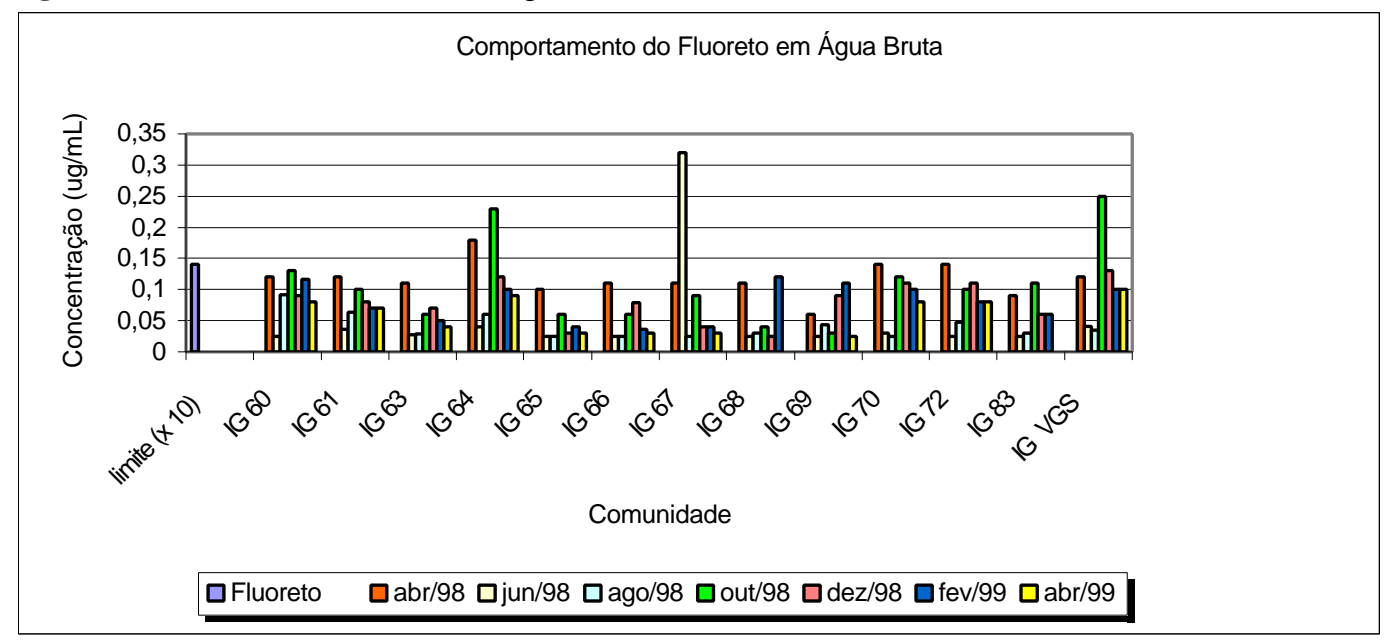

Figura 6.9 - Perfil do fluoreto na água bruta 


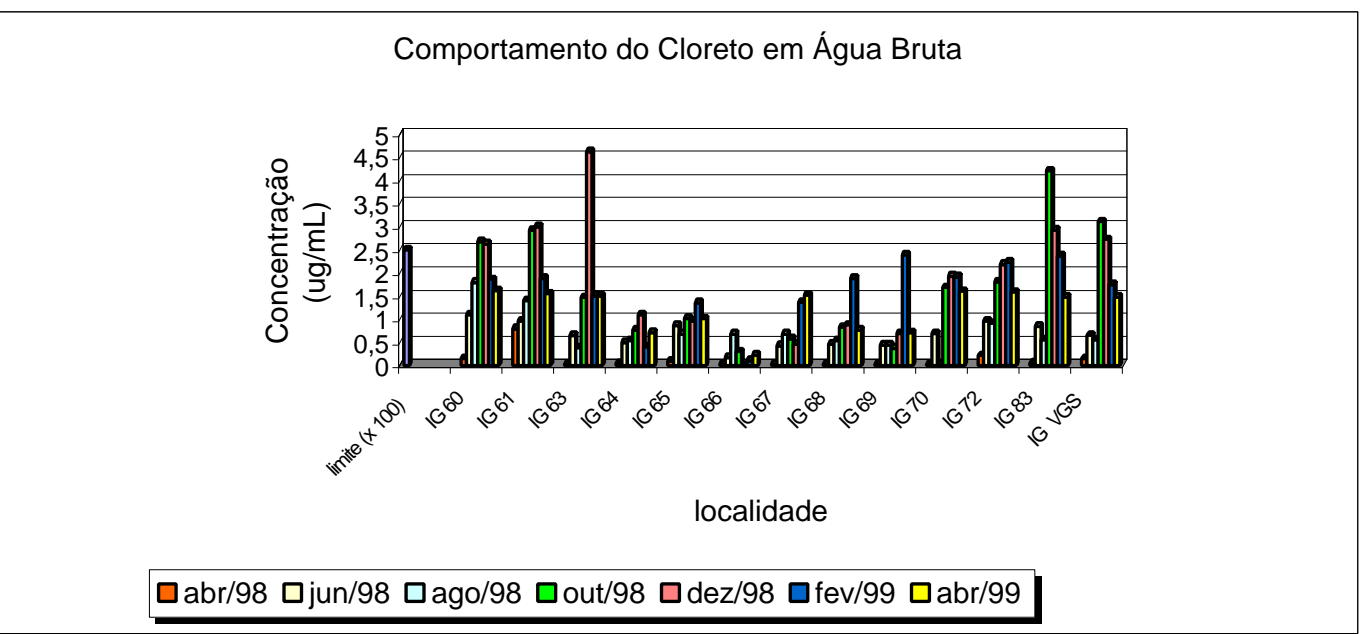

Figura 6.10 - Perfil do cloreto na água bruta

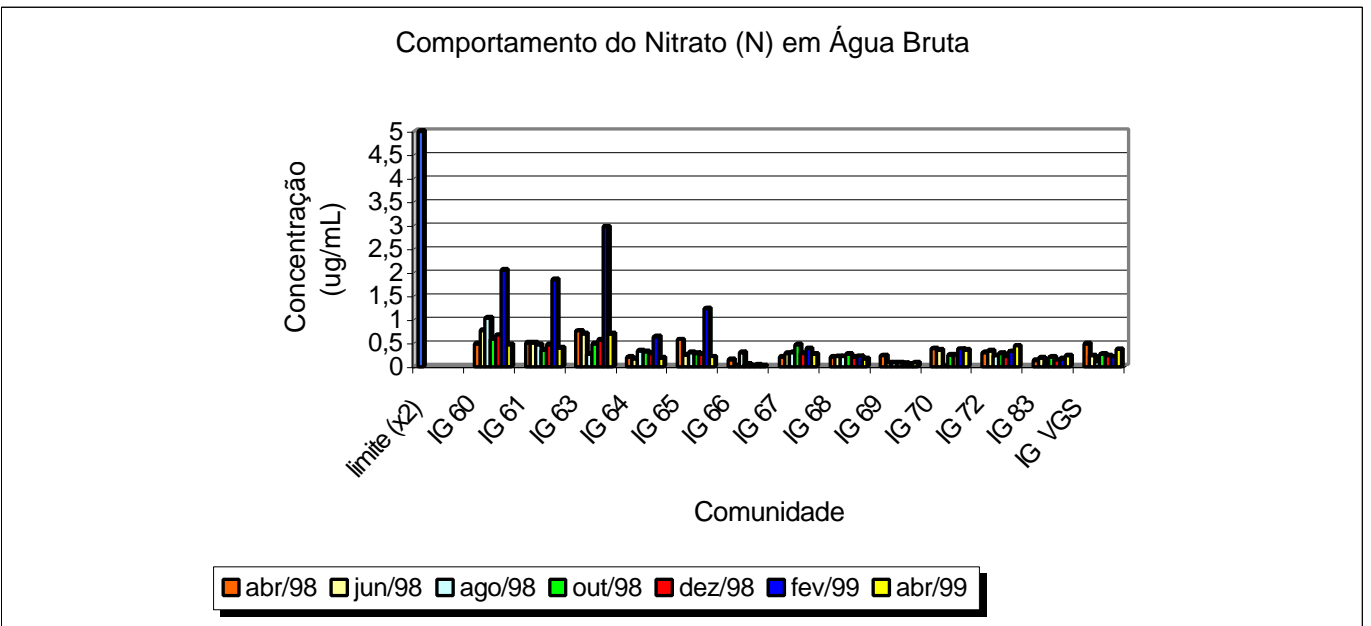

Figura 6.11 - Perfil do nitrato na água bruta

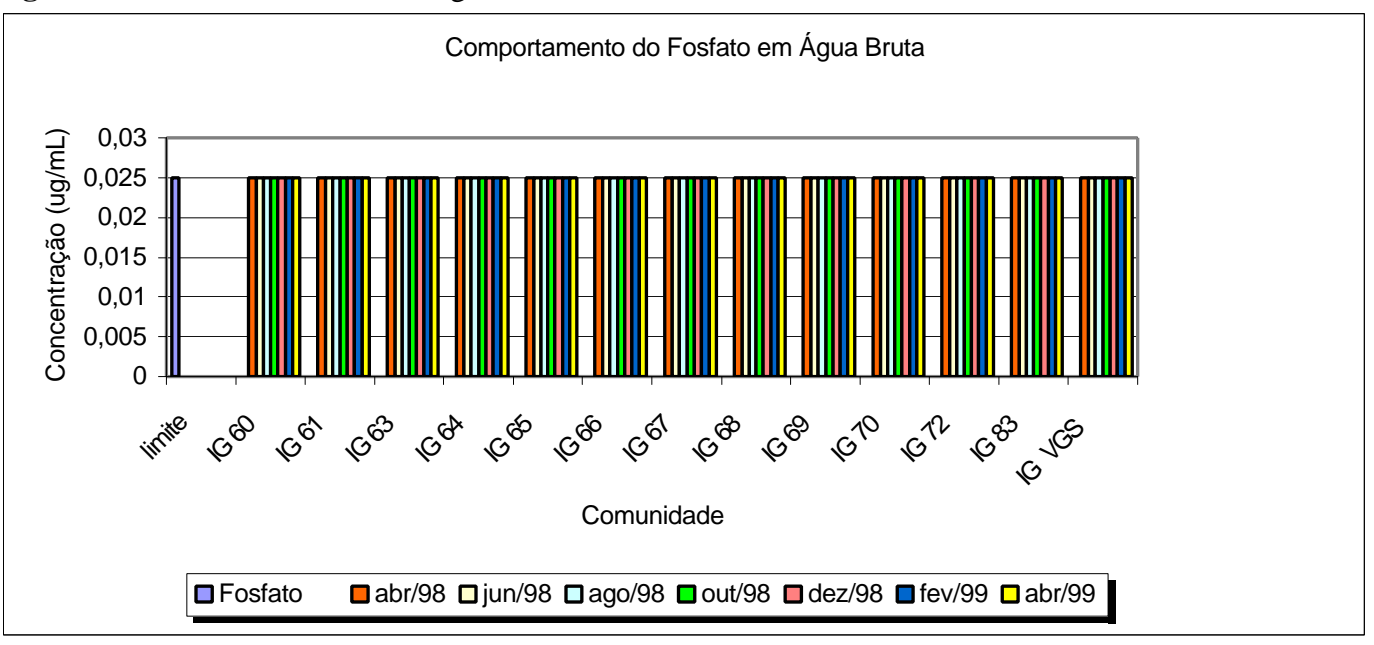

Figura 6.12 - Perfil do fosfato na água bruta 
Comportamento do Sulfato em Água Bruta

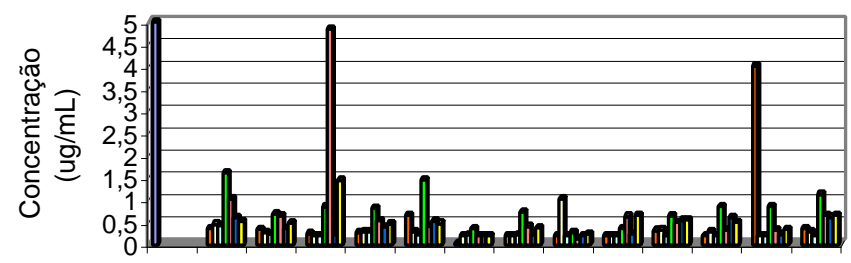

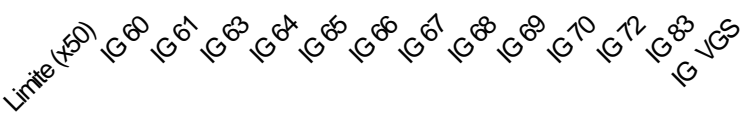

Localidade

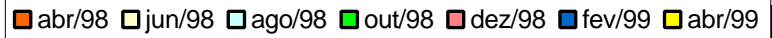

Figura 6.13 - Perfil do sulfato na água bruta

Comportamento do Sódio em Água Bruta
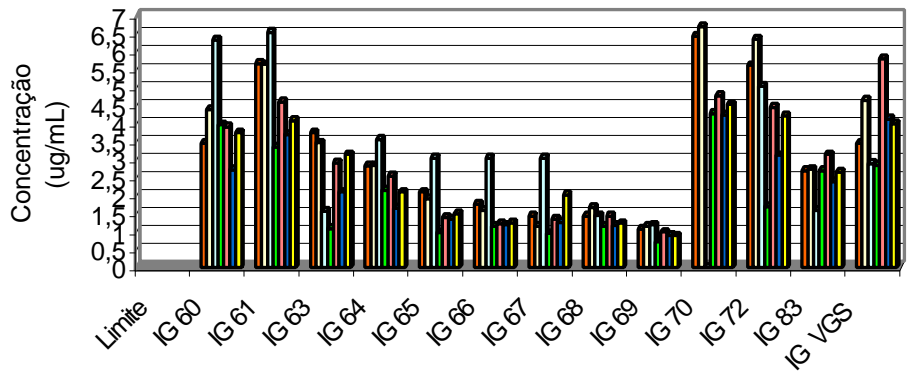

Localidade

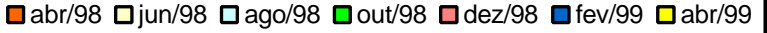

Figura 6.14 - Perfil do sódio na água bruta

Comportamento do Amônio em Água Bruta

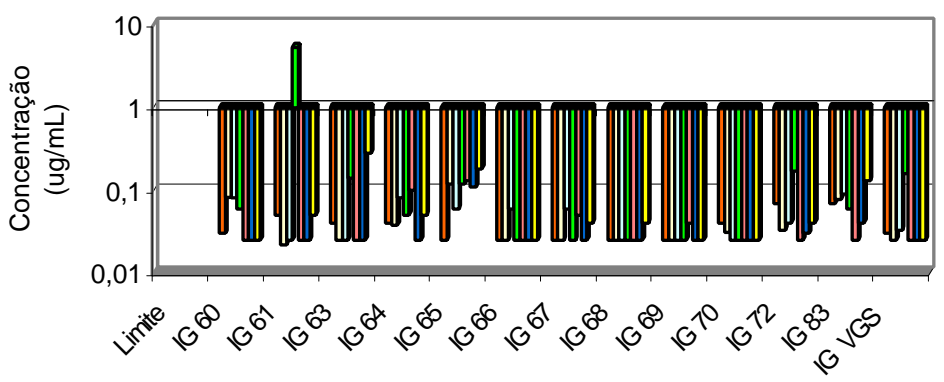

Localidade

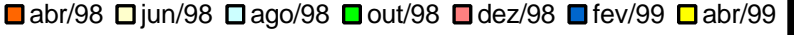

Figura 6.15 - Perfil do amônio na água bruta 


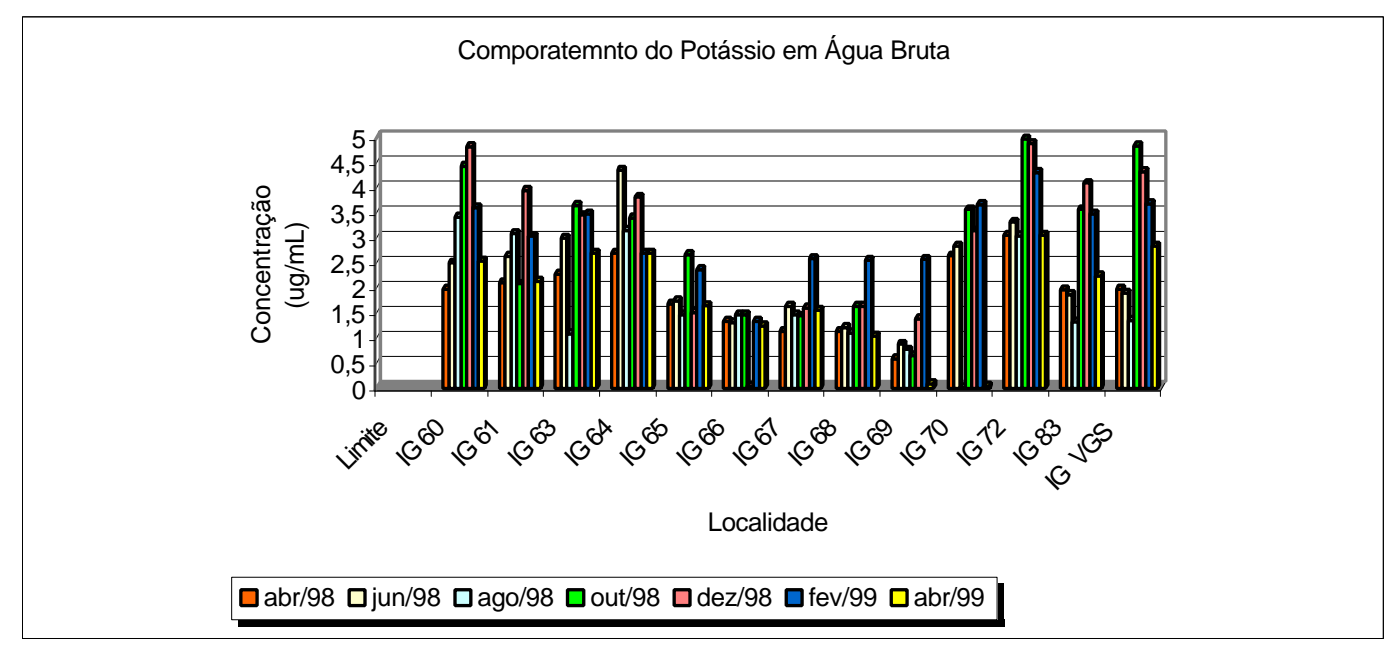

Figura 6.16 - Perfil do potássio na água bruta 


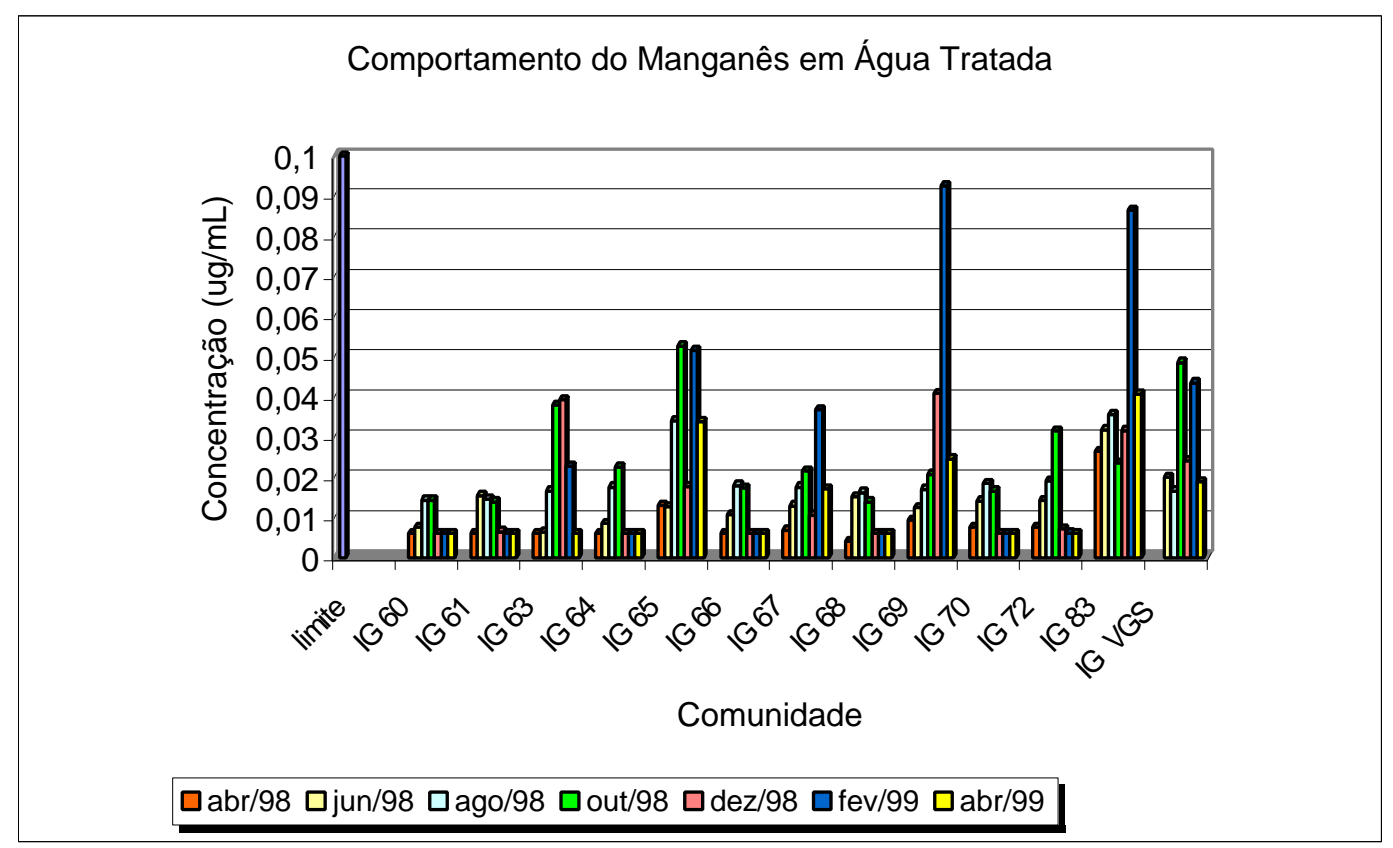

Figura 6.17 - Perfil do manganês na água tratada

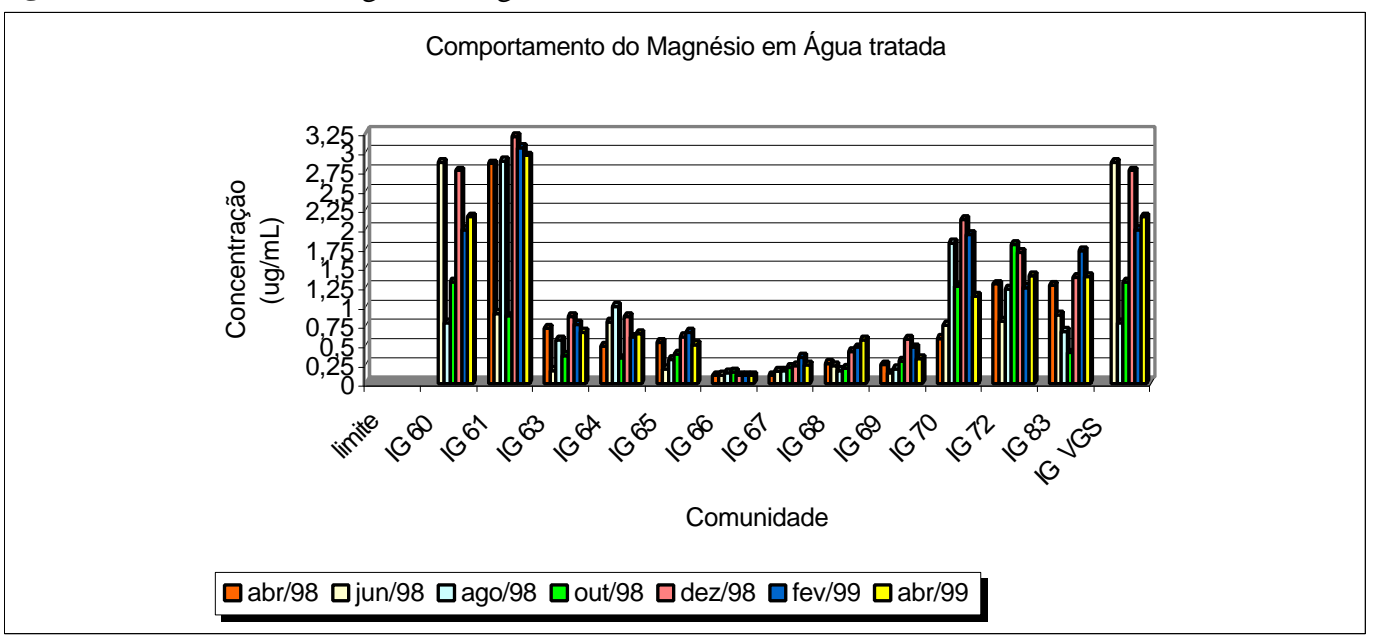

Figura 6.18 - Perfil do magnésio na água tratada

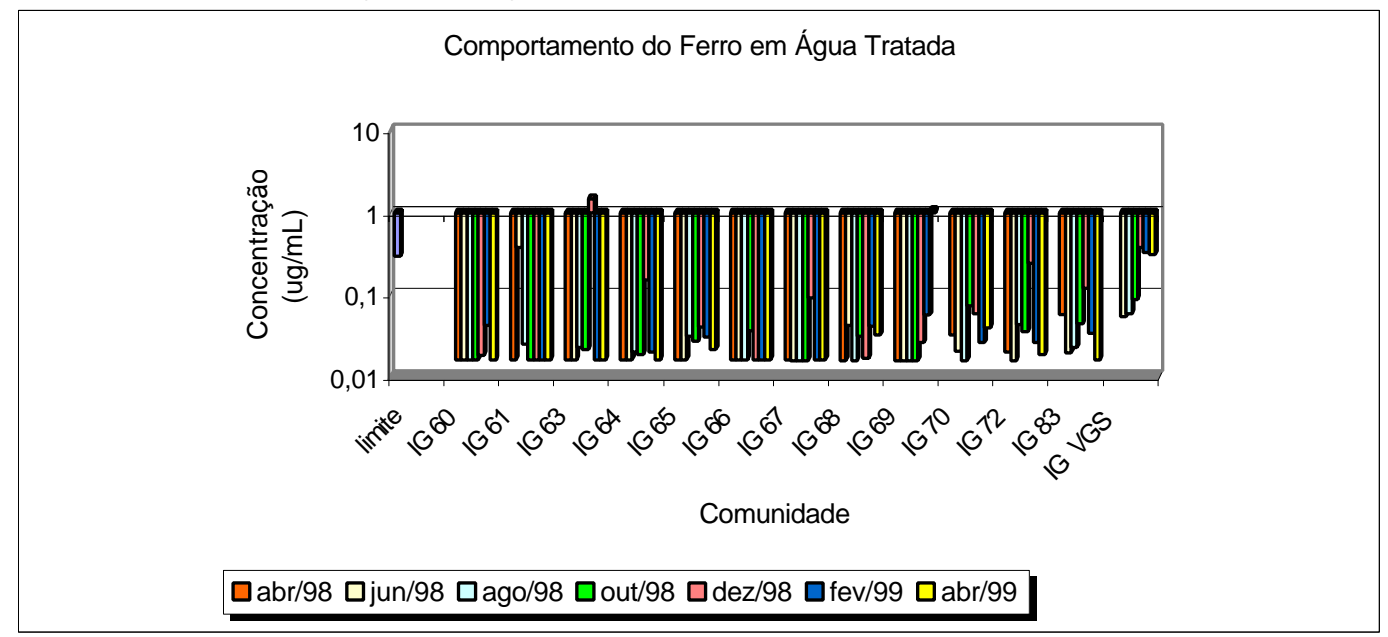

Figura 6.19 - Perfil do ferro na água tratada 
Comportamento do Alumínio em Água Tratada

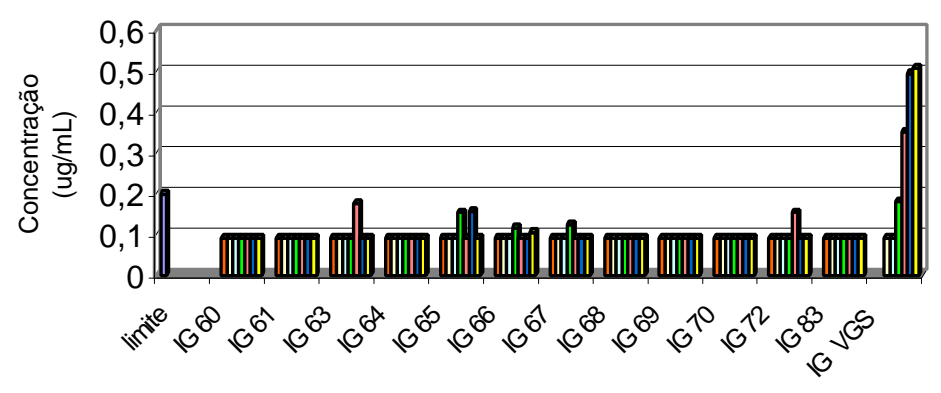

Comunidade

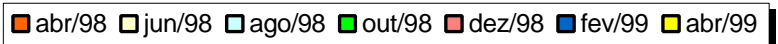

Figura 6.20 - Perfil do alumínio na água tratada

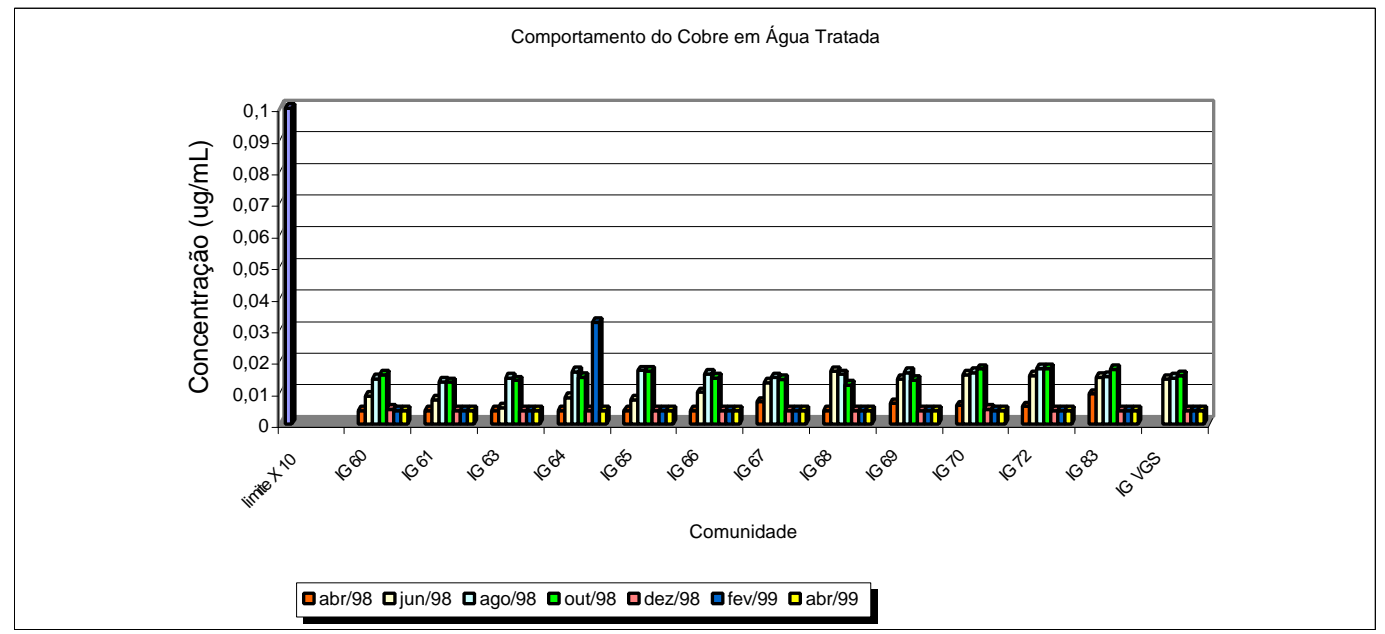

Figura 6.21 - Perfil do cobre na água tratada

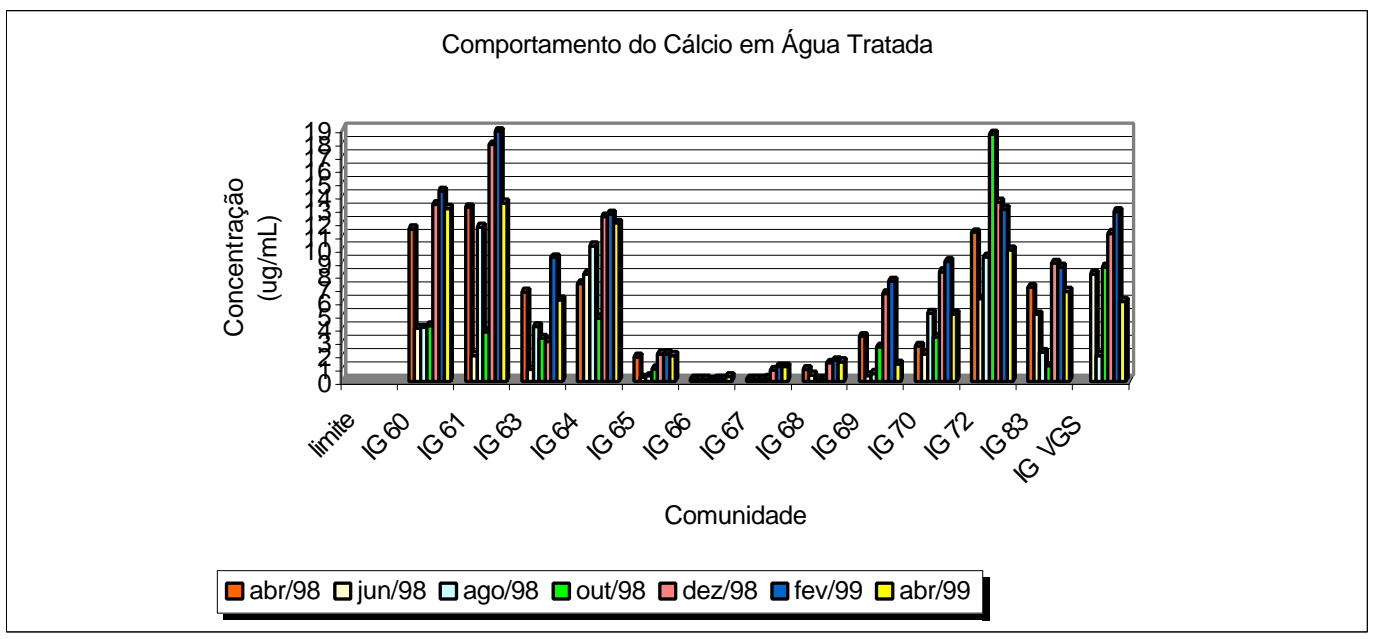

Figura 6.22 - Perfil do cálcio na água tratada 
Comportamento do Cobalto em Água Tratada

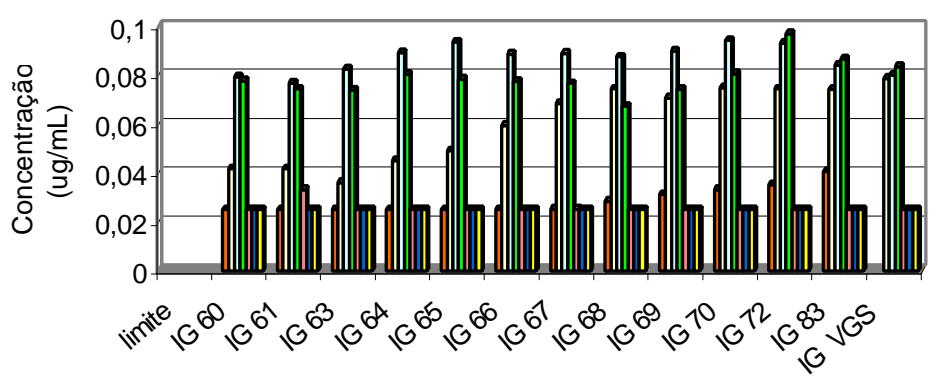

Comunidade

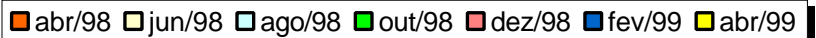

Figura 6.23 - Perfil do cobalto na água tratada

Comportamento do Fósforo Total em Água Tratada

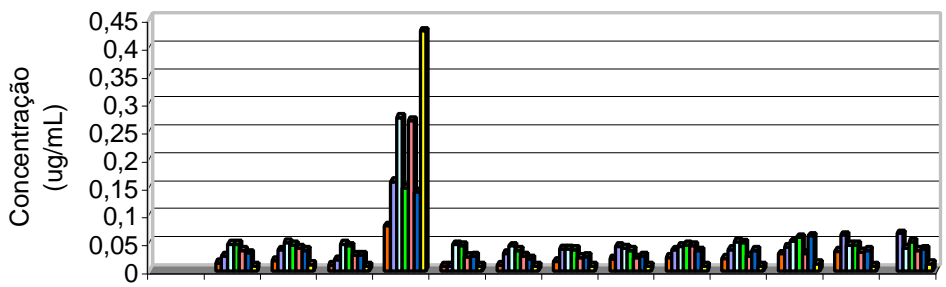

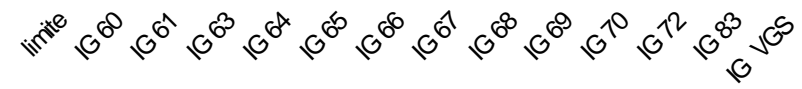

Comunidade

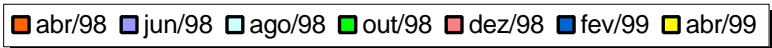

Figura 6.24 - Perfil do fósforo total na água tratada

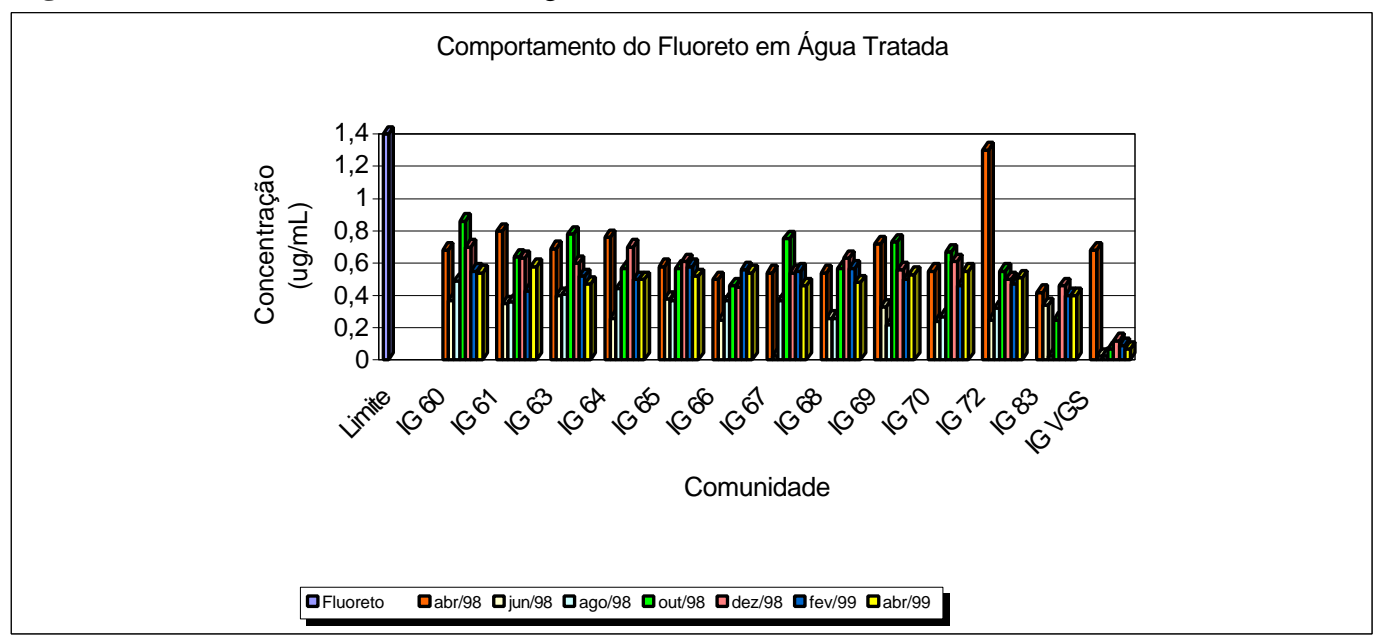

Figura 6.25 - Perfil do fluoreto na água tratada 


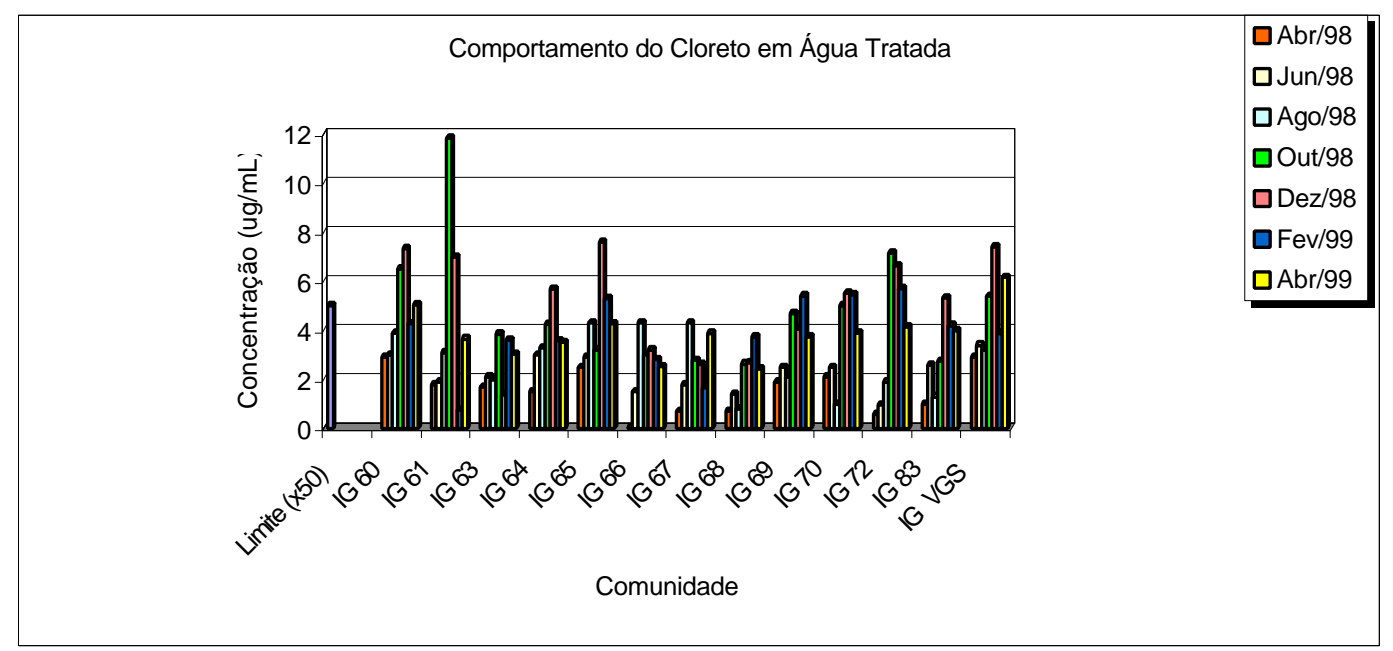

Figura 6.26 - Perfil do cloreto na água tratada

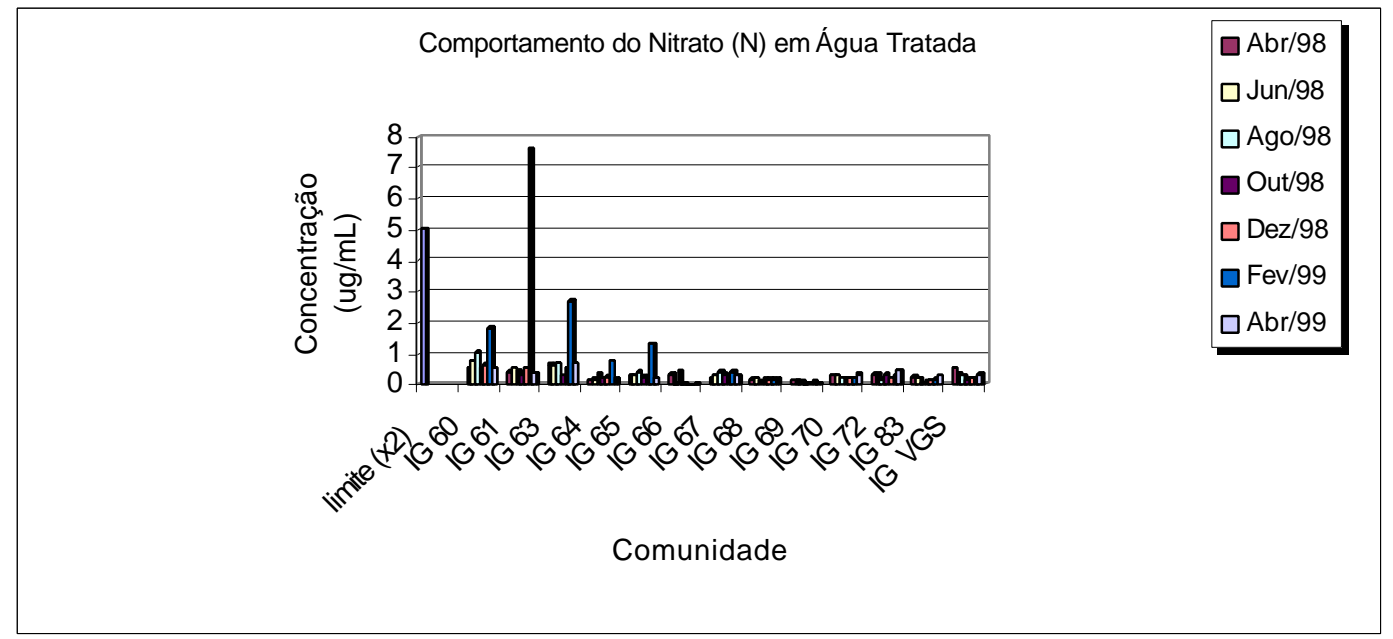

Figura 6.27 - Perfil do nitrato na água tratada

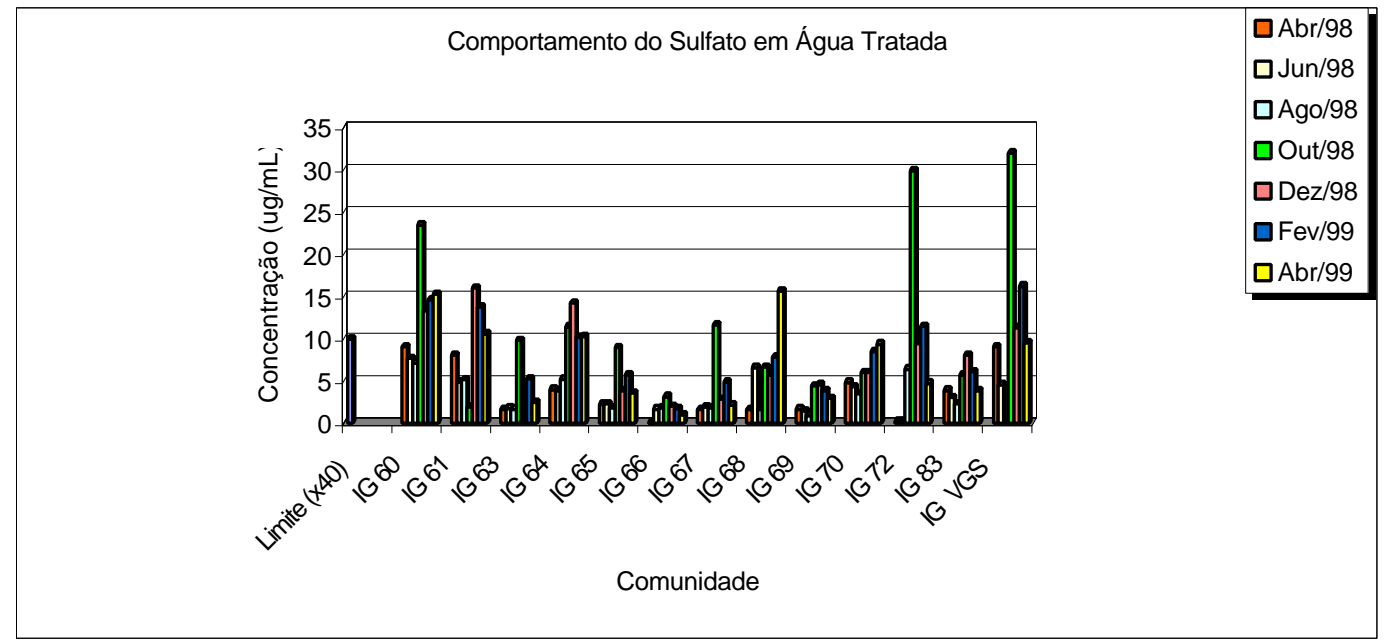

Figura 6.28 - Perfil do sulfato na água tratada 


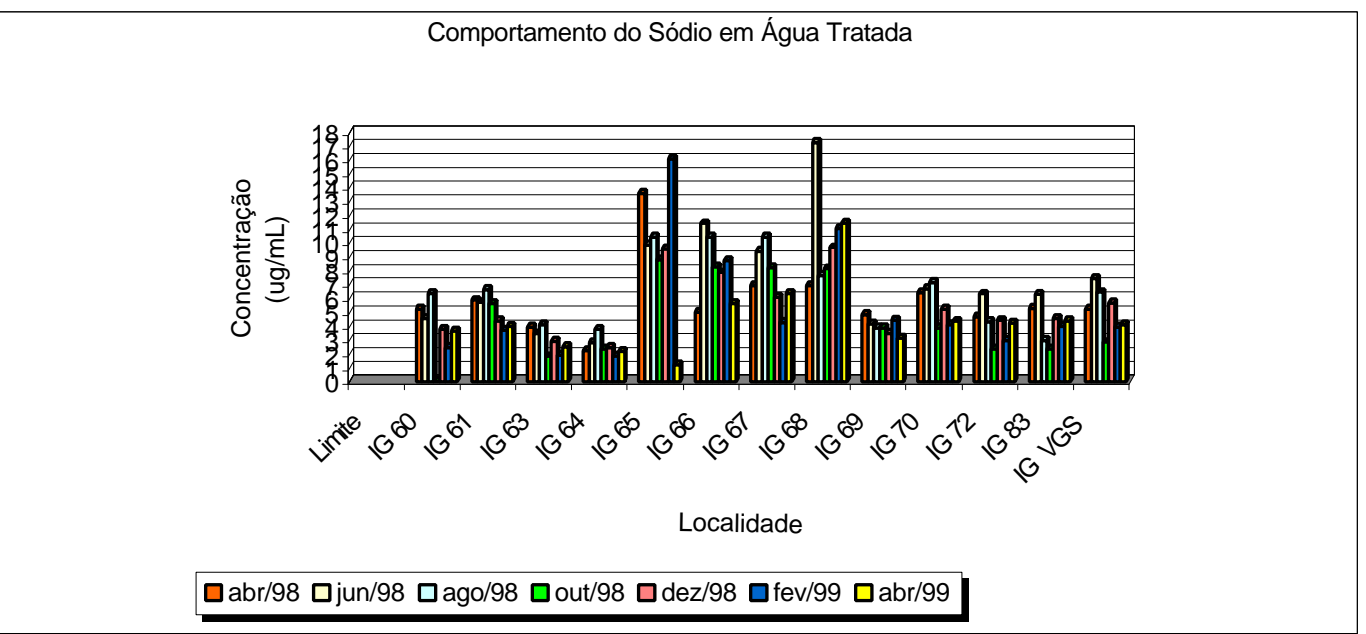

Figura 6.29 - Perfil do sódio na água tratada

Comportamento do Amônio em Água Tratada

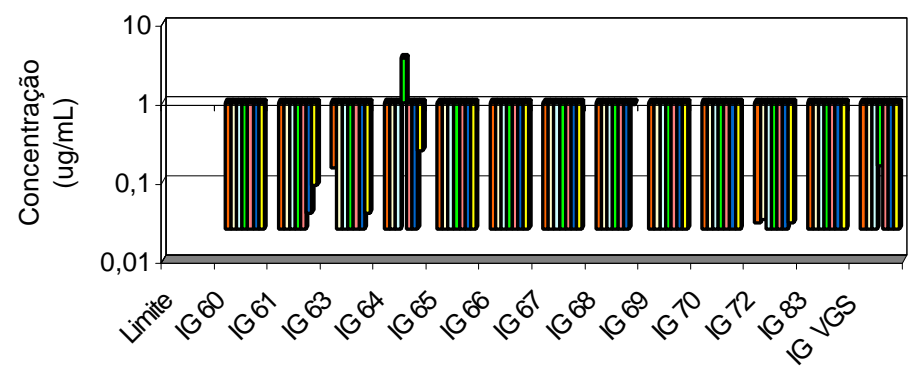

Localidade

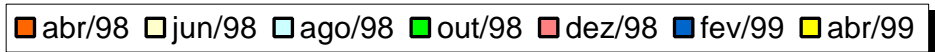

Figura 6.30 - Perfil do amônio na água tratada

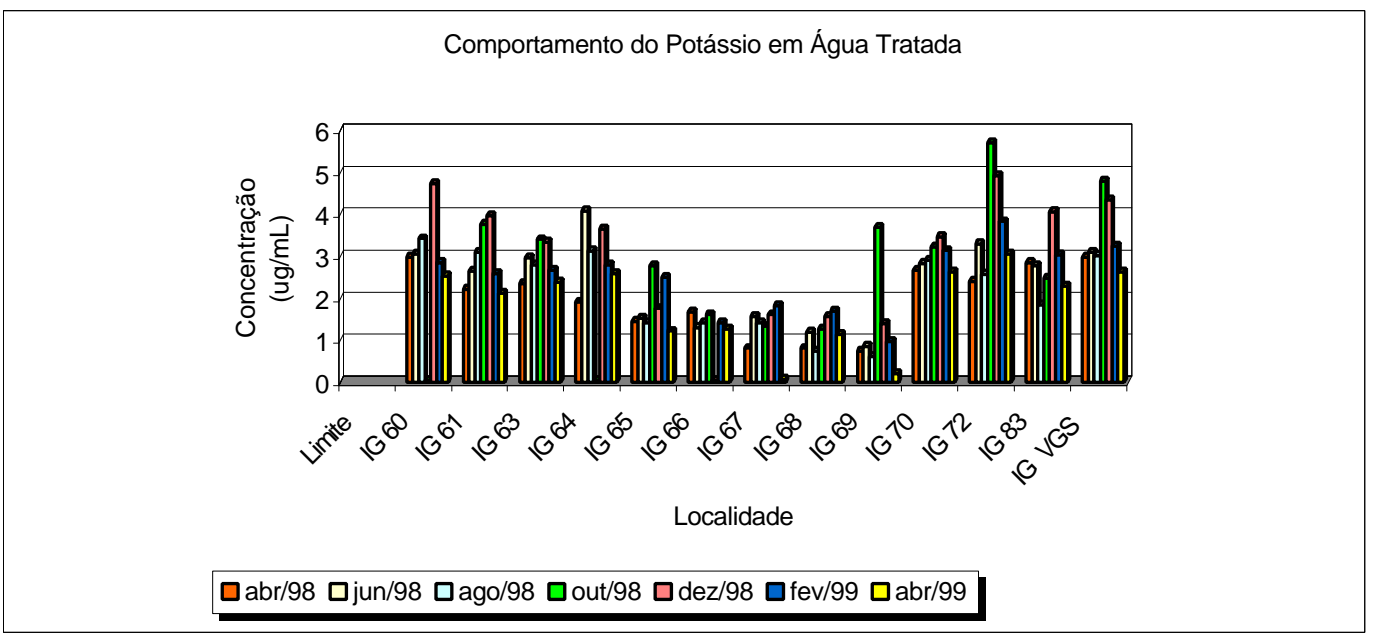

Figura 6.31 - Perfil do potássio na água tratada 
Avaliando-se as medidas da concentração dos elementos metálicos e iônicos obtidas pelas técnicas aqui apresentadas verificou-se que alguns valores ficaram abaixo do limite de determinação da metodologia aplicada ( $\mathrm{Cd}, \mathrm{Cr}, \mathrm{Ni}, \mathrm{Zn}$ e $\mathrm{PO}_{4}{ }^{3-}$ ). Nestes casos utilizou-se como valor medido o limite de determinação do método. Estes valores não detectados não refletem exatamente a concentração existente do elemento em questão, mas indicam que sua concentração é bastante baixa.

As Tabelas A.1 a A.4 (Apêndice 1) apresentam os resultados da variação das concentrações dos metais e elementos iônicos nas águas bruta e tratada aplicando análise estatística descritiva.

As representações gráficas do tipo Blox-plot, estão apresentadas no Apêndice 2 onde o perfil espacial de cada parâmetro selecionado em cada comunidade é apresentado, permitindo identificar os trechos mais críticos, isto é, onde a qualidade se encontra significativamente comprometida, possibilitando visualizar a assimetria da distribuição e a faixa de variação dos dados. Para melhor avaliar os parâmetros foram também incluídos os limites de determinação da metodologia aplicada (linhas em vermelho) e as concentrações máximas permitidas pela legislação. As linhas em cor verde correspondem ao limite estabelecido pelo CONAMA 20, e as linhas em azul, os limites estabelecidos pela Portaria 36/90. E, alguns casos, as linhas que identificam os limites da legislação não foram representados por estarem bem acima da concentração máxima apresentada no gráfico. No caso em que esses limites eram iguais ou muito próximos, a visualização das linhas ficou comprometida.

As representações de box-plot possibilitam ainda a visualização das seguintes grandezas estatísticas: a média, a mediana (divide o conjunto de dados ao meio, deixando metade dos dados abaixo e metade acima dela), o máximo, o mínimo, o primeiro quartil (é o valor que deixa 1/4 das observações abaixo dele), o terceiro quartil (é o valor que deixa 3/4 das observações abaixo dele) e os valores extremos da distribuição dos dados.

Os pontos extremos podem indicar erros de amostragem, de medida e, mesmo, de transcrição dos dados, ou ainda, simplesmente, um comportamento fora do habitual. Por isto, dispensou-se uma atenção especial a eles, já que afetam a média e a variabilidade dos dados, podendo até distorcer o resultado das inferências estatísticas. 
De um modo geral as observações sensíveis dos metais se concentram na época de seca (de junho a outubro).

\section{a) COMPARAÇÃO ENTRE AS COMUNIDADES (APÊNDICE 2)}

Comparando-se as concentrações dos metais nas águas bruta e tratada em cada comunidade (Figura B.1), podemos observar que no caso do ferro e do manganês, houve uma grande redução nas concentrações da água tratada em todas as comunidades. Essa diminuição é justificada pelo processo de tratamento que a água bruta sofre nas estações de tratamento de água (ETA). A alta concentração de ferro presente na região, bem acima dos padrões estabelecidos pela CONAMA 20, está relacionado provavelmente a matriz mineralógica, no qual o ferro deve estar associado (podemos observar na Tabela A.10 (Apêndice 1) que a concentração de Fe varia de 1,5 a 17\% nas comunidades).

OBS: O processo de tratamento convencional de uma ETA normalmente segue as seguintes etapas: 1) processo de captação de água de rios, lagos; b) processo de coagulação por adição de sulfato de alumínio, cloreto férrico ou sulfato ferroso, que tem a função de remover partículas suspensas na água. A remoção é realizada pela co-precipitação das partículas com o reagente, a combinação destes, forma partículas mais pesadas que se decantam no fundo do tanque durante a sedimentação; c) processo de sedimentação ocorre após a etapa $\boldsymbol{b}$ para clarear a água d) o processo de filtração é realizado para remover pequenas partículas (o filtro é composto de carvão antracitio, areia e cascalhos)]; e) processo de desinfecção é realizado antes da distribuição da água para a comunidade para eliminar alguma bactéria ou microorganismo que podem estar na água, a desinfecção realizada com adição de cloro, o flúor é adicionado para combate as cáries e; f) processo de estocagem e distribuição à comunidade [EPA, 2000].

Na comunidade VGS podemos observar que a água tratada apresenta concentrações de ferro em concentrações mais elevadas em comparação com as outras comunidades. Cabe salientar que o tratamento da água desta comunidade em particular não é realizado pela SABESP e sim pela prefeitura, demostrando problemas na qualidade de tratamento desta comunidade. Para os demais metais, foram observadas altas 
concentrações de magnésio nas águas bruta e tratada da comunidade IG 61 (podemos observar também que o magnésio não sofre nenhuma alteração após o tratamento químico na ETA), manganês na água bruta da comunidade IG 64, alumínio na água bruta da comunidade IG 60, cálcio na água tratada da comunidade IG 61 e fósforo na água tratada da comunidade IG 60, quando comparada com as demais comunidades.

Quanto a fluoretação da água nas ETAs, podemos observar que esta é realizada em todas as comunidades, com exceção de VGS. Era de se esperar também altas concentrações de cloro na água tratada, por ser o cloro um agente de desinfecção utilizado no tratamento da água. O sulfato e o sódio também apresentaram uma maior concentração na água tratada do que na água bruta, visto que também são constituintes químicos utilizados nas ETAs.

As Tabelas 6.1 e 6.2 apresentam um resumo dos resultados quanto a razão entre o número de valores que não estão de acordo com a legislação e o número de coletas realizadas para cada parâmetro, na água bruta e tratada, por comunidade. É possível observar que, a água distribuída está dentro das especificações exigidas pela legislação como exceção da comunidade VGS e salvo três valores para o ferro.

\section{B) ANÁlISE do PH dA ÁGUA}

Avaliando a variação do $\mathrm{pH}$ da água bruta e tratada em todas as comunidades (Figura B.5), podemos observar que a água bruta, em todas as comunidades, não apresentou valores fora do intervalo exigido pela legislação.

Com relação aos valores obtidos para o $\mathrm{pH}$ nas comunidades, foram observadas situações distintas entre os períodos de seca e de chuva. No período seco, a água esteve com pH variando entre 6,2 e 8,9 (Figura 6.32) e, no período chuvoso a amplitude de variação do pH aumentou, registrando-se valores entre 6,1 e 7,2 (Figura 6.33). 
Tabela 6.1 - Razão entre o número de valores que não estão de acordo com a legislação e o número de coletas para os metais e elementos iônicos na fração bruta nas comunidades.

\begin{tabular}{|c|c|c|c|c|c|c|c|c|c|c|c|c|c|c|c|c|c|c|c|c|c|}
\hline Comunidade & $\mathrm{Fe}$ & $\mathrm{Mg}$ & Mn & $\mathrm{Al}$ & $\mathrm{Ca}$ & $\mathrm{Co}$ & $\begin{array}{c}\mathrm{P} \\
\text { (Total) }\end{array}$ & $\mathrm{Ba}$ & $\mathrm{Cr}$ & $\mathrm{Ni}$ & $\mathrm{Cu}$ & $\mathrm{Zn}$ & $\mathrm{Cd}$ & $\mathrm{Pb}$ & $\mathrm{F}^{-}(*)$ & $\mathrm{Cl}^{-}$ & $\mathrm{NO}_{3}^{-}$ & $\mathrm{SO}_{4}{ }^{2-}$ & $\mathrm{Na}^{+}$ & $\mathrm{NH}_{4}{ }^{+}$ & $\mathrm{K}^{+}$ \\
\hline IG-60 & 07/07 & $\bullet$ & $04 / 07$ & 07/07 & $\bullet$ & $\bullet$ & $\bullet$ & $\bullet$ & $\bullet$ & $\bullet$ & $\bullet$ & $\bullet$ & $\bullet$ & $\bullet$ & $\bullet$ & $\bullet$ & $\bullet$ & • & • & • & $\bullet$ \\
\hline IG-61 & $\bullet$ & $\bullet$ & $\bullet$ & $06 / 07$ & $\bullet$ & $\bullet$ & $\bullet$ & $\bullet$ & $\bullet$ & $\bullet$ & $\bullet$ & $\bullet$ & $\bullet$ & $\bullet$ & $\bullet$ & $\bullet$ & $\bullet$ & $\bullet$ & $\bullet$ & $\bullet$ & $\bullet$ \\
\hline IG-63 & $\bullet$ & • & $01 / 07$ & $04 / 07$ & $\bullet$ & $\bullet$ & $\bullet$ & $\bullet$ & • & $\bullet$ & $\bullet$ & $\bullet$ & $\bullet$ & $\bullet$ & $\bullet$ & • & $01 / 07$ & $\bullet$ & - & $\bullet$ & $\bullet$ \\
\hline IG-64 & $\bullet$ & $\bullet$ & $01 / 07$ & $05 / 07$ & $\bullet$ & $\bullet$ & $\bullet$ & $\bullet$ & $\bullet$ & $\bullet$ & $\bullet$ & $\bullet$ & $\bullet$ & $\bullet$ & $\bullet$ & $\bullet$ & $01 / 07$ & $\bullet$ & $\bullet$ & $\bullet$ & $\bullet$ \\
\hline IG-65 & $\bullet$ & $\bullet$ & $01 / 07$ & $07 / 07$ & $\bullet$ & $\bullet$ & $\bullet$ & $\bullet$ & $\bullet$ & $\bullet$ & $\bullet$ & $\bullet$ & $\bullet$ & $\bullet$ & $\bullet$ & $\bullet$ & $\bullet$ & $\bullet$ & $\bullet$ & $\bullet$ & $\bullet$ \\
\hline IG-66 & $\bullet$ & $\bullet$ & $03 / 07$ & $\bullet$ & $\bullet$ & $\bullet$ & $\bullet$ & $\bullet$ & $\bullet$ & $\bullet$ & $\bullet$ & $\bullet$ & $\bullet$ & $\bullet$ & $\bullet$ & $\bullet$ & $\bullet$ & $\bullet$ & $\bullet$ & $\bullet$ & $\bullet$ \\
\hline IG-67 & $\bullet$ & $\bullet$ & $01 / 07$ & $01 / 07$ & $\bullet$ & $\bullet$ & $\bullet$ & $\bullet$ & $\bullet$ & $\bullet$ & $\bullet$ & $\bullet$ & $\bullet$ & $\bullet$ & $\bullet$ & $\bullet$ & $\bullet$ & $\bullet$ & $\bullet$ & $\bullet$ & $\bullet$ \\
\hline IG-68 & $\bullet$ & $\bullet$ & $\bullet$ & $05 / 07$ & $\bullet$ & $\bullet$ & $\bullet$ & $\bullet$ & $\bullet$ & $\bullet$ & $\bullet$ & $\bullet$ & $\bullet$ & $\bullet$ & $\bullet$ & $\bullet$ & $\bullet$ & $\bullet$ & $\bullet$ & $\bullet$ & $\bullet$ \\
\hline IG-69 & $\bullet$ & $\bullet$ & $\bullet$ & $02 / 07$ & $\bullet$ & $\bullet$ & $\bullet$ & $\bullet$ & $\bullet$ & $\bullet$ & $\bullet$ & $\bullet$ & $\bullet$ & $\bullet$ & $\bullet$ & $\bullet$ & $\bullet$ & $\bullet$ & $\bullet$ & $\bullet$ & $\bullet$ \\
\hline IG-70 & $\bullet$ & - & $04 / 07$ & \begin{tabular}{|l|}
$04 / 07$ \\
\end{tabular} & $\bullet$ & $\bullet$ & $\bullet$ & • & • & $\bullet$ & - & • & - & - & $\bullet$ & - & $\bullet$ & $\bullet$ & $\bullet$ & $\bullet$ & $\bullet$ \\
\hline IG-72 & $\bullet$ & $\bullet$ & $03 / 07$ & $06 / 07$ & $\bullet$ & $\bullet$ & $\bullet$ & $\bullet$ & $\bullet$ & $\bullet$ & $\bullet$ & $\bullet$ & $\bullet$ & $\bullet$ & $\bullet$ & $\bullet$ & $\bullet$ & $\bullet$ & $\bullet$ & $\bullet$ & $\bullet$ \\
\hline IG-83 & $\bullet$ & $\bullet$ & $02 / 07$ & \begin{tabular}{|l|}
$01 / 07$ \\
\end{tabular} & $\bullet$ & $\bullet$ & $\bullet$ & $\bullet$ & $\bullet$ & $\bullet$ & $\bullet$ & $\bullet$ & $\bullet$ & $\bullet$ & $\bullet$ & $\bullet$ & $\bullet$ & $\bullet$ & $\bullet$ & $\bullet$ & $\bullet$ \\
\hline IG-VGS & $\bullet$ & $\bullet$ & $02 / 06$ & $03 / 06$ & $\bullet$ & $\bullet$ & $\bullet$ & $\bullet$ & $\bullet$ & $\bullet$ & $\bullet$ & $\bullet$ & $\bullet$ & $\bullet$ & $\bullet$ & $\bullet$ & $\bullet$ & $\bullet$ & $\bullet$ & $\bullet$ & $\bullet$ \\
\hline
\end{tabular}

(*) Fora da faixa de concentração de $0,6-1,7 \mu \mathrm{g} \mathrm{mL} \mathrm{m}^{-1}$ para a água tratada 
Tabela 6.2 - Razão entre o número de valores que não estão de acordo com a legislação e o número de coletas para os metais e elementos iônicos na fração tratada nas comunidades.

\begin{tabular}{|c|c|c|c|c|c|c|c|c|c|c|c|c|c|c|c|c|c|c|c|c|c|}
\hline Elemento & $\mathrm{Fe}$ & $\mathrm{Mg}$ & $\mathrm{Mn}$ & $\mathrm{Al}$ & $\mathrm{Ca}$ & Co & $\begin{array}{c}\mathrm{P} \\
\text { (Total) }\end{array}$ & $\mathrm{Ba}$ & $\mathrm{Cr}$ & $\mathrm{Ni}$ & $\mathrm{Cu}$ & $\mathrm{Zn}$ & $\mathrm{Cd}$ & $\mathrm{Pb}$ & $\mathrm{F}^{-}(*)$ & $\mathrm{Cl}^{-}$ & $\mathrm{NO}_{3}^{-}$ & $\mathrm{SO}_{4}{ }^{2-}$ & $\mathrm{Na}^{+}$ & $\mathrm{NH}_{4}^{+}$ & $\mathrm{K}^{+}$ \\
\hline IG-60 & $\bullet$ & $\bullet$ & $\bullet$ & $\bullet$ & $\bullet$ & $\bullet$ & $\bullet$ & $\bullet$ & $\bullet$ & $\bullet$ & $\bullet$ & $\bullet$ & $\bullet$ & $\bullet$ & $04 / 07$ & $\bullet$ & $\bullet$ & $\bullet$ & • & • & $\bullet$ \\
\hline IG-61 & $01 / 07$ & $\bullet$ & $\bullet$ & $\bullet$ & $\bullet$ & $\bullet$ & $\bullet$ & $\bullet$ & $\bullet$ & $\bullet$ & $\bullet$ & $\bullet$ & $\bullet$ & $\bullet$ & \begin{tabular}{|l|}
$04 / 07$ \\
\end{tabular} & $\bullet$ & $01 / 07$ & $\bullet$ & $\bullet$ & $\bullet$ & $\bullet$ \\
\hline IG-63 & $01 / 07$ & $\bullet$ & $\bullet$ & $\bullet$ & $\bullet$ & $\bullet$ & $\bullet$ & $\bullet$ & $\bullet$ & $\bullet$ & $\bullet$ & $\bullet$ & $\bullet$ & $\bullet$ & \begin{tabular}{|l|}
$04 / 07$ \\
\end{tabular} & $\bullet$ & $01 / 07$ & $\bullet$ & $\bullet$ & $\bullet$ & $\bullet$ \\
\hline IG-64 & $\bullet$ & $\bullet$ & $\bullet$ & $\bullet$ & $\bullet$ & $\bullet$ & $\bullet$ & $\bullet$ & $\bullet$ & $\bullet$ & $\bullet$ & $\bullet$ & $\bullet$ & $\bullet$ & \begin{tabular}{|l|}
$04 / 07$ \\
\end{tabular} & $\bullet$ & $01 / 07$ & $\bullet$ & $\bullet$ & $\bullet$ & $\bullet$ \\
\hline IG-65 & $\bullet$ & $\bullet$ & $\bullet$ & $\bullet$ & $\bullet$ & $\bullet$ & $\bullet$ & $\bullet$ & $\bullet$ & $\bullet$ & $\bullet$ & $\bullet$ & $\bullet$ & $\bullet$ & 06/07 & $\bullet$ & $\bullet$ & $\bullet$ & $\bullet$ & $\bullet$ & $\bullet$ \\
\hline IG-66 & $\bullet$ & $\bullet$ & $\bullet$ & $\bullet$ & $\bullet$ & $\bullet$ & $\bullet$ & $\bullet$ & $\bullet$ & $\bullet$ & $\bullet$ & $\bullet$ & $\bullet$ & $\bullet$ & 07/07 & $\bullet$ & $\bullet$ & $\bullet$ & $\bullet$ & $\bullet$ & $\bullet$ \\
\hline IG-67 & $\bullet$ & $\bullet$ & $\bullet$ & $\bullet$ & $\bullet$ & $\bullet$ & $\bullet$ & $\bullet$ & $\bullet$ & $\bullet$ & $\bullet$ & $\bullet$ & $\bullet$ & $\bullet$ & $\bullet$ & $\bullet$ & $\bullet$ & $\bullet$ & $\bullet$ & $\bullet$ & $\bullet$ \\
\hline IG-68 & $\bullet$ & $\bullet$ & $\bullet$ & $\bullet$ & $\bullet$ & $\bullet$ & $\bullet$ & $\bullet$ & $\bullet$ & $\bullet$ & $\bullet$ & $\bullet$ & $\bullet$ & $\bullet$ & \begin{tabular}{|l|}
$06 / 07$ \\
\end{tabular} & $\bullet$ & $\bullet$ & $\bullet$ & $\bullet$ & $\bullet$ & $\bullet$ \\
\hline IG-69 & $\bullet$ & $\bullet$ & $\bullet$ & $\bullet$ & $\bullet$ & $\bullet$ & $\bullet$ & $\bullet$ & $\bullet$ & $\bullet$ & $\bullet$ & $\bullet$ & $\bullet$ & $\bullet$ & $05 / 07$ & $\bullet$ & $\bullet$ & $\bullet$ & $\bullet$ & $\bullet$ & $\bullet$ \\
\hline IG-70 & $01 / 07$ & $\bullet$ & $\bullet$ & $\bullet$ & $\bullet$ & $\bullet$ & $\bullet$ & $\bullet$ & $\bullet$ & $\bullet$ & $\bullet$ & $\bullet$ & $\bullet$ & $\bullet$ & $05 / 07$ & $\bullet$ & $\bullet$ & $\bullet$ & $\bullet$ & $\bullet$ & $\bullet$ \\
\hline IG-72 & $\bullet$ & $\bullet$ & $\bullet$ & $\bullet$ & $\bullet$ & $\bullet$ & $\bullet$ & $\bullet$ & $\bullet$ & $\bullet$ & $\bullet$ & $\bullet$ & $\bullet$ & $\bullet$ & 06/07 & $\bullet$ & $\bullet$ & $\bullet$ & $\bullet$ & $\bullet$ & $\bullet$ \\
\hline IG-83 & $\bullet$ & $\bullet$ & $\bullet$ & $\bullet$ & $\bullet$ & $\bullet$ & $\bullet$ & $\bullet$ & $\bullet$ & $\bullet$ & $\bullet$ & $\bullet$ & $\bullet$ & $\bullet$ & 07/07 & $\bullet$ & $\bullet$ & $\bullet$ & $\bullet$ & $\bullet$ & $\bullet$ \\
\hline IG-VGS & $03 / 06$ & $\bullet$ & $\bullet$ & $03 / 06$ & $\bullet$ & $\bullet$ & $\bullet$ & $\bullet$ & $\bullet$ & $\bullet$ & $\bullet$ & $\bullet$ & $\bullet$ & $\bullet$ & $05 / 07$ & $\bullet$ & $\bullet$ & $\bullet$ & $\bullet$ & $\bullet$ & $\bullet$ \\
\hline
\end{tabular}

(*) Fora da faixa de concentração de $0,6-1,7 \mu \mathrm{g} \mathrm{mL}$ para a água tratada 
Comportamento do pH na Água Bruta nos Meses de Seca

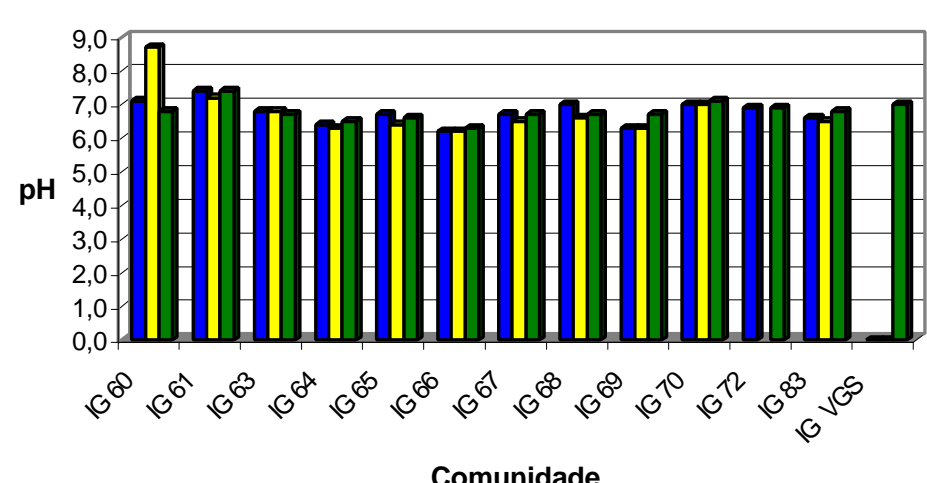

Comunidade

Figura 6.32 - Comportamento do pH na água bruta durante o período de seca.

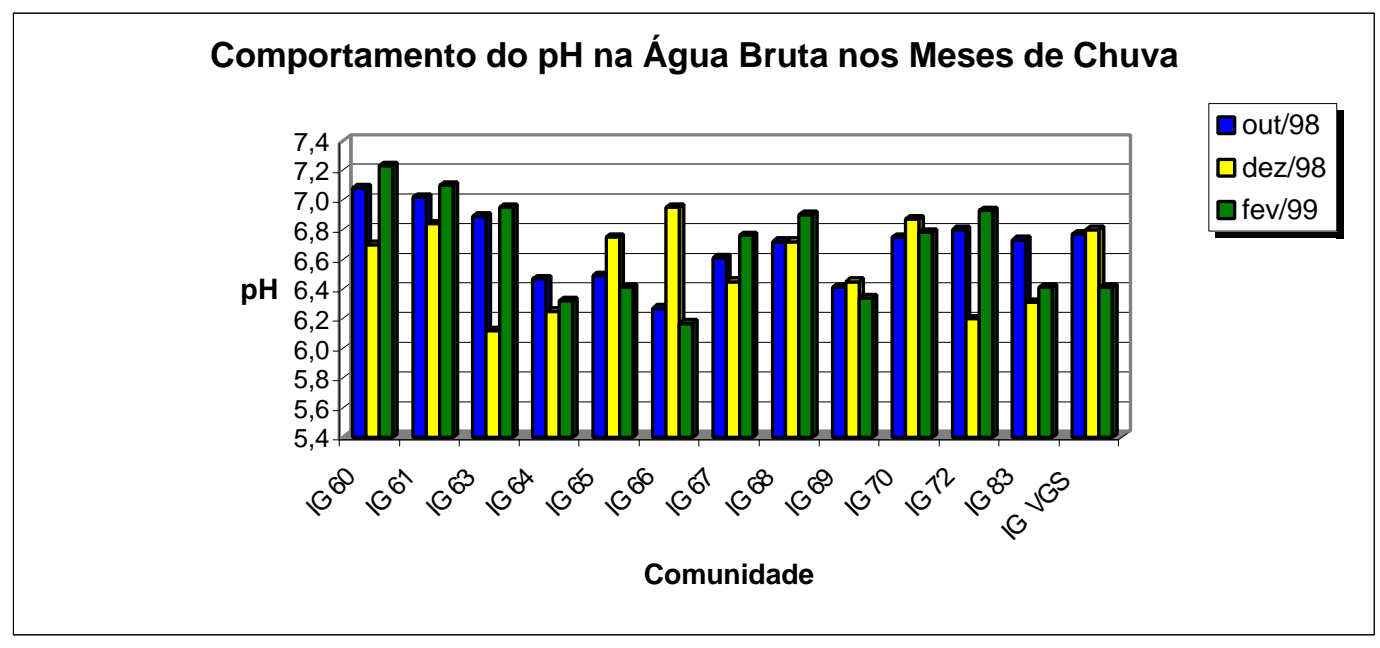

Figura 6.33 - Comportamento do $\mathrm{pH}$ na água bruta durante o período de chuva.

\section{C) Índice PluViométrico}

As coletas dos dados referentes aos índices pluviométricos mensais e do período foram realizadas em apenas 08 das 13 comunidades, uma vez que estas não possuíam estação meteorológica. 
Analisando os índices pluviométricos em relação ao tempo de coleta (Figura B.6), verifica-se existência de uma época do ano com altos índices pluviométricos, coincidindo com o verão, e uma época do ano mais seca, correspondendo ao inverno.

Os dados hidrológicos referentes a área em estudo, utilizados neste trabalho, foram fornecidos pelo DAEE (Departamento de Água e Energia Elétrica) e estão apresentados na forma de índice pluviométrico mensal e do período (correspondendo a pluviometria de 07 dias antes da coleta) em $\mathrm{mm}$.

\section{D) ANÁliSe AO LONGO do TEMPO (APÊNDICE 3)}

Com o objetivo de avaliar diferenças de concentrações dos metais naturais ao longo do tempo, foram construídos gráficos onde são representados alisamentos dos diagramas de dispersão da concentração dos tempos de coleta.

Nas águas bruta e tratada (Figuras C.1 e C.3), para quase todos os metais, é possível identificar dois grupos de comunidades com concentrações de metais diferentes entre si. Para o $1^{\underline{0}}$ grupo $(\mathrm{Mg}, \mathrm{Mn}$ e $\mathrm{Ca})$, a concentração uniformemente constante ao longo do tempo e mais baixa, após o tratamento, do que o $2^{\underline{o}}$ grupo (Fe, $\mathrm{Al}, \mathrm{P}$ e $\left.\mathrm{Ba}\right)$, que tem indícios de sofrer influência do tempo. O elemento que não seguiu este padrão, na água bruta, foi o fósforo, indicando uma possível eutrofização no inverno, onde todas as comunidades apresentaram concentrações similares.

Na água tratada, o ferro e o alumínio passaram a ter medidas de concentração uniformemente constante devido ao processo de tratamento da água nas ETA's, com exceção da comunidade IG VGS, como avaliado anteriormente. Somente a comunidade IG 66 apresentou, durante todo o período de coleta, concentrações menores que as demais comunidades.

No período seco, verificou-se o aumento da concentração de cobre, com valores entre 0,008 a $0,020 \mu \mathrm{g} \mathrm{mL} \mathrm{L}^{-1}$, mostrando uma forte influência do tempo nas concentrações deste elemento. 
Os gráficos de alisamento das concentrações dos elementos iônicos na água bruta em relação ao tempo de coleta (Figura C.2) sugerem, de um modo geral, comportamentos similares entre as comunidades, além de não evidenciar influências do tempo nas concentrações das espécies.

Com relação a água tratada (Figura C.4), o comportamento da concentração dos elementos se assemelha, no geral, ao encontrado na água bruta. No caso do fluoreto e do cloreto, que sofrem intervenções nas estações de tratamento de água no sentido de aumentar as suas concentrações, nota-se que a comunidade IG VGS apresenta concentrações uniformemente menores de fluoreto ao longo do tempo e, para todas as comunidades provando que o fluoreto realmente não é adicionado na água tratada. Parece ter uma tendência linear crescente das concentrações de cloreto ao longo do tempo. Alguns picos foram localizados (nitrato na comunidade IG 61) e sulfato nas comunidades IG 60 e IG VGS demonstrando um possível problema operacional nestes períodos e, no caso do potássio, pode-se observar a existência de dois grupos com comportamentos semelhantes no tempo.

\section{E) RelaÇÃo entre PluViometria E CONCENTRAÇÃo DE METAIS E ESPÉCIES- IÔNICAS}

As concentrações dos metais analisados na água bruta foram relacionados com as variações dos índices pluviométricos mensal e do período (correspondente a chuva de uma semana antes da coleta) utilizando os gráficos de alisamento (Figuras C.8 a C11). De uma maneira geral, esses gráficos não sugerem uma tendência na relação entre as variáveis. Podemos observar dois comportamentos distintos dos elementos aqui estudados, um grupo que apresenta concentrações elevadas quando o índice pluviométrico é relativamente baixo sendo que a concentração destes elementos vai abaixando quando o índice pluviométrico vai aumentando. Esse comportamento pode ser observado para o $\mathrm{Al}, \mathrm{Cu}$ e $\mathrm{P}$. Comportamento inverso é observado para o ferro, manganês e magnésio.

\section{F) ÍNDICE DE ESTADo TRÓFICO (IET)}

O estado trófico de um determinado corpo hídrico pode ser determinado, de forma muito confiável, a partir do levantamento das concentrações do nutriente limitante. $\mathrm{O}$ 
nutriente limitante é aquele que controla o crescimento da plantas aquáticas. Diversos estudos têm demonstrado ser o fósforo, na sua fração inorgânica disponível, o nutriente limitante do crescimento de algas na maioria dos corpos de água doce [CETESB, 1999].

O IET deve ser entendido como uma medida do potencial de eutrofização, já que este nutriente atua como agente causador do processo.

$\mathrm{Na}$ Tabela 6.3 são apresentados os valores calculados para o índice de estado trófico para o fósforo [IET $(\mathrm{P})$ ], além dos valores médios obtido a partir destas variáveis e na Tabela 6.4 está descrito a classificação trófica.

O estado trófico das comunidades foi calculado utilizando-se o índice de estado trófico ou IET proposto por Carlson em 1977, modificado por Toledo em 1983 para região tropical [PAMPLIN, 1999]. Na Tabela 6.4 podemos observar a classificação trófica através do IET segundo Toledo.

Valores obtidos do índice de estado trófico (IET) para as comunidades nos períodos de seca (Junho e Agosto/98) e chuvoso (Outubro, Dezembro/98 e Fevereiro/99).

Tabela 6.3 - Valores obtidos do índice de estado trófico (IET)

\begin{tabular}{lcc}
\hline \multicolumn{1}{c}{ Estação de coleta } & $\begin{array}{c}\text { Período chuvoso } \\
\text { IET (P) }\end{array}$ & $\begin{array}{c}\text { Período seco } \\
\text { IET (P) }\end{array}$ \\
\hline IG 60 & 56,60 & 65,65 \\
IG 61 & 46,65 & 56,59 \\
IG 63 & 47,61 & 49,71 \\
IG 64 & 49,02 & 55,08 \\
IG 65 & 49,32 & 45,03 \\
IG 66 & 43,05 & 49,20 \\
IG 67 & 44,54 & 49,35 \\
IG 68 & 46,48 & 54,12 \\
IG 69 & 48,87 & 52,11 \\
IG 70 & 50,45 & 55,84 \\
IG 72 & 53,97 & 59,12 \\
IG 83 & 48,17 & 53,49 \\
IG VGS & 53,59 & 56,39 \\
Media & 49,10 & 53,98 \\
Desvio padrão & 2,83 & 5,21 \\
Coeficiente de variação & 5,77 & 9,66 \\
\hline
\end{tabular}


Tabela 6.4 - Critério de classificação trófica.

\begin{tabular}{lcc} 
& ESTADO TRÓFICO & \\
\hline Oligotrófico & $<44$ \\
Mesotrófico & $44-54$ \\
Eutrófico & $>54$ \\
\hline
\end{tabular}

O índice de estado trófico para o fósforo total variou de 45,03 a 65,65, no período seco e entre 43,05 e 56,60. Para estas duas variáveis, foi possível notar que no período seco existiu uma nítida tendência a uma condição mais eutrófica para a comunidade de São João da Boa Vista e, uma condição menos eutrófica ou mesotrófica para a comunidade São Roque da Fartura. Este resultado obtido pelo IET condiz com os portes das comunidades, sendo São João da Boa Vista a maior cidade da região estudada e São Roque da Fartura a menor. Já no período chuvoso, observou-se uma tendência bastante homogênea à eutrofia entre as diferentes comunidades ou compartimentos amostrados.

\section{G) AnÁlise de Agrupamentos (DENDrogramas - APÊNDICE 4)}

Com o objetivo de verificar a hipótese de que a concentração dos metais da água bruta poderia estar ligada a matriz mineralógica da região, realizou-se o estudo para analisar se existe relação entre os metais. Foi utilizada a técnica de dendrograma com o método do Centróide e distância Euclidiana.

A partir dos dendrogramas da água bruta (Figura D.1), verifica-se que, para o ferro, cálcio e bário, não se observa nenhuma comunidade cujo comportamento se distancia das demais. Para os demais metais, houve pelo menos uma comunidade que apresentou um comportamento no decorrer das coletas diferente das demais, casos do magnésio (IG 61) que possivelmente provem de rochas calcossilicáticas que existe na região, manganês (IG 64) que existe em grande quantidade na região proveniente do maciço de Poço de Caldas, fósforo (IG 60 e IG 61) que provem de diques de rocha do grupo da apatita $\mathrm{Ca}_{10}\left(\mathrm{PO}_{4} \mathrm{CO}_{3}\right)_{6}(\mathrm{~F}, \mathrm{Cl}, \mathrm{OH})_{2}$ e/ou fontes antrópicas orgânicas ou agrícolas e alumínio (IG 63) que possivelmente seja do complexo granito-gnaisse que é rico em feldspato e bauxita, que contem alumínio. A difícil interpretação da maioria dos elementos na água 
bruta se caracteriza por ser uma área de rochas fraturadas com várias composições geoquímicas.

Em relação à água tratada (Figura D.2), podemos verificar que algumas comunidades apresentaram um comportamento nas concentrações durante o período de estudo diferentes das demais. Estes comportamentos anômalos não representam uma preocupação, pois são apenas um pequeno aumento de concentrações nestas comunidades, que neste tipo de gráfico se mostra em evidência.

Nos dendrogramas da fração digestão (Figura D.3), nenhuma comunidade se destaca das demais quanto às concentrações de cobalto. Destacam-se as comunidades IG 64 quanto ao ferro e manganês, possivelmente das rochas alcalinas de Poços de Caldas, ricas em ferromagnesianos (biotita e hornblenda); IG 69 quanto ao alumínio, cálcio e bário a, possível diferenciação possivelmente venha do processo de migmatização (rochas antigas que sofreram lixiviação ao longo do tempo) que apresenta estes elementos em concentrações mais elevadas do que em outras comunidades, no IG VGS (quanto ao magnésio, alumínio e fósforo) os elementos $\mathrm{Mg}$ e Al possivelmente venham da presença das rochas anfibolíticas que contem estes elementos. O P se destaca-se em IG 60 possivelmente seja proveniente de fontes mineralógica e/ou antrópicas por ser a comunidade de maior porte das estudadas neste trabalho.

Analisando os dendrogramas das concentrações dos elementos iônicos para a água bruta e água tratada (Figuras D.4), verifica-se que, para as concentrações de potássio, nenhuma comunidade se distancia das demais. A mesma conclusão pode ser obtida com relação ao sódio na água tratada. Nos demais elementos iônicos, foram encontrados pelo menos uma comunidade com acentuadas diferenças no comportamento em relação às demais comunidades, caso do fluoreto (IG VGS na água tratada e IG 83 nos dois tipos de água), cloreto (IG 66 na água bruta - presença de apatita e IG 61 na água tratada), nitrato (IG 63 na água bruta e IG 60 na água tratada), sulfato (IG 63 na água bruta e IG VGS na água tratada) e sódio (IG 61 na água bruta - presença de augita). 


\subsubsection{Análise Estatística Multivariada}

Com objetivo de entender melhor esta base de dados, saber se os elementos (a maior parte metais) podem ter algum grau de interrelação, isto é, se a parte da informação contida por suas séries temporais são comuns à elementos, aplicou-se análise de componentes principais (ACP), nas coletas de água bruta, água tratada (e, no caso dos sedimentos as fases sobrenadante, intersticial e digestão). Para isso, foi utilizado o programa estatístico SPSS (Statistical Package for Social Science).

\subsubsection{AnÁlise de Componentes Principais na Água Bruta}

No estudo da água bruta nas comunidades, foram consideradas as variáveis: $\mathrm{Mg}$, $\mathrm{Al}, \mathrm{P}, \mathrm{Ca}, \mathrm{Mn}, \mathrm{Fe}, \mathrm{Co}, \mathrm{Cu}, \mathrm{Cd}, \mathrm{Ba}, \mathrm{F}^{-}, \mathrm{Cl}^{-}, \mathrm{NO}_{3}{ }^{-}, \mathrm{SO}_{4}{ }^{2-}, \mathrm{Na}^{+}, \mathrm{NH}_{4}{ }^{+}, \mathrm{K}^{+}$, pluviometria do período e pH. A Tabela 6.5 apresenta um resumo da estatística obtida inicialmente, onde são mostrados os autovalores obtidos para cada componente, depois de submeter a matriz à rotação Varimax (onde o valor de corte é igual a 1), onde temos a fração explicada por cada componente e a porcentagem acumulada.

Em função do critério dos autovalores acima de 1, os 6 componentes foram considerados como significativos, sendo que a porcentagem da variabilidade acumulada explicada por elas é $73,5 \%$ da variabilidade total dos elementos. Observa-se que o primeiro componente é responsável por $22 \%$, o segundo $14 \%$, o terceiro $13,5 \%$, o quarto $9.5 \%$, a quinta $7,8 \%$ e o sexto $6,4 \%$ da variabilidade dos dados, indicando que cada vez menos variabilidade é explicada, à mediada que o autovalor da componente diminui.

Tabela 6.5 - Análise de componentes principais nos elementos da água bruta

\begin{tabular}{cccc}
\hline Fator & $\begin{array}{c}\text { Autovalor da } \\
\text { componente }\end{array}$ & $\begin{array}{c}\text { Variabilidade } \\
\text { explicada pela } \\
\text { componente }(\%)\end{array}$ & $\begin{array}{c}\text { Variabilidade total } \\
\text { explicada }\end{array}$ \\
\hline 1 & 4,02 & 22,30 & 22,3 \\
2 & 2,50 & 13,90 & 36,2 \\
3 & 2,44 & 13,60 & 49,8 \\
4 & 1,71 & 9,50 & 59,2 \\
5 & 1,40 & 7,80 & 67,0 \\
6 & 1,16 & 6,40 & 73,5 \\
\hline
\end{tabular}


A Tabela 6.6 apresenta os componentes retidos e sua matriz dos fatores e a comunalidade para cada variável, isto é, o quanto de cada variável foi explicada pelo modelo proposto pela ACP.

Tabela 6.6 - Resultados da análise de componentes principais para a água bruta

\begin{tabular}{lccccccc}
\hline Elemento & Fator 1 & Fator 2 & Fator 3 & Fator 4 & Fator 5 & Fator 6 $\begin{array}{c}\text { Comunalidade } \\
(\%)\end{array}$ \\
\hline $\mathrm{Al}$ & 0,00 & 0,35 & $-0,21$ & 0,23 & $-0,02$ & 0,71 & 73 \\
$\mathrm{Ba}$ & 0,87 & $-0,18$ & 0,21 & 0,13 & $-0,08$ & 0,07 & 86 \\
$\mathrm{Ca}$ & 0,92 & $-0,11$ & 0,16 & 0,04 & 0,05 & 0,01 & 90 \\
$\mathrm{Cl}^{-}$ & 0,31 & 0,15 & 0,71 & $-0,23$ & 0,27 & 0,00 & 75 \\
$\mathrm{Co}$ & $-0,35$ & 0,88 & 0,01 & $-0,05$ & $-0,04$ & $-0,05$ & 89 \\
$\mathrm{Cu}$ & $-0,11$ & 0,78 & 0,02 & $-0,16$ & $-0,04$ & $-0,16$ & 67 \\
$\mathrm{~F}^{-}$ & $-0,10$ & $-0,04$ & 0,10 & 0,05 & 0,80 & $-0,09$ & 67 \\
$\mathrm{Fe}$ & 0,63 & $-0,10$ & $-0,04$ & 0,60 & $-0,10$ & 0,23 & 83 \\
$\mathrm{~K}$ & 0,21 & 0,12 & 0,42 & 0,27 & 0,70 & 0,12 & 81 \\
$\mathrm{Mg}$ & 0,96 & 0,04 & $-0,07$ & 0,02 & 0,03 & 0,01 & 92 \\
$\mathrm{Mn}$ & 0,12 & 0,03 & $-0,18$ & 0,77 & 0,20 & $-0,06$ & 68 \\
$\mathrm{Na}$ & 0,58 & 0,14 & $-0,34$ & $-0,39$ & 0,44 & $-0,02$ & 82 \\
$\mathrm{NH}_{4}{ }^{+}$ & $-0,04$ & 0,20 & 0,13 & $-0,31$ & $-0,08$ & $-0,17$ & 19 \\
$\mathrm{NO}_{3}{ }^{2-}$ & 0,07 & $-0,24$ & 0,11 & $-0,12$ & $-0,03$ & 0,82 & 77 \\
$\mathrm{P}^{-}$ & 0,26 & 0,81 & $-0,07$ & 0,05 & 0,15 & 0,27 & 83 \\
$\mathrm{pH}$ & 0,15 & 0,08 & $-0,48$ & $-0,57$ & 0,08 & 0,39 & 75 \\
$\mathrm{PO}_{4}{ }^{2-}$ & $-0,03$ & $-0,10$ & 0,67 & 0,10 & 0,41 & 0,12 & 66 \\
\hline
\end{tabular}

Com intuito de auxiliar a interpretação da análise ACP, foi montada a Tabela 6.7, que contém as informações e salienta os elementos retidos em cada componente, a importância de cada componente na explicação da variabilidade dos elementos na água bruta.

Tabela 6.7 - Esquematização das informações da ACP para os elementos da água bruta

\begin{tabular}{llc} 
& \multicolumn{2}{c}{$\mathrm{ACP}$} \\
\cline { 2 - 3 } & Elementos retidos & Variabilidade explicada (\%) \\
\hline Fator 1 & $\mathrm{Ba}, \mathrm{Ca}, \mathrm{Fe}, \mathrm{Mg}$ e Na & 22,30 \\
Fator 2 & $\mathrm{Co}, \mathrm{Cu} \mathrm{e} \mathrm{P}$ & 13,90 \\
Fator 3 & $\mathrm{Cl}^{-}, \mathrm{SO}_{4}{ }^{2-}$ e pluviometria & 13,60 \\
Fator 4 & $\mathrm{Fe}, \mathrm{Mn} \mathrm{e} \mathrm{pH}^{-}$ & 9,50 \\
Fator 5 & $\mathrm{F}^{-} \mathrm{K}$ & 7,80 \\
Fator 6 & $\mathrm{Al} \mathrm{e} \mathrm{NO}{ }_{3}^{-}$ & 6,40 \\
\hline
\end{tabular}

Observando a Tabela 6.7 nota-se que, apesar da variabilidade total explicada ser de $73,5 \%$, o primeiro, o segundo e quarto fator explicam $46 \%$ da variabilidade na água bruta. Os elementos retidos sugerem que o fator está associado a fatores mineralógicos que é 
composto pelo Complexo Granito-gnaisse e rochas metabasicas e meta-ultrabasicas. A predominância dos argilominerais caulinita, ilita e vermiculita indica uma boa capacidade de troca iônica entre o sedimento e a coluna de água.

O terceiro fator sugere possivelmente que esteja associado a fonte antrópica de efluentes das cidades e aplicação de pesticidas, respectivamente. Os pesticidas são largamente utilizados na região como o sulfato de zinco e oxicloreto de cobre [KATSUÓKA et al., 2000; PIRES et al., 2000].

\subsubsection{Análise de Correlação dos Elementos COM Pluviometria E PH da Água Bruta}

Com o objetivo de verificar a hipótese de que o índice pluviométrico e o pH poderiam interferir na concentração dos elementos na água bruta, realizou-se o estudo para analisar se existe correlação entre os elementos metálicos, iônicos, pluviometria do período e o $\mathrm{pH}$.

Na Tabela 6.8 são apresentados os coeficientes de correlação entre a pluviometria do período, pH e os elementos metálicos e iônicos. Podemos observar uma forte correlação entre $\mathrm{Ba} / \mathrm{Ca}(0,82), \mathrm{Ba} / \mathrm{Mg}(0,80), \mathrm{Co} / \mathrm{Cu}(0,76)$ e $\mathrm{Ca} / \mathrm{Mg}(0,90)$, estejam relacionados a matriz mineralógica devido a rochas metabasicas e álcalis. Uma correlação mediana para $\mathrm{Ba} / \mathrm{Fe}(0,66), \mathrm{Ca} / \mathrm{Fe}(0,58), \mathrm{Ca} / \mathrm{Na}(0,58), \mathrm{Fe} / \mathrm{Mg}(0,65), \mathrm{Fe} / \mathrm{Mn}(0,51), \mathrm{Mg} / \mathrm{Na}(0,66)$, $\mathrm{Cl} / \mathrm{K}(0,64)$ e $\mathrm{Co} / \mathrm{P}(0,63)$, estejam relacionados a matriz mineralógica devido as rochas alcalinas de Poços de Caldas. O K/PLUV $(0,53)$ possivelmente esteja relacionado à lixiviação dos fertilizantes (empregados na lavoura) no solo que ocorre durante as chuvas.

\subsubsection{Análise de Componentes Principais na Água Tratada}

No estudo da água tratada nas comunidades, foram consideradas as variáveis: $\mathrm{Mg}$,

$\mathrm{P}, \mathrm{Ca}, \mathrm{Mn}, \mathrm{Ba}, \mathrm{F}^{-}, \mathrm{Cl}^{-}, \mathrm{NO}_{3}{ }^{-}, \mathrm{SO}_{4}{ }^{2-}, \mathrm{Na}^{+}$e $\mathrm{K}^{+}$. A Tabela 6.9 apresenta um resumo da estatística obtida inicialmente, onde são mostrados os autovalores obtidos para cada componente, depois de submeter a matriz à rotação Varimax (onde o valor de corte é igual a 1), qual é a fração explicada por cada componente e a porcentagem acumulada. 
Tabela 6.8 - Matriz de correlação entre a pluviometria, $\mathrm{pH}$ e os elementos metálicos e iônicos na água b

\begin{tabular}{|c|c|c|c|c|c|c|c|c|c|c|c|c|c|c|c|}
\hline & $\mathrm{Al}$ & $\mathrm{Ba}$ & $\mathrm{Ca}$ & $\mathrm{Cl}^{-}$ & $\mathrm{Co}$ & $\mathrm{Cu}$ & $\mathrm{F}^{-}$ & $\mathrm{Fe}$ & $\mathrm{K}$ & $\mathrm{Mg}$ & $\mathrm{Mn}$ & $\mathrm{Na}$ & $\mathrm{NH}_{4}^{+}$ & $\mathrm{NO}_{3}{ }^{2-}$ & \\
\hline 1 & & & & & & & & & & & & & & & \\
\hline & 1 & 0,08 & 0,16 & $-0,03$ & 0,19 & 0,11 & 0,05 & 0,33 & 0,25 & 0,20 & 0,21 & 0,23 & $-0,04$ & 0,37 & 0 \\
\hline $\mathrm{Ba}$ & 0,08 & 1 & 0,82 & 0,38 & $-0,42$ & $-0,25$ & 0,00 & 0,66 & 0,31 & 0,80 & 0,22 & 0,41 & $-0,05$ & 0,20 & 0 \\
\hline $\mathrm{Ca}$ & 0,16 & 0,82 & 1 & 0,39 & $-0,30$ & $-0,19$ & 0,04 & 0,58 & 0,35 & 0,90 & 0,29 & 0,58 & $-0,04$ & 0,20 & 0 \\
\hline $\mathrm{Cl}^{-}$ & $-0,03$ & 0,38 & 0,39 & 1 & $-0,06$ & $-0,01$ & 0,18 & 0,28 & 0,64 & 0,33 & 0,02 & 0,28 & 0,21 & 0,19 & 0 \\
\hline $\mathrm{Co}$ & 0,19 & $-0,42$ & $-0,30$ & $-0,06$ & 1 & 0,76 & $-0,12$ & $-0,31$ & $-0,03$ & $-0,16$ & $-0,08$ & $-0,01$ & 0,12 & $-0,17$ & 0 \\
\hline $\mathrm{Cu}$ & 0,11 & $-0,25$ & $-0,19$ & $-0,01$ & 0,76 & 1 & $-0,07$ & $-0,30$ & 0,01 & $-0,05$ & $-0,09$ & 0,03 & 0,12 & $-0,13$ & 0 \\
\hline $\mathrm{F}^{-}$ & 0,05 & 0,00 & 0,04 & 0,18 & $-0,12$ & $-0,07$ & 1 & 0,06 & 0,36 & 0,06 & 0,08 & 0,15 & 0,05 & 0,03 & 0 \\
\hline $\mathrm{Fe}$ & 0,33 & 0,66 & 0,58 & 0,28 & $-0,31$ & $-0,30$ & 0,06 & 1 & 0,42 & 0,65 & 0,51 & 0,24 & $-0,07$ & 0,23 & 0 \\
\hline $\mathrm{K}$ & 0,25 & 0,31 & 0,35 & 0,64 & $-0,03$ & 0,01 & 0,36 & 0,42 & 1 & 0,37 & 0,36 & 0,49 & $-0,01$ & 0,31 & 0 \\
\hline $\mathrm{Mg}$ & 0,20 & 0,80 & 0,90 & 0,33 & $-0,16$ & $-0,05$ & 0,06 & 0,65 & 0,37 & 1 & 0,30 & 0,66 & 0,00 & 0,20 & 0 \\
\hline $\mathrm{Mn}$ & 0,21 & 0,22 & 0,29 & 0,02 & $-0,08$ & $-0,09$ & 0,08 & 0,51 & 0,36 & 0,30 & 1 & 0,10 & $-0,04$ & 0,05 & 0 \\
\hline $\mathrm{Na}$ & 0,23 & 0,41 & 0,58 & 0,28 & $-0,01$ & 0,03 & 0,15 & 0,24 & 0,49 & 0,66 & 0,10 & 1 & 0,03 & 0,20 & 0 \\
\hline $\mathrm{NH}_{4}{ }^{+}$ & $-0,04$ & $-0,05$ & $-0,04$ & 0,21 & 0,12 & 0,12 & 0,05 & $-0,07$ & $-0,01$ & 0,00 & $-0,04$ & 0,03 & 1 & $-0,01$ & 0 \\
\hline $\mathrm{NO}_{3}{ }^{2-}$ & 0,37 & 0,20 & 0,20 & 0,19 & $-0,17$ & $-0,13$ & 0,03 & 0,23 & 0,31 & 0,20 & 0,05 & 0,20 & $-0,01$ & 1 & 0 \\
\hline$P$ & 0,48 & 0,05 & 0,22 & 0,16 & 0,63 & 0,49 & 0,01 & 0,19 & 0,32 & 0,35 & 0,15 & 0,38 & 0,05 & 0,12 & \\
\hline $\mathrm{pH}$ & 0,29 & 0,13 & 0,20 & 0,06 & 0,00 & 0,05 & 0,01 & 0,07 & 0,05 & 0,32 & $-0,05$ & 0,42 & 0,08 & 0,30 & 0 \\
\hline \begin{tabular}{|l|} 
Pluv. \\
Período
\end{tabular} & $-0,06$ & 0,09 & 0,13 & 0,41 & $-0,07$ & $-0,10$ & 0,32 & $-0,02$ & 0,53 & $-0,05$ & $-0,01$ & $-0,09$ & $-0,02$ & 0,12 & -0 \\
\hline $\mathrm{SO}_{4}{ }^{2-}$ & $-0,03$ & 0,11 & 0,27 & 0,42 & $-0,03$ & 0,01 & 0,12 & 0,02 & 0,27 & 0,09 & $-0,04$ & 0,06 & 0,04 & 0,08 & 0 \\
\hline
\end{tabular}


Em função do critério dos autovalores acima de 1, os 4 componentes foram considerados como significativos, sendo que a porcentagem da variabilidade acumulada explicada por elas é $69 \%$ da variabilidade total dos elementos. Observa-se que o primeiro componente é responsável por $34 \%$, o segundo $13 \%$, o terceiro $12,2 \%$, o quarto $9,5 \%$ da variabilidade dos dados, indicando que cada vez menos variabilidade é explicada, à mediada que o autovalor da componente diminui.

Tabela 6.9 - Análise de componentes principais nos elementos da água tratada

\begin{tabular}{cccc}
\hline Fator & $\begin{array}{c}\text { Autovalor da } \\
\text { componente }\end{array}$ & $\begin{array}{c}\text { Variabilidade } \\
\text { explicada pela } \\
\text { componente }(\%)\end{array}$ & $\begin{array}{c}\text { Variabilidade total } \\
\text { explicada }\end{array}$ \\
\hline 1 & 3,7 & 34,0 & 34,0 \\
2 & 1,4 & 12,9 & 47,0 \\
3 & 1,3 & 12,2 & 59,1 \\
4 & 1,0 & 09,5 & 68,7 \\
\hline
\end{tabular}

A Tabela 6.10 apresenta os componentes retidos e sua matriz dos fatores e a comunalidade para cada variável, isto é, o quanto de cada variável foi explicada pelo modelo proposto pela ACP.

Tabela 6.10 - Resultados da análise de componentes principais para a água tratada

\begin{tabular}{lrrrrc}
\hline Elemento & Fator 1 & Fator 2 & Fator 3 & Fator 4 & $\begin{array}{c}\text { Comunalidade } \\
(\%)\end{array}$ \\
\hline $\mathrm{Mg}$ & 0,88 & $-0,10$ & $-0,14$ & $-0,09$ & 82 \\
$\mathrm{P}$ & 0,04 & 0,91 & 0,00 & $-0,07$ & 83 \\
$\mathrm{Ca}$ & 0,88 & 0,27 & $-0,15$ & 0,12 & 89 \\
$\mathrm{Mn}$ & 0,11 & $-0,17$ & 0,60 & $-0,38$ & 54 \\
$\mathrm{Ba}$ & 0,79 & $-0,36$ & 0,08 & $-0,09$ & 77 \\
$\mathrm{~F}^{-}$ & $-0,02$ & $-0,03$ & $-0,02$ & 0,93 & 87 \\
$\mathrm{Cl}^{-}$ & 0,46 & 0,07 & 0,65 & 0,23 & 69 \\
$\mathrm{NO}_{3}{ }^{-}$ & 0,40 & $-0,10$ & $-0,65$ & $-0,02$ & 59 \\
$\mathrm{SO}_{4}{ }^{-}$ & 0,61 & 0,28 & 0,22 & 0,13 & 52 \\
$\mathrm{Na}^{+}$ & $-0,44$ & $-0,42$ & 0,00 & $-0,21$ & 42 \\
$\mathrm{~K}^{+}$ & 0,73 & 0,22 & 0,15 & $-0,12$ & 62 \\
\hline
\end{tabular}

Com intuito de auxiliar a interpretação da análise ACP, foi montada a Tabela 6.11, que contém as informações e salienta os elementos retidos em cada componente, a importância de cada componente na explicação da variabilidade dos elementos na água tratada. 
Tabela 6.11 - Esquematização das informações da ACP para os elementos da água tratada

\begin{tabular}{lll} 
& \multicolumn{2}{c}{$\mathrm{ACP}$} \\
\cline { 3 - 3 } & Elementos retidos & Variabilidade explicada (\%) \\
\hline Fator 1 & $\mathrm{Mg}, \mathrm{Ca}, \mathrm{Ba} \mathrm{e} \mathrm{K}^{+}$ & 34,0 \\
Fator 2 & $\mathrm{P}$ & 12,9 \\
Fator 3 & $\mathrm{Cl}^{-} \mathrm{e} \mathrm{NO}_{3}^{-}$ & 12,2 \\
Fator 4 & $\mathrm{~F}^{-}$ & 09,5 \\
\hline
\end{tabular}

Observando a Tabela 6.11 nota-se que, apesar da variabilidade total explicada ser de $69 \%$, o primeiro e o segundo fatores explica $47 \%$ da variabilidade na água tratada. Os elementos retidos sugerem que o fator está associado tanto a fatores mineralógicos quanto aos insumos adicionados (Ca) é explicado no tópico 6.1.2.1. Os elementos $\mathrm{Mg}$ e $\mathrm{K}$ não sofrem interferência no tratamento da ETA.

No terceiro e quarto fator sugere que estes elementos são adicionados no tratamento da água.

\subsubsection{Análise de CorrelaÇão da Água Tratada}

Com o objetivo de verificar a hipótese de que o material usado para o tratamento da água poderia interferir na qualidade da água tratada, realizou-se o estudo para analisar se existe correlação entre os elementos metálicos e iônicos.

Na Tabela 6.12 são apresentados os coeficientes de correlação entre os elementos metálicos e iônicos. Para a matriz do $\mathrm{Mg}$ verificasse boa correlação para $\mathrm{Ca}(0,79), \mathrm{Ba}$ $(0,71)$ e K $(0,57)$, o Ca e o K possivelmente provem de matriz mineralógica. 
Tabela 6.12 - Matriz de correlação entre os elementos metálicos e iônicos na água tratada

\begin{tabular}{|l|c|c|c|c|c|c|c|c|c|c|c|}
\hline & $\mathrm{Mg}$ & $\mathrm{P}$ & $\mathrm{Ca}$ & $\mathrm{Mn}$ & $\mathrm{Ba}$ & $\mathrm{F}$ & $\mathrm{Cl}^{-}$ & $\mathrm{NO}_{3}{ }^{-}$ & $\mathrm{SO}_{4}{ }^{--}$ & $\mathrm{Na}^{+}$ & $\mathrm{K}^{+}$ \\
\hline $\mathrm{Mg}$ & 1 & $-0,02$ & 0,79 & $-0,01$ & 0,71 & $-0,09$ & 0,29 & 0,31 & 0,41 & $-0,25$ & 0,57 \\
\hline $\mathrm{P}$ & $-0,02$ & 1 & 0,28 & $-0,06$ & $-0,19$ & $-0,01$ & 0,09 & $-0,04$ & 0,17 & $-0,24$ & 0,18 \\
\hline $\mathrm{Ca}$ & 0,79 & 0,28 & 1 & $-0,04$ & 0,56 & 0,11 & 0,31 & 0,36 & 0,56 & $-0,48$ & 0,62 \\
\hline $\mathrm{Mn}$ & $-0,01$ & $-0,06$ & $-0,04$ & 1 & 0,21 & $-0,18$ & 0,17 & $-0,10$ & 0,09 & $-0,04$ & 0,07 \\
\hline $\mathrm{Ba}$ & 0,71 & $-0,19$ & 0,56 & 0,21 & 1 & $-0,06$ & 0,30 & 0,21 & 0,26 & $-0,25$ & 0,47 \\
\hline $\mathrm{F}^{-}$ & $-0,09$ & $-0,01$ & 0,11 & $-0,18$ & $-0,06$ & 1 & 0,08 & 0,02 & 0,03 & $-0,14$ & $-0,09$ \\
\hline $\mathrm{Cl}^{-}$ & 0,29 & 0,09 & 0,31 & 0,17 & 0,30 & 0,08 & 1 & $-0,10$ & 0,44 & $-0,15$ & 0,39 \\
\hline $\mathrm{NO}_{3}{ }^{-}$ & 0,31 & $-0,04$ & 0,36 & $-0,10$ & 0,21 & 0,02 & $-0,10$ & 1 & 0,17 & $-0,10$ & 0,11 \\
\hline $\mathrm{SO}_{4}{ }^{2-}$ & 0,41 & 0,17 & 0,56 & 0,09 & 0,26 & 0,03 & 0,44 & 0,17 & 1 & $-0,28$ & 0,41 \\
\hline $\mathrm{Na}^{+}$ & $-0,25$ & $-0,24$ & $-0,48$ & $-0,04$ & $-0,25$ & $-0,14$ & $-0,15$ & $-0,10$ & $-0,28$ & 1 & $-0,30$ \\
\hline $\mathrm{K}^{+}$ & 0,57 & 0,18 & 0,62 & 0,07 & 0,47 & $-0,09$ & 0,39 & 0,11 & 0,41 & $-0,30$ & 1 \\
\hline
\end{tabular}

\subsubsection{AVAliaÇão dos RESUltados EnCONTRAdOS PARA METAIS EM ÁGUA BRUTA EM RELAÇÃo A LITERATURA}

Para auxiliar na análise dos resultados de água bruta obtidas neste trabalho, foi montada a Tabela 6.13 contendo vários resultados obtidos em trabalhos reportados na literatura [FÖRSTNER \& WITTMANN, 1981].

Analisando a Tabela 6.13 e comparando os resultados encontrados neste estudo com os demais estudos da literatura, observa-se que, de maneira geral, os valores dos metais $\mathrm{Al}, \mathrm{Fe}$ e Mn, estão cima em média dos valores encontrados por outros autores em diferentes locais, sendo estes valores relacionados a mineralogia da região. 
Tabela 6.13 - Concentração de metais em água bruta, em coletânea de vários trabalhos para intercomparação com os resultados obtidos neste trabalho.

\begin{tabular}{|c|c|c|c|c|}
\hline Elemento & $\begin{array}{c}\text { Concentração } \\
\text { Média } \\
\left(\mathrm{ng} \mathrm{mL}^{-1}\right)\end{array}$ & $\begin{array}{c}\text { Faixa de } \\
\text { Concentração } \\
\left(\text { ng mL }^{-1}\right)\end{array}$ & Local & $\begin{array}{c}\text { Referência } * * \\
\text { (apud FÖRSTNER \& } \\
\text { WITTMANN [1981]) }\end{array}$ \\
\hline \multirow[t]{4}{*}{ Alumínio } & 15 & $<7-30$ & Rios da Califórnia & Silvey (1967) \\
\hline & & $0,5-3$ & Califórnia (E.U.A.) & Jones et al. (1974) \\
\hline & 154 & $<92-578$ & Bacia do Rio Pardo & * deste trabalho \\
\hline & 313 & $<92-828$ & Bacia do Rio Mogi-Guaçu & * deste trabalho \\
\hline \multirow[t]{8}{*}{ Bário } & 45 & $9-152$ & América do Norte & Durum e Haffty (1961) \\
\hline & & $10-50$ & Rio Laranja (Rússia) & De Villiers (1962) \\
\hline & & $40-70$ & Mecong (Camboja ) & Durum e Haffty (1963) \\
\hline & & $12-50$ & Patuxent (E.U.A.) & Heidel e Frenier (1965) \\
\hline & 10 & $2->80$ & Riacho Connecticut & Turekian (1966) \\
\hline & & $5,7-22$ & Rio Neuse & Turekian et al. (1967) \\
\hline & 71 & $11-180$ & Bacia do Rio Pardo & * deste trabalho \\
\hline & 73 & $12-151$ & Bacia do Rio Mogi-Guaçu & * deste trabalho \\
\hline \multirow[t]{15}{*}{ Cádmio } & 3,0 & & Sibéria (Rússia) & Udov e Parilov (1961) \\
\hline & 0,7 & & Califórnia (E.U.A.) & Silvey (1967) \\
\hline & 0,5 & $0-1,2$ & Rio Conway (Inglaterra) & Elderfield et al. (1971) \\
\hline & 0,2 & & Bacia Cayuga (E.U.A) & Mills e Oplesby (1971) \\
\hline & & $0,4-3,7$ & Wales & Abdullah e Royle (1972) \\
\hline & 2,0 & $0,6-14$ & Delaware & Biggs et al. (1972) \\
\hline & & $0,02-0,12$ & Austrália & Doolan e Smythe (1973) \\
\hline & & $1,2-16,4$ & Baixo Reno (Alemanha) & Kempf (1973) \\
\hline & 1,0 & $03-1,9$ & Áustria & $\begin{array}{l}\text { Korkich e Dimitriadis } \\
\text { (1973) }\end{array}$ \\
\hline & 0,8 & $0-5$ & Rio Missouri & Proctor et al. (1973) \\
\hline & $<0,5$ & & Austrália & Philip et al. (1975) \\
\hline & 2,7 & $2-4$ & Ruhr (Alemanha) & Ruhrverband (1975) \\
\hline & 0,2 & & Parmir (Afeganistão) & $\begin{array}{l}\text { Buchroithner e Förstner } \\
\text { (não publ.) }\end{array}$ \\
\hline & $<4$ & & Bacia do Rio Pardo & * deste trabalho \\
\hline & $<4$ & & Bacia do Rio Mogi-Guaçu & * deste trabalho \\
\hline \multirow[t]{11}{*}{ Crômio } & 0,2 & & Maine (E.U.A.) & $\begin{array}{l}\text { Turekian e Kleinkopf } \\
\text { (1956) }\end{array}$ \\
\hline & $<0,7$ & & Califórnia (E.U.A.) & Silvey (1967) \\
\hline & 1,4 & $0,1-4,1$ & E.U.A e Amazônia & Kharkar et al. (1968) \\
\hline & 1,2 & & Lago Superior (E.U.A) & Weiler e Chawla (1969) \\
\hline & $<1,0$ & $0,7-19$ & E.U.A & Durum et al. (1971) \\
\hline & 3,0 & $0,3-69$ & Lago de Michigan & Robbins et al (1972) \\
\hline & 7,2 & $3,0-18$ & Danúbio (Áustria) & Quentin e Winkler (1974) \\
\hline & 5,7 & $2,0-10$ & $\begin{array}{l}\text { Lago Constance } \\
\text { (Lindau) }\end{array}$ & Quentin e Winkler (1974) \\
\hline & 25 & $10-115$ & Ruhr (Alemanha) & Ruhverband (1975) \\
\hline & $<4$ & & Bacia do Rio Pardo & deste trabalho \\
\hline & $<4$ & & Bacia do Rio Mogi-Guaçu & * deste trabalho \\
\hline \multirow[t]{9}{*}{ Cobalto } & 0,2 & $0,06-6,1$ & Riachos de Connecticut & Turekian (1966) \\
\hline & $<0,5$ & & Califórnia & Silvey (1967) \\
\hline & 0,05 & $0,03-0,85$ & Rio Neuse (E.U.A.) & Turekian et al. (1967) \\
\hline & 0,19 & $0,037-0,36$ & E.U.A. e Amazônia & Kharkar et al. (1968) \\
\hline & 0,04 & & Lago Cayuga & Mills e Oglesby (1971) \\
\hline & & $1-4500$ & E.U.A. & Durum et al (1971) \\
\hline & 6,3 & $<5-11$ & Ruhr (Alemanha) & Ruhrverband (1975) \\
\hline & 49 & $<17-95$ & Bacia do Rio Pardo & * deste trabalho \\
\hline & 48 & $<17-98$ & Bacia do Rio Mogi-Guaçu & * deste trabalho \\
\hline Cobre & $\begin{array}{l}15 \\
14\end{array}$ & $\begin{array}{c}8-29 \\
04-32\end{array}$ & Saale (Alemanha) & Heide e Seiger (1954) \\
\hline
\end{tabular}




\begin{tabular}{|c|c|c|c|c|}
\hline Cont. & & & & \\
\hline \multirow[t]{22}{*}{ Elemento } & $\begin{array}{l}\text { Concentração } \\
\text { Média } \\
\left(\mathrm{ng} \mathrm{mL}^{-1}\right)\end{array}$ & $\begin{array}{c}\text { Faixa de } \\
\text { Concentração (ng } \\
\left.\mathrm{mL}^{-1}\right)\end{array}$ & Local & Referência \\
\hline & 1,9 & $0,5-7$ & Japão & Morita (1955) \\
\hline & 12,0 & & Maine (E.U.A.) & $\begin{array}{l}\text { Turekian e Kleinkopf } \\
\text { (1956) }\end{array}$ \\
\hline & 10,3 & $0,1-20710$ & Sibéria (Rússi) & Ududov e Parilov (1961) \\
\hline & 5,3 & $0,83-105$ & Améria do Norte & Durum e Haffty (1963) \\
\hline & 3,8 & $0,7-27,5$ & Rio Colúmbia (E.U.A.) & Silker (1964) \\
\hline & 1,2 & $0,4-5$ & Sierra Nevada (E.U.A.) & Bradforf et al. (1968) \\
\hline & 1,5 & & Lago Eire & Chawla e Chau (1969) \\
\hline & 10 & & Rússia & Konovalov (1969) \\
\hline & 8,3 & & Reno (Alemanha) & Kölle et al. (1971) \\
\hline & 0,7 & & Lago Cayuga & Mills e Oglesby (1971) \\
\hline & & $0,7-5,5$ & Wales & Abdullah e Royle (1972) \\
\hline & 2,0 & $<1-10$ & Mackenzie (Canadá) & Reeder et al. (1972) \\
\hline & 3,0 & $0,3-52$ & Lago de Michigan & Robbins et al. (1972) \\
\hline & 10 & $5-26$ & Danúbio (Áustria) & Ebner e Gams (1973) \\
\hline & 3 & $0-31$ & Missouri (E.U.A.) & Proctor et al. (1973) \\
\hline & 40 & $<5-120$ & Kansas (E.U.A.) & Angini et al. (1974) \\
\hline & 8,2 & $4-19$ & Lgo Constance (Lindau) & Quentin e Winkler (1974) \\
\hline & 30 & $22-70$ & Ruhr (Alemanha) & Ruhrverband (1975) \\
\hline & 3 & & Pamir (Afeganistão) & $\begin{array}{l}\text { Buchroithner e Förstner } \\
\text { (não publicado) }\end{array}$ \\
\hline & 9 & $<\mathbf{3}-\mathbf{2 0}$ & Bacia do Rio Pardo & * deste trabalho \\
\hline & 9 & $<3-18$ & Bacia do Rio Mogi-Guaçu & * deste trabalho \\
\hline \multirow[t]{9}{*}{ Ferro } & 670 & $10-1400$ & Média Mundial & Livingstone (1963) \\
\hline & 300 & $31-1670$ & América do Norte & Durun e Haffty (1963) \\
\hline & 33 & $<100$ & Rios de Califórnia & Silvey (1967) \\
\hline & 39 & $6-309$ & L. Michigan (E.U.A.) & Robbins et al. (1972) \\
\hline & 74 & $12-130$ & Danúbio & Quentin e Winkler (1974) \\
\hline & 32 & $5-53$ & L. Constance & Quentin e Winkler (1974) \\
\hline & $<10$ & $0,7-8,8$ & $\begin{array}{l}\text { Rios da costa da } \\
\text { Califórnia (E.U.A.) }\end{array}$ & Jones et al. (1974) \\
\hline & 1114 & $42-3396$ & Bacia do Rio Pardo & * deste trabalho \\
\hline & 1331 & $16-3041$ & Bacia do Rio Mogi-Guaçu & * deste trabalho \\
\hline \multirow[t]{18}{*}{ Chumbo } & 2,6 & & Maine (E.U.A.) & $\begin{array}{l}\text { Turekian e Kleinkopf } \\
\text { (1956) }\end{array}$ \\
\hline & 3,9 & $1,4-10,22$ & Saale, Elbe (Alemanha) & Heide et al. (1957) \\
\hline & 1,5 & $0,1-2,07$ & Sibéria (Rússia) & Ududov et al. (1957) \\
\hline & 4,0 & $<1-55$ & América do Norte & Durum e Haffty (1963) \\
\hline & 0,5 & & Sierra Nevada (E.U.A.) & Bradford et al. (1968) \\
\hline & 2,7 & $2,2-3,3$ & L. Superior (Canadá) & Weilre e Chawla (1969) \\
\hline & 2,0 & $<1-890$ & E.U.A & Durum et al. (1971) \\
\hline & & & & Durum e Hem (1972) \\
\hline & 3,2 & & Reno (Alemanha) & Kölle et al. (1971) \\
\hline & 0,9 & & L. Cayuga & Mills e Oglesby (1971) \\
\hline & 3 & $0,7-17,6$ & Wales & Abdullah et al. (1972) \\
\hline & 6 & $0,6-14$ & Rio Delaware & Biggs et al. (1972) \\
\hline & 9 & $5-50$ & Danúbio (Áustria) & Ebner e Gams (1972) \\
\hline & 3 & $0-70$ & Rio Missuri (E.U.A) & Proctor et al. (1973) \\
\hline & 41 & $<10-78$ & Kansas (E.U.A) & Angino et al. (1974) \\
\hline & 15 & $5-48$ & Ruhr (Alemanha) & Ruhrverban (1975) \\
\hline & $<16$ & & Bacia do Rio Pardo & $*$ deste trabalho \\
\hline & $<16$ & & Bacia do Rio Mogi-Guaçu & * deste trabalho \\
\hline Manganês & 4 & & Maine (E.U.A.) & $\begin{array}{l}\text { Turekian e Kleinkopf } \\
\text { (1956) }\end{array}$ \\
\hline
\end{tabular}




\begin{tabular}{|c|c|c|c|c|}
\hline \multicolumn{5}{|l|}{ Cont. } \\
\hline \multirow[t]{14}{*}{ Elemento } & $\begin{array}{l}\text { Concentração } \\
\text { Média } \\
\left(\mathrm{ng} \mathrm{mL}^{-1}\right)\end{array}$ & $\begin{array}{c}\text { Faixa de } \\
\text { Concentração (ng } \\
\mathrm{mL}^{-1} \text { ) }\end{array}$ & Local & Referência \\
\hline & 5 & & Rio Colúmbia & Silvey (1964) \\
\hline & 7 & & Rio Colúmbia & Silvey (1967) \\
\hline & $<0,6$ & & & \\
\hline & 26 & & Lago Eire & Chawla e Chau (1969) \\
\hline & 12 & & Rússia & Konovalov (1969) \\
\hline & & $0,8-28$ & Wales & Abdullah e Royle (1972) \\
\hline & 12 & $0,3-130$ & L. Michigan (E.U.A.) & Robbins et al. (1974) \\
\hline & 34 & $<4-170$ & Kansas (E.U.A.) & Angino et al. (1974) \\
\hline & 29 & $4-64$ & Danúbio (E.U.A.) & Quentin e Winkler (1974) \\
\hline & 5,4 & $3-10$ & L. Constance (Lindau) & Quentin e Winkler (1974) \\
\hline & 117 & $58-240$ & Ruhr (Alemanha) & Ruhrverband (1976) \\
\hline & 62 & $6-228$ & Bacia do Rio Pardo & * deste trabalho \\
\hline & 138 & $8-815$ & Bacia do Rio Mogi-Guaçu & * deste trabalho \\
\hline \multirow[t]{14}{*}{ Níquel } & 0,4 & & Maine (E.U.A.) & $\begin{array}{l}\text { Turekian e Kleinkopf } \\
\text { (1956) }\end{array}$ \\
\hline & 10 & $0-71$ & América do Norte & Durum e Haffty (1963) \\
\hline & 3 & $<0.3-5$ & Rios da Califórnia & Silvey (1967) \\
\hline & 19 & $1-130$ & E.U.A. & Kopp e Kroner (1968) \\
\hline & 3.5 & $2-5.6$ & L. Superior (Canadá) & Weiler e Chawla (1969) \\
\hline & & $0.5-3.5$ & Wales & Abdullah e Royle (1972) \\
\hline & 27 & $<10-89$ & Kansas (E.U.A.) & Angino et al. (1974) \\
\hline & 10 & $2-17$ & Danúbio (Austria) & Quentin e Winkler (1974) \\
\hline & 5 & $3-7$ & L. Constance (Lindau) & Quentin e Winkler (1974) \\
\hline & 62 & $35-100$ & Ruhr (Alemanha) & Ruhrverband (1975) \\
\hline & & $3.2-6.9$ & Rio St. Lawrence & Subramanian e \\
\hline & & & & D’Anglejan (1976) \\
\hline & $<16$ & & Bacia do Rio Pardo & * deste trabalho \\
\hline & $<16$ & & Bacia do Rio Mogi-Guaçu & * deste trabalho \\
\hline \multirow[t]{5}{*}{ Prata } & 0.5 & $0.2-3.5$ & Riachos de Connecticut & Turekian (1966) \\
\hline & 3.3 & & Rio Neuse (E.U.A.) & Turekian et al. (1967) \\
\hline & & $0.0-0.94$ & América do Norte & Kharkar et al. (1968) \\
\hline & 12 & $<1-28$ & Bacia do Rio Pardo & * deste trabalho \\
\hline & 12 & $<1-27$ & Bacia do Rio Mogi-Guaçu & * deste trabalho \\
\hline \multirow[t]{20}{*}{ Zinco } & 2.5 & $0.25-34$ & Maine (E.U.A.) & Kleinkopf (1960) \\
\hline & 13 & $0.1-5,770$ & Siberia (Rússia) & Ududov e Parilov (1961) \\
\hline & 29 & $<14$ & Rios da Califórnia & Silvey (1967) \\
\hline & 1.5 & $0.3-100$ & Sierra Nevada (E.U.A.) & Bradford et al. (1968) \\
\hline & 64 & $2-1,183$ & E.U.A. & Kopp e Kroner (1968) \\
\hline & 39 & & Rússia & Konovalov (1969) \\
\hline & 35 & $11-71$ & L. Superior (Canadá) & Weiler e Chawla (1969) \\
\hline & & $121-566$ & Reno (Alemanha) & Haberer (1969) \\
\hline & 20 & $<12-42,000$ & E.U.A. & Durum et al. (1971) \\
\hline & 180 & & Reno (Alemanha) & Kölle et al. (1971) \\
\hline & 3 & & L. Cayuga & Mills e Oglesby (1972) \\
\hline & & $11-600$ & Wales & Abbullah e Royle (1972) \\
\hline & 60 & $3.6-176$ & Reno (Alemanha) & Reichert et al. (1972) \\
\hline & 4 & $0.9-32$ & L. Michigan (E.U.A.) & Robbins et al. (1972) \\
\hline & 72 & $21-296$ & Danúbio (Áustria) & Ebner e Gams (1973) \\
\hline & 31 & $3-140$ & Rio Missouri (E.U.A.) & Proctor et al. (1973) \\
\hline & 70 & $11-120$ & Danúbio (Austria) & Quentin e Winkler (1974) \\
\hline & 37 & $19-95$ & L. Constance (Lindau) & Quentin e Winkler (1974) \\
\hline & & $3.5-40$ & $\begin{array}{l}\text { Marbyrnong, Yarra } \\
\text { (Austrália) }\end{array}$ & Philip et al. (1975) \\
\hline & 209 & $100-300$ & Ruhr (Alemanha) & Ruhrverband (1975) \\
\hline
\end{tabular}




\begin{tabular}{|c|c|c|c|c|}
\hline Cont. & & & & \\
\hline \multirow[t]{4}{*}{ Elemento } & $\begin{array}{c}\text { Concentração } \\
\text { Média } \\
\left(\mathrm{ng} \mathrm{mL}^{-1}\right)\end{array}$ & $\begin{array}{c}\text { Faixa de } \\
\text { Concentração (ng } \\
\left.\mathrm{mL}^{-1}\right)\end{array}$ & Local & Referência \\
\hline & & $29.2-32.5$ & Rio St. Lawrence & $\begin{array}{l}\text { Subramanian e } \\
\text { D’Anglejan (1976) }\end{array}$ \\
\hline & $<3$ & & Bacia do Rio Pardo & * deste trabalho \\
\hline & $<3$ & & Bacia do Rio Mogi-Guaçu & * deste trabalho \\
\hline
\end{tabular}

FONTE: autores apud FÖRSTNER \& WITTMANN [1981]

\subsection{ANÁLISE FÍSICA E QUÍMICA DO SEDIMENTO}

\subsubsection{ConCENTRAÇÃo de MATÉRIA ORgÂNICA NOS SEDIMENTOS}

A concentração relativa de matéria orgânica presente no sedimento das 13 comunidades foi avaliada utilizando-se a técnica titulométrica. Na Tabela 6.14, podemos observar que os valores da matéria orgânica nos sedimentos das comunidades estudadas variam provavelmente se relacionando com a decomposição de vegetais. As comunidades que apresentam níveis de matéria orgânica elevado foram IG 64 (6,92\%), IG 66-2 (26,05\%), IG 69 (6,69\%), IG 70 (5,69\%) e IG 83 (6,64\%).

A comunidade Cascata (IG 66) apresenta dois valores de matéria orgânica, IG 66-1 $(5,40 \%)$ e IG 66-2 (26,05\%). Pois o local IG 66-1 refere-se a nascente e o IG 66-2 localizase próximo da ETA.

As comunidades que apresentaram valores baixos de matéria orgânica como IG 61 (1,03\%), IG 67 (0,59\%) IG 72 (0,52\%) e IG VGS (0,19\%), são locais onde as amostra de sedimento apresentaram maior granulometria (arenosa). 
Figura 6.14 - Resultado do carbono orgânico e matéria orgânica

\begin{tabular}{lcc}
\hline \multicolumn{1}{c}{ Localidade } & Carbono Orgânico & Matéria Orgânica (\%) \\
\hline IG 60 - São João da Boa Vista & 1,71 & 2,95 \\
IG 61 - Mococa & 0,60 & 1,03 \\
IG 63 - Espírito Sto. do Pinhal & 1,47 & 2,53 \\
IG 64 - Águas da Prata & 4,01 & 6,92 \\
IG 65 - São Roque da Fartura & 2,64 & 4,55 \\
IG 66 (1) - Cascata & 3,13 & 5,40 \\
IG 66 (2) - Cascata & 15,10 & 26,05 \\
IG 67 - V.N.S. Aparecida & 0,34 & 0,59 \\
IG 68 - Divinolândia & 1,53 & 2,64 \\
IG 69 - Campestrinho & 5,04 & 8,69 \\
IG 70 - Itobi & 3,30 & 5,69 \\
IG 72 - Sto. Antonio do Jardim & 0,30 & 0,52 \\
IG 83 - São Sebastião da Grama & 3,85 & 6,64 \\
IG VGS - Vargem Grande do Sul & 0,11 & 0,19 \\
\hline N=2 & &
\end{tabular}

A matéria orgânica tem grande influência sobre a capacidade de troca de íons, uma vez que $100 \mathrm{~g}$ de matéria orgânica apresenta uma capacidade de 150 a 200 meq [SANTOS, 1989].

A faixa usual de valores de capacidade de troca catiônica e aniônica dos vários argilominerais é apresentada na Tabela 6.15.

Tabela 6.15 - Capacidade de troca catiônica e aniônica dos grupos mineralógicos e da matéria orgânica, em miliequivalentes por $100 \mathrm{~g}(\mathrm{pH}=7,0)$

\begin{tabular}{lccc}
\hline \multicolumn{1}{c}{ Grupo de Mineralógico } & CTC $\left({\left.\mathrm{meq} 100 \mathrm{~g}^{-1}\right)}\right.$ CTA $\left(\mathrm{meq} 100 \mathrm{~g}^{-1}\right)$ & Tamanho $(\mu \mathrm{m})$ \\
\hline Caulinita & $3-15$ & 2 & $0,1-5,0$ \\
Montmorilonita & $80-150$ & 1 & $0,01-1,0$ \\
Ilita & $10-40$ & 3 & $0,1-2,0$ \\
Vermiculita & $100-150$ & 0 & - \\
Clorita & $10-40$ & - & - \\
Matéria Orgânica & $150-500$ & - & - \\
\hline Fonte: GRIM [1953] \& BRADY [1989] &
\end{tabular}




\subsubsection{CARACTERIZAÇÃO DA COMPOSIÇÃO DO SEDIMENTO POR ESPECTROMETRIA DE FLUORESCÊNCIA DE RAIOS X}

A avaliação da composição química das amostras de sedimento nas diferentes áreas de captação foi realizada utilizando-se a análise de fluorescência de raios X. Os resultados estão descritos na Tabela A.10 (Apêndice 1). Podemos observar na Tabela A.10 que os principais constituintes são a sílica e o óxido de alumínio, seguido pelo óxido de ferro e manganês, sendo este último destacando-se no sedimento da comunidade IG 66.

\subsubsection{ANÁLISE MINERALÓGICA DOS SEDIMENTOS}

O estudo mineralógico das comunidades IG 60, IG 61, IG 63, IG 64, IG 65, IG 66, IG 67, IG 68, IG 69, IG 70 IG 72, IG 83 e IG VGS por difração de raios X, em amostras sólidas maceradas, aponta como sendo as espécies predominantes os minerais do grupo das caulinitas, ilitas e vermiculitas. A titulo de ilustração os difratogramas estão representados nas Figuras E.1 a E.5 (Apêndice 5), em que os picos mais altos e característicos são de caulinitas. Esta análise foi realizada com sedimento na fração de 2 a $4 \mu \mathrm{m}$ (obtida da forma descrita nos tópicos 5.5.5.1 e 5.5.5.2), utilizando-se o Difratômetro de Raios X da Rigaku, modelo D-Max 2000, radiação Cuk (ânodo de cobre no intervalo de 3 a $90^{\circ}$ 2Theta).

A predominância dos grupos argilominerais caulinita, ilita e vermiculita com presença de esmectita e montmorilonita, como mostrado na Tabela 6.16, sugere que em alguns pontos de coletas pode ocorrer maior ou menor troca de elementos do sedimento para a coluna de água como mostrado na Tabela 6.15. 
Tabela 6.16 - Presença dos grupos argilominerais nas comunidades, identificados a partir da análise de difração de raios $\mathrm{X}$

\begin{tabular}{|c|c|c|c|c|c|}
\hline $\begin{array}{r}\text { Grupo } \\
\text { yedominante }\end{array}$ & Caulinita & Ilita & Vermiculita & Montmorilonita & Esmectita \\
\hline Comunidade & $\mathrm{Al}_{4} \mathrm{Si}_{4} \mathrm{O}_{10}(\mathrm{OH})_{8}$ & $\begin{array}{c}\left(\mathrm{K}, \mathrm{H}_{2} \mathrm{O}\right)_{2}(\mathrm{Si})_{8}(\mathrm{Al}, \mathrm{Mg}, \mathrm{Fe})_{4} \\
\mathrm{O}_{20}(\mathrm{OH})_{4}\end{array}$ & $\mathrm{KAl}_{3} \mathrm{Si}_{3} \mathrm{O}_{10}(\mathrm{OH})_{2}$ & $\begin{array}{c}(\mathrm{Al}, \mathrm{Mg})_{2} \mathrm{Si}_{4} \mathrm{O}_{10} \\
(\mathrm{OH})_{2} .4 \mathrm{H}_{2} \mathrm{O}\end{array}$ & $\begin{array}{c}(\mathrm{Al}, \mathrm{Mg})_{2} \mathrm{Si}_{4} \mathrm{O}_{10} \\
(\mathrm{OH})_{2} \cdot \mathrm{nH}_{2} \mathrm{O}\end{array}$ \\
\hline IG 60 & ++ & + & i & $?$ & $?$ \\
\hline IG 61 & ++ & + & $?$ & $?$ & i \\
\hline IG 63 & ++ & + & $?$ & $?$ & $?$ \\
\hline IG 64 & + & + & $?$ & $?$ & $?$ \\
\hline IG 65 & ++ & 1 & i & $?$ & $?$ \\
\hline IG 66 (1) & + & + & $?$ & i & $?$ \\
\hline IG 66 (2) & + & + & ? & $i$ & $?$ \\
\hline IG 67 & + & + & ? & i & ? \\
\hline IG 68 & ++ & 1 & $?$ & $?$ & $?$ \\
\hline IG 69 & + & $?$ & $?$ & $?$ & $?$ \\
\hline IG 70 & ++ & + & $?$ & $?$ & 1 \\
\hline IG 72 & ++ & + & $?$ & $?$ & $?$ \\
\hline IG 83 & ++ & + & $?$ & $?$ & $?$ \\
\hline IG VGS & + & $i$ & $?$ & $?$ & $?$ \\
\hline
\end{tabular}

?: ausente; 1 : traços; +: presente; ++:predominante

\subsubsection{VARIAÇÃO DA CONCENTRAÇÃO DE FÓSFORO BIODISPONÍVEL NO SEDIMENTO}

Nas Figuras 6.34 e 6.35 têm-se os resultados da variação temporal e espacial da concentração de fósforo total presente no sedimento das 13 áreas de captação estudadas. No período seco a concentração de fósforo total no sedimento variou de 4.94 a 63,43 ug $\mathrm{g}^{-1}$, enquanto que no período chuvoso esta concentração variou de 0,69 a 30,59 ug $\mathrm{g}^{-1}$. Comparando-se os valores obtidos podemos observar que as maiores concentrações foram no período seco. 


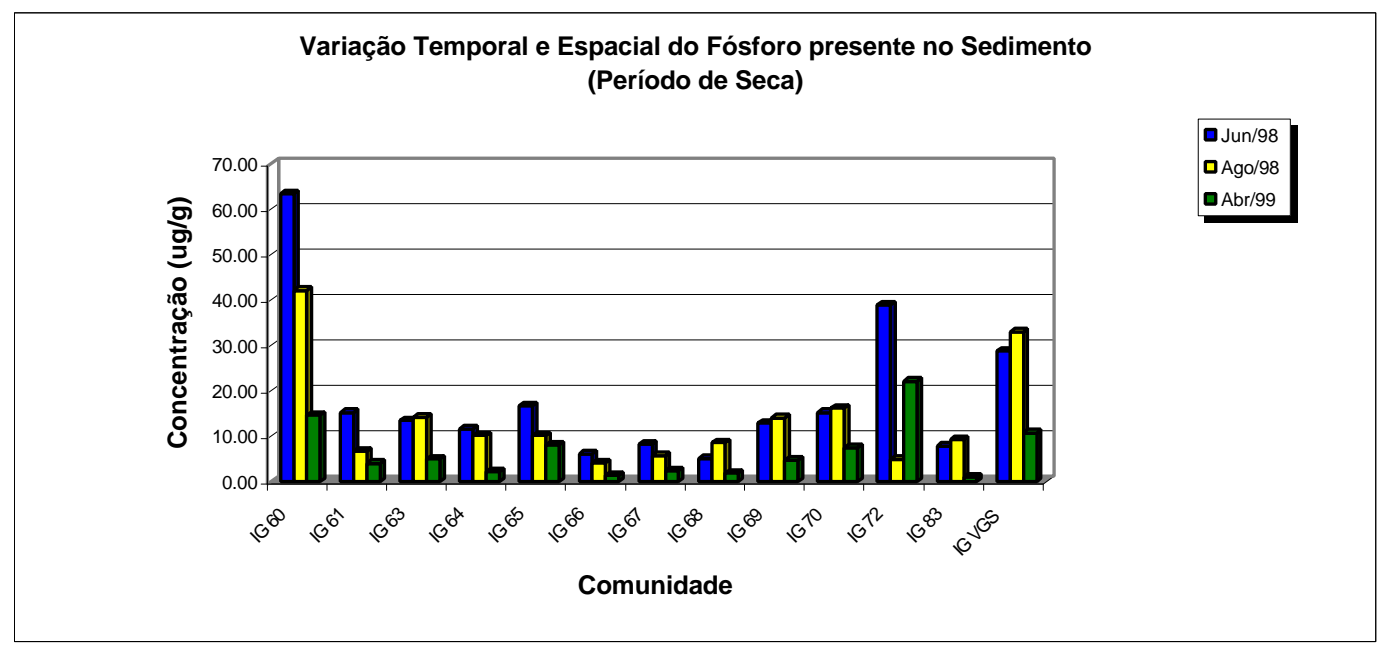

Figura 6.34 - Variação temporal e espacial do fósforo no período de seca

Variação Temporal e Espacial do Fósforo presente no Sedimento (Período de Chuva)

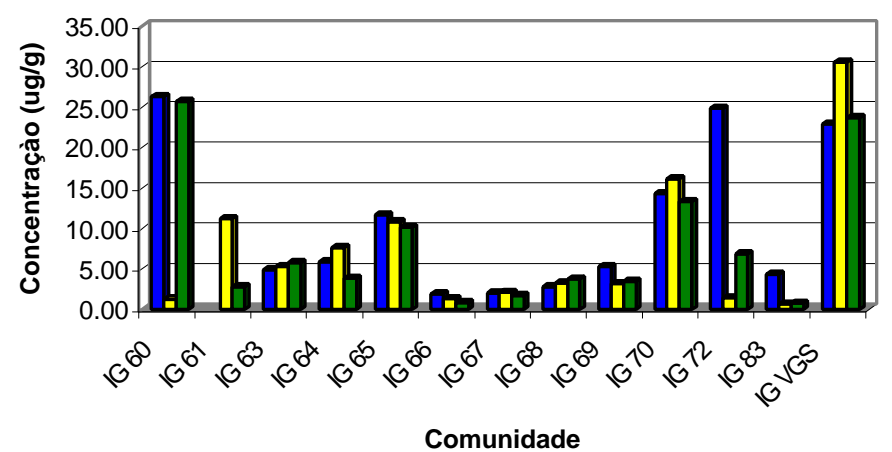

Figura 6.35 - Variação temporal e espacial do fósforo no período de chuva

Isso evidência que, apesar de vários autores afirmaram que no sedimento não ocorrem mudanças nítidas na características físicas e químicas, em função dos períodos de amostragem, evidenciando ser este um comportamento mais estável, esta observação não pode ser incluído o fósforo, que pode ocorrer uma grande influencia sazonal.

\subsubsection{VARIAÇÃO DA CONCENTRAÇÃO DE METAIS NO SEDIMENTO NAS FASES SOBRENADANTE, INTERSTICIAL E BIODISPONÍVEL}

Nas Tabelas A.5 a A.7 (Apêndice 1) estão apresentados os resultados da variação das concentrações dos metais nas frações sobrenadante, intersticial e biodisponível (Digestão em meio $\mathrm{HCl} \quad 0,1 \mathrm{~mol} \mathrm{~L}^{-1}$ ) aplicando-se a análise estatística descritiva. 
O perfil espacial de cada parâmetro, bem como a assimetria da distribuição e a faixa de variação dos resultados podem ser observados nas representações gráficas do tipo Blox-plot (Apêndice 2), Figuras B.3 e B.4.

De um modo geral, as observações sensíveis dos metais se concentram na época de seca em todas as frações, com exceção da fração biodisponível. Nesta fração observa-se proporções altas de valores detectados durante todo o período de observação, com exceção dos metais níquel, zinco e chumbo, que não possuem medidas detectadas nas concentrações de outubro/98 e abril/99.

Para as frações sobrenadante e intersticial (Figura B.3) observam-se altas concentrações nas duas frações, com relação ao ferro para a comunidade IG 63, magnésio para a comunidades IG 60, IG 61, IG 63, IG 65, IG 70 e IG VGS e fósforo nas comunidades IG 65 e IG 68. Para outros metais foram encontradas baixas faixas de concentração nas duas frações para o manganês na comunidade IG 72 e cálcio para as comunidades IG 67 e IG 72. Podemos observar também que na maioria dos elementos não existe diferença significativa entre as duas frações, sendo desnecessário obtê-las ao mesmo tempo. Podemos optar pela fase sobrenadante, pois é a mais simples e rápida de ser obtida, dispensando equipamentos e ganhando tempo.

$\mathrm{Na}$ fração biodisponível ou denominada digestão, verifica-se que o sedimento da comunidade IG 64 apresenta altas concentrações de ferro, manganês e cobalto. A comunidade IG 69 possui altas concentrações de manganês, alumínio, cálcio e cobalto, enquanto a comunidade IG VGS temos em destaque o magnésio e o fósforo. Esses dados podem ser avaliados observando-se a composição mineralógica da região. Avaliando os resultados da Tabela A.10, podemos observar que o ferro e o manganês estão presentes no sedimento da comunidade IG 64 em concentrações elevadas, até muito acima do teor do folhelho médio, enquanto que o sedimento coletado na comunidade IG 69, apresenta concentrações de Mn acima do folhelho médio, como observado na Tabela A.11 (Apêndice 1).

Avaliando os resultados ao longo do tempo podemos observar que os metais nas frações sobrenadante e intersticial (Figuras C.5 e C.6) apresentam o mesmo 
comportamento nas duas frações, com exceção da comunidade IG 67, onde o alumínio apresentou um comportamento anormal. O cobre apresentou um acréscimo na fração intersticial. O cádmio apresentou concentrações mais elevadas nas comunidades IG 69, IG 83 e IG VGS.

Na fração biodisponível (Figura C.7), de um modo geral, as concentrações dos metais não parecem sofrer alterações ao longo do tempo, indicando estabilidade destes elementos ao longo do período. Esse fato não foi observado na concentração do ferro na comunidade IG 64 e, para o manganês (IG 64), alumínio (IG 69) e bário (IG 64, IG 69, IG 70 e IG VGS. No caso do manganês e do alumínio, estas elevações nas referidas comunidades podem estar relacionadas à mineralogia da região, que apresenta elevada concentração desses metais. A comunidade IG 64 apresenta uma elevada concentração de ferro, bem maior do que das demais comunidades.

A fração biodisponível observa-se proporção alta de valores detectados durante todo o período de observação, com exceção dos metais níquel, zinco e chumbo, que não puderam ser detectados no período de outubro e abril de 99. Estes valores relativamente elevados não quer dizer necessariamente que a região está impactada por metais pesados.

A Tabela 6.17 apresenta um resumo dos resultados quanto a razão entre o número de valores que não estão de acordo com os valores relativos ao valor de referência do folhelho médio [TUREKIAN \& WEDEPOHI, 1961] e o número de coletas realizadas para cada parâmetro, na fração biodisponível, por comunidade. É possível observar que de, um modo geral, as concentrações de metais na fração biodisponível estão abaixo dos valores de referência do folhelho médio, Tabela A.11 (Apêndice 1).

\subsubsection{ANÁlise de COMPONENTES PRINCIPAIS DAS VARIÁVEIS DO SEDIMENTO}

\subsubsection{ANÁliSE DE COMPONENTES PRINCIPAIS DA FASE SOBRENADANTE}

No estudo da fase sobrenadante nas comunidades, foram consideradas as variáveis: $\mathrm{Mg}, \mathrm{Al}, \mathrm{P}, \mathrm{Ca}, \mathrm{Mn}, \mathrm{Fe}, \mathrm{Ni}, \mathrm{Cu}$ e Ba. A Tabela 6.18 apresenta um resumo da análise estatística obtida inicialmente, onde são mostrados os autovalores obtidos para cada 
Tabela 6.17 - Razão entre o número de valores que não estão de acordo com o valor referência do folhelho médio ${ }^{(* *)}$ e o número de coletas para os metais na fração digestão nas comunidades.

\begin{tabular}{|c|c|c|c|c|c|c|c|c|c|c|c|c|c|c|c|}
\hline $\begin{array}{c}\text { Elemento } \\
\text { Comunidade }\end{array}$ & $\mathrm{Fe}$ & $\mathrm{Mg}$ & $\mathrm{Mn}$ & $\mathrm{Al}$ & $\mathrm{Ca}$ & $\mathrm{Co}$ & $\begin{array}{c}\mathrm{P} \\
(\mathrm{Total})\end{array}$ & $\mathrm{Ag}$ & $\mathrm{Ba}$ & $\mathrm{Cr}$ & $\mathrm{Ni}$ & $\mathrm{Cu}$ & $\mathrm{Zn}$ & $\mathrm{Cd}$ & $\mathrm{Pb}$ \\
\hline $\mathrm{IG}-60$ & $\bullet$ & $\bullet$ & $04 / 07$ & $\bullet$ & $\bullet$ & $\bullet$ & $\bullet$ & $\bullet$ & $04 / 04$ & $\bullet$ & $\bullet$ & $\bullet$ & $\bullet$ & $07 / 07$ & $\bullet$ \\
\hline $\mathrm{IG}-61$ & $\bullet$ & $\bullet$ & $01 / 06$ & $\bullet$ & $\bullet$ & $\bullet$ & $\bullet$ & $\bullet$ & $03 / 04$ & $\bullet$ & $\bullet$ & $\bullet$ & $\bullet$ & $03 / 06$ & $\bullet$ \\
\hline $\mathrm{IG}-63$ & $01 / 07$ & $\bullet$ & $01 / 07$ & $\bullet$ & $\bullet$ & $\bullet$ & $\bullet$ & $\bullet$ & $04 / 04$ & $\bullet$ & $\bullet$ & $\bullet$ & $\bullet$ & $04 / 07$ & $\bullet$ \\
\hline $\mathrm{IG}-64$ & $01 / 07$ & $\bullet$ & $07 / 07$ & $\bullet$ & $\bullet$ & $\bullet$ & $\bullet$ & $\bullet$ & $04 / 04$ & $\bullet$ & $\bullet$ & $\bullet$ & $\bullet$ & $07 / 07$ & $\bullet$ \\
\hline IG-65 & $\bullet$ & $\bullet$ & $02 / 07$ & $\bullet$ & $\bullet$ & $\bullet$ & $\bullet$ & $\bullet$ & $02 / 04$ & $\bullet$ & $\bullet$ & $\bullet$ & $\bullet$ & $04 / 07$ & $\bullet$ \\
\hline IG-66 & $\bullet$ & $\bullet$ & $\bullet$ & $\bullet$ & $\bullet$ & $\bullet$ & $\bullet$ & $\bullet$ & $04 / 04$ & $\bullet$ & $\bullet$ & $\bullet$ & $\bullet$ & $\bullet$ & $04 / 04$ \\
\hline IG-67 & $\bullet$ & $\bullet$ & $02 / 07$ & $\bullet$ & $\bullet$ & $\bullet$ & $\bullet$ & $\bullet$ & $04 / 07$ & $\bullet$ & $\bullet$ & $\bullet$ & $\bullet$ & $04 / 07$ & $\bullet$ \\
\hline IG-68 & $\bullet$ & $\bullet$ & $02 / 07$ & $\bullet$ & $\bullet$ & $\bullet$ & $\bullet$ & $\bullet$ & $02 / 04$ & $\bullet$ & $\bullet$ & $\bullet$ & $\bullet$ & $03 / 07$ & $\bullet$ \\
\hline IG-69 & $\bullet$ & $\bullet$ & $06 / 07$ & $\bullet$ & $\bullet$ & $\bullet$ & $\bullet$ & $\bullet$ & $03 / 04$ & $\bullet$ & $\bullet$ & $\bullet$ & $\bullet$ & $06 / 07$ & $\bullet$ \\
\hline IG-70 & $\bullet$ & $\bullet$ & $07 / 07$ & $\bullet$ & $\bullet$ & $\bullet$ & $\bullet$ & $\bullet$ & $04 / 07$ & $\bullet$ & $\bullet$ & $\bullet$ & $\bullet$ & $07 / 07$ & $\bullet$ \\
\hline IG-72 & $\bullet$ & $\bullet$ & $\bullet$ & $\bullet$ & $\bullet$ & $\bullet$ & $\bullet$ & $\bullet$ & $03 / 04$ & $\bullet$ & $\bullet$ & $\bullet$ & $\bullet$ & $01 / 07$ & $\bullet$ \\
\hline IG-83 & $\bullet$ & $\bullet$ & $\bullet$ & $\bullet$ & $\bullet$ & $\bullet$ & $\bullet$ & $\bullet$ & $\bullet$ & $\bullet$ & $\bullet$ & $\bullet$ & $\bullet$ & $03 / 07$ & $\bullet$ \\
\hline IG-VGS & $\bullet$ & $\bullet$ & $02 / 06$ & $\bullet$ & $\bullet$ & $\bullet$ & $\bullet$ & $\bullet$ & $04 / 04$ & $\bullet$ & $\bullet$ & $\bullet$ & $\bullet$ & $04 / 06$ & $\bullet$ \\
\hline
\end{tabular}

(**) Folhelho médio [TUREKIAN, 1961] 
componente, depois de submeter a matriz à rotação Varimax (onde o valor de corte é igual a 1), podemos observar qual é a fração explicada por cada componente e a porcentagem acumulada.

Em função do critério dos autovalores acima de 1, os 3 componentes foram considerados como significativos, sendo que a porcentagem da variabilidade acumulada explicada por elas é $69 \%$ da variabilidade total dos elementos. Observa-se que o primeiro componente é responsável por $41 \%$, o segundo $15 \%$, o terceiro $14 \%$ da variabilidade dos dados, indicando que cada vez menos variabilidade é explicada, à mediada que o autovalor da componente diminui.

Tabela 6.18 - Análise de componentes principais nos elementos da fase sobrenadante

\begin{tabular}{cccc}
\hline Fator & $\begin{array}{c}\text { Autovalor da } \\
\text { componente }\end{array}$ & $\begin{array}{c}\text { Variabilidade } \\
\text { explicada pela } \\
\text { componente }(\%)\end{array}$ & $\begin{array}{c}\text { Variabilidade total } \\
\text { explicada }\end{array}$ \\
\hline 1 & 3,7 & 40,9 & 40,9 \\
2 & 1,3 & 14,6 & 55,5 \\
3 & 1,2 & 13,7 & 69,2 \\
\hline
\end{tabular}

A Tabela 6.19 apresenta os componentes retidos e sua matriz dos fatores e a comunalidade para cada variável, isto é, o quanto de cada variável foi explicada pelo modelo proposto pela ACP.

Tabela 6.19 - Resultados da análise de componentes principais para a fase sobrenadante

\begin{tabular}{lrrrc}
\hline Elemento & Fator 1 & Fator 2 & Fator 3 & $\begin{array}{c}\text { Comunalidade } \\
(\%)\end{array}$ \\
\hline $\mathrm{Mg}$ & 0,88 & 0,11 & 0,00 & 0,78 \\
$\mathrm{Al}$ & $-0,54$ & 0,24 & $-0,10$ & 0,36 \\
$\mathrm{P}$ & 0,67 & $-0,51$ & $-0,09$ & 0,72 \\
$\mathrm{Ca}$ & 0,91 & 0,08 & 0,06 & 0,84 \\
$\mathrm{Mn}$ & 0,87 & $-0,04$ & 0,10 & 0,77 \\
$\mathrm{Fe}$ & 0,64 & $-0,40$ & $-0,07$ & 0,57 \\
$\mathrm{Ni}$ & 0,01 & $-0,28$ & 0,78 & 0,69 \\
$\mathrm{Cu}$ & 0,07 & 0,25 & 0,79 & 0,69 \\
$\mathrm{Ba}$ & $-0,01$ & 0,90 & $-0,04$ & 0,80 \\
\hline
\end{tabular}

Com intuito de auxiliar a interpretação da análise ACP, foi montada a Tabela 6.20, que contém as informações e salienta os elementos retidos em cada componente, a importância de cada componente na explicação da variabilidade dos elementos na fase intersticial da água. 
Tabela 6.20 - Esquematização das informações da ACP para os elementos da fase sobrenadante

\begin{tabular}{llc} 
& \multicolumn{2}{c}{ ACP } \\
\cline { 2 - 3 } & Elementos retidos & Variabilidade explicada (\%) \\
\hline Fator 1 & $\mathrm{Mg}, \mathrm{P}, \mathrm{Ca}, \mathrm{Mn}$ e Fe & 40,9 \\
Fator 2 & $\mathrm{Ba}$ & 14,6 \\
Fator 3 & $\mathrm{Ni} \mathrm{e} \mathrm{Cu}$ & 13,7 \\
\hline
\end{tabular}

Observando a Tabela 6.20 nota-se que, apesar da variabilidade total explicada ser de $69 \%$, o primeiro fator explica $41 \%$ da variabilidade da fase sobrenadante. Os elementos retidos sugerem que o fator 1 está associado a fatores mineralógicos do complexo Granitognaisse, o P que não é fortemente significativo, possivelmente esteja ligado a mineralogia da região nas rochas de apatita do complexo de Poços de Caldas, quanto a efluentes domésticos.. O segundo e terceiro fatores sugerem associação com as rochas metabasicas e meta-ultrabasica que contem estes elementos.

\subsubsection{Análise de CorrelaÇÃo dos Elementos Metálicos da FASE SOBRENADANTE}

Com o objetivo de verificar a hipótese de que a concentração dos metais da fase sobrenadante poderia estar ligado a matriz mineralógica da região, realizou-se o estudo para analisar se existe correlação entre os metais.

Na Tabela 6.21 são apresentados os coeficientes de correlação entre os metais. Para a matriz do $\mathrm{Mg}$ verificasse boa correlação para $\mathrm{Ca}(0,85)$ e $\mathrm{Mn}(0,70)$, o Ca e o $\mathrm{Mn}$ possivelmente provem de matriz mineralógica.

Podemos verificar que os elementos Al, Mn e Fe não apresentam boa correlação entre eles por serem de rochas antigas e por estes elementos fazerem parte da rede cristalina do sedimento, não são facilmente com a lixiviados como outros elementos. $\mathrm{O}$ elemento P esta associado ao Fe e Mn no Complexo de Poços de Caldas. 
Tabela 6.21 - Matriz de correlação entre os metais da fase sobrenadante

\begin{tabular}{|l|c|c|c|c|c|c|c|c|c|}
\hline & $\mathrm{Mg}$ & $\mathrm{Al}$ & $\mathrm{P}$ & $\mathrm{Ca}$ & $\mathrm{Mn}$ & $\mathrm{Fe}$ & $\mathrm{Ni}$ & $\mathrm{Cu}$ & $\mathrm{Ba}$ \\
\hline $\mathrm{Mg}$ & 1 & $-0,39$ & 0,42 & 0,85 & 0,70 & 0,41 & 0,10 & $-0,04$ & 0,00 \\
\hline $\mathrm{Al}$ & $-0,39$ & 1 & $-0,36$ & $-0,41$ & $-0,45$ & $-0,26$ & $-0,05$ & $-0,06$ & 0,22 \\
\hline $\mathrm{P}$ & 0,42 & $-0,36$ & 1 & 0,49 & 0,60 & 0,68 & 0,02 & $-0,02$ & $-0,35$ \\
\hline $\mathrm{Ca}$ & 0,85 & $-0,41$ & 0,49 & 1 & 0,71 & 0,50 & 0,10 & 0,05 & 0,00 \\
\hline $\mathrm{Mn}$ & 0,70 & $-0,45$ & 0,60 & 0,71 & 1 & 0,48 & 0,05 & 0,16 & $-0,10$ \\
\hline $\mathrm{Fe}$ & 0,41 & $-0,26$ & 0,68 & 0,50 & 0,48 & 1 & 0,08 & $-0,04$ & $-0,20$ \\
\hline $\mathrm{Ni}$ & 0,10 & $-0,05$ & 0,02 & 0,10 & 0,05 & 0,08 & 1 & 0,25 & $-0,19$ \\
\hline $\mathrm{Cu}$ & $-0,04$ & $-0,06$ & $-0,02$ & 0,05 & 0,16 & $-0,04$ & 0,25 & 1 & 0,15 \\
\hline $\mathrm{Ba}$ & 0,00 & 0,22 & $-0,35$ & 0,00 & $-0,10$ & $-0,20$ & $-0,19$ & 0,15 & 1 \\
\hline
\end{tabular}

\subsubsection{Análise de Componentes Principais da Fase INTERSTICIAL}

No estudo da fase intersticial nas comunidades, foram consideradas as variáveis: $\mathrm{Mg}, \mathrm{Al}, \mathrm{P}, \mathrm{Ca}, \mathrm{Mn}, \mathrm{Fe}, \mathrm{Ni}, \mathrm{Cu}$ e Ba. A Tabela 6.22 apresenta um resumo da análise estatística obtida inicialmente, onde são mostrados os autovalores obtidos para cada componente, depois de submeter a matriz à rotação Varimax (onde o valor de corte é igual a 1), podemos observar qual é a fração explicada por cada componente e a porcentagem acumulada.

Em função do critério dos autovalores acima de 1, os 3 componentes foram considerados como significativos, sendo que a porcentagem da variabilidade acumulada explicada por elas é $72 \%$ da variabilidade total dos elementos. Observa-se que o primeiro componente é responsável por $37,5 \%$, o segundo $21 \%$, o terceiro $14 \%$ da variabilidade dos dados, indicando que cada vez menos variabilidade é explicada, à medida que o autovalor da componente diminui.

Tabela 6.22 - Análise de componentes principais nos elementos da fase intersticial

\begin{tabular}{cccc}
\hline Fator & $\begin{array}{c}\text { Autovalor da } \\
\text { componente }\end{array}$ & $\begin{array}{c}\text { Variabilidade } \\
\text { explicada pela } \\
\text { componente }(\%)\end{array}$ & $\begin{array}{c}\text { Variabilidade total } \\
\text { explicada }\end{array}$ \\
\hline 1 & 3,4 & 37,4 & 37,4 \\
2 & 1,9 & 20,8 & 58,2 \\
3 & 1,2 & 13,7 & 72,0 \\
\hline
\end{tabular}


A Tabela 6.23 apresenta os componentes retidos e sua matriz dos fatores e a comunalidade para cada variável, isto é, o quanto de cada variável foi explicada pelo modelo proposto pela ACP.

Tabela 6.23 - Resultados da análise de componentes principais para a fase intersticial

\begin{tabular}{lcccc}
\hline Elemento & Fator 1 & Fator 2 & Fator 3 & $\begin{array}{c}\text { Comunalidade } \\
(\%)\end{array}$ \\
\hline $\mathrm{Mg}$ & 0,93 & $-0,09$ & 0,10 & 88 \\
$\mathrm{Al}$ & $-0,54$ & $-0,48$ & 0,30 & 62 \\
$\mathrm{P}$ & 0,24 & 0,54 & 0,60 & 71 \\
$\mathrm{Ca}$ & 0,94 & $-0,07$ & 0,13 & 91 \\
$\mathrm{Mn}$ & 0,86 & 0,24 & 0,10 & 81 \\
$\mathrm{Fe}$ & 0,38 & 0,21 & 0,57 & 51 \\
$\mathrm{Ni}$ & 0,09 & 0,29 & $-0,71$ & 60 \\
$\mathrm{Cu}$ & $-0,15$ & 0,81 & 0,09 & 69 \\
$\mathrm{Ba}$ & $-0,14$ & $-0,86$ & 0,10 & 76 \\
\hline
\end{tabular}

Com intuito de auxiliar a interpretação da análise ACP, foi montada a Tabela 6.24, que contém as informações e salienta os elementos retidos em cada componente, a importância de cada componente na explicação da variabilidade dos elementos na água bruta.

Tabela 6.24 - Esquematização das informações da ACP para os elementos da fase intersticial

\begin{tabular}{llc} 
& \multicolumn{2}{c}{ ACP } \\
\cline { 3 - 3 } & Elementos retidos & Variabilidade explicada (\%) \\
\hline Fator 1 & $\mathrm{Mg}, \mathrm{Ca}$ e $\mathrm{Mn}$ & 37,4 \\
Fator 2 & $\mathrm{Cu}$ e Ba & 20,8 \\
Fator 3 & $\mathrm{P} \mathrm{e} \mathrm{Ni}$ & 13,7 \\
\hline
\end{tabular}

Observando a Tabela 6.24 nota-se que, apesar da variabilidade total explicada ser de $72 \%$, o primeiro fator explica $37,5 \%$ da variabilidade da fase intersticial. Os elementos retidos sugerem que o fator 1 está associado a fatores mineralógicos como apresentado na Tabela A.10 e pela região apresentar o Complexo granito-gnaisse. O segundo e terceiro fatores sugerem estar associado rochas metabasica, meta-ultrabasica e em rochas alcalinas de Poços de Caldas, com exceção do $\mathrm{P}$ que possivelmente também provém de efluentes domésticos. 


\subsubsection{Análise de Correlação dos Elementos Metálicos da FASE INTERSTICIAL}

Com o objetivo de verificar a hipótese de que a concentração dos metais da fase sobrenadante poderia estar ligado a matriz mineralógica da região, realizou-se o estudo para analisar se existe correlação entre os metais.

Na Tabela 6.25 são apresentados os coeficientes de correlação entre os metais. Para a matriz do $\mathrm{Mg}$ verificasse boa correlação para $\mathrm{Ca}(0,85)$ e $\mathrm{Mn}(0,70)$, o $\mathrm{Ca}$ e o $\mathrm{Mn}$ possivelmente provêm de matriz mineralógica.

Tabela 6.25 - Matriz de correlação entre dos metais da fase intersticial

\begin{tabular}{|l|c|c|c|c|c|c|c|c|c|}
\hline & $\mathrm{Mg}$ & $\mathrm{Al}$ & $\mathrm{P}$ & $\mathrm{Ca}$ & $\mathrm{Mn}$ & $\mathrm{Fe}$ & $\mathrm{Ni}$ & $\mathrm{Cu}$ & $\mathrm{Ba}$ \\
\hline $\mathrm{Mg}$ & 1 & $-0,33$ & 0,27 & 0,89 & 0,75 & 0,32 & 0,03 & $-0,13$ & $-0,02$ \\
\hline $\mathrm{Al}$ & $-0,33$ & 1 & $-0,20$ & $-0,39$ & $-0,48$ & $-0,10$ & $-0,15$ & $-0,12$ & 0,56 \\
\hline $\mathrm{P}$ & 0,27 & $-0,20$ & 1 & 0,24 & 0,37 & 0,36 & $-0,15$ & 0,36 & $-0,37$ \\
\hline $\mathrm{Ca}$ & 0,89 & $-0,39$ & 0,24 & 1 & 0,76 & 0,37 & $-0,04$ & $-0,13$ & $-0,07$ \\
\hline $\mathrm{Mn}$ & 0,75 & $-0,48$ & 0,37 & 0,76 & 1 & 0,38 & 0,07 & 0,15 & $-0,25$ \\
\hline $\mathrm{Fe}$ & 0,32 & $-0,10$ & 0,36 & 0,37 & 0,38 & 1 & $-0,08$ & 0,12 & $-0,15$ \\
\hline $\mathrm{Ni}$ & 0,03 & $-0,15$ & $-0,15$ & $-0,04$ & 0,07 & $-0,08$ & 1 & 0,21 & $-0,19$ \\
\hline $\mathrm{Cu}$ & $-0,13$ & $-0,12$ & 0,36 & $-0,13$ & 0,15 & 0,12 & 0,21 & 1 & $-0,50$ \\
\hline $\mathrm{Ba}$ & $-0,02$ & 0,56 & $-0,37$ & $-0,07$ & $-0,25$ & $-0,15$ & $-0,19$ & $-0,50$ & 1 \\
\hline
\end{tabular}

\subsubsection{ANÁlise de COMPONENTES PrinCIPAIS dA Digestão}

No estudo da digestão nas comunidades, foram consideradas as variáveis: $\mathrm{Mg}, \mathrm{Al}$, $\mathrm{P}, \mathrm{Ca}, \mathrm{Cr}, \mathrm{Mn}, \mathrm{Fe}, \mathrm{Co}, \mathrm{Ni}, \mathrm{Cu}, \mathrm{Zn}, \mathrm{Cd}, \mathrm{Ba}$ e Pb. A Tabela 6.26 apresenta um resumo da análise estatística obtida inicialmente, onde são mostrados os autovalores obtidos para cada componente, depois de submeter a matriz à rotação Varimax (onde o valor de corte é igual a 1), podemos observar qual é a fração explicada por cada componente e a porcentagem acumulada.

Em função do critério dos autovalores acima de 1, os 5 componentes foram considerados como significativos, sendo que a porcentagem da variabilidade acumulada explicada por elas é $79 \%$ da variabilidade total dos elementos. Observa-se que o primeiro 
componente é responsável por $35 \%$, o segundo $15 \%$, o terceiro $12 \%$, o quarto $9 \%$ e o quinto $8 \%$ da variabilidade dos dados, indicando que cada vez menos variabilidade é explicada, à mediada que o autovalor da componente diminui.

Tabela 6.26 - Análise de componentes principais nos elementos da digestão

\begin{tabular}{cccc}
\hline Fator & $\begin{array}{c}\text { Autovalor da } \\
\text { componente }\end{array}$ & $\begin{array}{c}\text { Variabilidade } \\
\text { explicada pela } \\
\text { componente }(\%)\end{array}$ & $\begin{array}{c}\text { Variabilidade total } \\
\text { explicada }\end{array}$ \\
\hline 1 & 4,9 & 34,9 & 34,9 \\
2 & 2,1 & 15,2 & 50,1 \\
3 & 1,6 & 11,8 & 61,9 \\
4 & 1,2 & 8,7 & 70,6 \\
5 & 1,1 & 8,0 & 78,6 \\
\hline
\end{tabular}

A Tabela 6.27 apresenta os componentes retidos e sua matriz dos fatores e a comunalidade para cada variável, isto é, o quanto de cada variável foi explicada pelo modelo proposto pela ACP.

Tabela 6.27 - Resultados da análise de componentes principais para a fase digestão

\begin{tabular}{lcccccc}
\hline Elemento & Fator 1 & Fator 2 & Fator 3 & Fator 4 & Fator 5 & $\begin{array}{c}\text { Comunalidade } \\
(\%)\end{array}$ \\
\hline $\mathrm{Mg}$ & $-0,01$ & 0,56 & 0,72 & 0,10 & 0,04 & 83 \\
$\mathrm{Al}$ & 0,09 & 0,74 & $-0,34$ & $-0,14$ & 0,39 & 84 \\
$\mathrm{P}$ & 0,05 & $-0,04$ & $-0,01$ & 0,94 & 0,02 & 88 \\
$\mathrm{Ca}$ & $-0,04$ & 0,93 & 0,11 & $-0,09$ & $-0,07$ & 89 \\
$\mathrm{Cr}$ & 0,40 & 0,57 & 0,16 & 0,39 & $-0,08$ & 67 \\
$\mathrm{Mn}$ & 0,93 & 0,14 & $-0,10$ & $-0,08$ & $-0,07$ & 91 \\
$\mathrm{Fe}$ & 0,75 & 0,01 & $-0,07$ & $-0,05$ & $-0,08$ & 58 \\
$\mathrm{Co}$ & 0,91 & 0,15 & 0,06 & 0,27 & 0,08 & 92 \\
$\mathrm{Ni}$ & $-0,06$ & $-0,05$ & 0,72 & $-0,19$ & 0,10 & 57 \\
$\mathrm{Cu}$ & 0,75 & 0,02 & 0,44 & 0,09 & 0,21 & 81 \\
$\mathrm{Zn}$ & 0,00 & 0,03 & 0,03 & 0,03 & 0,95 & 91 \\
$\mathrm{Cd}$ & 0,71 & 0,32 & $-0,06$ & 0,53 & 0,07 & 89 \\
$\mathrm{Ba}$ & 0,49 & 0,78 & 0,07 & 0,22 & $-0,01$ & 90 \\
$\mathrm{~Pb}$ & $-0,07$ & 0,01 & $-0,59$ & $-0,10$ & 0,09 & 37 \\
\hline
\end{tabular}

Com intuito de auxiliar a interpretação da análise ACP, foi montada a Tabela 6.28, que contém as informações e salienta os elementos retidos em cada componente, a importância de cada componente na explicação da variabilidade dos elementos na água bruta. 
Tabela 6.28 - Esquematização das informações da ACP para os elementos da fase digestão

\begin{tabular}{llc} 
& \multicolumn{2}{c}{ ACP } \\
\cline { 3 - 3 } & Elementos retidos & Variabilidade explicada (\%) \\
\hline Fator 1 & $\mathrm{Mn}, \mathrm{Fe}, \mathrm{Co}, \mathrm{Cu}$ e Cd & 34,9 \\
Fator 2 & $\mathrm{Al}, \mathrm{Ca}$ e Ba & 15,2 \\
Fator 3 & $\mathrm{Mg} \mathrm{e} \mathrm{Ni}$ & 11,8 \\
Fator 4 & $\mathrm{P}$ & 8,7 \\
Fator 5 & $\mathrm{Zn}$ & 8,0 \\
\hline
\end{tabular}

Observando a Tabela 6.28 nota-se que, apesar da variabilidade total explicada ser de $79 \%$, o primeiro fator explica $62 \%$ da variabilidade da digestão. Os elementos retidos sugerem que os fatores 1, 2 e 3 que estão associados ao Complexo Granito-gnaisse, a rochas metabasicas e meta-ultrabasicas que pertence a matriz mineralógica. O quarto fator sugere que estes possivelmente provém tanto da apatita que se encontra no Complexo de Poços de Caldas quanto de efluentes domésticos

\subsubsection{Análise de Correlação dos Elementos Metálicos da FASE DigeStão}

Com o objetivo de verificar a hipótese de que a concentração dos metais da fase biodisponível poderia estar ligado a matriz mineralógica da região, realizou-se o estudo para analisar se existe correlação entre os metais.

Na Tabela 6.29 são apresentados os coeficientes de correlação entre os metais. A grande maioria das correlações não apresenta uma forte correlação exceto para $\mathrm{Mn} / \mathrm{Co}$, $\mathrm{Co} / \mathrm{Cd}$, uma correlação mediana para $\mathrm{Co} / \mathrm{Cu}, \mathrm{Cd} / \mathrm{Ba}$ e $\mathrm{Ca} / \mathrm{Ba}$ e poucas correlações para $\mathrm{Mg} / \mathrm{Ca}, \mathrm{Al} / \mathrm{Ca}, \mathrm{Al} / \mathrm{Ba}, \mathrm{P} / \mathrm{Cd}, \mathrm{Cr} / \mathrm{Co}, \mathrm{Cr} / \mathrm{Cd}, \mathrm{Mn} / \mathrm{Cu}, \mathrm{Mn} / \mathrm{Cd}, \mathrm{Fe} / \mathrm{Co}$ e $\mathrm{Cu} / \mathrm{Cd}$. Todos estes elementos correlacionados fazem perfeitamente parte da geoquímica da região. 
Tabela 6.29 - Matriz de correlação entre os metais da digestão

\begin{tabular}{|l|c|c|c|c|c|c|c|c|c|c|c|c|c|c|}
\hline & $\mathrm{Mg}$ & $\mathrm{Al}$ & $\mathrm{P}$ & $\mathrm{Ca}$ & $\mathrm{Cr}$ & $\mathrm{Mn}$ & $\mathrm{Fe}$ & $\mathrm{Co}$ & $\mathrm{Ni}$ & $\mathrm{Cu}$ & $\mathrm{Zn}$ & $\mathrm{Cd}$ & $\mathrm{Ba}$ & $\mathrm{Pb}$ \\
\hline $\mathrm{Mg}$ & 1 & 0,14 & 0,05 & 0,54 & 0,44 & $-0,04$ & $-0,03$ & 0,14 & 0,41 & 0,36 & 0,07 & 0,19 & 0,47 & $-0,28$ \\
\hline $\mathrm{Al}$ & 0,14 & 1 & $-0,10$ & 0,60 & 0,25 & 0,21 & 0,07 & 0,16 & $-0,14$ & 0,00 & 0,30 & 0,32 & 0,51 & 0,18 \\
\hline $\mathrm{P}$ & 0,05 & $-0,10$ & 1 & $-0,05$ & 0,25 & 0,01 & 0,08 & 0,29 & $-0,05$ & 0,09 & 0,02 & 0,52 & 0,18 & $-0,04$ \\
\hline $\mathrm{Ca}$ & 0,54 & 0,60 & $-0,05$ & 1 & 0,44 & 0,12 & 0,04 & 0,07 & 0,06 & 0,00 & 0,00 & 0,17 & 0,70 & $-0,09$ \\
\hline $\mathrm{Cr}$ & 0,44 & 0,25 & 0,25 & 0,44 & 1 & 0,39 & 0,27 & 0,50 & $-0,17$ & 0,46 & 0,02 & 0,58 & 0,68 & $-0,20$ \\
\hline $\mathrm{Mn}$ & $-0,04$ & 0,21 & 0,01 & 0,12 & 0,39 & 1 & 0,65 & 0,84 & $-0,12$ & 0,63 & $-0,07$ & 0,63 & 0,53 & $-0,01$ \\
\hline $\mathrm{Fe}$ & $-0,03$ & 0,07 & 0,08 & 0,04 & 0,27 & 0,65 & 1 & 0,56 & $-0,09$ & 0,36 & 0,00 & 0,48 & 0,32 & $-0,10$ \\
\hline $\mathrm{Co}$ & 0,14 & 0,16 & 0,29 & 0,07 & 0,50 & 0,84 & 0,56 & 1 & $-0,02$ & 0,75 & 0,06 & 0,87 & 0,65 & $-0,07$ \\
\hline $\mathrm{Ni}$ & 0,41 & $-0,14$ & $-0,05$ & 0,06 & $-0,17$ & $-0,12$ & $-0,09$ & $-0,02$ & 1 & 0,18 & 0,01 & $-0,09$ & $-0,03$ & $-0,10$ \\
\hline $\mathrm{Cu}$ & 0,36 & 0,00 & 0,09 & 0,00 & 0,46 & 0,63 & 0,36 & 0,75 & 0,18 & 1 & 0,18 & 0,54 & 0,41 & $-0,21$ \\
\hline $\mathrm{Zn}$ & 0,07 & 0,30 & 0,02 & 0,00 & 0,02 & $-0,07$ & 0,00 & 0,06 & 0,01 & 0,18 & 1 & 0,04 & 0,03 & $-0,05$ \\
\hline $\mathrm{Cd}$ & 0,19 & 0,32 & 0,52 & 0,17 & 0,58 & 0,63 & 0,48 & 0,87 & $-0,09$ & 0,54 & 0,04 & 1 & 0,73 & $-0,01$ \\
\hline $\mathrm{Ba}$ & 0,47 & 0,51 & 0,18 & 0,70 & 0,68 & 0,53 & 0,32 & 0,65 & $-0,03$ & 0,41 & 0,03 & 0,73 & 1 & $-0,07$ \\
\hline $\mathrm{Pb}$ & $-0,28$ & 0,18 & $-0,04$ & $-0,09$ & $-0,20$ & $-0,01$ & $-0,10$ & $-0,07$ & $-0,10$ & $-0,21$ & $-0,05$ & $-0,01$ & $-0,07$ & 1 \\
\hline
\end{tabular}

\subsubsection{COMParação ENTRE OS Resultados DA Fase SOBRENADANTE E INTERSTICIAL}

Em função dos resultados obtidos para as fases sobrenadante e intersticial das comunidades podemos verificar nas análises estatísticas de $\mathrm{ACP}$ e correlação que não existe uma diferença significativa entre elas.

$\mathrm{Na}$ análise de ACP podemos verificar que foram retidos os mesmos números de fatores e, os elementos que as compõem se distribuem de uma forma geral idêntica, exceto no caso do $\mathrm{P}$ e Fe que se deslocaram do primeiro fator (proveniente de matriz mineralógica) para o terceiro fator que sugere que estes componentes possivelmente provêm do minério apatita e que não sofre facilmente uma lixiviação, contendo o $\mathrm{P}$ e o Fe em sua forma mineralógica.

O mesmo comportamento pode também ser verificado na análise de correlação entre as matrizes $\mathrm{Mg} / \mathrm{Ca}$ e $\mathrm{Ca} / \mathrm{Mn}$ que também sugere que provêm de matriz mineralógica. 


\subsubsection{Análise Estatística dos Metais COM A MAtéria ORGÂNICA}

Inicialmente foi realizando a análise estatística de componentes principais nos resultados obtidos para os metais dos sedimentos nas comunidades estudadas para depois, avaliarmos a correlação existente entre elas. Como as associações com a matéria orgânica (M.O.) estão fortemente correlacionadas com a biodisponibilidade, os valores de matéria orgânica foram incluídos na análise. A matéria orgânica foi determinada apenas nas amostras de sedimento da coleta de Abril/99.

No estudo da digestão com a matéria orgânica nas comunidades, foram consideradas as variáveis: $\mathrm{Mg}, \mathrm{Al}, \mathrm{P}, \mathrm{Ca}, \mathrm{Cr}, \mathrm{Mn}, \mathrm{Fe}, \mathrm{Co}, \mathrm{Cu}, \mathrm{Cd}, \mathrm{Ba}, \mathrm{Pb}$ e matéria orgânica. A Tabela 6.30 apresenta um resumo da avaliação estatística obtida inicialmente, onde são mostrados os autovalores obtidos para cada componente, depois de submeter a matriz à rotação Varimax (onde o valor de corte é igual a 1), qual é a fração explicada por cada componente e a porcentagem acumulada.

Em função do critério dos autovalores acima de 1, os 3 componentes foram considerados como significativos, sendo que a porcentagem da variabilidade acumulada explicada por elas é $80 \%$ da variabilidade total dos elementos. Observa-se que o primeiro componente é responsável por $43 \%$, o segundo $21,5 \%$, o terceiro $16 \%$ da variabilidade dos dados, indicando que cada vez menos variabilidade é explicada, à mediada que o autovalor da componente diminui.

Tabela 6.30 - Análise de componentes principais nos elementos da fração digestão com matéria orgânica

\begin{tabular}{cccc}
\hline Fator & $\begin{array}{c}\text { Autovalor da } \\
\text { componente }\end{array}$ & $\begin{array}{c}\text { Variabilidade } \\
\text { explicada pela } \\
\text { componente }(\%)\end{array}$ & $\begin{array}{c}\text { Variabilidade total } \\
\text { explicada }\end{array}$ \\
\hline 1 & 5,6 & 42,8 & 42,8 \\
2 & 2,8 & 21,4 & 64,2 \\
3 & 2,1 & 16,1 & 80,3 \\
\hline
\end{tabular}

A Tabela 6.31 apresenta os componentes retidos e sua matriz dos fatores e a comunalidade para cada variável, isto é, o quanto de cada variável foi explicada pelo modelo proposto pela ACP. 
Tabela 6.31 - Resultados da análise de componentes principais para a fração digestão e matéria orgânica

\begin{tabular}{lcccc}
\hline Elemento & Fator 1 & Fator 2 & Fator 3 & $\begin{array}{c}\text { Comunalidade } \\
(\%)\end{array}$ \\
\hline $\mathrm{Mg}$ & 0,64 & 0,11 & 0,59 & 77 \\
$\mathrm{Al}$ & 0,87 & $-0,09$ & $-0,39$ & 91 \\
$\mathrm{P}$ & $-0,01$ & $-0,15$ & 0,79 & 65 \\
$\mathrm{Ca}$ & 0,96 & $-0,04$ & $-0,04$ & 92 \\
$\mathrm{Cr}$ & 0,75 & 0,25 & 0,27 & 69 \\
$\mathrm{Mn}$ & 0,08 & 0,94 & $-0,10$ & 91 \\
$\mathrm{Fe}$ & $-0,05$ & 0,90 & $-0,16$ & 84 \\
$\mathrm{Co}$ & 0,25 & 0,89 & 0,13 & 88 \\
$\mathrm{Cu}$ & 0,09 & 0,72 & 0,44 & 72 \\
$\mathrm{Cd}$ & 0,74 & 0,60 & 0,09 & 91 \\
$\mathrm{Ba}$ & 0,98 & 0,14 & 0,04 & 98 \\
$\mathrm{~Pb}$ & 0,03 & $-0,11$ & $-0,65$ & 44 \\
$\mathrm{M} . \mathrm{O}$. & 0,59 & 0,50 & $-0,47$ & 82 \\
\hline
\end{tabular}

Com intuito de auxiliar a interpretação da análise ACP, foi montada a Tabela 6.32, que contém as informações e salienta os elementos retidos em cada componente, a importância de cada componente na explicação da variabilidade dos elementos da fração digestão.

Tabela 6.32 - Esquematização das informações da ACP para os elementos da digestão e matéria orgânica

\begin{tabular}{llc} 
& \multicolumn{2}{c}{ ACP } \\
\cline { 2 - 3 } & Elementos retidos & Variabilidade explicada (\%) \\
\hline Fator 1 & Al, Ca, Cr, Cd, Ba e M.O. & 42,8 \\
Fator 2 & Mn, Fe, Co, Cu e M.O. & 21,4 \\
Fator 3 & P, Pb e M.O. & 16,1 \\
\hline
\end{tabular}

Observando a Tabela 6.32 nota-se que, apesar da variabilidade total explicada ser de $80 \%$, o primeiro fator explica $43 \%$ da variabilidade da digestão com a matéria orgânica. Os elementos retidos sugerem que o fator 1 e 2 estão associados a matriz mineralógica. Os elementos $\mathrm{Cr}, \mathrm{Cd}$ e $\mathrm{Cu}$ aparecem nestes fatores, mas com uma intensidade menor em comparação com o restante. $\mathrm{O}$ terceiro fator sugere que os elementos $\mathrm{P}$ e $\mathrm{Pb}$ provêm de uma fonte mineralógica diferente. A matéria orgânica aparece nos três fatores, influenciando na mesma intensidade, não podendo explicar muito. Os elementos que estão em negrito apresentam uma intensidade alta. 


\subsubsection{ANÁlise de CoRrelaÇão dos Elementos da Digestão COM A MATÉRIA ORGÂNICA}

Com o objetivo de verificar a hipótese de que a concentração da matéria orgânica se correlacionaria com os metais da digestão, realizou-se o estudo para analisar se existe correlação entre os metais.

Na Tabela 6.33 são apresentados os coeficientes de correlação entre os metais da fração digestão com a componente da matéria orgânica. Podemos observar mais claramente que a matéria orgânica apresenta correlação de intensidade média com $\mathrm{Al}, \mathrm{Ca}$, Mn, Co, Cd e Ba, que na análise de ACP. Na análise de ACP estes elementos estavam associados ao fator mineralógico e a matéria orgânica esta distribuída quase que uniforme.

Tabela 6.33 - Matriz de correlação entre dos metais da digestão com matéria orgânica

\begin{tabular}{|l|c|c|c|c|c|c|c|c|c|c|c|c|c|}
\hline & $\mathrm{Mg}$ & $\mathrm{Al}$ & $\mathrm{P}$ & $\mathrm{Ca}$ & $\mathrm{Cr}$ & $\mathrm{Mn}$ & $\mathrm{Fe}$ & $\mathrm{Co}$ & $\mathrm{Cu}$ & $\mathrm{Cd}$ & $\mathrm{Ba}$ & $\mathrm{Pb}$ & $\mathrm{M} . \mathrm{O}$ \\
\hline $\mathrm{Mg}$ & 1 & 0,27 & 0,32 & 0,51 & 0,50 & 0,04 & $-0,11$ & 0,45 & 0,35 & 0,69 & 0,65 & $-0,31$ & 0,14 \\
\hline $\mathrm{Al}$ & 0,27 & 1 & $-0,25$ & 0,88 & 0,46 & 0,07 & $-0,02$ & 0,02 & $-0,13$ & 0,54 & 0,82 & 0,24 & 0,62 \\
\hline $\mathrm{P}$ & 0,32 & $-0,25$ & 1 & $-0,03$ & 0,21 & $-0,13$ & $-0,19$ & $-0,10$ & 0,21 & $-0,02$ & 0,02 & $-0,28$ & $-0,43$ \\
\hline $\mathrm{Ca}$ & 0,51 & 0,88 & $-0,03$ & 1 & 0,70 & 0,10 & 0,02 & 0,12 & 0,01 & 0,63 & 0,95 & $-0,08$ & 0,52 \\
\hline $\mathrm{Cr}$ & 0,50 & 0,46 & 0,21 & 0,70 & 1 & 0,26 & 0,15 & 0,39 & 0,42 & 0,66 & 0,76 & $-0,12$ & 0,44 \\
\hline $\mathrm{Mn}$ & 0,04 & 0,07 & $-0,13$ & 0,10 & 0,26 & 1 & 0,97 & 0,76 & 0,58 & 0,61 & 0,23 & $-0,05$ & 0,49 \\
\hline $\mathrm{Fe}$ & $-0,11$ & $-0,02$ & $-0,19$ & 0,02 & 0,15 & 0,97 & 1 & 0,67 & 0,44 & 0,46 & 0,10 & $-0,11$ & 0,41 \\
\hline $\mathrm{Co}$ & 0,45 & 0,02 & $-0,10$ & 0,12 & 0,39 & 0,76 & 0,67 & 1 & 0,70 & 0,77 & 0,35 & $-0,13$ & 0,62 \\
\hline $\mathrm{Cu}$ & 0,35 & $-0,13$ & 0,21 & 0,01 & 0,42 & 0,58 & 0,44 & 0,70 & 1 & 0,52 & 0,19 & $-0,24$ & 0,25 \\
\hline $\mathrm{Cd}$ & 0,69 & 0,54 & $-0,02$ & 0,63 & 0,66 & 0,61 & 0,46 & 0,77 & 0,52 & 1 & 0,81 & 0,00 & 0,65 \\
\hline $\mathrm{Ba}$ & 0,65 & 0,82 & 0,02 & 0,95 & 0,76 & 0,23 & 0,10 & 0,35 & 0,19 & 0,81 & 1 & $-0,03$ & 0,61 \\
\hline $\mathrm{Pb}$ & $-0,31$ & 0,24 & $-0,28$ & $-0,08$ & $-0,12$ & $-0,05$ & $-0,11$ & $-0,13$ & $-0,24$ & 0,00 & $-0,03$ & 1 & 0,23 \\
\hline $\mathrm{M} . \mathrm{O} .0,14$ & 0,62 & $-0,43$ & 0,52 & 0,44 & 0,49 & 0,41 & 0,62 & 0,25 & 0,65 & 0,61 & 0,23 & 1 \\
\hline
\end{tabular}




\subsection{Comparação entre Resultados Encontrados para Metais POTENCIALMENTE BIODISPONIVEIS}

Para auxiliar na análise dos resultados de sedimento obtidos neste trabalho, foi elaborada a Tabela 6.34 contendo um resumo comparativo dos resultados obtidos neste trabalho e em trabalhos reportados na literatura [BEVELACQUA, 1996; GATTI, 1997; FIZMAN et al., 1984].

Analisando esta Tabela 6.34 e comparando os resultados encontrados neste estudo com os demais estudos, observa-se que, de maneira geral, os valores de metais pesados $(\mathrm{Cr}, \mathrm{Ni}, \mathrm{Cu}, \mathrm{Zn}, \mathrm{Cd}$ e $\mathrm{Pb}$ ) estão abaixo dos valores encontrados em ambientes sabidamente impactados antropicamente. A primeira comparação a ser feita é com o estudo de GATTI [1997] realizado em duas lagoas no rio Mogi-Guaçu, um local próximo ao local donde foi realizado este trabalho, onde os valores encontrados foram superiores aos do presente estudo, exceto para Ca e Mn.

A comparação com os valores de LIMA apud GATTI [1997], permite observar que todos os valores encontrados no presente trabalho estão próximos aos reportados por este autor, exceto pata os elementos $\mathrm{Mn}$ e Fe. A similaridade de resultados possivelmente pode ser explicada pelo motivo dos estudo de LIMA apud GATTI [1997] também ser em uma área preservada (Estação Ecológica de Jataí).

Comparando os valores encontrados por BEVILACQUA [1996], observa-se que os valores encontrados para Barra Bonita estão próximos ao do presente trabalho, exceto para o Mn. Em Pirapora os valores encontrados por BEVILACQUA [1996] estão superiores ao indicando um local impactado com o próprio autor descreve, quando ele compara ao folhelho médio.

A comparação com os valores encontrados por FIZMAN et al. [1984], permite observar que todos os valores encontrados no presente trabalho estão abaixo dos reportados por este autor para a Lagoa de Sepetiba, conforme pode ser observado na Tabela 6.34, no entanto, estão acima em relação aos valores reportados para Angra dos Reis. Em relação a este estudo os resultados da Baia de Sepetiba foram muito mais elevados ao obtidos neste estudo. Enquanto, os valores encontrados em Angra dos Reis tem um comportamento 
aleatório. O $\mathrm{Cr}$ e o $\mathrm{Zn}$ apresentam valores abaixo, o $\mathrm{Cu}$ e o $\mathrm{Pb}$ estão na mesma faixa de concentração, e o $\mathrm{Cd}$ apresenta valores muito acima do que o encontrado neste estudo.

Por último, comparando-se os resultados do presente estudo com os encontrados na Lagoa de Jacarepaguá e seus tributários FERNANDES et al. [1994] apud GATTI [1997], nota-se grande variação nas concentrações encontradas pelos autores. Comparando os resultados das comunidades estudadas com os valores máximo e mínimo da Lagoa de Jacarepaguá, podemos observar que os valores encontrados neste estudo estão numa forma geral, bem abaixo, exceto para Mn.

Em relação às áreas de captação estudadas, pertencentes as bacias hidrográficas do rio Mogi-Guaçu e do rio Pardo, não apresentam indícios de impactamento ambiental por metais tóxicos, destacando-se na região a presença acentuada de Mn e Fe, proveniente da matriz mineralógica. 
Tabela 6.34 - Comparação entre as concentrações de metais na fase biodisponível em $\mu \mathrm{g}$ $\mathrm{g}^{-1}$ de sedimento seco, em vários trabalhos da literatura com os resultados nas comunidades estudadas encontrados neste trabalho

\begin{tabular}{|c|c|c|c|c|c|c|c|c|c|c|c|c|c|c|c|}
\hline \multirow{2}{*}{$\begin{array}{l}\text { Sedimento } \\
\text { de lagoas, } \\
\text { rios e } \\
\text { córregos }\end{array}$} & \multicolumn{15}{|c|}{ Concentração $\left(\mu \mathrm{g} \mathrm{g}^{-1}\right)$} \\
\hline & $\mathrm{Mg}$ & Al & $\mathrm{P}$ & $\mathrm{Ca}$ & $\mathrm{Cr}$ & $\mathrm{Mn}$ & $\mathrm{Fe}$ & $\mathrm{Co}$ & $\mathrm{Ni}$ & $\mathrm{Cu}$ & $\mathrm{Zn}$ & $\mathrm{Ag}$ & $\mathrm{Cd}$ & $\mathrm{Ba}$ & $\mathrm{Pb}$ \\
\hline $\begin{array}{l}\text { Rio Jaguari } \\
\text { Mirim (*) }\end{array}$ & 136 & 436 & 18,9 & 826 & 1,1 & 763 & 3134 & 3,5 & 1,0 & 7,7 & 10,4 & 2,6 & 0,3 & 1358 & 4,7 \\
\hline Rio Canoas(*) & 205 & 349 & 8,0 & 987 & 1,7 & 499 & 3144 & 4,3 & 1,7 & 6,5 & 5,5 & 0,14 & 1,5 & 973 & 2,3 \\
\hline $\begin{array}{l}\text { Ribeirão da } \\
\text { Capelinha (*) }\end{array}$ & 120 & 625 & 8,1 & 743 & 1,2 & 493 & 10721 & 3,7 & 1,7 & 2,8 & 7,1 & n.d & 0,4 & 898 & 5,7 \\
\hline $\begin{array}{l}\text { Ribeirão da } \\
\text { Prata }(*)\end{array}$ & 91 & 1058 & 6,9 & 1006 & 2,0 & 4310 & 18386 & 615,5 & 4,0 & 11,1 & 14,8 & 0,14 & 1,3 & 2983 & 5,9 \\
\hline $\begin{array}{l}\text { Córrego da } \\
\text { Fartura }(*)\end{array}$ & 99 & 1289 & 11,3 & 818 & 1,1 & 1005 & 3973 & 4,6 & 1,8 & 4,7 & 19,3 & n.d & 0,5 & 1090 & 3,0 \\
\hline $\begin{array}{l}\text { Córrego dos } \\
\text { Cascais (*) }\end{array}$ & 55 & 1003 & 3 & 503 & 0,6 & 520 & 769 & 1,7 & 0,6 & 0,6 & 10,8 & 0,04 & 0,2 & 782 & 3,5 \\
\hline $\begin{array}{l}\text { Mina da } \\
\text { Encosta }(*)\end{array}$ & 107 & 740 & 3,7 & 767 & 1,0 & 686 & 3672 & 2,5 & 1,2 & 1,9 & 6,6 & n.d & 0,4 & 876 & 6,3 \\
\hline $\begin{array}{l}\text { rrego Sto } \\
\text { brósio }(*)\end{array}$ & 102 & 881 & 4,3 & 927 & 0,9 & 565 & 1983 & 2,6 & 1,3 & 3,4 & 5,5 & n.d & 5,8 & 819 & 3,0 \\
\hline $\begin{array}{l}\text { Rio do Peixe } \\
(*)\end{array}$ & 291 & 2231 & 7,3 & 4151 & 2,0 & 1232 & 6389 & 3,3 & 2,1 & 2,9 & 6,0 & 0,03 & 0,7 & 3669 & 4,6 \\
\hline $\begin{array}{l}\text { Ribeirão Doce } \\
(*)\end{array}$ & 168 & 863 & 14 & 1280 & 1,7 & 1809 & 11083 & 9,1 & 3,0 & 5,8 & 7,1 & 0,05 & 1,0 & 3635 & 5,9 \\
\hline $\begin{array}{l}\text { rrego do } \\
\operatorname{dim}(*)\end{array}$ & 101 & 370 & 15,0 & 1004 & 0,9 & 340 & 1656 & 1,8 & 1,1 & 1,9 & 3,4 & n.d & 0,2 & 916 & 2,4 \\
\hline & 120 & 637 & 4,0 & 637 & 1,5 & 312 & 5907 & 5,4 & 2,3 & 4,5 & 7,0 & n.d & 0,4 & 1211 & 4,5 \\
\hline Rio Verde (*) & 399 & 1248 & 52 & 809 & 1,2 & 628 & 5372 & 5,4 & $4 \quad 2,3$ & $3 \quad 3,7$ & 6,8 & 0,15 & 1,8 & 2085 & 4,5 \\
\hline $\begin{array}{l}\text { Lagoa do } \\
\text { Infernão }{ }^{a}\end{array}$ & $\bullet$ & 2942 & 345 & 200 & 7,33 & 104 & 13251 & $\bullet$ & 6,90 & $\begin{array}{ll}0 & 17,9\end{array}$ & 31,5 & $\bullet$ & 0,44 & $\bullet$ & 5,24 \\
\hline $\begin{array}{l}\text { Lagoa do } \\
\text { Frutal }^{a}\end{array}$ & - & 2297 & 64,6 & 230 & 7,96 & 255 & 12991 & - & 3,76 & 617,3 & 21,4 & - & 0,35 & - & 4,41 \\
\hline $\begin{array}{l}\text { Lagoa do } \\
\text { Infernão }\end{array}$ & - & $\bullet$ & • & • & 1,40 & 120 & 4300 & $\bullet$ & 1,9 & 8,50 & 3,90 & - & 0,09 & - & 2,60 \\
\hline L. do Óleo ${ }^{b}$ & - & • & • & - & 0,94 & 120 & 5300 & - & 0,90 & $\begin{array}{ll}0 & 6,70\end{array}$ & 14,8 & - & 0,03 & - & 0,85 \\
\hline & - & 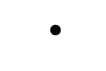 & - & - & 1,50 & 300 & 4300 & - & 0,76 & 67,50 & 13,1 & • & 0,03 & - & 2,00 \\
\hline L. do Diogo & • & $\bullet$ & $\bullet$ & - & 1,50 & 168 & 3200 & - & 0,90 & $0 \quad 7,00$ & 6,0 & - & 0,01 & - & 2,00 \\
\hline $\begin{array}{l}\text { C. do } \\
\text { Cafundó }\end{array}$ & - & $\bullet$ & - & $\bullet$ & $\bullet$ & 36,2 & 1364 & $\bullet$ & 0,1 & $4 \quad 4,66$ & 6,15 & $\bullet$ & 0,08 & $\bullet$ & 1,22 \\
\hline C. Boa Sorte & - & • & - & - & 0,44 & 81,0 & 2722 & . & • & 2,20 & 3,00 & - & - & - & 0,15 \\
\hline C. Jataí ${ }^{b}$ & - & - & • & • & 1,06 & 127 & 2464 & 4 & 1,03 & $3 \quad 6,65$ & 7,15 & - & 05 & - & 1,31 \\
\hline B. Bonita ${ }^{c}$ & - & $\bullet$ & ${ }^{\circ}$ & • & & 136 & 10100 & 0 & 5,80 & $0 \quad 5,20$ & 10,7 & • & • & - & 4,50 \\
\hline Pirapora $^{\mathrm{c}}$ & - & - & - & - & 44,0 & 412 & 13700 & 0 & 105 & $5 \quad 121$ & 147 & • & 4,0 & $\bullet$ & 61 \\
\hline $\begin{array}{l}\text { Baia de } \\
\text { Sepetiba }^{\mathrm{d}}\end{array}$ & $\bullet$ & - & $\bullet$ & • & 38,0 & $\bullet$ & 13200 & - & . & 25,6 & 96,5 & • & 1,9 & - & 8,8 \\
\hline & - & $\bullet$ & - & $\bullet$ & 0,5 & - & • & - & - & 3,6 & 3,0 & • & 9,5 & - & 6,4 \\
\hline C Fundo ${ }^{e}$ & - & 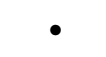 & . & - & 8,0 & 141 & 11800 & . & 5,6 & 73 & 291 & $\bullet$ & 0,52 & • & 81 \\
\hline C. Pavuna ${ }^{e}$ & - & 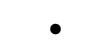 & $\bullet$ & • & 16,0 & 185 & 15000 & 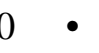 & 26 & 97 & 254 & $\bullet$ & & 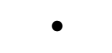 & 52 \\
\hline Rio Anil ${ }^{e}$ & - & 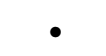 & $\bullet$ & - & 11,0 & 166 & 8700 & 0 & 14 & 63 & 189 & - & 0,61 & - & 94 \\
\hline Rio Cacambe $^{e}$ & • & • & • & • & & 114 & 10000 & 0 & 2,9 & 163 & 92 & - & & - & 23 \\
\hline & - & 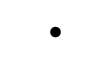 & 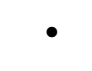 & $\bullet$ & 6,40 & 148 & 73000 & 0 & 2,8 & 22 & 147 & - & 0,22 & - & 30 \\
\hline Rio Camorim ${ }^{e}$ & - & 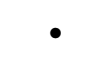 & • & - & 4,0 & 285 & & 0 & & 9,8 & 56 & • & & - & 17 \\
\hline Rio Marinho ${ }^{e}$ & • & $\bullet$ & 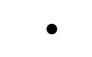 & - & 4,0 & 69 & 5900 & 0 & 3,5 & 17 & 136 & $\bullet$ & 0,26 & - & 35 \\
\hline & & & & & & & & & & & & & & & \\
\hline & $\bullet$ & 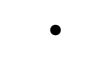 & $\bullet$ & $\bullet$ & 12 & 264 & 17770 & $\bullet$ & 271 & 133 & 470 & $\bullet$ & 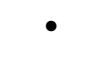 & - & 64 \\
\hline $\begin{array}{l}\text { Valor } \\
\text { mínimo }\end{array}$ & - & - & • & $\bullet$ & 4,5 & 19 & 2500 & - & 9,2 & 3,8 & 62 & $\bullet$ & $\bullet$ & $\bullet$ & 11 \\
\hline
\end{tabular}


Fonte: (a) GATTI, 1997 - Lagoas do rio Moji-Guaçu - extração com $\mathrm{HCl}$ 0,1 mol L ${ }^{-1}$

(b) LIMA, 1990 apud GATTI,1997 - Lagoas e córrego na Estação Ecológica de Jataí - extração com

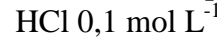

(c) BEVILACQUA, 1996 - Rio Tietê - extração com $\mathrm{HCl}$ 0,1 mol L ${ }^{-1}$

(d) FIZMAN, 1984 - Baia de Sepetiba e Angra dos Reis - extração com $\mathrm{HCl}$ 0,1 mol L"1

(e) FERNANDES et al,1994 apud GATTI,1997 - Lagoa de Jacarepaguá e os rios tributários - extração com $\mathrm{HCl} 0,5 \mathrm{~mol} \mathrm{~L}^{-1}$

(*) Média de 4 coletas - n.d.= não detectado (menor que o limite de quantificação, 4 ng $\mathrm{mL}^{-1}$ ) 


\section{Conclusão}

O surgimento e desenvolvimento de centros urbanos, industriais e agrícolas próximos aos ambientes aquáticos destinados a captação de água potável tem sido o principal fator de deterioração da qualidade da água dos mesmos.

O uso inadequado dos recursos hídricos tem acarretado, não somente sérios danos ao ecossistema, mas também a toda a área da bacia hidrográfica na qual estão inseridos. $\mathrm{O}$ aumento no suprimento e disponibilidade de nutrientes na água afeta a produção primária, modificando as condições ambientais.

A avaliação das condições ambientais utilizando variáveis físicas e químicas principalmente nutrientes e metais, observadas na coluna de água e nas frações de água sobrenadante, intersticial e biodisponível do sedimento é uma importante ferramenta não só para o conhecimento da distribuição dos metais no ecossistema, e seu perfil em função do tempo, como também para o balizamento de medidas a serem tomadas para melhorar e preservar a qualidade ambiental e proteger a saúde da população nas áreas circunvizinhas.

Os resultados das análises efetuadas nos pontos de monitoramento são um reflexo da porcentagem de área preservada existente, da utilização do recurso hídrico como depositário direto das atividades desenvolvidas próximas as áreas de captação.

Em função dos resultados encontrados e das discussões até este ponto, sobre os estudos da concentração dos elementos na água bruta, a eficácia do tratamento das ETA's e a biodisponibilidade podemos concluir:

As áreas de captação estudadas, pertencentes as Bacias Hidrográficas do Rio Mogi-Guaçu e do Rio Pardo, não estão comprometidas quanto a contribuição de metais tóxicos $(\mathrm{Cd}, \mathrm{Pb}, \mathrm{Ni}, \mathrm{Cr}$ e $\mathrm{Cu})$ possibilitando observar a assimetria da distribuição.

As observações sensíveis dos metais se concentram na época de seca.

> A matéria orgânica formada por substâncias húmicas, as quais são os constituintes orgânicos mais abundantes em sedimentos finos, pode se associar a metais provenientes do fluxo fluvial. A porcentagem dos metais biodisponíveis de $\mathrm{Mn}, \mathrm{Cu}, \mathrm{Pb}, \mathrm{Fe}$ e do P, em algumas estações (IG 64, IG 
66 e IG VGS) foi elevada, provavelmente devido a presença destes metais em rochas metabasicas e meta-ultrabasica que fazem parte da mineralogia da região. Os resultados mostram também que os valores da concentração dos biodisponíveis são comparáveis a composição do folhelho médio.

A pequena correlação da matéria orgânica com os metais estudados sugere que estes não sejam de origem antrópica passíveis a biodisponibilidade e que sejam de suporte geoquímico.

No sedimento não ocorre nítida mudança nas características física e química principalmente dos metais, em função dos períodos de amostragem, evidenciando ser este um compartimento mais estável. Porém, o mesmo não pode ser observado para o fósforo.

$>$ Na maioria dos elementos estudados não existe diferença significativa entre as duas frações, sobrenadante e intersticial, extraídas para sedimento não contaminado, sendo desnecessário obtê-las ao mesmo tempo. Podemos optar pela fase sobrenadante, pois é a mais simples e rápida de ser obtida, dispensando equipamentos e ganhando tempo.

Existe sazonalidade nas características físicas e químicas da coluna de água e nas frações de água intersticial do sedimento, sendo a distribuição entre períodos de coleta nítida e resultante, principalmente, de variação nos fatores climatológicos, particularmente da precipitação pluviométrica.

Sendo a área estudada uma área preservada o estado trófico deveria ser oligotrófico, mas as análises revelaram um estado mesotrófico (IG 63, IG 65, IG 66, IG 67, IG 69 e IG 83) e eutrófico (IG 60, IG 61, IG 64, IG 68, IG 70, IG 72 e IG VGS). Esta diferença de estado trófico possivelmente seja, em parte, pela área estar situada numa região de rochas alcalinas, que contêm o minério apatita, tendo o fósforo em sua composição, sendo a geomorfologia da região de rochas fraturadas, este fato pode ajudar para que o elemento se distribua por ela, aumentado o estado trófico. Devemos considerar também que, a captação pertencente a São João da Boa Vista e ao município de Mococa e demais comunidades menores, nas proximidades de áreas urbanas que recebem grande número de tributários ou áreas de captação próximas a pastagem e áreas agrícolas, temos também um aumento da carga orgânica recebida [KATSUÓKA, 2001]. 
Apesar de área em estudo ser agrícola e pastoril, não foram observadas contribuições significativas de $\mathrm{Cu}, \mathrm{P}$ e $\mathrm{K}$.

Não foram detectados na presença de $\mathrm{Cr}, \mathrm{Ni}, \mathrm{Zn}, \mathrm{Pb}$ e fosfato nas amostras de água bruta e tratada sendo o fator limitante o limite de quantificação da técnica utilizada, prejudicando a visualização dos perfis destes elementos:

$$
\begin{array}{ll}
\mathrm{Cr}\left(<44 \mathrm{ng} \mathrm{mL}^{-1}\right) ; & \mathrm{Ni}\left(<26 \mathrm{ng} \mathrm{mL}^{-1}\right) ; \\
\mathrm{Zn}\left(<3 \mathrm{n} \mathrm{mL}^{-1}\right) ; & \mathrm{Cd}\left(<4 \mathrm{ng} \mathrm{mL}^{-1}\right) ; \\
\mathrm{Pb}\left(<16 \mathrm{ng} \mathrm{mL}^{-1}\right) ; & \mathrm{PO}_{4}{ }^{3-}\left(<25 \mathrm{ng} \mathrm{mL}^{-1}\right) .
\end{array}
$$

$>\mathrm{Cr}$ e $\mathrm{Cd}$ não foram observados na fase intersticial e sobrenadante do sedimento. Ni e Ag apresentam poucos valores sensíveis nas duas fases. Mostrando novamente que mesmos os sedimentos da áreas de captação não estão comprometidos por fontes antrópicas.

> A água potável em todas comunidades, com exceção da IG VGS, está em conformidade com o padrão substâncias químicas que não apresentam riscos para a saúde, expresso na Portaria nº 1469 (29/12/2000).

Obs.: Vale a pena salientar que essa comunidade é operada pela prefeitura local.

$>$ A alteração de determinados elementos, após a etapa de tratamento nas ETA's, mostra claramente a necessidade de controlar a qualidade dos insumos utilizados. Foi observado um aumento significativo principalmente nas concentrações de $\mathrm{Ca}, \mathrm{Mg}, \mathrm{Na}$ e $\mathrm{SO}_{4}{ }^{2-}$. Foi observado também que o $\mathrm{Mg}$, $\mathrm{P}, \mathrm{NO}_{3}{ }^{-}$e $\mathrm{Cu}$ não foram influenciados na etapa de tratamento.

$>\mathrm{O}$ alto teor de $\mathrm{Mn}$ e Fe encontrado na região de Águas da Prata (IG 64) e Cascata (IG 66) provém do maciço de Poços de Caldas, rico em ferromagnesiano. $\mathrm{Cu}$, Ni e $\mathrm{P}$ também apresentam elevações em suas concentrações nessa região.

É importante considerar estes dados como referência para o monitoramento da região e para evitar modificações no conteúdo de metais que possam levá-la a uma situação negativa, sob o aspecto ecológico. Este trabalho poderá subsidiar os responsáveis pela operação de sistemas de tratamento e também as Secretarias Municipais de Saúde, pois atende ao Artigo 9 ${ }^{\circ}$, item III e VI da Portaria $n^{0}$ 1469/00 - com informações sobre a qualidade nos mananciais e com estatística descritiva dos valores de parâmetros de qualidade detectados na água e sua origem. 


\section{Conclusão}

O surgimento e desenvolvimento de centros urbanos, industriais e agrícolas próximos aos ambientes aquáticos destinados a captação de água potável tem sido o principal fator de deterioração da qualidade da água dos mesmos.

O uso inadequado dos recursos hídricos tem acarretado, não somente sérios danos ao ecossistema, mas também a toda a área da bacia hidrográfica na qual estão inseridos. $\mathrm{O}$ aumento no suprimento e disponibilidade de nutrientes na água afeta a produção primária, modificando as condições ambientais.

A avaliação das condições ambientais utilizando variáveis físicas e químicas principalmente nutrientes e metais, observadas na coluna de água e nas frações de água sobrenadante, intersticial e biodisponível do sedimento é uma importante ferramenta não só para o conhecimento da distribuição dos metais no ecossistema, e seu perfil em função do tempo, como também para o balizamento de medidas a serem tomadas para melhorar e preservar a qualidade ambiental e proteger a saúde da população nas áreas circunvizinhas.

Os resultados das análises efetuadas nos pontos de monitoramento são um reflexo da porcentagem de área preservada existente, da utilização do recurso hídrico como depositário direto das atividades desenvolvidas próximas as áreas de captação.

Em função dos resultados encontrados e das discussões até este ponto, sobre os estudos da concentração dos elementos na água bruta, a eficácia do tratamento das ETA's e a biodisponibilidade podemos concluir:

As áreas de captação estudadas, pertencentes as Bacias Hidrográficas do Rio Mogi-Guaçu e do Rio Pardo, não estão comprometidas quanto a contribuição de metais tóxicos $(\mathrm{Cd}, \mathrm{Pb}, \mathrm{Ni}, \mathrm{Cr}$ e $\mathrm{Cu})$ possibilitando observar a assimetria da distribuição.

As observações sensíveis dos metais se concentram na época de seca.

> A matéria orgânica formada por substâncias húmicas, as quais são os constituintes orgânicos mais abundantes em sedimentos finos, pode se associar a metais provenientes do fluxo fluvial. A porcentagem dos metais biodisponíveis de $\mathrm{Mn}, \mathrm{Cu}, \mathrm{Pb}, \mathrm{Fe}$ e do P, em algumas estações (IG 64, IG 
66 e IG VGS) foi elevada, provavelmente devido a presença destes metais em rochas metabasicas e meta-ultrabasica que fazem parte da mineralogia da região. Os resultados mostram também que os valores da concentração dos biodisponíveis são comparáveis a composição do folhelho médio.

A pequena correlação da matéria orgânica com os metais estudados sugere que estes não sejam de origem antrópica passíveis a biodisponibilidade e que sejam de suporte geoquímico.

No sedimento não ocorre nítida mudança nas características física e química principalmente dos metais, em função dos períodos de amostragem, evidenciando ser este um compartimento mais estável. Porém, o mesmo não pode ser observado para o fósforo.

$>$ Na maioria dos elementos estudados não existe diferença significativa entre as duas frações, sobrenadante e intersticial, extraídas para sedimento não contaminado, sendo desnecessário obtê-las ao mesmo tempo. Podemos optar pela fase sobrenadante, pois é a mais simples e rápida de ser obtida, dispensando equipamentos e ganhando tempo.

Existe sazonalidade nas características físicas e químicas da coluna de água e nas frações de água intersticial do sedimento, sendo a distribuição entre períodos de coleta nítida e resultante, principalmente, de variação nos fatores climatológicos, particularmente da precipitação pluviométrica.

Sendo a área estudada uma área preservada o estado trófico deveria ser oligotrófico, mas as análises revelaram um estado mesotrófico (IG 63, IG 65, IG 66, IG 67, IG 69 e IG 83) e eutrófico (IG 60, IG 61, IG 64, IG 68, IG 70, IG 72 e IG VGS). Esta diferença de estado trófico possivelmente seja, em parte, pela área estar situada numa região de rochas alcalinas, que contêm o minério apatita, tendo o fósforo em sua composição, sendo a geomorfologia da região de rochas fraturadas, este fato pode ajudar para que o elemento se distribua por ela, aumentado o estado trófico. Devemos considerar também que, a captação pertencente a São João da Boa Vista e ao município de Mococa e demais comunidades menores, nas proximidades de áreas urbanas que recebem grande número de tributários ou áreas de captação próximas a pastagem e áreas agrícolas, temos também um aumento da carga orgânica recebida [KATSUÓKA, 2001]. 
Apesar de área em estudo ser agrícola e pastoril, não foram observadas contribuições significativas de $\mathrm{Cu}, \mathrm{P}$ e $\mathrm{K}$.

Não foram detectados na presença de $\mathrm{Cr}, \mathrm{Ni}, \mathrm{Zn}, \mathrm{Pb}$ e fosfato nas amostras de água bruta e tratada sendo o fator limitante o limite de quantificação da técnica utilizada, prejudicando a visualização dos perfis destes elementos:

$$
\begin{array}{ll}
\mathrm{Cr}\left(<44 \mathrm{ng} \mathrm{mL}^{-1}\right) ; & \mathrm{Ni}\left(<26 \mathrm{ng} \mathrm{mL}^{-1}\right) ; \\
\mathrm{Zn}\left(<3 \mathrm{n} \mathrm{mL}^{-1}\right) ; & \mathrm{Cd}\left(<4 \mathrm{ng} \mathrm{mL}^{-1}\right) ; \\
\mathrm{Pb}\left(<16 \mathrm{ng} \mathrm{mL}^{-1}\right) ; & \mathrm{PO}_{4}{ }^{3-}\left(<25 \mathrm{ng} \mathrm{mL}^{-1}\right) .
\end{array}
$$

$>\mathrm{Cr}$ e $\mathrm{Cd}$ não foram observados na fase intersticial e sobrenadante do sedimento. Ni e Ag apresentam poucos valores sensíveis nas duas fases. Mostrando novamente que mesmos os sedimentos da áreas de captação não estão comprometidos por fontes antrópicas.

> A água potável em todas comunidades, com exceção da IG VGS, está em conformidade com o padrão substâncias químicas que não apresentam riscos para a saúde, expresso na Portaria nº 1469 (29/12/2000).

Obs.: Vale a pena salientar que essa comunidade é operada pela prefeitura local.

$>$ A alteração de determinados elementos, após a etapa de tratamento nas ETA's, mostra claramente a necessidade de controlar a qualidade dos insumos utilizados. Foi observado um aumento significativo principalmente nas concentrações de $\mathrm{Ca}, \mathrm{Mg}, \mathrm{Na}$ e $\mathrm{SO}_{4}{ }^{2-}$. Foi observado também que o $\mathrm{Mg}$, $\mathrm{P}, \mathrm{NO}_{3}{ }^{-}$e $\mathrm{Cu}$ não foram influenciados na etapa de tratamento.

$>\mathrm{O}$ alto teor de $\mathrm{Mn}$ e Fe encontrado na região de Águas da Prata (IG 64) e Cascata (IG 66) provém do maciço de Poços de Caldas, rico em ferromagnesiano. $\mathrm{Cu}$, Ni e $\mathrm{P}$ também apresentam elevações em suas concentrações nessa região.

É importante considerar estes dados como referência para o monitoramento da região e para evitar modificações no conteúdo de metais que possam levá-la a uma situação negativa, sob o aspecto ecológico. Este trabalho poderá subsidiar os responsáveis pela operação de sistemas de tratamento e também as Secretarias Municipais de Saúde, pois atende ao Artigo 9 ${ }^{\circ}$, item III e VI da Portaria $n^{0}$ 1469/00 - com informações sobre a qualidade nos mananciais e com estatística descritiva dos valores de parâmetros de qualidade detectados na água e sua origem. 


\section{APÊNDICE 1}

Tabelas 
Tabela A.1 - Estatísticas descritivas para as concentrações $\left(\mu \mathrm{g} \mathrm{mL}^{-1}\right)$ dos metais na água bruta.

Comunidade

\begin{tabular}{|c|c|c|c|c|c|c|c|c|c|c|c|c|c|c|}
\hline & RÁMETRO & $I G 60$ & $I G 61$ & $I G 63$ & IG 64 & IG 65 & $I G 66$ & $I G 67$ & IG 68 & $I G 69$ & $I G 70$ & IG 72 & IG 83 & $I G V G S$ \\
\hline \multirow[t]{5}{*}{$\overline{A g}$} & $\mathbf{N}$ & 7 & 7 & 7 & 7 & 7 & 7 & 7 & 7 & 7 & 7 & 7 & 7 & 6 \\
\hline & Média & 0,013 & 0,010 & 0,010 & 0,011 & 0,012 & 0,011 & 0,012 & 0,012 & 0,013 & 0,013 & 0,014 & 0,012 & 0,014 \\
\hline & Mediana & 0,013 & 0,005 & 0,004 & 0,004 & 0,004 & 0,004 & 0,007 & 0,008 & 0,009 & 0,009 & 0,010 & 0,004 & 0,013 \\
\hline & Mínimo & $<0,001$ & $<0,001$ & $<0,001$ & $<0,001$ & $<0,001$ & $<0,001$ & $<0,001$ & $<0,001$ & $<0,001$ & $<0,001$ & $<0,001$ & $<0,001$ & $<0,001$ \\
\hline & Máximo & 0,023 & 0,022 & 0,023 & 0,025 & 0,027 & 0,027 & 0,026 & 0,026 & 0,028 & 0,027 & 0,027 & 0,026 & 0,025 \\
\hline \multirow[t]{5}{*}{$A l$} & $\mathbf{N}$ & 7 & 7 & 7 & 7 & 7 & 7 & 7 & 7 & 7 & 7 & 7 & 7 & 6 \\
\hline & Média & 0,452 & 0,225 & 0,334 & 0,197 & 0,253 & 0,119 & 0,128 & 0,118 & 0,102 & 0,212 & 0,270 & 0,097 & 0,135 \\
\hline & Mediana & 0,368 & 0,165 & 0,380 & 0,195 & 0,308 & 0,097 & 0,092 & 0,117 & 0,092 & 0,150 & 0,206 & 0,092 & 0,108 \\
\hline & Mínimo & 0,146 & $<0,001$ & $<0,001$ & $<0,001$ & 0,108 & $<0,001$ & $<0,001$ & 0,092 & $<0,001$ & $<0,001$ & $<0,001$ & $<0,001$ & $<0,001$ \\
\hline & Máximo & 0,828 & 0,578 & 0,886 & 0,293 & 0,423 & 0,192 & 0,344 & 0,147 & 0,145 & 0,423 & 0,656 & 0,117 & 0,213 \\
\hline \multirow[t]{5}{*}{$B a$} & $\mathbf{N}$ & 7 & 7 & 7 & 7 & 7 & 7 & 7 & 7 & 7 & 7 & 7 & 7 & 6 \\
\hline & Média & 0,068 & 0,086 & 0,079 & 0,044 & 0,045 & 0,037 & 0,047 & 0,038 & 0,039 & 0,124 & 0,099 & 0,103 & 0,120 \\
\hline & Mediana & 0,082 & 0,094 & 0,076 & 0,041 & 0,025 & 0,019 & 0,025 & 0,037 & 0,030 & 0,135 & 0,121 & 0,106 & 0,133 \\
\hline & Mínimo & 0,032 & 0,029 & 0,031 & 0,012 & 0,014 & 0,011 & 0,014 & 0,014 & 0,013 & 0,041 & 0,041 & 0,031 & 0,041 \\
\hline & Máximo & 0,115 & 0,139 & 0,123 & 0,071 & 0,090 & 0,076 & 0,102 & 0,079 & 0,074 & 0,180 & 0,151 & 0,169 & 0,179 \\
\hline \multirow[t]{5}{*}{$\mathrm{Ca}$} & $\mathbf{N}$ & 7 & 7 & 7 & 7 & 7 & 7 & 7 & 7 & 7 & 7 & 7 & 7 & 6 \\
\hline & Média & 3,283 & 4,576 & 2,620 & 2,209 & 1,136 & 0,210 & 0,565 & 1,005 & 1,609 & 4,761 & 3,796 & 2,747 & 5,040 \\
\hline & Mediana & 4,632 & 5,260 & 2,280 & 2,019 & 0,763 & 0,209 & 0,258 & 1,270 & 0,851 & 5,220 & 4,225 & 3,523 & 5,990 \\
\hline & Mínimo & 1,280 & 1,795 & 0,520 & 0,911 & $<0,360$ & $<0,360$ & $<0,360$ & $<0,360$ & $<0,360$ & 1,424 & 0,589 & 0,633 & 0,860 \\
\hline & Máximo & 4,749 & 7,500 & 8,550 & 4,669 & 2,071 & 0,360 & 1,108 & 1,796 & 6,150 & 6,270 & 6,080 & 4,604 & 7,980 \\
\hline$C d$ & $\mathbf{N}$ & 7 & 7 & 7 & 7 & 7 & 7 & 7 & 7 & 7 & 7 & 7 & 7 & 6 \\
\hline & Média & - & - & - & - & - & - & - & - & - & - & - & - & - \\
\hline & Mediana & - & - & - & - & - & - & - & - & - & - & - & - & - \\
\hline & Mínimo & $<0,004$ & $<0,004$ & $<0,004$ & $<0,004$ & $<0,004$ & $<0,004$ & $<0,004$ & $<0,004$ & $<0,004$ & $<0,004$ & $<0,004$ & $<0,004$ & $<0,004$ \\
\hline & Máximo & - & - & - & - & - & - & - & - & - & - & - & - & - \\
\hline Co & $\mathbf{N}$ & 7 & 7 & 7 & 7 & 7 & 7 & 7 & 7 & 7 & 7 & 7 & 7 & 6 \\
\hline & Média & 0,052 & 0,043 & 0,043 & 0,044 & 0,046 & 0,046 & 0,048 & 0,048 & 0,048 & 0,051 & 0,053 & 0,053 & 0,054 \\
\hline & Mediana & 0,039 & 0,027 & 0,025 & 0,025 & 0,025 & 0,025 & 0,029 & 0,026 & 0,029 & 0,033 & 0,033 & 0,041 & 0,053 \\
\hline & Mínimo & $<0,017$ & $<0,017$ & $<0,017$ & $<0,017$ & $<0,017$ & $<0,017$ & $<0,017$ & $<0,017$ & $<0,017$ & $<0,017$ & $<0,017$ & $<0,017$ & $<0,017$ \\
\hline & Máximo & 0,089 & 0,077 & 0,081 & 0,089 & 0,092 & 0,090 & 0,088 & 0,086 & 0,089 & 0,095 & 0,098 & 0,090 & 0,086 \\
\hline $\mathrm{Cr}$ & $\mathbf{N}$ & 7 & 7 & 7 & 7 & 7 & 7 & 7 & 7 & 7 & 7 & 7 & 7 & 6 \\
\hline & Média & - & - & - & - & - & - & - & - & - & - & - & - & - \\
\hline & Mediana & - & - & - & - & - & - & - & - & - & - & - & - & - \\
\hline & Mínimo & $<0,044$ & $<0,044$ & $<0,044$ & $<0,044$ & $<0,044$ & $<0,044$ & $<0,044$ & $<0,044$ & $<0,044$ & $<0,044$ & $<0,044$ & $<0,044$ & $<0,044$ \\
\hline & Máximo & - & - & - & - & - & - & - & - & - & - & - & - & - \\
\hline $\mathrm{Cu}$ & $\mathbf{N}$ & 7 & 7 & 7 & 7 & 7 & 7 & 7 & 7 & 7 & 7 & 7 & 7 & 6 \\
\hline & Média & 0,010 & 0,008 & 0,008 & 0,008 & 0,008 & 0,010 & 0,008 & 0,010 & 0,009 & 0,009 & 0,009 & 0,010 & 0,009 \\
\hline & Mediana & 0,009 & 0,004 & 0,005 & 0,004 & 0,004 & 0,010 & 0,005 & 0,004 & 0,005 & 0,005 & 0,006 & 0,009 & 0,009 \\
\hline & Mínimo & $<0,004$ & $<0,004$ & $<0,004$ & $<0,004$ & $<0,004$ & $<0,004$ & $<0,004$ & $<0,004$ & $<0,004$ & $<0,004$ & $<0,004$ & $<0,004$ & $<0,004$ \\
\hline & Máximo & 0,018 & 0,016 & 0,016 & 0,015 & 0,017 & 0,017 & 0,016 & 0,020 & 0,016 & 0,016 & 0,017 & 0,017 & 0,015 \\
\hline $\mathrm{Fe}$ & $\mathbf{N}$ & 7 & 7 & 7 & 7 & 7 & 7 & 7 & 7 & 7 & 7 & 7 & 7 & 6 \\
\hline & Média & 1,394 & 1,595 & 1,031 & 1,506 & 1,170 & 0,073 & 0,486 & 1,086 & 0,898 & 1,532 & 1,395 & 1,947 & 1,246 \\
\hline & Mediana & 1,588 & 2,067 & 0,931 & 1,181 & 1,090 & 0,063 & 0,336 & 1,240 & 0,470 & 1,547 & 0,913 & 1,810 & 0,964 \\
\hline & Mínimo & 0,394 & 0,379 & 0,016 & 0,665 & 0,421 & 0,042 & 0,074 & 0,241 & 0,126 & 0,523 & 0,594 & 0,538 & 0,618 \\
\hline & Máximo & 2,970 & 2,658 & 1,943 & 3,041 & 2,071 & 0,113 & 1,290 & 1,910 & 3,239 & 2,667 & 2,826 & 3,396 & 2,145 \\
\hline$M g$ & $\mathbf{N}$ & 7 & 7 & 7 & 7 & 7 & 7 & 7 & 7 & 7 & 7 & 7 & 7 & 6 \\
\hline & Média & 1,121 & 1,872 & 0,597 & 0,696 & 0,397 & 0,117 & 0,201 & 0,335 & 0,325 & 1,682 & 1,115 & 1,121 & 1,833 \\
\hline & Mediana & 1,434 & 1,692 & 0,645 & 0,612 & 0,326 & 0,106 & 0,203 & 0,321 & 0,313 & 1,781 & 1,208 & 1,366 & 2,083 \\
\hline & Mínimo & 0,540 & 0,678 & 0,301 & 0,255 & 0,185 & $<0,008$ & 0,116 & 0,184 & 0,139 & 0,710 & 0,424 & 0,433 & 0,538 \\
\hline & Máximo & 1,765 & 3,207 & 0,941 & 1,451 & 0,636 & 0,149 & 0,344 & 0,566 & 0,587 & 2,151 & 1,748 & 1,759 & 2,769 \\
\hline$M n$ & $\mathbf{N}$ & 7 & 7 & 7 & 7 & 7 & 7 & 7 & 7 & 7 & 7 & 7 & 7 & 6 \\
\hline & Média & 0,109 & 0,066 & 0,049 & 0,301 & 0,064 & 0,021 & 0,055 & 0,032 & 0,037 & 0,112 & 0,095 & 0,077 & 0,092 \\
\hline & Mediana & 0,116 & 0,082 & 0,043 & 0,226 & 0,053 & 0,013 & 0,026 & 0,038 & 0,021 & 0,125 & 0,094 & 0,072 & 0,094 \\
\hline & Mínimo & 0,027 & 0,016 & 0,008 & 0,070 & 0,021 & 0,007 & 0,019 & 0,016 & $<0,001$ & 0,031 & 0,039 & 0,033 & 0,042 \\
\hline & Máximo & 0,290 & 0,106 & 0,116 & 0,815 & 0,124 & 0,042 & 0,178 & 0,045 & 0,096 & 0,228 & 0,139 & 0,137 & 0,142 \\
\hline $\mathrm{Ni}$ & $\mathbf{N}$ & 7 & 7 & 7 & 7 & 7 & 7 & 7 & 7 & 7 & 7 & 7 & 7 & 6 \\
\hline & Média & - & - & - & - & - & - & - & - & - & - & - & - & - \\
\hline & Mediana & - & - & - & - & - & - & - & - & - & - & - & - & - \\
\hline & Mínimo & $<0,026$ & $<0,026$ & $<0,026$ & $<0,026$ & $<0,026$ & $<0,026$ & $<0,026$ & $<0,026$ & $<0,026$ & $<0,026$ & $<0,026$ & $<0,026$ & $<0,026$ \\
\hline & Máximo & - & - & - & - & - & - & - & - & - & - & - & - & - \\
\hline$P$ & $\mathbf{N}$ & 7 & 7 & 7 & 7 & 7 & 7 & 7 & 7 & 7 & 7 & 7 & 7 & 6 \\
\hline & Média & 0,073 & 0,056 & 0,030 & 0,035 & 0,028 & 0,024 & 0,027 & 0,033 & 0,034 & 0,042 & 0,052 & 0,037 & 0,053 \\
\hline & Mediana & 0,064 & 0,047 & 0,026 & 0,032 & 0,034 & 0,021 & 0,022 & 0,031 & 0,040 & 0,042 & 0,055 & 0,041 & 0,057 \\
\hline & Mínimo & 0,034 & 0,011 & $<0,009$ & $<0,009$ & $<0,009$ & $<0,009$ & $<0,009$ & $<0,009$ & $<0,009$ & 0,010 & 0,018 & 0,010 & 0,029 \\
\hline & Máximo & 0,170 & 0,122 & 0,053 & 0,057 & 0,048 & 0,047 & 0,043 & 0,061 & 0,052 & 0,067 & 0,096 & 0,056 & 0,072 \\
\hline$P b$ & $\mathbf{N}$ & 7 & 7 & 7 & 7 & 7 & 7 & 7 & 7 & 7 & 7 & 7 & 7 & 6 \\
\hline & Média & - & - & - & - & - & - & - & - & - & - & - & - & - \\
\hline & Mediana & - & - & - & - & - & - & - & - & - & - & - & - & - \\
\hline & Mínimo & $<0,016$ & $<0,016$ & $<0,016$ & $<0,016$ & $<0,016$ & $<0,016$ & $<0,016$ & $<0,016$ & $<0,016$ & $<0,016$ & $<0,016$ & $<0,016$ & $<0,016$ \\
\hline & Máximo & - & - & - & - & - & - & - & - & - & - & - & - & - \\
\hline$\overline{Z n}$ & $\mathbf{N}$ & 7 & 7 & 7 & 7 & 7 & 7 & 7 & 7 & 7 & 7 & 7 & 7 & 6 \\
\hline & Média & - & - & - & - & - & - & - & - & - & - & - & - & - \\
\hline & Mediana & - & - & - & - & - & - & - & - & - & - & - & - & - \\
\hline & Mínimo & $<0,003$ & $<0,003$ & $<0,003$ & $<0,003$ & $<0,003$ & $<0,003$ & $<0,003$ & $<0,003$ & $<0,003$ & $<0,003$ & $<0,003$ & $<0,003$ & $<0,003$ \\
\hline & Máximo & - & - & - & - & - & - & - & - & - & - & - & - & - \\
\hline
\end{tabular}

$\mathbf{N}=$ QUANTIDADE DE DADOS NO PERIODO DA PESQUISA

OS VALORES AQUI PRESENTES FORAM DESCONTADOS OS VALORES DO BRANCO 
Tabela A.2 - Estatísticas descritivas para as concentrações $\left(\mu \mathrm{g} \mathrm{mL} \mathrm{L}^{-1}\right)$ dos elementos iônicos na água bruta.

Comunidade

\begin{tabular}{|c|c|c|c|c|c|c|c|c|c|c|c|c|c|c|}
\hline & RÁMETRO & $I G 60$ & $I G 6 I$ & IG 63 & $I G 64$ & IG 65 & IG 66 & IG 67 & IG 68 & IG 69 & $I G 70$ & $I G 72$ & IG 83 & $I G V G S$ \\
\hline \multirow[t]{5}{*}{$F^{-}$} & $\mathbf{N}$ & 7 & 7 & 7 & 7 & 7 & 7 & 7 & 7 & 7 & 7 & 7 & 7 & 6 \\
\hline & Média & 0,093 & 0,077 & 0,055 & 0,117 & 0,044 & 0,052 & 0,094 & 0,067 & 0,055 & 0,086 & 0,115 & 0,061 & 0,109 \\
\hline & Mediana & 0,091 & 0,070 & 0,050 & 0,100 & 0,030 & 0,036 & 0,040 & 0,040 & 0,044 & 0,100 & 0,100 & 0,060 & 0,100 \\
\hline & Mínimo & $<0,025$ & 0,036 & 0,027 & 0,040 & $<0,025$ & $<0,025$ & $<0,025$ & $<0,025$ & $<0,025$ & $<0,025$ & 0,048 & $<0,025$ & 0,035 \\
\hline & Máximo & 0,130 & 0,120 & 0,110 & 0,230 & 0,100 & 0,110 & 0,320 & 0,120 & 0,110 & 0,140 & 0,250 & 0,110 & 0,250 \\
\hline \multirow[t]{5}{*}{$\mathrm{Cl}^{-}$} & $\mathbf{N}$ & 7 & 7 & 7 & 7 & 7 & 6 & 7 & 7 & 7 & 7 & 7 & 7 & 6 \\
\hline & Média & 1,691 & 1,787 & 1,452 & 0,583 & 0,857 & 0,254 & 0,724 & 0,769 & 0,728 & 1,126 & 1,417 & 1,780 & 1,713 \\
\hline & Mediana & 1,800 & 1,550 & 1,470 & 0,540 & 0,960 & 0,205 & 0,580 & 0,770 & 0,450 & 1,600 & 1,590 & 1,480 & 1,615 \\
\hline & Mínimo & 0,150 & 0,800 & $<0,025$ & 0,050 & 0,100 & $<0,025$ & $<0,025$ & $<0,025$ & $<0,025$ & $<0,025$ & 0,220 & 0,060 & 0,560 \\
\hline & Máximo & 2,680 & 3,000 & 4,620 & 1,100 & 1,360 & 0,680 & 1,520 & 1,880 & 2,390 & 1,930 & 2,240 & 4,210 & 3,110 \\
\hline \multirow[t]{5}{*}{$\mathrm{NO}_{3}^{-}$} & $\mathbf{N}$ & 7 & 7 & 7 & 7 & 7 & 7 & 7 & 7 & 7 & 7 & 7 & 7 & 6 \\
\hline & Média & 3,829 & 2,847 & 4,060 & 1,321 & 1,957 & 0,361 & 1,371 & 0,941 & 0,424 & 1,226 & 1,336 & 0,700 & 1,033 \\
\hline & Mediana & 2,980 & 2,070 & 3,080 & 1,250 & 1,220 & 0,140 & 1,260 & 0,950 & 0,350 & 1,530 & 1,300 & 0,750 & 1,020 \\
\hline & Mínimo & 2,070 & 1,510 & 1,150 & 0,700 & 0,910 & $<0,050$ & 0,880 & 0,750 & 0,240 & $<0,050$ & 0,940 & 0,230 & 0,490 \\
\hline & Máximo & 9,070 & 8,170 & 13,180 & 2,790 & 5,460 & 1,330 & 2,070 & 1,170 & 1,020 & 1,680 & 1,940 & 1,040 & 1,620 \\
\hline \multirow[t]{5}{*}{$\mathrm{PO}_{4}{ }^{3-}$} & $\mathbf{N}$ & 7 & 7 & 7 & 7 & 7 & 7 & 7 & 7 & 7 & 7 & 7 & 7 & 6 \\
\hline & Média & - & - & - & - & - & - & - & - & - & - & - & - & - \\
\hline & Mediana & - & - & - & - & - & - & - & - & - & - & - & - & - \\
\hline & Mínimo & $<0,025$ & $<0,025$ & $<0,025$ & $<0,025$ & $<0,025$ & $<0,025$ & $<0,025$ & $<0,025$ & $<0,025$ & $<0,025$ & $<0,025$ & $<0,025$ & $<0,025$ \\
\hline & Máximo & - & - & - & - & - & - & - & - & - & - & - & - & - \\
\hline \multirow[t]{5}{*}{$\mathrm{SO}_{4}=$} & $\mathbf{N}$ & 7 & 7 & 7 & 7 & 7 & 7 & 7 & 7 & 7 & 7 & 7 & 7 & 6 \\
\hline & Média & 0,721 & 0,437 & 1,123 & 0,443 & 0,583 & 0,119 & 0,326 & 0,301 & 0,330 & 0,420 & 0,416 & 0,849 & 0,595 \\
\hline & Mediana & 0,520 & 0,360 & 0,250 & 0,400 & 0,480 & 0,080 & 0,230 & 0,210 & 0,240 & 0,510 & 0,330 & 0,330 & 0,640 \\
\hline & Mínimo & 0,370 & 0,240 & $<0,200$ & 0,270 & 0,220 & $<0,200$ & $<0,200$ & $<0,200$ & $<0,200$ & $<0,200$ & $<0,200$ & $<0,200$ & $<0,200$ \\
\hline & Máximo & 1,620 & 0,690 & 4,850 & 0,820 & 1,460 & 0,360 & 0,730 & 1,040 & 0,670 & 0,650 & 0,860 & 4,020 & 1,130 \\
\hline \multirow[t]{5}{*}{$\mathrm{Na}^{+}$} & $\mathbf{N}$ & 7 & 7 & 7 & 7 & 7 & 7 & 7 & 7 & 7 & 7 & 7 & 7 & 6 \\
\hline & Média & 4,083 & 9,580 & 2,586 & 2,539 & 1,763 & 1,611 & 1,613 & 1,374 & 0,997 & 4,436 & 4,366 & 2,567 & 4,065 \\
\hline & Mediana & 3,920 & 5,650 & 2,930 & 2,560 & 1,510 & 1,250 & 1,360 & 1,440 & 1,000 & 4,540 & 4,470 & 2,700 & 4,075 \\
\hline & Mínimo & 2,730 & 3,360 & 1,100 & 1,660 & 0,980 & 1,160 & 0,960 & 1,170 & 0,730 & 0,012 & 1,710 & 1,600 & 2,860 \\
\hline & Máximo & 6,330 & 37,100 & 3,760 & 3,580 & 3,060 & 3,060 & 3,060 & 1,690 & 1,200 & 6,710 & 6,350 & 3,150 & 5,810 \\
\hline \multirow[t]{5}{*}{$\mathrm{NH}_{4}{ }^{+}$} & $\mathbf{N}$ & 7 & 7 & 7 & 7 & 7 & 7 & 7 & 7 & 7 & 7 & 7 & 7 & 6 \\
\hline & Média & 0,047 & 0,781 & 0,080 & 0,055 & 0,106 & 0,030 & 0,036 & 0,027 & 0,027 & 0,028 & 0,058 & 0,070 & 0,049 \\
\hline & Mediana & 0,030 & 0,025 & 0,025 & 0,050 & 0,120 & 0,025 & 0,025 & 0,025 & 0,025 & 0,025 & 0,040 & 0,070 & 0,025 \\
\hline & Mínimo & $<0,025$ & $<0,025$ & $<0,025$ & $<0,025$ & $<0,025$ & $<0,025$ & $<0,025$ & $<0,025$ & $<0,025$ & $<0,025$ & $<0,025$ & $<0,025$ & $<0,025$ \\
\hline & Máximo & 0,082 & 5,270 & 0,280 & 0,100 & 0,180 & 0,060 & 0,060 & 0,040 & 0,040 & 0,040 & 0,170 & 0,130 & 0,160 \\
\hline \multirow[t]{5}{*}{$\mathrm{K}^{+}$} & $\mathbf{N}$ & 7 & 7 & 7 & 7 & 7 & 7 & 7 & 7 & 7 & 7 & 7 & 7 & 6 \\
\hline & Média & 3,324 & 2,714 & 2,803 & 3,253 & 1,869 & 1,176 & 1,634 & 1,474 & 0,991 & 2,270 & 3,799 & 2,644 & 3,153 \\
\hline & Mediana & 3,410 & 2,630 & 2,990 & 3,150 & 1,680 & 1,340 & 1,560 & 1,220 & 0,770 & 2,840 & 3,310 & 2,240 & 3,260 \\
\hline & Mínimo & 1,980 & 2,080 & 1,090 & 2,690 & 1,470 & $<0,010$ & 1,130 & 1,040 & 0,090 & $<0,010$ & 3,040 & 1,320 & 1,350 \\
\hline & Máximo & 4,820 & 3,940 & 3,640 & 4,340 & 2,660 & 1,470 & 2,590 & 2,560 & 2,570 & 3,660 & 4,970 & 4,090 & 4,830 \\
\hline
\end{tabular}

OS VALORES AQUI PRESENTES FORAM DESCONTADOS OS VALORES DO BRANCO 


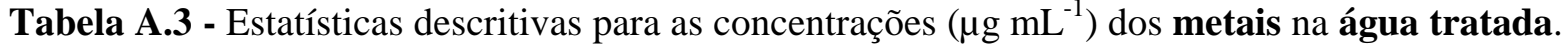

\begin{tabular}{|c|c|c|c|c|c|c|c|c|c|c|c|c|c|c|}
\hline \multirow{2}{*}{\multicolumn{2}{|c|}{ PARÂMETRO }} & \multicolumn{13}{|c|}{ Comunidade } \\
\hline & & $I G 60$ & $I G 61$ & IG 63 & IG 64 & IG 65 & IG 66 & IG 67 & IG 68 & IG 69 & IG 70 & IG 72 & IG 83 & $I G$ VGS \\
\hline \multirow[t]{5}{*}{$A g$} & $\mathbf{N}$ & 7 & 7 & 7 & 7 & 7 & 7 & 7 & 7 & 7 & 7 & 7 & 7 & 6 \\
\hline & Média & 0,011 & 0,011 & 0,010 & 0,011 & 0,011 & 0,012 & 0,012 & 0,012 & 0,013 & 0,013 & 0,014 & 0,012 & 0,014 \\
\hline & Mediana & 0,001 & 0,006 & 0,004 & 0,004 & 0,004 & 0,005 & 0,008 & 0,008 & 0,009 & 0,010 & 0,011 & 0,004 & 0,013 \\
\hline & Mínimo & $<0,001$ & $<0,001$ & $<0,001$ & $<0,001$ & $<0,001$ & $<0,001$ & $<0,001$ & $<0,001$ & $<0,001$ & $<0,001$ & $<0,001$ & $<0,001$ & $<0,001$ \\
\hline & Máximo & 0,024 & 0,022 & 0,024 & 0,026 & 0,027 & 0,027 & 0,027 & 0,027 & 0,026 & 0,027 & 0,028 & 0,026 & 0,024 \\
\hline$A l$ & $\mathbf{N}$ & 7 & 7 & 7 & 7 & 7 & 7 & 7 & 7 & 7 & 7 & 7 & 7 & 6 \\
\hline & Média & - & - & 0,104 & 0,092 & 0,110 & 0,098 & 0,097 & 0,092 & 0,092 & 0,092 & 0,101 & 0,092 & 0,287 \\
\hline & Mediana & - & - & 0,092 & 0,092 & 0,092 & 0,092 & 0,092 & 0,092 & 0,092 & 0,092 & 0,092 & 0,092 & 0,266 \\
\hline & Mínimo & $<0,001$ & $<0,001$ & $<0,001$ & $<0,001$ & $<0,001$ & $<0,001$ & $<0,001$ & $<0,001$ & $<0,001$ & $<0,001$ & $<0,001$ & $<0,001$ & $<0,001$ \\
\hline & Máximo & - & - & 0,177 & 0,092 & 0,157 & 0,117 & 0,124 & 0,092 & 0,092 & 0,092 & 0,154 & 0,092 & 0,508 \\
\hline$B a$ & $\mathbf{N}$ & 7 & 7 & 7 & 7 & 7 & 7 & 7 & 7 & 7 & 7 & 7 & 7 & 6 \\
\hline & Média & 0,057 & 0,070 & 0,069 & 0,030 & 0,044 & 0,036 & 0,040 & 0,029 & 0,039 & 0,088 & 0,088 & 0,086 & 0,106 \\
\hline & Mediana & 0,071 & 0,060 & 0,066 & 0,028 & 0,042 & 0,025 & 0,025 & 0,021 & 0,024 & 0,096 & 0,082 & 0,079 & 0,104 \\
\hline & Mínimo & 0,028 & 0,030 & 0,017 & 0,013 & 0,013 & 0,012 & 0,014 & 0,012 & 0,010 & 0,037 & 0,051 & 0,028 & 0,056 \\
\hline & Máximo & 0,078 & 0,115 & 0,108 & 0,053 & 0,075 & 0,073 & 0,076 & 0,057 & 0,088 & 0,134 & 0,126 & 0,135 & 0,144 \\
\hline $\mathrm{Ca}$ & $\mathbf{N}$ & 7 & 7 & 7 & 7 & 7 & 7 & 7 & 7 & 7 & 7 & 7 & 7 & 6 \\
\hline & Média & 9,240 & 11,550 & 4,810 & 9,670 & 1,385 & 0,220 & 0,568 & 0,893 & 3,240 & 5,100 & 11,740 & 5,710 & 8,150 \\
\hline & Mediana & 11,530 & 13,160 & 4,170 & 10,250 & 1,876 & 0,209 & 0,267 & 0,919 & 2,630 & 5,080 & 11,270 & 6,810 & 8,390 \\
\hline & Mínimo & 4,050 & 1,980 & 0,900 & 4,830 & 0,287 & $<0,360$ & $<0,360$ & $<0,360$ & 0,440 & 2,110 & 6,250 & 1,180 & 1,970 \\
\hline & Máximo & 14,390 & 18,890 & 9,380 & 12,640 & 2,110 & 0,385 & 1,119 & 1,588 & 7,590 & 9,050 & 18,700 & 8,940 & 12,850 \\
\hline$C d$ & $\mathbf{N}$ & 7 & 7 & 7 & 7 & 7 & 7 & 7 & 7 & 7 & 7 & 7 & 7 & 6 \\
\hline & Média & - & - & - & - & - & - & - & - & - & - & - & - & - \\
\hline & Mediana & - & - & - & - & - & - & - & - & - & - & - & - & - \\
\hline & Mínimo & $<0,004$ & $<0,004$ & $<0,004$ & $<0,004$ & $<0,004$ & $<0,004$ & $<0,004$ & $<0,004$ & $<0,004$ & $<0,004$ & $<0,004$ & $<0,004$ & $<0,004$ \\
\hline & Máximo & - & - & - & - & - & - & - & - & - & - & - & - & - \\
\hline Co & $\mathbf{N}$ & 7 & 7 & 7 & 7 & 7 & 7 & 7 & 7 & 7 & 7 & 7 & 7 & 6 \\
\hline & Média & 0,043 & 0,043 & 0,042 & 0,045 & 0,046 & 0,047 & 0,048 & 0,048 & 0,049 & 0,052 & 0,054 & 0,052 & 0,053 \\
\hline & Mediana & 0,025 & 0,034 & 0,025 & 0,025 & 0,025 & 0,025 & 0,026 & 0,029 & 0,031 & 0,034 & 0,036 & 0,041 & 0,052 \\
\hline & Mínimo & $<0,017$ & $<0,017$ & $<0,017$ & $<0,017$ & $<0,017$ & $<0,017$ & $<0,017$ & $<0,017$ & $<0,017$ & $<0,017$ & $<0,017$ & $<0,017$ & $<0,017$ \\
\hline & Máximo & 0,080 & 0,077 & 0,083 & 0,090 & 0,094 & 0,089 & 0,089 & 0,088 & 0,090 & 0,095 & 0,097 & 0,087 & 0,084 \\
\hline $\mathrm{Cr}$ & $\mathbf{N}$ & 7 & 7 & 7 & 7 & 7 & 7 & 7 & 7 & 7 & 7 & 7 & 7 & 6 \\
\hline & Média & - & - & - & - & - & - & - & - & - & - & - & - & - \\
\hline & Mediana & - & - & - & - & - & - & - & - & - & - & - & - & - \\
\hline & Mínimo & $<0,044$ & $<0,044$ & $<0,044$ & $<0,044$ & $<0,044$ & $<0,044$ & $<0,044$ & $<0,044$ & $<0,044$ & $<0,044$ & $<0,044$ & $<0,044$ & $<0,044$ \\
\hline & Máximo & - & - & - & - & - & - & - & - & - & - & - & - & - \\
\hline $\mathrm{Cu}$ & $\mathbf{N}$ & 7 & 7 & 7 & 7 & 7 & 7 & 7 & 7 & 7 & 7 & 7 & 7 & 6 \\
\hline & Média & 0,008 & 0,007 & 0,007 & 0,012 & 0,008 & 0,008 & 0,009 & 0,009 & 0,009 & 0,010 & 0,010 & 0,010 & 0,009 \\
\hline & Mediana & 0,005 & 0,004 & 0,004 & 0,008 & 0,004 & 0,004 & 0,007 & 0,004 & 0,007 & 0,006 & 0,006 & 0,010 & 0,009 \\
\hline & Mínimo & $<0,004$ & $<0,004$ & $<0,004$ & $<0,004$ & $<0,004$ & $<0,004$ & $<0,004$ & $<0,004$ & $<0,004$ & $<0,004$ & $<0,004$ & $<0,004$ & $<0,004$ \\
\hline & Máximo & 0,016 & 0,013 & 0,015 & 0,032 & 0,017 & 0,016 & 0,015 & 0,017 & 0,016 & 0,017 & 0,018 & 0,017 & 0,015 \\
\hline $\mathrm{Fe}$ & $\mathrm{N}$ & 7 & 7 & 7 & 7 & 7 & 7 & 7 & 7 & 7 & 7 & 7 & 7 & 6 \\
\hline & Média & 0,021 & 0,070 & 0,229 & 0,038 & 0,027 & 0,019 & 0,027 & 0,029 & 0,176 & 0,039 & 0,058 & 0,046 & 0,205 \\
\hline & Mediana & 0,016 & 0,017 & 0,016 & 0,019 & 0,028 & 0,016 & 0,017 & 0,031 & 0,017 & 0,033 & 0,026 & 0,035 & 0,201 \\
\hline & Mínimo & $<0,010$ & 0,017 & $<0,010$ & 0,017 & $<0,010$ & $<0,010$ & $<0,010$ & 0,017 & 0,017 & 0,017 & 0,017 & 0,017 & 0,055 \\
\hline & Máximo & 0,043 & 0,379 & 1,494 & 0,155 & 0,041 & 0,037 & 0,094 & 0,043 & 1,086 & 0,075 & 0,243 & 0,123 & 0,382 \\
\hline$M g$ & $\mathbf{N}$ & 7 & 7 & 7 & 7 & 7 & 7 & 7 & 7 & 7 & 7 & 7 & 7 & 6 \\
\hline & Média & 1,137 & 2,390 & 0,590 & 0,676 & 0,457 & 0,119 & 0,208 & 0,302 & 0,320 & 1,372 & 1,353 & 1,104 & 1,981 \\
\hline & Mediana & 1,442 & 2,882 & 0,669 & 0,648 & 0,503 & 0,106 & 0,213 & 0,267 & 0,293 & 1,261 & 1,290 & 1,277 & 2,077 \\
\hline & Mínimo & 0,488 & 0,876 & 0,170 & 0,329 & 0,190 & 0,106 & $<0,008$ & 0,170 & 0,137 & 0,583 & 0,812 & 0,400 & 0,793 \\
\hline & Máximo & 1,656 & 3,199 & 0,871 & 1,003 & 0,665 & 0,155 & 0,341 & 0,471 & 0,579 & 2,123 & 1,804 & 1,723 & 2,864 \\
\hline$M n$ & $\mathbf{N}$ & 7 & 7 & 7 & 7 & 7 & 7 & 7 & 7 & 7 & 7 & 7 & 7 & 6 \\
\hline & Média & 0,009 & 0,010 & 0,019 & 0,010 & 0,031 & 0,010 & 0,018 & 0,010 & 0,031 & 0,011 & 0,013 & 0,040 & 0,029 \\
\hline & Mediana & 0,006 & 0,007 & 0,017 & 0,006 & 0,034 & 0,006 & 0,017 & 0,006 & 0,021 & 0,008 & 0,008 & 0,032 & 0,022 \\
\hline & Mínimo & $<0,001$ & $<0,001$ & $<0,001$ & $<0,001$ & 0,013 & $<0,001$ & 0,007 & $<0,001$ & 0,009 & $<0,001$ & $<0,001$ & 0,024 & 0,017 \\
\hline & Máximo & 0,014 & 0,016 & 0,039 & 0,023 & 0,053 & 0,018 & 0,037 & 0,016 & 0,093 & 0,019 & 0,032 & 0,087 & 0,049 \\
\hline $\mathrm{Ni}$ & $\mathbf{N}$ & 7 & 7 & 7 & 7 & 7 & 7 & 7 & 7 & 7 & 7 & 7 & 7 & 6 \\
\hline & Média & - & - & - & - & - & - & - & - & - & - & - & - & - \\
\hline & Mediana & - & - & - & - & - & - & - & - & - & - & - & - & - \\
\hline & Mínimo & $<0,026$ & $<0,026$ & $<0,026$ & $<0,026$ & $<0,026$ & $<0,026$ & $<0,026$ & $<0,026$ & $<0,026$ & $<0,026$ & $<0,026$ & $<0,026$ & $<0,026$ \\
\hline & Máximo & - & - & - & - & - & - & - & - & - & - & - & - & - \\
\hline$P$ & $\mathbf{N}$ & 7 & 7 & 7 & 7 & 7 & 7 & 7 & 7 & 7 & 7 & 7 & 7 & 6 \\
\hline & Média & 0,031 & 0,035 & 0,027 & 0,215 & 0,025 & 0,026 & 0,028 & 0,029 & 0,035 & 0,034 & 0,042 & 0,039 & 0,042 \\
\hline & Mediana & 0,032 & 0,038 & 0,028 & 0,160 & 0,026 & 0,027 & 0,026 & 0,027 & 0,038 & 0,037 & 0,042 & 0,037 & 0,040 \\
\hline & Mínimo & $<0,009$ & 0,012 & $<0,009$ & 0,081 & $<0,009$ & $<0,009$ & $<0,009$ & $<0,009$ & $<0,009$ & $<0,009$ & 0,013 & $<0,009$ & 0,014 \\
\hline & Máximo & 0,048 & 0,051 & 0,048 & 0,429 & 0,048 & 0,045 & 0,040 & 0,043 & 0,047 & 0,052 & 0,063 & 0,064 & 0,067 \\
\hline$P b$ & $\mathbf{N}$ & 7 & 7 & 7 & 7 & 7 & 7 & 7 & 7 & 7 & 7 & 7 & 7 & 6 \\
\hline & Média & - & - & - & - & - & - & - & - & - & - & - & - & - \\
\hline & Mediana & - & - & - & - & - & - & - & - & - & - & - & - & - \\
\hline & Mínimo & $<0,016$ & $<0,016$ & $<0,016$ & $<0,016$ & $<0,016$ & $<0,016$ & $<0,016$ & $<0,016$ & $<0,016$ & $<0,016$ & $<0,016$ & $<0,016$ & $<0,016$ \\
\hline & Máximo & - & - & - & - & - & - & - & - & - & - & - & - & - \\
\hline$Z n$ & $\mathbf{N}$ & 7 & 7 & 7 & 7 & 7 & 7 & 7 & 7 & 7 & 7 & 7 & 7 & 6 \\
\hline & Média & - & - & - & - & - & - & - & - & - & - & - & - & - \\
\hline & Mediana & - & - & - & - & - & - & - & - & - & - & - & - & - \\
\hline & Mínimo & $<0,003$ & $<0,003$ & $<0,003$ & $<0,003$ & $<0,003$ & $<0,003$ & $<0,003$ & $<0,003$ & $<0,003$ & $<0,003$ & $<0,003$ & $<0,003$ & $<0,003$ \\
\hline & Máximo & - & - & - & - & - & - & - & - & - & - & - & - & - \\
\hline
\end{tabular}

$\mathbf{N}=$ QUANTIDADE DE DADOS NO PERIODO DA PESQUISA

OS VALORES AQUI PRESENTES FORAM DESCONTADOS OS VALORES DO BRANCO 
Tabela A.4 - Estatísticas descritivas para as concentrações $\left(\mu \mathrm{g} \mathrm{mL} \mathrm{L}^{-1}\right)$ dos elementos iônicos

na água tratada.

Comunidade

\begin{tabular}{|c|c|c|c|c|c|c|c|c|c|c|c|c|c|c|}
\hline & RÁMETRO & IG 60 & $I G 6 I$ & IG 63 & IG 64 & $I G 65$ & $I G 66$ & $I G 67$ & IG 68 & IG 69 & IG 70 & $I G 72$ & $I G 83$ & $I G \mathrm{VGS}$ \\
\hline \multirow[t]{5}{*}{$\mathrm{Cl}^{-}$} & $\mathbf{N}$ & 7 & 7 & 7 & 7 & 7 & 7 & 7 & 7 & 7 & 7 & 7 & 7 & 6 \\
\hline & Média & 4,707 & 4,300 & 2,524 & 3,544 & 4,300 & 2,484 & 2,534 & 2,057 & 3,486 & 3,644 & 4,093 & 3,023 & 4,910 \\
\hline & Mediana & 4,280 & 3,100 & 2,100 & 3,520 & 4,280 & 2,810 & 2,630 & 2,440 & 3,740 & 3,890 & 4,160 & 2,740 & 4,640 \\
\hline & Mínimo & 2,900 & 0,780 & 1,380 & 1,500 & 2,500 & 0,025 & 0,700 & 0,700 & 1,900 & 1,000 & 0,590 & 1,000 & 3,200 \\
\hline & Máximo & 7,330 & 11,840 & 3,850 & 5,680 & 7,600 & 4,300 & 4,300 & 3,740 & 5,410 & 5,530 & 7,150 & 5,320 & 7,410 \\
\hline \multirow[t]{5}{*}{$F^{*}$} & $\mathbf{N}$ & 7 & 7 & 7 & 7 & 7 & 7 & 7 & 7 & 7 & 7 & 7 & 7 & 6 \\
\hline & Média & 0,599 & 0,541 & 0,553 & 0,533 & 0,516 & 0,447 & 0,462 & 0,473 & 0,513 & 0,479 & 0,527 & 0,328 & 0,067 \\
\hline & Mediana & 0,550 & 0,580 & 0,520 & 0,500 & 0,570 & 0,460 & 0,540 & 0,540 & 0,530 & 0,550 & 0,500 & 0,400 & 0,070 \\
\hline & Mínimo & 0,370 & 0,350 & 0,400 & 0,260 & 0,370 & 0,250 & 0,025 & 0,260 & 0,220 & 0,240 & 0,040 & 0,025 & 0,025 \\
\hline & Máximo & 0,860 & 0,800 & 0,780 & 0,760 & 0,610 & 0,560 & 0,750 & 0,630 & 0,730 & 0,670 & 1,300 & 0,460 & 0,120 \\
\hline \multirow[t]{5}{*}{$\overline{K^{+}}$} & $\mathbf{N}$ & 7 & 7 & 7 & 7 & 7 & 7 & 7 & 7 & 7 & 7 & 7 & 7 & 6 \\
\hline & Média & 2,811 & 2,926 & 2,850 & 2,609 & 1,817 & 1,254 & 1,244 & 1,209 & 1,221 & 2,987 & 3,706 & 2,774 & 3,525 \\
\hline & Mediana & 2,990 & 2,660 & 2,810 & 2,800 & 1,530 & 1,420 & 1,430 & 1,200 & 0,870 & 2,910 & 3,400 & 2,790 & 3,175 \\
\hline & Mínimo & $<0,010$ & 2,130 & 2,350 & $<0,010$ & 1,230 & $<0,010$ & 0,090 & 0,750 & 0,210 & 2,640 & 2,420 & 1,860 & 2,630 \\
\hline & Máximo & 4,740 & 3,980 & 3,410 & 4,090 & 2,780 & 1,680 & 1,830 & 1,700 & 3,700 & 3,470 & 5,710 & 4,080 & 4,800 \\
\hline \multirow[t]{5}{*}{$\mathrm{Na}^{+}$} & $\mathbf{N}$ & 7 & 7 & 7 & 7 & 7 & 7 & 7 & 7 & 7 & 7 & 7 & 7 & 6 \\
\hline & Média & 3,743 & 5,149 & 2,971 & 2,540 & 9,940 & 8,210 & 7,403 & 10,320 & 3,990 & 5,426 & 4,199 & 4,280 & 5,083 \\
\hline & Mediana & 3,800 & 5,630 & 2,940 & 2,380 & 9,860 & 8,290 & 6,960 & 9,680 & 3,910 & 5,240 & 4,340 & 4,400 & 4,905 \\
\hline & Mínimo & 0,050 & 3,730 & 1,830 & 1,880 & 1,240 & 5,040 & 4,280 & 6,960 & 3,140 & 3,910 & 2,370 & 2,390 & 2,850 \\
\hline & Máximo & 6,390 & 6,640 & 4,140 & 3,770 & 16,100 & 11,430 & 10,440 & 17,270 & 4,850 & 7,180 & 6,370 & 6,320 & 7,430 \\
\hline \multirow[t]{5}{*}{$\mathrm{NH}_{4}^{+}$} & $\mathbf{N}$ & 7 & 7 & 7 & 7 & 7 & 7 & 7 & 7 & 7 & 7 & 7 & 7 & 6 \\
\hline & Média & - & 0,036 & 0,045 & 0,586 & - & - & - & 0,159 & - & - & 0,026 & - & 0,048 \\
\hline & Mediana & - & 0,025 & 0,025 & 0,025 & - & - & - & 0,025 & - & - & 0,025 & - & 0,025 \\
\hline & Mínimo & $<0,025$ & $<0,025$ & $<0,025$ & $<0,025$ & $<0,025$ & $<0,025$ & $<0,025$ & $<0,025$ & $<0,025$ & $<0,025$ & $<0,025$ & $<0,025$ & $<0,025$ \\
\hline & Máximo & - & 0,090 & 0,150 & 3,730 & - & - & - & 0,960 & - & - & 0,030 & - & 0,160 \\
\hline \multirow[t]{5}{*}{$\mathrm{NO}_{3}{ }^{-}$} & $\mathbf{N}$ & 7 & 7 & 7 & 7 & 7 & 7 & 7 & 7 & 7 & 7 & 7 & 7 & 6 \\
\hline & Média & 3,764 & 6,490 & 3,980 & 1,380 & 1,980 & 0,564 & 1,407 & 0,849 & 0,430 & 1,170 & 1,377 & 0,866 & 1,255 \\
\hline & Mediana & 3,000 & 2,070 & 3,000 & 1,040 & 1,340 & 0,200 & 1,440 & 0,910 & 0,450 & 1,030 & 1,330 & 0,810 & 1,170 \\
\hline & Mínimo & 2,320 & 1,310 & 1,280 & 0,600 & 1,010 & 0,050 & 0,910 & 0,500 & 0,190 & 0,930 & 0,790 & 0,390 & 0,900 \\
\hline & Máximo & 8,070 & 33,600 & 11,950 & 3,550 & 5,960 & 1,830 & 1,830 & 0,940 & 0,620 & 1,480 & 1,990 & 1,400 & 1,770 \\
\hline \multirow[t]{5}{*}{$\mathrm{PO}_{4}^{3-}$} & $\mathbf{N}$ & 7 & 7 & 7 & 7 & 7 & 7 & 7 & 7 & 7 & 7 & 7 & 7 & 6 \\
\hline & Média & - & - & - & - & - & - & - & - & - & - & - & - & - \\
\hline & Mediana & - & - & - & - & - & - & - & - & - & - & - & - & - \\
\hline & Mínimo & $<0,025$ & $<0,025$ & $<0,025$ & $<0,025$ & $<0,025$ & $<0,025$ & $<0,025$ & $<0,025$ & $<0,025$ & $<0,025$ & $<0,025$ & $<0,025$ & $<0,025$ \\
\hline & Máximo & - & - & - & - & - & - & - & - & - & - & - & - & - \\
\hline \multirow[t]{5}{*}{$\mathrm{SO}_{4}{ }^{=}$} & $\mathbf{N}$ & 7 & 7 & 7 & 7 & 7 & 7 & 7 & 7 & 7 & 7 & 7 & 7 & 5 \\
\hline & Média & 12,950 & 8,650 & 3,300 & 8,480 & 4,101 & 1,680 & 3,880 & 6,580 & 2,886 & 6,127 & 10,180 & 4,729 & 14,750 \\
\hline & Mediana & 13,350 & 8,090 & 1,830 & 10,180 & 3,610 & 1,770 & 2,190 & 6,640 & 3,010 & 6,040 & 8,930 & 3,960 & 11,340 \\
\hline & Mínimo & 7,190 & 1,950 & 0,260 & 3,930 & 1,890 & 0,080 & 1,710 & 1,670 & 0,980 & 3,550 & 0,250 & 2,300 & 4,590 \\
\hline & Máximo & 23,460 & 16,030 & 9,800 & 14,250 & 8,970 & 3,220 & 11,670 & 15,660 & 4,590 & 9,410 & 29,920 & 8,080 & 31,980 \\
\hline
\end{tabular}

OS VALORES AQUI PRESENTES FORAM DESCONTADOS OS VALORES DO BRANCO 
Tabela A.5 - Estatísticas descritivas para as concentrações $\left(\mu \mathrm{g} \mathrm{mL} \mathrm{L}^{-1}\right)$ dos metais na fração sobrenadante.

\begin{tabular}{|c|c|c|c|c|c|c|c|c|c|c|c|c|c|c|}
\hline \multirow{2}{*}{\multicolumn{2}{|c|}{ PARÁMETRO }} & & \multicolumn{12}{|c|}{ Comunidade } \\
\hline & & $I G 60$ & $I G 6 I$ & IG 63 & $I G 64$ & IG 65 & $I G 66$ & $I G 67$ & IG 68 & IG 69 & IG 70 & IG 72 & IG 83 & IG VGS \\
\hline \multirow[t]{5}{*}{$A g$} & & 3 & 2 & 3 & 4 & 3 & 4 & 4 & 4 & 5 & 4 & 4 & 4 & 3 \\
\hline & Média & - & 0,009 & - & - & - & - & - & - & - & - & - & - & 0,005 \\
\hline & Mediana & - & 0,009 & - & - & - & - & - & - & - & - & - & - & 0,004 \\
\hline & Mínimo & $<0,001$ & $<0,001$ & $<0,001$ & $<0,001$ & $<0,001$ & $<0,001$ & $<0,001$ & $<0,001$ & $<0,001$ & $<0,001$ & $<0,001$ & $<0,001$ & $<0,001$ \\
\hline & Máximo & - & 0,013 & - & - & - & - & - & - & - & - & - & - & 0,008 \\
\hline$A l$ & $\mathbf{N}$ & 6 & 4 & 6 & 7 & 6 & 6 & 7 & 6 & 7 & 7 & 7 & 7 & 5 \\
\hline & Média & 0,249 & 0,174 & 0,151 & 0,152 & 0,238 & 1,412 & 0,773 & 0,288 & 0,288 & 0,252 & 1,130 & 0,274 & 0,304 \\
\hline & Mediana & 0,205 & 0,136 & 0,168 & 0,141 & 0,169 & 1,052 & 0,503 & 0,191 & 0,199 & 0,206 & 0,899 & 0,193 & 0,140 \\
\hline & Mínimo & $<0,001$ & $<0,001$ & $<0,001$ & $<0,001$ & $<0,001$ & $<0,001$ & $<0,001$ & $<0,001$ & $<0,001$ & $<0,001$ & $<0,001$ & $<0,001$ & $<0,001$ \\
\hline & Máximo & 0,630 & 0,330 & 0,204 & 0,324 & 0,539 & 3,086 & 1,786 & 0,932 & 0,932 & 0,534 & 2,300 & 0,873 & 1,053 \\
\hline$B a$ & $\mathbf{N}$ & 3 & 2 & 3 & 4 & 3 & 4 & 4 & 4 & 5 & 4 & 4 & 4 & 3 \\
\hline & Média & 19,500 & 12,900 & 7,060 & 15,090 & 15,600 & 19,060 & 10,200 & 8,630 & 8,600 & 21,500 & 25,140 & 24,400 & 27,000 \\
\hline & Mediana & 15,600 & 12,900 & 4,600 & 8,770 & 10,500 & 15,750 & 8,500 & 5,980 & 7,850 & 13,600 & 26,150 & 19,000 & 29,300 \\
\hline & Mínimo & 0,200 & 0,0372 & 1,210 & 0,160 & 0,700 & 0,070 & 0,280 & 0,620 & 0,390 & 0,500 & 0,200 & 0,100 & 1,200 \\
\hline & Máximo & 42,700 & 25,700 & 15,390 & 42,660 & 35,700 & 44,680 & 23,530 & 21,930 & 17,340 & 58,100 & 48,080 & 59,500 & 50,500 \\
\hline $\mathrm{Ca}$ & $\mathbf{N}$ & 6 & 4 & 6 & 7 & 6 & 6 & 7 & 6 & 7 & 7 & 7 & 7 & 5 \\
\hline & Média & 20,190 & 24,900 & 28,330 & 8,780 & 7,950 & 3,210 & 1,880 & 8,350 & 11,720 & 17,240 & 2,297 & 3,940 & 21,030 \\
\hline & Mediana & 17,960 & 18,800 & 26,820 & 8,770 & 2,360 & 0,760 & 0,410 & 8,120 & 7,440 & 9,570 & 1,606 & 2,280 & 22,360 \\
\hline & Mínimo & 4,600 & 4,600 & 6,290 & 2,930 & $<0,360$ & $<0,360$ & $<0,360$ & 1,560 & 0,630 & 6,970 & 0,330 & 0,340 & 3,210 \\
\hline & Máximo & 47,200 & 57,200 & 65,300 & 15,500 & 31,020 & 15,840 & 6,830 & 17,570 & 34,110 & 31,010 & 5,520 & 11,030 & 37,280 \\
\hline$\overline{C d}$ & $\mathbf{N}$ & 6 & 4 & 6 & 7 & 6 & 6 & 7 & 6 & 7 & 7 & 7 & 7 & 5 \\
\hline & Média & - & - & 0,004 & 0,004 & - & 0,005 & 0,004 & 0,004 & 0,005 & 0,005 & 0,005 & 0,005 & 0,004 \\
\hline & Mediana & - & - & 0,004 & 0,004 & - & 0,004 & 0,004 & 0,004 & 0,004 & 0,004 & 0,004 & 0,004 & 0,004 \\
\hline & Mínimo & $<0,004$ & $<0,004$ & $<0,004$ & $<0,004$ & $<0,004$ & $<0,004$ & $<0,004$ & $<0,004$ & $<0,004$ & $<0,004$ & $<0,004$ & $<0,004$ & $<0,004$ \\
\hline & Máximo & - & - & 0,005 & 0,005 & - & 0,007 & 0,005 & 0,005 & 0,007 & 0,006 & 0,006 & 0,006 & 0,005 \\
\hline Co & $\mathbf{N}$ & 6 & 4 & 6 & 7 & 6 & 6 & 7 & 6 & 7 & 7 & 7 & 7 & 5 \\
\hline & Média & - & 0,030 & 0,030 & 0,026 & 0,027 & 0,026 & 0,025 & 0,025 & 0,033 & 0,030 & 0,025 & 0,026 & 0,029 \\
\hline & Mediana & - & 0,017 & 0,017 & 0,017 & 0,017 & 0,017 & 0,017 & 0,017 & 0,017 & 0,017 & 0,017 & 0,017 & 0,017 \\
\hline & Mínimo & $<0,017$ & $<0,017$ & $<0,017$ & $<0,017$ & $<0,017$ & $<0,017$ & $<0,017$ & $<0,017$ & $<0,017$ & $<0,017$ & $<0,017$ & $<0,017$ & $<0,017$ \\
\hline & Máximo & - & 0,045 & 0,045 & 0,030 & 0,038 & 0,030 & 0,026 & 0,025 & 0,082 & 0,041 & 0,025 & 0,029 & 0,041 \\
\hline $\mathrm{Cr}$ & $\mathbf{N}$ & 6 & 4 & 6 & 7 & 6 & 6 & 7 & 6 & 7 & 7 & 7 & 7 & 5 \\
\hline & Média & - & - & - & - & - & - & - & - & - & - & - & - & - \\
\hline & Mediana & - & - & - & - & - & - & - & - & - & - & - & - & - \\
\hline & Mínimo & $<0,044$ & $<0,044$ & $<0,044$ & $<0,044$ & $<0,044$ & $<0,044$ & $<0,044$ & $<0,044$ & $<0,044$ & $<0,044$ & $<0,044$ & $<0,044$ & $<0,044$ \\
\hline & Máximo & - & - & - & - & - & - & - & - & - & - & - & - & - \\
\hline $\mathrm{Cu}$ & $\mathbf{N}$ & 6 & 4 & 6 & 7 & 6 & 6 & 7 & 6 & 7 & 7 & 7 & 7 & 5 \\
\hline & Média & 0,006 & 0,008 & 0,007 & 0,008 & 0,007 & 0,006 & 0,006 & 0,008 & 0,005 & 0,007 & 0,007 & 0,007 & 0,007 \\
\hline & Mediana & 0,005 & 0,009 & 0,005 & 0,004 & 0,005 & 0,004 & 0,004 & 0,004 & 0,004 & 0,004 & 0,006 & 0,004 & 0,005 \\
\hline & Mínimo & $<0,003$ & $<0,003$ & $<0,003$ & $<0,003$ & $<0,003$ & $<0,003$ & $<0,003$ & $<0,003$ & $<0,003$ & $<0,003$ & $<0,003$ & $<0,003$ & $<0,003$ \\
\hline & Máximo & 0,010 & 0,011 & 0,011 & 0,023 & 0,010 & 0,010 & 0,013 & 0,015 & 0,008 & 0,013 & 0,017 & 0,014 & 0,012 \\
\hline $\mathrm{Fe}$ & $\mathbf{N}$ & 6 & 4 & 6 & 7 & 6 & 6 & 7 & 6 & 7 & 7 & 7 & 7 & 5 \\
\hline & Média & 3,714 & 1,478 & 15,000 & 5,520 & 15,200 & 1,616 & 2,400 & 3,450 & 19,230 & 7,860 & 1,025 & 3,760 & 7,290 \\
\hline & Mediana & 4,251 & 1,301 & 9,810 & 3,930 & 1,300 & 0,558 & 1,410 & 2,210 & 10,330 & 8,420 & 0,590 & 2,920 & 8,110 \\
\hline & Mínimo & 0,842 & $<0,010$ & 0,080 & 2,490 & 0,100 & 0,117 & 0,300 & 0,070 & 0,560 & 2,220 & 0,032 & 0,620 & 0,810 \\
\hline & Máximo & 5,580 & 3,295 & 52,500 & 13,790 & 77,900 & 4,523 & 10,330 & 8,110 & 56,800 & 11,830 & 2,390 & 11,400 & 13,150 \\
\hline$\overline{M g}$ & $\mathbf{N}$ & 6 & 4 & 6 & 7 & 6 & 6 & 7 & 6 & 7 & 7 & 7 & 7 & 5 \\
\hline & Média & 8,590 & 10,600 & 10,830 & 2,518 & 2,760 & 0,587 & 0,690 & 2,810 & 1,591 & 6,460 & 0,777 & 1,741 & 7,660 \\
\hline & Mediana & 7,420 & 2,450 & 10,000 & 2,248 & 1,210 & 0,186 & 0,208 & 2,767 & 1,502 & 4,640 & 0,537 & 1,140 & 9,030 \\
\hline & Mínimo & 2,540 & 0,110 & 1,850 & 0,827 & 0,110 & $<0,010$ & $<0,010$ & 0,970 & 0,204 & 2,510 & $<0,010$ & 0,108 & 1,390 \\
\hline & Máximo & 20,220 & 37,410 & 26,900 & 5,980 & 9,520 & 2,670 & 2,750 & 5,900 & 2,957 & 11,860 & 1,582 & 3,650 & 13,970 \\
\hline$\overline{M n}$ & $\mathbf{N}$ & 6 & 4 & 6 & 7 & 6 & 6 & 7 & 6 & 7 & 7 & 7 & 7 & 5 \\
\hline & Média & 5,160 & 0,987 & 7,710 & 7,500 & 2,110 & 3,820 & 1,591 & 4,500 & 3,460 & 5,570 & 0,419 & 1,382 & 10,250 \\
\hline & Mediana & 4,370 & 0,875 & 8,520 & 6,570 & 0,440 & 0,240 & 0,121 & 4,260 & 2,880 & 3,650 & 0,130 & 0,780 & 10,930 \\
\hline & Mínimo & 0,530 & 0,008 & 2,880 & 2,460 & 0,010 & 0,060 & $<0,001$ & 0,150 & 0,010 & 1,870 & $<0,001$ & $<0,001$ & 0,010 \\
\hline & Máximo & 10,600 & 2,190 & 12,300 & 12,020 & 9,000 & 18,930 & 4,325 & 10,090 & 10,650 & 14,320 & 1,493 & 5,930 & 15,960 \\
\hline $\mathrm{Ni}$ & $\mathbf{N}$ & 6 & 4 & 6 & 7 & 6 & 6 & 7 & 6 & 7 & 7 & 7 & 7 & 5 \\
\hline & Média & 0,033 & 0,033 & 0,028 & 0,027 & 0,026 & 0,026 & 0,026 & - & - & 0,032 & 0,035 & 0,029 & 0,042 \\
\hline & Mediana & 0,026 & 0,026 & 0,026 & 0,026 & 0,026 & 0,026 & 0,026 & - & - & 0,026 & 0,026 & 0,026 & 0,026 \\
\hline & Mínimo & $<0,026$ & $<0,026$ & $<0,026$ & $<0,026$ & $<0,026$ & $<0,026$ & $<0,026$ & $<0,026$ & $<0,026$ & $<0,026$ & $<0,026$ & $<0,026$ & $<0,026$ \\
\hline & Máximo & 0,075 & 0,073 & 0,060 & 0,054 & 0,051 & 0,050 & 0,041 & - & - & 0,070 & 0,110 & 0,090 & 0,100 \\
\hline$P$ & $\mathbf{N}$ & 5 & 3 & 5 & 6 & 5 & 5 & 6 & 5 & 7 & 6 & 6 & 6 & 5 \\
\hline & Média & 0,237 & 0,067 & 0,215 & 0,189 & 0,438 & 0,053 & 0,157 & 0,507 & 0,419 & 0,258 & 0,059 & 0,227 & 0,309 \\
\hline & Mediana & 0,233 & 0,081 & 0,141 & 0,178 & 0,104 & 0,066 & 0,081 & 0,337 & 0,191 & 0,264 & 0,049 & 0,076 & 0,160 \\
\hline & Mínimo & $<0,009$ & 0,026 & 0,022 & 0,095 & 0,026 & 0,014 & 0,028 & 0,095 & 0,095 & 0,094 & 0,010 & 0,043 & 0,060 \\
\hline & Máximo & 0,462 & 0,095 & 0,591 & 0,301 & 1,623 & 0,094 & 0,552 & 1,434 & 1,360 & 0,403 & 0,144 & 0,970 & 0,881 \\
\hline$P b$ & $\mathbf{N}$ & 3 & 2 & 3 & 4 & 3 & 4 & 4 & 4 & 5 & 4 & 4 & 4 & 3 \\
\hline & Média & 0,036 & 0,038 & 0,030 & 0,036 & 0,032 & - & - & - & - & - & - & - & - \\
\hline & Mediana & 0,016 & 0,038 & 0,016 & 0,035 & 0,016 & - & - & - & - & - & - & - & - \\
\hline & Mínimo & $<0,016$ & $<0,030$ & $<0,016$ & $<0,016$ & $<0,016$ & $<0,016$ & $<0,016$ & $<0,016$ & $<0,016$ & $<0,016$ & $<0,016$ & $<0,016$ & $<0,016$ \\
\hline & Máximo & 0,048 & 0,046 & 0,030 & 0,046 & 0,036 & - & - & - & - & - & - & - & - \\
\hline$Z n$ & $\mathbf{N}$ & 6 & 4 & 6 & 7 & 6 & 6 & 7 & 6 & 7 & 7 & 7 & 7 & 5 \\
\hline & Média & - & - & 0,083 & 0,082 & - & - & 0,073 & 0,087 & 0,077 & 0,113 & - & - & - \\
\hline & Mediana & - & - & 0,003 & 0,003 & - & - & 0,003 & 0,003 & 0,003 & 0,003 & - & - & - \\
\hline & Mínimo & $<0,003$ & $<0,003$ & $<0,003$ & $<0,003$ & $<0,003$ & $<0,003$ & $<0,003$ & $<0,003$ & $<0,003$ & $<0,003$ & $<0,003$ & $<0,003$ & $<0,003$ \\
\hline & Máximo & - & - & 0,141 & 0,148 & - & - & 0,085 & 0,166 & 0,114 & 0,360 & - & - & - \\
\hline
\end{tabular}

$\mathbf{N}=$ QUANTIDADE DE DADOS NO PERIODO DA PESQUISA

OS VALORES AQUI PRESENTES FORAM DESCONTADOS OS VALORES DO BRANCO 
Tabela A.6 - Estatísticas descritivas para as concentrações $\left(\mu \mathrm{g} \mathrm{mL} L^{-1}\right)$ dos metais na fração intersticial.

\begin{tabular}{|c|c|c|c|c|c|c|c|c|c|c|c|c|c|c|}
\hline \multirow{2}{*}{\multicolumn{2}{|c|}{ PARÁMETRO }} & \multicolumn{13}{|c|}{ Comunidade } \\
\hline & & $I G 60$ & $I G 61$ & $I G 63$ & $I G 64$ & $I G 65$ & $I G 66$ & $I G 67$ & IG 68 & IG 69 & IG 70 & IG 72 & IG 83 & IG VGS \\
\hline \multirow[t]{5}{*}{$\mathrm{Ag}$} & $\mathbf{N}$ & 4 & 2 & 3 & 4 & 4 & 4 & 3 & 4 & 4 & 4 & 1 & 4 & 2 \\
\hline & Média & 0,006 & 0,004 & 0,006 & 0,007 & 0,007 & 0,007 & 0,008 & 0,007 & 0,007 & 0,007 & 0,004 & 0,008 & 0,013 \\
\hline & Mediana & 0,001 & 0,001 & 0,001 & 0,001 & 0,001 & 0,001 & 0,001 & 0,001 & 0,001 & 0,001 & 0,001 & 0,001 & 0,013 \\
\hline & Mínimo & $<0,001$ & $<0,001$ & $<0,001$ & $<0,001$ & $<0,001$ & $<0,001$ & $<0,001$ & $<0,001$ & $<0,001$ & $<0,001$ & $<0,001$ & $<0,001$ & $<0,001$ \\
\hline & Máximo & 0,012 & 0,004 & 0,011 & 0,014 & 0,015 & 0,015 & 0,017 & 0,017 & 0,016 & 0,018 & 0,004 & 0,020 & 0,022 \\
\hline$A l$ & $\mathbf{N}$ & 7 & 5 & 5 & 6 & 7 & 5 & 5 & 7 & 7 & 7 & 2 & 7 & 4 \\
\hline & Média & 2,050 & 2,206 & 0,524 & 0,587 & 1,045 & 3,640 & 4,080 & 0,807 & 0,511 & 0,902 & 2,890 & 0,614 & 0,259 \\
\hline & Mediana & 0,650 & 2,168 & 0,281 & 0,523 & 0,560 & 3,550 & 2,730 & 0,258 & 0,442 & 0,447 & 2,890 & 0,300 & 0,196 \\
\hline & Mínimo & $<0,001$ & 0,180 & $<0,001$ & $<0,001$ & 0,119 & 0,180 & 0,240 & $<0,001$ & $<0,001$ & $<0,001$ & 0,620 & 0,160 & $<0,001$ \\
\hline & Máximo & 9,950 & 4,371 & 1,184 & 1,111 & 3,055 & 6,780 & 12,360 & 3,508 & 1,738 & 3,499 & 5,160 & 1,616 & 0,553 \\
\hline$B a$ & $\mathbf{N}$ & 5 & 2 & 3 & 4 & 4 & 4 & 3 & 4 & 4 & 4 & 1 & 4 & 2 \\
\hline & Média & 16,280 & 27,300 & 12,000 & 8,150 & 12,620 & 17,840 & 8,960 & 11,080 & 8,680 & 24,900 & 48,990 & 20,070 & 18,900 \\
\hline & Mediana & 16,760 & 27,300 & 15,570 & 8,460 & 12,130 & 17,170 & 12,400 & 12,450 & 7,970 & 21,400 & 48,990 & 18,440 & 18,900 \\
\hline & Mínimo & 0,150 & 16,800 & 2,380 & 0,200 & 0,640 & 0,210 & 0,170 & 0,740 & 0,330 & 0,400 & 48,990 & 0,100 & 1,100 \\
\hline & Máximo & 43,350 & 37,800 & 18,050 & 15,490 & 25,570 & 36,820 & 14,300 & 18,700 & 18,440 & 56,300 & 48,990 & 43,300 & 36,600 \\
\hline$C a$ & $\mathbf{N}$ & 7 & 5 & 5 & 6 & 7 & 5 & 5 & 7 & 7 & 7 & 2 & 7 & 4 \\
\hline & Média & 21,610 & 30,000 & 21,960 & 6,150 & 7,730 & 3,860 & 0,864 & 20,090 & 18,430 & 18,870 & 2,970 & 5,410 & 21,020 \\
\hline & Mediana & 14,410 & 34,600 & 21,570 & 4,980 & 3,450 & 1,330 & 0,557 & 16,520 & 8,090 & 13,200 & 2,970 & 1,350 & 20,880 \\
\hline & Mínimo & 3,110 & 3,200 & 7,570 & 1,190 & $<0,360$ & $<0,360$ & $<0,360$ & 1,960 & $<0,360$ & 7,430 & 1,590 & $<0,360$ & 13,200 \\
\hline & Máximo & 61,300 & 57,200 & 37,260 & 15,500 & 21,550 & 15,840 & 2,337 & 61,400 & 59,700 & 33,780 & 4,350 & 20,370 & 29,100 \\
\hline$C d$ & $\mathbf{N}$ & 7 & 5 & 5 & 6 & 7 & 5 & 5 & 7 & 7 & 7 & 2 & 7 & 4 \\
\hline & Média & 0,005 & 0,004 & 0,004 & 0,004 & 0,005 & 0,005 & 0,004 & 0,006 & 0,005 & 0,005 & 0,005 & 0,005 & 0,004 \\
\hline & Mediana & 0,004 & 0,004 & 0,004 & 0,004 & 0,004 & 0,004 & 0,004 & 0,004 & 0,004 & 0,004 & 0,004 & 0,004 & 0,004 \\
\hline & Mínimo & $<0,004$ & $<0,004$ & $<0,004$ & $<0,004$ & $<0,004$ & $<0,004$ & $<0,004$ & $<0,004$ & $<0,004$ & $<0,004$ & $<0,004$ & $<0,004$ & $<0,004$ \\
\hline & Máximo & 0,006 & 0,005 & 0,004 & 0,005 & 0,007 & 0,007 & 0,004 & 0,013 & 0,009 & 0,007 & 0,005 & 0,008 & 0,005 \\
\hline Co & $\mathbf{N}$ & 7 & 5 & 5 & 6 & 7 & 5 & 5 & 7 & 7 & 7 & 2 & 7 & 4 \\
\hline & Média & 0,031 & 0,026 & 0,038 & 0,031 & 0,032 & 0,032 & 0,032 & 0,036 & 0,032 & 0,033 & 0,025 & 0,035 & 0,040 \\
\hline & Mediana & 0,017 & 0,017 & 0,017 & 0,017 & 0,017 & 0,017 & 0,017 & 0,017 & 0,017 & 0,017 & 0,017 & 0,017 & 0,017 \\
\hline & Mínimo & $<0,017$ & $<0,017$ & $<0,017$ & $<0,017$ & $<0,017$ & $<0,017$ & $<0,017$ & $<0,017$ & $<0,017$ & $<0,017$ & $<0,017$ & $<0,017$ & $<0,017$ \\
\hline & Máximo & 0,047 & 0,028 & 0,087 & 0,058 & 0,073 & 0,055 & 0,060 & 0,062 & 0,061 & 0,064 & 0,025 & 0,068 & 0,084 \\
\hline $\mathrm{Cr}$ & $\mathbf{N}$ & 7 & 5 & 5 & 6 & 7 & 5 & 5 & 7 & 7 & 7 & 2 & 7 & 4 \\
\hline & Média & - & - & - & - & - & - & - & - & - & - & - & - & - \\
\hline & Mediana & - & - & - & - & - & - & - & - & - & - & - & - & - \\
\hline & Mínimo & $<0,044$ & $<0,044$ & $<0,044$ & $<0,044$ & $<0,044$ & $<0,044$ & $<0,044$ & $<0,044$ & $<0,044$ & $<0,044$ & $<0,044$ & $<0,044$ & $<0,044$ \\
\hline & Máximo & - & - & - & - & - & - & - & - & - & - & - & - & - \\
\hline $\mathrm{Cu}$ & $\mathbf{N}$ & 7 & 5 & 5 & 6 & 7 & 5 & 5 & 7 & 7 & 7 & 2 & 7 & 4 \\
\hline & Média & 0,011 & 0,014 & 0,011 & 0,011 & 0,015 & 0,007 & 0,009 & 0,011 & 0,010 & 0,010 & 0,009 & 0,011 & 0,013 \\
\hline & Mediana & 0,007 & 0,012 & 0,007 & 0,008 & 0,010 & 0,004 & 0,008 & 0,013 & 0,007 & 0,009 & 0,009 & 0,012 & 0,013 \\
\hline & Mínimo & $<0,003$ & $<0,004$ & $<0,004$ & $<0,004$ & $<0,004$ & $<0,004$ & $<0,004$ & $<0,004$ & $<0,004$ & $<0,004$ & $<0,004$ & $<0,004$ & $<0,004$ \\
\hline & Máximo & 0,031 & 0,033 & 0,032 & 0,027 & 0,053 & 0,012 & 0,019 & 0,023 & 0,023 & 0,019 & 0,013 & 0,020 & 0,025 \\
\hline $\mathrm{Fe}$ & $\mathbf{N}$ & 7 & 5 & 5 & 6 & 7 & 5 & 5 & 7 & 7 & 7 & 2 & 7 & 4 \\
\hline & Média & 3,050 & 3,970 & 9,900 & 3,408 & 7,660 & 2,210 & 4,900 & 7,620 & 9,140 & 5,290 & 2,732 & 8,250 & 3,480 \\
\hline & Mediana & 2,120 & 3,950 & 1,460 & 2,949 & 2,850 & 1,250 & 3,330 & 4,160 & 5,660 & 3,160 & 2,732 & 3,260 & 3,520 \\
\hline & Mínimo & 0,460 & 0,940 & 0,640 & 1,041 & 0,590 & 0,410 & 0,190 & 1,630 & 0,450 & 0,630 & 2,390 & 0,090 & 0,850 \\
\hline & Máximo & 9,010 & 7,320 & 43,940 & 6,940 & 34,920 & 6,640 & 10,480 & 29,030 & 29,860 & 13,740 & 3,075 & 43,440 & 6,030 \\
\hline$M g$ & $\mathbf{N}$ & 7 & 5 & 5 & 6 & 7 & 5 & 5 & 7 & 7 & 7 & 2 & 7 & 4 \\
\hline & Média & 9,010 & 15,550 & 7,390 & 1,947 & 2,830 & 0,717 & 0,325 & 6,320 & 2,025 & 6,930 & 0,726 & 2,040 & 8,580 \\
\hline & Mediana & 7,020 & 9,490 & 10,180 & 1,205 & 1,350 & 0,252 & 0,219 & 3,370 & 1,423 & 4,990 & 0,726 & 0,280 & 9,300 \\
\hline & Mínimo & 1,910 & 1,140 & 2,030 & 0,381 & 0,110 & $<0,008$ & $<0,008$ & 0,640 & $<0,008$ & 2,370 & 0,293 & 0,110 & 3,860 \\
\hline & Máximo & 25,990 & 39,410 & 10,360 & 5,980 & 7,060 & 2,666 & 0,926 & 16,850 & 6,420 & 12,830 & 1,160 & 7,760 & 11,860 \\
\hline$M n$ & $\mathbf{N}$ & 7 & 5 & 5 & 6 & 7 & 5 & 5 & 7 & 7 & 7 & 2 & 7 & 4 \\
\hline & Média & 5,350 & 4,360 & 6,260 & 4,308 & 1,630 & 4,060 & 0,469 & 10,050 & 5,760 & 5,100 & 0,684 & 1,800 & 8,580 \\
\hline & Mediana & 2,840 & 2,190 & 4,740 & 4,957 & 0,422 & 0,280 & 0,273 & 8,300 & 1,930 & 5,030 & 0,684 & 0,220 & 10,160 \\
\hline & Mínimo & 0,260 & 0,310 & 3,270 & 0,714 & $<0,001$ & 0,160 & $<0,001$ & 0,330 & 0,010 & 1,430 & 0,209 & 0,010 & 1,610 \\
\hline & Máximo & 15,430 & 11,140 & 13,060 & 6,300 & 6,534 & 18,930 & 1,075 & 31,280 & 20,950 & 11,280 & 1,160 & 5,660 & 12,380 \\
\hline $\mathrm{Ni}$ & $\mathbf{N}$ & 7 & 5 & 5 & 6 & 7 & 5 & 5 & 7 & 7 & 7 & 2 & 7 & 4 \\
\hline & Média & 0,041 & 0,048 & 0,043 & 0,030 & 0,025 & 0,016 & 0,031 & 0,026 & 0,020 & 0,037 & 0,052 & 0,034 & 0,037 \\
\hline & Mediana & 0,026 & 0,028 & 0,044 & 0,026 & 0,026 & 0,026 & 0,026 & 0,026 & 0,026 & 0,026 & 0,052 & 0,014 & 0,032 \\
\hline & Mínimo & $<0,026$ & $<0,026$ & $<0,026$ & $<0,026$ & $<0,026$ & $<0,026$ & $<0,026$ & $<0,026$ & $<0,026$ & $<0,026$ & $<0,026$ & $<0,026$ & $<0,026$ \\
\hline & Máximo & 0,107 & 0,112 & 0,080 & 0,080 & 0,054 & 0,026 & 0,068 & 0,046 & 0,033 & 0,110 & 0,090 & 0,080 & 0,070 \\
\hline$P$ & $\mathbf{N}$ & 6 & 4 & 5 & 5 & 6 & 4 & 5 & 6 & 6 & 6 & 2 & 6 & 4 \\
\hline & Média & 0,316 & 0,165 & 0,356 & 0,319 & 0,399 & 0,061 & 0,468 & 0,699 & 0,443 & 0,343 & 0,055 & 0,115 & 0,347 \\
\hline & Mediana & 0,174 & 0,137 & 0,238 & 0,248 & 0,139 & 0,054 & 0,229 & 0,354 & 0,337 & 0,301 & 0,055 & 0,103 & 0,282 \\
\hline & Mínimo & 0,059 & 0,072 & 0,075 & 0,181 & 0,070 & 0,012 & 0,010 & 0,095 & 0,056 & 0,090 & 0,022 & 0,060 & 0,070 \\
\hline & Máximo & 0,770 & 0,315 & 1,001 & 0,520 & 1,593 & 0,122 & 1,298 & 2,012 & 1,109 & 0,660 & 0,087 & 0,215 & 0,756 \\
\hline$P b$ & $\mathbf{N}$ & 5 & 2 & 3 & 4 & 4 & 4 & 3 & 4 & 4 & 4 & 1 & 4 & 2 \\
\hline & Média & 0,033 & 0,038 & 0,032 & 0,016 & 0,016 & 0,016 & 0,016 & 0,016 & 0,031 & 0,033 & 0,016 & 0,016 & 0,016 \\
\hline & Mediana & 0,016 & 0,038 & 0,016 & 0,016 & 0,016 & 0,016 & 0,016 & 0,016 & 0,016 & 0,016 & 0,016 & 0,016 & 0,016 \\
\hline & Mínimo & $<0,016$ & $<0,016$ & $<0,016$ & $<0,016$ & $<0,016$ & $<0,016$ & $<0,016$ & $<0,016$ & $<0,016$ & $<0,016$ & $<0,016$ & $<0,016$ & $<0,016$ \\
\hline & Máximo & 0,046 & 0,046 & 0,036 & 0,016 & 0,016 & 0,016 & 0,016 & 0,016 & 0,036 & 0,044 & 0,016 & 0,016 & 0,016 \\
\hline$\overline{Z n}$ & $\mathbf{N}$ & 7 & 4 & 5 & 6 & 7 & 5 & 5 & 7 & 7 & 7 & 2 & 7 & 4 \\
\hline & Média & 0,077 & 0,003 & 0,073 & 0,078 & 0,003 & 0,003 & 0,074 & 0,003 & 0,003 & 0,003 & 0,003 & 0,003 & 0,003 \\
\hline & Mediana & 0,003 & 0,003 & 0,003 & 0,003 & 0,003 & 0,003 & 0,003 & 0,003 & 0,003 & 0,003 & 0,003 & 0,003 & 0,003 \\
\hline & Mínimo & $<0,003$ & $<0,003$ & $<0,003$ & $<0,003$ & $<0,003$ & $<0,003$ & $<0,003$ & $<0,003$ & $<0,003$ & $<0,003$ & $<0,003$ & $<0,003$ & $<0,003$ \\
\hline & Máximo & 0,107 & 0,003 & 0,079 & 0,095 & 0,071 & 0,003 & 0,084 & 0,003 & 0,003 & 0,003 & 0,003 & 0,003 & 0,003 \\
\hline
\end{tabular}

$\mathbf{N}=$ QUANTIDADE DE DADOS NO PERIODO DA PESQUISA

OS VALORES AQUI PRESENTES FORAM DESCONTADOS OS VALORES DO BRANCO 
Tabela A.7 - Estatísticas descritivas para as concentrações $\left(\mu \mathrm{g}^{-1}\right)$ dos metais na fração digestão (biodisponível).

\begin{tabular}{|c|c|c|c|c|c|c|c|c|c|c|c|c|c|c|}
\hline \multirow{2}{*}{\multicolumn{2}{|c|}{ PARÁMETRO }} & \multicolumn{13}{|c|}{ Comunidade } \\
\hline & & $I G 60$ & $I G 61$ & $I G 63$ & $I G 64$ & IG 65 & $I G 66$ & $I G 67$ & $I G 68$ & IG 69 & $I G 70$ & IG 72 & IG 83 & IG VGS \\
\hline \multirow[t]{5}{*}{$\mathrm{Ag}$} & $\mathbf{N}$ & 4 & 4 & 4 & 4 & 4 & 4 & 4 & 4 & 4 & 4 & 4 & 4 & 4 \\
\hline & Média & 0,680 & 0,039 & 0,004 & 0,139 & 0,004 & 0,021 & 0,004 & 0,004 & 0,011 & 0,029 & 0,001 & 0,001 & 0,041 \\
\hline & Mediana & 0,062 & 0,001 & 0,001 & 0,143 & 0,001 & 0,011 & 0,001 & 0,001 & 0,001 & 0,018 & 0,001 & 0,001 & 0,001 \\
\hline & Mínimo & $<0,001$ & $<0,001$ & $<0,001$ & 0,056 & $<0,001$ & $<0,001$ & $<0,001$ & $<0,001$ & $<0,001$ & $<0,001$ & $<0,001$ & $<0,001$ & $<0,001$ \\
\hline & Máximo & 2,591 & 0,144 & 0,004 & 0,214 & 0,004 & 0,056 & 0,004 & 0,004 & 0,030 & 0,074 & 0,001 & 0,001 & 0,150 \\
\hline$A l$ & $\mathbf{N}$ & 7 & 6 & 7 & 7 & 7 & 7 & 7 & 7 & 7 & 7 & 7 & 7 & 6 \\
\hline & Média & 463,0 & 349,2 & 624,8 & $1.058,0$ & $1.290,0$ & $1.003,0$ & 740,0 & 880,9 & $2.231,0$ & 862,5 & 370,0 & 636,7 & $1.248,0$ \\
\hline & Mediana & 507,4 & 318,7 & 597,4 & $1.134,0$ & $1.206,0$ & $1.106,0$ & 804,0 & 859,4 & $2.344,0$ & 919,5 & 308,4 & 649,2 & 626,0 \\
\hline & Mínimo & 46,1 & 143,6 & 435,6 & 457,0 & 752,0 & 161,0 & 11,0 & 642,5 & $1.046,0$ & 576,1 & 156,3 & 337,0 & 134,0 \\
\hline & Máximo & 752,3 & 619,9 & 878,4 & $1.321,0$ & $2.199,0$ & $1.429,0$ & $1.182,0$ & $1.168,8$ & $3.169,0$ & $1.191,0$ & 630,0 & 906,6 & $5.115,0$ \\
\hline$B a$ & $\mathbf{N}$ & 4 & 4 & 4 & 4 & 4 & 4 & 4 & 4 & 4 & 4 & 4 & 4 & 4 \\
\hline & Média & $1.358,0$ & 973,0 & 897,8 & $2.983,0$ & $1.090,0$ & 782,4 & 876,0 & 819,0 & $3.669,0$ & $3.635,0$ & 916,0 & $1.211,0$ & $2.085,0$ \\
\hline & Mediana & $1.394,2$ & $1.012,0$ & 890,7 & $3.431,0$ & 993,0 & 767,2 & 876,0 & 692,0 & $3.897,0$ & $3.838,0$ & $1.030,0$ & $1.063,0$ & $1.810,0$ \\
\hline & Mínimo & $1.133,8$ & 318,0 & 782,6 & $1.118,0$ & 315,0 & 702,1 & 630,0 & 496,0 & 531,0 & $2.722,0$ & 476,0 & 406,0 & 592,0 \\
\hline & Máximo & $1.509,7$ & $1.551,0$ & $1.027,3$ & $3.952,0$ & $2.059,0$ & 893,2 & $1.122,0$ & $1.395,0$ & $6.350,0$ & $4.140,0$ & $1.128,0$ & $2.314,0$ & $4.127,0$ \\
\hline $\mathrm{Ca}$ & $\mathbf{N}$ & 7 & 6 & 7 & 7 & 7 & 7 & 7 & 7 & 7 & 7 & 7 & 7 & 6 \\
\hline & Média & 822,0 & 987,0 & 743,0 & $1.006,0$ & 818,0 & 503,0 & 767,1 & 927,3 & $4.151,0$ & $1.279,6$ & $1.004,0$ & 636,9 & 809,4 \\
\hline & Mediana & 741,0 & 978,0 & 653,0 & 844,0 & 912,0 & 470,0 & 673,8 & 883,2 & $2.072,0$ & $1.225,4$ & 731,0 & 571,1 & 838,0 \\
\hline & Mínimo & 59,0 & 571,0 & 27,0 & 670,0 & 411,0 & 73,0 & 573,1 & 717,9 & 891,0 & $1.114,0$ & 498,0 & 372,8 & 511,1 \\
\hline & Máximo & $1.274,0$ & $1.473,0$ & $1.394,0$ & $1.983,0$ & $1.194,0$ & 942,0 & $1.025,0$ & $1.147,5$ & $11.393,0$ & $1.605,8$ & $2.829,0$ & 952,0 & $1.112,3$ \\
\hline$C d$ & $\mathbf{N}$ & 7 & 6 & 7 & 7 & 7 & 7 & 7 & 7 & 7 & 7 & 7 & 7 & 6 \\
\hline & Média & 0,436 & 1,550 & 0,442 & 1,250 & 0,501 & 0,167 & 0,431 & 0,260 & 0,715 & 1,041 & 0,175 & 0,423 & 1,760 \\
\hline & Mediana & 0,394 & 0,270 & 0,336 & 1,277 & 0,518 & 0,174 & 0,308 & 0,314 & 0,743 & 1,084 & 0,194 & 0,196 & 0,760 \\
\hline & Mínimo & 0,052 & 0,020 & 0,162 & 0,558 & 0,080 & 0,025 & 0,212 & 0,082 & 0,148 & 0,760 & 0,016 & 0,048 & 0,040 \\
\hline & Máximo & 0,920 & 8,200 & 0,900 & 1,820 & 1,539 & 0,264 & 0,723 & 0,390 & 1,136 & 1,263 & 0,370 & 1,156 & 7,050 \\
\hline Co & $\mathbf{N}$ & 7 & 6 & 7 & 7 & 7 & 7 & 7 & 7 & 7 & 7 & 7 & 7 & 6 \\
\hline & Média & 4,074 & 4,260 & 3,745 & 15,540 & 4,640 & 1,659 & 2,538 & 2,588 & 3,323 & 9,095 & 1,798 & 5,396 & 5,410 \\
\hline & Mediana & 4,080 & 3,650 & 3,192 & 16,270 & 2,610 & 1,721 & 2,372 & 2,425 & 3,643 & 9,091 & 1,792 & 5,839 & 6,000 \\
\hline & Mínimo & 0,431 & 0,700 & 2,374 & 9,080 & 1,260 & 0,320 & 1,654 & 1,177 & 0,807 & 6,360 & 0,936 & 1,837 & 0,760 \\
\hline & Máximo & 7,997 & 9,880 & 6,238 & 18,710 & 16,390 & 2,235 & 4,036 & 4,036 & 4,751 & 11,299 & 2,660 & 8,948 & 11,690 \\
\hline $\mathrm{Cr}$ & $\mathbf{N}$ & 7 & 6 & 7 & 7 & 7 & 7 & 7 & 7 & 7 & 7 & 7 & 7 & 6 \\
\hline & Média & 1,185 & 1,663 & 1,229 & 1,972 & 1,053 & 0,569 & 0,966 & 1,033 & 1,955 & 1,746 & 0,898 & 1,508 & 1,229 \\
\hline & Mediana & 1,338 & 1,482 & 1,035 & 1,385 & 0,846 & 0,626 & 0,901 & 0,953 & 1,734 & 1,465 & 0,887 & 1,616 & 1,282 \\
\hline & Mínimo & 0,131 & 0,320 & 0,825 & 0,920 & 0,450 & 0,110 & 0,652 & 0,659 & 1,029 & 1,041 & 0,658 & 0,885 & 0,714 \\
\hline & Máximo & 1,639 & 3,573 & 2,004 & 3,160 & 2,829 & 0,752 & 1,770 & 1,630 & 3,260 & 2,508 & 1,151 & 2,280 & 1,777 \\
\hline $\mathrm{Cu}$ & $\mathbf{N}$ & 7 & 6 & 7 & 7 & 7 & 7 & 7 & 7 & 7 & 7 & 7 & 7 & 6 \\
\hline & Média & 8,020 & 6,490 & 2,827 & 11,120 & 4,740 & 0,647 & 1,928 & 3,363 & 2,854 & 5,793 & 1,919 & 4,457 & 3,725 \\
\hline & Mediana & 8,930 & 6,510 & 2,586 & 11,770 & 3,690 & 0,508 & 1,642 & 3,293 & 2,753 & 5,517 & 1,700 & 4,941 & 4,486 \\
\hline & Mínimo & 0,800 & 2,420 & 1,779 & 5,700 & 1,390 & 0,190 & 1,112 & 1,822 & 1,536 & 4,704 & 0,759 & 1,753 & 0,844 \\
\hline & Máximo & 12,600 & 12,090 & 4,564 & 14,530 & 13,590 & 1,162 & 4,090 & 5,970 & 4,370 & 7,059 & 3,361 & 6,820 & 6,488 \\
\hline $\mathrm{Fe}$ & $\mathbf{N}$ & 7 & 6 & 7 & 7 & 7 & 7 & 7 & 7 & 7 & 7 & 7 & 7 & 6 \\
\hline & Média & $3.134,0$ & $3.144,0$ & $10.721,0$ & $18.386,0$ & $3.973,0$ & 769,0 & $3.672,0$ & $1.983,0$ & $6.389,0$ & $11.083,0$ & $1.656,0$ & $5.907,0$ & $5.372,0$ \\
\hline & Mediana & $3.439,0$ & $2.627,0$ & $3.813,0$ & $12.332,0$ & $2.339,0$ & 510,0 & $3.368,0$ & $2.266,0$ & $7.261,0$ & $12.039,0$ & $1.349,0$ & $5.216,0$ & $6.271,0$ \\
\hline & Mínimo & 408,0 & 446,0 & $1.585,0$ & $9.574,0$ & 527,0 & 454,0 & $1.668,0$ & 843,0 & $1.452,0$ & $7.334,0$ & 634,0 & 937,0 & 808,0 \\
\hline & Máximo & $4.781,0$ & $8.153,0$ & $50.466,0$ & $52.637,0$ & $13.934,0$ & $1.888,0$ & $6.398,0$ & $3.385,0$ & $8.434,0$ & $12.435,0$ & $3.051,0$ & $11.998,0$ & $9.032,0$ \\
\hline$\overline{M g}$ & $\mathbf{N}$ & 7 & 6 & 7 & 7 & 7 & 7 & 7 & 7 & 7 & 7 & 7 & 7 & 6 \\
\hline & Média & 135,1 & 204,7 & 119,7 & 90,9 & 99,8 & 55,1 & 107,2 & 102,5 & 291,0 & 168,4 & 101,4 & 120,5 & 399,0 \\
\hline & Mediana & 132,7 & 232,2 & 99,4 & 93,6 & 109,0 & 57,5 & 92,2 & 98,5 & 121,0 & 154,9 & 115,9 & 109,7 & 139,0 \\
\hline & Mínimo & 10,8 & 57,7 & 76,6 & 62,9 & 43,6 & 7,2 & 71,0 & 67,3 & 107,0 & 123,1 & 33,2 & 55,8 & 85,0 \\
\hline & Máximo & 213,4 & 293,2 & 174,9 & 114,0 & 145,4 & 87,5 & 151,0 & 140,3 & $1.146,0$ & 236,8 & 130,9 & 193,3 & $1.728,0$ \\
\hline$M n$ & $\mathbf{N}$ & 7 & 6 & 7 & 7 & 7 & 7 & 7 & 7 & 7 & 7 & 7 & 7 & 6 \\
\hline & Média & 880,0 & 499,0 & 493,3 & $4.310,0$ & $1.006,0$ & 519,9 & 686,2 & 565,0 & $1.232,0$ & $1.809,0$ & 340,0 & 312,4 & 628,0 \\
\hline & Mediana & 814,0 & 425,0 & 414,0 & $4.130,0$ & 398,0 & 508,0 & 610,2 & 417,0 & $1.185,0$ & $2.057,0$ & 338,6 & 241,6 & 718,0 \\
\hline & Mínimo & 68,0 & 55,0 & 307,0 & $3.467,0$ & 64,0 & 131,2 & 322,7 & 286,0 & 141,0 & $1.158,0$ & 206,7 & 192,8 & 145,0 \\
\hline & Máximo & $1.763,0$ & $1.363,0$ & 902,0 & $5.790,0$ & $4.174,0$ & 753,7 & $1.008,5$ & $1.128,0$ & $2.348,0$ & $2.333,0$ & 474,4 & 519,7 & $1.043,0$ \\
\hline $\mathrm{Ni}$ & $\mathbf{N}$ & 7 & 6 & 7 & 7 & 7 & 7 & 7 & 7 & 7 & 7 & 7 & 7 & 6 \\
\hline & Média & 1,011 & 1,750 & 1,668 & 3,990 & 1,840 & 0,646 & 1,166 & 1,270 & 2,090 & 3,040 & 1,125 & 2,280 & 2,250 \\
\hline & Mediana & 0,080 & 0,660 & 0,080 & 0,080 & 0,080 & 0,080 & 0,080 & 0,080 & 0,140 & 0,080 & 0,080 & 0,080 & 0,080 \\
\hline & Mínimo & $<0,026$ & $<0,026$ & $<0,026$ & $<0,026$ & $<0,026$ & $<0,026$ & $<0,026$ & $<0,026$ & $<0,026$ & $<0,026$ & $<0,026$ & $<0,026$ & $<0,026$ \\
\hline & Máximo & 3,345 & 7,080 & 4,930 & 9,370 & 9,050 & 2,098 & 3,451 & 3,998 & 7,100 & 10,260 & 4,052 & 7,670 & 7,380 \\
\hline$P$ & $\mathbf{N}$ & 6 & 5 & 6 & 6 & 6 & 6 & 6 & 6 & 6 & 6 & 7 & 6 & 6 \\
\hline & Média & 26,410 & 8,010 & 8,110 & 6,920 & 11,290 & 2,639 & 3,720 & 4,255 & 7,280 & 13,790 & 15,020 & 4,000 & 51,900 \\
\hline & Mediana & 26,020 & 6,690 & 5,550 & 6,770 & 10,500 & 1,664 & 2,250 & 3,537 & 5,020 & 14,790 & 6,820 & 2,700 & 29,700 \\
\hline & Mínimo & 3,170 & 2,830 & 4,900 & 2,270 & 8,100 & 0,854 & 1,740 & 1,918 & 3,190 & 7,500 & 1,470 & 0,690 & 10,800 \\
\hline & Máximo & 46,380 & 15,250 & 14,230 & 11,670 & 16,710 & 6,131 & 8,280 & 8,653 & 14,060 & 16,170 & 38,960 & 9,310 & 63,460 \\
\hline$P b$ & $\mathbf{N}$ & 4 & 4 & 4 & 4 & 4 & 4 & 4 & 4 & 4 & 4 & 4 & 4 & 4 \\
\hline & Média & 5,364 & 2,303 & 5,677 & 5,850 & 3,002 & 35,410 & 6,290 & 3,032 & 4,573 & 5,880 & 2,413 & 4,477 & 4,550 \\
\hline & Mediana & 4,896 & 2,098 & 5,846 & 5,910 & 2,661 & 37,790 & 6,328 & 3,264 & 4,600 & 5,656 & 2,725 & 4,174 & 4,040 \\
\hline & Mínimo & 4,265 & 1,390 & 4,010 & 3,290 & 1,902 & 21,490 & 5,658 & 1,965 & 3,534 & 5,547 & 1,171 & 3,401 & 1,320 \\
\hline & Máximo & 7,397 & 3,623 & 7,007 & 8,310 & 4,782 & 44,590 & 6,844 & 3,635 & 5,559 & 6,661 & 3,031 & 6,159 & 8,780 \\
\hline$\overline{Z n}$ & $\mathbf{N}$ & 7 & 6 & 7 & 7 & 7 & 7 & 7 & 7 & 7 & 7 & 7 & 7 & 6 \\
\hline & Média & 11,630 & 5,510 & 7,150 & 14,830 & 19,300 & 10,810 & 6,630 & 5,480 & 6,020 & 7,090 & 3,380 & 7,010 & 6,810 \\
\hline & Mediana & 6,580 & 3,730 & 0,910 & 0,910 & 4,700 & 0,910 & 0,910 & 0,910 & 3,140 & 0,910 & 0,910 & 3,930 & 1,770 \\
\hline & Mínimo & 2,600 & 1,880 & 0,910 & 0,900 & 0,900 & 0,910 & 0,900 & 0,910 & 0,900 & 0,600 & 0,900 & 0,910 & 0,910 \\
\hline & Máximo & 23,440 & 16,470 & 19,220 & 34,430 & 82,600 & 39,050 & 16,180 & 17,030 & 14,600 & 24,640 & 10,330 & 16,960 & 19,750 \\
\hline
\end{tabular}

$\mathbf{N}=$ QUANTIDADE DE DADOS NO PERIODO DA PESQUISA

OS VALORES AQUI PRESENTES FORAM DESCONTADOS OS VALORES DO BRANCO 
Tabela A.8 - Estatísticas descritivas dos índices pluviométricos mensais e do período.

\begin{tabular}{|c|c|c|c|c|c|c|c|c|c|c|c|c|c|c|c|}
\hline & & \multicolumn{14}{|c|}{ Comunidade } \\
\hline \multicolumn{2}{|c|}{ PARÁMETRO } & $I G 60$ & $I G 6 I$ & IG 63 & $I G 64$ & IG 65 & IG 66 & IG 67 & $I G 68$ & $I G 69$ & IG 70 & & IG 72 & IG 83 & $I G V G S$ \\
\hline Pluv. & $\mathbf{N}$ & 7 & 7 & 7 & 7 & 6 & & 0 & 0 & 0 & 0 & 0 & 7 & 1 & 7 \\
\hline \multirow[t]{4}{*}{ Mensal } & Média & 116,80 & 108,50 & 142,50 & 150,40 & 148,10 & & * & * & * & * & * & 212,10 & 31,80 & 115,10 \\
\hline & Mediana & 96,60 & 104,70 & 115,60 & 132,40 & 155,60 & & * & * & * & * & * & 222,40 & 31,80 & 96,10 \\
\hline & Mínimo & 6,80 & 9,30 & 12,50 & 17,10 & 5,40 & & * & $*$ & $*$ & $*$ & * & 0,50 & 31,80 & 0,60 \\
\hline & Máximo & 318,40 & 254,00 & 329,30 & 389,30 & 344,20 & & * & * & * & * & * & 340,20 & 31,80 & 243,30 \\
\hline Pluv. & $\mathbf{N}$ & 7 & 7 & 7 & 7 & 6 & & 0 & 0 & 0 & 0 & 0 & 7 & 7 & 7 \\
\hline \multirow[t]{4}{*}{ Período } & Média & 36,90 & 25,80 & 52,30 & 50,90 & 36,80 & & * & * & * & * & * & 58,90 & 16,29 & 31,80 \\
\hline & Mediana & 25,70 & 3,90 & 14,50 & 29,30 & 20,70 & & * & $*$ & $*$ & $*$ & * & 21,10 & 15,50 & 7,30 \\
\hline & Mínimo & - & - & - & - & - & & * & * & * & * & * & - & - & - \\
\hline & Máximo & 143,20 & 107,60 & 165,40 & 207,30 & 142,60 & & * & * & * & * & * & 175,30 & 42,00 & 115,90 \\
\hline
\end{tabular}

N = QUANTIDADE DE DADOS NO PERIODO DA PESQUISA

Tabela A.9 - Estatísticas descritivas para o pH nas águas bruta e tratada.

\begin{tabular}{|c|c|c|c|c|c|c|c|c|c|c|c|c|c|c|}
\hline & & \multicolumn{13}{|c|}{ Comunidade } \\
\hline \multicolumn{2}{|c|}{ PARÁMETRO } & $I G 60$ & $I G 61$ & $I G 63$ & $I G 64$ & $I G 65$ & $I G 66$ & IG 67 & IG 68 & IG 69 & $I G 70$ & $I G 72$ & IG 83 & $I G V G S$ \\
\hline$p H$ & $\mathbf{N}$ & 7 & 7 & 7 & 7 & 7 & 7 & 7 & 7 & 7 & 7 & 7 & 7 & 5 \\
\hline \multirow[t]{4}{*}{ Bruta } & Média & 7,22 & 7,20 & 6,69 & 6,45 & 6,59 & 6,39 & 6,60 & 6,81 & 6,42 & 6,92 & 6,79 & 6,55 & 6,78 \\
\hline & Mediana & 7,08 & 7,20 & 6,80 & 6,40 & 6,60 & 6,27 & 6,61 & 6,72 & 6,41 & 6,97 & 6,90 & 6,52 & 6,80 \\
\hline & Mínimo & 6,70 & 6,84 & 6,12 & 6,25 & 6,40 & 6,17 & 6,45 & 6,60 & 6,30 & 6,75 & 6,20 & 6,31 & 6,41 \\
\hline & Máximo & 8,70 & 7,43 & 6,95 & 6,89 & 6,81 & 6,95 & 6,76 & 7,02 & 6,70 & 7,10 & 6,99 & 6,80 & 7,00 \\
\hline$p H$ & $\mathbf{N}$ & 7 & 7 & 7 & 6 & 7 & 7 & 7 & 7 & 7 & 7 & 7 & 7 & 5 \\
\hline \multirow[t]{4}{*}{ Tratada } & Média & 7,01 & 7,29 & 7,54 & 6,77 & 6,88 & 6,74 & 6,82 & 7,19 & 7,35 & 6,80 & 7,18 & 7,33 & 6,67 \\
\hline & Mediana & 6,93 & 7,40 & 7,50 & 6,80 & 6,74 & 6,73 & 6,80 & 7,10 & 7,32 & 6,80 & 7,22 & 7,30 & 6,55 \\
\hline & Mínimo & 6,79 & 6,60 & 7,10 & 6,60 & 6,60 & 6,50 & 6,45 & 7,00 & 7,07 & 6,33 & 6,80 & 6,70 & 6,43 \\
\hline & Máximo & 7,30 & 7,62 & 7,90 & 6,93 & 7,30 & 6,95 & 7,01 & 7,51 & 7,60 & 7,50 & 7,47 & 8,28 & 7,15 \\
\hline
\end{tabular}

$\mathbf{N}=$ QUANTIDADE DE DADOS NO PERIODO DA PESQUISA 
Tabela A.10 - Resultado da análise de Fluorescência de Raios X

\begin{tabular}{|c|c|c|c|c|c|c|c|c|c|c|c|}
\hline Identificação & $\begin{array}{l}\mathrm{SiO}_{2} \\
(\%)\end{array}$ & $\begin{array}{c}\text { MgO } \\
(\%)\end{array}$ & $\begin{array}{c}\mathrm{Al}_{2} \mathrm{O}_{3} \\
(\%)\end{array}$ & $\begin{array}{c}\mathrm{Fe}_{2} \mathrm{O}_{3} \\
(\%)\end{array}$ & $\begin{array}{l}\mathrm{CaO} \\
(\%)\end{array}$ & $\begin{array}{c}\mathrm{Na}_{2} \mathrm{O} \\
(\%)\end{array}$ & $\begin{array}{c}\mathrm{P}_{2} \mathrm{O}_{5} \\
(\%)\end{array}$ & $\begin{array}{l}\mathrm{K}_{2} \mathrm{O} \\
(\%)\end{array}$ & $\begin{array}{l}\mathrm{MnO} \\
(\%)\end{array}$ & $\begin{array}{l}\text { TiO } \\
(\%)\end{array}$ & PFogo \\
\hline IG 60 & 55.57 & 0.71 & 20.41 & 6.53 & 0.43 & 0.62 & 0.23 & 3.59 & 0.27 & 1.62 & 10.00 \\
\hline IG 61 & 81,36 & 48 & 7,85 & 2,96 & 0,33 & 0,53 & 0,05 & 1,33 & 0,04 & 1,12 & 3,89 \\
\hline IG 63 & 75,02 & 0,42 & 11,68 & 3,30 & 0,17 & 0,40 & 0,10 & 2,55 & 0,06 & 0,74 & 5,51 \\
\hline IG 64 & 32,00 & 0,27 & 25,12 & 17,63 & 0,25 & 0,21 & 0,38 & 2,54 & 0,99 & 2,48 & 18,08 \\
\hline IG 65 & 53,83 & 0,38 & 16,88 & 9,29 & 0,30 & 0,31 & 0,28 & 0,89 & 0,16 & 3,01 & 14,61 \\
\hline IG 66 (1) & 24,22 & 0,00 & 39,69 & 9,05 & 0,17 & 0,26 & 0,10 & 1,80 & 0,50 & 1,44 & 22,71 \\
\hline IG 66 (2) & 31,62 & 0,00 & 35,03 & 7,25 & 0,24 & 0,78 & 0,08 & 3,92 & 0,21 & 1,21 & 19,61 \\
\hline IG 67 & 77,20 & 0,27 & 10,83 & 3,96 & 0,16 & 0,38 & 0,06 & 0,76 & 0,06 & 0,48 & 5,79 \\
\hline IG 68 & 42,48 & 0,05 & 25,47 & 9,10 & 0,28 & 0,35 & 0,25 & 0,70 & 0,18 & 2,32 & 18,77 \\
\hline IG 69 & 34,99 & 0,03 & 26,69 & 11,97 & 0,94 & 0,32 & 0,24 & 0,34 & 0,21 & 1,71 & 22,56 \\
\hline IG 70 & 52,11 & 0,47 & 19,83 & 9,40 & 0,34 & 0,24 & 0,21 & 1,72 & 0,28 & 1,22 & 14,13 \\
\hline IG 72 & 89,69 & 0,40 & 4,43 & 1,46 & 0,20 & 0,27 & 0,02 & 1,84 & 0,06 & 0,54 & 1,03 \\
\hline IG 83 & 55,02 & 0,25 & 21,56 & 7,60 & 0,16 & 0,28 & 0,13 & 0,76 & 0,09 & 1,15 & 12,95 \\
\hline IG VGS & 83,76 & 0,45 & 6,98 & 2,12 & 0,35 & 1,02 & 0,03 & 3,09 & 0,08 & 0,66 & 1,41 \\
\hline
\end{tabular}

Tabela A.11 - Valores médios do folhelho

\begin{tabular}{l|r}
\hline \multicolumn{1}{c|}{ Elemento } & Concentração $\left(\mu \mathrm{g} \mathrm{g}^{-1}\right)$ \\
\hline $\mathrm{Al}$ & 80.000 \\
$\mathrm{Ca}$ & 22.100 \\
$\mathrm{Cd}$ & 0,3 \\
$\mathrm{Co}$ & 19 \\
$\mathrm{Cr}$ & 90 \\
$\mathrm{Cu}$ & 45 \\
$\mathrm{Fe}$ & 47.200 \\
$\mathrm{Mg}$ & 15.000 \\
$\mathrm{Mn}$ & 580 \\
$\mathrm{Na}$ & 9.600 \\
$\mathrm{Ni}$ & 68 \\
$\mathrm{P}$ & 700 \\
$\mathrm{~Pb}$ & 20 \\
$\mathrm{Zn}$ & 95 \\
\hline $\mathrm{Font}$ &
\end{tabular}

Fonte: TUREKIAN \& WEDEPOHI[1961] 


\title{
9. APÊNDICE 2
}

\author{
Box-plots
}


A) Ferro
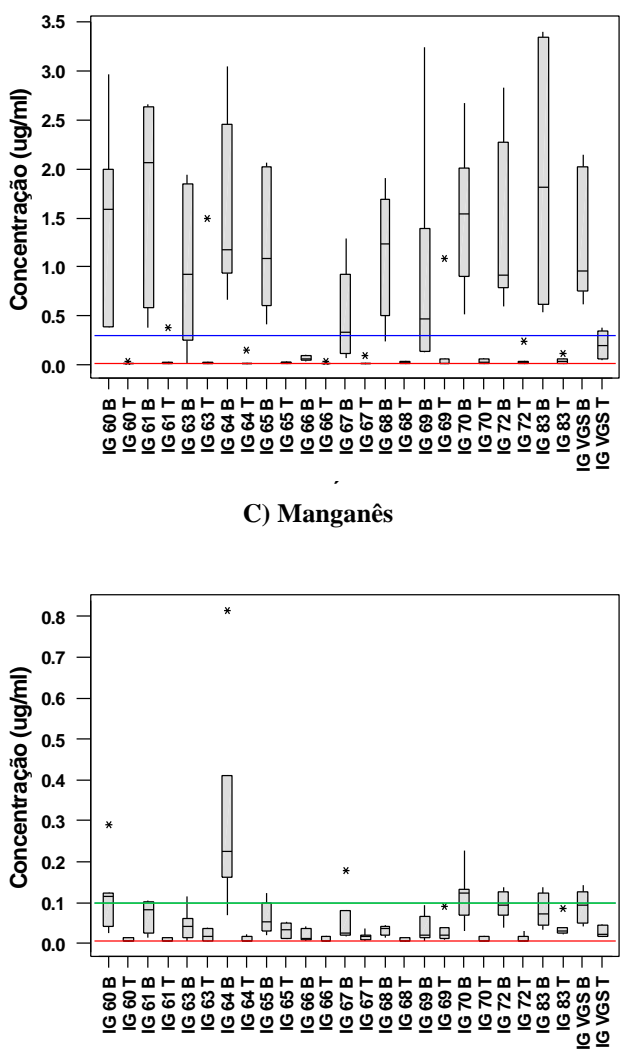

E) Cálcio

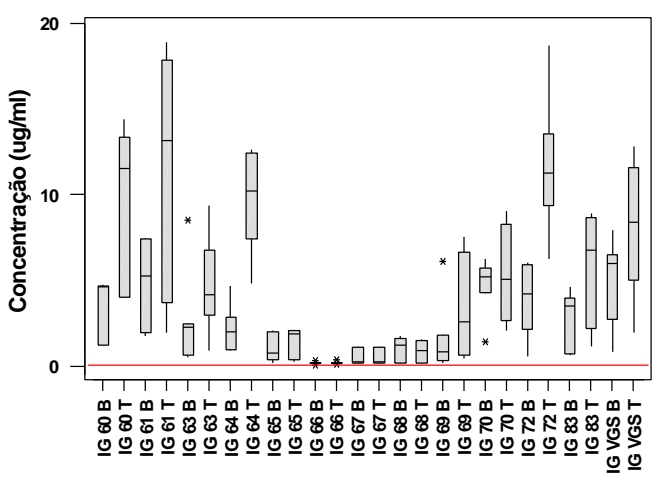

B) Magnésio
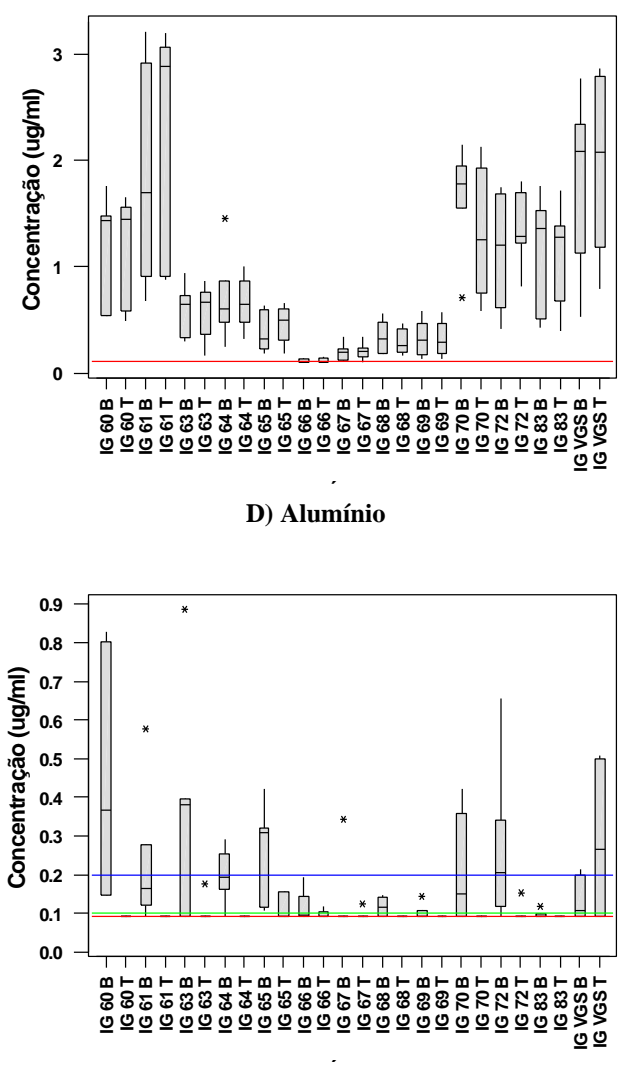

F) Cobalto

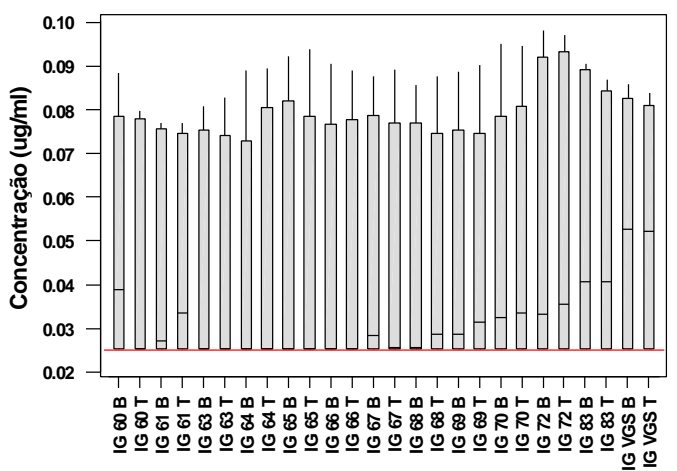

Figura B.1 - Concentração dos metais $\left(\mathrm{em} \mu \mathrm{g} \mathrm{mL} \mathrm{m}^{-1}\right.$ ) nas águas bruta e tratada para cada comunidade.

Legenda: Limite do CONAMA

Limite da metodologia analítica

Limite da Portaria 36/90 
Figura B.1 (continuação).

\section{G) Fósforo}

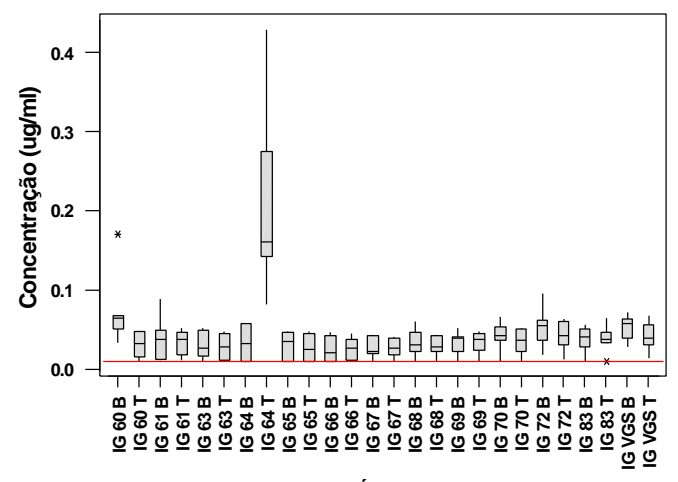

H) Cobre

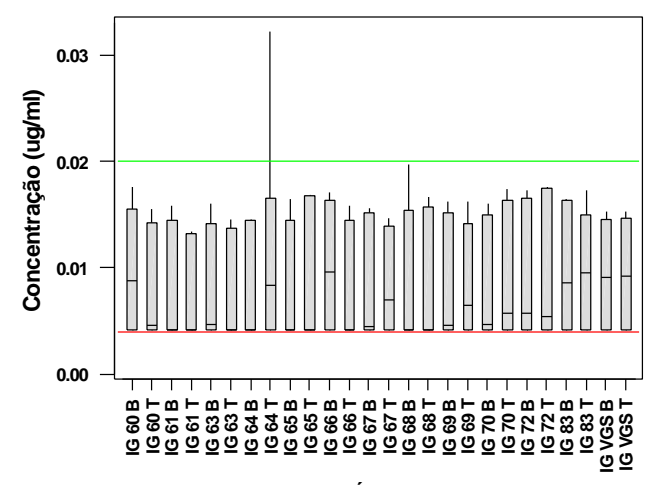


A) Fluoreto

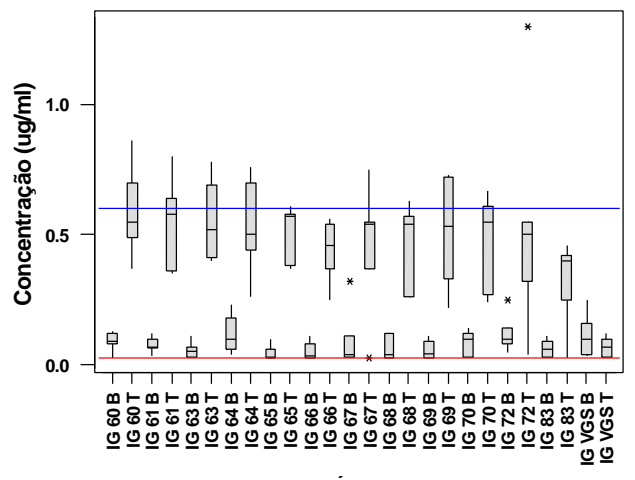

C) Nitrato

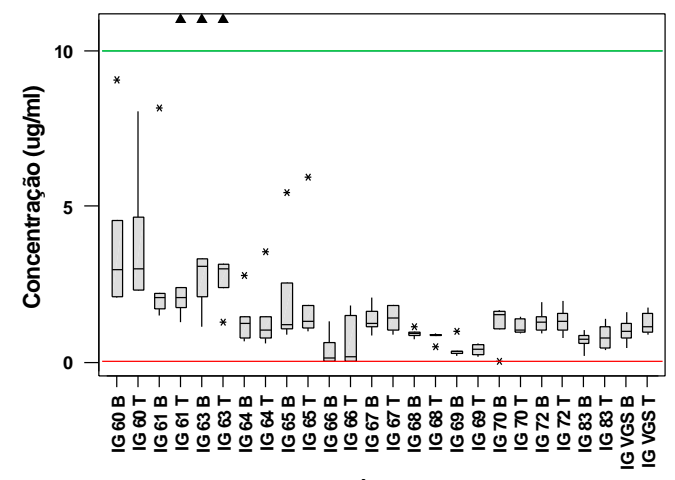

? valor aberrante IG $61 \mathrm{~T}: 33,60 \mu \mathrm{g} \mathrm{ml}^{-1}$ valor aberrante IG $63 \mathrm{~B}: 33,60 \mu \mathrm{g} \mathrm{ml}^{-1}$ valor aberrante IG $63 \mathrm{~T}: 33,60 \mu \mathrm{g} \mathrm{ml}^{-1}$

E) Sódio

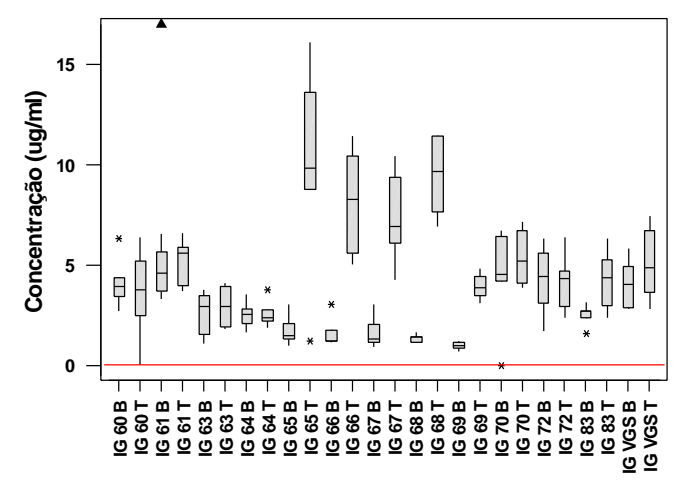

? valor aberrante IG $61 \mathrm{~B}: 37,10 \mu \mathrm{g} \mathrm{ml}^{-1}$
B) Cloreto

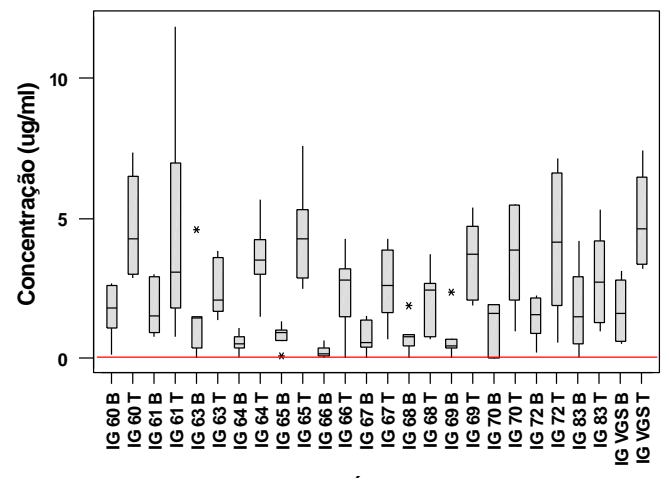

D) Sulfato

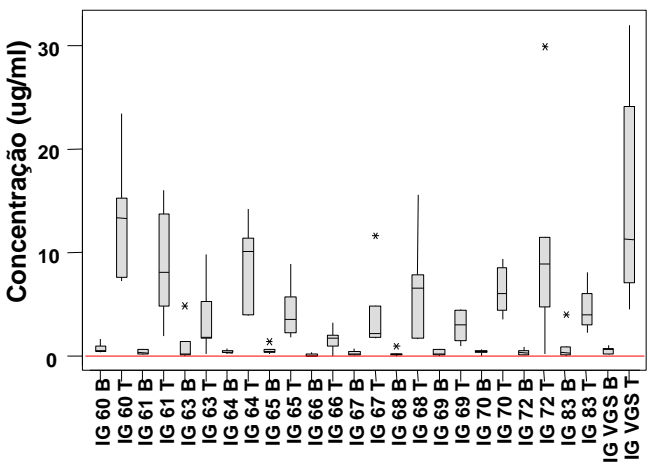

F) Potássio

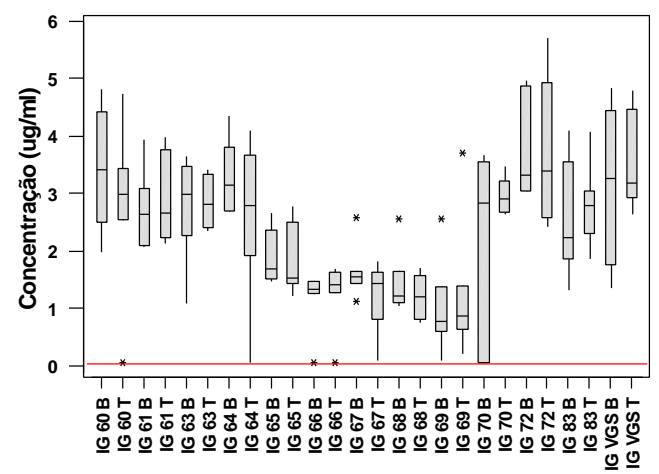

Figura B.2 - Concentração dos elementos iônicos $\left(\mathrm{em} \mu \mathrm{g} \mathrm{mL}^{-1}\right)$ nas águas bruta e tratada para cada comunidade. 
A) Ferro

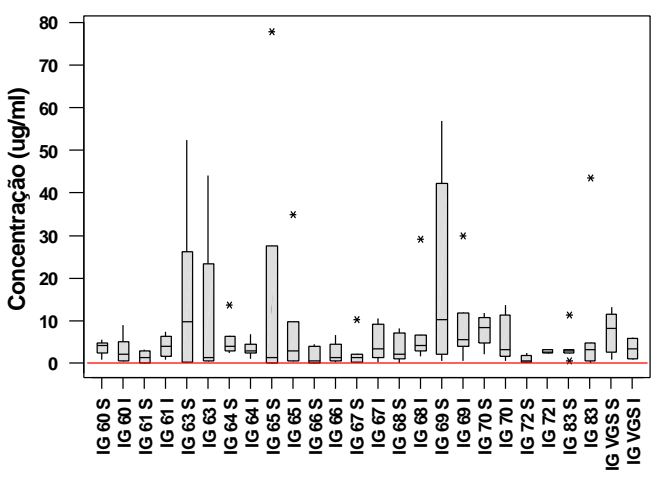

C) Manganês

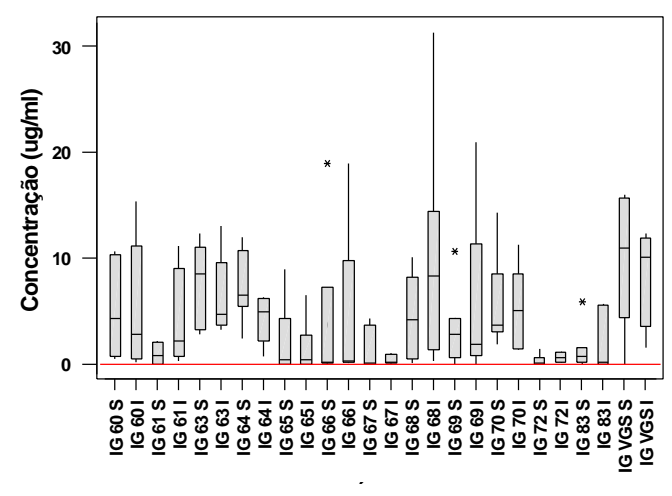

E) Cálcio

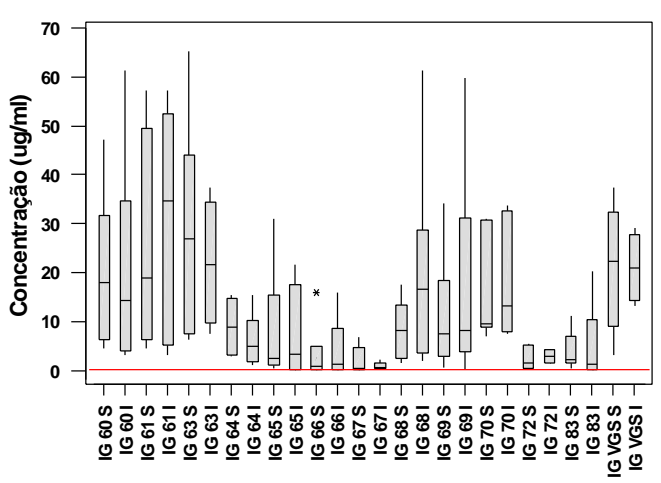

B) Magnésio

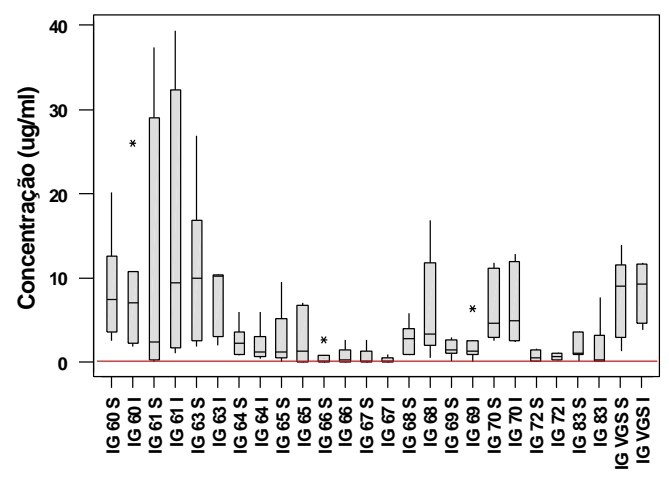

D) Alumínio

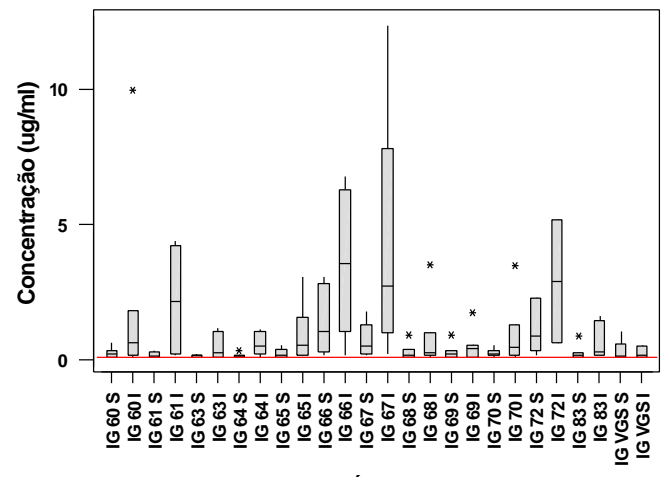

F) Cobalto

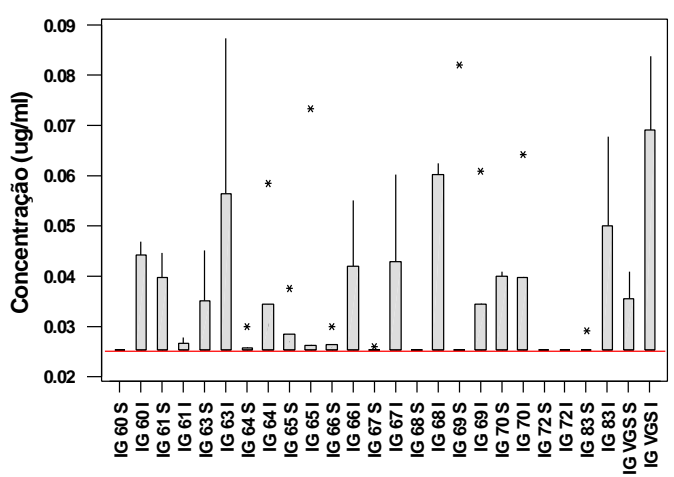

Figura B.3 - Concentração dos metais $\left(\mathrm{em} \mu \mathrm{g} \mathrm{mL}^{-1}\right)$ nas frações sobrenadante e intersticial para cada comunidade. 
Figura B.3 (continuação).

\section{G) Fósforo}

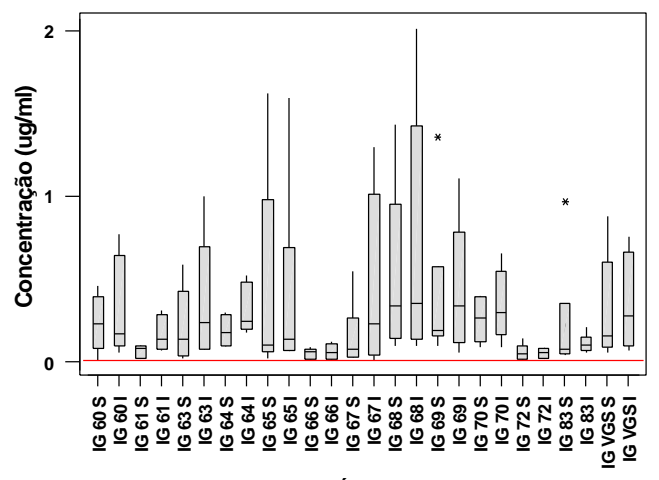

I) Cádmio

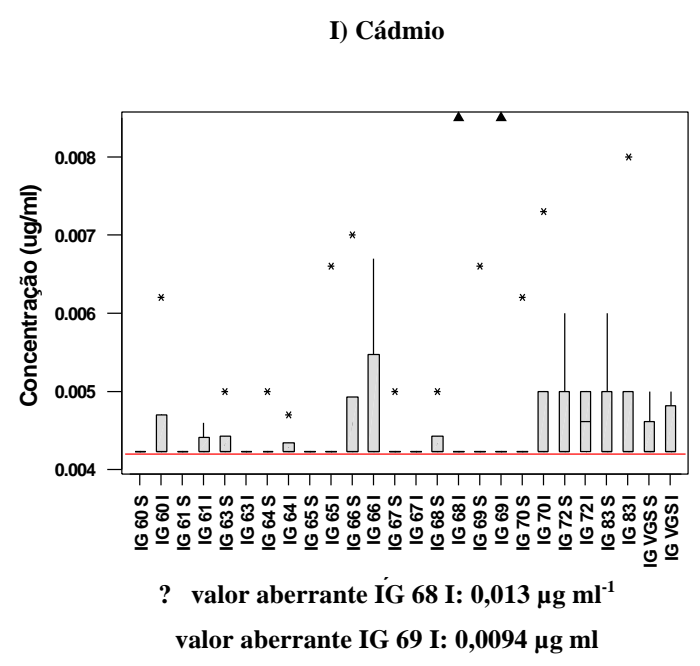

H) Cobre

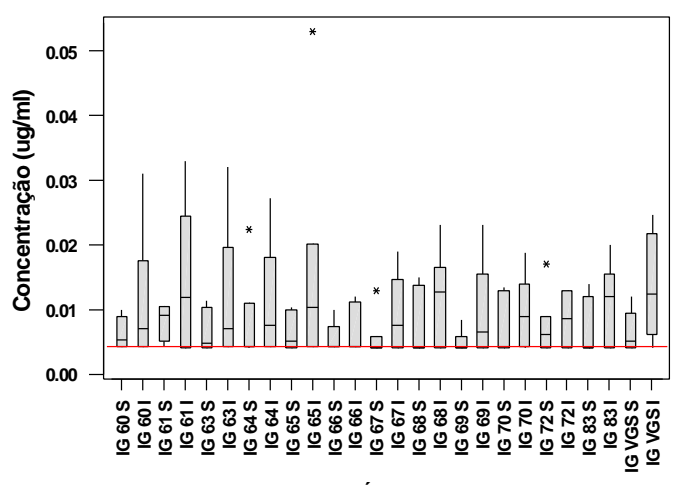


A) Ferro

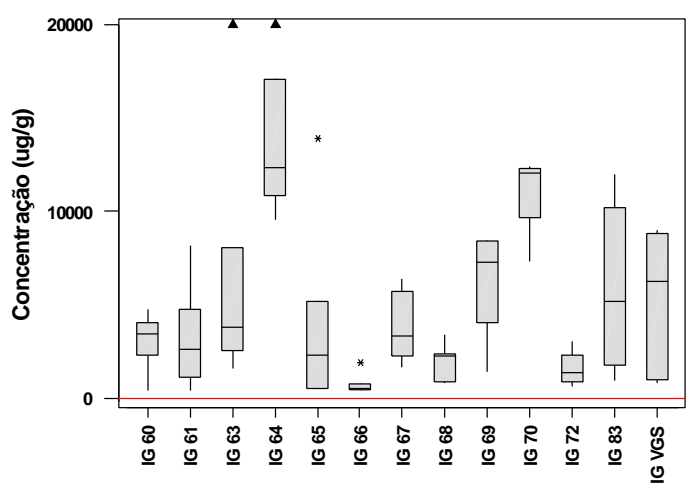

? valor aberrante IG 63: $50446 \mu \mathrm{g} \mathrm{g}^{-1}$

valor aberrante IG 64: $52637 \mu \mathrm{g} \mathrm{g}^{-1}$

C) Manganês

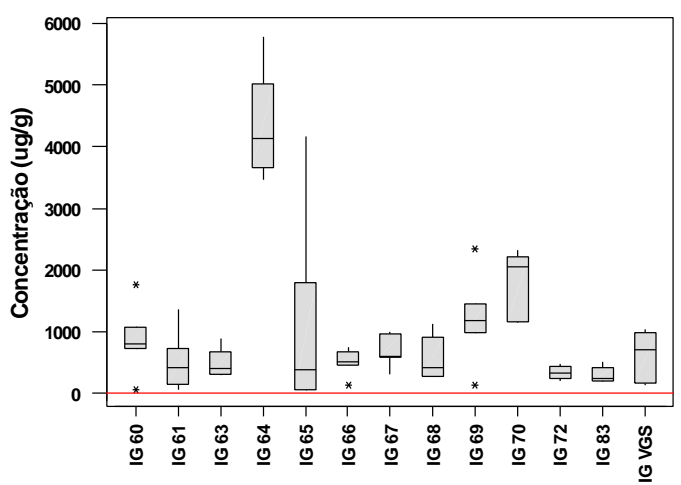

E) Cálcio

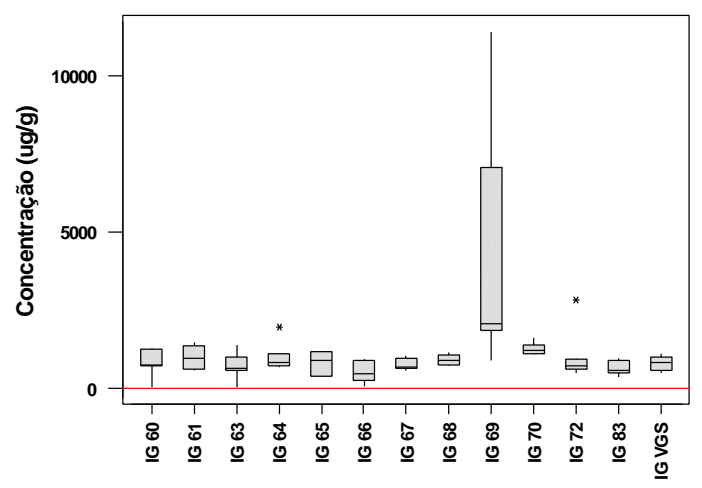

B) Magnésio

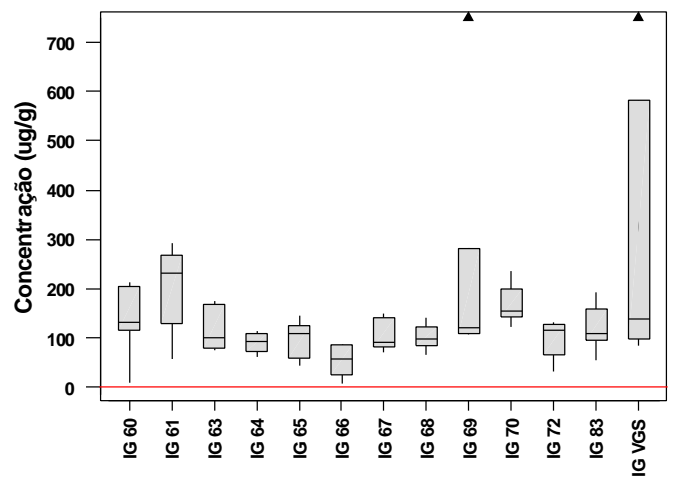

? valor aberrante IG 69: $1146 \mu \mathrm{g} \mathrm{g}^{-1}$

valor aberrante IG VGS: $1728 \mu \mathrm{g} \mathrm{g}^{-1}$

D) Alumínio

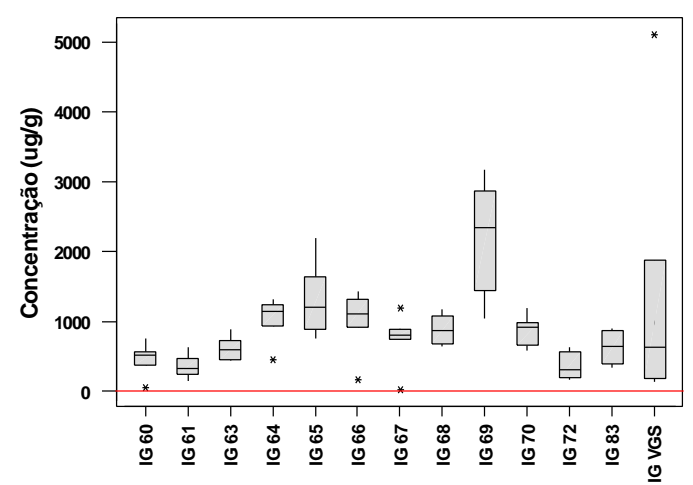

F) Cobalto

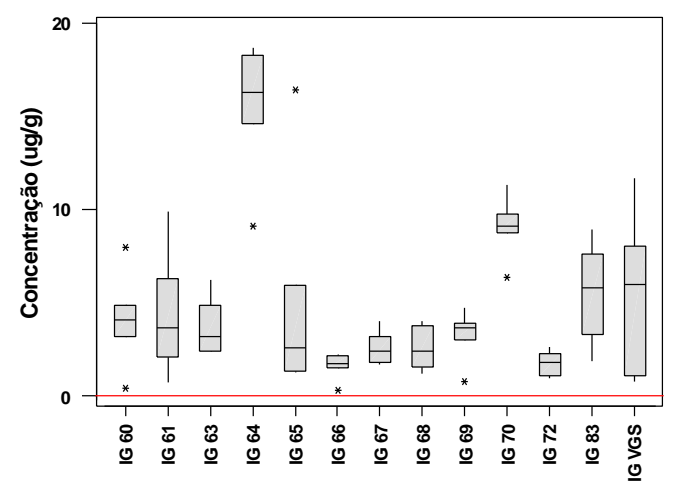

Figura B.4 - Concentração dos metais $\left(e m \mu g \mathrm{~mL}^{-1}\right)$ na fração digestão para cada comunidade. 
Figura B.4 (continuação)

\section{G) Fósforo}

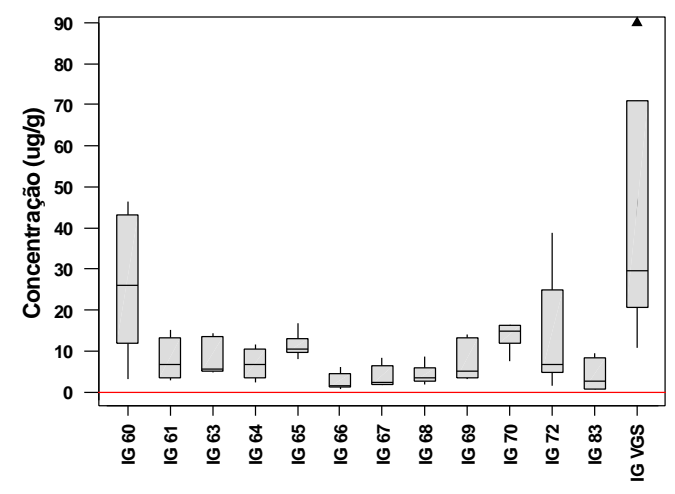

? valor aberrante IG VGS: $184 \mu \mathrm{g} \mathrm{g}^{-1}$

I) Níquel

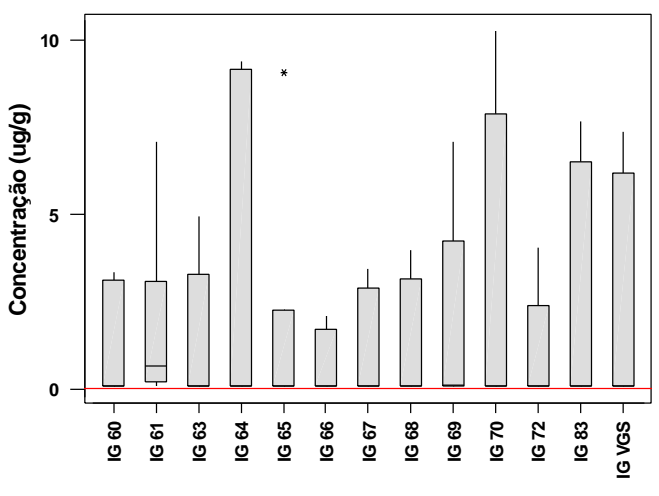

L) Chumbo
H) Cobre

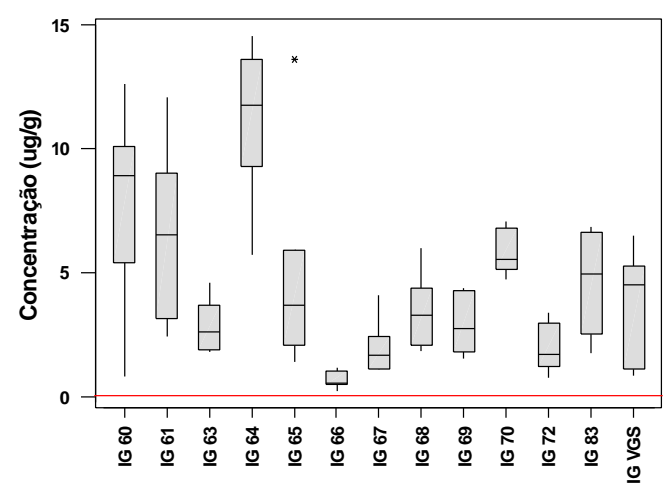

H) Prata

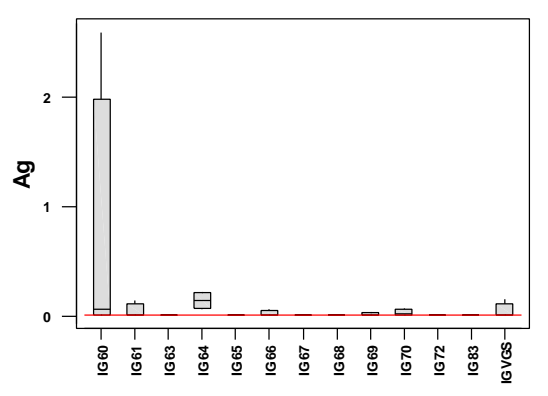

J) Cádmio

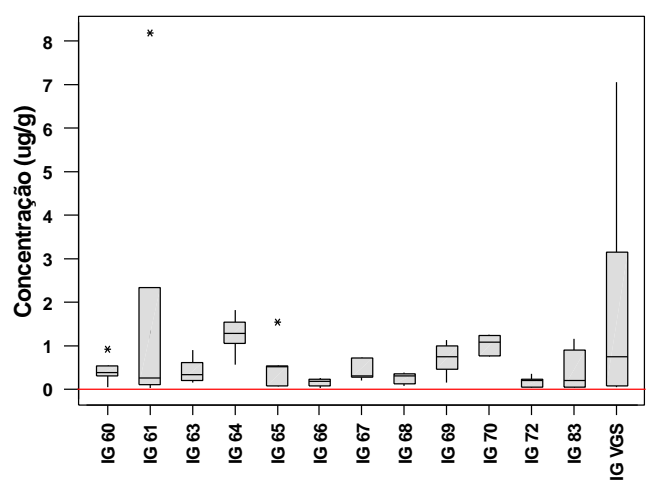

M) Cromo 

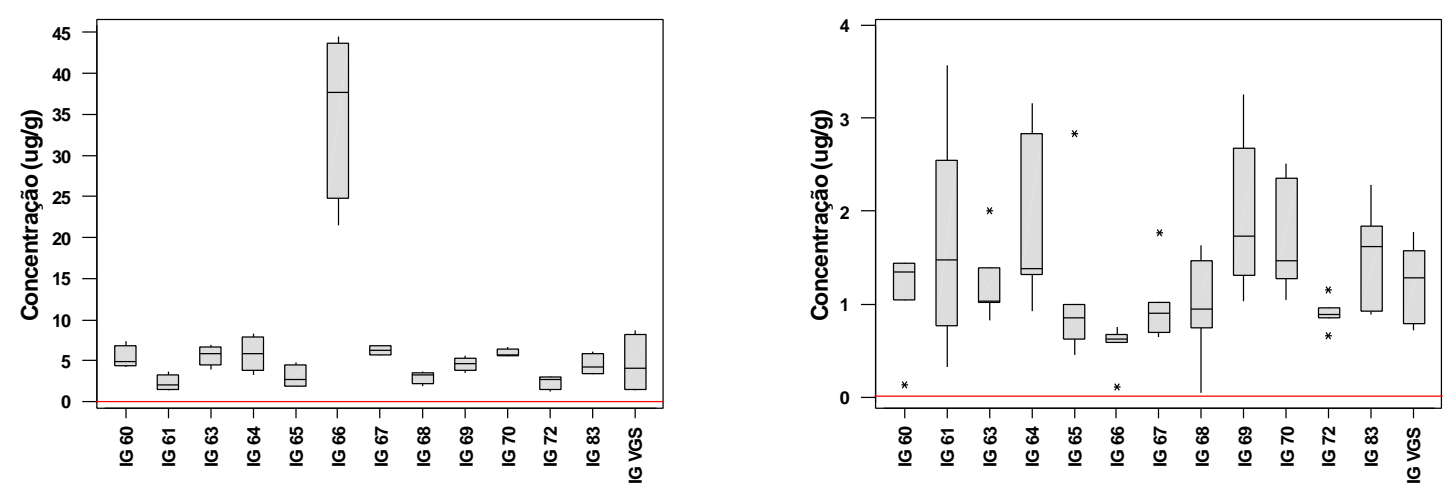

Figura B.4 (continuação)

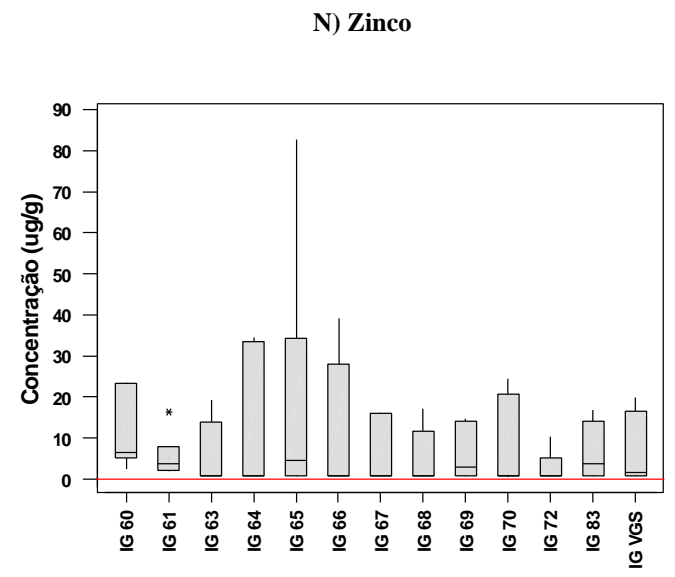




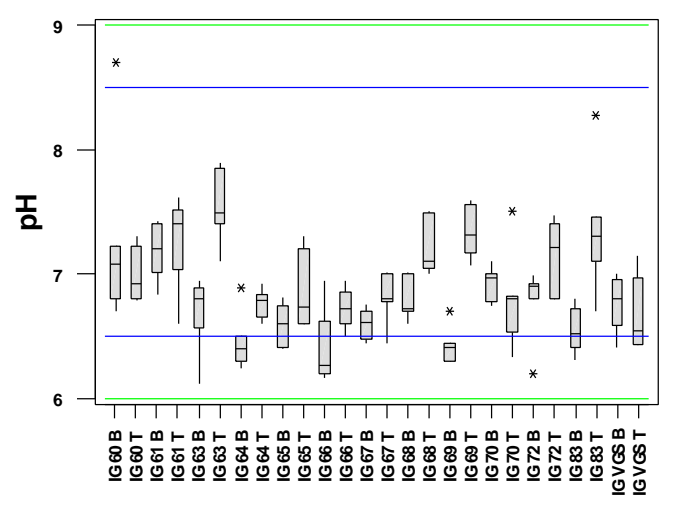

Figura B.5 - Índice de pH nas águas bruta e tratada por comunidade.

Índice Pluviométrico Mensal

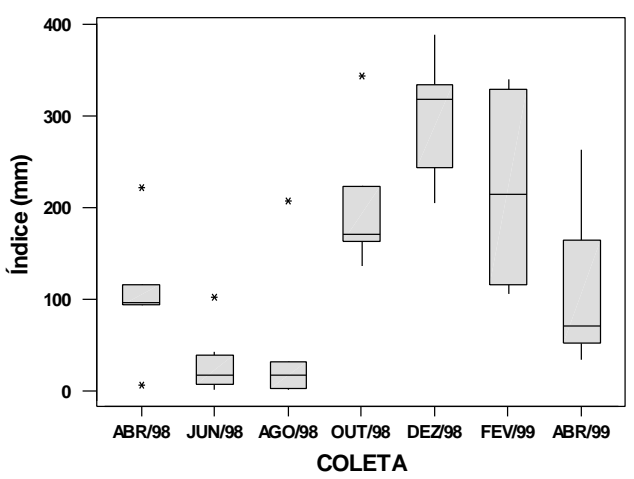

Índice Pluviométrico do Período

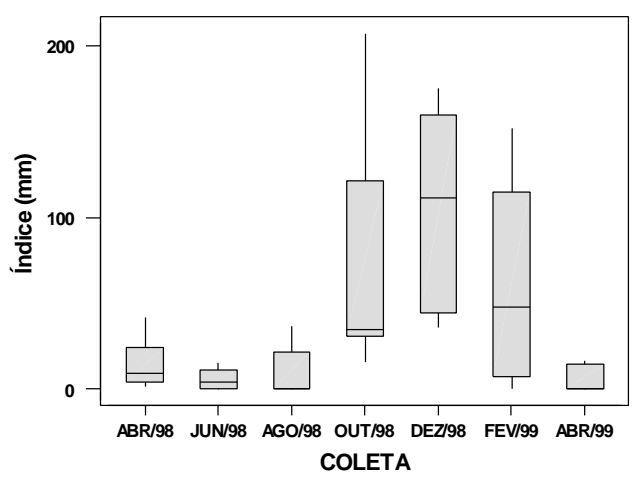


Figura B.6 - Índices pluviométricos mensais e do período em cada bimestre.. 


\section{APÊNDICE 3}

Gráficos de alisamento 
A) Ferro

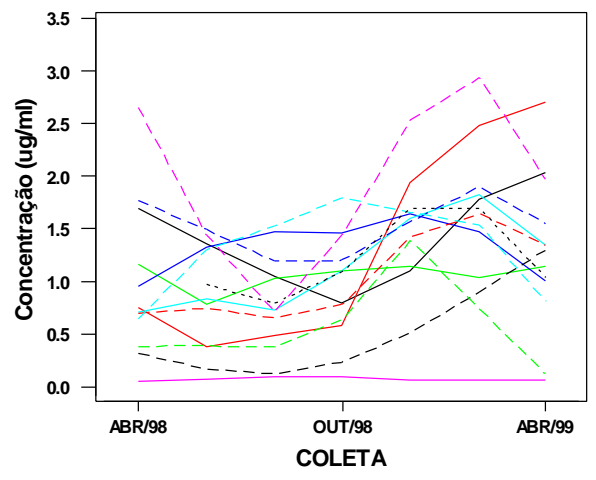

C) Manganês

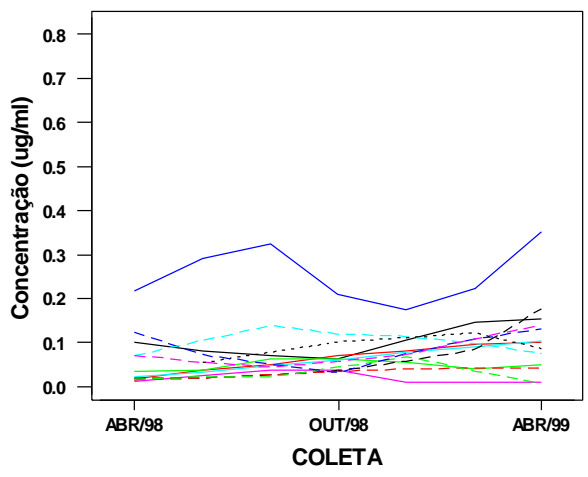

E) Cálcio

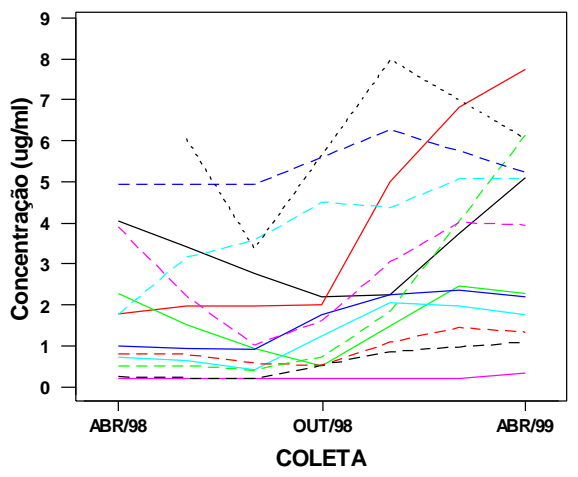

B) Magnésio

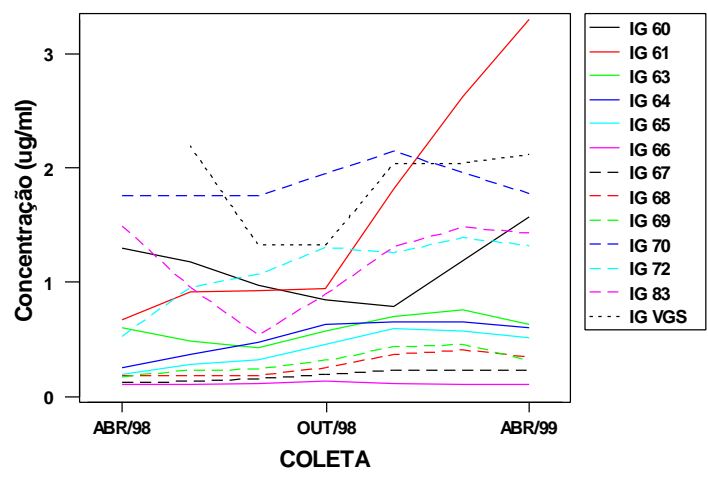

D) Alumínio

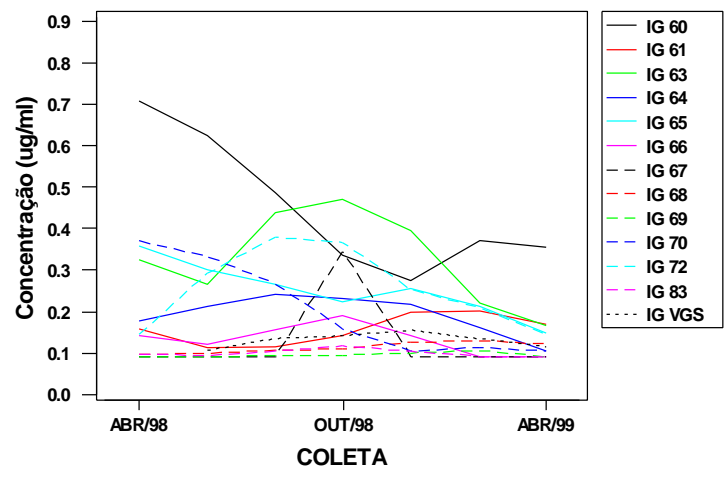

F) Fósforo

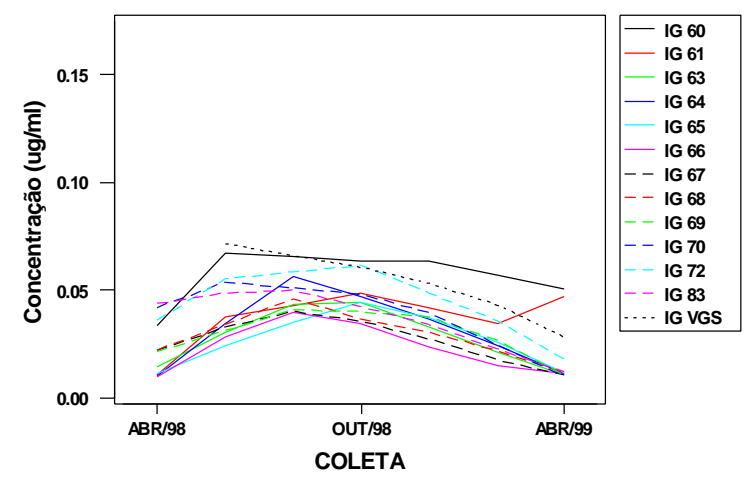

Figura C.1 - Alisamentos das concentrações dos metais na água bruta em função do tempo de coleta. 
Figura C.1 (continuação)

G) Bário

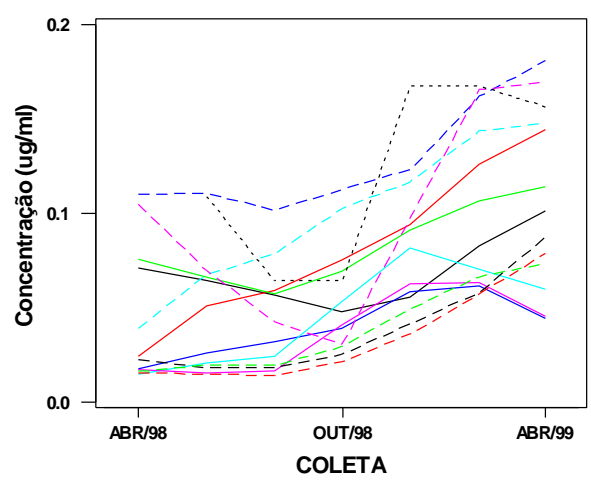

H) Cobre

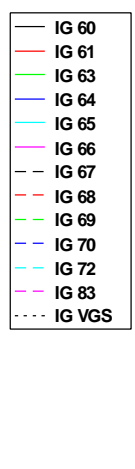

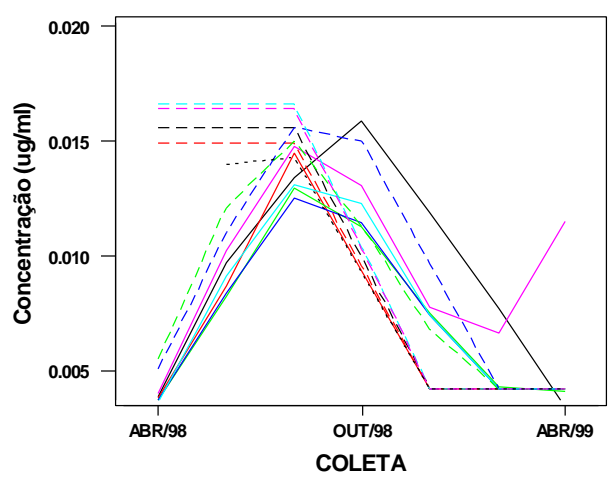

\begin{tabular}{|l|}
\hline- IG 60 \\
- IG 61 \\
IG 63 \\
- IG 64 \\
IG 65 \\
- IG 66 \\
-- IG 67 \\
-- IG 68 \\
- IG 69 \\
-- IG 70 \\
- IG 72 \\
- IG 83 \\
- IG VGS \\
\hline
\end{tabular}


A) Fluoreto

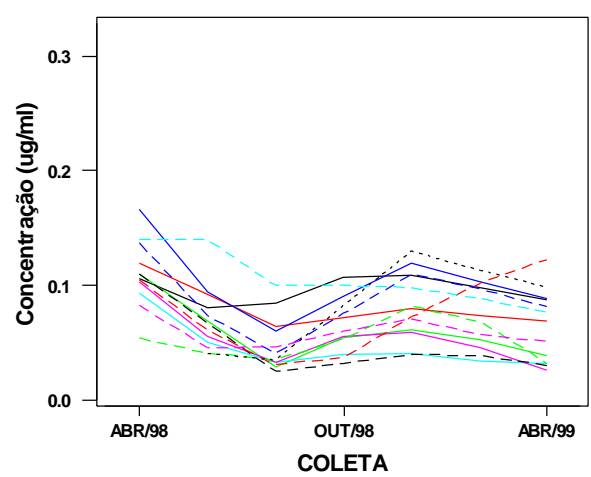

C) Nitrato

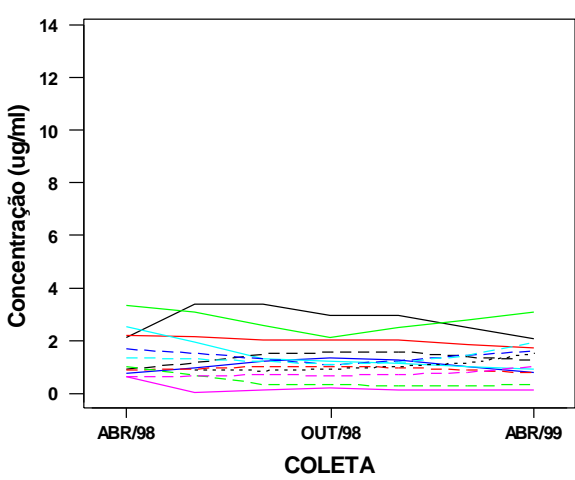

E) Sódio

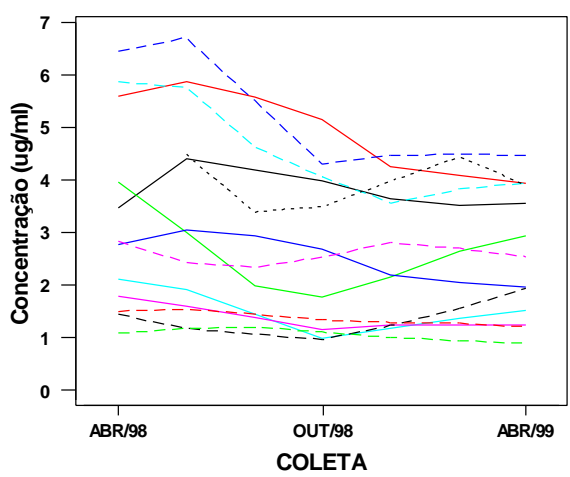

B) Cloreto
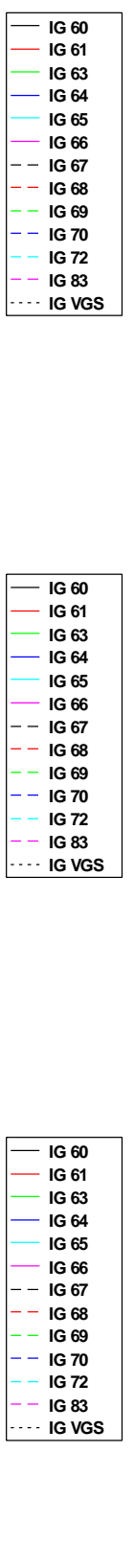

D) Sulfato

F) Potássio

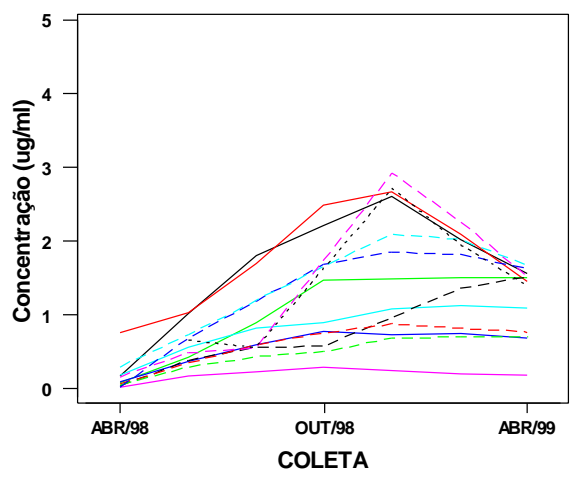

\begin{tabular}{|c|}
- IG 60 \\
- IG 61 \\
- IG 63 \\
- IG 64 \\
- IG 65 \\
- IG 66 \\
-- IG 67 \\
-- IG 68 \\
-- IG 69 \\
-- IG 70 \\
-- IG 72 \\
-- IG 83 \\
-- IG VGS \\
\hline
\end{tabular}
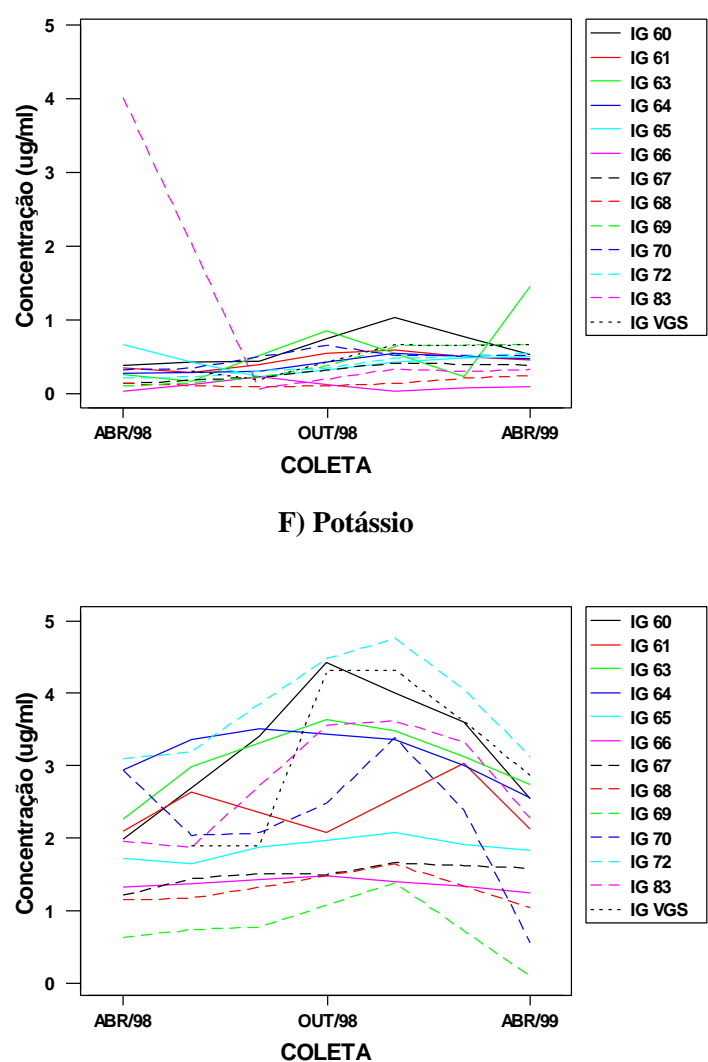

Figura C.2 - Alisamentos das concentrações dos elementos iônicos na água bruta em função do tempo de coleta. 
A) Ferro

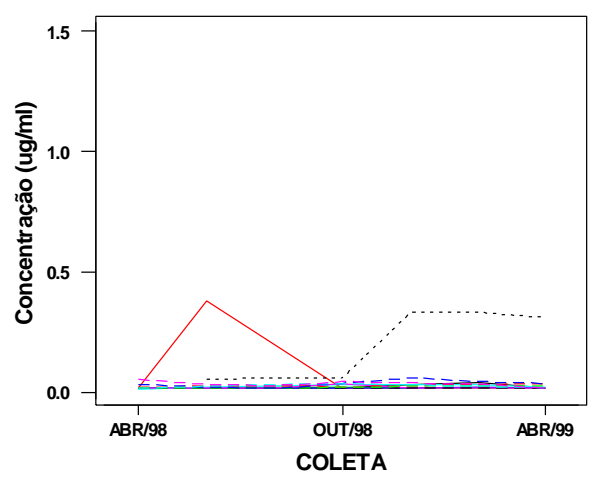

C) Manganês

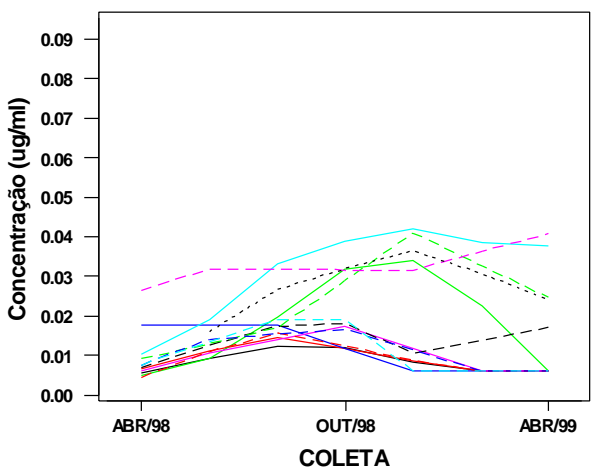

E) Cálcio

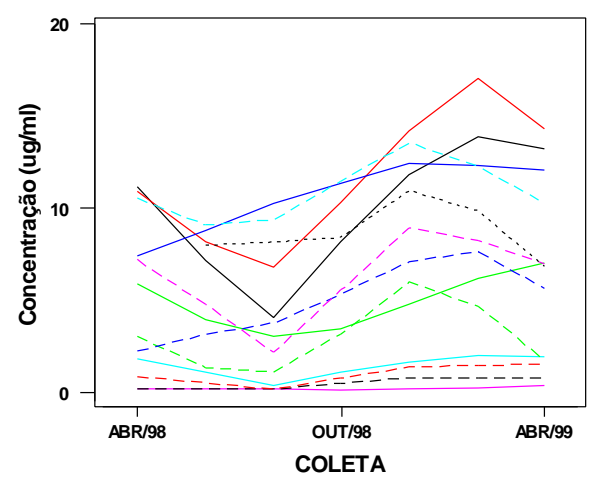

B) Magnésio
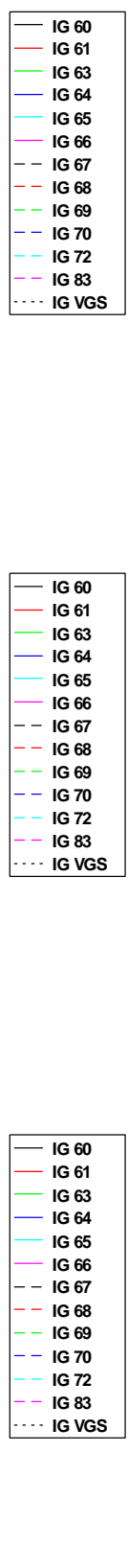

D) Alumínio

F) Fósforo
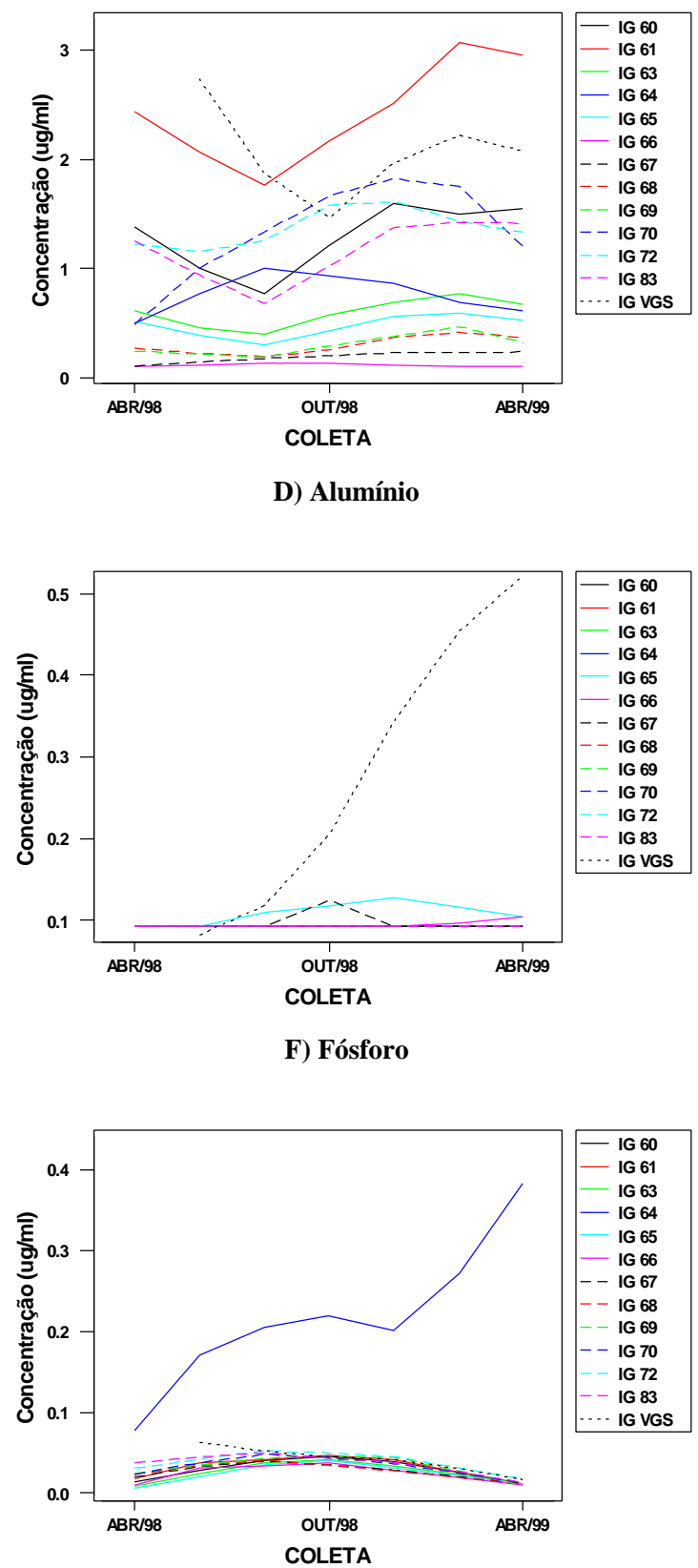

Figura C.3 - Alisamentos das concentrações dos metais na água tratada em função do tempo de coleta. 
Figura C.3: (continuação)

G) Bário

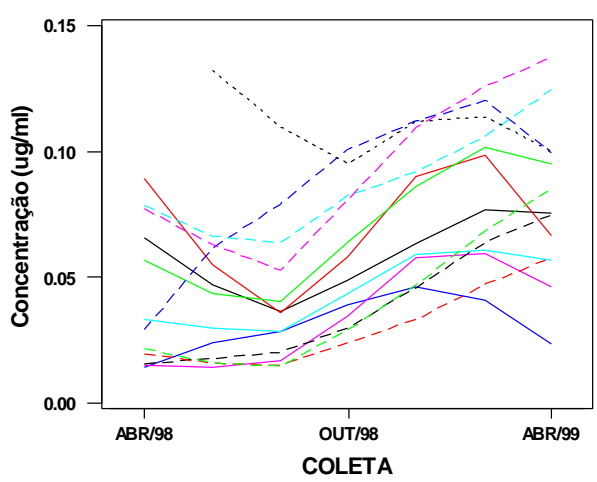

H) Cobre

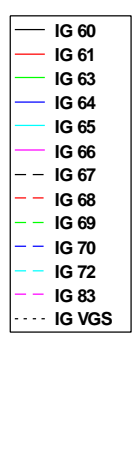

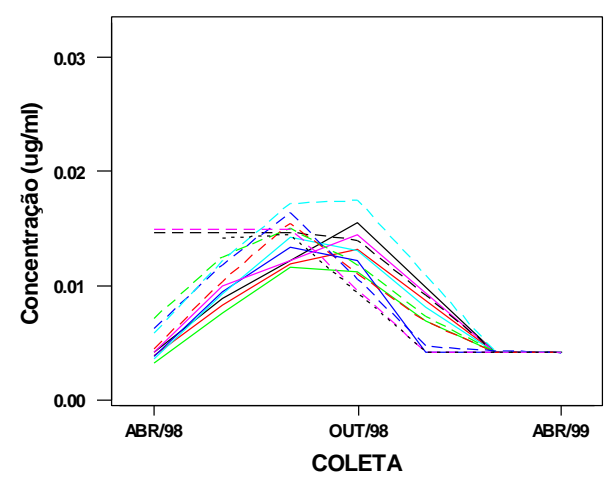


A) Fluoreto

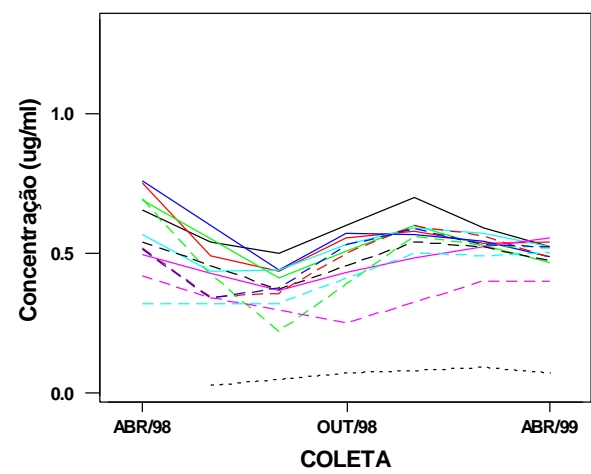

C) Nitrato

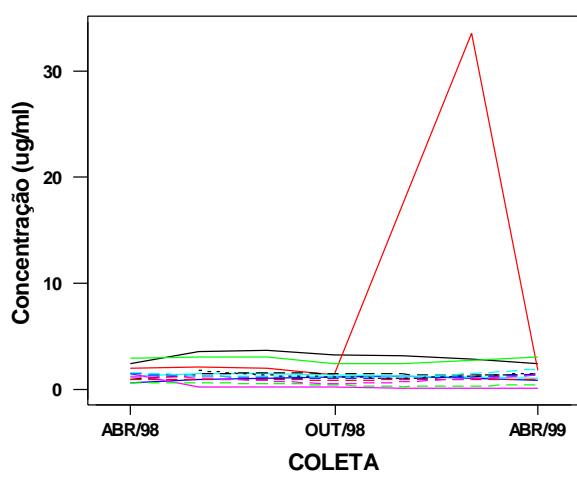

E) Sódio

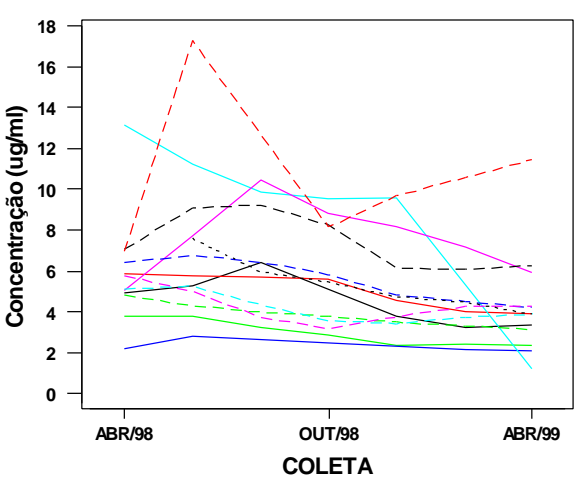

B) Cloreto

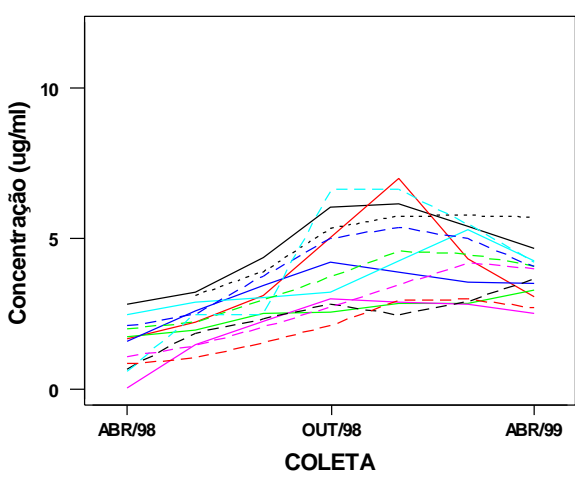

D) Sulfato
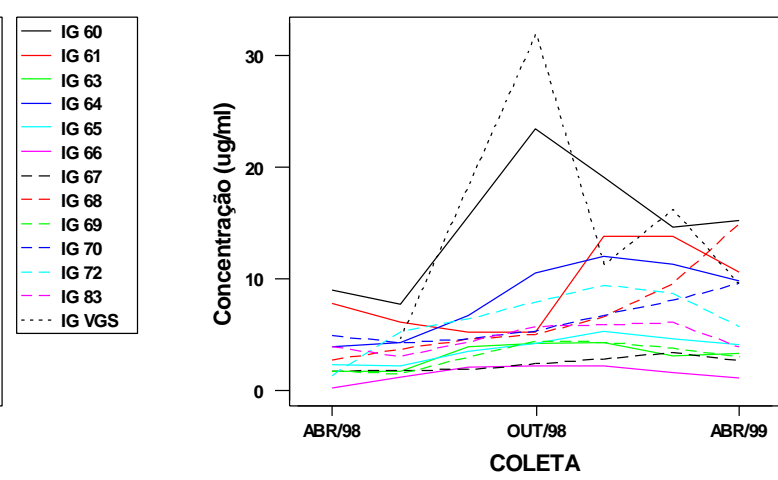

F) Potássio

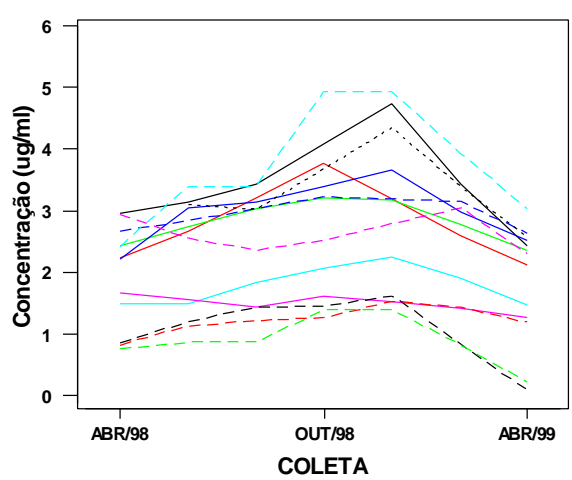

Figura C.4 - Alisamentos das concentrações dos elementos iônicos na água tratada em função do tempo de coleta. 
A) Ferro

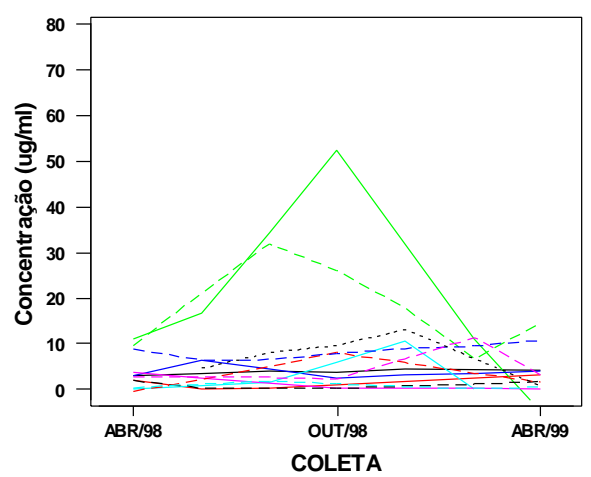

C) Manganês

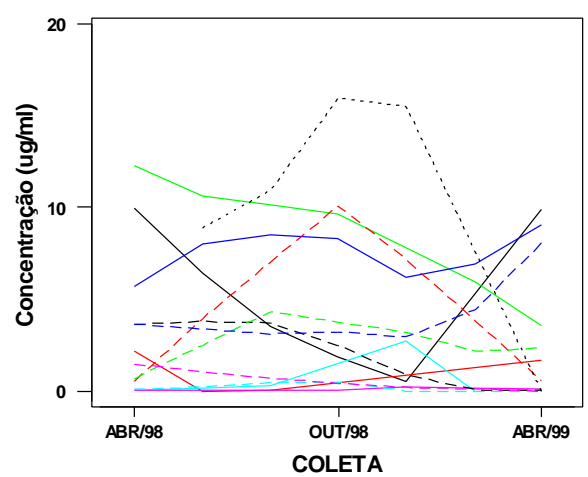

E) Cálcio

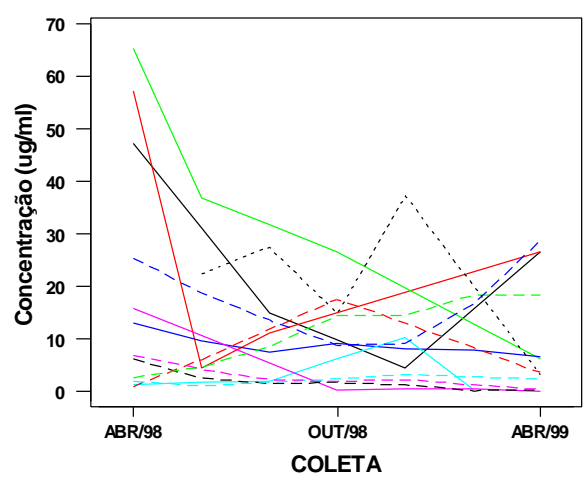

B) Magnésio
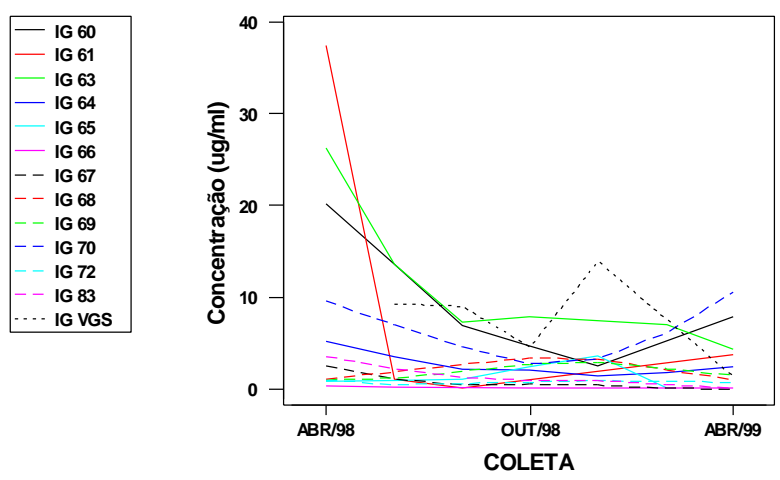

D) Alumínio
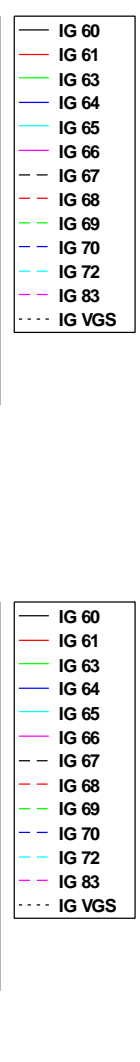

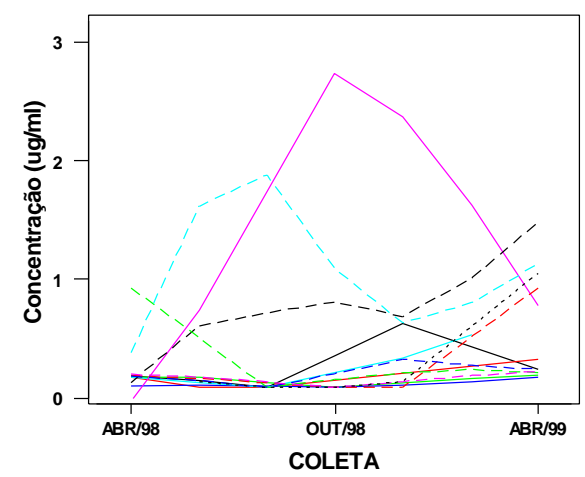

F) Fósforo

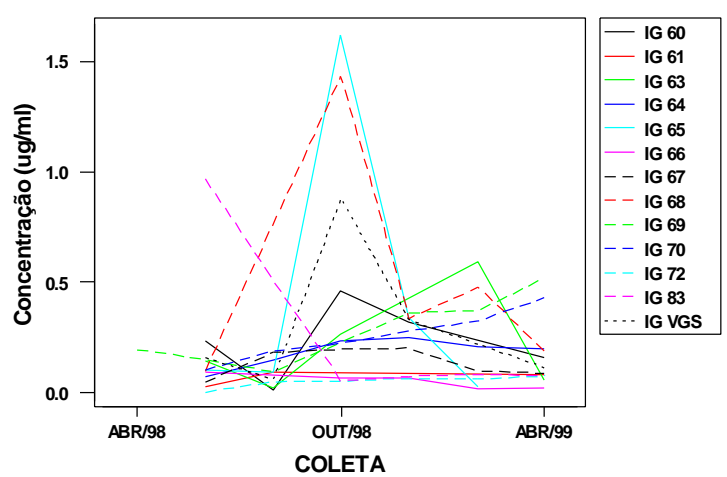

Figura C.5 - Alisamentos das concentrações dos metais na fração sobrenadante em função do tempo de coleta. 
Figura C.5: (continuação)

G) Bário

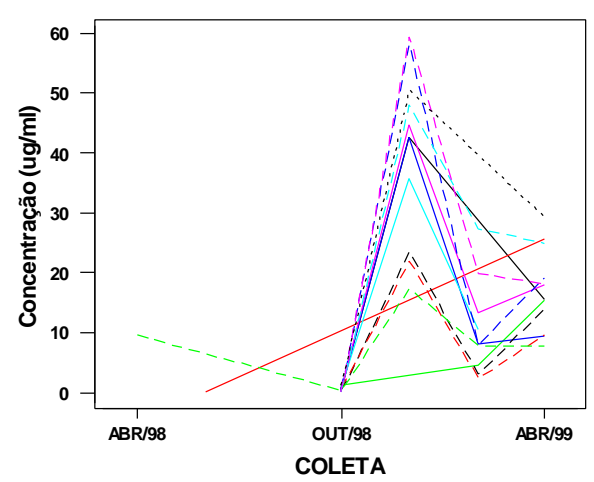

H) Cobre

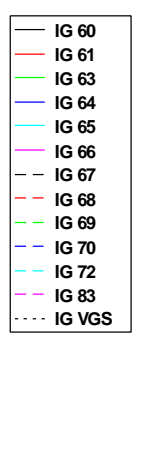

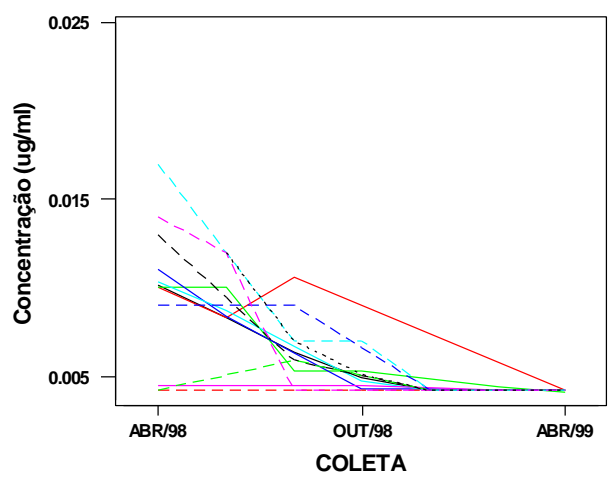

\begin{tabular}{|l|}
- IG 60 \\
- IG 61 \\
IG 63 \\
- IG 64 \\
IG 65 \\
- IG 66 \\
-- IG 67 \\
-- IG 68 \\
- IG 69 \\
-- IG 70 \\
- IG 72 \\
- IG 83 \\
- IG VGS \\
\hline
\end{tabular}


A) Ferro

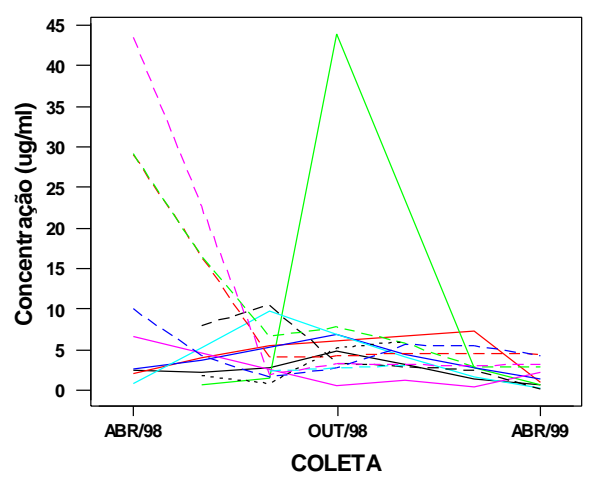

C) Manganês

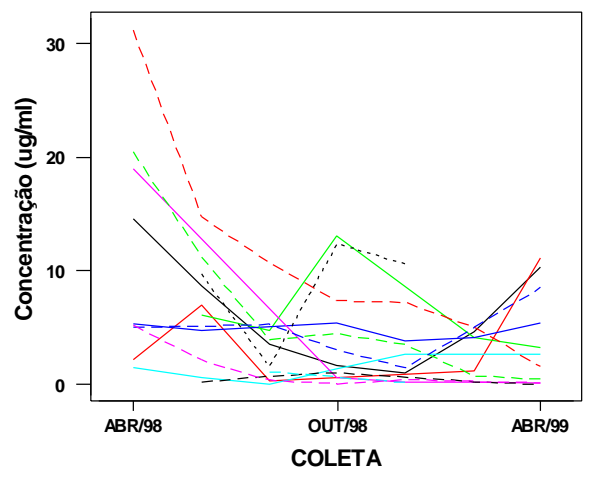

E) Cálcio

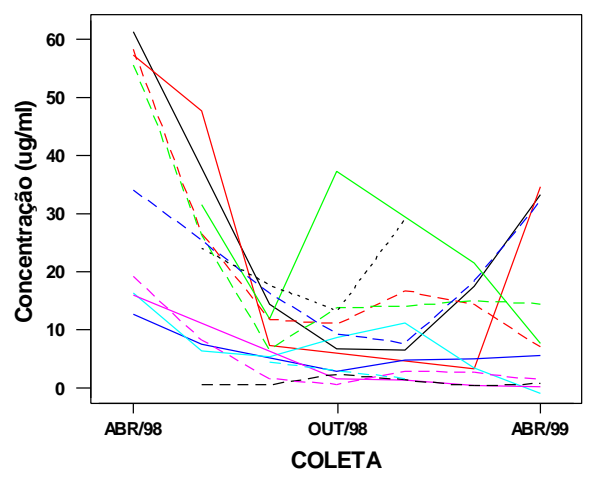

B) Magnésio

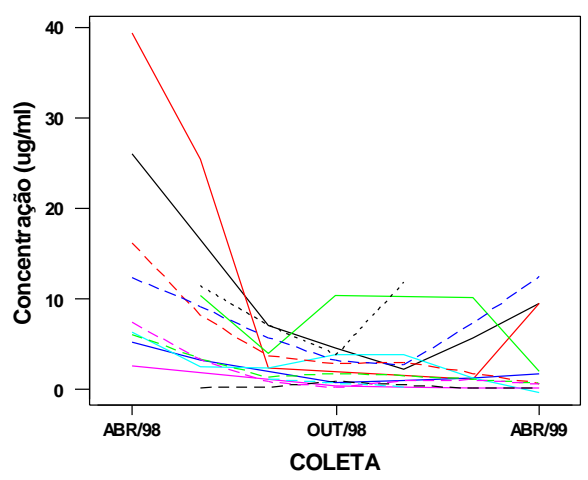

D) Alumínio

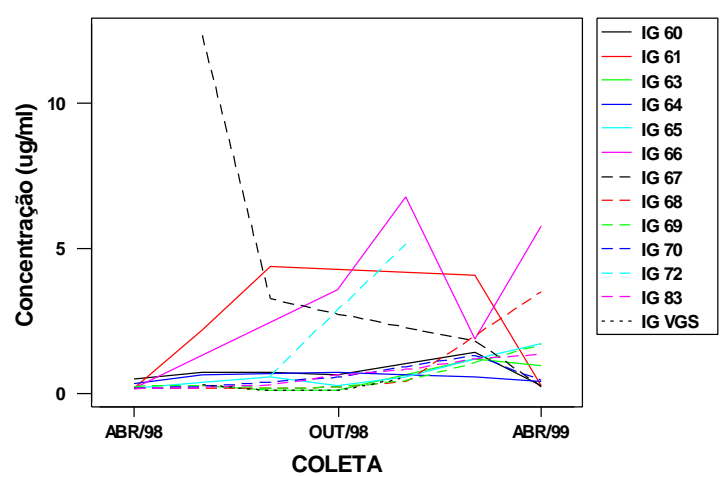

F) Fósforo
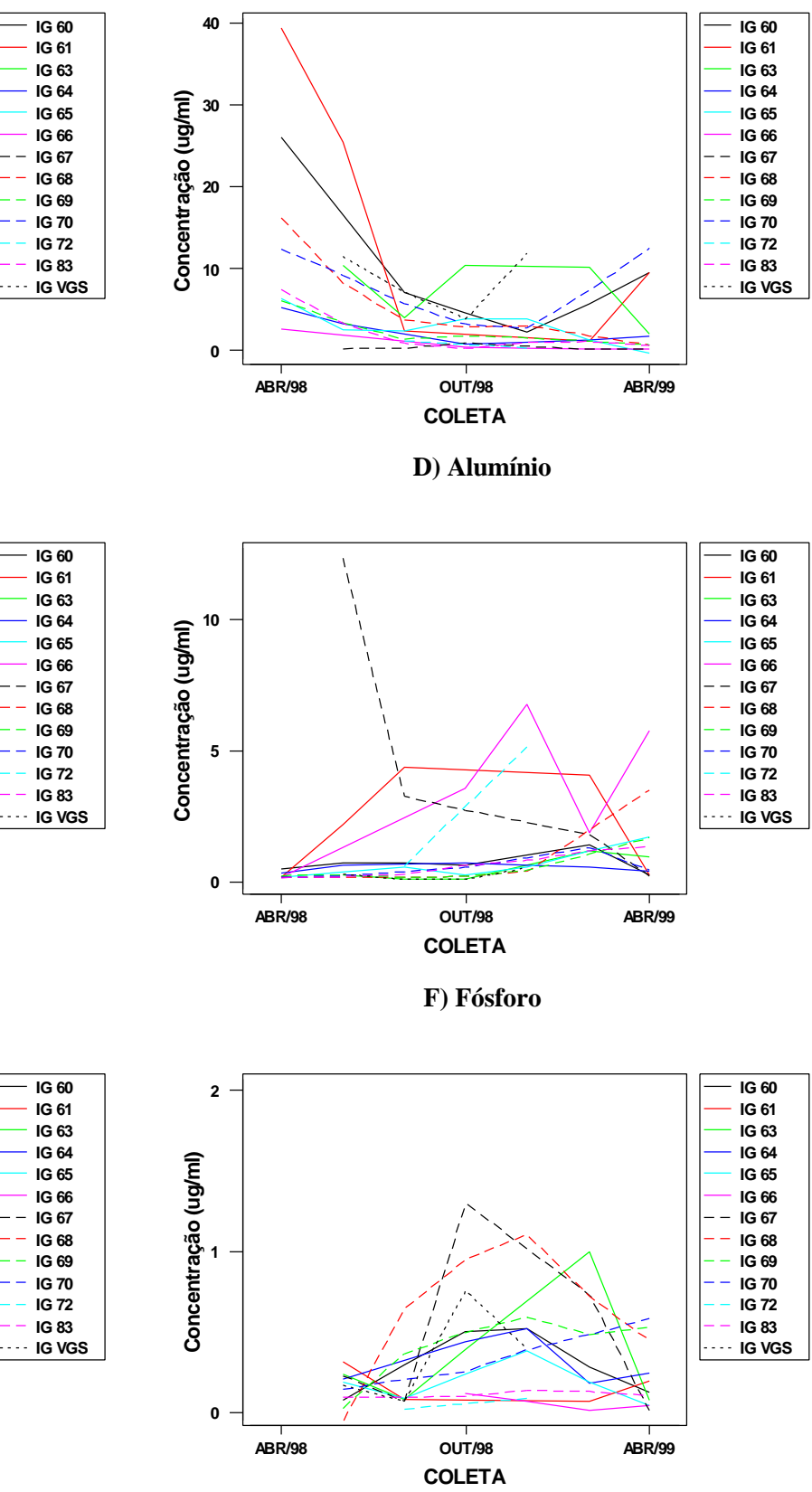

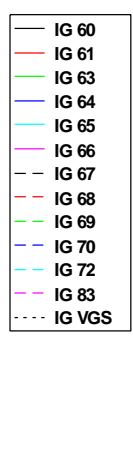

Figura C.6 - Alisamentos das concentrações dos metais na fração intersticial em função do tempo de coleta. 
Figura C.6: (continuação)

\section{G) Bário}

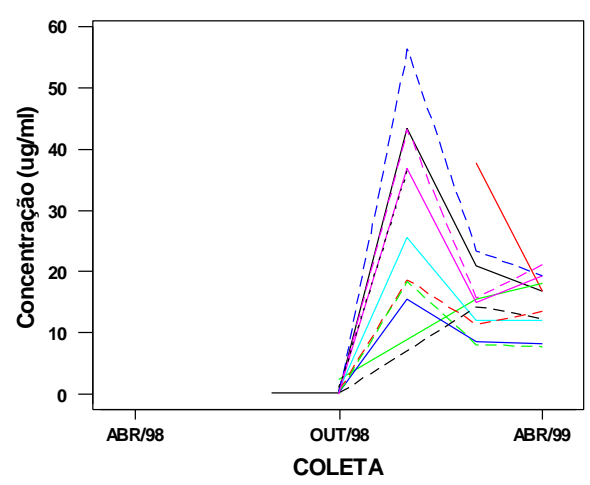

H) Cobre

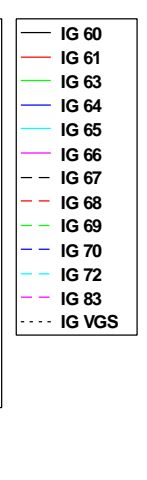

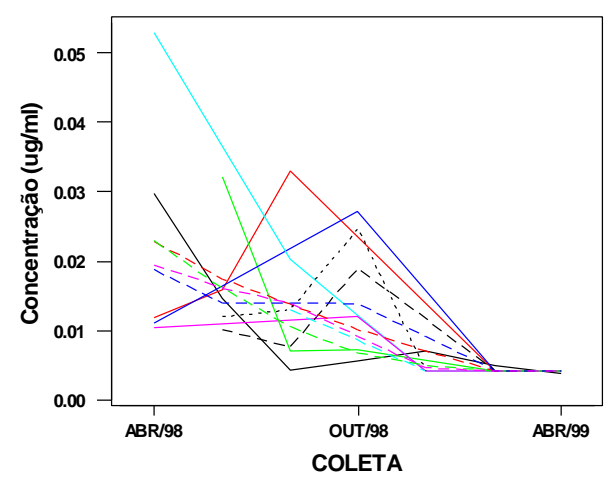

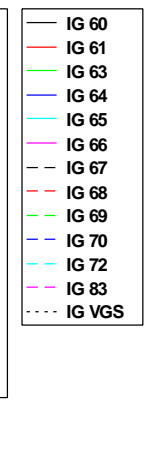

I) Cádmio

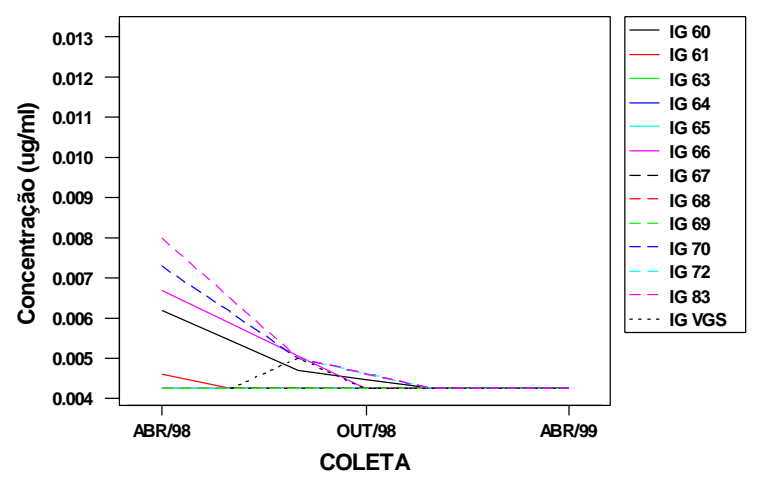


A) Ferro

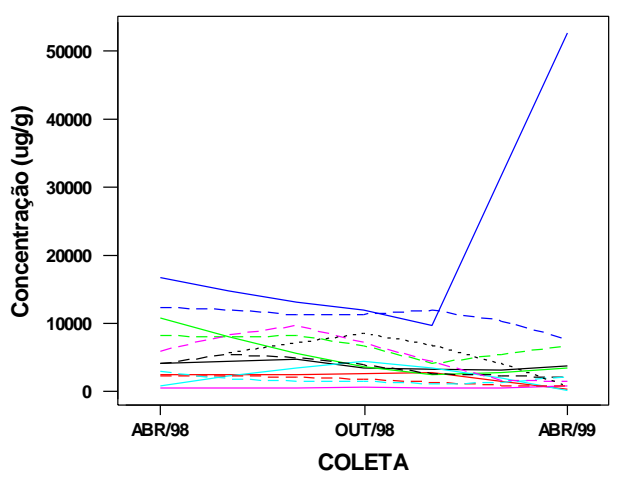

C) Manganês

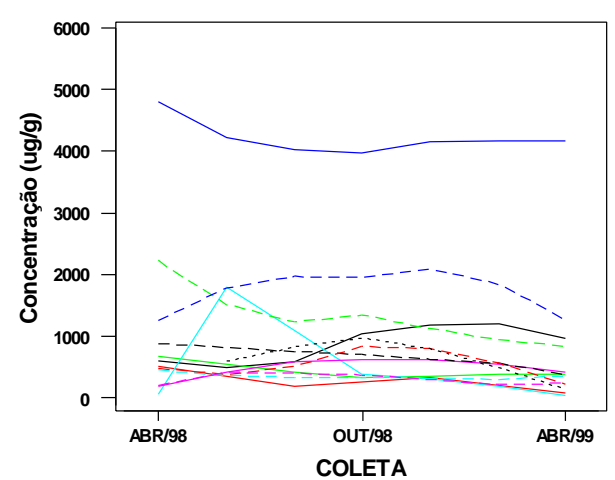

E) Cálcio

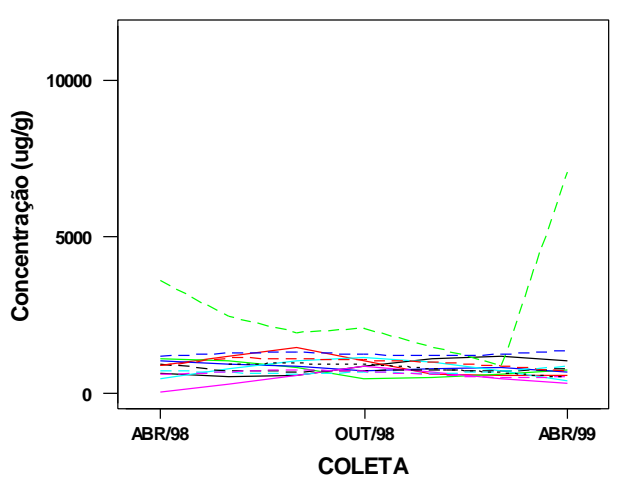

B) Magnésio
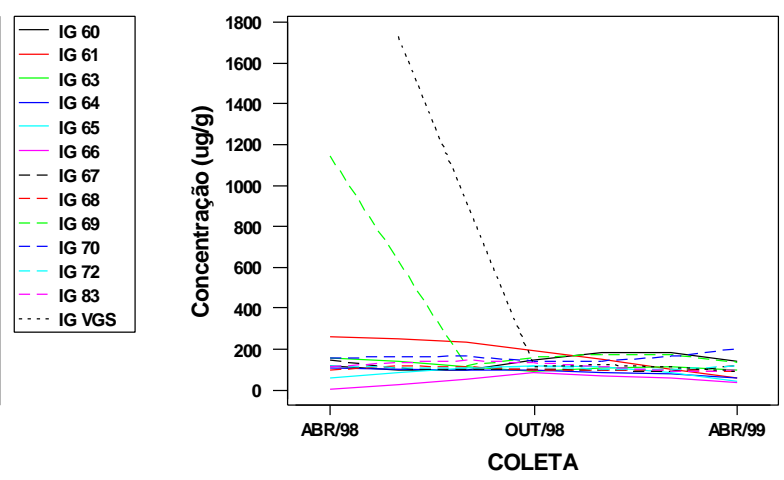

D) Alumínio
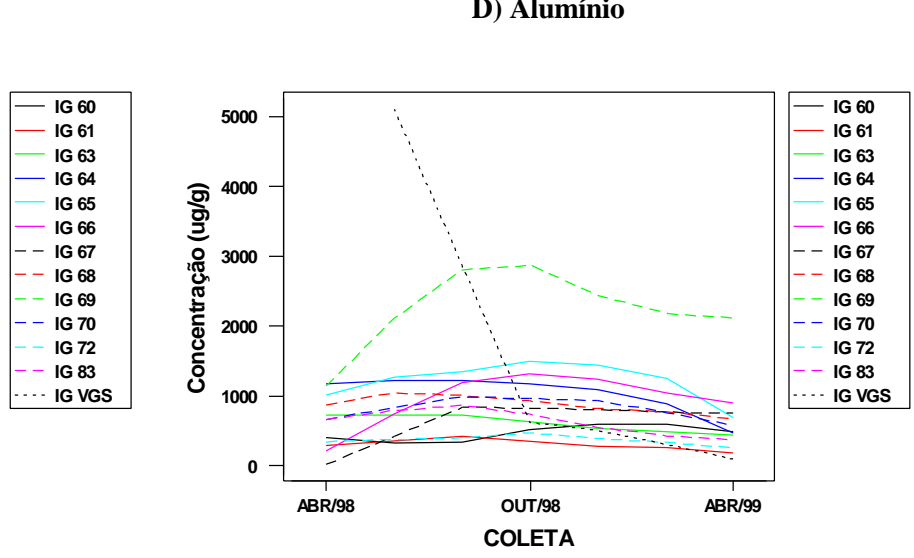

F) Fósforo
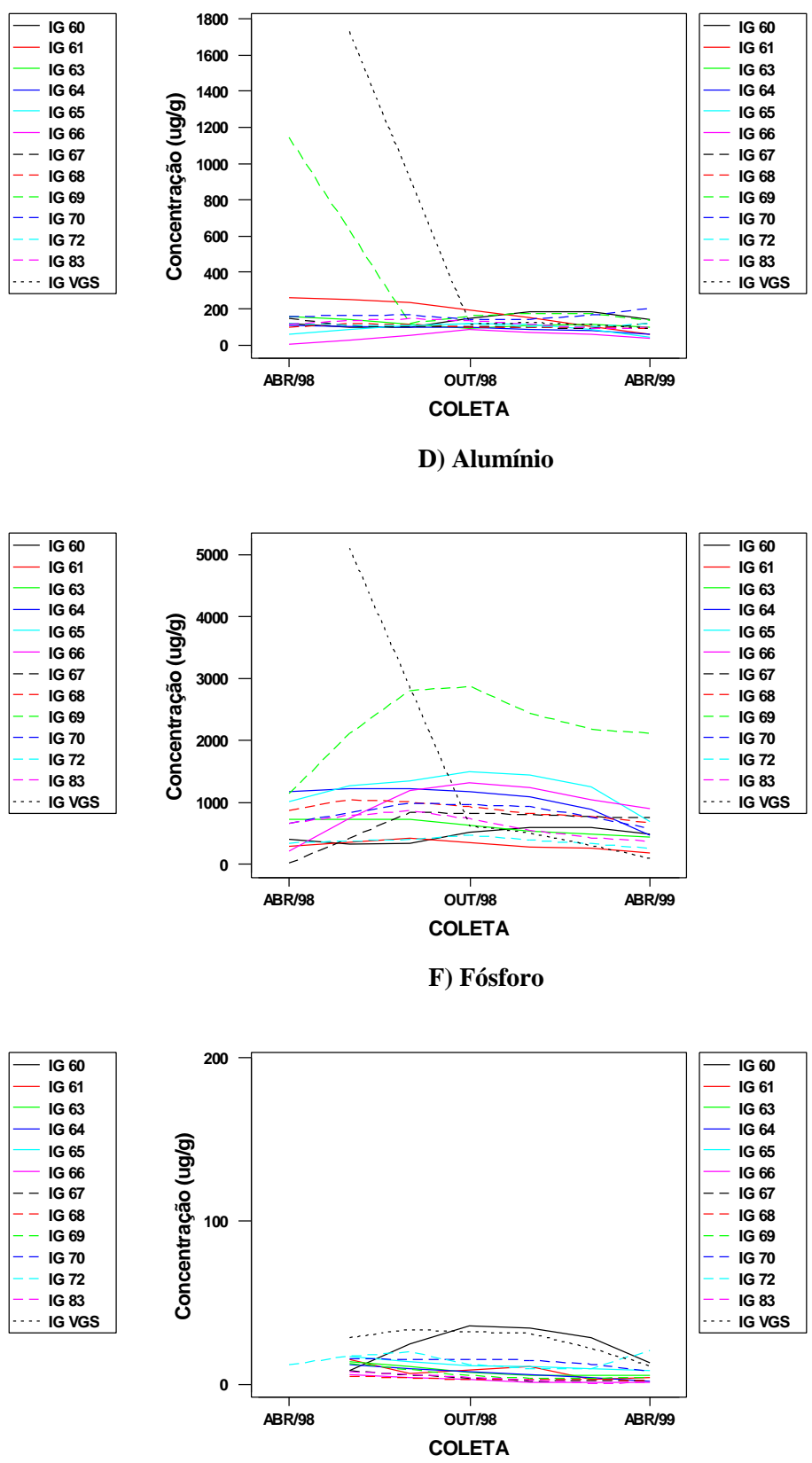

Figura C.7 - Alisamentos das concentrações dos metais na fração digestão em função do tempo de coleta. 
Figura C.7: (continuação)

G) Bário

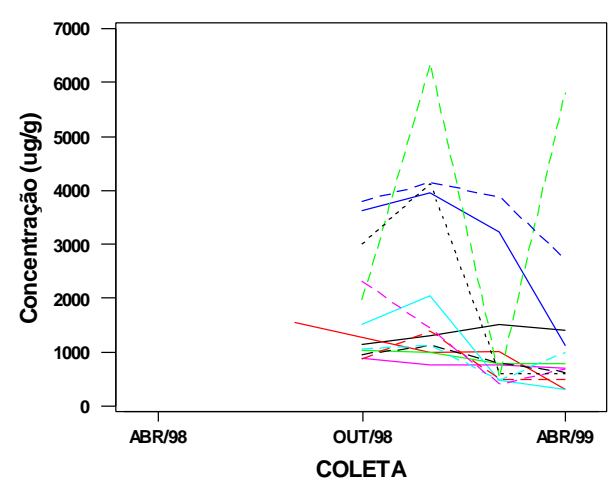

H) Cobre

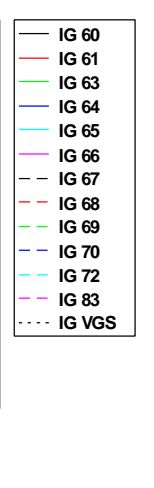

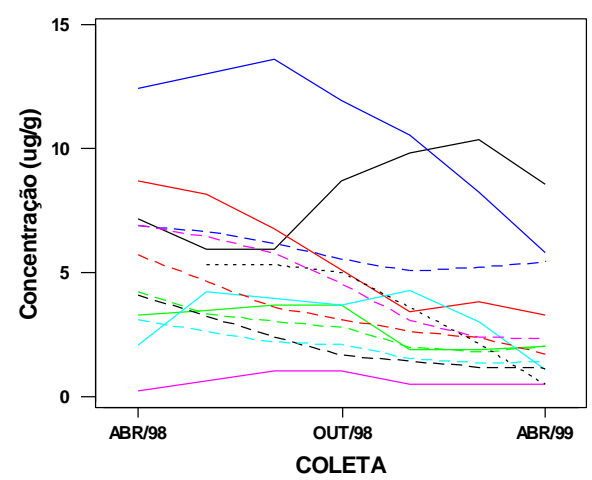

I) Cádmio

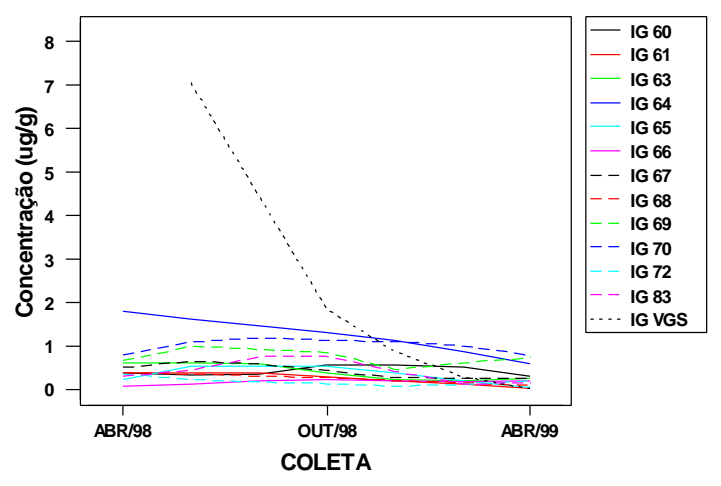


A) Ferro

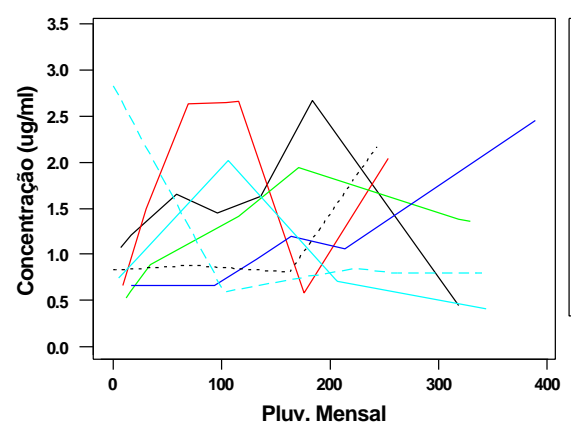

C) Manganês

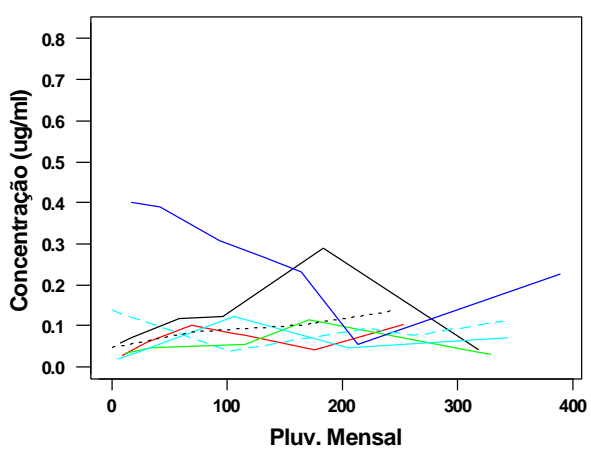

E) Cálcio

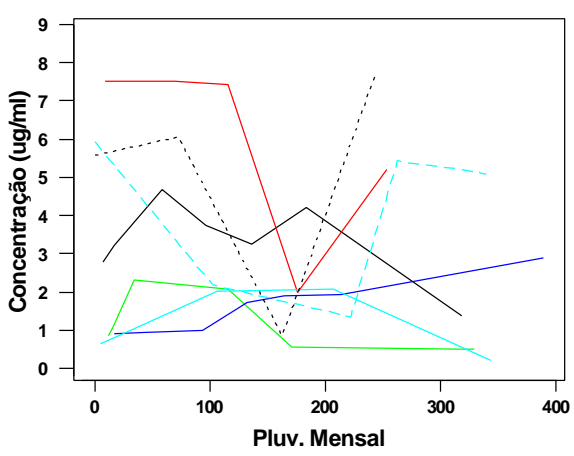

B) Magnésio

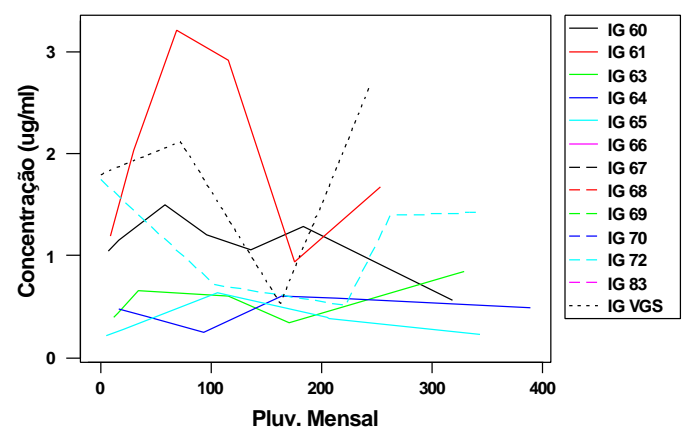

D) Alumínio
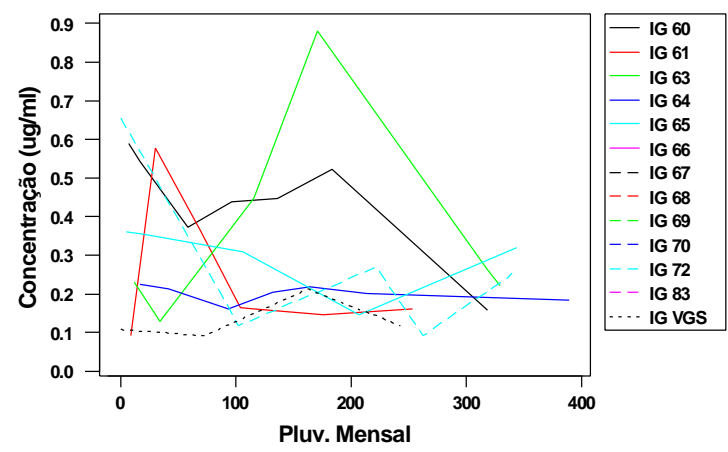

F) Fósforo

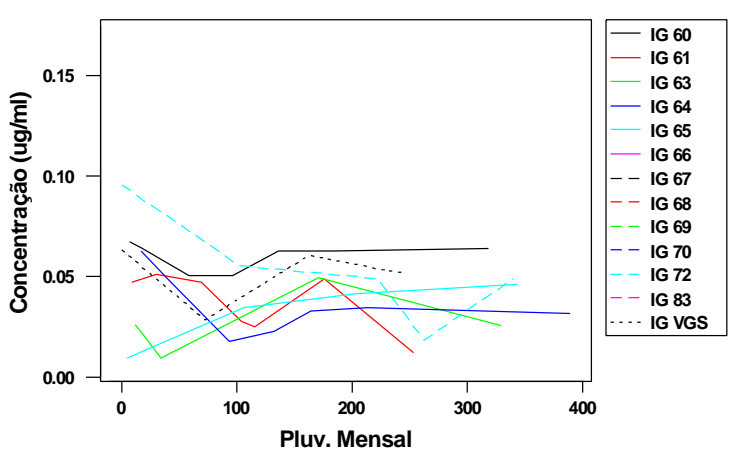

Figura C.8 - Alisamentos dos índices pluviométricos mensais (mm) em função das concentrações dos metais analisados na água bruta. 
Figura C.8: (continuação)

G) Bário

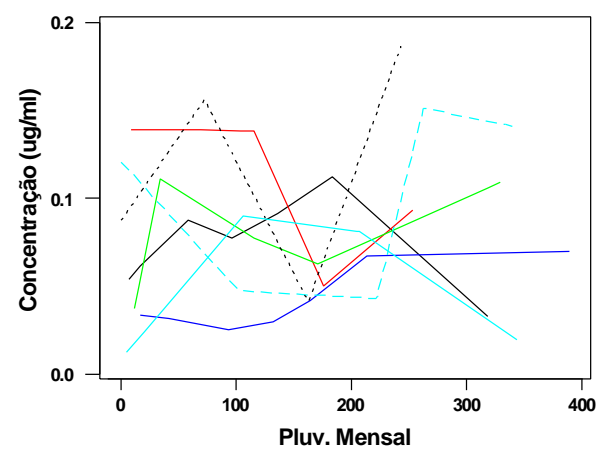

H) Cobre

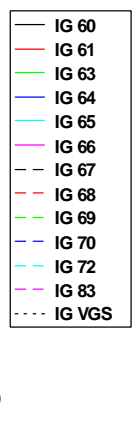

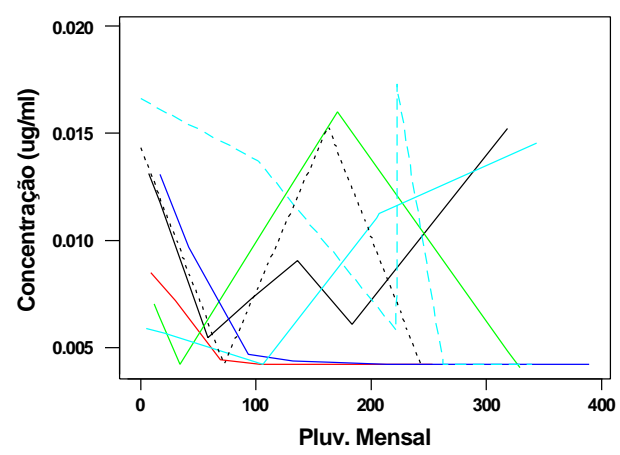

\begin{tabular}{|l|}
- IG 60 \\
- IG 61 \\
IG 63 \\
- IG 64 \\
IG 65 \\
- IG 66 \\
-- IG 67 \\
-- IG 68 \\
- IG 69 \\
-- IG 70 \\
- IG 72 \\
- IG 83 \\
- IG VGS \\
\hline
\end{tabular}


A) Fluoreto

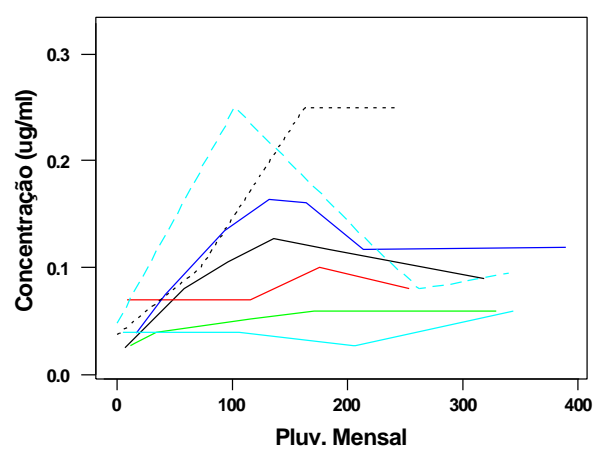

C) Nitrato

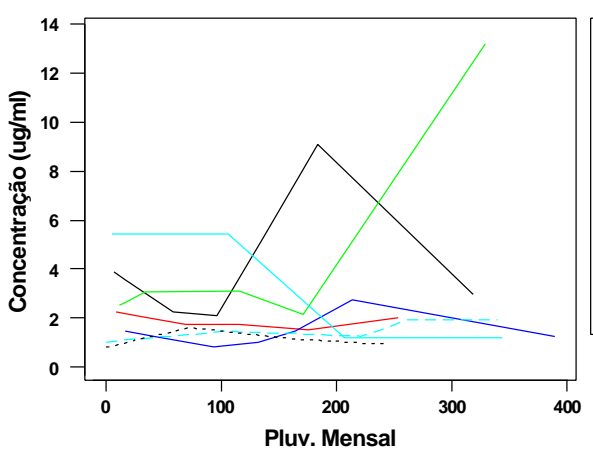

E) Sódio

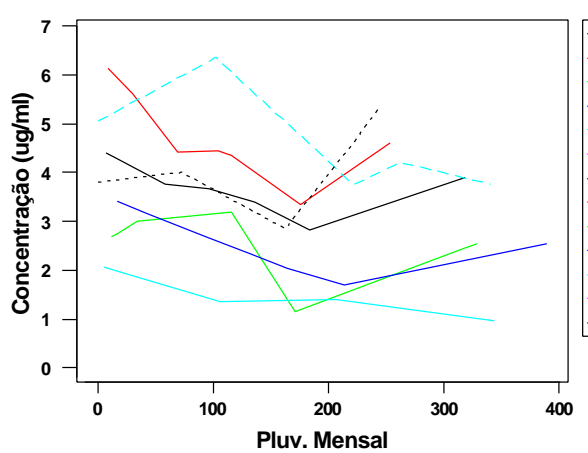

B) Cloreto
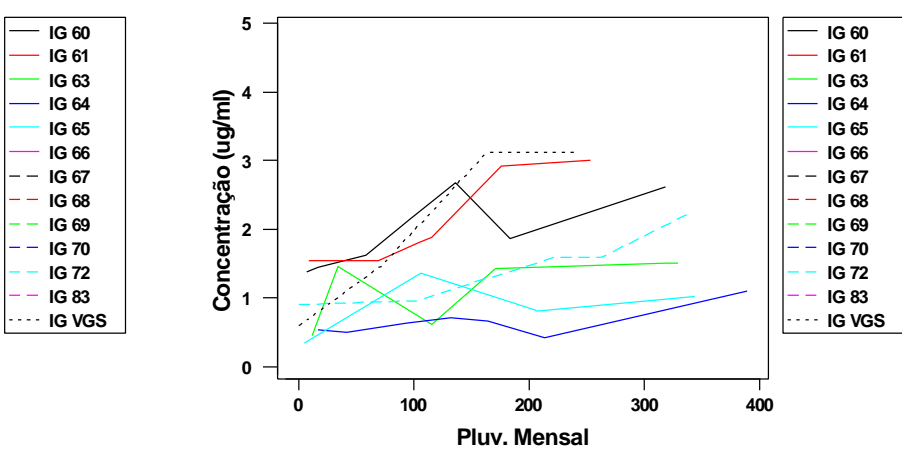

D) Sulfato

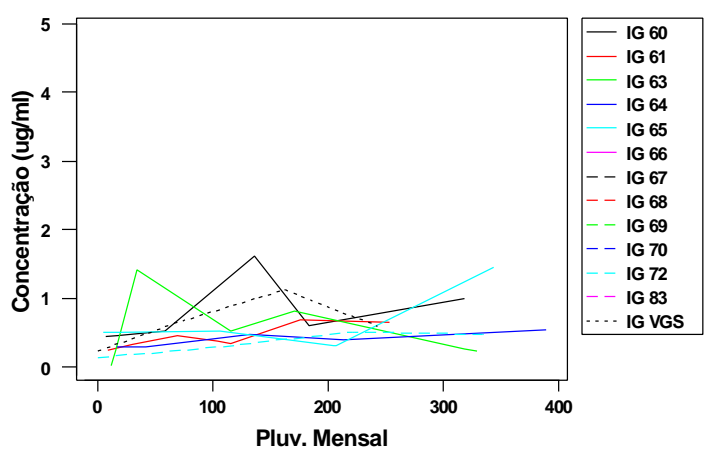

F) Potássio

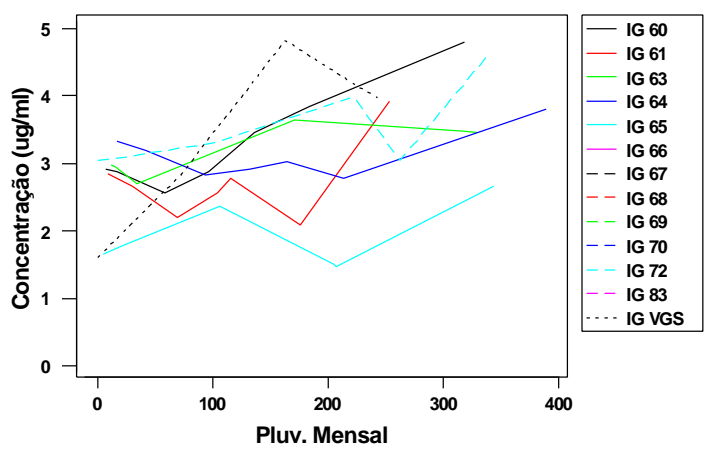

Figura C.9 - Alisamentos dos índices pluviométricos mensais (mm) em função das concentrações dos elementos iônicos analisados na água bruta. 
A) Ferro

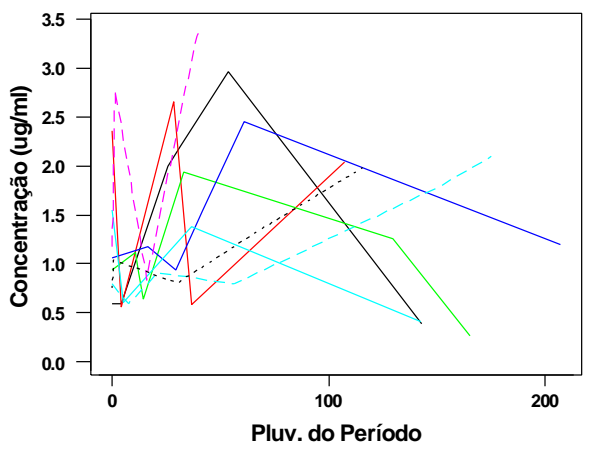

C) Manganês

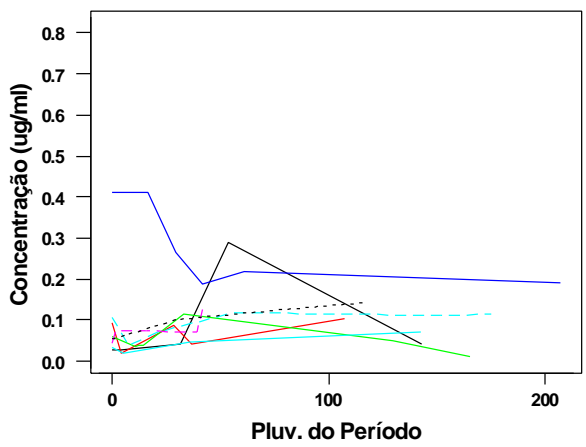

E) Cálcio

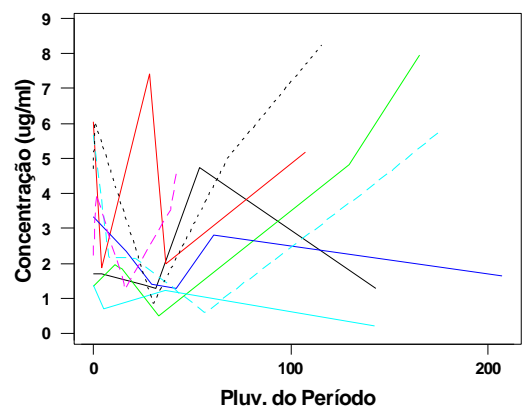

B) Magnésio

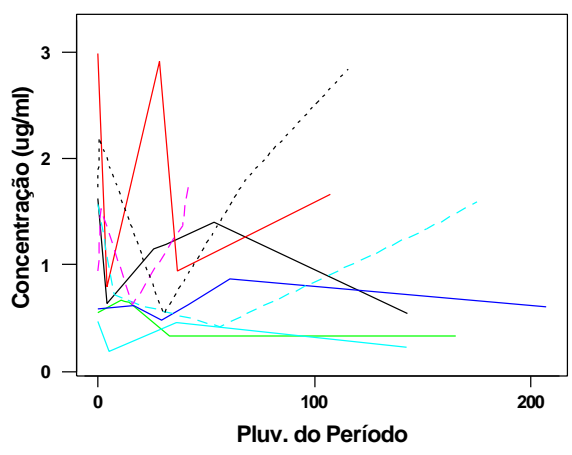

D) Alumínio
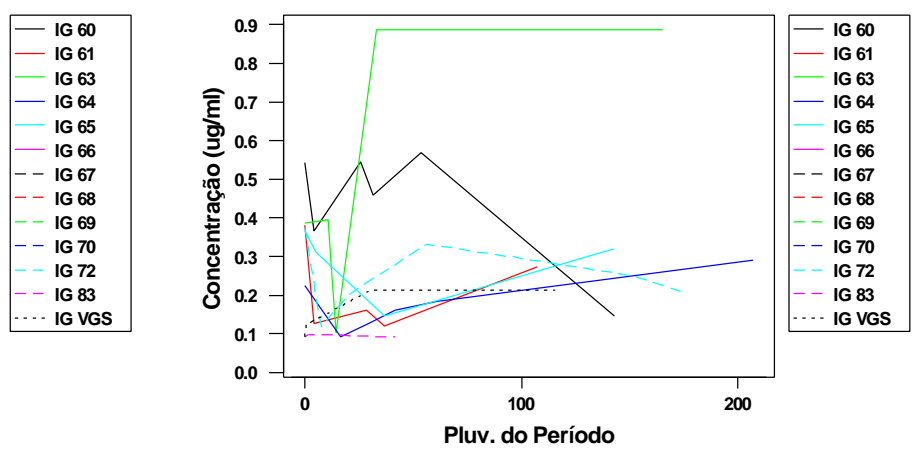

F) Fósforo

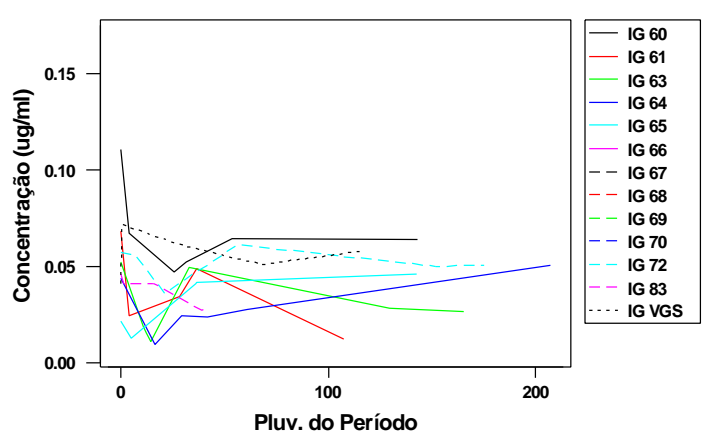

Figura C.10 - Alisamentos dos índices pluviométricos do período (mm) em função das concentrações dos metais analisados na água bruta. 
Figura C.10: (continuação)

G) Bário

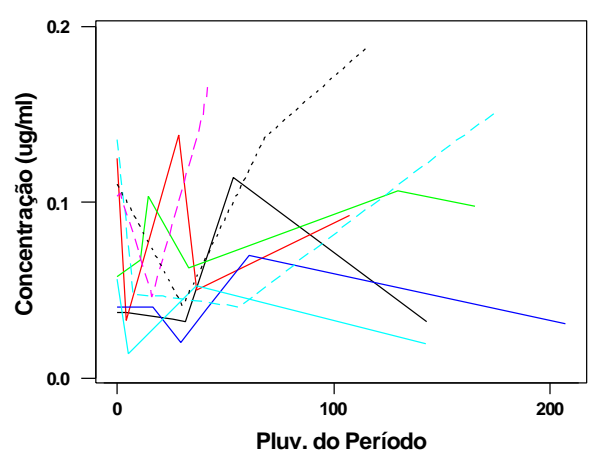

H) Cobre

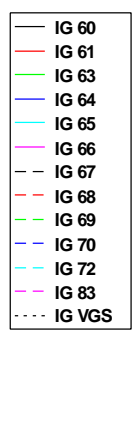

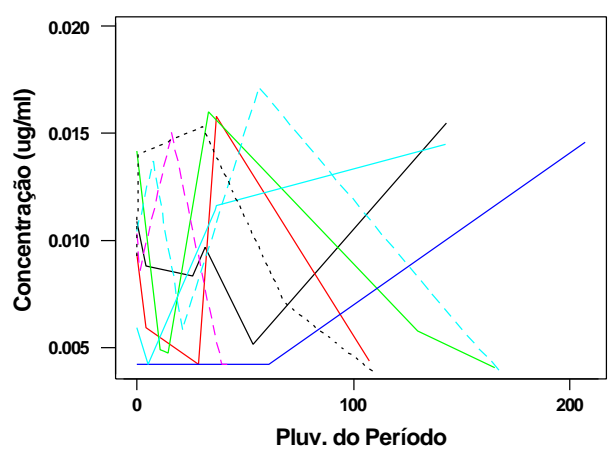

\begin{tabular}{|l|}
\hline- IG 60 \\
- IG 61 \\
IG 63 \\
- IG 64 \\
IG 65 \\
- IG 66 \\
-- IG 67 \\
-- IG 68 \\
- IG 69 \\
-- IG 70 \\
- IG 72 \\
- IG 83 \\
- IG VGS \\
\hline
\end{tabular}


A) Fluoreto

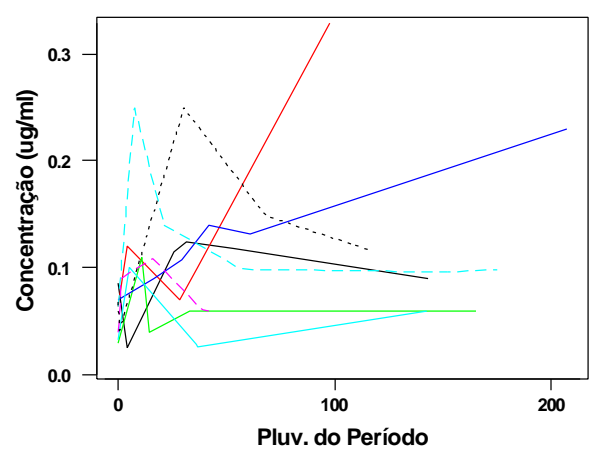

C) Nitrato

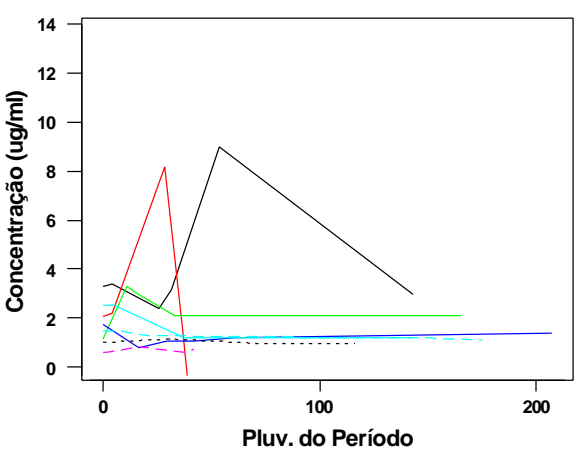

E) Sódio
B) Cloreto
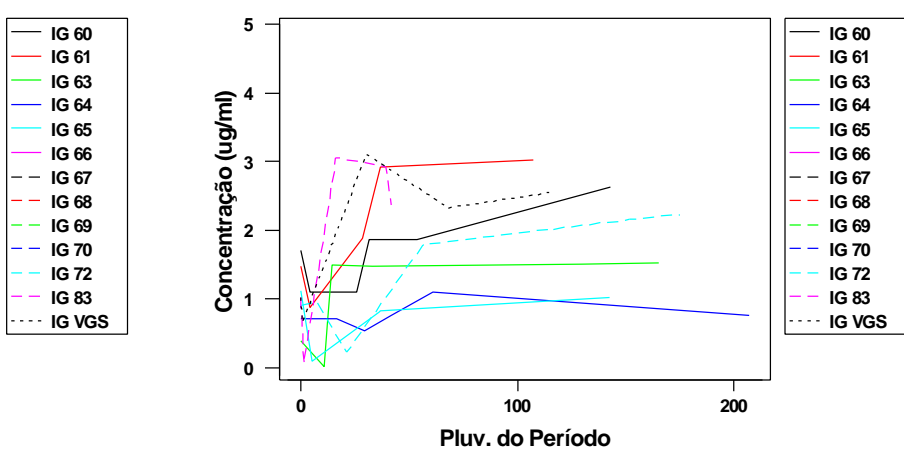

D) Sulfato
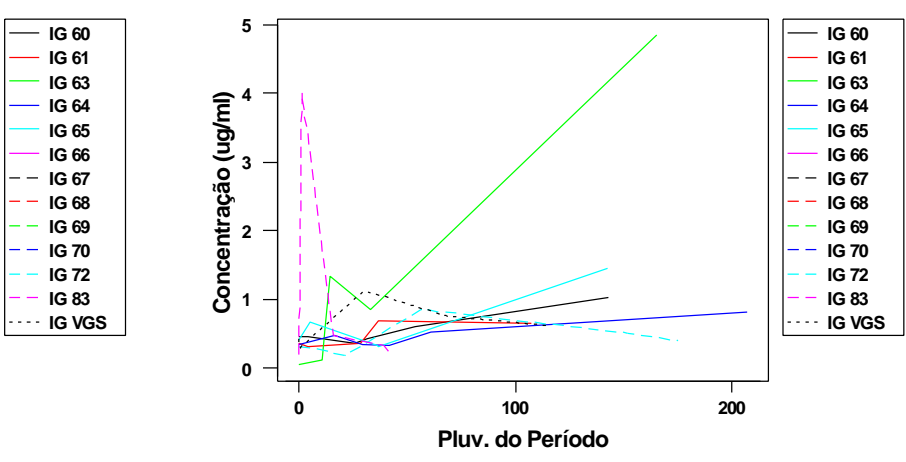

F) Potássio
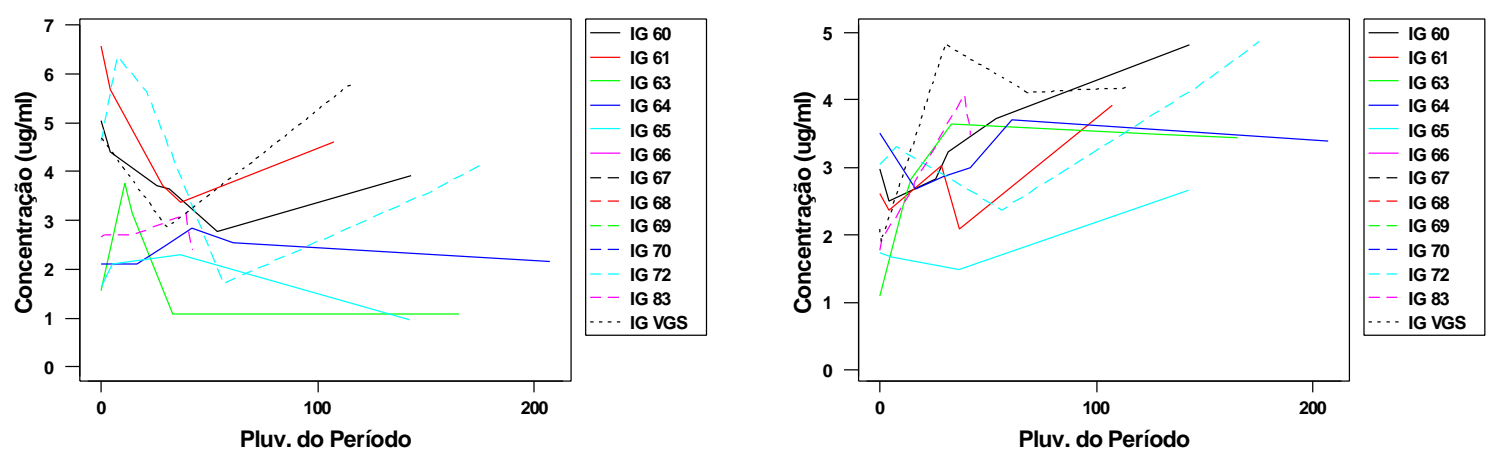

Figura C.11 - Alisamentos dos índices pluviométricos do período (mm) em função das concentrações dos elementos iônicos analisados na água tratada. 


\section{APÊNDICE 5}

Difratogramas da fração argila dos sedimentos

(natural, glicolada e aquecida) nas trezes comunidades estudadas 


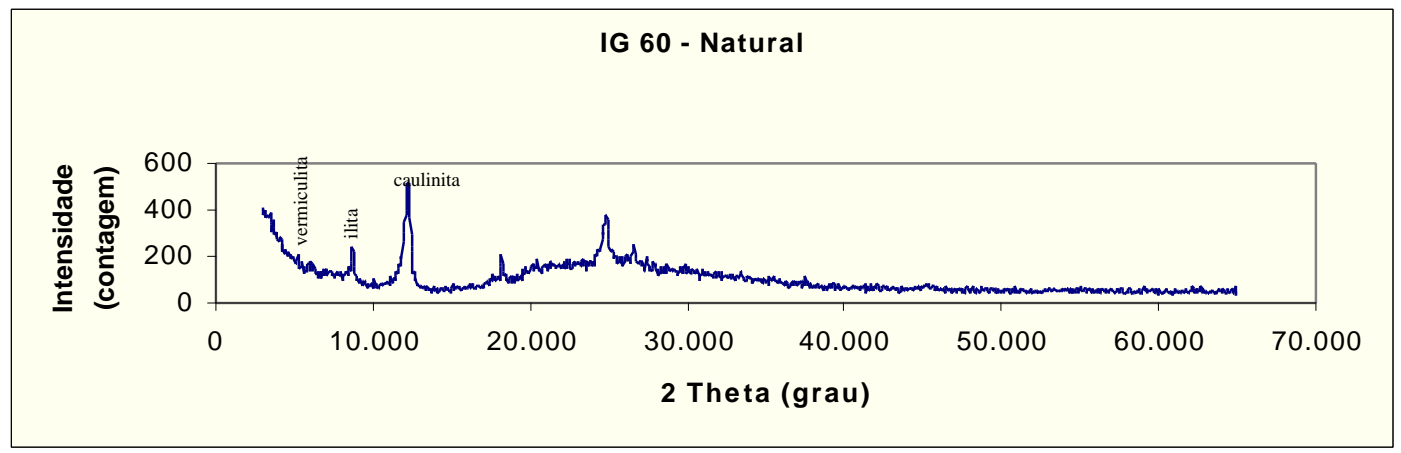

Figura E.1 - Difratograma da fração argila de sedimento pertencente a comunidade IG 60 (Natural)

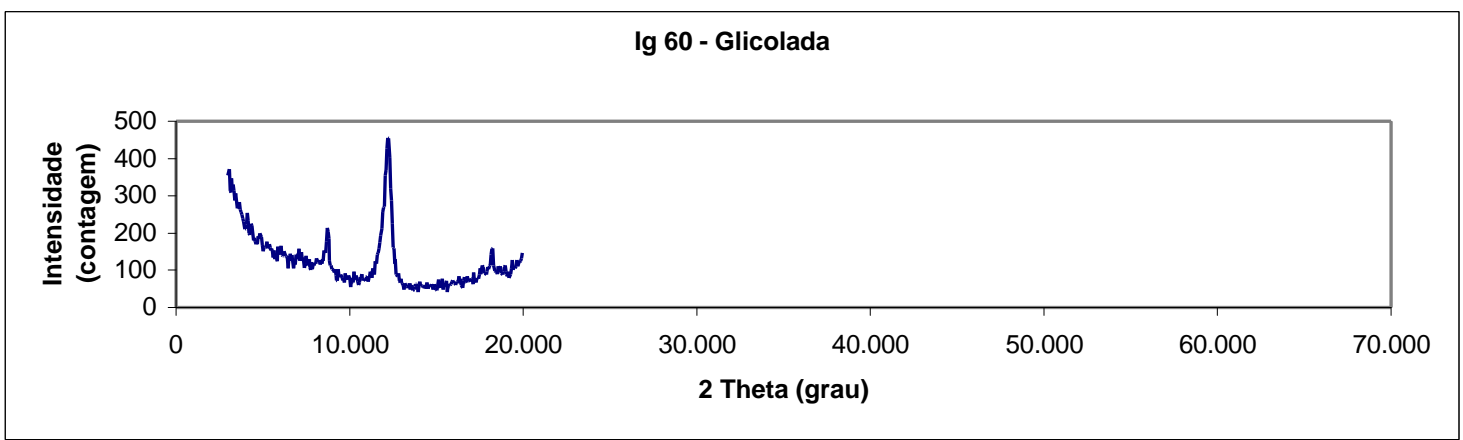

Figura E.2 - Difratograma da fração argila de sedimento pertencente a comunidade IG 60 (Glicolada)

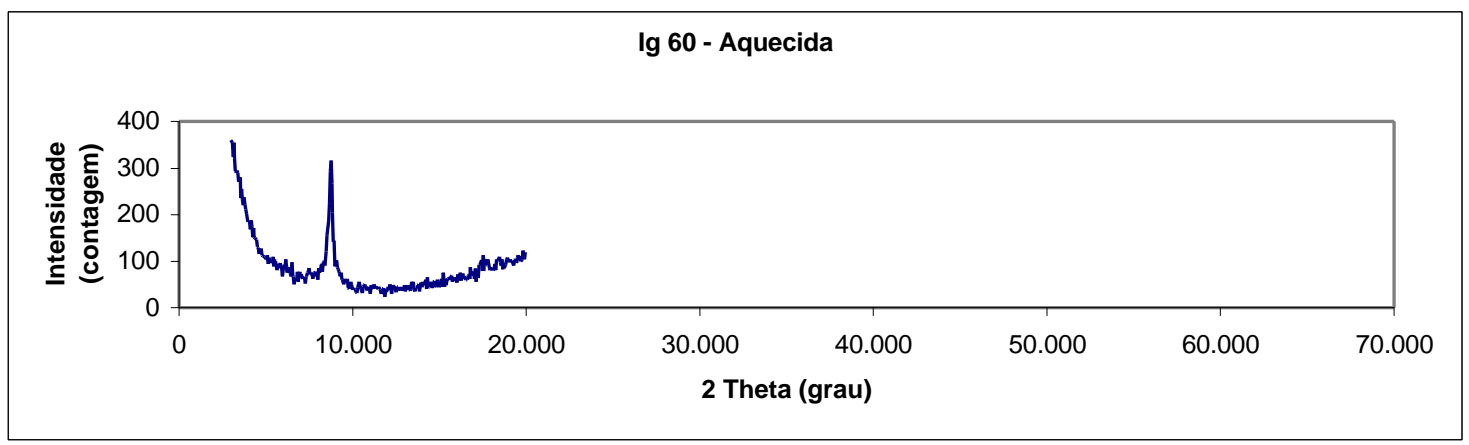

Figura E.3 - Difratograma da fração argila de sedimento pertencente a comunidade IG 60 (Aquecida) 


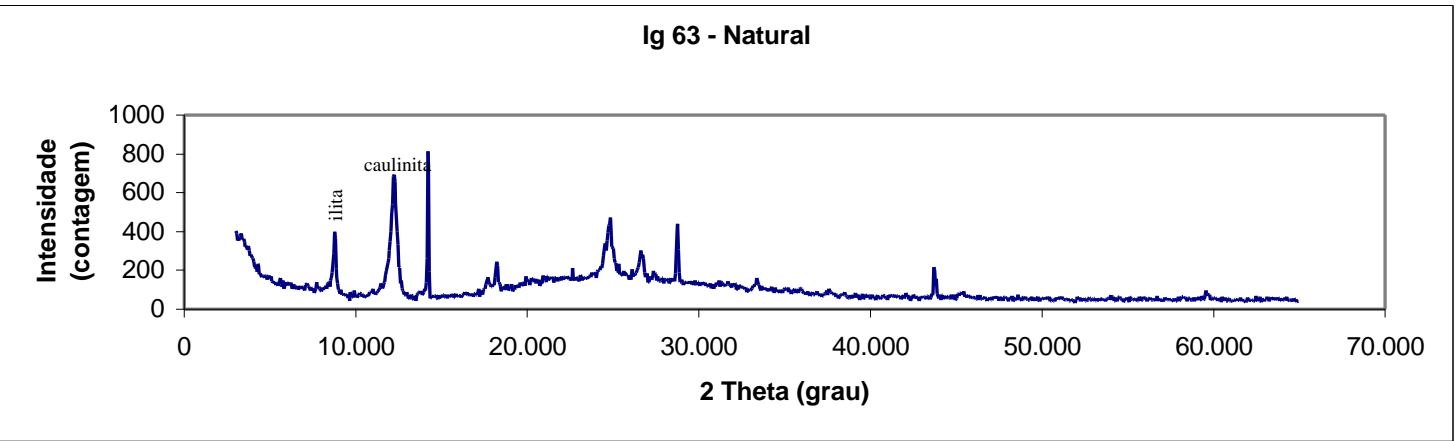

Figura E.4 - Difratograma da fração argila de sedimento pertencente a comunidade IG 63 (Natural)

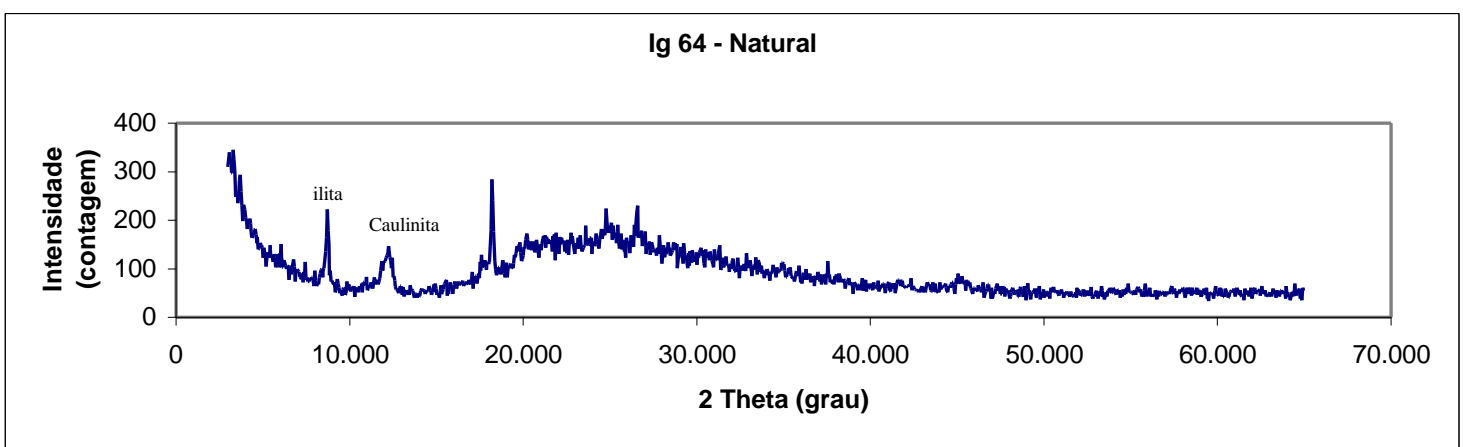

Figura E.5 - Difratograma da fração argila de sedimento pertencente a comunidade IG 64 (Natural) 


\section{APÊNDICE 4}

Dendrogramas 

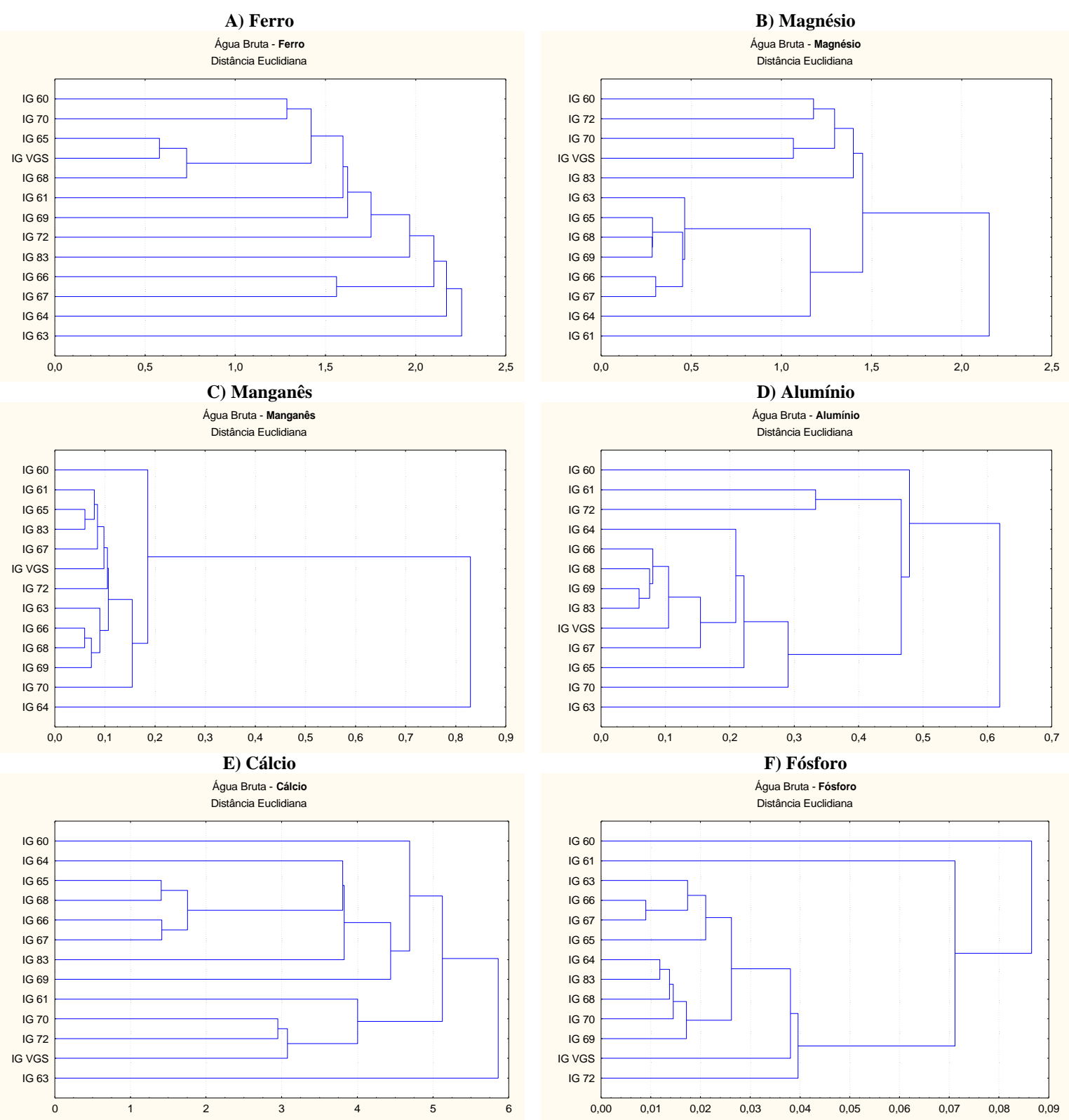

Figura D.1 - Dendrogramas das concentrações dos metais na água bruta em relação à época de coleta. 
Figura D.1: (continuação)

G) Bário

Água Bruta - Bário
Distância Euclidiana

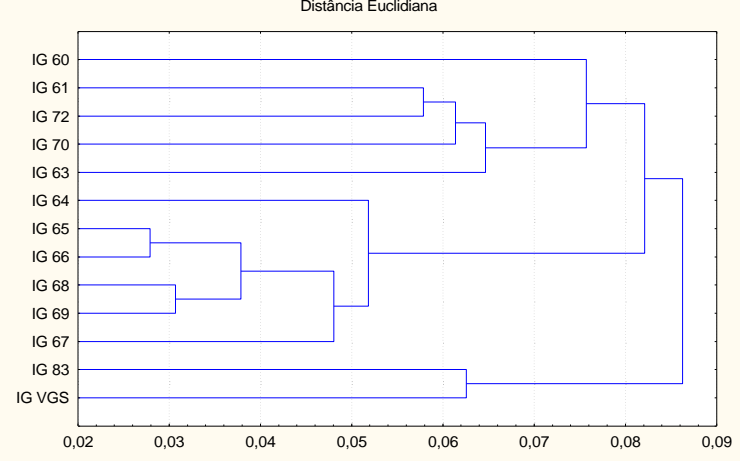

H) Cobre

Água Bruta - Cobre

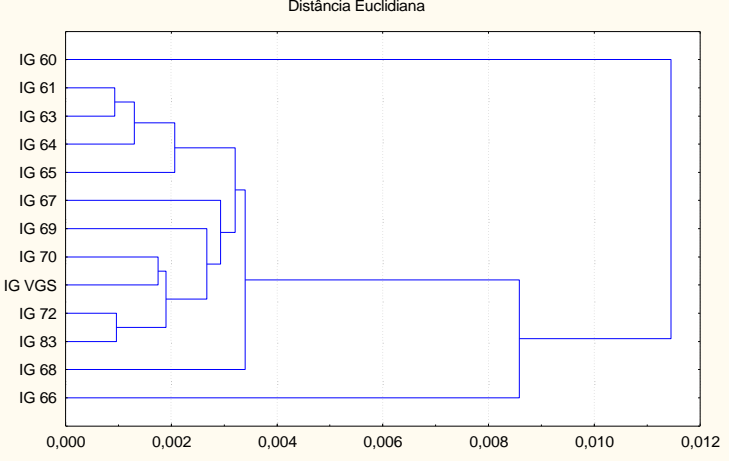



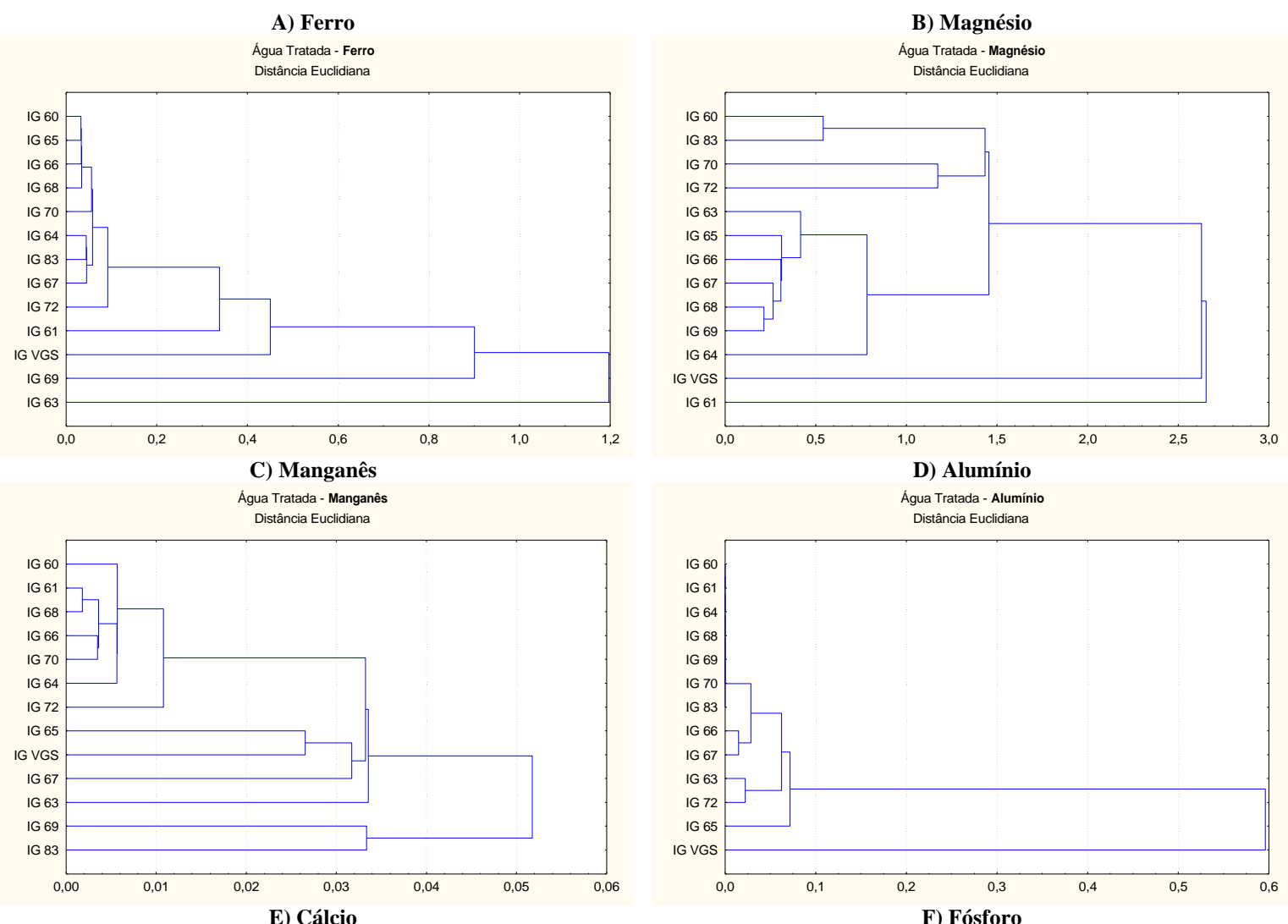

Água Tratada - Cálcio
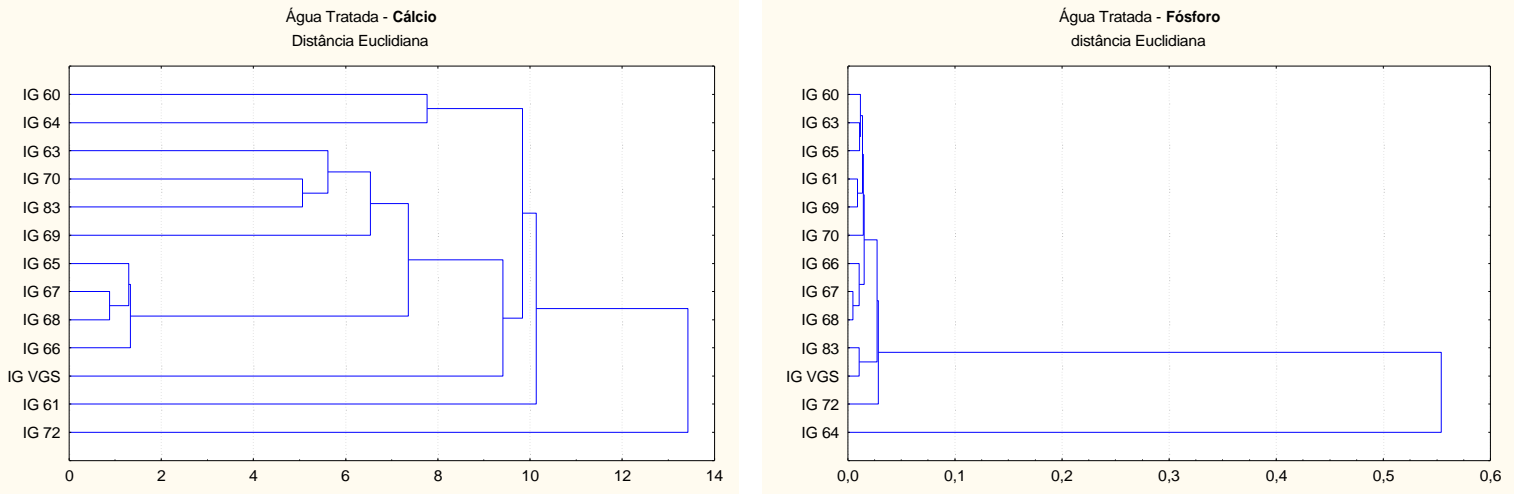

Figura D.2 - Dendrogramas das concentrações dos metais na água tratada em relação à época de coleta. 
Figura D.2: (continuação)

G) Bário

Água Tratada - Bário
Distância Euclidiana

H) Cobre

Distância Euclidiana

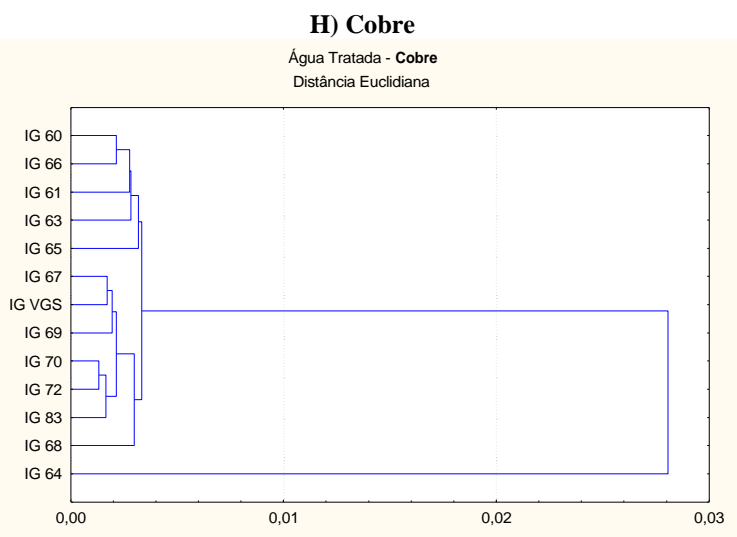



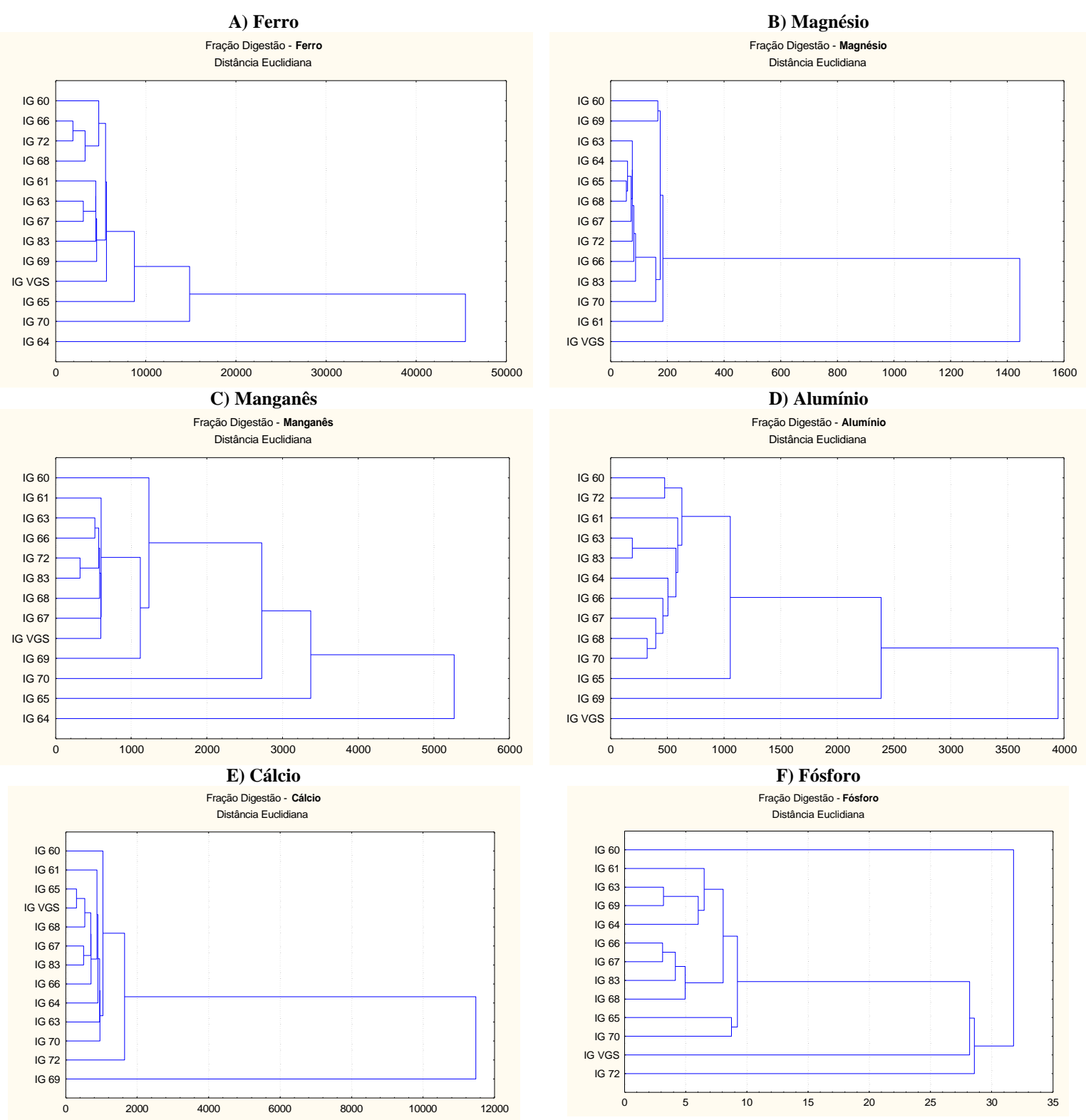

Figura D.3 - Dendrogramas das concentrações dos metais na fração digestão em relação à época de coleta. 
Figura D.3: (continuação)

G) Bário

Fração Digestão - Bário
Distância Euclidiana
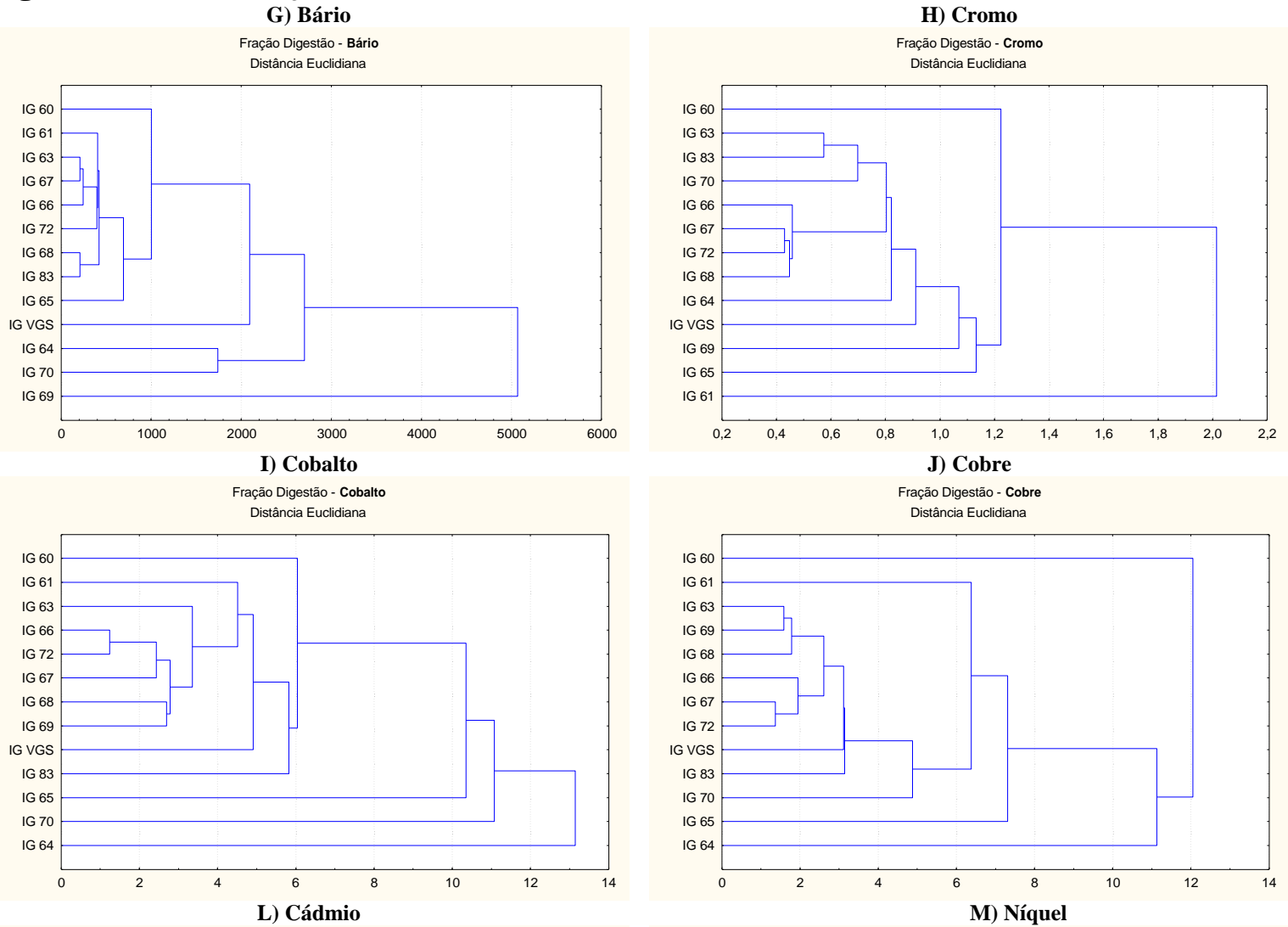

Fração Digestão - Cádmi

Distância Euclidiana

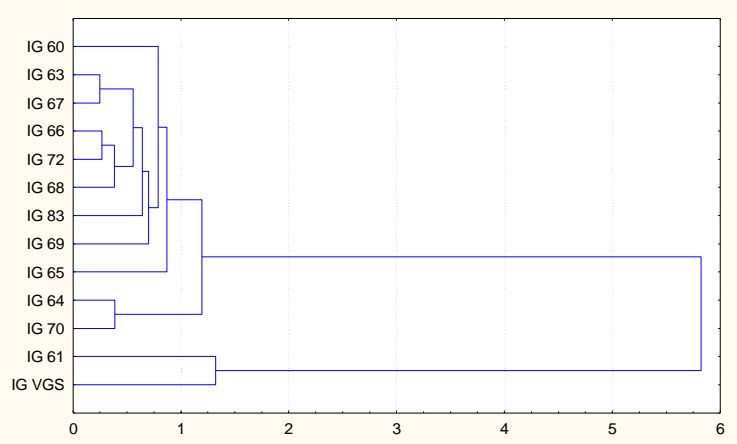

Fração Digestão - Niquel

Distância Euclidiana

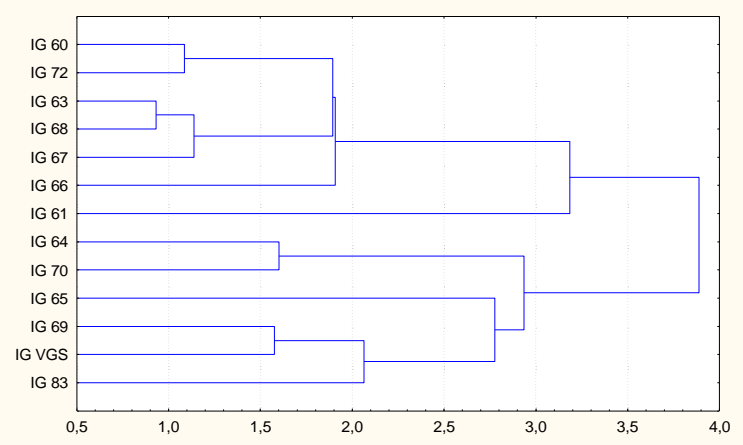


Figura D.3: (continuação)

N) Zinco

Fração Digestão - Zinco
Distância Euclidiana

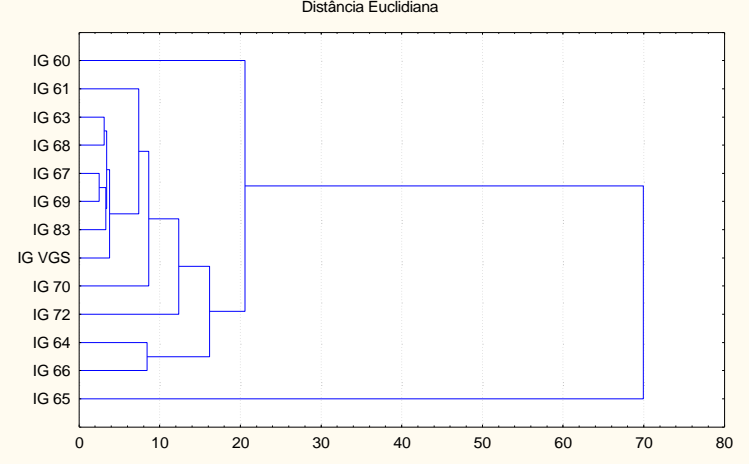

O) Chumbo

Fração Digestão - Chumbo

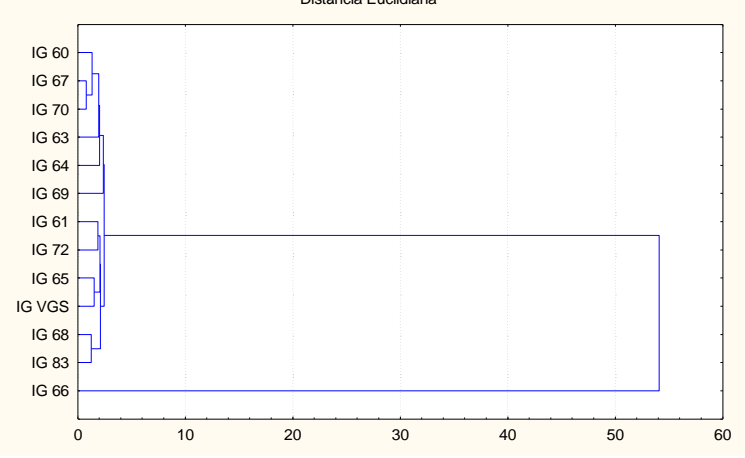



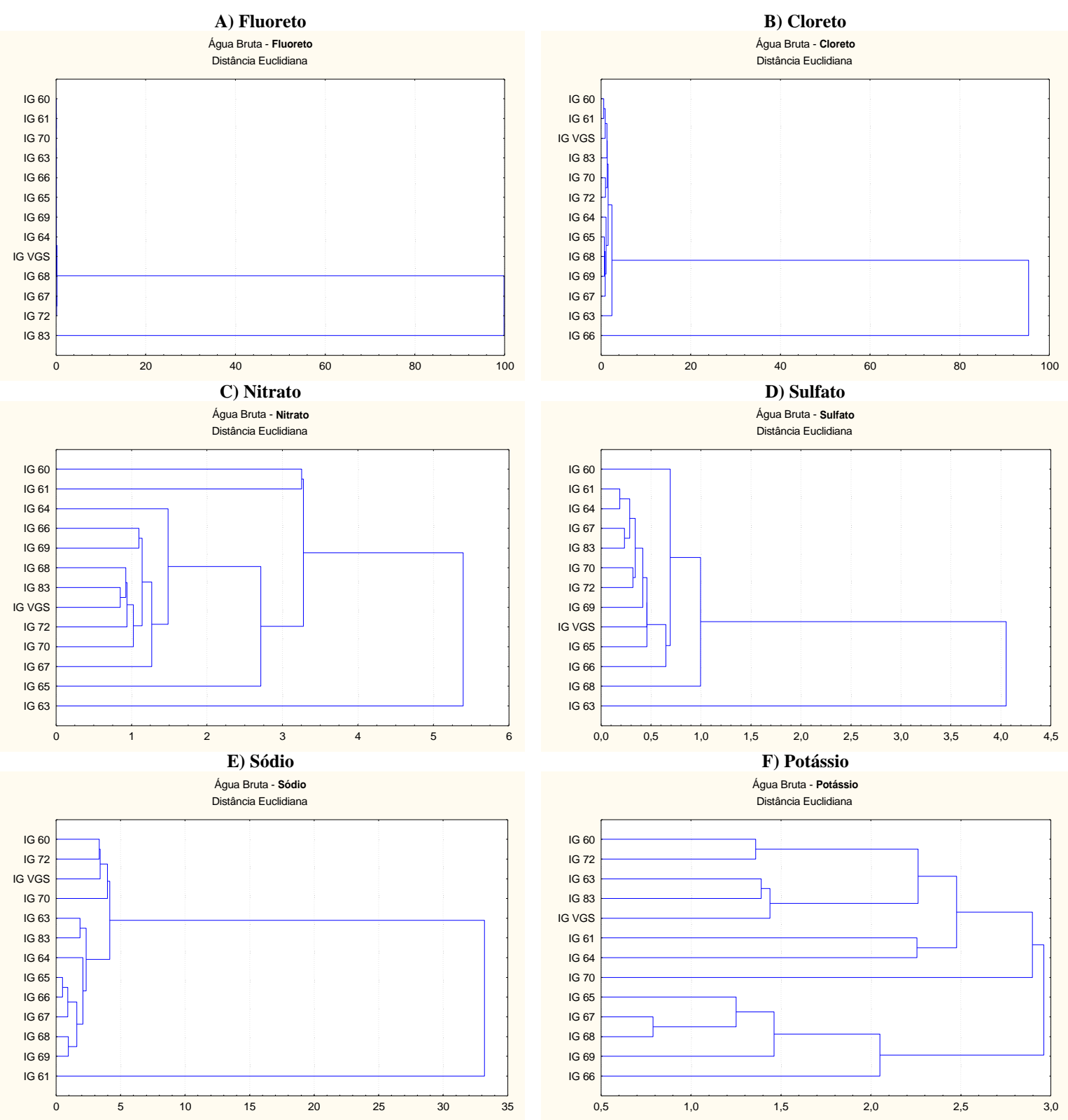

Figura D.4 - Dendrogramas das concentrações dos elementos iônicos na água bruta em relação à época de coleta. 
A) Fluoreto Água Tratada - Fluoreto Distância Euclidiana
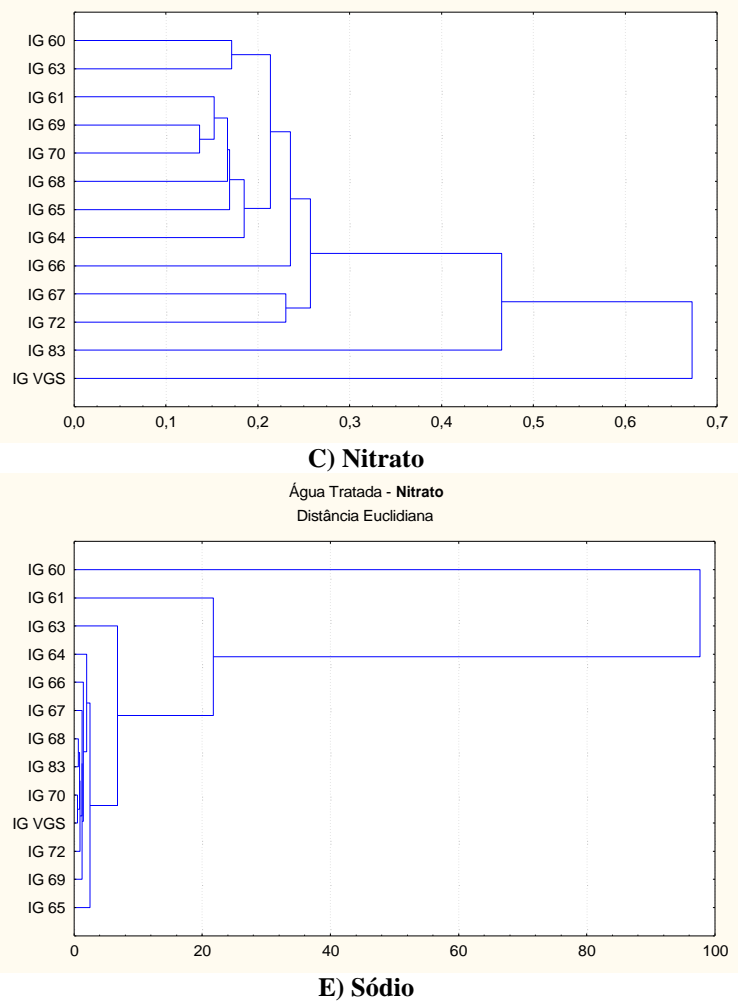

Água Tratada - Sódio

Distância Euclidiana

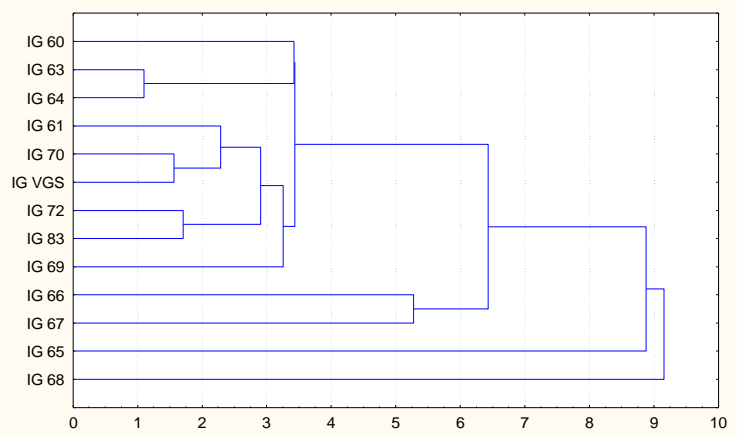

B) Cloreto

Água Tratada - Cloreto

Distância Euclidiana
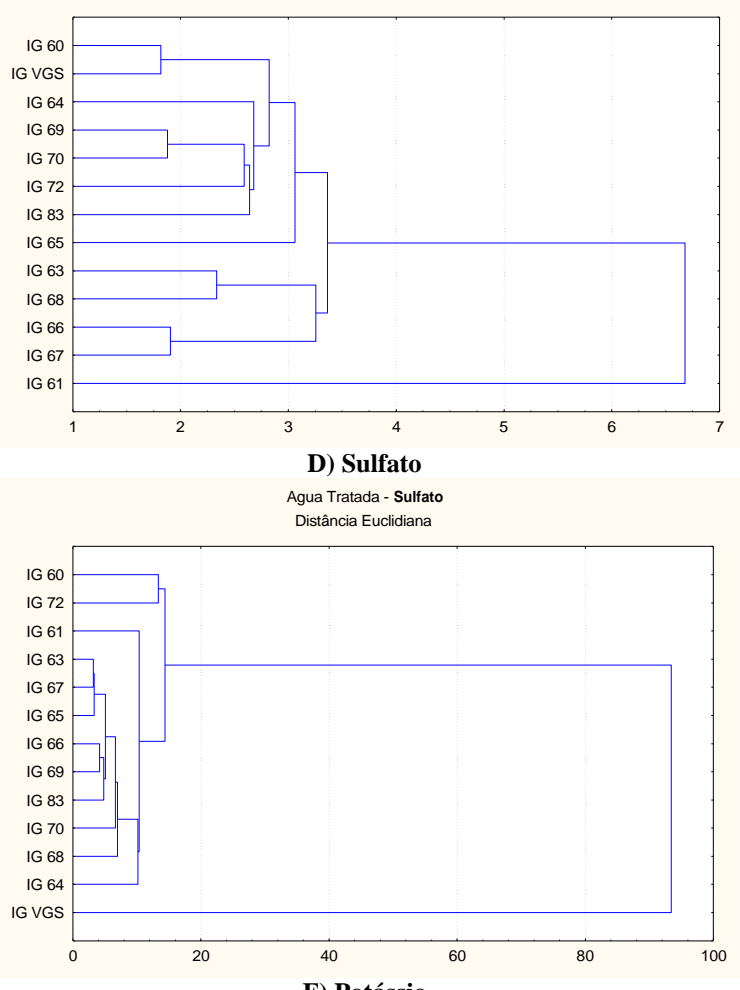

F) Potássio

Água Tratada - Potássio Distância Euclidiana

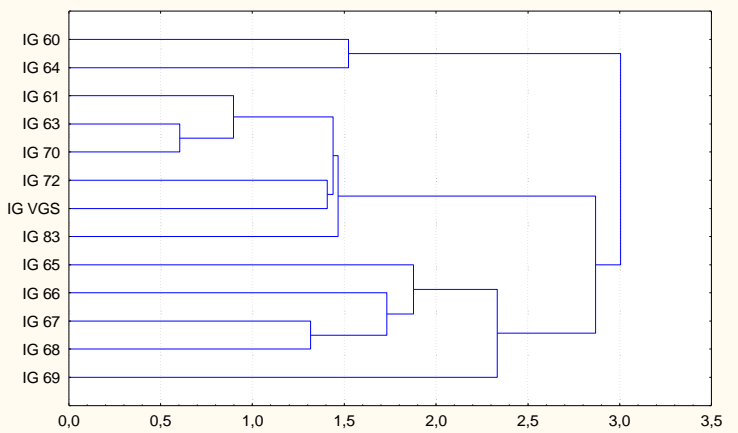

Figura D.5 - Dendrogramas das concentrações dos elementos iônicos na água tratada em relação à época de coleta. 


\section{APÊEDICE 6}

Documentação Fotográfica 


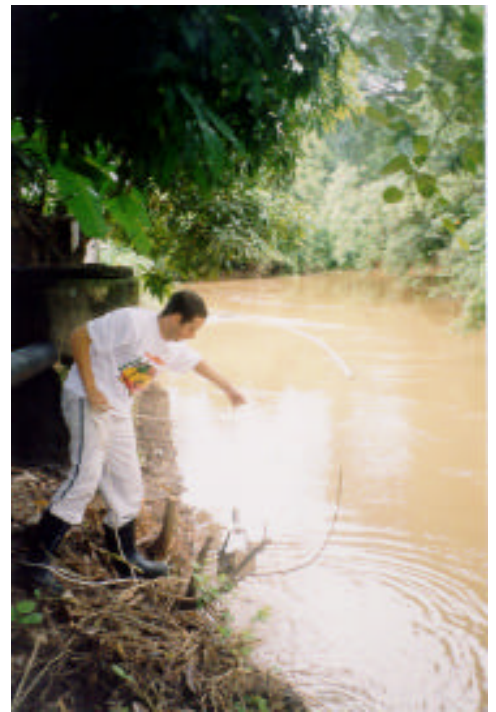

A - Rio Jaguari Mirim - São João da Boa Vista (IG 60)

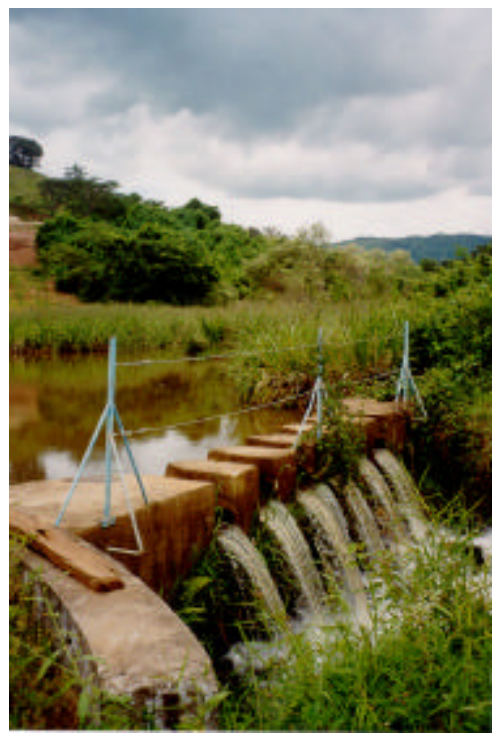

C - Ribeirão da Prata - Águas da Prata (IG 64)

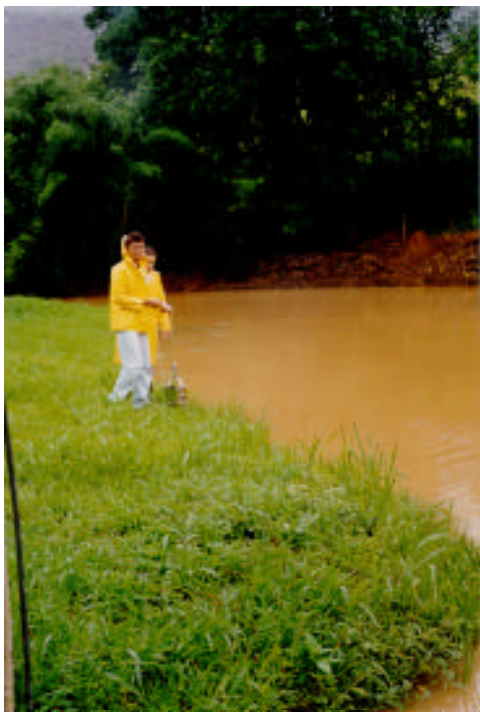

B - Ribeirão da Capelinha - Espiríto Santo do Pinhal (IG 63)

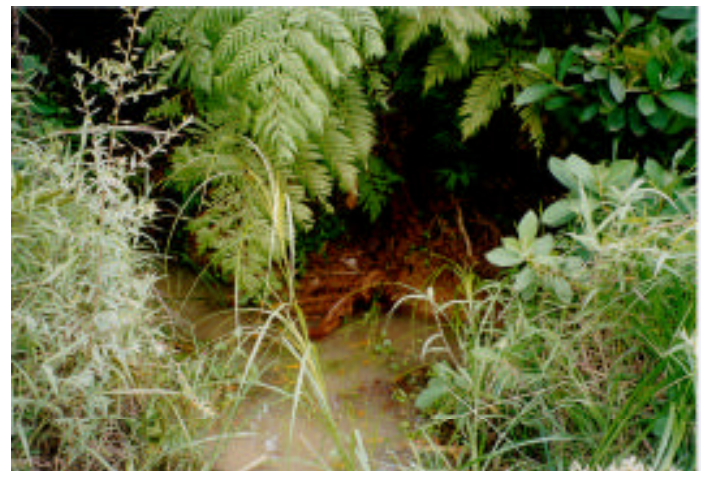

D - Córrego dos Cascais - Cascata (IG 66)

Figura F.1 - Áreas de captação de água para abastecimento da SABESP, pertencente a UGRHI 9 - Mogi-Guaçu 


\section{Cont. F.1}

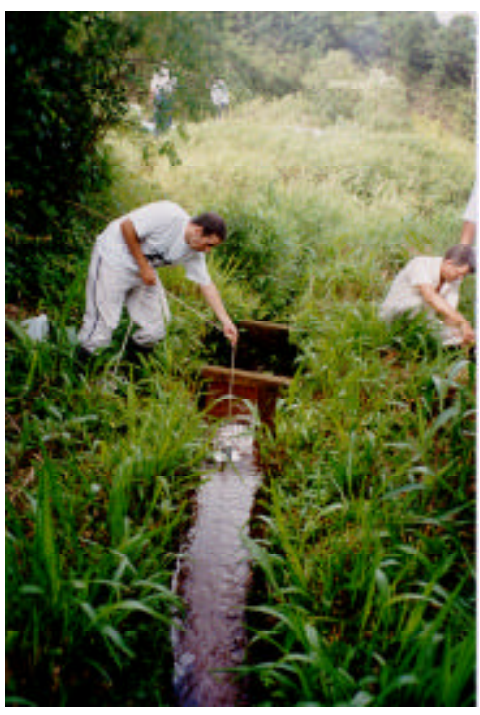

E - Mina da Encosta - Vila Nossa Senhora Aparecida (IG67)

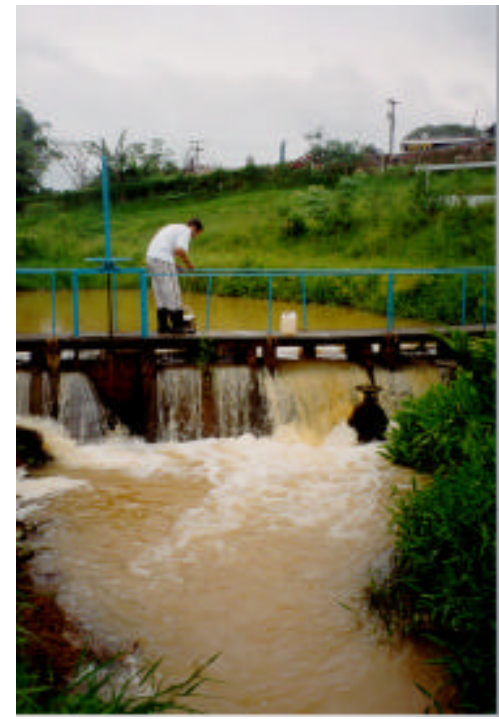

F - Córrego do Jardim - Santo Antonio do Jardim (IG72) 

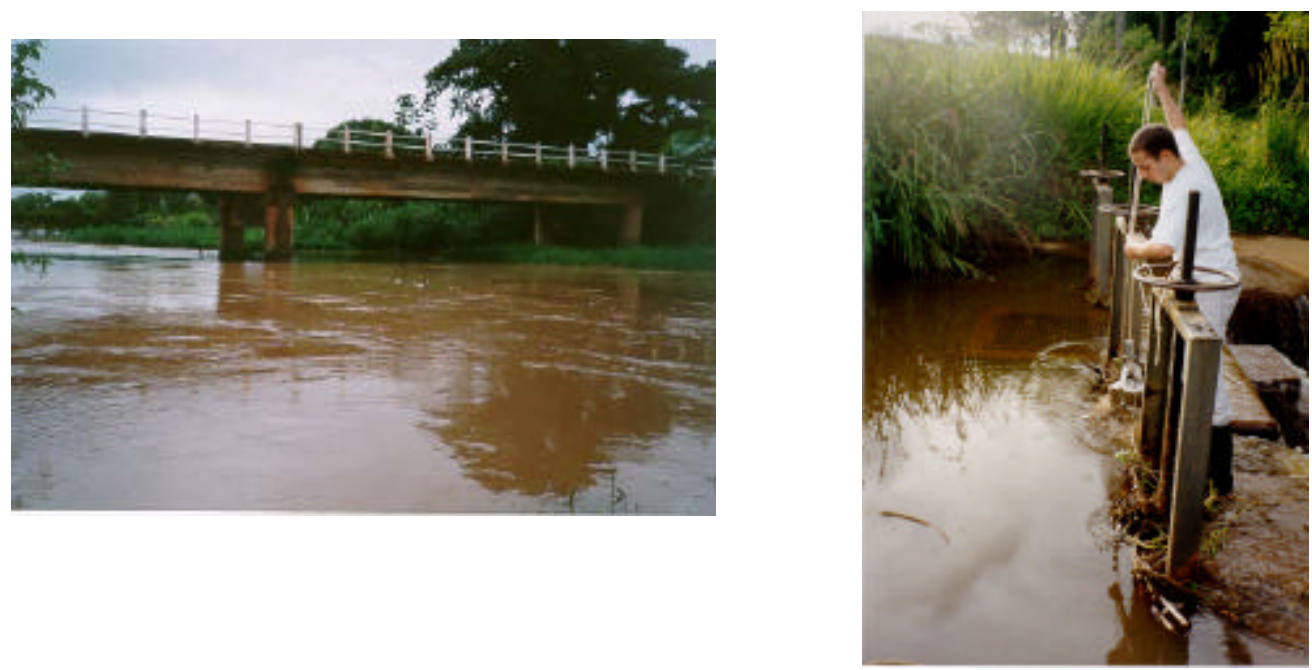

A - Rio Canoas - Mococa (IG 61)
B - Córrego da Fartura - São Roque da Fartura (IG 65)
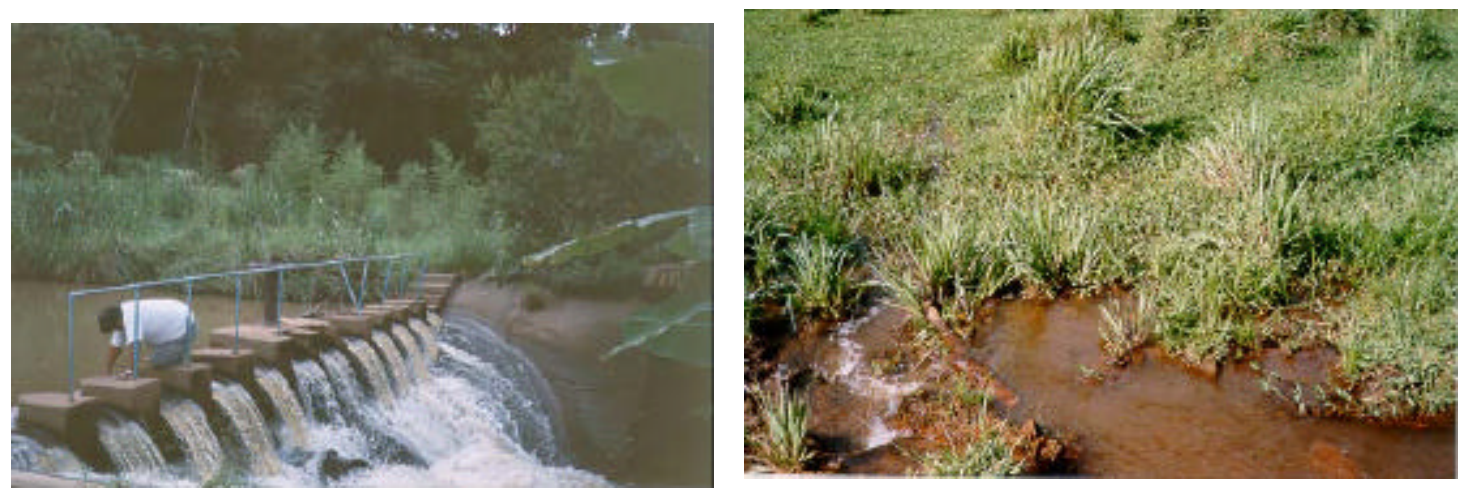

C - Córrego Santo Ambrósio - Divinolândia D - Rio do Peixe - Campestrinho (IG 69) (IG 68)

Figura F.2 - Áreas de captação de água para abastecimento da SABESP, pertencentes a UGRHI-4 - Pardo 


\section{Cont. F.2}
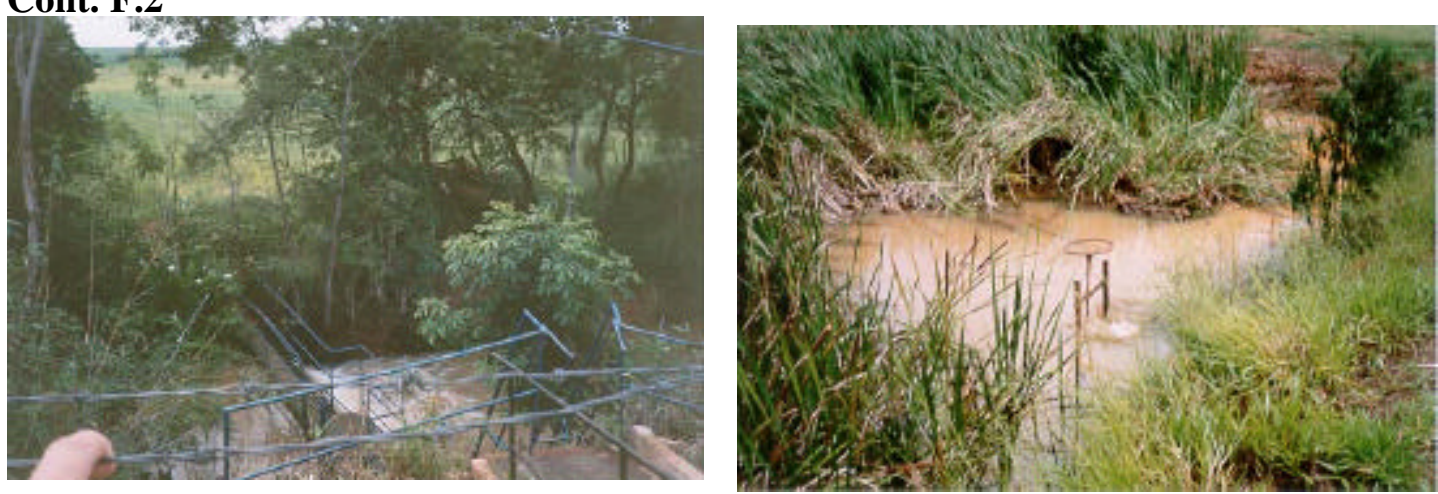

E - Ribeirão Doce - Itobi (IG 70) $\quad$ F - Córrego da Anhuma - São Sebastião da Grama (IG83)

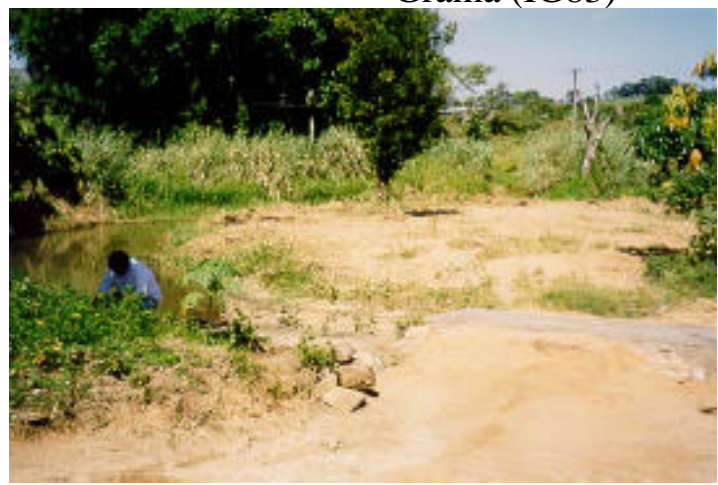

G - Rio Verde - Vargem Grande do Sul (IG VGS) 


\section{APÊNDICE 5}

Difratogramas da fração argila dos sedimentos

(natural, glicolada e aquecida) nas trezes comunidades estudadas 


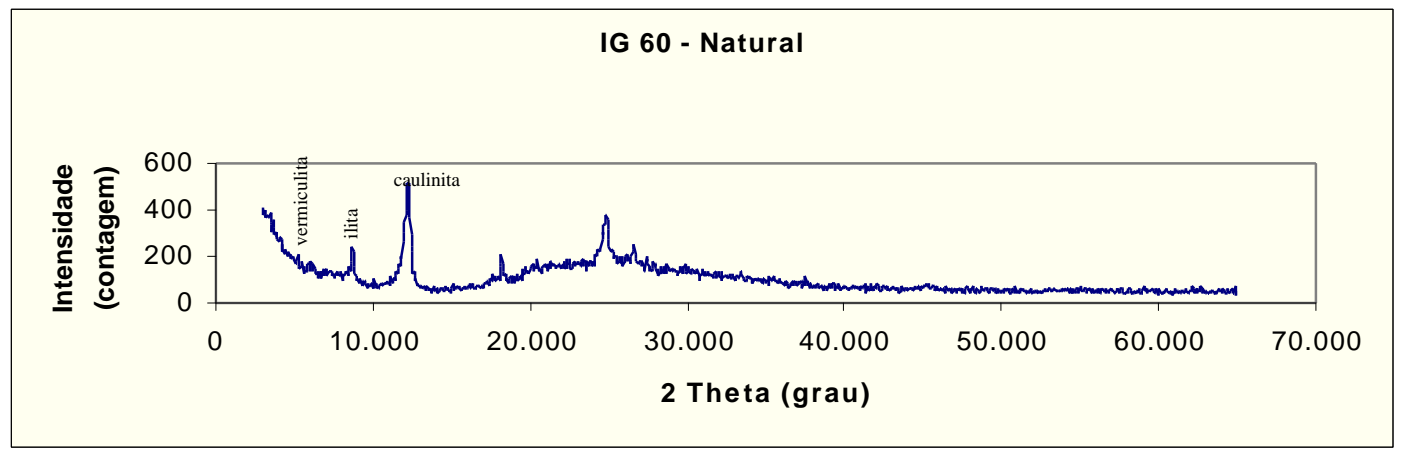

Figura E.1 - Difratograma da fração argila de sedimento pertencente a comunidade IG 60 (Natural)

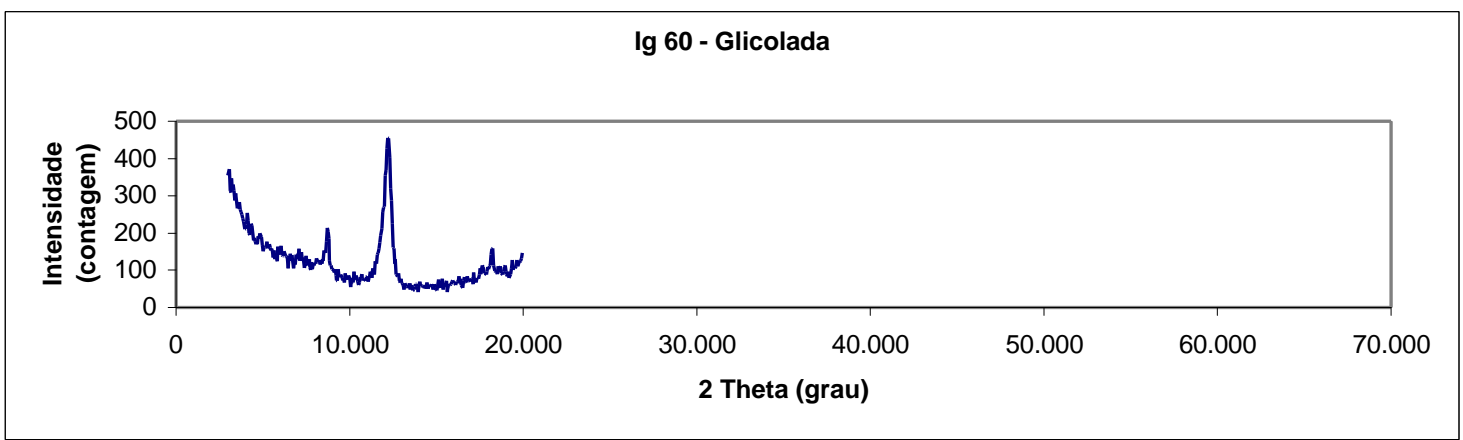

Figura E.2 - Difratograma da fração argila de sedimento pertencente a comunidade IG 60 (Glicolada)

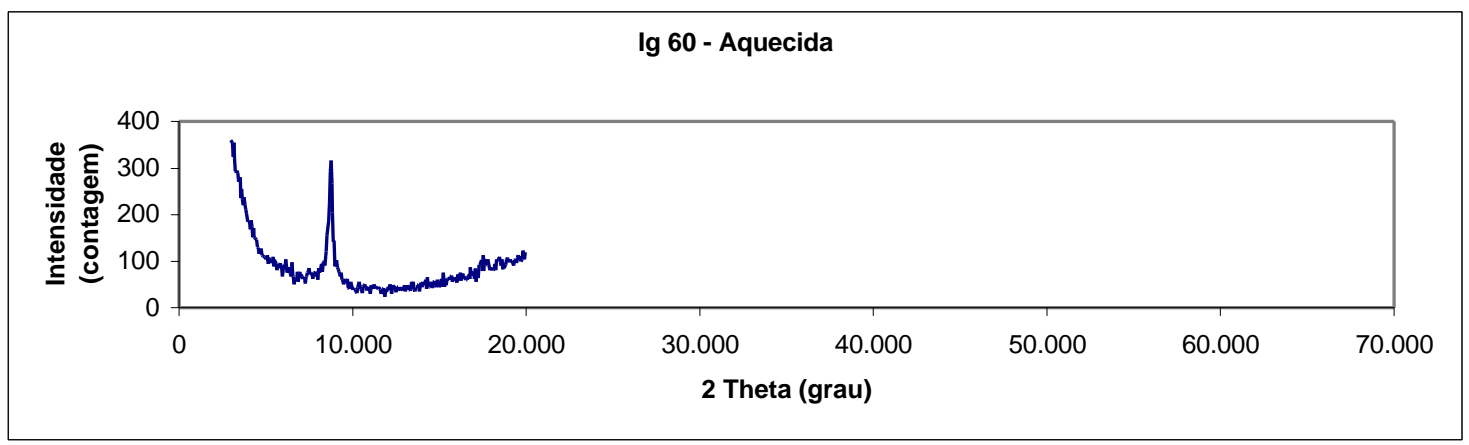

Figura E.3 - Difratograma da fração argila de sedimento pertencente a comunidade IG 60 (Aquecida) 


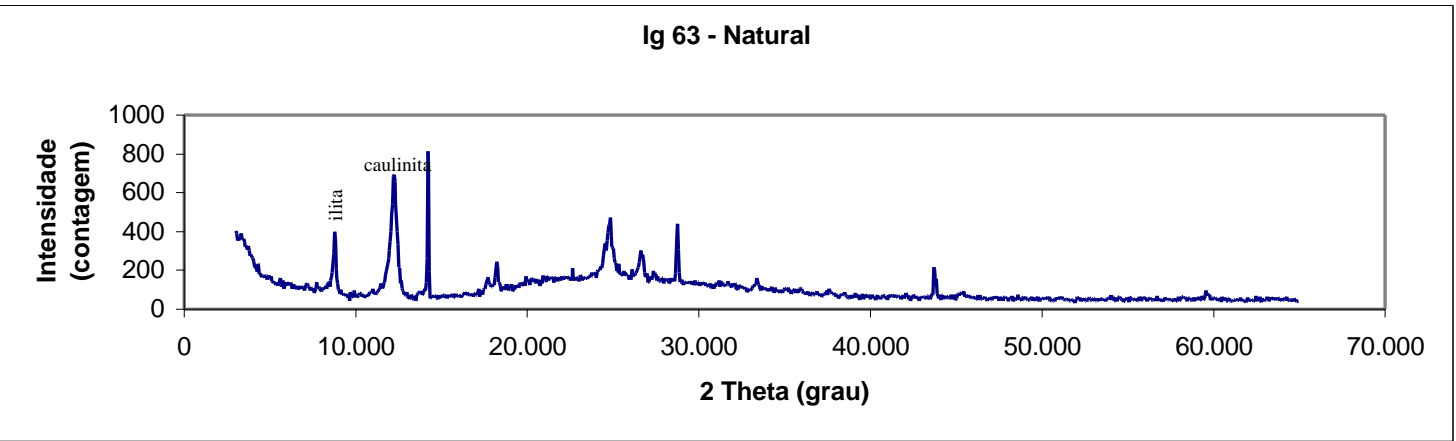

Figura E.4 - Difratograma da fração argila de sedimento pertencente a comunidade IG 63 (Natural)

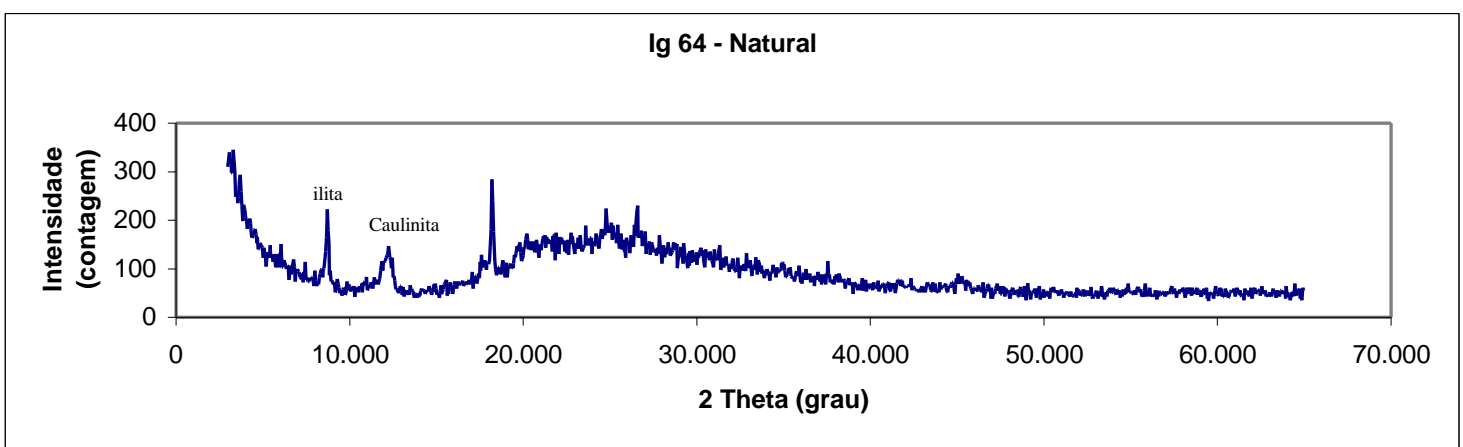

Figura E.5 - Difratograma da fração argila de sedimento pertencente a comunidade IG 64 (Natural) 


\section{REFERÊNCIAS BIBLIOGRÁFICAS}

Alloway, B.J. \& AYRES, D.C. (1997). Chemical Principles of Environmental Pollution, 2 ed., Ed. Chapman \& Hall, New York.

ANKLEY, G.T. \& SCHUBAUERBERIGAN, M.K. (1994). Comparison of Techniques for the Isolation of Sediment Pore-Water for Toxicity Testing. Arch. Environ. Contamination and Toxicology, 27 (4), p. 507-512.

APHA-AWWA-WPCF (1989). Standard Methods._17 $7^{\text {th }}$ edition, p.170.

AUALIITIA, T.U. \& PICKERING, W.F. (1988). Sediment Analysis - Liability of Selectively Extracted Fractions; Talanta; 35 (7); p. 559-566.

AVILA-PÉREZ ， P. ; BALCÁZAR, M. ; ZARAZÚA-ORTEGA, G. ; BARCELÓQUINTAL, I. ; DÍAZ-DELGADO, C. (1999). Heavy Metal Concentration in Water and Bottom Sediments of a Mexican Reservoir. The Sci. Of the Total Environment, 234, p. 185-196.

AZEVEDO, C.M.A. (1994) A Decisão de Preservar: O Caso da Mata Ripária no Médio Rio Jaguari-Mirim, S.P., Dissertação de Mestrado - PROCOM/USP

BENOLIEL, M.J. (1994). Sample Storage for Inorganic Compounds in Surface Water. Intern. J. Environ. Anal. Chem., 57, p. 197-206.

BETTI, M. \& PAPOFF, P. (1988). Trace Elements: Data and Information in the Characterization of an Aqueous Ecosystem. CRC Critical Reviews in Analytical Chemistry, 19, 4, p.271-322 
BEVILACQUA, J. E. (1996). Estudos sobre a Caracterização e Estabilidade de Amostras de Sedimento do Rio Tiete, SP., Tese de Doutoramento - IQ-USP.

BOHRER, M.B.C. (1995). Biomonitoramento das lagoas de tratamento terciário do sistema de tratamento dos afluentes líquidos Industriais (SITEL) do Pólo Petroquímico do Sul, Triunfo.RS, Através da comunidade Zooplanetômica, São Carlos, SP:. Tese de Doutorado - Universidade de São Carlos.

BRADY, N.C. (1989). Natureza e Propriedades do Solo. $7^{0}$ ed.. Livraria Freitas Bastos. São Paulo, 898 p.

BUBB, J.M. \& LESTER, J.N. (1991). The Impact of Heavy Metals on Lowland Rivers and the Implications for Man and the Environment. The Science of the Total Environment, 100, p. 207-233.

BUFFLATER, S.E. \& ALLEN, H.E. (1995). Sediment Pore-Water Collection Methods for Trace-Metal Analysis - A Review. Water Research, 29(1), p. 165-177.

BUSSAB, W.O \& MORETTINI, P.A. (1987). Estatística Básica. $4^{0}$ ed. São Paulo. Atual, $321 \mathrm{p}$.

BUSSAB, W.O.; MIAZAKI, E.S.; ANDRADE, D.F. (1990). Introdução à Análise de Agrupamentos. $9^{\underline{0}}$ Simpósio Nacional de Probabilidade e Estatística. São Paulo. 105 p.

BUTLER, E.C.V. \& GERSHEY, R. M. (1984). Application of Ion-Exchange Chromatography with an Ion-Selective Electrode detector to Iodine determination in Natural Waters. Analytica Chimica Acta, 164, p. 1153-161. 
CERK, T.; GORENC, D.; GORENC, B. (1993). Ion Chromatographic Determination of Select Anions in Mineral Waters. Analytical Letters, 26 (1), pp. 2701-2710.

CETESB (1989). Relatório de Mortandade de Peixes no Estado de São Paulo: Síntese da Década de 80.

CETESB (1991). Microbiologia Ambiental, v.1, nº 10, São Paulo.

CETESB (1995). Relatório de Qualidade das Águas Interiores do Estado de São Paulo, São Paulo, 382 p.

CETESB (1999). Relatório de Qualidade das Águas Interiores do Estado de São Paulo, São Paulo, 391 p.

CHAPMAN, D.V. (1989). Concepts and Strategies for Biological Monitoring. GEMS. University of London, 45p, In: ROSADO, R.M. Diagnóstico Ambiental da Baía de Ipanema, Lago Guaíba, Porto Alegre, RS, Brasil: O uso de bioensaios com subsídio para uma avaliação integrativa, Porto Alegre, RS (1998). Dissertação Universidade do Rio Grande do Sul.

CHARLES, B. \& FREDEEN, K. J. (1997). Concepts, Instrumentation and Techniques in Inductively Coupled Plasma Optical Emission Spectrometry - Perkin Elmer Corporation

CLEMENT, R.E. \& YANG, P.W. (1995). Environmental Analysis - Review. Anal. Chem., 69, p. 251R-287R.

CHRISTOFOLETTI, S.R. (1999). Estudo Mineralógico, Químico e Textural das Rochas Sedimentares da Formação Corumbataí “Jazida Cruzeiro”, e suas Implicações nos Processos e Produtos Cerâmico, Tese de Doutorado - UNESP- Rio Claro/SP 
CPRM (Serviço Geológico do Brasil) (1999). Projeto Araxá: Estudo Geoambiental das Fontes Hidrominerais, São Paulo, 125 p.

DANTAS, E.S.K. (1999). Procedimentos Analíticos em Determinações Multi Elementares de Particulados do Aerossol Atmosférico para Uso em Modelo Receptor, Dissertação de Mestrado - Instituto de Química/USP.

DAUS, B. \& ZWANZIGER, H. W. (1995). Heavy Metals in River Sediments - A Chemometrical Evaluation. Fresenius J. Anal. Chem, 352,. pp. 444-450.

DAVIDSON, C.; THOMAS, R.P.; McVEY, S.E.; PERALA, R.; LITTLEJOHN, D. ; URE, A.M. (1994). Evaluation of a Sequential Extraction Procedure for the Speciation of Heavy Metals in Sediments. Analytica Chimica Acta, 291, p. 277-286.

DIÁRIO OFICIAL DA UNIÃO (D.O.U.).1990. Ministério da Saúde, portaria n⿳0 36, de 19 de Janeiro de 1990 (publicada em 23 de Janeiro de 1990).

DIÁRIO OFICIAL DA UNIÃO (D.O.U.).2000. Ministério da Saúde, portaria n⿳0 1469, de 29 de Dezembro de 2000 (publicada em 10 de Janeiro de 2001).

DIONEX (1998). Apresentação sobre Cromatografia de Íons: Métodos Oficiais.

DIONEX CORPORATION (1993a). User's Guide of Anions Self-Regenerating Suppressor Controller.

DIONEX CORPORATION (1993b). User's Guide of Cation Self-Regenerating Suppressor Controller.

DROPPO, I.G. \& JASKOT, C. (1995). Impact of River Transport Characteristics on Contaminant Sampling Error and Design. Environ. Sci. Technol., 29, p. 161-170. 


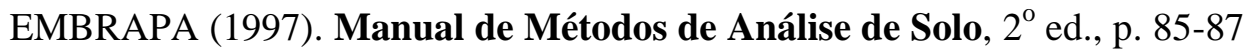

EPA (1986a). Chloride, Orthophosphate, Nitrate e Sulfate in Wet Deposition by Chemical Suppressed Ion Chromatography. Method 300.6.

EPA (1986b). Dissolved Sodium, Ammonium, Potassium, Magnesium, and Calcium in Wet Deposition by Chemical Suppressed Ion Chromatography. Method 300.7.

EPA (1991). Handbook of Remediation of Contaminates Sediments - 625/6-91/028

EPA (2000) Available from World Wide Web: <http://www.epa.gov/safewater/kids/treat.html>

ESTEVES, F.A. (1988). Limnologia. Ed. Interciência, Rio de Janeiro, 575p.

FIZMAN, M.; PFEIFFER, W.C.; LACERDA, L.D. (1984). Comparison of Methods Used for Extraction and Geochemical Distribution of Heavy Metals in Bottom Sediments from Sepetiba Bay, R.J.. Environ. Tech. Letters, 5, p. 567-575.

FÖRSTNER, U. (1977). Metal Concentration in Freshwater Sediments - Natural Background and cultural Effects. In: Interactions Between Sediments and Freshwater. Golterman, H.L.. Wagening, p. 94-103.

FÖRstner, U. \& WiTtMann, G. T. W. (1981). Metal Pollution in the Aquatic Environment. $2^{\circ}$ ed. Berlin: Springer-Verlag.

FRANKENBERGER JR., W.T.; MEHRA, H.C.; GJERDE, D.T. (1990). Environmental Applications of Ion Chromatography - Review. Journal of Chromatography, 504, p. 211-245 
GATTI, L.V. (1997). Distribuição de Metais em Testemunhos de Sedimentos de Duas Lagoas Marginais do Rio Moji-Guaçu (E.E. de Jataí, Luiz Antônio, SP) - Tese de Doutorado - São Carlos, SP.

GERAB, F. (1996). Técnicas Analíticas Nucleares Aplicadas à Medida em Larga Escala de Aerossóis Atmosféricos na Região Amazônica, Tese de Doutoramento - Instituto de Física/USP,SP

GOBBI, D.L.; ZAITSEV, D.; MISTURA, C.M.; VAITSMAN, D.S. (1999). Monitoramento Ambiental da Água do Rio Marau na Região do Planalto Médio do Rio Grande do Sul. Anais Assoc. Bras, Quím., 48 (1), p. 1-6

GONZALEZ, M.J.; RAMOS, L.; HERNÁNDEZ, L.M. (1994). Distribution of Trace Metals in Sediments and the Relationship with their Accumulation in Earthworms. Intern. J. Environ. Anal. Chem., 57, p. 135-150

GRIM, R.E. (1953). Clay Mineral, McGraw-Hill Book Company. New York, 384 p.

HANSEN.L.D., RICHTER, B.E.; ROLLINS, D.K.; LAMB, J.D.; TEATOUGH, D.J. (1979). Determination of Arsenic and Sulfur Species in Environmental Samples by Ion Chromatography. Analytical Chemistry, 61 (6), p. 633-637.

HOOVER, T.B. \& YAGER, G. (1984). Determination of Trace Anions in Water by Multidimensional Ion Chromatography. Anal. Chem., 56, pp. 221-225.

IBGE (1997). Censo Agropecuário 1995/1996, nº 19, São Paulo.

IG/CETESB/DAEE (1997). Mapeamento da Vulnerabilidade e Risco de Poluição das Águas Subterrâneas no Estado de São Paulo, vol.1, Governo do Estado do São Paulo, Secretaria do Estado do Meio Ambiente, Secretaria dos Recursos Hídricos, Saneamento e Obras, São Paulo. 
IPT (1981). Mapa Geológico do Estado de São Paulo, Vol. II

KATSUÓKA, L., PIRES, M.A.F., VAZ, J.M., CONTRIM, M.E.B. (2000) Monitoramento de Compostos Orgânicos em Águas e Sedimentos em Municípios Pertencentes à Unidade Gerencial de Recursos Hídricos 9 - Alto Mogi-Guaçu. VI Encontro de Ecotoxicologia. p. 68-69. Realizado em 3 a 6 de Setembro de 2000.

KATSUÓKA, L. (2001) Avaliação do Impacto da Atividade Agropecuária na Qualidade da Água de Captação Superficial nas Bacias Hidrográficas dos Rios Mogi-Guaçu e Pardo, São Paulo, Tese de Doutorado - IPEN/SP

KRAMER, K.J.M. (1994). Inorganic Contaminants in the Water Column: Sampling and Sampling Strategy. Intern. J. Environ. Anal. Chem.,. 57, p. 179-188.

KRAUSE, P.; ERBSLÖH, R.; NIEDERGESÄß, R.; PEPELNIK, E.; PRANGE, A. (1995). Comparative Study of Different Digestion Procedures Using Supplementary Analytical Methods for Multielement-Screening of more than 50 Elements in Sediments of the River Elbe. Fresenius, 353, pp. 3-11.

LACERDA, L.D.; PAUL, F.C.F.; OVALLE, A.R.C.; PFEIFFER, W.C.; MALN, O. (1990). Trace Metals in Fluvial Sediments of the Madeira River Watershed, Amazon, Brazil. The Science of the Total Environmental, 97/98, p. 525-530.

LEE, G. \& HAAK, K. (1988). On-Line Monitoring of Transition Metals in Wastewater. Dionex Corporation, \# 1178.

LIANG, J. \& SCHOENAU, J.J. (1995). Development of Resin Membranes as a Sensivity Indicator of Heavy Toxicity in the Soil Environment. Intern. J. Environ. Anal. Chem., 59. p. 265-275. 
LIU, W.; WANG, W.; WEN, X.; TANG, H. (1999). The Application of Preliminary Sediment Quality Criteria to Metal Contamination in the Le An River. Environmental Pollution, 105, p. 355-366.

MACKNIGHT, S.D. (1994). Selection of Botton Sediment Sampling Stations. In: Handbook of Techniques for Aquatic Sediments Sampling. Boca Raton, p. 1728.

MARKICH, S. J. \& BROWN, P. L. (1998). Relative Importance of Natural and Anthropogenic Influence on the Fresh Surface Water Chemistry of the HawkesburyNepean River, South-Eastern, Australia. The Science of the Total Environment, 217. p. 201-230.

MARQUES, M.N. (1999). Cromatografia de Íons Aplicada na Especiação de Crômio Hexavalente em Amostras de Interesse Ambiental., Dissertação de Mestrado IPEN/CNEN.

MONTASER, A. \& GOLIGHTLY, D. W. (1992). Inductively Coupled Plasma in Analytical Atomic Spectrometry, $2^{\text {nd }}$, Ed. VCH Publisher

MOSKO, J.A. (1984). Automated Determination of Inorganic Anions in Water by Ion Chromatography. Anal. Chem., 56, p. 629-633.

MOU, S. (1991). Environmental Application of Ion Chromatography in China. Journal of Chromatography, 546, p. 317-324.

MOZETO, A.A. \& ALBUQUERQUE, A.L.S. (1997). Biogeochemical Properties at the Jataí Ecological Estation Wetland (Mogi-Guaçu River, São Paulo, SP), Ciência e Cultura, 49 1/2, p. 25-33. 
MUDROCH, A. \& MACKNIGHT, S.D. (1994). Handbook of Techniques for Aquatic Sediments Sampling, $2^{\text {nd }}$, Ed. Lewis Publishers, 236 p.

NGUYEN, VAN DY. (1996). Ion Chromatographic Determination of Trace Anions and Cations in High-Purity Water. Fresenius J. Anal. Chem, 354, p. 738-741.

NOLTING,R.F. \& DE JONG, J.T.M. (1994). Sample and Analytical Methods for the Determination of Trace Metals in Surface Seawater. Intern. J. Environ. Anal. Chem., 57, p. 189-196.

NOVIC, M.; LECNIK, B.; HUDNIK, V.; PIHLAR, B. (1997). Carbonate Interferences by ion Chromatographic Determination of Anions in Mineral Waters. Journal of Chromatography A., 764, p. 249-256.

NOVOZAMSKY, I. ; LEXMOND, T.M. ; HOUBA, V.J.G. (1993). A Single Extraction Procedure of Soil for Evaluation of Uptake if some Heavy Metals by Plants. Intern. J. Environ, Chem., 51, p. 47-58.

OLIVEIRA, E.M; ISHIHATA, L.; LORENÇO, M.R. (1995). Macrozoneamento das Bacias dos Rios Mogi-Guaçu e Pardo. Questões Sócio-Ambientais Regionais. Governo do Estado de São Paulo, Secretaria da Agricultura e Abastecimento, Secretaria de Economia e Planejamento, São Paulo.

OLIVEIRA, A.M.S. \& BRITO, S.N.A. (1998) Geologia de Engenharia, ABGE, 2 ${ }^{\underline{o}}$ edição, São Paulo.

OliVEIRA, E. (1998). Apostila do Curso de Espectrometria de Emissão Atômica: ICP-AES, Pós-Graduação (IQ-USP)

PADILHA, A.F. \& FILHO, F.A. (1985). Técnicas de Análise Micro-Estrutural, Hemus, São Paulo. 
PAMPLIN, P.A.Z (1999). Avaliação da Qualidade Ambiental da Represa de Americana (SP-Brasil) com Ênfase no Estudo da Comunidade de Microinvertebredos Bentônicos e Par6ametros Ecotoxocológicos, Dissertação de Mestrado - UFScar/SP

PETRONI, S.L.G. (1999). Estudos de adsorção de Zinco e Cádmio em Turfa. Potencialidade de Utilização de um Bioadsorvedor Natural em Sistemas de Tratamento de Efluente, Dissertação de Mestrado - IPEN/SP.

PIRES, M.A.F. (1989). Aplicação da Cromatografia de Íons no Controle de Materiais de Interesse Nuclear., Tese de Doutoramento - IPEN/SP.

PIRES, M.A.F., KATSUÓKA, L., COTRIM, M.E.B, MARTINS, E.A.J., BITENCOURT, M., IGNÁCIO, M. (2000) Avaliação de Riscos de Contaminação de Áreas Destinadas à Captação de Água Superficial para Abastecimento Público nos Municípios de São João da Boa Vista, Águas da Prata, Espírito Santo do Pinhal e Santo Antônio do Jardim, SP. VI Encontro de Ecotoxicologia. Realizado em 3 a 6 de Setembro de 2000, p. 76

PORTO, R.L.L., BRANCO, S.M.; CLEARY, R.W.; COIMBRA, R.M.; EIGER, S.; LUCA, S.J.; NOGUEIRA, V.P.Q.; PORTO, M.F.A. (1991). Hidrologia Ambiental, $3^{\mathrm{o}}$ ed. Edusp, São Paulo, 414 p.

RAURET, G. (1998). Extraction Procedures for the Determination of Heavy Metals Contaminated Soil and Sediment. Talanta, 46. p. 449-455.

ROSADO, R.M. (1998). Diagnóstico Ambiental da Baía de Ipanema, Lago Guaíba, Porto Alegre, RS: O Uso de Bioensaios como Subsídio para uma Avaliação Interativa. (Dissertação de Mestrado), Instituto de Biociências - UFRS

REBOUÇAS, A.C. (1999). Água doce no mundo e no Brasil. In: REBOUÇAS, A.C.; BRAGA, B. \& TUNDISI, J. G. (Coordenadores). Águas Doces no Brasil Capital Ecológico, Uso e Conservação. São Paulo, Escrituras editora. 
RUBIO, R. \& URE, A.M. (1993). Approaches to Sampling and Sample Pretreatments for Metal Speciation in Soils and Sediments. Intern. J. Environ. Anal. Chem., 51, p. 205$217,$.

SANTOS, P.S. (1989a). Tecnologia de Argilas Aplicadas as Argilas Brasileiras, Edgard Blücher, $2^{\circ}$ edição, São Paulo. p. 409.

SANTOS, P.S. (1992b). Ciência e Tecnologia de Argilas, editora Edgard Blücher, $2^{\circ}$ edição, São Paulo, p. 813.

SANTOS, E. J. (1999). Determinação de Nutrientes e Contaminantes Inorgânicos em Café Solúvel por Espectrometria de Emissão Atômica com Plasma de Argônio Induzido (ICP-AES), Dissertação de Mestrado - Instituto de Química/USP

SEILER, H.G. \& SIGEL, H. (1998). Handbook on Toxicity of Inorganic Compounds, Marcel Dekker Inc. New York

SILVA, D.L. \& LIMA, W.N. (1999). Utilização de Matérias Geológicas como Agentes Depuradores de Águas Residuárias. Parte I - Caracterização Químico-Mineralógica. Anais Assoc. Brás. Quím., 48 (1), p. 46-52.

SCHULTS, D.W.; FERRARO, S.P.; SMITH, L.M.; ROBRETS, F.A.; POINDDEXTER, C.K. (1992). A comparison of Methods for Collecting Interstitial Water for Trace Organic Compounds and Metals Analyses. Water Research., 26 (7), p. 989-995.

SOARES, H.M.V.M ; BOAVENTURA, R.A.R.; MACHADO, A.A.S.C.; SILVA, J.C.G.E. (1999). Sediments as Monitors of Heavy Metal Contamination in the Ave River Basin (Portugal): Multivariate Analysis of Data. Experimental Pollution, 105, p. 311323. 
SPECTRO (1999). User's Guide of SPECTRO-ICP-AES, Manual do usuário, 240 p.

STANDARD METHODS FOR THE EXAMINATION OF WATER AND WASTEWATER (1985) $17^{\circ}$ edição.APHA AWWA, WPCF

SUGUI, K. (1980). Rochas Sedimentares. Editora Edgard Blücher Ltda, 500 p.

STURGEON, R. \& BERMAN, S. (1987). Sampling and Storage of Natural Water for trace Metals. In: CRC Critical Reviews in Analytical Chemistry, 18(3), p. 209-245.

TAVARES, T.M. \& CARVALHO, F.M. (1992). Avaliação de Exposição de populações Humanas a Metais Pesados no Ambientes: Exemplos do Recôncavo Baiano. Química Nova, 15, 2, p. 147-155.

TEIXEIRA, S.R. (1981). Estudo do Comportamento Estrutural e Cinética de Oxidação de Dióxido de Urânio, por Difratometria de Raios X em Alta Temperatura, Dissertação de Mestrado - IPEN/SP

THOMPSON, M. (1987). Analytical Performance of Inductively Coupled Plasma Atomic Emission Spectrometry. In: MONTASER, A. e GOLIGHTLY, D. W. Inductively Coupled Plasma in Analytical Spectrometry, New York: VHC publishers INC, p. 163-199.

TRUCKENBRODT, D. \& EINAX, J. (1995). Sampling Representatively and Homogeneity of River Sediments. Fresenius J. Anal. Chem., 352, p. 437-443.

TUREKIAN, K.K. \& WEDEPOHI, K. H. (1961). Distribution of the elements in Some Major Units of the Earth's Crust. Bull; Geological Society Am; NY, 72; p. 175-192.

URASA, I.T. \& MACHA, S.F. (1996). Speciation of Heavy Metals in Soils, Sediments, and Sludges Using D.C. Plasma Atomic Emission Spectrometry Coupled with Ion Chromatography. Intern. J. Environ. Anal.,. 64, p. 83-95. 
VICENT-BECKETT, V.A.; PASCUAL, C.B.; KAWN, C.S.; BECKETT, R. (1991). Levels and Distribution of Trace Metals in Sediments of Laguna Lake (Philippines); Inter. Journal. Anal. Chem.; 45; p. 101-116.

WALKLEY, A. e BLACK, A. (1933). An Examination of the Deggtjarefff Method for Determination Mining Soil Organic Matter, and a Proposed Modification of the Chromic Acid Titration Method. Soil Sci.; 37, p. 29-38.

WEISS, J. (1986). Handbook of Ion Chromatography. Ed. Edward L. Johnson. Dionex Corporation, Califórnia, 486p.

WETZEL, R. G., (1983). Limnology. $2^{\circ}$ ed. Chicago: Sauders College Publishing.

YABE, M. J. S. (1995). Determinação de Metais Pesados em Águas Superficiais por ICPAES Objetivando Caracterização e Recuperação de Bacias Hidrográficas, Tese de Doutorado - USP 